\title{
A Revision of the Australian Cladocera (Crustacea)
}

\author{
N.N. SMIRNOV and B.V. TIMMS \\ ${ }^{a}$ Institute of Evolutionary Morphology and Ecology of Animals, U.S.S.R. Academy of Sciences, Leninski \\ Prospect 33, Moscow V-71, 117071, U.S.S.R. \\ bSciences Department, Avondale College, Cooranbong, N.S.W., Australia, 2265
}

\begin{abstract}
The Australian Cladocera are revised on the basis of numerous samples, collections in the Australian Museum and a critical consideration of the literature.

Six families are represented in inland waters of Australia: Sididae, Chydoridae, Macrothricidae, Moinidae, Bosminidae, and Daphniidae. Altogether 125 species in 40 genera were found, 15 species being new: Pseudosida australiensis n.sp., Archepleuroxus baylyi n. gen., n.sp., Rak obtusus n. gen., n.sp., Rak labrosus n. gen., n.sp., Australochydorus aporus n. gen., n.sp., Rhynchochydorus australiensis n. gen., n.sp., Alona macracantha n.sp., Alona investis n.sp., Alona setuloides n.sp., Biapertura rusticoides n.sp., Monospilus diporus n.sp., Monospilus elongatus n.sp., Echinisca williamsi n.sp., Echinisca flagellata n.sp., and Simocephalus victoriensis n.sp. One new subspecies is recognized: Alona davidi vermiculata n.subsp. Some 49 species (including the new species) are recorded in Australia for the first time. In addition, the presence of a further 6 species of marine Cladocera in the families Podonidae and Sididae is noted.

The cladoceran fauna of Australia, besides including many cosmopolitan and pantropical forms, also has some species widely distributed in the Holarctic, some Gondwanaland species, and a large number (46) of endemics. Keys to all families and genera of Cladocera are given as well as keys for Australian species. Ecology, community structure, faunal composition and zoogeography are considered. The revision provides a basis for the identification of Australian Cladocera and for further taxonomic studies.
\end{abstract}

Smirnov, N.N., \& B.V. Timms, 1983. A Revision of the Australian Cladocera (Crustacea). Records of the Australian Museum. Supplement $1.132 \mathrm{pp}$.

\section{CONTENTS}

Abstract $\ldots \ldots \ldots \ldots \ldots \ldots \ldots \ldots \ldots \ldots \ldots \ldots \ldots \ldots \ldots \ldots \ldots \ldots$

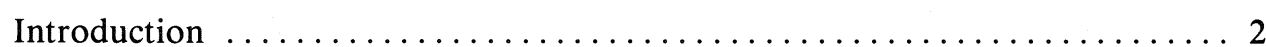

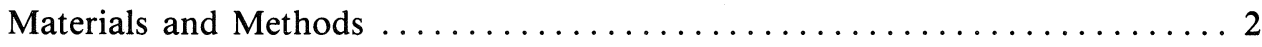

Morphology $\ldots \ldots \ldots \ldots \ldots \ldots \ldots \ldots \ldots \ldots \ldots \ldots \ldots \ldots \ldots \ldots$

Key to All Families of Cladocera $\ldots \ldots \ldots \ldots \ldots \ldots \ldots \ldots \ldots \ldots \ldots \ldots$

Family Sididae (Diaphanosoma by V. Kořínek, Latonopsis, Pseudosida

\& Penilia by N.M. Korovchinsky) ................... 5

Family Podonidae (by the late P.D. Mordukhai-Boltovskoi) . . . . . . . 13

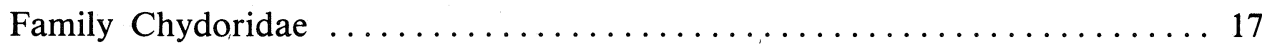

Subfamily Sayciinae $\ldots \ldots \ldots \ldots \ldots \ldots \ldots \ldots \ldots \ldots \ldots \ldots \ldots \ldots$

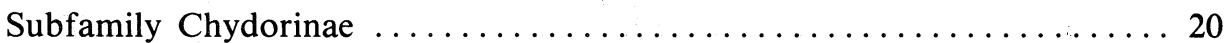

Subfamily Aloninae $\ldots \ldots \ldots \ldots \ldots \ldots \ldots \ldots \ldots \ldots \ldots \ldots \ldots \ldots \ldots$

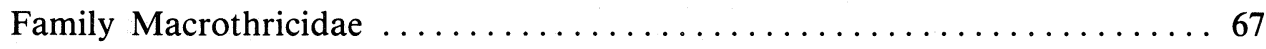

Family Moinidae .......................... 84

Family Bosminidae (Bosmina by V. Koř́nek) ............... 89

Family Daphniidae (Daphnia by P.D.N. Hebert, Simocephalus \&

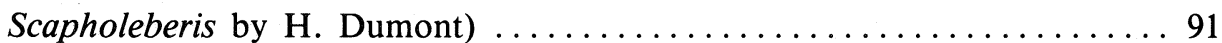




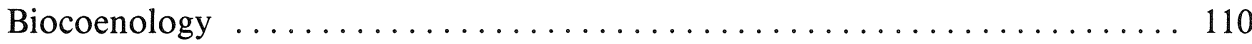

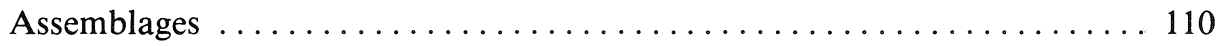

Species Groups ................................. 112

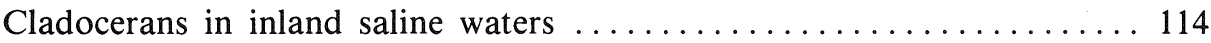

Faunal Composition and Zoogeography ..................... 114

Acknowledgements ................................. 119

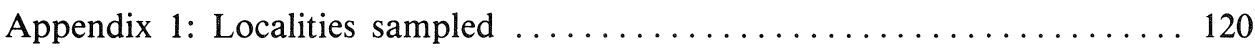

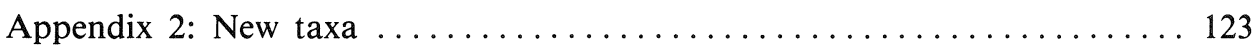

Appendix 3: Species indicated in Australia for the first time ........... 124

Appendix 4: Species common in Australian inland waters ............ 124

Appendix 5: Species rare in Australian inland waters .............. 124

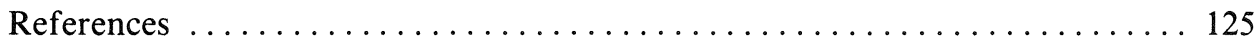

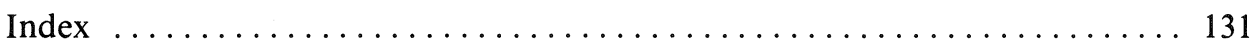

There is a renewed interest in the study of Cladocera, stimulated mainly by their importance in biological processes of inland waters and by their significance as biological indicators, particularly in palaeolimnological studies. Since 1959 there have been significant advances in detailed descriptive morphology, in functional morphology and in palaeolimnology based on the remains of Cladocera in lake deposits (see Smirnov, 1975). Several world revisions and regional faunas have been published. This work has been based mainly on the Holarctic fauna, which is comparatively well known.

By contrast the Australian fauna is inadequately studied, yet it is of zoogeographical interest and contains forms of considerable phylogenetic and ecological interest. Only a few zoologists have contributed knowledge on Australian species. The first was the Rev. King, who in the 1850 's noted 17 species. G.O. Sars, working mainly on specimens raised from dried mud, added 16 species to make the total 33. Miss Marguerite Henry in two papers $(1919,1922)$ increased this number to 52. Gurney (1927) comments on 17 species, 4 being new. Various authors subsequently described a few additional species or discussed those previously described. As a result, by 1954 a total of 63 valid species were known from Australian inland waters. New South Wales is the most intensively studied area (due to King, Sars, Henry) followed by Queensland (due to Sars, Gurney) and Tasmania (due to Smith, Brehm). A few records are available for Western Australia (Sars, Serventy, Petkovski), Victoria (Searle, Searle et al.) and South Australia (Henry), and apparently none at all for the Northern Territory. Unfortunately for comparative purposes, only a few taxonomic papers (by Sars, Brehm) have been published on New Zealand Cladocera although a book has recently become available on N.Z. freshwater crustaceans (Chapman and Lewis, 1976), and little information is available for New Guinea (Brehm, 1959).

Despite the above, the Australian Cladocera cannot be considered to have been studied in any detail since (a) a figure of 63 species for Australia is very low by comparison with faunas of other continents and suggests that the fauna is either depauperate (hardly likely for a largely cosmopolitan group) or incompletely known, (b) most distribution records are from only a few areas indicating inadequate collecting, and (c) a study of the 70 published papers on Australian Cladocera reveals little pertinent information. Although there has been a recent partial review of Australian Cladocera (Petkovski, 1973a, 1973b-in German and a journal unobtainable in Australia and based on few new collections) and reference to Australian specimens and species in world reviews (of Moinidae, Goulden, 1968; of Chydoridae, Smirnov, 1971b; of Macrothricidae and Moinidae, Smirnov, 1976), the present work is by far the most comprehensive to date. It considers all families known for Australia (including marine species) and is based on a large number (330) of new collections, a study of museum material and a critical evaluation of all literature on Australian Cladocera. The collections are from most areas of Australia, but unfortunately there are very few from north-west Western Australia, from the Northern Territory and from far inland areas of other mainland states.

Several authors (H. Dumont, P. Hebert, V. Kořinek, N. Korovchinsky and P. Mordukhai-Boltovskoi) have contributed on particular genera. N.N. Smirnov performed mainly the taxonomical part of the study. B.V. Timms made collections, contributed notes on the ecology and distribution of each species, and analysed faunal composition, communities and zoogeographical relationships. The text is composed by both authors, each with equal responsibility.

\section{Materials and Methods}

A large variety of inland waters were sampled over a period from 1964 to 1978 by one of us (B.V.T.); some collections were also made available by other workers, particularly Dr I.A.E. Bayly, Mr D. Morton and Dr R. Shiel. Data on the collection sites are listed in Table 1; they are numbered for conciseness in later listing of materials for each species. Most littoral collections were made with a Birge cone net (diameter $17 \mathrm{~cm}$ ) and limnetic collections with a plankton net $(33 \mathrm{~cm}$ in diameter); mesh size in both nets was $159 \mu \mathrm{m}$. Samples 
were preserved in $5 \%$ formalin. More than 330 collections were obtained and in addition collections in the Australian Museum, including Henry's types, were examined. The section on Daphnia by P.D.N. Hebert is based on his own materials and methods (Hebert, 1977).

For the Chydoridae and some other species having resistant exoskeletons slides were made using Canada balsam. Whole specimens of soft-shelled cladocerans, and where necessary dissected specimens of others, were mounted in polyvinyl alcohol (as described in Smirnov, 1975). Slides of representatives of most species, including holotypes of most new species, have been deposited in the Australian Museum. Many paratypes have been lodged in the Zoological Museum of Moscow University, as well as some other slides. Paratypes and slides of many species have been placed in the Zoological Institute of the U.S.S.R. Academy of Sciences, Leningrad. A few paratypes have been given to the British Museum, London.

For each new species and also for those recently described by Dr N.N. Smirnov or Dr T. Petkovski full descriptions of available material are given. This approach is adopted for the latter group because most of the original descriptions are in Russian or German and in publications not readily available in Australia. For the remainder only differential diagnoses are given, though in some difficult cases or in synonymies some discussion of taxonomic features is provided. In the family and generic keys all known extant taxa are included, even though we have not found some of them in Australia. Since at least some of them could occur (e.g. we have only recently found Kurzia and Euryalona despite 15 years study) this will facilitate their recognition. In the species keys we generally preferred to include only species known to occur in Australia; in cases where specimens do not conform with the characteristics given in the couplets it will be necessary to consult specialized monographs (see References).

A number of abbreviations are used in the test. They are explained below:
AM Australian Museum (Sydney
Bb. billabong (oxbow lake)
BM British Museum (London)
$\mathrm{Ck} \quad$ creek
D. dam
DF D.G. Frey's collection
F.D. farm dam
I.D. irrigation dam
I. island
L. lake
Lag. lagoon (commonly a shallow lake)
MGU Zoological Museum of Moscow University
MNHB Museum of Natural History, Budapest, Hungary
N.S.W. New South Wales
N.T. Northern Territory
P. pond
Qld Queensland

$\begin{array}{ll}\text { R. } & \text { river } \\ \text { Res. } & \text { reservoir } \\ \text { S.A. } & \text { South Australia } \\ \text { Sw. } & \text { swamp } \\ \text { Tas. } & \text { Tasmania } \\ \text { Vic. } & \text { Victoria } \\ \text { W.A. } & \text { Western Australia } \\ \text { ZIN } & \text { Zoological Institute of the U.S.S.R. } \\ & \quad \text { Academy of Sciences, Leningrad } \\ \text { ZMO } & \text { Zoological Museum, Oslo. }\end{array}$

\section{Morphology}

In all Australian species of Cladocera the body is contained within a two-valved shell, fused anteriorly to the head shield. The body consists of the head, thorax, abdomen (that part of the trunk posterior to the thoracic limbs), and postabdomen. The latter is peculiar to the Cladocera; it is chitinized and bent forwards and commonly ends in two claws. The appendages of the head are: antennule (first antenna), antenna (second antenna), maxillule, mandibule. The thorax bears I-VI thoracic limbs. All appendages are paired.

Of the internal organs the shape of the intestine is useful taxonomically; there may be convolutions, and in addition, caeca either anteriorly or posteriorly. In species diagnosis, size and situation of the eye is important, as well as presence or absence of an ocellus (eye-spot).

At the generic and subfamily level of identification the structure and setation of thoracic limbs I, II, IV, the head pores and also body proportions are important. For identification of species it is necessary to consider the general form, shape and setation of the postabdomen and valve borders, characters of the claws, sculpture of the valves, and relative sizes of the head

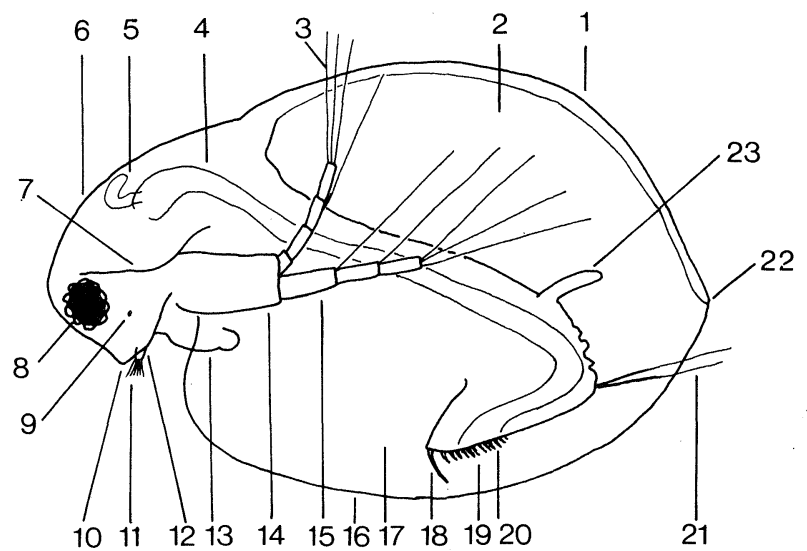

Fig. 1. Schematic representation of a cladoceran with planktonic adaptations (Daphniopsis) (thoracic limbs omitted). $1=$ dorsal side, 2 = brood chamber, $3=$ antennal setae, $4=$ gut, $5=$ hepatic caecum, $6=$ head, $7=$ fornix, $8=$ eye, $9=$ ocellus, $10=$ rostrum, 11 = sensory papillae, 12 = antennule (1st antenna), 13 = labrum, $14=$ antenna (2nd antenna), $15=$ antenna branch, $16=$ ventral side, $17=$ valve, $18=$ claw, $19=$ postabdomen, $20=$ anal teeth, 21 = setae natatoriae, 22 = dorso-posterior corner of the shell, 23 = abdominal outgrowth. 
appendages. Sometimes (as in species of Moina) it is necessary to have parthenogenetic females, gamogenetic females, and males. Features of taxonomic importance are illustrated in Figs 1-3.

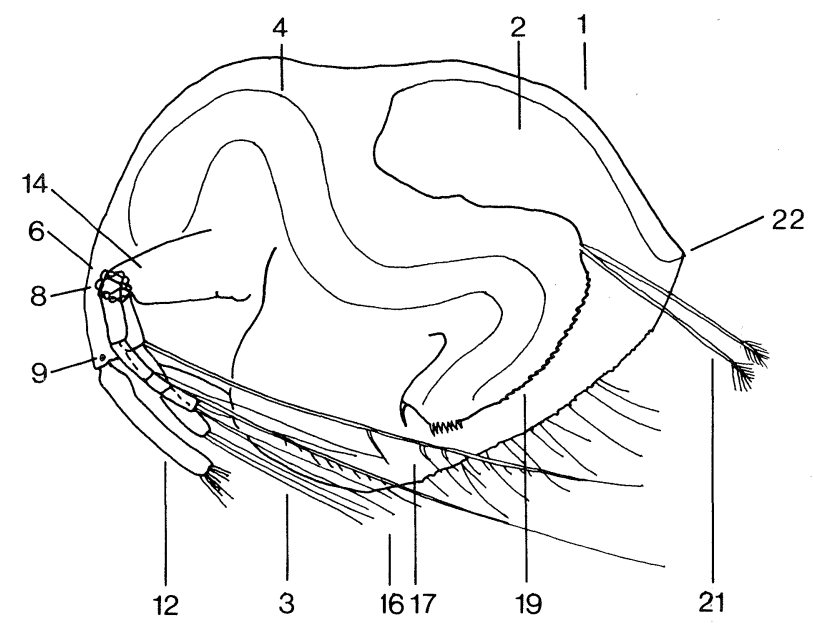

Fig. 2. Schematic representation of a cladoceran with bottom-living adaptations (Echinisca) (thoracic limbs omitted). Code as in Fig. 1.

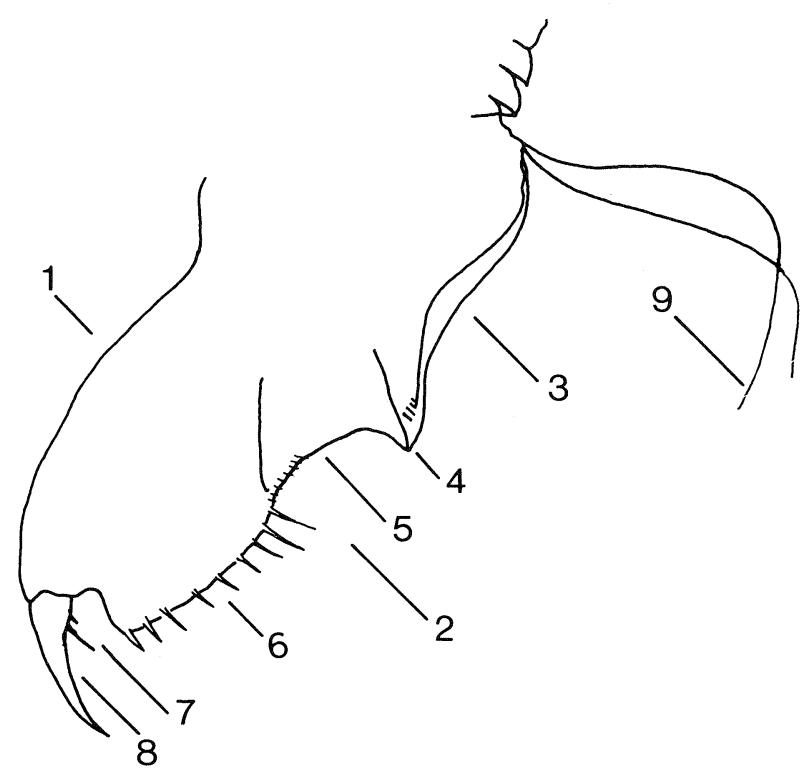

Fig. 3. Postabdomen of a chydorid $(R a k)$. Code: $1=$ ventral side, $2=$ dorsal side, $3=$ pre-anal margin, $4=$ pre-anal angle, $5=$ anal margin, $6=$ post-anal margin with anal teeth, $7=$ basal spines, 8 = claw, $9=$ setae natatoriae.

\section{Key to All Families of Cladocera}

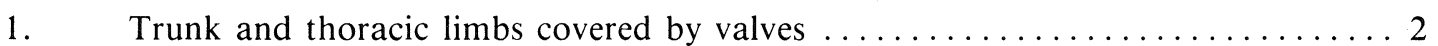

Trunk and thoracic limbs not covered by valves $\ldots \ldots \ldots \ldots \ldots \ldots \ldots$

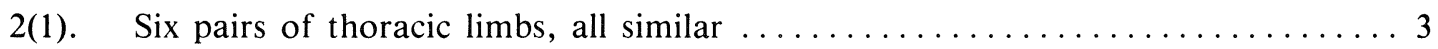

Five or six pairs of thoracic limbs, dissimilar ................... 4

3(2). Body length much greater than height; head usually clearly delimited; antenna branched ........................... SIDIDAE Baird, 1850

Body length no greater than height; head not clearly delimited; antenna not branched in female (Holarctic and North Neotropical)

$\ldots \ldots \ldots \ldots \ldots \ldots \ldots \ldots \ldots \ldots \ldots \ldots \ldots$ HOLOPEDIDAE Sars, 1865

4(2). Antenule fused with rostrum $\ldots \ldots \ldots \ldots \ldots \ldots \ldots$ BOSMINIDAE Sars, 1865

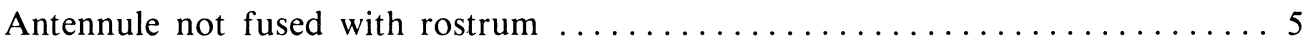

5(4). Both branches of antenna 3-segmented ......... CHYDORIDAE Stebbing, 1902

One branch of antenna 3 -segmented, the other 4-segmented $\ldots \ldots \ldots \ldots \ldots 6$

6(5). Antennule immovable and short (in females) ....... DAPHNIIDAE Straus, 1820

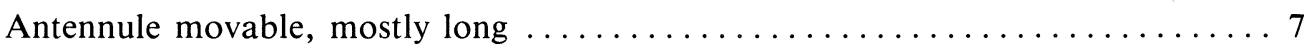

7(6). Antennule situated on anterior side of head ... MACROTHRICIDAE Baird, 1843

Antennule situated on posterior side of head ....... MOINIDAE Goulden, 1968

8(1). Head elongated (Holarctic) ............. LEPTODORIDAE Lilljeborg, 1861

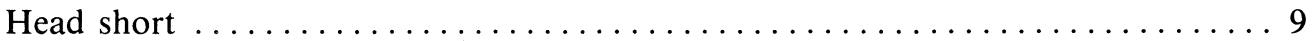

9(8). Caudal appendix very short $\ldots \ldots \ldots$ PODONIDAE Mordukhai-Boltovskoi, 1968

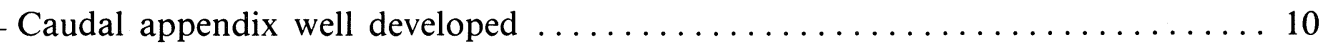


10(9). Caudal appendix somewhat shorter than body (Holarctic) POLYPHEMIDAE Baird, 1845

Caudal appendix much longer than body

(Palearctic) ............. CERCOPAGIDAE Mordukhai-Boltovskoi, 1968

Family SIDIDAE Baird, 1860

Sididae Baird, 1850: 89.

\section{Key to All Known Genera of the Sididae}

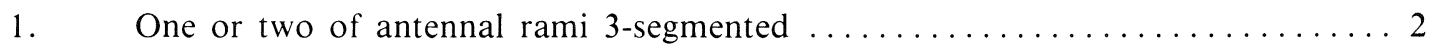
Both rami of antenna 2-segmented (marine) ............. Penilia Dana, 1849

2(1). Both antennal rami 3-segmented (in Sida the proximal segment of

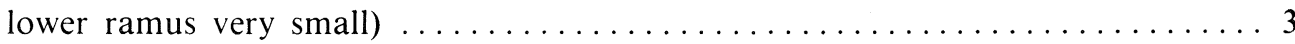

One ramus of antenna 3 -segmented, the other 2 -segmented $\ldots \ldots \ldots \ldots \ldots 4$

3(2). Head round-rectangular, with a small distinct rostrum (Holarctic and north Neotropical) .................... Sida Straus, 1820

- Head triangular, no rostrum (Palearctic) . . . ........... Limnosida Sars, 1862

4(2). Ventral side of head with a foliar outgrowth (Holarctic, India) ........................... Lathona Straus, 1820

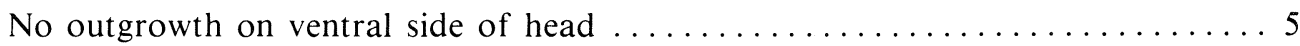

5(4). Body and head elongated, narrow; long setulated setae present only along ventral edge of valves ............... Diaphanosoma Fischer, 1850

Body and head massive; long setulated setae along whole edge of valve .....6 6

6(5). Anal teeth of postabdomen conical and arranged singly . . . Latonopsis Sars, 1888

Anal teeth of postabdomen lanceolate and arranged in groups Pseudosida Herrick, 1884

\section{Genus Latonopsis Sars, 1888}

(section written by N.M. Korovchinsky)

Latonopsis Sars, 1888: 6.-Richard, 1895: 376-378.

Massive head and body connected without noticeable folds (but folds sometimes formed after preservation as an artefact). Rostrum very small (if any), as a short outgrowth between bases of antennules. Antennule short, cylindrical, bearing on its distal end sensory papillae and a sensory seta possessing setules. Ocellus small and situated near bases of antennules. Eye situated closer to dorsal side of head. Antenna with a twosegmented and a three-segmented branch. Two ventralmost setae of three-segmented ramus noticeably larger than the others, their ends hooked. Whole free posterior margin of valve with long setulated setae. Three especially long naked setae on ventro-posterior corner of valve.

Postabdomen with conical and single anal teeth (sometimes grouped into 2's or 3's). Setae natatoriae situated on separate processes. Intestine lacks convolutions and caeca. In both known Australian species shell-gland tripartite, with long posterior loop. The type species is Latonopsis australis Sars, 1888.

\section{Key to Australian species of Latonopsis}

1. Biarticulate branch of antenna with $<12$ setae; claw with two basal spines; female length to $1.6 \mathrm{~mm} \ldots \ldots \ldots \ldots$....... australis Sars, 1888

- Biarticulate branch of antenna with $>20$ setae; claw with three basal spines; female length to $3.5 \mathrm{~mm}$......... L. brehmi Petkovski, 1973

\section{Latonopsis australis Sars, 1888}

Fig. 4

Latonopsis australis Sars, 1888: 6-15, pl. I.-Richard, 1895: 378-80, pl. XVI, figs 11, 13, 20; Petkovski, 1973b, 162.

Material. Qld: $12,15,17,22,24,25,40,48$. N.S.W.: $80,85,98,100,133,134$. W.A.: 411.

Slides. $\mathrm{AM}$ \& $\mathrm{P} 27759, \mathrm{MGU}$ \& 106, ZIN 286. 


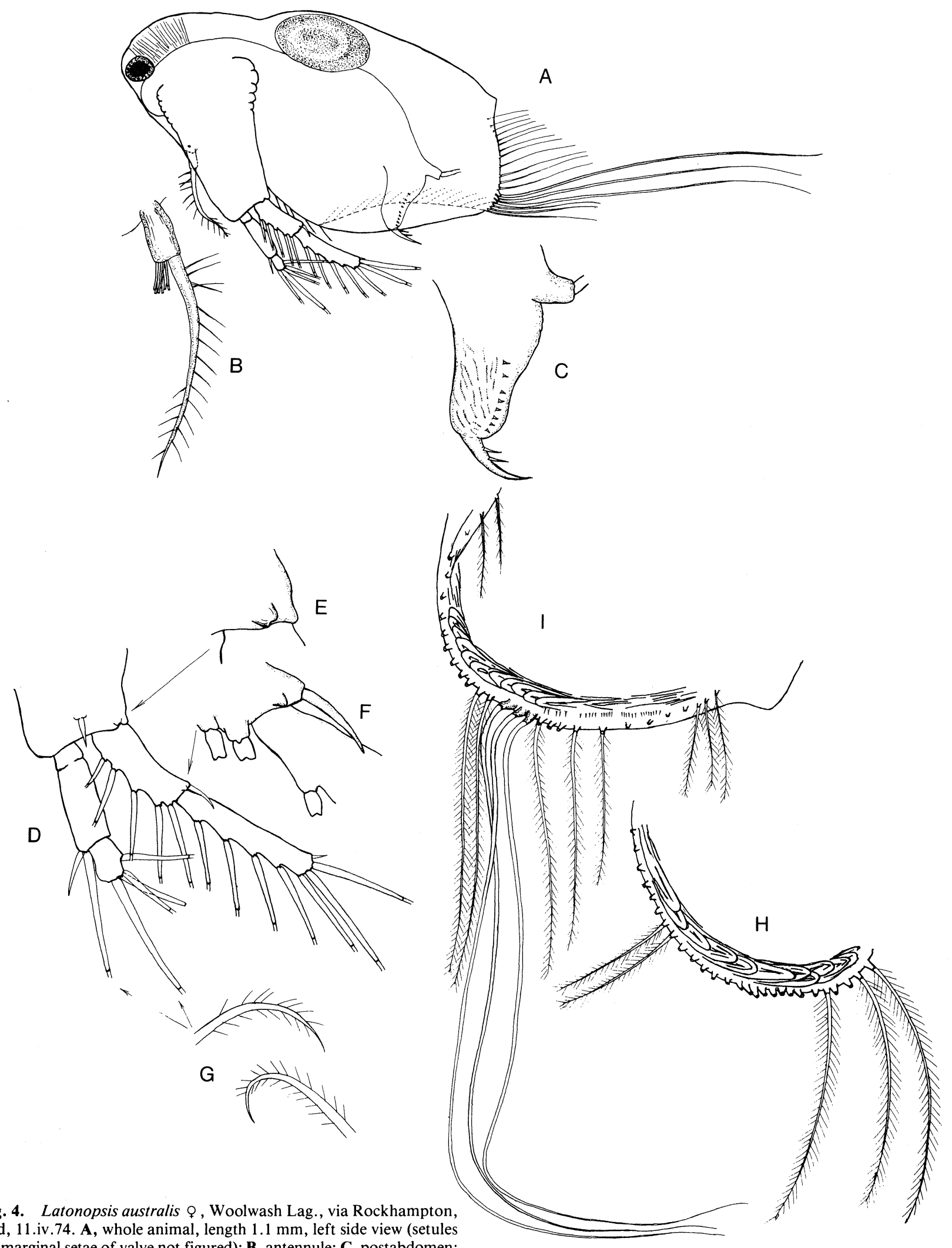
on marginal setae of valve not figured); $\mathbf{B}$, antennule; $\mathbf{C}$, postabdomen; $\mathbf{D}$, antenna; E, distal end of antennal base; $\mathbf{F}$, distal end of proximal segment of bipartite branch of antenna; $\mathbf{G}$, hooked ends of larger ventral setae of tripartite branch of antenna; $\mathbf{H}$, anterior margin of valve from outside; I, posterior margin of valve from inside (not all setae figured). 
Comments. From a comparison of specimens of Latonopsis australis from Australia (including some from near the type locality) with those of related species, it is clear that Sars' description is too general. The following characteristics now seem to be taxonomically important: density of setulation of the sensory setae of the antennule, the form of the postabdomen, the ratio of the width of the proximal part of the postabdomen to its length, body size, and probably egg number.

Female. Antennule with sparsely-spaced setae three to four times longer than it. Antenna on a thick base; its length about $60 \%$ of body length. Distal end of antennal basipodite with a spine on outer side from bases of rami; two rounded outgrowths on its dorsal corner. Proximal segment of biarticulated branch noticeably shorter and wider than distal one. Distally, the proximal segment bears a large, slightly incurved spine and a small rounded outgrowth. Antennal setae 5(4)-7/0-1-4. (Proximal segment with 4 setae in about $40 \%$ of individuals studied.) Two ventral-most setae of triarticulate branch especially large and with their ends hooked (cf. similar structure in Pseudosida [Rühe, 1921]).

Setulated setae of valve edges mounted on conical bases. These setae longer on anterior and posterior edges of valves. Ventral margin of valve incurved, so its setae directed inwards and somewhat posteriorly. The ventroposterior corner of valve has 3 especially long, naked, diverging setae, mounted on larger and deflexed bases. Length of these setae $70-80 \%$ of body length. Coiled, newly-forming, pre-moulting marginal setae discernible inside valve margin. A few groups of spinules on inside surface of posterior margin of valve.

Postabdomen relatively small, averaging $33 \%$ of body length, slightly dilated in proximal part. Its maximum width $54-67 \%$, averaging $60.7 \%$ of length. Anal teeth small, 7-9 in number, more often 8-9, and situated closer to distal end of postabdomen. Some anal teeth doubled. Numerous small setules on lateral surface of postabdomen, arranged in oblique rows on its distal part. Claw much incurved. Two basal spines.

Length. Up to $1.6 \mathrm{~mm}$ (according to Sars, 1888, but no specimens in our material $>1.1 \mathrm{~mm}$ ). The length of a female with embryos $0.83 \mathrm{~mm}$ (slide 106).

Male. Unknown.

Ecology. Benthic, occasionally planktonic; hides itself in loose bottom deposits. In both the University Pond, Brisbane (Timms, 1967) and Borumba Res. (Timms and Midgley, 1969) it was present only during warmer months.

Type locality. A water-body $32 \mathrm{~km}$ from Rockhampton, Qld.

Distribution. Qld, N.S.W., W.A., i.e. probably Australia-wide except the colder southern parts. Present literature indications are that it occurs mainly in tropical regions of the world, but this needs revision.

Differential diagnosis. Latonopsis australis is separable from other Australian species by its comparatively small size, by having fewer setae on the antennae, and by the claw having two basal spines.

\section{Latonopsis brehmi Petkovski, 1973}

Fig. 5

Latonopsis (Birgella) brehmi Petkovski, 1973b: 163-170, figs $1-16$.

Material. Literature (Petkovski, 1973b).

Female. Ventral margin of valve incurved, bearing ciliated setae along its entire length. Posterior margin of the valve with spinules grouped in 3-5's. Antennule twice as long as wide; its flagellum about three times longer than the antennule itself, and densely covered with setules along its whole length. Antenna does not reach posterior third of body. The proximal segment of its biarticulate branch about 1.5 times longer than its width. Antennal setae 8(10)-12(13)/0-1-4, spines 1-1/0-1-0. Postabdomen wide, noticeably narrower distally. Its lateral sides with 13-16 anal teeth. Some of these double or triple. Claw slightly bent distally and with 3 basal spines, thick and straight, the distal one being twice as large as the rest. Short spinules located distally from basal teeth and thin setules on inner side of claw. Thoracic limbs I-V with an epipodite but VI with none. Limbs I-IV with a narrow exopodite, $V$ and

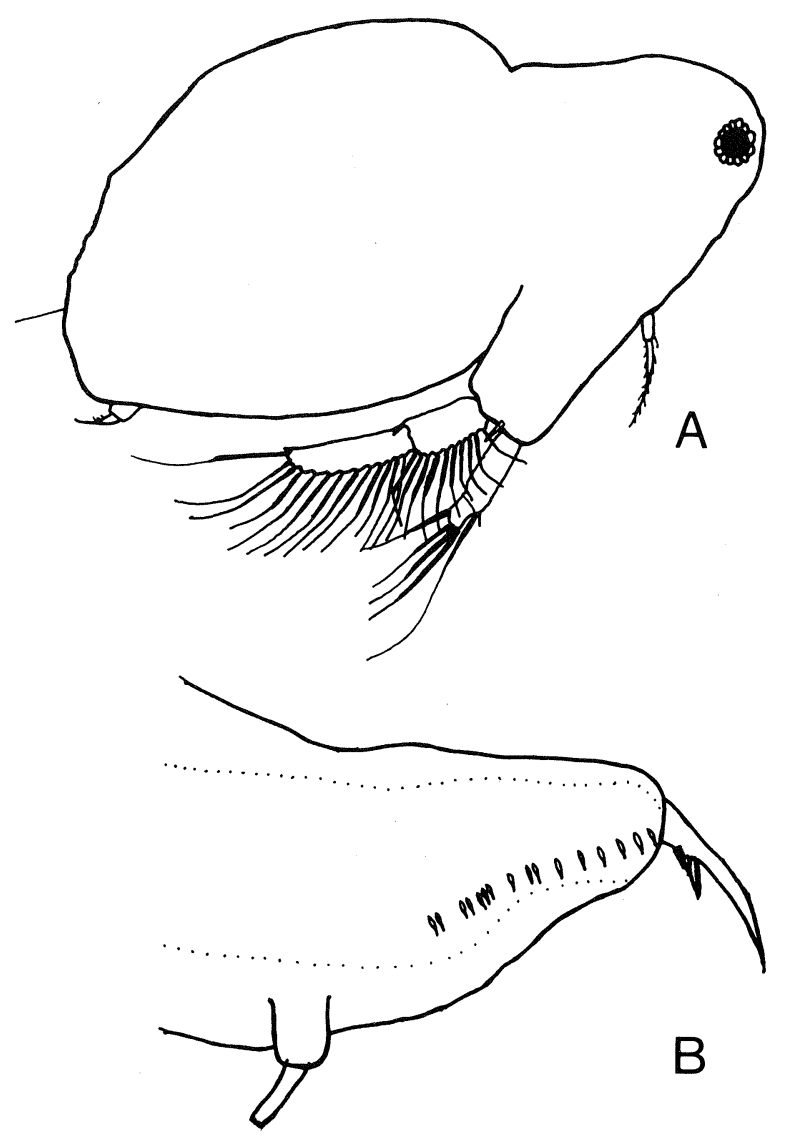

Fig. 5. Latonopsis brehmi $\bigcirc$ after Petkovski, 1973b. A, whole animal, B, postabdomen. 
VI with a short wide exopodite. Ten exopodite setae on limb I; filter plate of its endite large (with about 86 setae) and gnathobase small (13 setae). Eleven exopodite setae on limbs II-IV. Limb V with 9 exopodite setae and a large filter plate on its endite of similar size to the gnathobase; the two together compose one filter plate. Limb VI with 6 exopodite setae; its endite with setae similar to that of its exopodite, but with one much smaller; its gnathobase with two long and two short setae.

Length. Up to $3.5 \mathrm{~mm}$.

Male. Unknown.

Type locality. L. Cronin (East of Hyden, W.A.) and Clybucca Swamps (via Kempsey, N.S.W.) (two places are listed by Petkovski).

Distribution. N.S.W., W.A.

Differential diagnosis. Latonopsis brehmi differs by its larger body size, by more numerous setae on the antennae, and by three basal spines on the claw.

\section{Genus Pseudosida Herrick, 1884} (section written by N.M. Korovchinsky)

Figs 6,7
Pseudosida Herrick, 1884: 20.-Birge, 1910: 1027-1029. Parasida Daday, 1904: 111-112; 1905: 218.

Head of moderate size, rounded, with eye situated frontally, an ocellus and a small rostrum. Females of most species with long antennules with sensory papillae situated laterally and a sensory seta on the apex. Antenna with a thick big basipodite, a three-segmented branch and a two-segmented branch. Segments of branches with various numbers of setae in different species, generally (5-8)-(8-12)/0-1-4, the number of setae increasing with size. Two ventralmost setae of threesegmented branch may have hooked ends.

Ventral margin of valve infolded and bearing long setulated setae; similar or longer setae situated on anterior margin of valve. In some species the ventroposterior margin bears several long naked setae. Anal teeth of postabdomen grouped in 2-5's. Setae natatoriae situated on separate bases.

Male with long antennule; thoracic limb I with complex grasping structures, and copulating organs.

The type species is Pseudosida bidentata Herrick, 1884.

Until this review Pseudosida was unknown in Australia, though various species are sometimes found

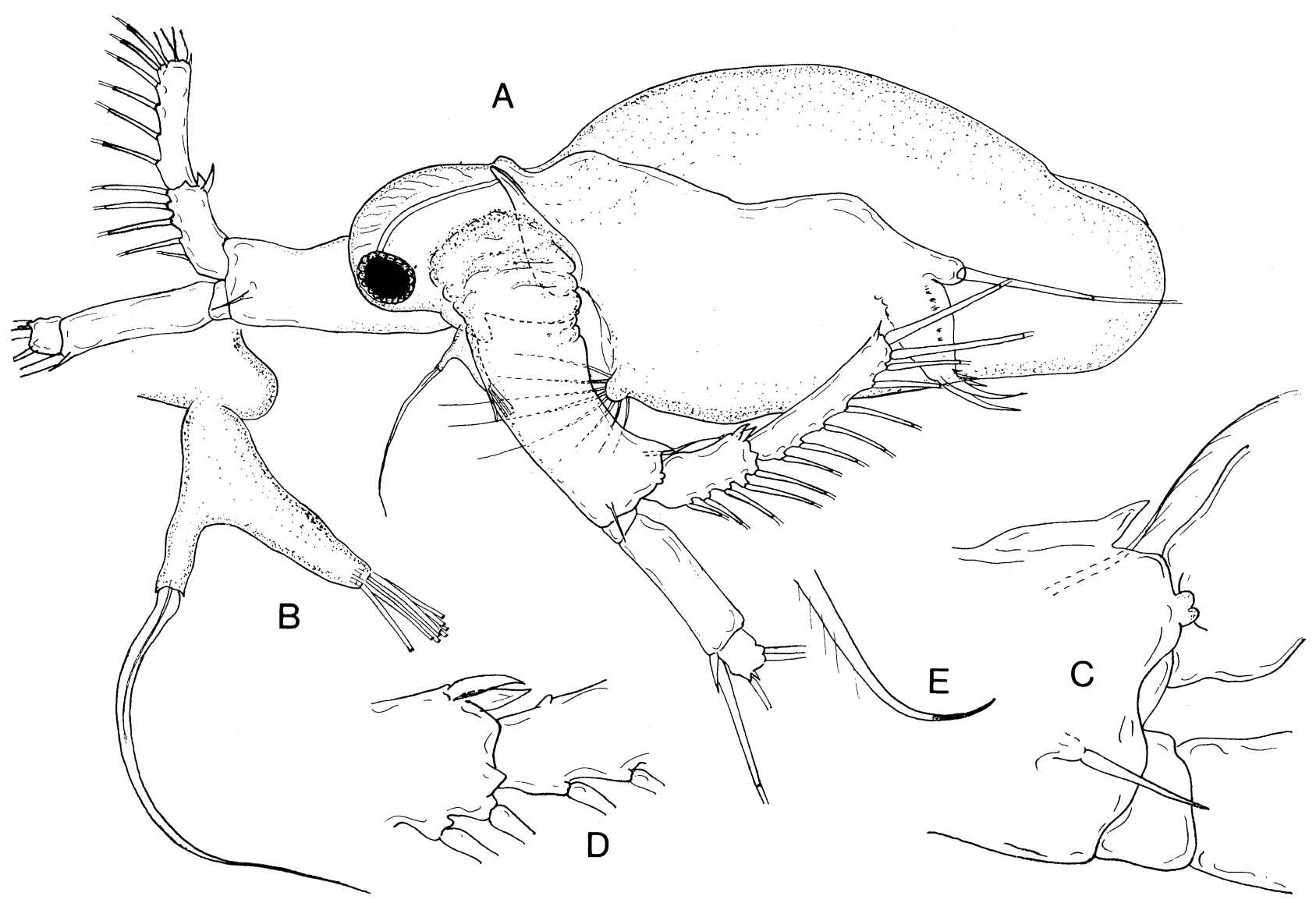

Fig. 6. Pseudosida australiensis $९$, a dune swamp near Red Rock National Park, via Woolgoolga, N.S.W. 16.iii.77. $\mathbf{A}$, left side view (antennal setae not shown in full length), length $1 \mathrm{~mm} ; \mathbf{B}$, antennule; $\mathbf{C}$, distal end of basipodite of antenna, from outside; D, distal end of first segment of two-segmented ramus of the antenna; $\mathbf{E}$, hooked end of the large seta of the second segment of the three-segmented ramus of the antenna. 
in New Guinea, Indonesia and continental South-East Asia. In this respect Brehm's (1953) indication of $P$. bidentata in Borneo and the Philippines needs confirmation. In samples from eastern New South Wales a few individuals were found of a new species. Due to the possibility of two species from nearby lands occurring in Australia, a key is given for all three.

\section{Key to Species of Pseudosida Occurring in Australia and Nearby Lands}

1. Antennule long, with papillae laterally; postabdomen with a lateral outgrowth at its distal end near base of postabdominal claws (India, Sri Lanka, Thailand, Sumatra, Africa and possibly elsewhere-data in need of revision) ................. P. szalayi Daday, 1898

Antennule short; postabdomen with no outgrowths $\ldots \ldots \ldots \ldots \ldots \ldots \ldots 2$

2(1). Antennule rod-like with sensory papillae and a sensory seta distally; basal spines of postabdominal claw long, of similar size ...... P. papuana Daday, 1901

Antennule bifurcated, with sensory papillae in an apical position and a sensory seta on apex of its other branch; proximal spine of postabdominal claw much smaller than other two spines ......... P. australiensis n.sp.

\section{Pseudosida australiensis n.sp.}

Figs 6, 7

Material. N.S.W.: 83, 91, 97

Holotype. AM $\odot$ P31301

Female. Head moderately sized, roundish. Eye large, situated closer to anterior-lower side of head. Antennule short and bifurcated; sensory papillae on apex of its larger branch and a sensory seta on apex of its smaller branch. Antenna with a long and thick basipodite. Distal end of basipodite with a thick spine on dorsal side, a small double tubercle at base of twosegmented branch and a long acute spine opposite the three-segmented branch. Inner distal end of basipodite with a long seta. Antennal seta 5-8/0-1-4. Large seta at end of middle segment slightly longer than body; its end hooked and chitinized as described (Rühe, 1927) for Pseudosida bidentata. Two large spines and a cone on distal end of first segment of two-segmented branch.

Shell oblong-oval with ventral edge infolded. Ventral and anterio-ventral edges with long setulated setae; these especially long anteriorly. Only small spinules on inner side of posterio-ventral edge.

Postabdomen thick and with 10 groups of anal teeth laterally. Each group with 2-4 teeth, commonly 3 . Claw with 3 basal spines, the proximal one much smaller than other two. Five bent spinules on middle convex side of claw. Terminal end of postabdomen with a few thin spines situated between claw bases.

Length. Up to $1 \mathrm{~mm}$.

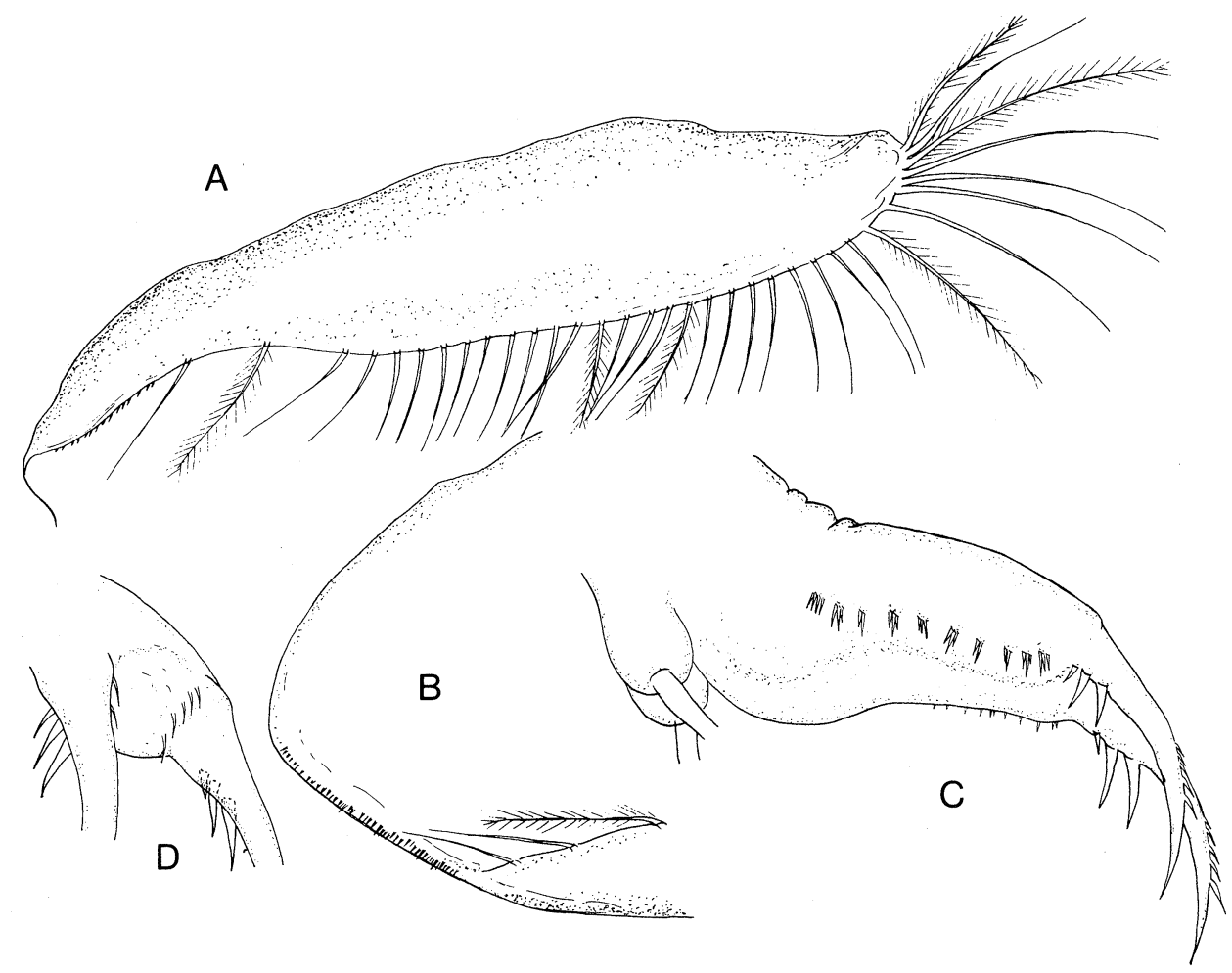

Fig.7. Pseudosida australiensis $९$, a dune swamp near Red Rock National Park via Woolgoolga, N.S.W. 16.iii.77. A, valve, from below (setules not shown on all setae); B, posterior part of valve, from inner side (setules are not shown on all setae); $\mathbf{C}$, postabdomen; $\mathbf{D}$, distal end of postabdomen. 
Male. Unknown.

Age variability. In larger individuals the relative size of the head decreases, the antennular outgrowth bearing sensory papillae increases, the number of antennal setae increases, and the number of anal teeth groups increases, as well as the number of teeth in each group. However, species identity can be confirmed even in the smallest individuals by the structure of the antennule.

Type locality. A dune swamp just north of the Red Rock National Park, via Woolgoolga, N.S.W.

Distribution. Acid coastal dune lakes in N.S.W.

Differential diagnosis. Pseudosida australiensis is readily distinguishable from other species by its short bifurcated antennule.

Genus Diaphanosoma Fischer, 1850

(section written by V. Korrinek)

Diaphanosoma Fisher, 1850: 3-11.

Daphnella Baird, 1850: 109.
Antenna with upper branch biarticulate and lower branch triarticulate. Number of setae natatoriae 4 - 7 to $8 / 0-1-4$. Head narrow and separated by a distinct dorsal impression from trunk. Postabdomen narrow, tapering posteriorly, and bearing long sickle-shaped terminal claws with three long spines near their bases. Intestine lacks convolutions. Males with long whip-like antennules and a pair of copulatory appendages over postabdomen.

The type species is Diaphanosoma brachyurum (Liévin, 1848).

When this was written in 1978 only two species, Diaphanosoma excisum and D. unguiculatum, were known for Australia, but a recent revision of Australian species by Korovchinsky (1981) listed 5 species. Two of his species, $D$. volzi and $D$. australiensis, are apparently uncommon and a third, D. sarsi, occurs mainly in northern Australia (BVT, unpublished data), while $D$. excisum and $D$. unguiculatum are widely distributed. Only the latter two species are considered here, but a key is given for all of Korovchinsky's species plus two others which occur in nearby areas and could conceivably be found in Australia.

\section{Key to Australasian Species of Diaphanosoma}

1. Valve inflexed ventrally, forming a free flap $\ldots \ldots \ldots \ldots \ldots \ldots \ldots \ldots \ldots$

Ventral margin of valve gradually inflexed without a broad free flap .......6

2(1). Denticles or spines along lower part of posterior margin of valve $\ldots \ldots \ldots$

No denticles or spines along lower part of posterior margin of valve; margin finely ciliated ...................... v. volzi Stingelin, 1905

(Thailand, China, north coast of N.S.W.)

3(2). Lateral rows of stout denticles on postabdomen $\ldots \ldots \ldots \ldots \ldots \ldots \ldots \ldots \ldots \ldots$ $\ldots \ldots \ldots \ldots \ldots \ldots \ldots \ldots \ldots \ldots \ldots \ldots \ldots \ldots$. senegal Gauthier, 1951 (India, Africa)

No lateral denticles on postabdomen $\ldots \ldots \ldots \ldots \ldots \ldots \ldots \ldots \ldots \ldots \ldots$

4(3). Free flap of valve tapering somewhat and joining its ventral margin almost at right angles; $<17$ (usually 12) denticles on lower part of posterior margin of valve ....... D. excisum Sars, 1885 (Asia, Africa, Australia)

Free flap of valve extending beyond its junction with the ventral margin;

$>18$ denticles on lower part of posterior margin of valve $\ldots \ldots \ldots \ldots \ldots$

5(4). 18-22 denticles on lower part of posterior margin of valve; distal part of flap on valve quite prominent ................. D. sarsi Richard, 1894

(Borneo, India, Taiwan, Nepal, Sumatra, Philippines, Aru Is, New Hebrides, northern Australia)

26-38 denticles on lower part of posterior margin of valve; distal part of free flap on valve not quite prominent $\ldots \ldots \ldots \ldots \ldots \ldots \ldots$. D. australiensis Korovchinsky 1981 (Cape York, Qld)

6(1). Postabdomen with lateral row of stout denticles .................... unguiculatum Gurney, 1927 (Australia) 
Diaphanosoma excisum Sars, 1885

Figs 8, 9

Diaphanosoma excisum Sars, 1885: 13-18, pl. 2.

Diaphanosoma paucispinosum Brehm, 1933: 656-657, pl. 80, figs 17-19.

Material. Qld: 15, 28. N.S.W.: 186.

Slides. $\quad$ AM $~$ P27757, MGU $~ 2881$, ZIN $\odot$ 2885, ZMO o $168 / 9724$.

Female. Head short with eye situated frontally near its top. Dorsal part of head vaulted serving as a support for antennal muscles. First segment of biarticulate branch of antenna with a well-developed spine on top. Ventral part of valve inflexed, forming a free flap gradually tapering distally and bordered with long feathered setae. Lower part of posterior margin of valve with a variable number (3-16) of thorn-like denticles (forms with only a few denticles were described by Brehm as D. paucispinosum). Denticles followed by a row of setules of diminishing size. Postabdomen with groups of setules on both sides, three basal spines and finely ciliated terminal claws.

Length. Up to $1.3 \mathrm{~mm}$.

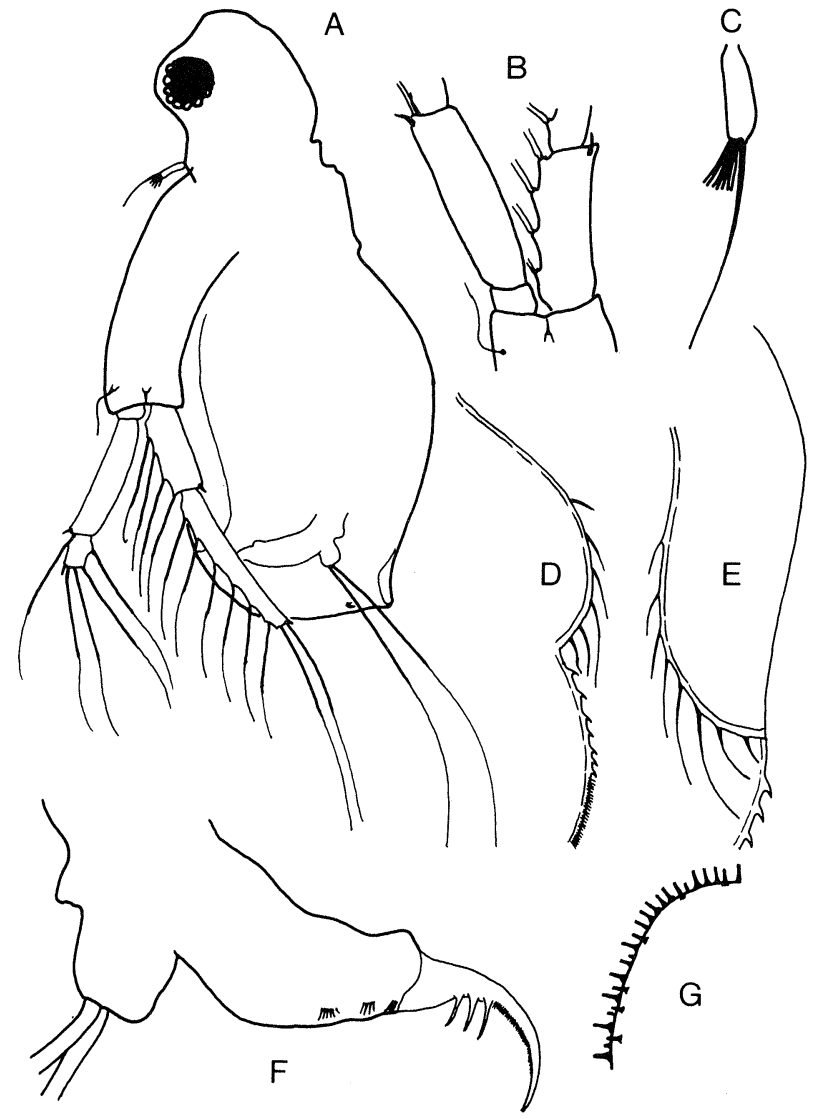

Fig. 8. Diaphanosoma excisum $\odot$. A, whole animal, Handapangala Tank, Ceylon, 10.vii.69; $\mathbf{B}$, antenna, idem, 28.xii.70, C, antennule, idem, 28.xii.70, D, free flap on the ventral margin of the valve, Bun Boraped Reservoir, Thailand, 12.i.72, E, same folded, Handapangala Tank, Ceylon, 10.vii.79, F, postabdomen, Gracemere Lagoon, Australia 7.i.60, G, sexual egg, 80x, New Pottery Pond, Malaysia, 3.xii.73.

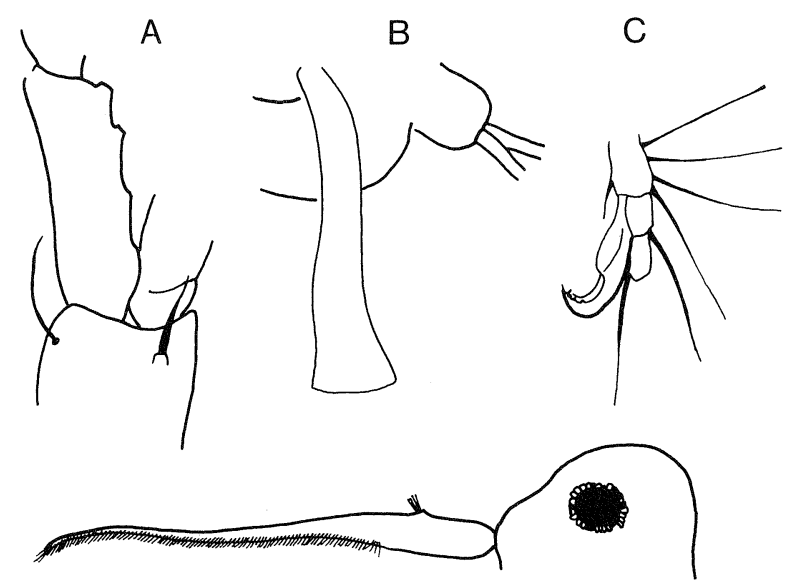

D

Fig. 9. Diaphanosoma excisum on. A, antenna, Volta Lake, Ghana, 27.xi.64; B, copulatory appendage, idem, C, first thoracic limb, idem, D, antennule, idem.

Male. Resembles female, but with long, whip-like antennules. A strong spine situated near end of basal segment of antenna. First leg with a slender hook on its distal end. Copulatory appendages resemble long, funnel-shaped tubes.

Length. Up to $1.1 \mathrm{~mm}$.

Ecology. Mostly limnetic; usually present only during summer and early autumn (Timms, 1967, 1970a, 1970b).

Type locality. Gracemere Lagoon $(11 \mathrm{~km} \mathrm{~W}$ of Rockhampton, Qld).

Distribution. Qld, N.S.W., (also Africa, S. Asia).

Differential diagnosis. Valve ventrally inflexed, its free flap tapering distally. There is a row of thorn-like denticles along the lower part of the posterior margin of the valve. The male has funnel-shaped copulatory appendages.

\section{Diaphanosoma unguiculatum Gurney, 1927}

Figs 10, 11

Diaphanosoma unguiculatum Gurney, 1927: 64-65, figs A-D. Diaphanosoma senegal.-Brehm, 1959: 2-3 (misidentification)

Material. Qld: 2, 12, Longreach (SYNTYPES): pool in dried river bed near Quilpie. N.S. W.: 83, 91, 96, 97, 184. Vic.: 228, Bostock Res., Prospector's diggings in Reith Reserve, Beralla. Tas.: Brady's L. S.A.: 351, 358.

Slides. AM $\odot$ P27758, MGU $\odot 709$, ZIN $\odot 838, \mathrm{BM}$ 14-3-1929 (SYNTYPES), ९ O* 9-11-1967.

Female. Head broad and not too distinctly marked off from shell. Antennules stout and with a long flagellum. All spines on antenna elongated and sometimes setae-like. Ventral margin of valve not inflexed; long hairs along its proximal part, followed distally by fine ciliation. More than two setae in the group near junction of both valves of shell. Postabdomen with stout lateral denticles (up to 10) on 


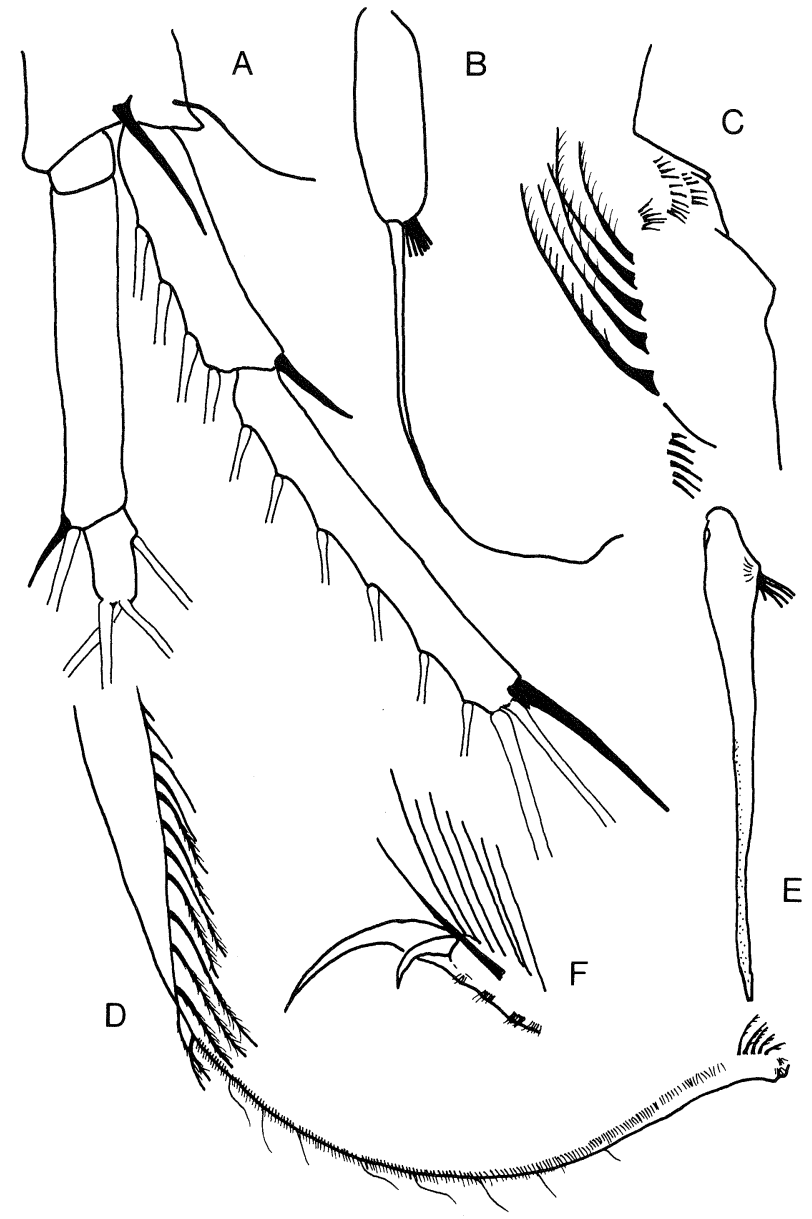

Fig. 10. Diaphanosoma unguiculatum. A, $\subsetneq$ antenna, Reith Reserve, Vic., 23.xi.64; B, $\subsetneq$ antennule, idem; $\mathbf{C}$, $\subsetneq$ posterior setae on the valve, idem; D, $\bigcirc$ ventral margin of the valve, idem; E, $\bigcirc$ antennule, idem; $\mathbf{F}, \sigma^{*}$ first thoracic limb and terminal hooks, idem.

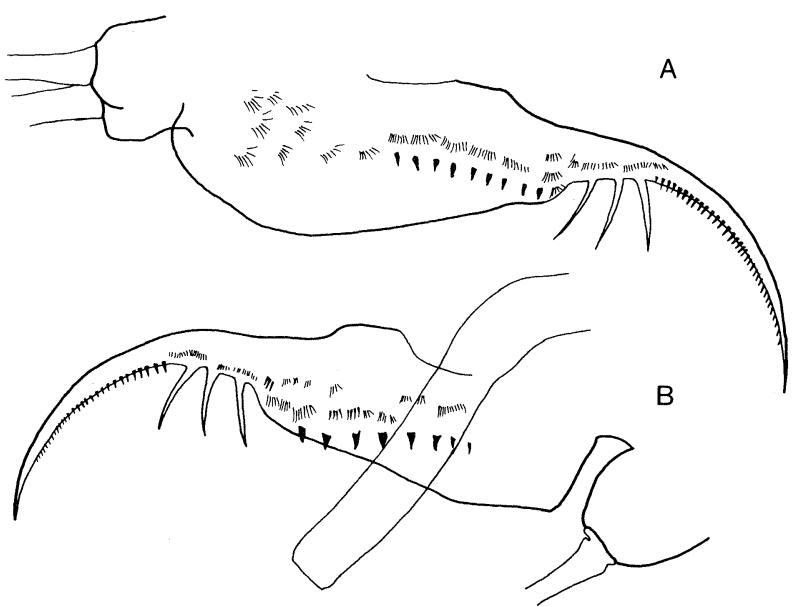

Fig. 11. Diaphanosoma unguiculatum. A, $९$ postabdomen, Reith Reserve, Vic., 23.xi.64; $\mathbf{B}$, $^{\circ}$ postabdomen with copulatory appendage, idem.

both sides. Terminal claws with three basal spines and a row of needle-like denticles along their dorsal margin.

Length. Up to $1.5 \mathrm{~mm}$.
Male. Head narrower than in female. Setae and spines on antenna same as those of female. One stout and one small hook on end of first thoracic leg. Tubelike copulatory appendages present.

Length. Up to $1.2 \mathrm{~mm}$.

Ecology. Mostly littoral; a number of records are from markedly acid waters, indicating a tolerance of a wide $\mathrm{pH}$ range.

Type locality. Reared from mud taken near Longreach, Qld.

Distribution. Qld, N.S.W., Vic., Tas., S.A., so probably Australia-wide. Endemic.

Differential diagnosis. The ventral margin of the valve is not inflexed. All spines on the antenna are elongated. There are stout lateral denticles on the postabdomen and the terminal claws have needle-like denticles along their dorsal margin.

Genus Penilia Dana, 1852

(Section written by N.M. Korovchinsky)

Penilia Dana, 1852a: 47; 1852b: 1268-1269.-Richard, 1895: 343-344.

Antennule small and stick-shaped with 6 olfactory setae. Two biarticulated branches on swimming antenna. Brood pouch closed.

This genus was considered to consist of several species (Richard, 1895; Kramer, 1895), but Calman (1917) and Steuer (1933) concluded that there is only one widely distributed species $P$. avirostris Dana. This position is adopted here, but further study is needed.

Type species is Penilia avirostris Dana, 1852.

\section{Penilia avirostris Dana, 1852}

Fig. 12

Penilia avirostris Dana, 1852a: 47; 1852b: 1269-1270, pl. 89, figs $2 \mathrm{a}, 2 \mathrm{~b}-$ Richard, 1895: 351-352, pl. 15, fig. 9; Calman, 1917: 157-158; Steuer, 1933: 80-83; Dakin \& Colefax, 1940: 73, fig. 93.; Dolgopolskaya, 1958: 38-46, figs 6-12.

Penilia orientalis Dana, 1852a: 47; 1852b: 1270-1271, pl. 89, figs 3a-e.-Richard, 1895: 350, pl. 15, fig. 12.

Penilia schmackeri Richard, 1895: 344-350, pl. 15, figs 5, 7 , 11, 15, pl. 16, fig. 8.; Zernov, 1908: 232.; Behning, 1927: 345-348, Abb. 1-12.

Penilia pacifica Kramer, 1895: 222-223, pl. 23, figs 1-5.

Female. Head relatively small and broad, with two ventral rostral projections. Antennal setae 2-6/1-4. Posterior dorsal part of the shell with a deep depression. Edges of the valve carry a number of larger denticles with some smaller ones between them. Postabdomen with anal denticles wanting and with numerous groups of the minute setae present on both its lateral sides. Terminal claw of the postabdomen very long with two small basal spines. The claw also possesses rows of the minute denticles along its dorsal and ventral margins.

Length. $0.6-1.2 \mathrm{~mm}$.

Male. Head relatively small and without two ventral 
rostral projections. Antennule very long, about 80 per cent of the body length with very long setules on the distal end. Copulatory appendages resemble long tubes.

Length of male. c. $0.8 \mathrm{~mm}$.

Ecology. Euryhaline marine, restricted to surface coastal waters (see Lochhead, 1954).

Type locality. Rio de Janeiro Harbour.

Distribution. Coastal waters off N.S.W. (Dakin and Colefax, 1940); off Port Hacking estuary, N.S.W. (Sheard, 1949); Lake Macquarie, estuaries, and coastal waters from Evans Head to Eden, N.S.W. (Kott, 1955, 1957); Port Phillip Bay, Vic. (Arnott, 1974); and the Great Australian Bight (Markina, 1975).

Differential diagnosis. Penilia avirostris is the only marine ctenopod and as such is easily recognized by its

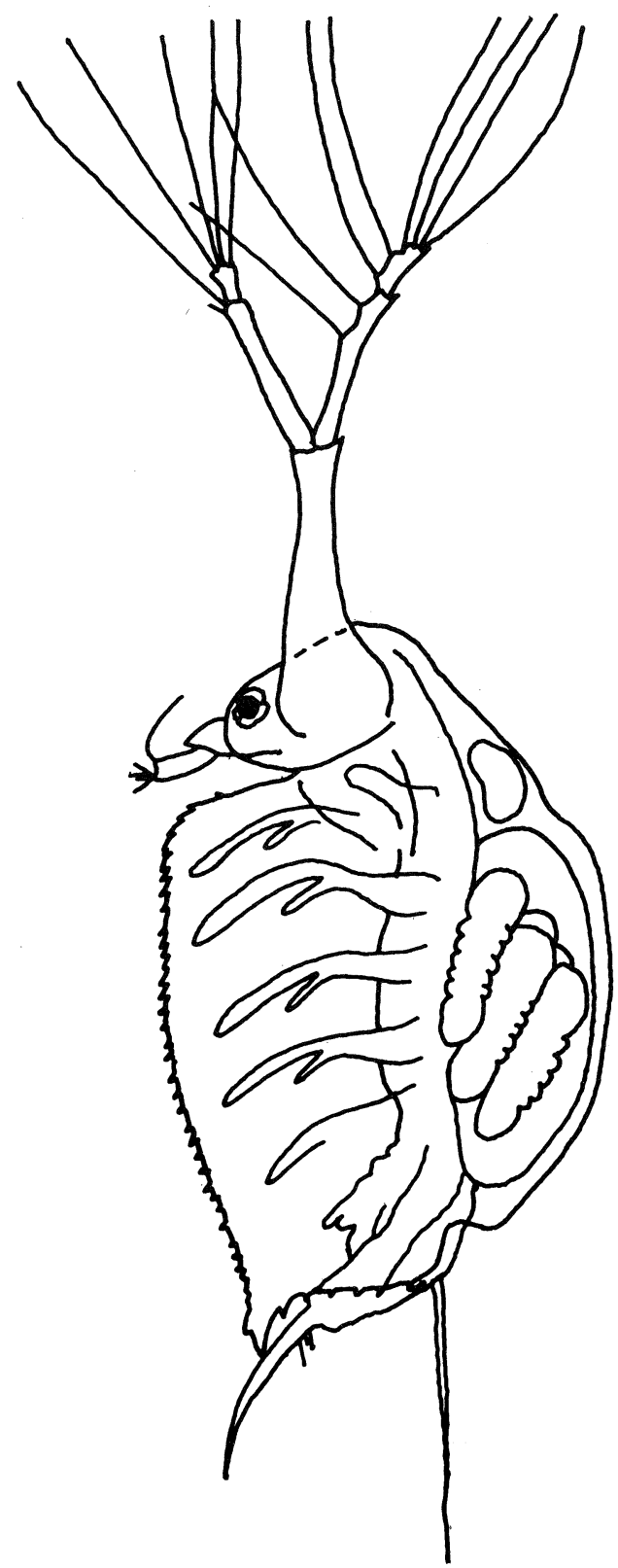

Fig. 12. Penilia avirostris $\odot$ after Zernov, 1908. six similar pairs of filter feeding trunk appendages enclosed by a bivalve carapace. Among the Ctenopoda it is the only form with both branches of the second antenna two-segmented.

\section{Family PODONIDAE}

(Section written by the late P.D. Mordukhai-Boltovskoi)

Podonidae Mordukhai-Boltovskoi, 1968: 200.

Antennules immovable and fixed to lower part of head. Antennae short with 6 or 7 setae on foursegmented branch. Mandibles terminate in an acute cutting denticle and in a peculiarly branched 'masticatory' process. Exopodites of legs poorly armed with only one to four almost unfeathered setae. Abdomen very short but with caudal claws variously strongly developed or in the form of triangular projections. Body covered dorsally with a welldeveloped, hard shell, surrounding the brood pouch and often larger than body. 'Cervical organ' small and situated above bases of antennae.

Males differ from females by presence of hooks on distal end of first leg, two penes, and the larger eye.

All species of Podonidae live in the upper layers of the oceans, preferably in the neritic zone but partly in brackish waters and estuaries. Usually they produce resting eggs in autumn and disappear till spring.

\section{Key to Australian Genera of Podonidae}

1. Exopodites of legs II and III bear three or four setae. Shell rounded on top .. 2

Exopodites of legs II and III bear one or two setae. Shell rounded or pointed on top ................ 3

2(1). Exopodites of leg I bear three or four setae. Shell hemispherical, delimited from head ..... Pleopis Dana, 1852

Exopodites of leg I bear two setae.

Shell elongated, elliptical or tapering to top (but still rounded at top) ............. Pseudevadne Claus, 1877

3(1). Exopodites of legs I and III bear only one strong seta. Head delimited by a depression from hemispherical shell ............ Podon Lilljeborg, 1853

Exopodite of leg II bears two setae, of leg III one or two setae. Head not delimited from elongated shell ........... ................ Evadne Loven, 1836

\section{Genus Pleopis Dana, 1852}

Pleopis Dana, 1852b: 1275; Sars, 1861: 292-293; P.E. Müller, 1867: 214-215 (Podon, partim); Lilljeborg, 1900: 625-627 (Podon, partim); Dolgopolskaya, 1958: 60-71 
(Podon, partim); Mordukhai-Boltovskoi, 1968: 197-209; 1969: 20-21.

Exopodites of legs I, II, and III with three or four setae, those of leg IV with two. Shell hemispherical, rounded and delimited from head. Caudal claws short.

There are two species, $P$. schmackeri, Poppe and $P$. polyphemoides (Leuckart), but only the latter occurs in Australian waters.

\section{Pleopis polyphemoides (Leuckart, 1859)}

Fig. 13

Pleopis brevicauda? Dana, 1852b: 1276.

Evadne polyphemoides Leuckart, 1859: 261.

Pleopis minutus Sars, 1862: 294.

Podon polyphemoides.-Poppe, 1889: 289; Lilljeborg, 1900: 627-636; Dolgopolskaya, 1958: 67-71; Manuilova, 1964: 303-304.

Pleopis polyphemoides Mordukhai-Boltovskoi, 1968, 1969: 21.

Female. Head comparatively large. Exopodites of legs I to III with three setae and those of leg IV two setae, so setal formula of 3.3.3.2. First segment of endopodite of leg I with six setae. Caudal claws short, in shape of triangular processes. Female length $0.35-0.45 \mathrm{~mm}$. Height approximately the same. (It

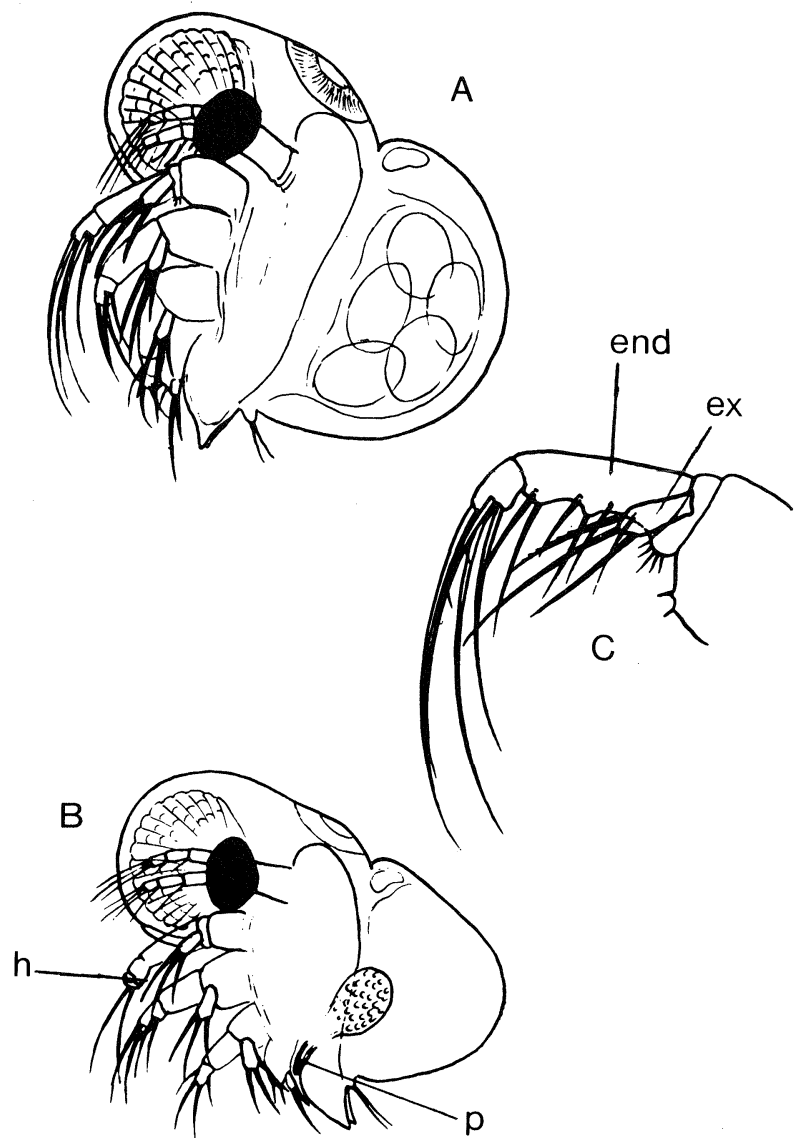

Fig. 13. Pleopis polyphemoides. A, ९; B, $\bigcirc^{*}$ : $\mathbf{C}$, thoracic limb I of ㅇ $($ ex $=$ exopodite, end $=$ endopodite, $p=$ penes, $h$, $=$ hook of leg I). should be kept in mind that all podonids are drawn in their natural positions, i.e. with the head upwards, so that the longitudinal body axis is vertical.)

Male. Shorter (length not greater than $0.4 \mathrm{~mm}$ ), with a larger eye and a smaller shell than female. Shell tapers upwards.

Ecology. Pleopis polyphemoides is eurythermic and euryhaline. It is especially common in shallow and brackish waters (to $5 \%$ oo).

Distribution. All oceans between $70^{\circ} \mathrm{N}$ and $40^{\circ} \mathrm{S}$; not so common in the equatorial zone. For Australia there are records in and off Sydney Harbour (Dakin and Colefax, 1940); Jibbon (Sheard, 1949); Port Stephens, off Jibbon (Port Hacking Point), L. Macquarie (Kott, 1955); N.S.W. coastal waters from Eden to Port Stephens (Kott, 1957); and Gippsland Lakes, Vic. (specimens ex G. Arnott).

\section{Genus Pseudevadne (Claus, 1877)}

Evadne Claus, 1877: 140.

Pseudevadne Mordukhai-Boltovskoi, 1969: 24.

Exopodites of leg I with two setae, of legs II and III three and of leg IV one seta, so setal formula of 2.3.3.1. Shell elongated, elliptical or tapering but rounded at the top, and often, but not always, delimited from body by a depression. Lateral sides of shell (crista of fornix) partly overhang, covering basipodites of legs. Caudal claws in form of triangular processes.

This genus, established by Claus and later united with Evadne and later still with Pleopis, must be reinstated.

\section{Pseudevadne tergestina (Claus, 1877) Figs 14, 15}

Evadne tergestina Claus, 1877: 140.

Podon schoedleri Caporiacio, 1938: 6-9.

Evadne tergestina.-Dolgopolskaya, 1958: 56-60.

Pleopis tergestina.-Mordukhai-Boltovskoi, 1969: 21-22.

Comments. The shape of the shell is variable; sometimes its upper part is considerably narrower, but it is always rounded on top. A distinguishing feature is the presence of some (5-8) rows of coloured hypodermal cells on the shell (sometimes decoloured if preserved in formalin). The female reaches $0.9 \mathrm{~mm}$ in length and $1.2 \mathrm{~mm}$ in height.

The male is smaller: length $0.6 \mathrm{~mm}$, height $0.8 \mathrm{~mm}$.

Distribution. All oceans, mainly between $40-45^{\circ} \mathrm{N}$ and $40^{\circ} \mathrm{S}$. Common in Australian waters-found off Sydney Harbour (Dakin and Colefax, 1940); Jibbon (Sheard, 1949); Jibbon, L. Macquarie and Port Stephens (Kott, 1955); N.S.W. coastal waters from Eden to Coff's Harbour (Kott, 1957); Gippsland Lakes and Port Phillip (specimens ex G. Arnott).

\section{Genus Podon Lilljeborg, 1853}

Podon Lilljeborg, 1853: 161.-Poppe, 1889: 295; Lilljeborg, 1900: 46-60 (partim); Mordukhai-Boltovskoi 1968: 197-208; 1969: 22. 


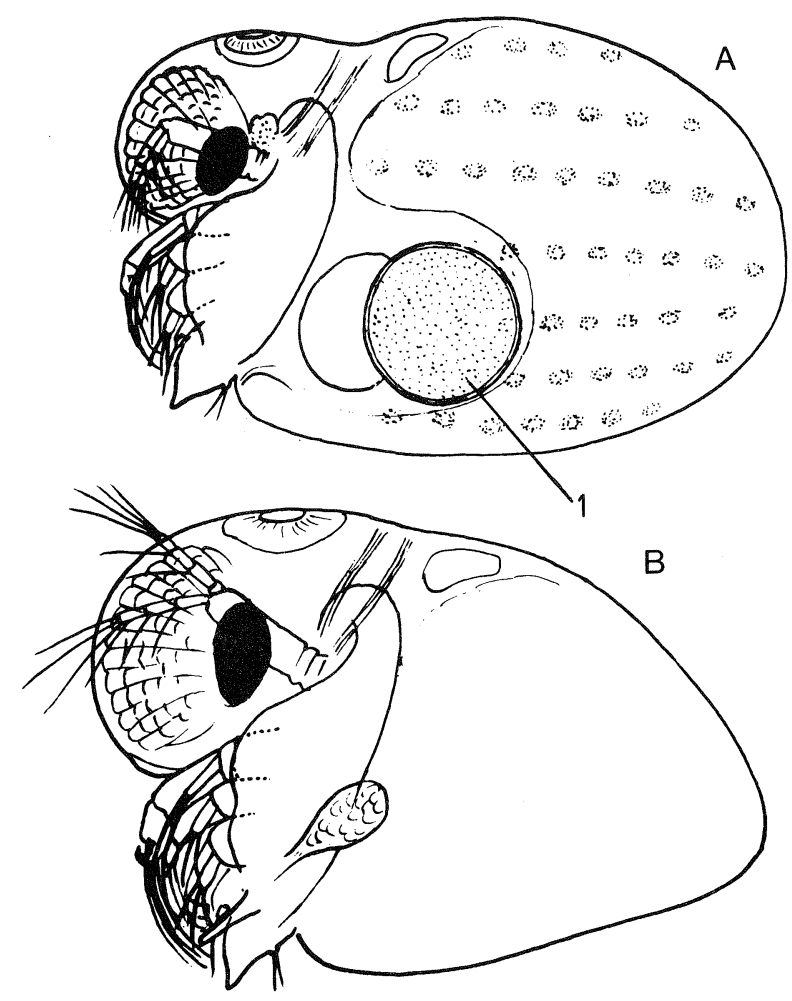

Fig. 14. Pseudevadne tergestina. $\mathbf{A}, \subsetneq ; \mathbf{B}$, $^{*}(l=$ latent egg $)$.

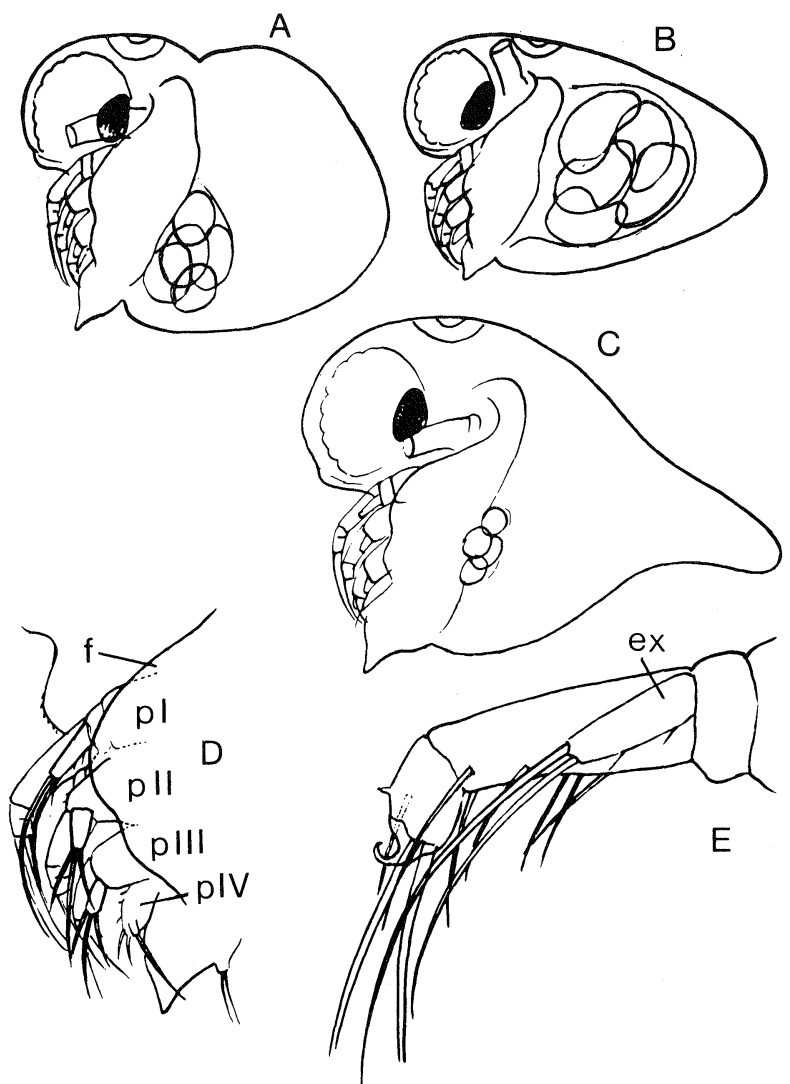

Fig. 15. Pseudevadne tergestina. A, B, C: various forms of the shell in the $\$ ; \mathbf{D}$, thoracic limbs I-IV of the $Q ; \mathbf{E}$, thoracic limb of the o* (ex = exopodite, $f$, = fornix, $p I-I V=$ thoracic limbs I-IV).
Exopodites of leg I with one or two setae, of legs II and III with one short but strong seta, and of leg IV with two setae. Head always clearly delimited by a depression from the hemispherical shell.

There are two species, $P$. leuckarti Sars and $P$. intermedius Lill., but only the latter occurs in Australian waters.

\section{Podon intermedius Lilljeborg, 1853}

Fig. 16

Podon intermedius Lilljeborg, 1853: 161.-P.E. Müller, 1867: 215-220; Lilljeborg, 1900: 627-633; Mordukhai-Boltovskoi, 1969: 22.

Female. Exopodites of leg I with two setae, legs II and III with one seta, and leg IV with two setae, so setal formula 2.1.1.2. Setae on exopodites of leg II and III short, strong and covered with spines. Postanal knobs with comparatively long setae. Shell spherical or somewhat elliptical. Female length up to $1.0 \mathrm{~mm}$ and height to $1.2 \mathrm{~mm}$.

Male. Larger head and a very small shell, triangular but rounded at top. Length up to $0.9 \mathrm{~mm}$ and height to $1.0 \mathrm{~mm}$.

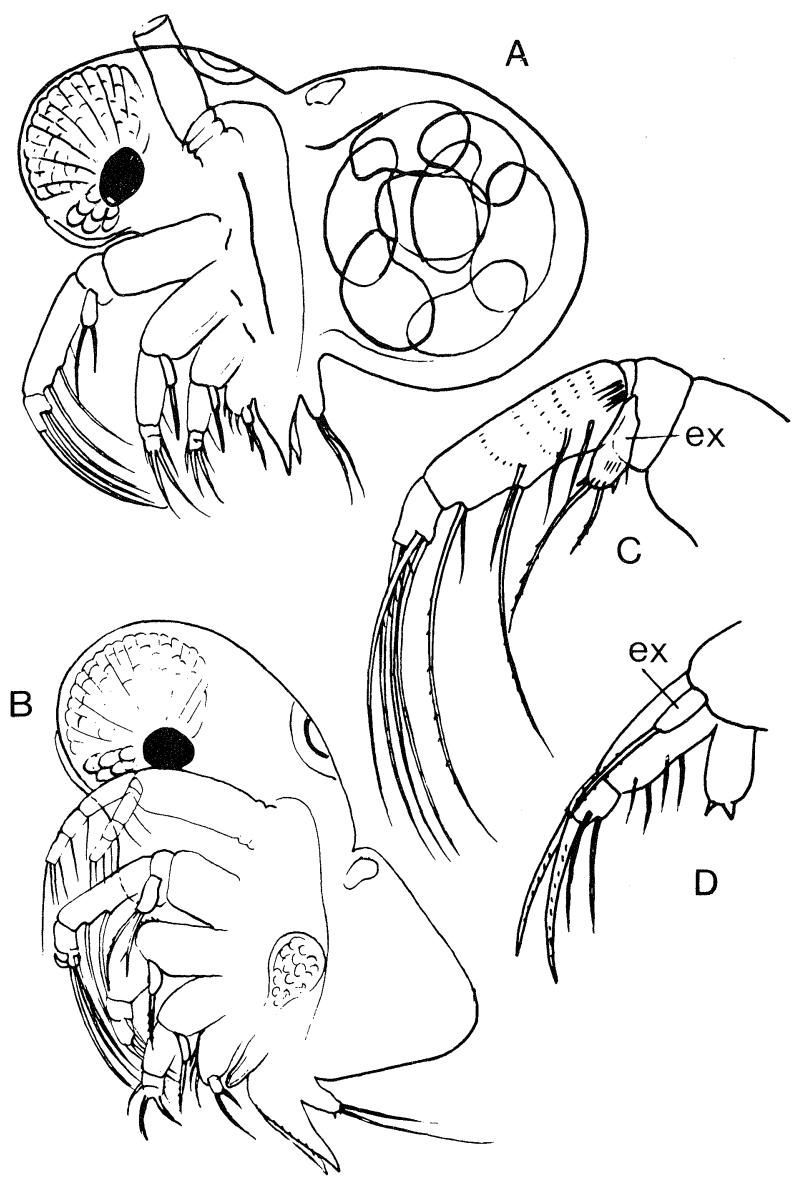

Fig. 16. Podon intermedius. $\mathbf{A}, \propto ; \mathbf{B}, \odot^{*} ; \mathbf{C}$, thoracic limb I of the $\odot$; D, thoracic limb III of the $९(e x=$ exopodite $)$. 
Distribution. In all oceans, mainly in temperate and northern zones, and preferably in neritic waters. In Australia it has been recorded from the Gippsland Lakes, Port Phillip Bay, Vic. (Arnott, 1974) and in the estuaries of the Paterson and Yarra Rivers, Vic. (Neale and Bayly, 1974).

\section{Genus Evadne Loven, 1836}

Evadne Loven, 1836: 3.-P.E. Müller, 1867: 222; Dolgoplskaya, 1958: 46-60 (partim); M.-Boltovskoi, 1969: 23.

Exopodites of legs I and II with setae, of leg III one or two setae, and of leg IV one seta. Head never delimited from shell. Latter elongated with an acute or pointed tip. Caudal claws clearly delimited, but with shape of triangular processes.
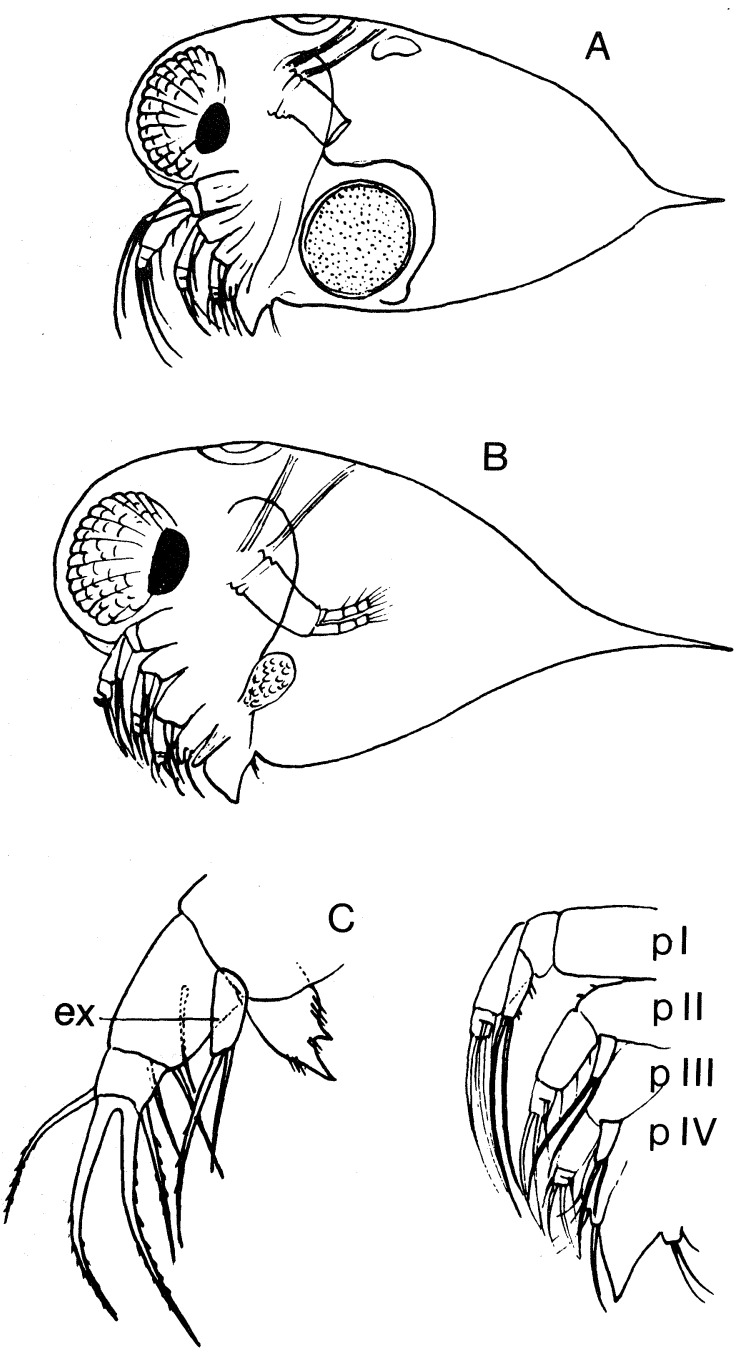

Fig. 17. Evade spinifera. $\mathbf{A}, \propto ; \mathbf{B}, \bigcirc^{*} ; \mathbf{C}$, thoracic limb III; D, thoracic limbs I-IV of the $\$(e x=$ exopodite, $p I-I V=$ thoracic limbs I-IV).

\section{Key to Australian Species of Evadne}

1. Exopodites of leg III with two setae; muscles of antennae diverge to dorsal side ......... E. spinifera P.E. Müller, 1867

- Exopodites of leg III with one seta; muscles of antennae parallel or approach one another to dorsal side .......... E. nordmanni Loven, 1836

Evadne spinifera P.E. Müller, 1867

Fig. 17

Evadne spinifera P.E. Müller, 1867: 225-226.-Lilljeborg, 1900: 647-649, tab. LXXXVI. fig. 18, tab. LXXXVII, figs 1-3; Dolgopolskaya, 1958: 51-55, figs 17-22.

Female. Setal formula for exopodites of legs 2.2.2.1. Muscles of antennae diverge to anteriodorsal side of shell. Tip of shell always with an obvious, though sometimes short, point. Female length $0.5-0.8 \mathrm{~mm}$ and height 1.3-1.4 $\mathrm{mm}$ (including the point).

Male. Larger head and a narrower shell with a longer point than female.

Distribution. All oceans, mainly between $60-65^{\circ} \mathrm{N}$ and $40^{\circ} \mathrm{S}$, preferably in neritic waters but also in the pelagic zone. In Australian waters it has been found off Sydney Harbour (Dakin and Colefax, 1940); Jibbon (Sheard, 1949); Jibbon, L. Macquarie, Port Stephens (Kott, 1955); and N.S.W. coastal waters from Coff's Harbour to Eden (Kott, 1957).

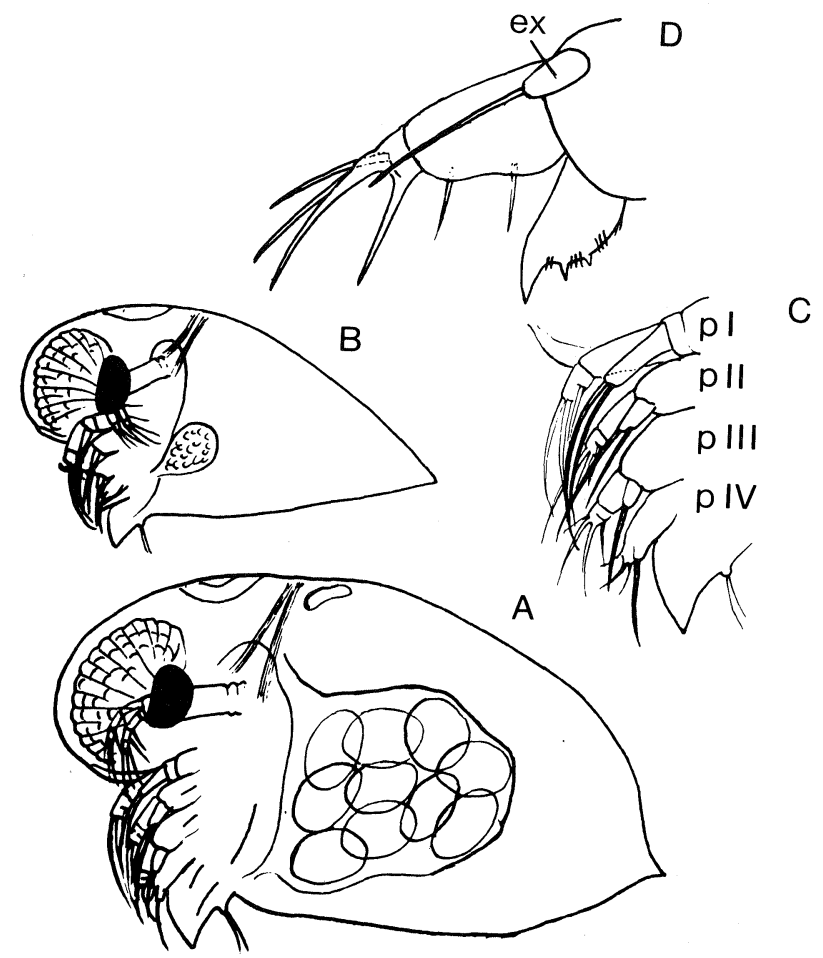

Fig. 18. Evadne nordmanni. $\mathbf{A}, \propto: \mathbf{B}, \bigcirc^{*}: \mathbf{C}$, thoracic limbs I-IV of the $Q$; D, thoracic limb III ( $e x=$ exopodite $p I-I V=$ thoracic limbs I-IV). 
Evadne nordmanni Loven, 1836

Fig. 18

Evadne nordmanni Loven, 1836: 3.-P.E. Müller, 1867: 222-225; Dolgopolskaya, 1958: 46-50, figs 14, 15.

Female. Setal formula for exopodites of legs 2.2.1.1. Muscles of antennae parallel or converge to dorsal side of shell. Shell tapers to top, acute or angulate, sometimes with a small point. Shell triangular in juveniles. Female length $0.4-0.7 \mathrm{~mm}$ and height $1.2-1.4 \mathrm{~mm}$.
Male. Larger head than female and with a triangular shell.

Distribution. All oceans, preferably in the neritic zone and mainly between $40^{\circ} \mathrm{N}$ and $40^{\circ} \mathrm{S}$. In Australian waters it has been found off Sydney Harbour (Dakin and Colefax, 1940); Jibbon (Sheard, 1949); Jibbon, L. Macquarie and Port Stephens (Kott, 1955); N.S.W. coastal waters from Port Macquarie to Eden and the east coast of Tasmania (Kott, 1957) and in Port Phillip Bay, Vic. (Arnott, 1974).

\section{Family CHYDORIDAE Stebbing, 1902}

Chydoridae Stebbing, 1902: 101-106.-Smirnov, 1971b:1-531.

Lynceidae Baird, 1850: 115.

Eurycercidae + Lynceidae.-Dybowski \& Grochowski, 1895: 149-154.

\section{Key to Subfamilies of Chydoridae}

1. Exopodites of thoracic limbs III and IV with $8-10$ setae $\ldots \ldots \ldots \ldots$

Exopodites of thoracic limbs III and IV with 7 or fewer setae $\ldots \ldots \ldots \ldots$

2(1). Six pairs of thoracic limbs; limb IV with an exopodite. Exopodite of limb V with 7 or 8 setae. Postabdomen long and wide, with many $(>80)$ denticles. Head pores present. Animal oval in lateral view. (Holarctic with records from South Africa and South America) ................ Eurycercinae Kurz, 1875

Five pairs of thoracic limbs. Postabdomen short. Major head pores absent. Animal circular in lateral view . . . . . . . . . . . . . . . . . Sayciinae Frey, 1967

3(2). Exopodites of limbs III and IV with 7 setae. Major and minor head pores on longitudinal axis of head shield; major pores are separate, or only a single major head pore. Two or more parthenogenetic eggs .... Chydorinae Stebbing, 1902

Exopodites of limb IV with 6 setae. Major head pores on longitudinal axis of head and connected, separate, or single; minor head pores laterally positioned. Two parthenogenetic eggs ................. Aloninae Frey, 1967

\section{A Shortened Key to the Genera of Chydoridae Known for Australia}

1. Parthenogenetic eggs numerous. No major head pores. Animal circular in

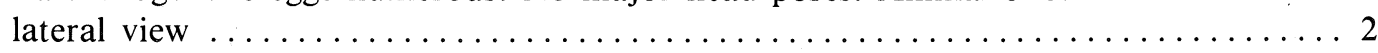

Parthenogenetic eggs two. Major head pores typically present (when absent, body oblong). Animal usually not circular in outline $\ldots \ldots \ldots \ldots \ldots \ldots \ldots$

2(1). Exopodites of thoracic limbs III and IV with 8 setae. Postabdomen short, wide, its dorsal side angular ........................ Saycia Sars, 1904

Exopodites of limbs III and IV with 7 setae. Postabdomen comparatively narrower, its dorsal side rounded ................... Archepleuroxus n.gen.

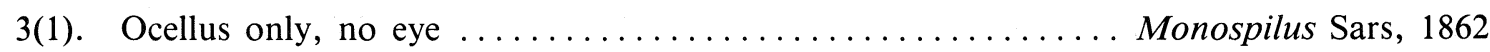

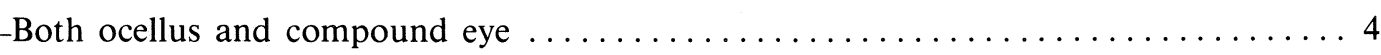

4(3). Exopodites of limbs III and IV with 7 setae. Major and minor head pores on longitudinal axis of head shield; major head pores separate, or only single major head pore, or rarely none 
Exopodite of limb IV with 6 setae. Major head pores on longitudinal axis of head shield and connected, separate, or single; minor head pores laterally

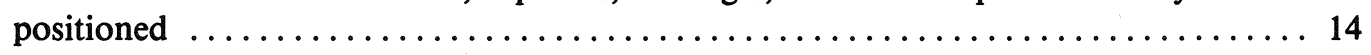

5(4). Labrum with a lamellar outgrowth $\ldots \ldots \ldots \ldots \ldots \ldots \ldots \ldots \ldots \ldots \ldots \ldots \ldots \ldots \ldots \ldots \ldots \ldots \ldots$ No lamellar outgrowth on labrum ............... Pseudochydorus Fryer, 1968

6(5). Rostrum extremely long, reflexed posteriorly ........... Rhynchochydorus n.gen.

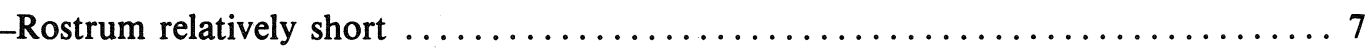

7(6). Setae on posterior half of ventral margin of valve inserted on its edge $\ldots \ldots \ldots \ldots 8$

Setae on posterior half of ventral margin of valve inserted on its inner surface . . 10

8(7). Labrum protrudes well beyond tip of the blunt rostrum .......... Rak n.gen.

Labrum comparatively short and rostrum acute $\ldots \ldots \ldots \ldots \ldots \ldots \ldots \ldots$

9(8). Height of posterior margin of valve about a third of body height (if more, postabdomen comparatively long and bent) ......... Pleuroxus Baird, 1843

Height of posterior margin of valve about half body height. Antennule almost reaches tip of rostrum, or slightly protrudes beyond its tip. ..... Alonella Sars, 1862

10(7). Head shield with two major head pores $\ldots \ldots \ldots \ldots \ldots \ldots \ldots \ldots \ldots \ldots \ldots \ldots \ldots \ldots$

Head shield with one major head pore or none $\ldots \ldots \ldots \ldots \ldots \ldots \ldots \ldots \ldots$

11(10).Spherical in outline. Postabdomen not oval; anal opening on its functionally

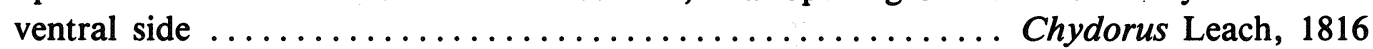
Oval in outline. Postabdomen oval; anal opening on its functionally posterior

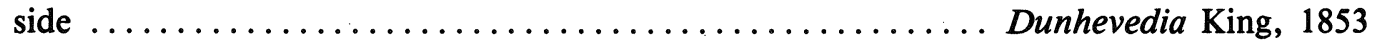

12(10).Head shield without head pores. Ventral margin of valve with a serrated infolded lobe anteriorly. Claw with two basal spines ........ Australochydorus n.gen.

Head shield with one major head pore $\ldots \ldots \ldots \ldots \ldots \ldots \ldots \ldots \ldots \ldots \ldots$

13(12).Eye and ocellus extremely large. Postabdomen not elongated. Labral lamella with an elongated pointed apex .................... Dadaya Sars, 1901 Eye and ocellus moderately sized. Postabdomen elongated. Labral lamella with a blunt apex, its tip with an impression ........... Monope (Smirnov, 1977)

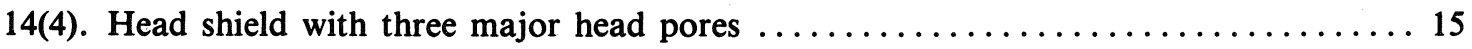

Head shield with one or two major head pores $\ldots \ldots \ldots \ldots \ldots \ldots \ldots \ldots \ldots$

15(14).Lateral setae of postabdomen extremely large. Anal teeth of postabdomen

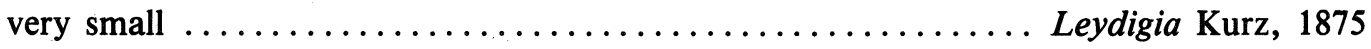

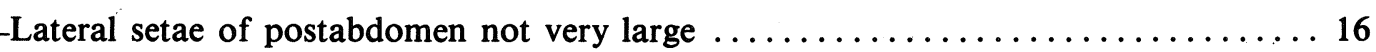

16(15).Anterior margin of head shield broadly rounded, protruding (if viewed laterally). Ventral margin of valve straight. Postabdomen short ....... Graptoleberis Sars, 1862 Anterior margin of head shield not broadly rounded and protruding

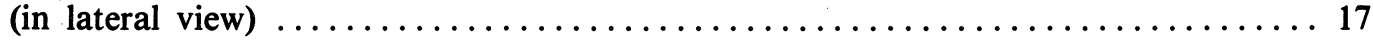

17(16).Postabdomen of various forms, but not narrow or very long ..... Alona Baird, 1843

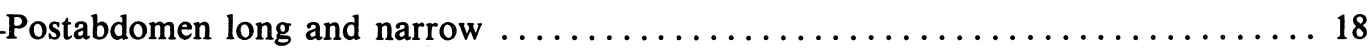

18(17).Postabdomen straight with parallel dorsal and ventral margins . Acroperus Baird, 1843

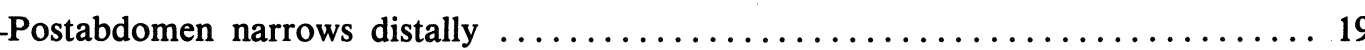


19(18). Rostrum elongated. Legs III and IV noticeably different

Kurzia Dybowski \& Grochowski, 1894

Rostrum not elongated. Legs III and IV superficially similar. Most species with a keel on carapace ...................... Camptocerus Baird, 1843

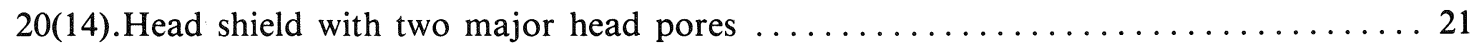

Head shield with one major head pore. Body length considerably exceeds its

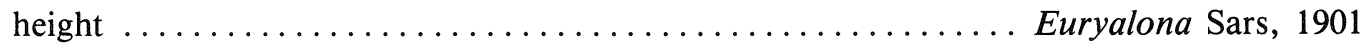

21(20).Major head pores connected by a narrow connection ..... Biapertura Smirnov, 1971 Major head pores separate ............ Oxyurella Dybowski \& Grochowski, 1894

\section{Subfamily SAYCIINAE Frey, 1967}

Sayciinae Frey, 1967: 35.-Smirnov, 1971b: 212-215.

The type genus is Saycia Sars, 1904.

Genus Saycia Sars, 1904

Saycia Sars, 1904a: 4-5.

Body circular in lateral view; no impression between head and rest of body. Antennule conical, not reaching the end of the acute rostrum. Antenna setae 0-0-3/1-1-3. Postabdomen short, with irregular groups of denticles. Polyembryonic.

Saycia is a monotypic genus endemic to Australasia. The type species is Saycia cooki (King, 1866).

\section{Saycia cooki (King, 1866)}

Fig. 19

Eurycercus cooki King, 1866: 165-166, pl. XIII.

Saycia orbicularis Sars, 1904a: 3-15, figs 1-15.

Saycia cooki.-Smirnov, 1966: 399-340; 1971b: 212-215, figs 196-199; Frey, 1971: 254-308.

\section{Key to Subspecies of Saycia cooki}

1. Anal margin comparatively more concave.

Preanal denticles comparatively less numerous (4-12) .. S. cooki cooki (King, 1866)

- Anal margin comparatively less concave. Preanal denticles comparatively more numerous (7-25) (New Zealand) ............ ........ S. cooki novaezealandiae Frey, 1971

\section{Saycia cooki cooki (King, 1866)}

Fig. 19

Saycia cooki cooki Frey, 1971: 254-308.

Material. Vic.: 205, 206, 216, 219.

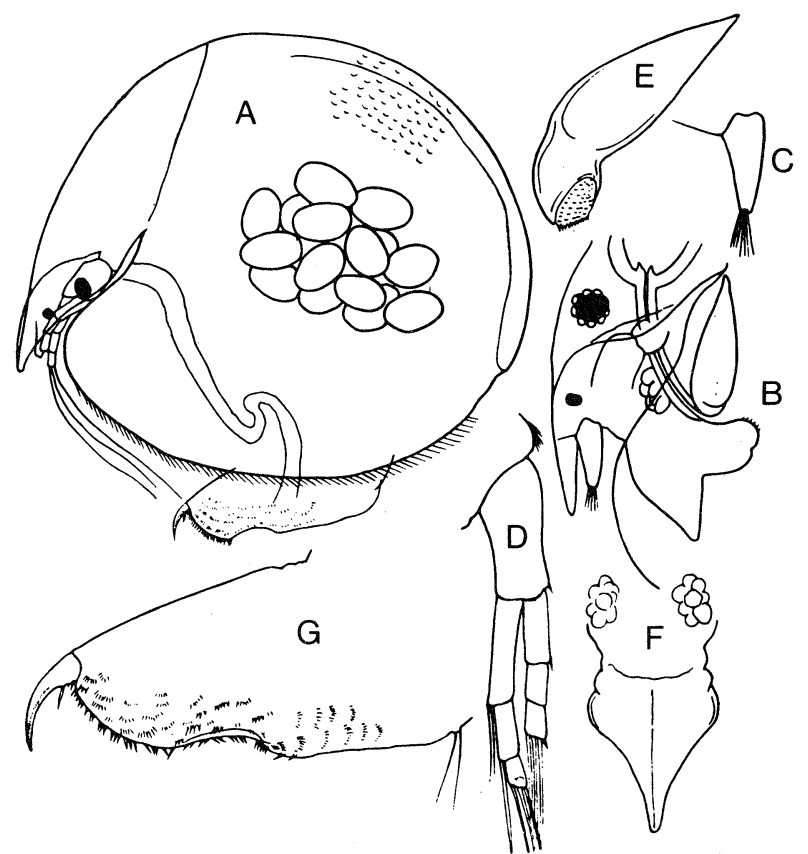

Fig. 19. Saycia cooki $\$$, after Smirnov, 1971b. A, whole animal, length $1.7 \mathrm{~mm}$; B, head; C, antennule; D, antenna; E, mandible; F, labrum; G, postabdomen.

Slides. AM $\odot$ P27725, $\odot$ o head shield P27726, MGU

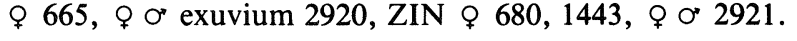

Comments. Our material is definitely $S$. cooki cooki. The New Zealand form differs morphologically and corresponds to the geographical criterion of subspecies.

Ecology. Saycia cooki cooki lives in temporary ponds where it is the dominant cladoceran. It is present mainly during the winter months (Morton, 1973).

Type locality. Environs of the cities of Sydney and Melbourne.

Distribution. Eastern Australia. 
Subfamily CHYDORINAE Stebbing, 1902

Chydorinae Frey, 1967: 36. - Smirnov, 1971b: 215-216.

The type genus is Chydorus Leach, 1816.

Key to the Genera of Chydorinae

1. Parthenogenetic eggs numerous ..................... Archepleuroxus n.gen.

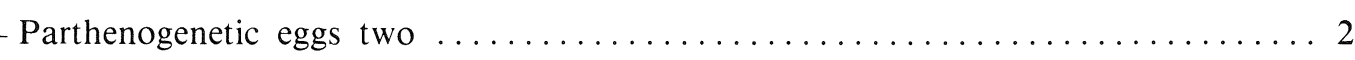

2(1). Ventral margin of valve entire (i.e. no tooth or impression) $\ldots \ldots \ldots \ldots \ldots \ldots$

Ventral margin of valve with a tooth and an impression behind it

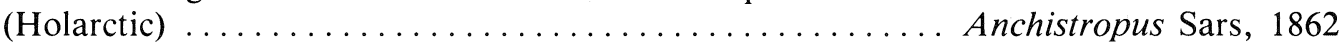

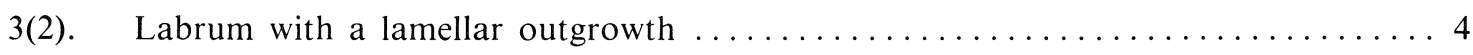
Labrum without a lamellar outgrowth ............ Pseudochydorus Fryer, 1968

4(3). Rostrum extremely long, reflexed posteriorly .......... Rhynchochydorus n.gen.

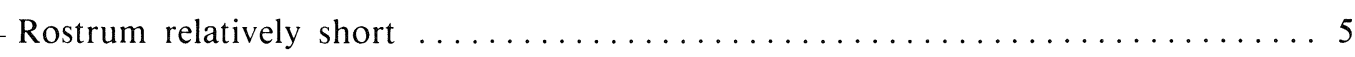

5(4). Setae on posterior half of ventral margin of valve inserted on its edge $\ldots \ldots \ldots 6$

Setae on posterior half of ventral margin of valve inserted on its inner surface ... 9

6(5). Labrum protrudes well beyond tip of the blunt rostrum .......... Rak n.gen.

Labrum comparatively short. Rostrum acute .................... 7

7(6). Height of posterior margin of valve about one third body height (if more, postabdomen comparatively long and slightly bent) ......... Pleuroxus Baird, 1843

Height of posterior margin of valve about half body height $\ldots \ldots \ldots \ldots \ldots \ldots$

8(7). Antennule almost reaches to tip of rostrum, or protudes slightly beyond it ........................................... Sars, 1862

Antennule does not reach tip of rostrum by about one antennule length (Holarctic, Ethiopian and Neotropical and recently found near Darwin by

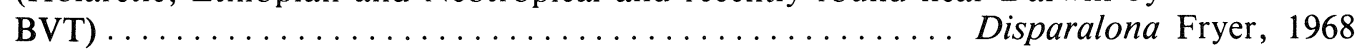

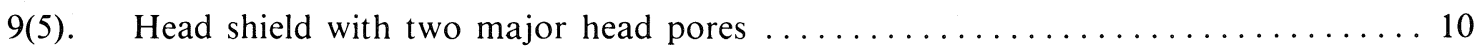

Head shield with one major head pore or none $\ldots \ldots \ldots \ldots \ldots \ldots \ldots \ldots \ldots$

10(9). Spherical in outline. Postabdomen not oval; anal opening on its functionally

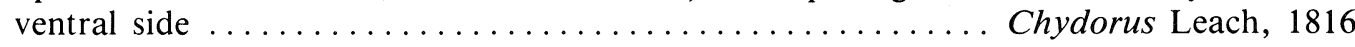

Oval in outline. Postabdomen oval; anal opening on its functionally

posterior side ........................... Dunhevedia King, 1853

11(9). Head shield without head pores. Ventral margin of valve with a serrated infolded lobe anteriorly. Claw with two basal spines ....... Australochydorus n.gen.

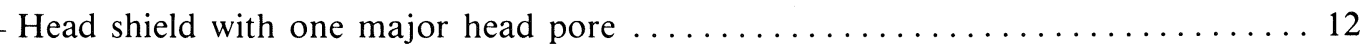

12(11). Eye and ocellus extremely large. Postabdomen not elongated. Labral lamella

with an elongated pointed apex . . . . . . . . . . . . . . . . Dadaya Sars, 1901

Eye and ocellus of moderate size. Postabdomen elongated. Labral lamella

with a blunt apex, the tip having an impression .......... Monope (Smirnov, 1977)

\section{Archepleuroxus. n.gen.}

Body circular in lateral view, but ventral edge less curved. No impression between head and rest of body. Rostrum acute. Head shield rounded posteriorly and lacking head pores. Ocellus situated closer to eye than to tip of rostrum. Antennule conical and almost reaching tip of rostrum. Antennal setae 0-0-3/1-1-3. Labral lamella with an acute apex. Mandibular articulation of chydorine type. 
Thoracic limbs of chydorine type, corresponding in structure to that of the type for this subfamilyChydorus. Limbs different from those of Saycia (Sayciinae). Exopodite of limb II with 7 setae. Postabdomen rounded distally, with anal aperture opening on middle of dorsal side. Polyembryonic.

The name is derived from Pleuroxus because of its external similarity, and "Arche" (Greek-origin) implying the presence of some primitive features. The gender is masculine. Archepleuroxus is a link in the series Saycia-Archepleuroxus-Pleuroxus jugosusPleuroxus-Alonella-specialized Chydorinae genera.

Archepleuroxus is a monotypic genus endemic to Australia. The type species is Archepleuroxus baylyi n.sp.

\section{Archepleuroxus baylyi n.sp.}

Fig. 20

Material. Vic.: 210, 213, Tas.: 296, 297, 311, 315, 318, 323, 331, W.A.: 416.

Holotype. AM ᄋ P27684.

Paratypes. MGU $\subsetneq 2903, \mathrm{ZIN} \odot 2$ 2905, BM $\subsetneq 1980.358$, DF $\subsetneq 2906$, MNHB $\% 2910$.

Slides. MGU @ 2901, 2902, 2903.

Female. Body approximately circular in lateral view. Posterior corners of valves rounded, and in some females denticles present on ventro-posterior corner. Setae of ventral margin of valve situated along its edge. Shell brownish and granulated. Rostrum acute. Head shield rounded posteriorly and lacking head pores. Antennule conical and almost reaching tip of rostrum; its sensory papillae rather long and of uniform length. Antennal setae 0-0-3/1-1-3, and spines 0-0-1/0-0-1; its basal segments with a few transverse rows of denticles. Labrum lamella elongated with an acute apex.

Thoracic limb I with three setae on external branch of its endite. One short; the two long ones unspecialized and similar to the long seta of exopodite. Internal branch of endite with three groups of four setae. Limb II with a big endopodite bearing a row of 8 stiff setae, unspecialized, but of various sizes. Its gnathobase with 7 setae and also short apical ones. Limb III with two rows of setae on its endite, 8 gnathobasic setae, and apical setae on the gnathobase. Its exopodite with 7 setae. Exopodite of limb IV with 7 setae, of limb V, 4 setae.

Postabdomen rounded in its distal part; anal aperture opening in middle of its dorsal side. Its postanal margin with groups of teeth and anal margin with groups of smaller teeth, which pass into groups of setae proximally. Claw with two basal spines.

Intestine convoluted. Ocellus smaller than eye, and situated closer to eye than to tip of rostrum.

Archepleuroxus baylyi is polyembryonic. In the holotypic female there are 22 embryos (and probably more as some may have been lost).

Length. $1.14 \mathrm{~mm}$ (holotype P27684). The other size characteristics of the type population (from a pool near
Yunderup, W.A.) are: juvenile females (minimum length) $0.33 \mathrm{~mm}$, minimum length of females with embryos $0.38 \mathrm{~mm}$ (such females have only two embryos). Egg diameter is $0.12 \mathrm{~mm}$, which is about $14 \%$ of female mean length, and length of developed embryos is about $0.25 \mathrm{~mm}$, which is $1 / 3$ of female mean length.

Male. Unknown.

Ecology. Archepleuroxus baylyi typically lives in temporary ponds, but is occasionally found in the littoral of permanent lakes and farm dams. Most records are from winter and spring. In a pool near Oatlands, Tas., it was found under ice.

Type locality. A pool near Yunderup, W.A. (Loc. No.416).

Etymology. The species is named after Dr I.A.E. Bayly, of Monash University.

Distribution. Southern Australia.

Differential diagnosis. Archepleuroxus baylyi is a polyembryonic Pleuroxus-like chydorid. It differs from Pleuroxus (including the very similar $P$. jugosus) by the polyembryonic condition. Externally it is similar to Saycia, but its rounded postabdomen, position of the anal aperture and structure of the thoracic limbs distinguishes it.

\section{Genus Pleuroxus Baird, 1843}

Subgenus Pleuroxus Baird, 1843: 93.

Pleuroxus.-Smirnov, 1966b: 161-194; 1971b: 217-258.

The setae of the ventral margin of the valve are situated on its edge along its whole length, this feature being shared also by Alonella and Disparalona. However, Pleuroxus can be distinguished from these genera in that the distance between the posterior major head pore and the hind margin of the head shield is greater than the distance between the two major head pores, whereas in Alonella and Disparalona it is shorter.

The type species is Pleuroxus aduncus (Jurine, 1820).

\section{Key to Australian Species of Pleuroxus}

1. Ventro-posterior corner of valve angular, with denticles $\ldots \ldots \ldots \ldots \ldots 1$

- Ventro-posterior corner of valve widely rounded, without denticles .......... P. inermis Sars, 1896

2(1). Large $(0.74 \mathrm{~mm})$, high, keeled, and heavily chitinized (brownish) ....... P. jugosus (Henry, 1922)

Smaller $(0.6 \mathrm{~mm})$, not so high and less chitinized ............... 3

3(2). Postabdominal anal teeth small and irregular; distal end of postabdomen rounded ........ P. aduncus (Jurine, 1820)

Postabdominal anal teeth comparatively large and regular ................ 4 
4(3). 8-12 anal teeth, four distal ones noticeably larger ............. P. denticulatus Birge, 1879

14-16 anal teeth, size gradually increasing distally ....P. similis Vavra, 1900
Pleuroxus jugosus (Henry, 1922) n.comb.

Figs 21, 22

Chydorus jugosus Henry, 1922: 46, pl. VII, figs 5, 5A.

Material. N.S.W.: 133, 137, 138, 140, 141, 145, 167. Tas.: 334. W.A.: $417,420,423$.

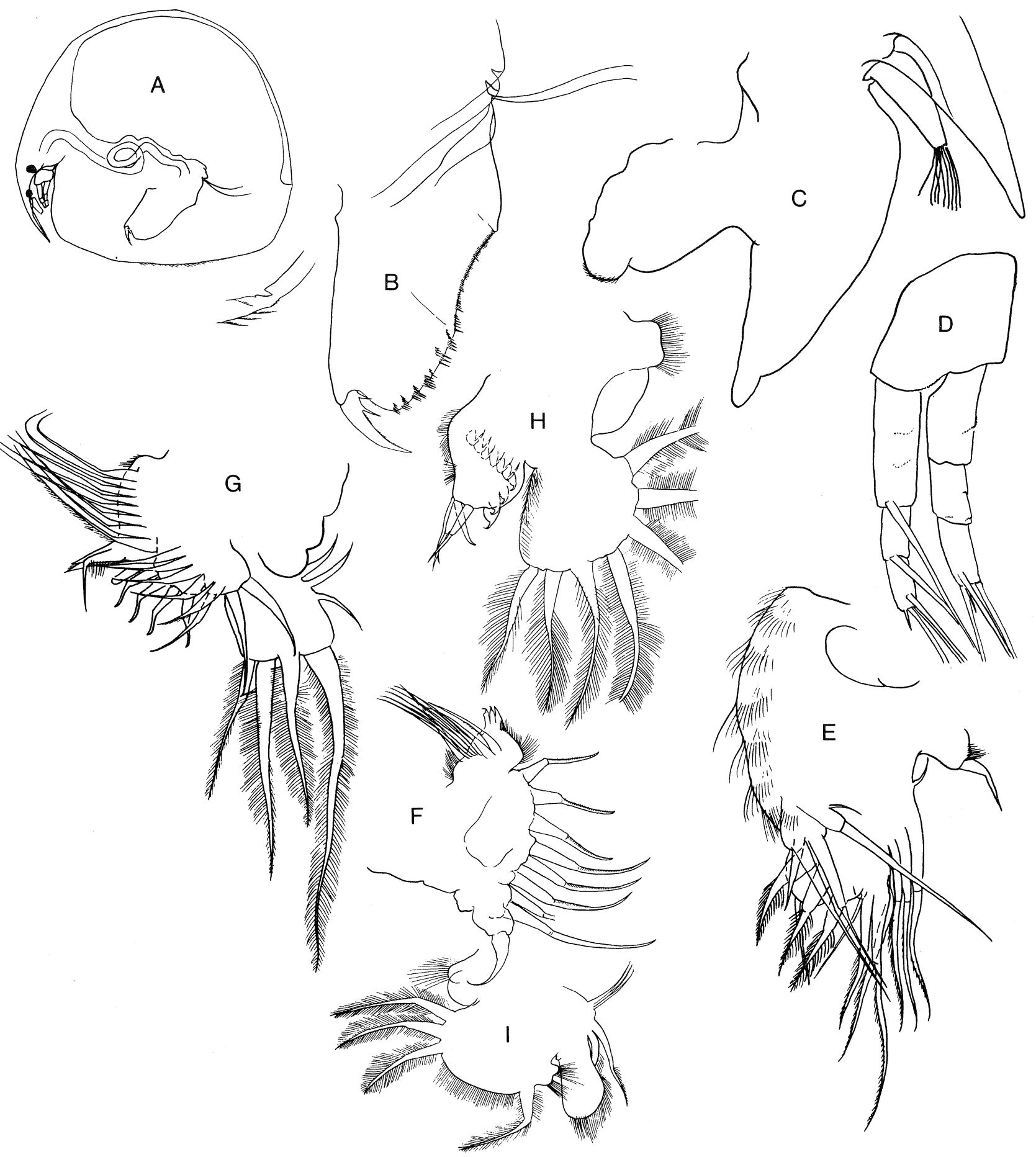

Fig. 20. Archepleuroxus baylyi , temporary pool near Yunderup, W.A., 17.viii.1973. A, whole animal, length $1.14 \mathrm{~mm}$, from holotype AMP 27684, also showing the ventro-posterior corners of the shell of the specimen on slide 2905 (paratype); B, postabdomen, slide 2902; C, labrum and antennule, slide 2902; D, antenna, slide 2901; E, thoracic limb I, slide 2903; F, limb II, slide 2901; G, limb III, slide 2901; H, limb IV, slide 2901; I, limb V, slide 2902. 

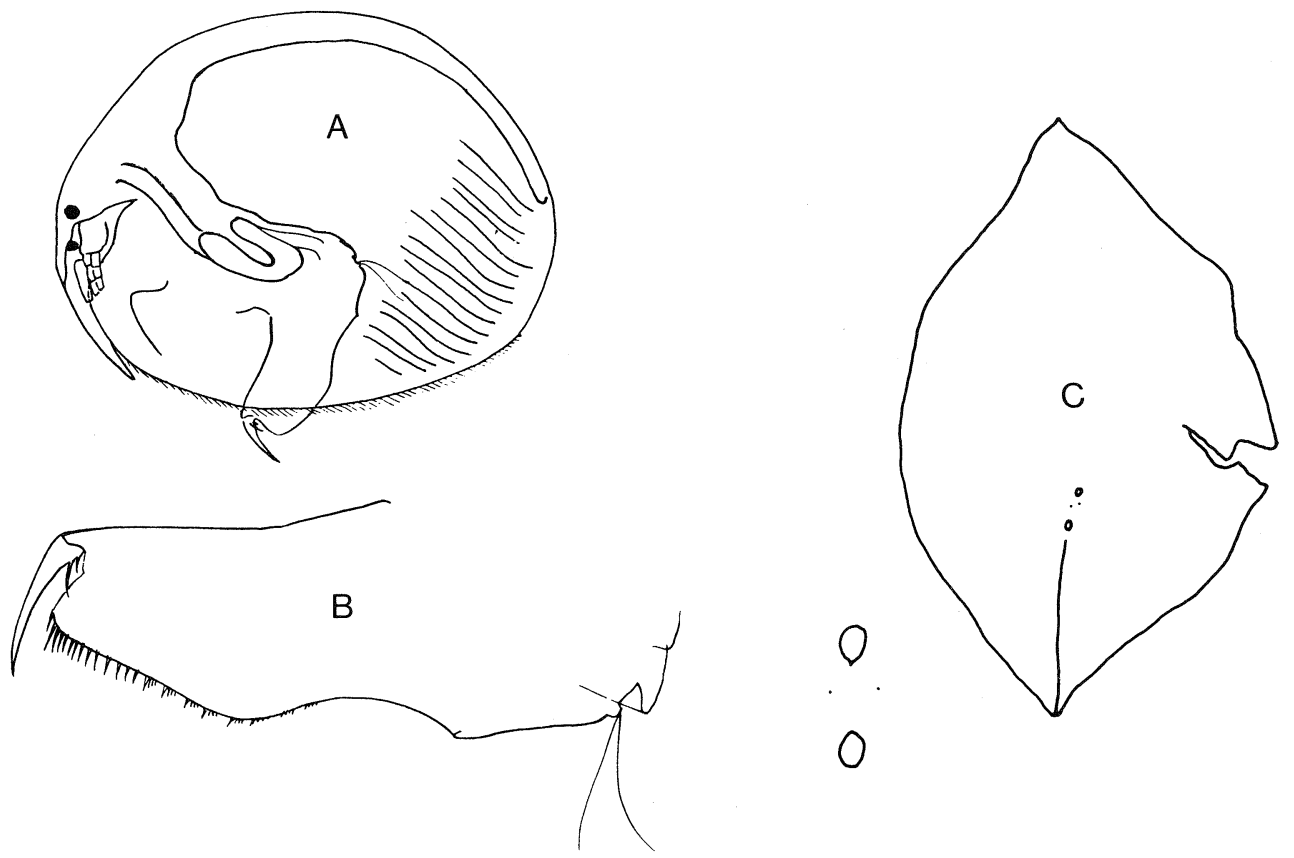

Fig. 21. Pleuroxus jugosus $\$$, pool on Muirillup Rock, near Northcliffe, W.A., 18.vi.77. A, whole animal, length $0.81 \mathrm{~mm}$, slide 2803; B, postabdomen, slide 2803; C, head shield and head pores, slide 2198 .

Holotype. "P:5889 Chydorus jugosus Henry (type). Loc.: Holbrook" in the Australian Museum.

Slides. $\mathrm{AM} \subsetneq \mathrm{P} 27723, \mathrm{MGU} \subsetneq 2803$, ephippial $\subsetneq 2808$ ơ 2196, ZIN \& 2804.

Comment. Since the type specimen has definite Pleuroxus characters, (namely the distance between the posterior head pore and the hind margin of the head shield is greater than the distance between the two major head pores and all the ventral setae of the valve are situated on its edge), it is concluded that this taxon belongs to that genus.

Female. Head shield expressly convex with both anterior and posterior ends angular and pointed; keeled behind posterior head pore and finely punctate. Distance behind posterior head pore exceeds interpore distance several times. Minor head pores very small.

Length. $0.81 \mathrm{~mm}$.

Mas novus. Lines on valve more expressed anteriorly; its ventral edge straight in anterior part; small denticles on its ventro-posterior corner. Thoracic limb I with a chitinized hook. Tip of rostrum bears two spines (a structure not described for any other cladoceran). Postabdomen elongated and without pre-anal and postanal angles. Anal teeth arranged proximally into about 4 groups and distally into about 7 single teeth.

Length. $0.61 \mathrm{~mm}$.

Ecology. Commonly benthic in gritty or silted sand.

Type locality. Holbrook (N.S.W.)

Distribution. Isolated areas of N.S.W. (mainly southern tablelands and slopes), midland Tas. and south-western W.A.

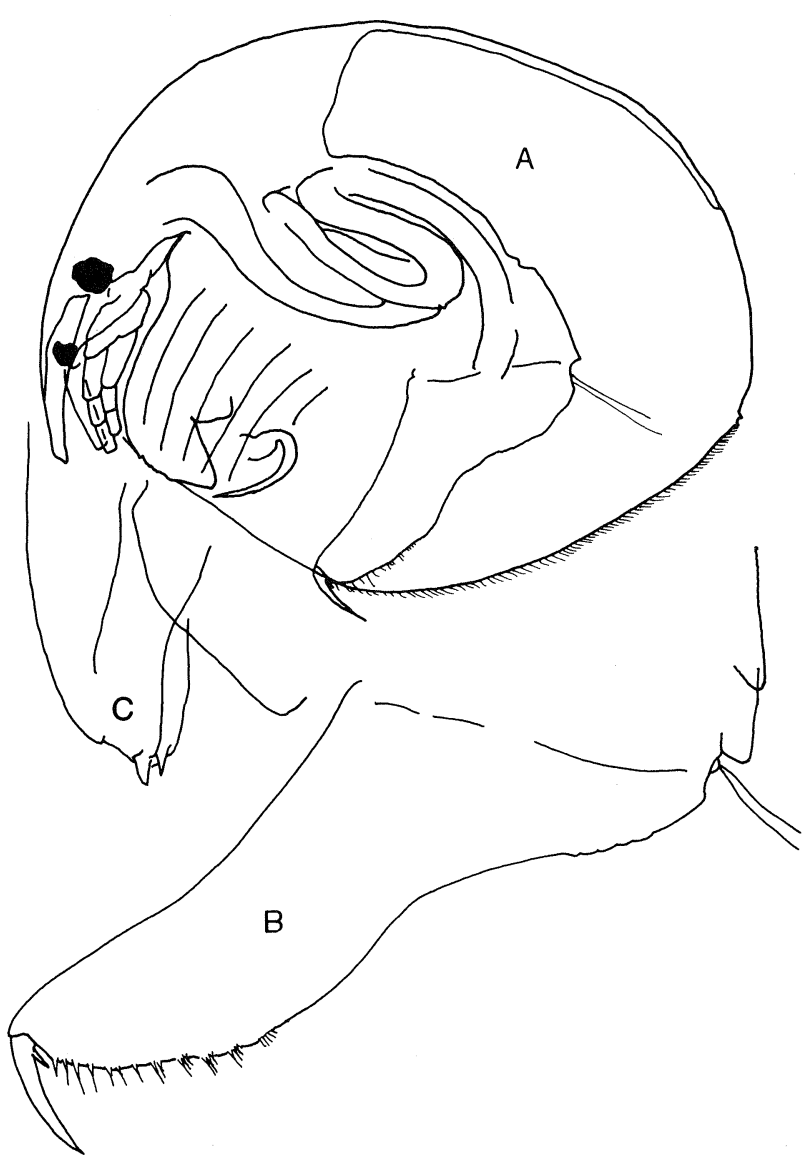

Fig. 22. Pleuroxus jugosus $\sigma^{\prime}$, pool on Muirillap Rock, near Northcliffe, W.A., 18.vi.77. A, whole animal, length $0.61 \mathrm{~mm} ; \mathbf{B}$, postabdomen; C, tip of rostrum. (Both from slide 2196.) 
Differential diagnosis. Female has a high body and is large and brown. The valve is roughly lineated (i.e. with widely spaced lines). There is a dorsal keel on the shell, partly advancing onto the posterior part of the head shield. The postabdomen is long, narrowing slightly distally. It is superficially similar to Archepleuroxus baylyi, but the latter is polyembryonic whereas two is the maximum number of embryos in $P$. jugosus.

\section{Pleuroxus aduncus (Jurine, 1820)}

Fig. 23

Monoculus aduncus Jurine, 1820: 152-153, t.15, figs 7, 8. Alonella nasuta Smith, 1909: 84, pl. 16, figs 4, 5; n. syn. Chydorus denticulatus Henry, 1919: 480-481, pl. XLII, fig. $15,16$.

Chydorus unispinus Henry, 1922: 46, pl. VIII, figs 4, 4A; n. syn.

Pleuroxus aduncus.-Harding, 1955: 348-350, figs 83-92; Smirnov, 1971b: 220-225, figs 201-206.

Material. Qld.: 52. N.S.W.: 94, 126, 131, 132, 133, 135, $137,143,144,153,155,156,160,165,184,187$. Vic.: 207, $208,210,216,218,230,236,238,242,246,249,251,254$, 255, 259, 260, 261. Tas.: 320, 321, 322, 326, 327, 329, 330, $332,333,336,337,339$. S.A.: $361,367,368,370,374,376$, 378, 382, 385, 388, 389, 392.W.A.: 415.

Slides: AM \& P27721, MGU ᄋ 995, 1225, 1591, (intestine packed with diatoms), ZIN $\$ 1590$.

Comment. A study of the type slides in the Australian Museum of Pleuroxus denticulatus Henry, 1919 ("P: 4334, University Pond") and Chydorus unispinus ("P: 5892 Loc. Botany") showed that these taxa are synonyms of Pleuroxus aduncus. In addition Alonella nasuta, 1909, most probably belongs to Pleuroxus aduncus sensu lato by reason of its long rostrum, general outline, form, and indentation and the postabdomen.

Female. Postabdomen comparatively short; anal teeth small and irregular. Ventro-posterior corner of

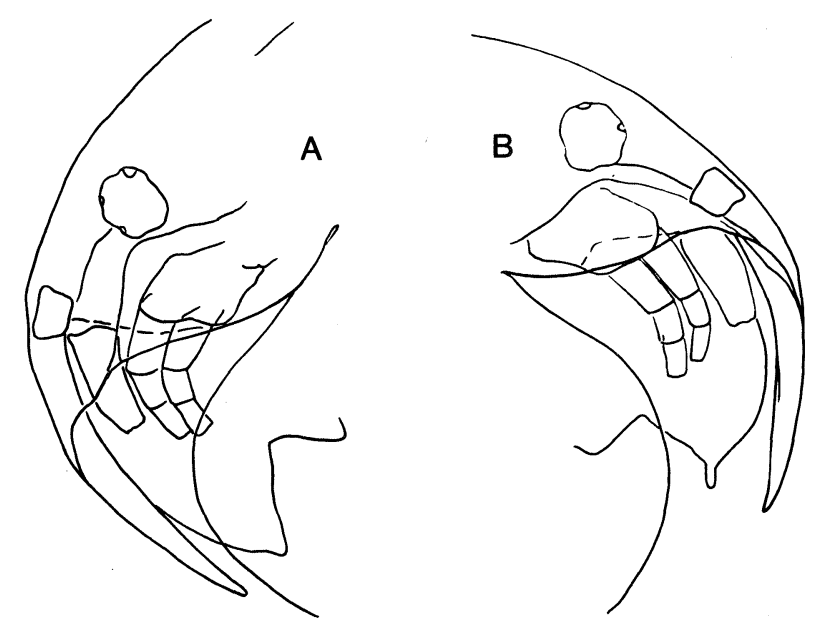

Fig. 23. Pleuroxus aduncus $९$, Sheepwash Lag., via Nelson, Vic., 11.viii.72. A, head, slide 1225; B, head of a modified $\%$, slide 995 . valve with denticles of various forms. Surface of valve variously sculptured, but usually faintly. This is a polymorphic species or a complex of related forms requiring further study (see Harding, 1955). A key to subspecies has been suggested by Smirnov (1971b).

A female having an abnormal labrum with an elongated tip was found in a sample from Victoria (Fig. 23b).

Length. Up to $0.66 \mathrm{~mm}$.

Ecology. $P$. aduncus is known from variety of water types, including temporary localities and slightly saline waters (salinity up to $2.9 \%$ o). In both Borumba Reservoir and Lake Purrumbete it occurs throughout the year (Timms, 1973; Timms and Midgley, 1969). In the latter site it was most common in Scirpus weedbeds.

Distribution. $P$. aduncus is a southern Australian species (southern N.S.W., Vic., Tas., S.A., south-west W.A.) with isolated occurrences in northern N.S.W. and southern Qld.

Differential diagnosis. $P$. aduncus differs from other species of Pleuroxus in having a postabdomen which is rounded distally and armed with small irregular anal teeth. The denticles of the ventro-posterior corner of the valve are small, variable, and sometimes absent.

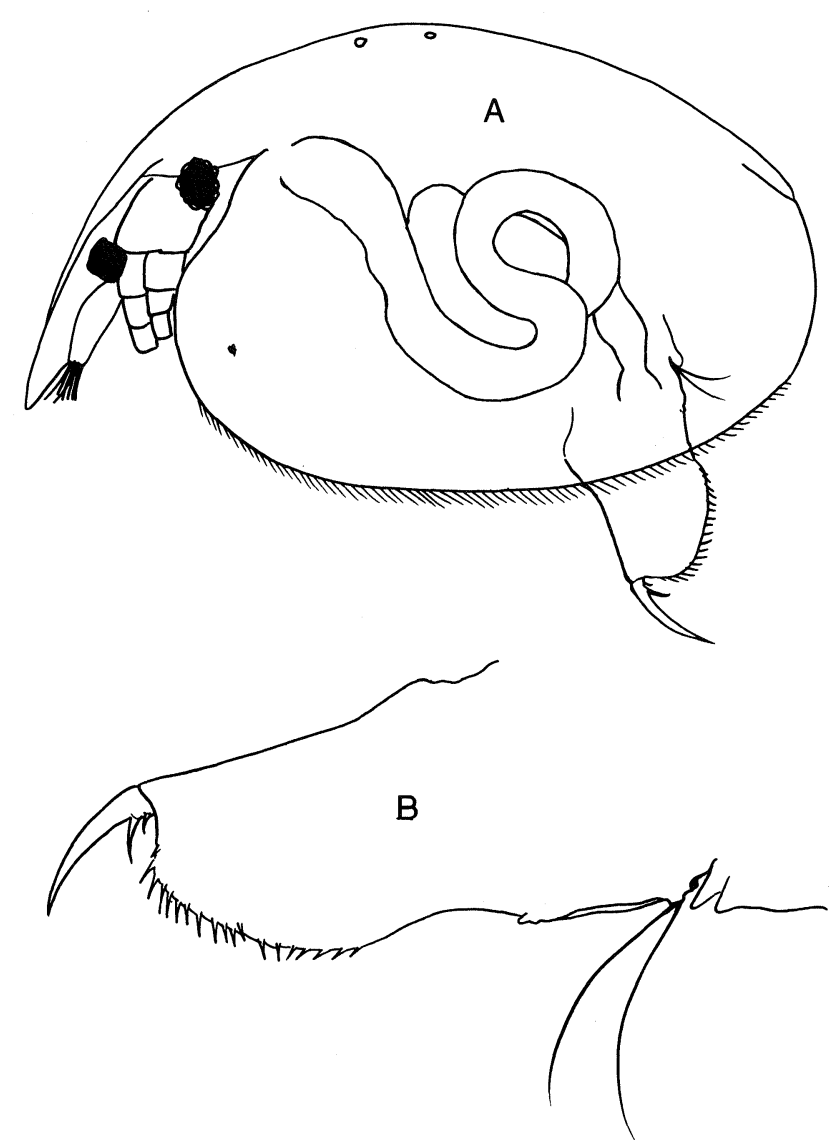

Fig. 24. Pleuroxus inermis $q$, Murray River at Mannum, S.A., 24.iii.78. A, whole animal, length $0.43 \mathrm{~m} ; \mathrm{B}$, postabdomen. (Both from slide 3080.) 


\section{Pleuroxus inermis Sars, 1896}

Fig. 24

Pleuroxus inermis Sars, 1896: 31-35, pl. 5, figs, 8, 9.-Henry, 1922: 44-45;Smirnov, 1971b: 221 (attributed to Pleuroxus aduncus sensu lato).

Material. S.A.: 394.

Slides. MGU ๆ 3078, 3077, ZIN 3079.

Female. Body oval in lateral view. Posterior corners of valves rounded; ventro-posterior corner without denticles. Rostrum acute. Antennule not reaching tip of rostrum.

Postabdomen narrows distally; its preanal angle not prominent. Anal margin slightly concave; postanal margin with numerous thin anal teeth. Intestine convoluted. Ocellus smaller than eye and sited slightly closer to eye than to tip of rostrum.

Length. $0.43 \mathrm{~mm}$.

Male. Unknown.

Distribution. Lower Murray River.

Differential diagnosis. Pleuroxus inermis is characterized by the rounded posterior corners of the valve, lack of denticles on ventro-posterior corner of valve, and the numerous thin anal teeth of the postabdomen. It is similar to the Holarctic Pleuroxus pigroides Lilljeborg (Frey, 1976), but differs from the latter by its non-protruding preanal angle.

\section{Pleuroxus denticulatus Birge, 1879}

\section{Fig. 25}

Pleuroxus denticulatus Birge, 1879: 20-21, pl. I, fig 21.Smirnov, 1971b: 231, fig. 220.

Non Chydorus denticulatus Henry, 1919.

Material. Qld.: 16, 39, 41. N.S.W.: 77, 81, 85, 86. Vic.: 203.

Slides. AM \& P27722, MGU @ 1901, ZIN 2297.

Comments. This species may be polymorphic, as according to Flössner and Kraus (1977: 470-471) "the female from New South Wales illustrated by Smirnov (1971b) cannot be considered as typical, because it differs from our specimens in the polygonal reticulation of the shell, the shape of the distal-dorsal angle of the postabdomen, and the minute proximal basal spine of the postabdominal claw. Most likely this is a separate subspecies."

Length. $0.6 \mathrm{~mm}$.

Distribution. Sparsely distributed in eastern Qld, N.S.W. and Vic.

Differential diagnosis. The postabdomen of the female is truncate; its width is about 4 times the width of the claw. The anal teeth are large, with the distal ones grouped on the dorsal angle of the postabdomen. The postabdomen of $P$. laevis is comparatively longer; its width in the distal part is much less than 4 times the width of the claw. In $P$. laevis there is a denticle on the

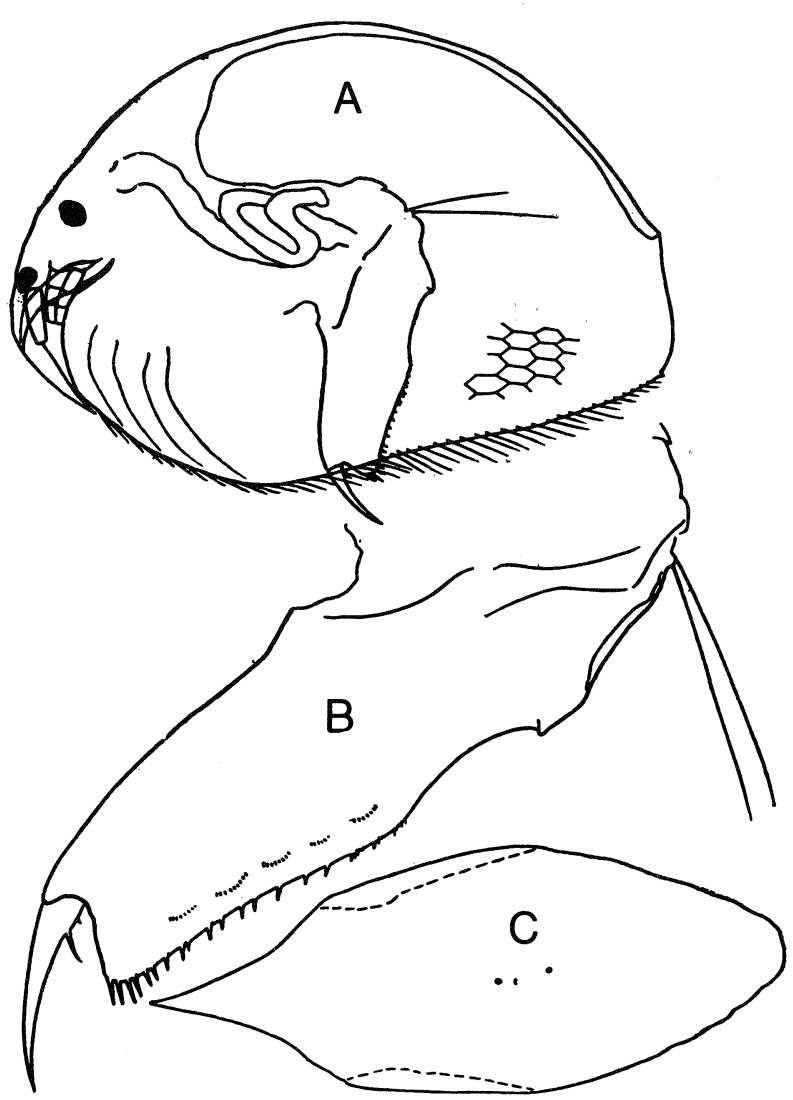

Fig. 25. Pleuroxus denticulatus $\$$, after Smirnov, 1971b. A, whole animal, length $0.6 \mathrm{~mm} ; \mathrm{B}$, postabdomen; $\mathrm{C}$, head shield.

ventro-posterior corner of the valve, while in $P$. denticulatus there are commonly several denticles situated on the vertex of this corner.

\section{Pleuroxus similis Vavra, 1900}

Pleuroxus similis Vavra, 1900: 23-24, fig. 6.-Smirnov, 1971b: 231, figs 218, 219.

Pleuroxus australis Henry, 1922: 45, pl. VII, fig. 3.

Material. Type slide of Pleuroxus australis in the Australian Museum "P: 5893 Pleuroxus australis Henry (Type). Loc. Bangalow."

Length. $0.5 \mathrm{~mm}$.

Distribution. Known only from coastal northern N.S.W. in Australia; elsewhere in the world it is found in southern U.S.S.R. and in Chile.

Differential diagnosis. The postabdomen is truncated, slightly narrowing distally, and the anal teeth are comparatively large, regularly diminishing proximally. Overall it is brownish and rather small.

\section{Incertae sedis}

Eurycercus cunninghami King, 1853b: 257, pl. VIIA.-Sars, 1888: 69 (Kingia). 


\section{Genus Alonella Sars, 1862}

Alonella Sars, 1862b: 300-301.-Smirnov 1971b: 258-259

Posterior margin of body high in comparison with body height. Head pores located near posterior margin of head shield. All setae of ventral border of valve originate from its edge.

The type species is Alonella excisa (Fischer, 1854).

\section{Key to Australian Species of Alonella}

1. Polygons of valve reticulation with fine longitudinal striations $\ldots \ldots \ldots \ldots \ldots 2$

Polygons without such striations ......A. exigua (Lilljeborg, 1853)

2(1). Ventro-posterior corner of valve with few blunt indentations. Postabdomen

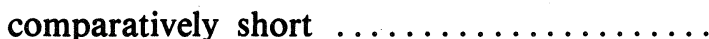
................ excisa (Fischer, 1854)

Ventro-posterior corner of valve without indentations; corner right-angled or rounded. Postabdomen comparatively elongated ........A. clathratula Sars, 1896

\section{Alonella excisa (Fischer, 1854)}

Lynceus excisus Fischer, 1854: 428-429, tab. 3, figs 11-14. Alonella excisa.-Lilljeborg, 1900: 510-513, tab. LXXII, figs 9-19.

Material. Qld: $37,41,43,48,49,51,55$. N.S.W.: 76, 81, 82, 89, 93, 176. Vic.: 222, 225, 232, 259, 260, 261. Tas.: 301, 303, 309, 314. S.A.: 369, 372, 388. W.A.: 421.

Slides. AM \& P27694, P27695, MGU \& 909, ZIN \& 1943.

Length. $0.45 \mathrm{~mm}$.

Ecology. In various waters, but rarely in acid dune lakes.

Distribution. Widespread in Australia.

Differential diagnosis. $A$. excisa is similar to $A$. clathratula in having striated polygons on the valve, but it differs because it has blunt indentations on the ventroposterior corner of the valve.

\section{Alonella clathratula Sars, 1896}

Fig. 26

Alonella clathratula Sars, 1896: 43-45, pl. 6, figs 7-8.Henry, 1922: 48.

Alonella excisa var. clathratula.-Delachaux, 1919: 31, pl. III, fig. 6.

Material. Qld.: 12, 13. N.S.W.: 79, 83, 91, 93, 96, 97, 98, 99, 100, 125. W.A.: 421, 425, 426.

Slides. AM \& P27693, MGU \& 2702, ZIN 2703.

Comments. Contrary to Delachaux's (1919) opinion, we now prefer the original status for it, as suggested by Sars (1896).

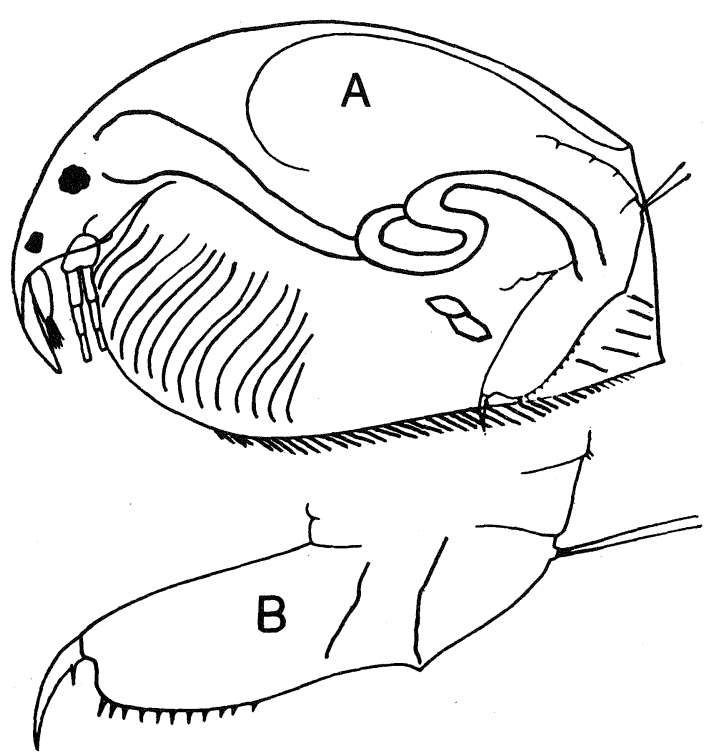

Fig. 26. Alonella clathratula $९$, after Smirnov, 1971b. A, whole animal, length $0.36 \mathrm{~mm} ; \mathrm{B}$, postabdomen.

Length. Sars (1896) indicates a length of up to $0.36 \mathrm{~mm}$, but a population from W.A. (No. 426) consisted of large individuals up to $0.49 \mathrm{~mm}$.

Ecology. A. clathratula is most likely to be found in very acid ( $\mathrm{pH}$ 3.5-5.0) coastal dune lakes, or similar acid waters in adjacent areas.

Type locality. Maroubra Swamp, Sydney (since drained).

Distribution. Eastern areas of Qld, N.S.W., and in south-west W.A.; also in southern Africa and South America.

Differential diagnosis. $A$. clathratula is readily distinguishable from $A$. excisa by comparatively more elongated valve and postabdomen, and by the lack of indentations at the ventro-posterior corner of the valve. The latter is right-angled or rounded.

\section{Alonella exigua (Lilljeborg, 1853)}

Lynceus exiguus Lilljeborg, 1853: 79, tab. VII, figs 9, 10. Alonella exigua.-P.E. Müller, 1867: 187-188, tab. IV, figs $16,17$.

Material. N.S. W.: 88 .

Comments. Pleuroxus reticulatus Henry, 1919: 478-479, pl. XLII, figs 13, 14, seems similar to Alonella exigua. However the holotype mentioned by Henry (Australian Museum N.P. 4333) has the surface of the carapace marked by reticulate sculpturing and minute pitting, so it is actually Monope reticulata (see later). In $A$. exigua there are no striations on the polygons of the shell (Fryer, 1968).

Length. $0.42 \mathrm{~mm}$

Distribution. Known only from one swamp (since drained) near Kempsey, N.S.W., but widespread in Holarctic. 
Differential diagnosis. There are no striations on the polygons of the valve.

\section{Nomen dubium}

Alonella propinqua Smith, 1909: 84, pl. 16, figs 6, 7

\section{Rak n. gen.}

Exopodite of thoracic limb IV with 7 setae. Head shield with one major head pore and broadly rounded anteriorly and posteriorly. Setae of ventral margin of valve situated on its edge, typically for its whole length. Antennule does not reach tip of rostrum, but lamellar outgrowth of labrum protrudes well beyond it. Mandibular articulation is of the Chydorinae type.

The name is derived from the Russian word for crustacean. The gender of the name is masculine.

The type species is Rak obtusus n. sp.

\section{Key to Species of $R a k$}

1. Blunt indentation on labrum ............. R. obtusus n. sp. Labrum entire ............ labrosus n. sp.

\section{Rak obtusus n. sp.}

Fig. 27

Material. N.S.W.: 81, 96, 98, 99, 100, W.A.: 426.

Holotype. AM \& P27698.

Paratypes. MGU @ 2841, ZIN 2842.

Slides. MGU @ 2848, 2849, 2850.

Female. Body in lateral view oval, length not much exceeding height. Dorso-posterior corner of shell just apparent. Ventro-posterior corner of valve rounded and usually with a denticle (absent on right valve of the paratype 2841). Setae of ventral border of valve situated

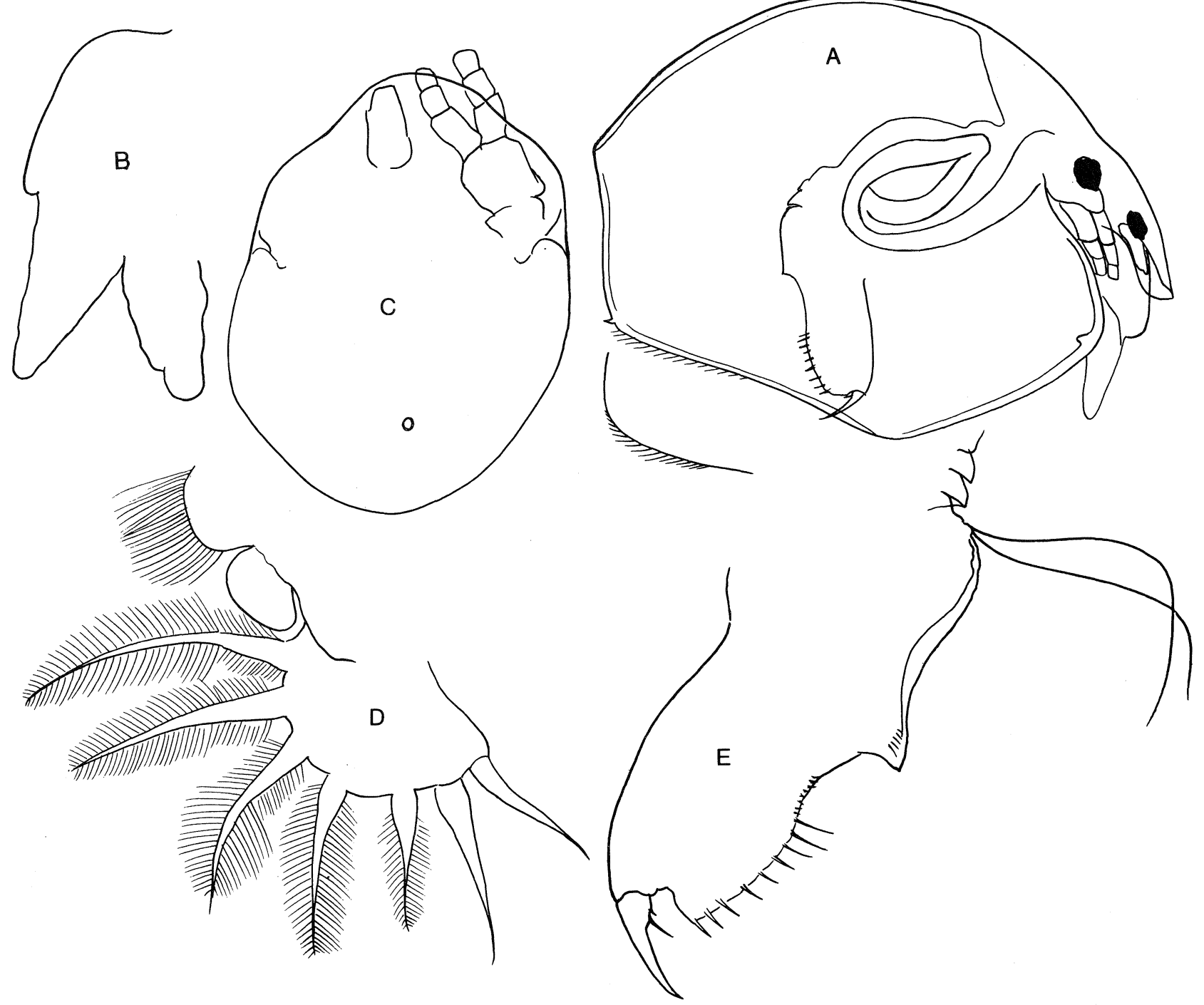

Fig. 27. Rak obtusus $९$, swamp near Sugar Point, The Broadwater, Myall Lakes, N.S.W., 13.iv.75. A, lateral view of whole animal, length $0.26 \mathrm{~mm}$, slide 2841; B, labrum, slide 2848; C, head shield, slide 2849; D, limb IV, slide 2848; E, postabdomen, slide 2850 . 
along its edge. Rostrum blunt. Ocellus situated between eye and tip of rostrum. Posterior end of head shield rounded. One head pore. Shell sculpture hardly visible.

Lamella of labrum unusual: apex blunt and a blunt indentation in middle of its front margin. Above this indentation, labrum noticeably more chitinized than below, where a lateral keel reaches to front edge of labral lamella. Antennule thick and short, not reaching to tip of rostrum. Exopodite of thoracic limb IV with 7 setae. Epipodites of legs I-IV lack outgrowths.

Postabdomen not elongated; its ventral margin convex, with anal edge concave, so that preanal angle protrudes noticeably. Distal side of postabdomen with a depression near base of claw.

Anal edge with small setae. About 9 anal teeth, which increase in size proximally.

Intestine convoluted.

Length. $0.26 \mathrm{~mm}$ (Holotype P27698).

Male. Unknown.

Ecology. R. obtusus lives amongst dense emergent vegetation in acid lakes on coastal sand dunes. It is active, swimming often from place to place. While on substrata all thoracic limbs move, otherwise they do not. It often simulates death.

Type locality. A dune swamp just inland from Sugar Point, The Broadwater, Myall Lakes National Park, N.S.W.

Distribution. In coastal dune lakes of north-eastern N.S.W.; isolated in W.A.

Differential diagnosis. The labral lamella has a blunt apex and a blunt indentation on the middle of its anterior edge. The setae of the ventral margin of the valve are all situated on its edge. There is one head pore. Adult size is relatively small (c. $0.26 \mathrm{~mm}$ ).

\section{Rak labrosus n. sp.}

Fig. 28

Material. Vic.: 204. Tas.: 314. S.A.: 372, 374. W.A.: 412.

Holotype. AM $\odot$ P27697.

Paratypes. MGU \& 2970, ZIN \& 2971.

Slide. MGU ๆ 2973.

Female. Body globular. Denticle on ventroposterior corner of valves not always present-in paratype 2970 it is absent on the left valve, but present on the right; in holotype $९$ P27697 and $९ 2973$ both corners have a denticle, but in paratype $\$ 2971$ only the left side has one. Setae of ventral border of valve situated along its edge, but at its end they pass, just slightly, onto the inner surface of valve. Rostrum blunt. One head pore.

Lamella of labrum large with an elongated, but blunt apex. No indentations on its edge. In the population from Loc. No. 374 the edge of the labral lamella is somewhat concave in the middle, while in the typical population (Loc. No. 372) it is evenly convex.

Postabdomen comparatively short, the preanal angle protruding.

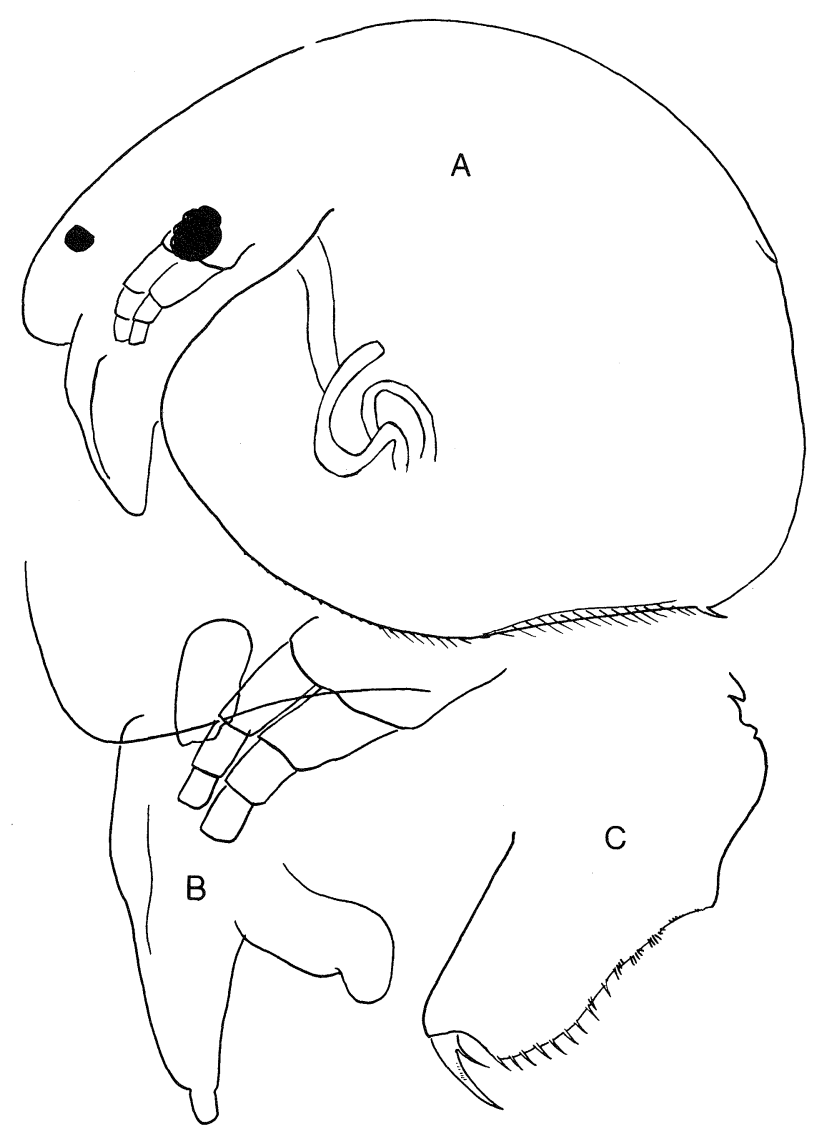

Fig. 28. Rak labrosus $\subsetneq$, Edwards Lag., Kangaroo I., S.A., 8.i.76. A, lateral view of whole animal, length $0.27 \mathrm{~mm}$, slide 2970 , pond near Forrestdale, W.A., 17.viii.73; B, labrum, slide 2973; C, postabdomen, slide 2973.

Length. $0.27 \mathrm{~mm}$ (holotype P27897).

Male. Unknown.

Type locality. Edwards Lagoon, Kangaroo Island, S.A.

Distribution. Southern coastal areas of Vic., S.A., and W.A.; also in Tas.

Differential diagnosis. The labral lamella is large; it has an elongated blunt apex. There are no indentations on the edge of the labrum, but it may be concave at its middle. The setae on the posterior end of the ventral margin of the valve pass just slightly onto its inner surface. The postabdomen is comparatively short. Adult size is relatively small (c. $0.27 \mathrm{~mm}$ ).

\section{Genus Chydorus Leach, 1816}

Chydorus Leach, 1816: 406.-Smirnov, 1971b: 277-79.

This and the following genera differ from Pleuroxus, Alonella and Rak in that the ventral setae of the valve are inserted on the inner surface of the valve in its posterior half instead of on its edge. As Fryer (1968) notes, the species of Chydorus exploit the globular form.

The status of Chydorus species has been recently described by Frey, 1980. 
The type species is Chydorus sphaericus (O.F. Müller, 1785).

\section{Key to Australian Species of Chydorus}

1. Labrum indented ................. 2

Labrum not indented ............... 3

2(1). Labrum with several denticles (serrations) ..... C. barroisi (Richard, 1894)

Labrum with one big tooth ............ .............. C. hybridus Daday, 1905

3(1). Apex of labrum rounded .............. ............... C. eurynotus Sars, 1901

Apex of labrum acute ............. 4

4(3). Apex of labrum elongated ........... 5

Apex of labrum not elongated ............

.............. C. clelandi Henry, 1919

$5(4)$. Valves smooth or marked in polygons

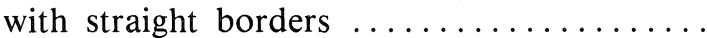
......... C. sphaericus (O.F. Müller, 1785)

Valves marked in polygons with sinuate borders ....... C. herrmanni Brehm, 1933

Chydorus sphaericus (O.F. Müller, 1785)

Fig. 29

Lynceus sphaericus O.F. Müller, 1785: 71-72, tab. IX, figs 7-9. Chydorus sphaericus. - Baird, 1843: 89-90, pl. II, figs 11-13; Smirnov, 1971b: 279-280.

Material. Qld: $56,57,58,65,66$. N.S.W.: 77, 82, 85, 87 , $102,103,104,105,106,108,109,110,111,112,113,114$, $115,117,121,125,128,129,132,133,142,147,148,166$, 168, 171, 172, 182, 184. Vic.: 201, 202, 204, 208, 218, 222, $227,229,232,236,237,238,241,245,249,252,255,256$, 257, 260, 261. Tas.: 292, 293, 294, 301, 302, 303, 305, 306, $307,309,310,312,313,314,315,317,324,325,328,329$, 330, 335, 339. S. A.: $362,365,366,367,369,382,383,384$, 388, 389, 391. W.A.: 406, 407, 411, 419.

Slides. AM $\subsetneq$ P27713, MGU $\subsetneq 1684$, ZIN $q 574$.

Comments. Chydorus sphaericus is polymorphic and a key to subspecies is available (Smirnov, 1971b). Although we have not delineated subspecies in this review, we report the presence of the distinctive form Chydorus sphaericus alexandrovi Poggenpol, 1874 from Locs Nos 117 and 369. This form is characterized by an expressed polygonal sculpture of the valves and by its small size $(0.32 \mathrm{~mm})$.

Length. Up to $0.6 \mathrm{~mm}$.

Ecology. This species lives in a wide range of environmental conditions and is often the dominant littoral cladoceran. Its numbers fluctuate seasonally - in L. Purrumbete it is uncommon during late summer and autumn and blooms in spring-early summer (Timms, 1973). When it is common in the littoral it may appear in the limnetic region, either clinging to algal filaments (Fryer, 1968), or swimming freely (Timms, 1973).

Distribution. Widespread in Australia, but apparently absent from tropical and adjacent areas.

Differential diagnosis. Body form is globular, with the ventro-posterior corner of the valve lacking denticles. The surface of the shell is smooth or has polygons with straight borders. The labrum is elongated and pointed; the labral lamella lacks serrations. The sensory papillae of the antennule are all placed at its end.

\section{Chydorus herrmanni Brehm, 1933}

Chydorus herrmanni Brehm, 1933: 759-761, figs 48-53.Frey, 1980: 98-99.

Material. Qld: 56.

Distribution. Known only from one site in southern Qld, but it could occur in tropical Australia as it is known from warm areas elsewhere (Smirnov, 1971b).

Differential diagnosis. It is very similar to $C$. sphaericus, but differs in that the polygons of the shell have sinuate borders.

\section{Chydorus eurynotus Sars, 1901}

Chydorus eurynotus Sars, 1901: 70, pl. II, fig. 3a-c.Paggi, 1972: 224-229.

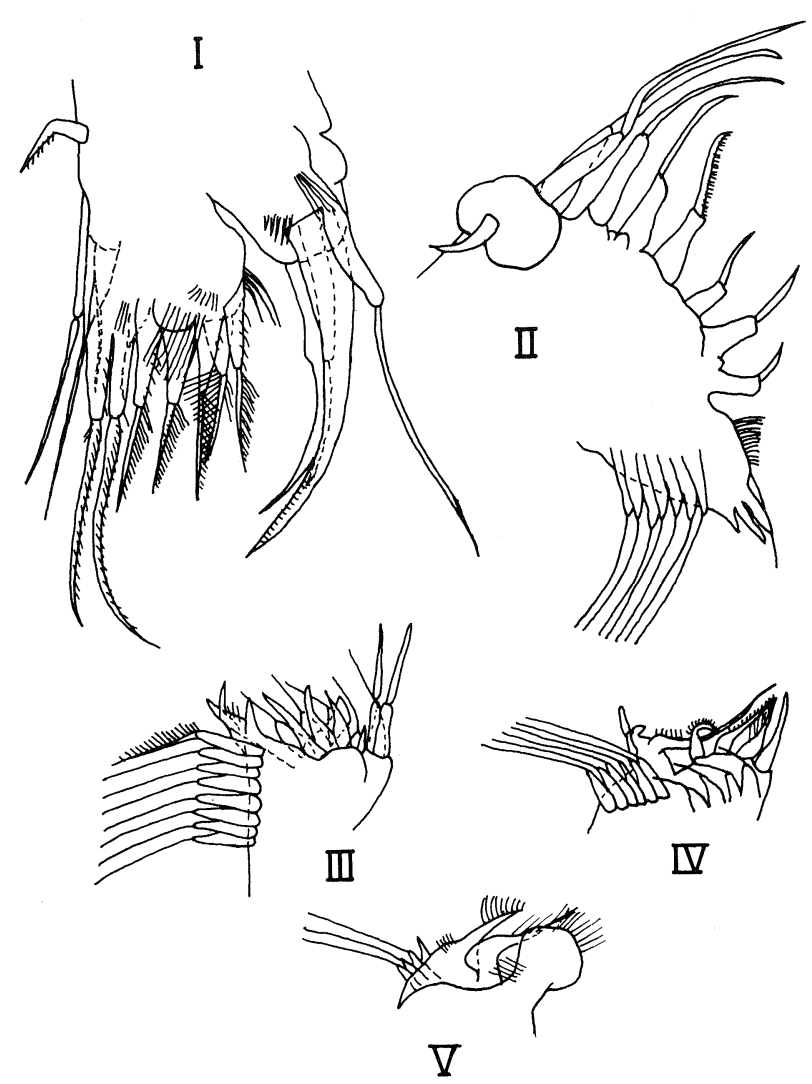

Fig. 29. Chydorus sphaericus $९$, thoracic limbs I-V, after Hann. 
Comments. Petkovski (1973: 146-152, figs 28-30, 33-35) ascribes specimens of this taxon, found in Clybucca Swamp, via Kempsey, N.S.W., to $C$. kallipigos Brehm, 1934. However, C. kallipigos has a wide blunt labrum without a concave depression at its tip, whereas in C. eurynotus the blunt labrum is slightly concave at its tip. All our specimens are very similar to C. eurynotus described in detail by Paggi (1972).

Length. Up to $0.47 \mathrm{~mm}$.

Differential diagnosis. Body form is globular, with the ventro-posterior corner of the valve lacking denticles. The labrum is blunt, slightly concave at its tip and with no serrations.

\section{Key to Australian Subspecies of Chydorus eurynotus}

1. Valve slightly reticulated, without depressions ....... C. eurynotus eurynotus Sars, 1901

Valve with depressions ...... C. eurynotus caelatus Smirnov, 1971

Chydorus eurynotus eurynotus Sars, 1901 Fig. 30

Chydorus eurynotus eurynotus Sars, 1901: 70, pl. 11, fig. 3a-c. -Paggi, 1972: 224-226, Lam. I, II.

Chydorus denticulatus Gurney, 1927: 76-77, fig. 11.

Material. Qld: 4, 5, 10, 11, 12, 19, 20, 21, 23, 25, 27, 28, $29,31,33,34,35,36,37,38,40,42,43,45,51,52,54,56$, $57,59,62,64$. N.S.W.: 80, 87, 89, 90, 92, 93, 95, 112, 117 , 119, 126, 127, 128, 131, 176. Vic.: 221, 222, 225, 249.
Slides. AM † P27710, MGU ๆ 1578, ZIN 1579.

Ecology. Like C. sphaericus, $C$. eurynotus occurs in a variety of waters, but mainly in warmer localities. It has been studied in Borumba Dam (Qld), where it is most common between February and August and is absent in summer (Timms and Midgly, 1969). It also strays into the limnetic region (Timms, 1970b).

Distribution. Mainly in Qld and coastal N.S.W.; also in inland N.S.W. and Vic.

Differential diagnosis. The shell surface is slightly reticulated and with no depressions.

Chydorus eurynotus caelatus Smirnov, 1971b Fig. 31

Chydorus eurynotus caelatus Smirnov, 1971b: 309, fig. 342.

Material. Qld: 13, 44.

Holotype. AM \& P27711.

Paratypes. MGU @ 1749, ZIN 1756.

Type locality. Farm dam near Gayndah, Qld.

Distribution. Qld.

Differential diagnosis. The shell has depressions.

Chydorus clelandi Henry, 1919

Chydorus clelandi Henry, 1919: 481-482, pl. XLII, figs $17,18$.

Material. Holotype N P:4335 (Kendall) in the Australian Museum.

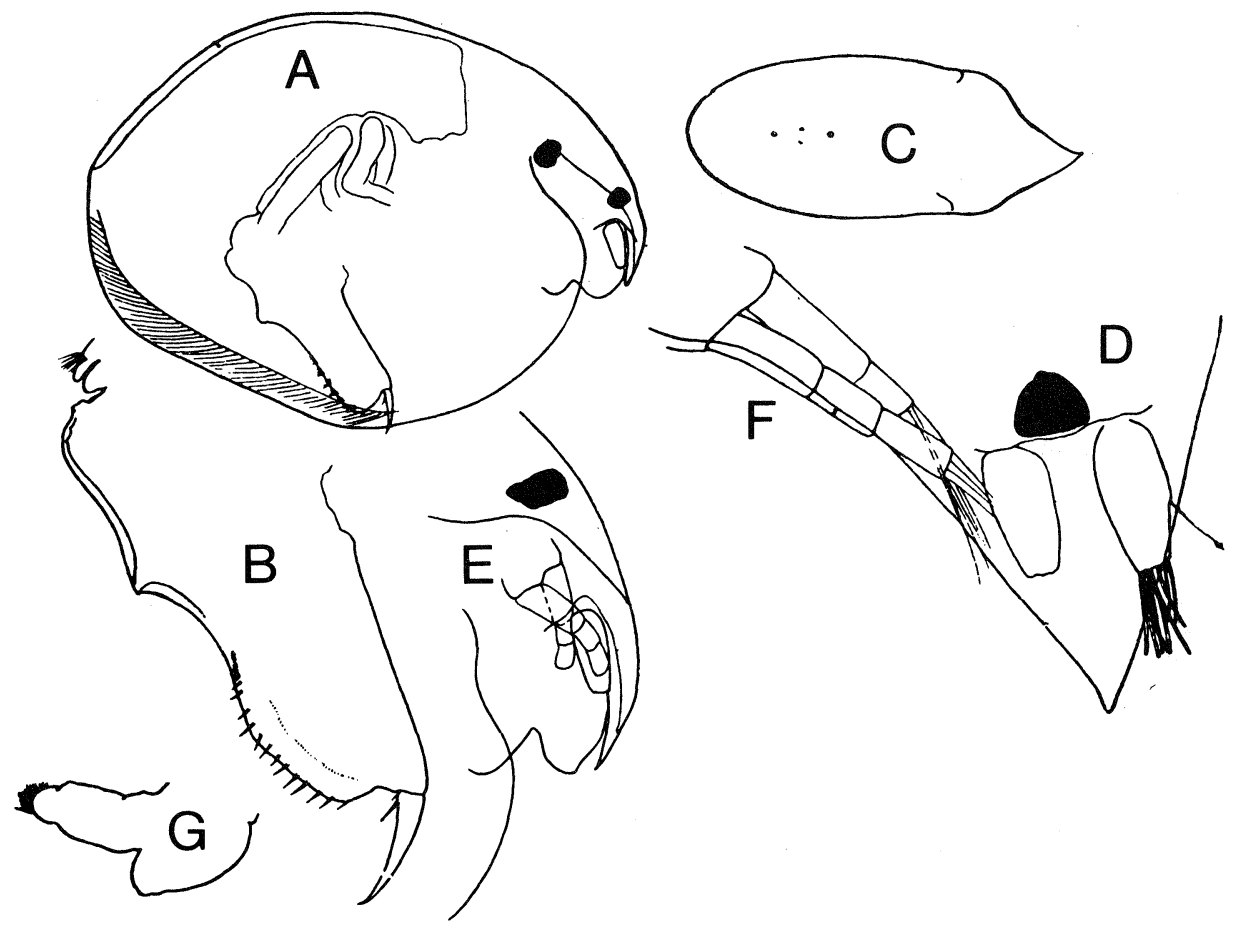

Fig. 30. Chydorus eurynotus eurynotus $\&$, after Smirnov, 1971b. A, whole animal, length $0.3 \mathrm{~mm}$; B, postabdomen; $\mathbf{C}$, head shield; D, anterior view of rostrum; E, head; F, antennule; G, labrum. 


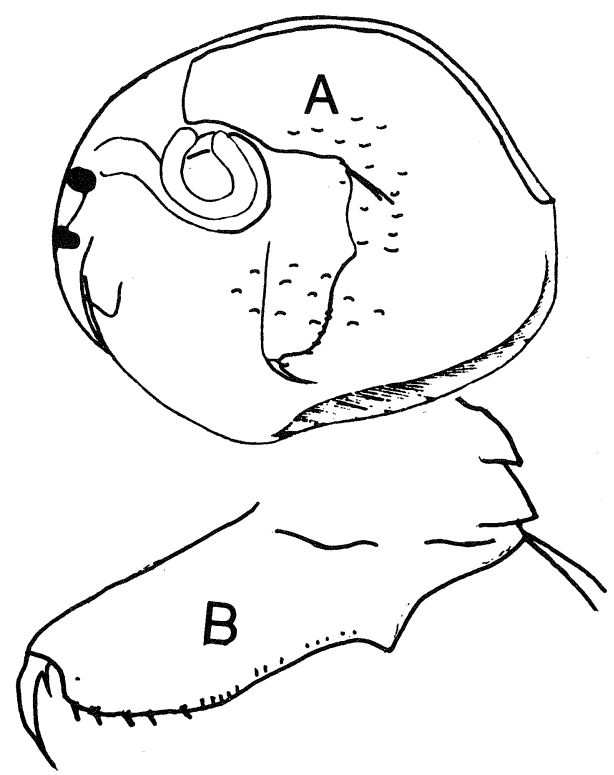

Fig. 31. Chydorus eurynotus caelatus $९$, after Smirnov, 1971b. A, whole animal, length $0.33 \mathrm{~mm} ; \mathbf{B}$, postabdomen.

Male. Unknown.

Type locality. Ponds at Kendall, Sydney, Lett River, N.S.W.

Distribution. N.S.W.

Differential diagnosis. It differs by having a wide labrum with the apex not elongated, but with an angular point. The post-anal edge of the postabdomen is somewhat convex and possesses rather thin anal teeth.

\section{Chydorus barroisi (Richard, 1894)}

Pleuroxus barroisi Richard, 1894: 375-377, figs 9-12.

Chydorus barroisi._Sars, 1895: 25-28, pl. 4, figs 9-13; Smirnov, 1971b: 298-301, figs 328-332.

Differential diagnosis. The ventro-posterior corner of the valve has a denticle, which, however, is sometimes absent. The labrum is serrated.

\section{Key to Subspecies of Chydorus barroisi}

1. Fore part of valve with lines parallel to its frontal margin ...................

...... C. barroisi barroisi (Richard, 1894)

Fore part of valve lacking such lines (described from New Zealand and not yet found in Australia) ................. .......... C. barroisi laevis (Sars, 1904)

\section{Chydorus barroisi barroisi (Richard, 1894)}

\section{Fig. 32}

Chydorus barroisi barroisi Smirnov, 1971b, 301, figs 328-333.-Petkovski, 1973a: 145, figs 25-27.

Since this was written in 1978, Chydorus barroisi and related species have been removed to a new genus Ephemeroporus, Frey, 1982.
Material. Qld: 2, 12, 14, 15, 17, 18, 22, 24, 25, 27, 28, $29,30,33,34,37,39,40,42,44,51,52,64$. N.S. W.: 76, 79, $81,83,88,96,125,170$. Vic.: 226. S.A.: 372, 374. W.A.: 405, 406.

Slides. AM \& P27708, O* P27709, MGU $९$ 1344, 1766, 1447, ZIN \& 1343.

Length. Up to $0.4 \mathrm{~mm}$.

Ecology. Judging from its distribution, C. barroisi is probably more eurythermic than $C$. eurynotus, but it is not successful in the colder areas of Australia, as C. sphaericus is. Although all three species are known to occur in markedly acid waters, $C$. barroisi is the one most likely to be found there. It is also planktonic at times of great abundance in the littoral (Timms and Midgly, 1969).

Distribution. Mainly in Qld and lowland N.S.W.; also in Vic., S.A., and W.A.

Differential diagnosis. The valve has polygons and lines; on the anterior part of the valve the latter are parallel to its frontal margin. The anal teeth of the postabdomen generally diminish gradually towards the anal aperture, but near it there are a few especially long teeth.

\section{Chydorus hybridus Daday, 1905}

\section{Fig. 33}

Chydorus hybridus Daday, 1905: 158-159, tab. X, figs 5-7. Material. Qld: 33. N.S.W.: 140, 160, 182.

Slides. AM ९ P27712, MGU \& 896, 1682, ZIN \& 1680.

Distribution. Inland areas of Qld and N.S.W.

Differential diagnosis. The shell is brown in Australian individuals. There is a denticle on the ventroposterior corner of the valve. The labral lamella has a single tooth. As in C. barroisi there are a few especially long anal teeth in the region of the anal aperture.

\section{Chydorus ovalis Kurz, 1874}

This species is mentioned by Henry (1922), in addition to the above species of Chydorus, as occurring in N.S.W. However she gives no figure, no morphological details in the text, and there are no specimens in her collection in the Australian Museum. As this is a Holarctic species, and further, since we have not encountered it in our extensive N.S.W. samples, we consider that this taxon is almost certainly absent from Australia.

The distinctive feature of $C$. ovalis is that not all the sensory papillae are situated on the distal end of the antennule; one is at some distance from its end.

\section{Incertae sedis}

Chydorus leonardi Sars, 1896: 30-31, pl. V, 4, 5. 

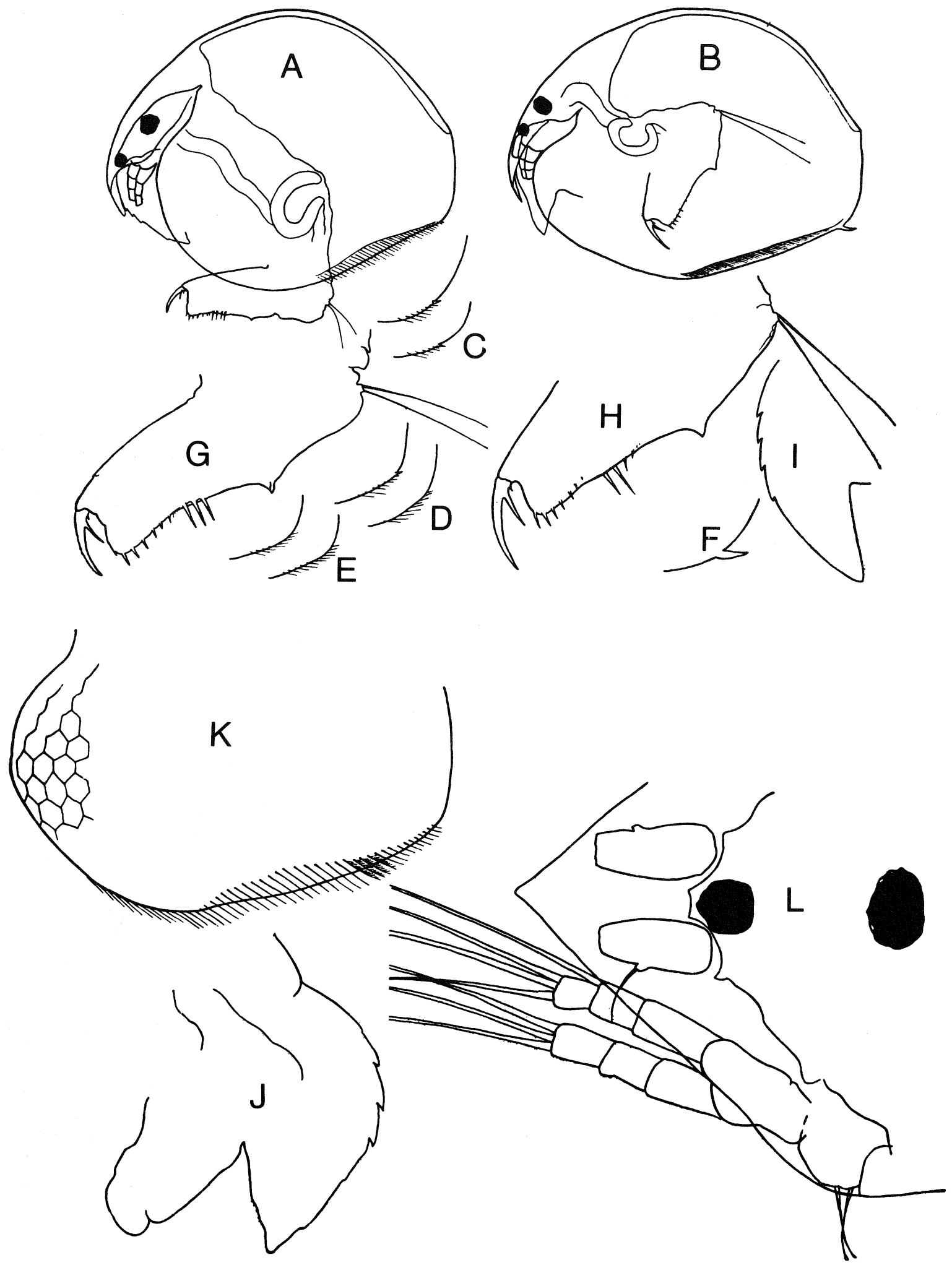

Fig. 32. Chydorus barroisi $ᄋ$, after Smirnov, 1971b. A \& B, whole animals, length $0.3 \mathrm{~mm}$; C, D, E, F: ventroposterior corner of valve; $\mathbf{G} \& \mathbf{H}$ : postabdomens; I \& J: labrum, $\mathbf{K}$, carapace; $\mathbf{L}$, rostrum. 


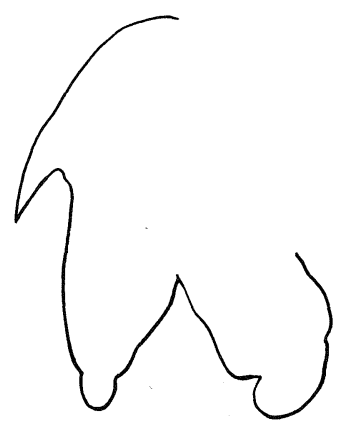

Fig. 33. Chydorus hybridus $\&$, labrum from Smirnov, 1971b.

\section{Genus Dunhevedia King, 1853}

Dunhevedia King, 1853b: 261.

Crepidocercus Birge, 1879: 24-25.

Landea Dybowski \& Grochowski, 1894: 382.

The type species is Dunhevedia crassa King, 1853.

\section{Dunhevedia crassa King, 1853}

Fig. 34

Dunhevedia crassa King, 1853b:261, pl. VII F._Sars, 1888: 42-46, pl. 5, figs 1-4; Henry, 1922: 44, pl. VI, figs 4, 4A; Brehm, 1953a: 68-69, fig. 8; Smirnov: 1971b: 319-320; Petkovski, 1973a: 143-145, figs 23, 24.

A number of forms have been described from Europe (Smirnov, 1971b), but only the typical subspecies has been found in Australia.

\section{Dunhevedia crassa crassa King, 1853}

Material. Qld: $2,8,11,12,16,18,22,23,24,32,35,37$, $41,43,44,52,57,64,65,66$. N.S. W.: 82, 93, 97, 99, 104, $105,111,112,114,115,117,127,129,130,133,136,140$, $142,156,159,164,166,168,170,174,176$. Vic.: 209, 224, 229, 230, 232, 237, 238, 245, 249. Tas.: 300, 312, 313, 319, $320,321,322,324,326,327,330,332,334$. S. A.: 367, 369, 380, 382, 390, 391.

Slides. AM \& P27715, MGU \& 1791.

Length. $0.55 \mathrm{~mm}$.

Ecology. D. crassa lives in a variety of habitats, but not in markedly acid waters. Seasonal peaks in numbers have been recorded between March and September in Borumba Reservoir (Timms and Midgly, 1969) and between March and April in L. Purrumbete (Timms, 1973). This species also sometimes strays into the limnetic zone.

Distribution. Widespread in eastern Australia; possibly also occurs in W.A.

Differential diagnosis. It is readily recognizable by its oval form, by the valve having a denticle below the ventro-posterior corner, by the oval postabdomen with the anal aperture on its functionally posterior side, and by the lack of serrations on the labral lamella.

\section{Incertae sedis}

Dunhevedia podagra King, 1853b: 261 , pl. VII E, has not been confirmed by any subsequent authors, including Henry (1922:44). King's description and figures are unconvincing. Accordingly we consider this taxon of doubtful validity.
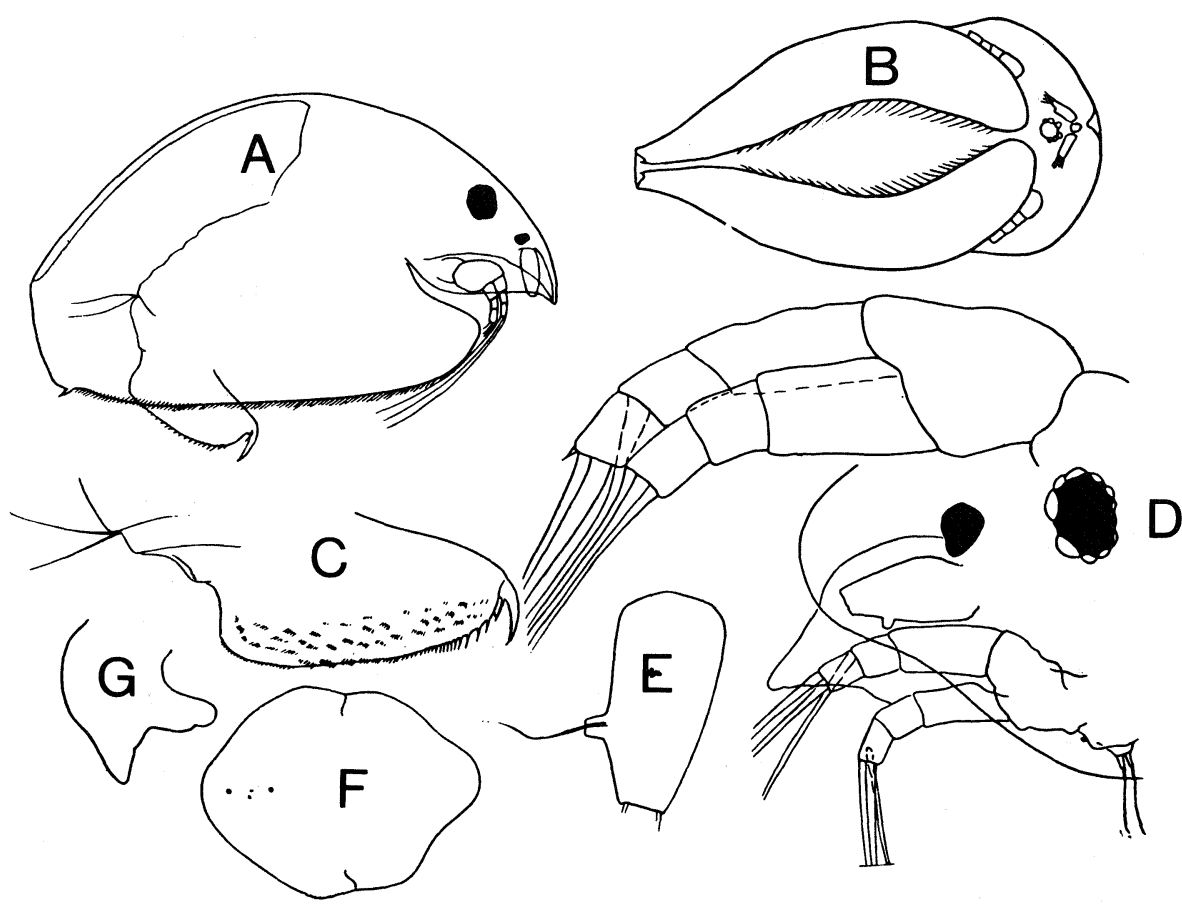

Fig. 34. Dunhevedia crassa $९$, after Smirnov, 1971b. A, lateral view of whole animal, length $0.44 \mathrm{~mm}$; B, ventral view of whole animal; $\mathbf{C}$, postabdomen; $\mathbf{D}$, rostrum and antenna; $\mathbf{E}$, antennule; $\mathbf{F}$, head shield; $\mathbf{G}$, labrum. 
Genus Dadaya Sars, 1901

Dadaya Sars, 1901: 73.-Smirnov, 1971b: 324-325.

Alona Daday, 1898: 38.

The type species is Dadaya macrops (Daday, 1898).

Dadaya macrops (Daday, 1898)

Fig. 35

Alona macrops Daday, 1898: 38-39, fig. 17.

Dadaya macrops.-Sars, 1901: 73-74, pl. XI, figs 5a, 5b; Smirnov, 1971b: 324-325.

Material. Qld: 2, 12, 14, 44, 48. N.S.W.: 82.

Slides. AM \& P27714, MGU ९ 1737, head shield 1748, ZIN $९ 2747$.

Length. Up to $0.41 \mathrm{~mm}$.

Ecology. Hyponeustonic (Fryer, 1968).

Distribution. Qld and northern N.S.W.

Differential diagnosis. It is dark brown. The antennule protrudes well beyond the tip of the rostrum. The eye and ocellus are very large.

\section{Genus Monope new name}

Monoporus Smirnov, 1977: 124-125. This name is a junior homonym of Monoporus Graff, 1891 (Turbellaria), so a new generic name is proposed.

Exopodite of thoracic limb IV with 7 setae. One major head pore. Head shield with a rounded posterior margin and an elongated rostral part. Antennule not reaching tip to rostrum. Labrum with a large lamellar outgrowth. Mandibular articulation of Chydorinae type.
The type species is Monope reticulata (Henry, 1922).

Monope reticulata (Henry, 1922)

Fig. 36

Pleuroxus reticulatus Henry, 1922: pl. VII, figs 2, 2 A.

Non Pleuroxus reticulatus Henry, 1919: 478-479, pl. XLII, figs $13,14$.

Monoporus henryae Smirnov, 1977: 125-126, fig 8.

Material. N.S.W.: 81, 82, 83, 96, 97, 98, 99, 100, 118, 142, Henry's slide in the Australian Museum "P.4333 Pleuroxus reticulatus Henry, Holotype, Pt. Stephens."

Holotype. Henry's slide in the Australian Museum 'P.4333 Pleuroxus reticulatus Henry, Holotype, Pt. Stephens". The type locality was mistakenly given as Myall Lakes in Smirnov, 1977.

Slides. AM \& P27719, MGU \& 1981, 1938, ZIN \& 1944, BM ᄋ 1974:126.

Female. Body oval in lateral view. Dorso-posterior corner of shell weakly developed and ventro-posterior corner with a blunt denticle. Valve covered with lines, which anastomose on its lower part to form elongated polygons. Ventral border of valve somewhat concave anterior to its midpoint; posteriorly setae of ventral margin of valve situated at some distance from its margin. Rostrum long and sharp. Ocellus situated closer to eye than to tip of rostrum.

Labral lamella well developed, protruding slightly beyond tip of rostrum and with a shallow depression on its apex. Both antennule and antenna not reaching to tip of rostrum; antennule narrows distally and antenna segments lack spines. Exopodite of thoracic limb IV with 7 setae.

Postabdomen elongated, its distal margin concave. Preanal angle blunt, not protruding. Anal teeth diminish

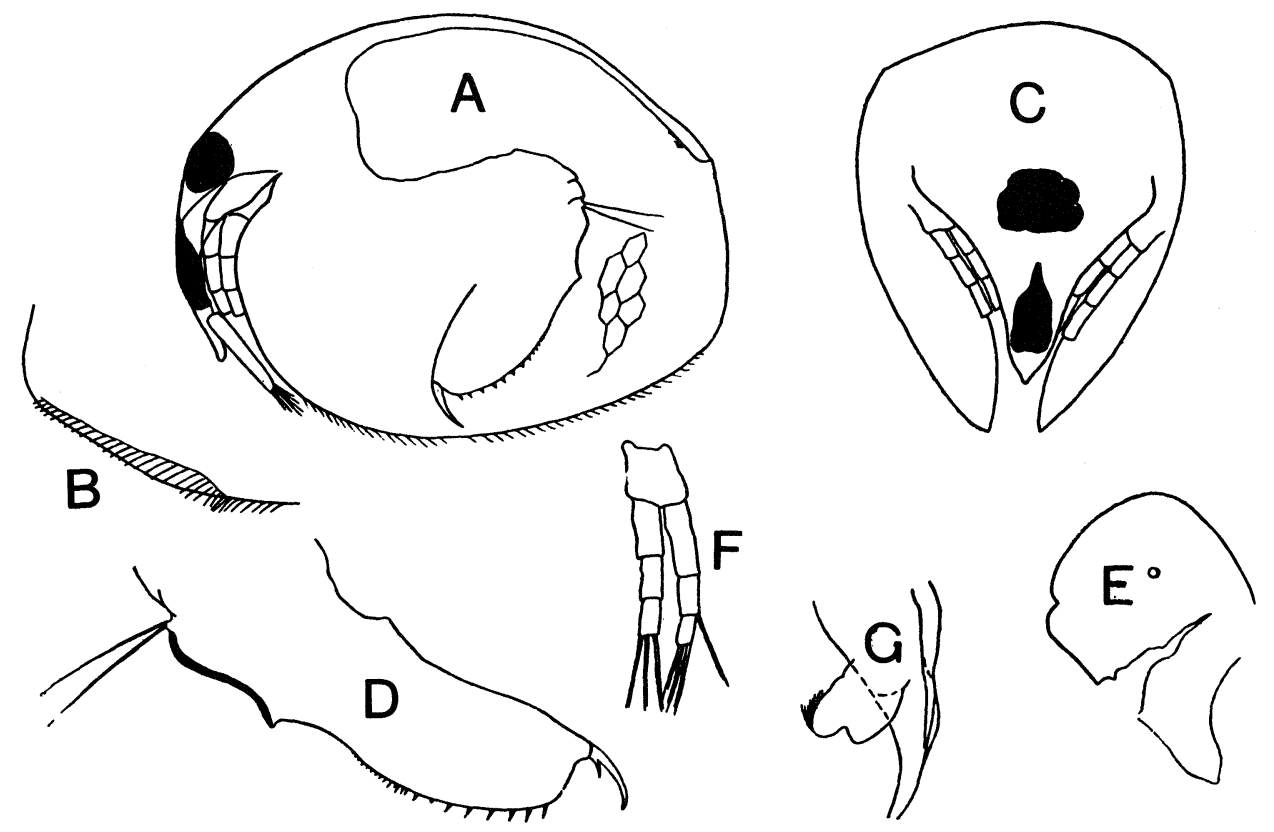

Fig. 35. Dadaya macrops $९$, after Smirnov, 1971b. A, lateral view of whole animal, length $0.35 \mathrm{~mm}$; B, edge of valve; C, frontal view of animal; D, postabdomen; E, head shield; F, antenna; G, labrum. 


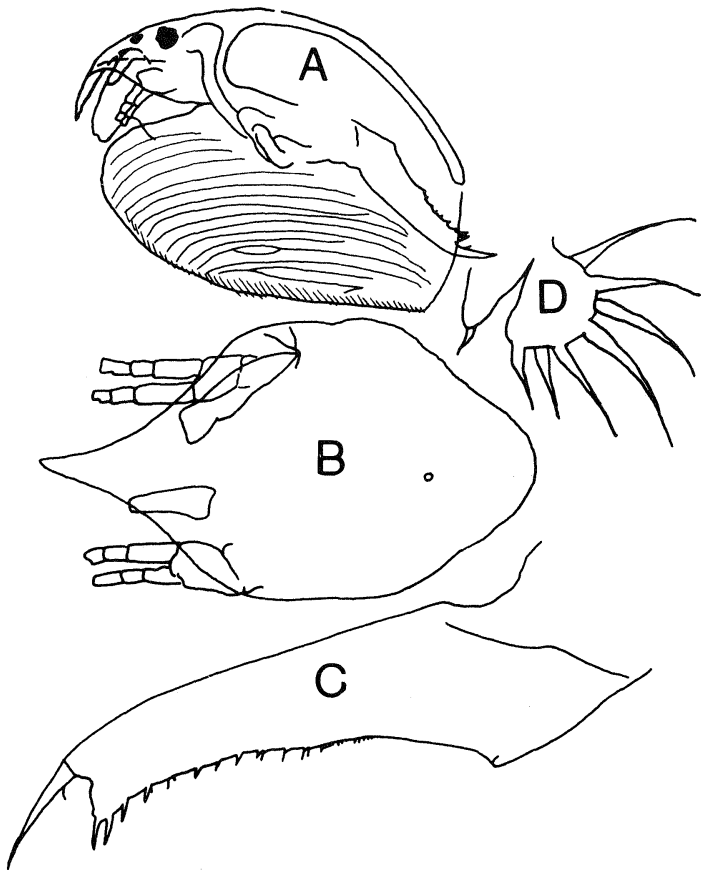

Fig. 36. Monope reticulata $९$, after Smirnov, 1977; A, whole animal, length $0.45 \mathrm{~mm}$; B, head with bases of antennule and antenna; $\mathbf{C}$, postabdomen; D, thoracic limb.

proximally and change from a regular to a clumped arrangement. Some of larger distal anal teeth attended by small denticles. About 14 anal teeth and groups of denticles.
Intestine convoluted.

Length. $0.45 \mathrm{~mm}$.

Male. Unknown.

Ecology. Usually found in acid waters amongst emergent vegetation.

Distribution. Coastal N.S.W.

Differential diagnosis. The postabdomen is greatly elongated. The head shield possesses one major head pore, a round posterior border, and its rostral part is elongated. The exopodite of thoracic limb IV has 7 setae. The antennule does not reach the tip of the rostrum.

\section{Genus Pseudochydorus Fryer, 1968}

Pseudochydorus Fryer, 1968: 323-324.-Smirnov, 1971b: 328-329.

The type species is Pseudochydorus globosus (Baird, 1843).

\section{Pseudochydorus globosus (Baird, 1843)}

Fig. 37

Chydorus globosus Baird, 1843: 90, tab. III, figs 1-4.-Sars, 1896: 31, pl. 5, figs 6, 7; Henry, 1919: 482; 1922: 46, pl. VII, figs $6,6 \mathrm{~A}$.

Pseudochydorus globosus.-Fryer, 1968: 323-324; Smirnov, 1971b: 328-329.

Material. Qld: 4, 48, 52, 64, 66. N.S.W.: 81, 127, 182, slide in the Australian Museum 'P: 5911 Chydorus globosus

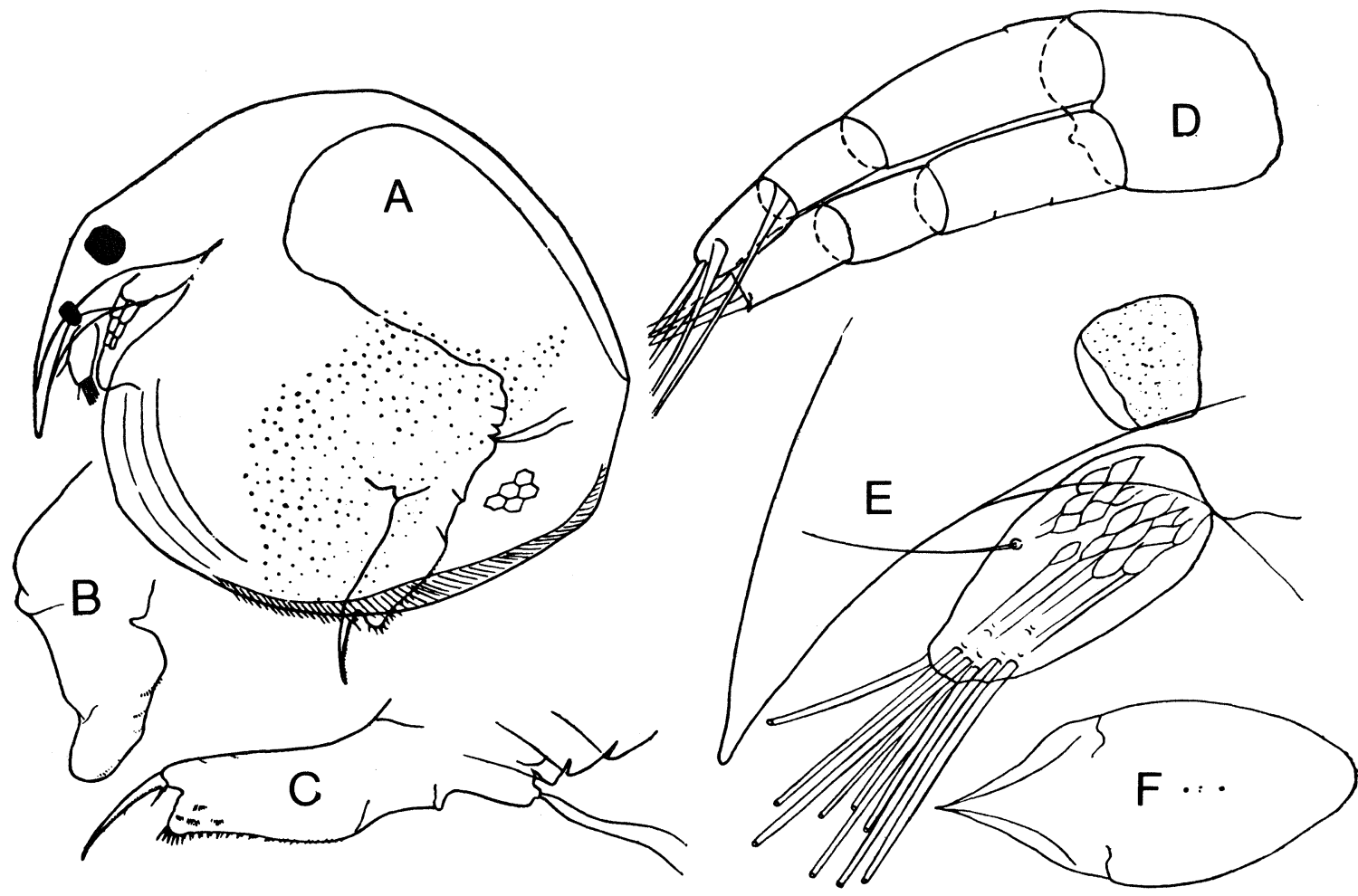

Fig. 37. Pseudochydorus globosus $९$, after Smirnov, 1971b. A, whole animal, length $0.72 \mathrm{~mm}$; B, labrum; C, postabdomen; D, antenna; E, rostrum and antennule; $\mathbf{F}$, head shield. 


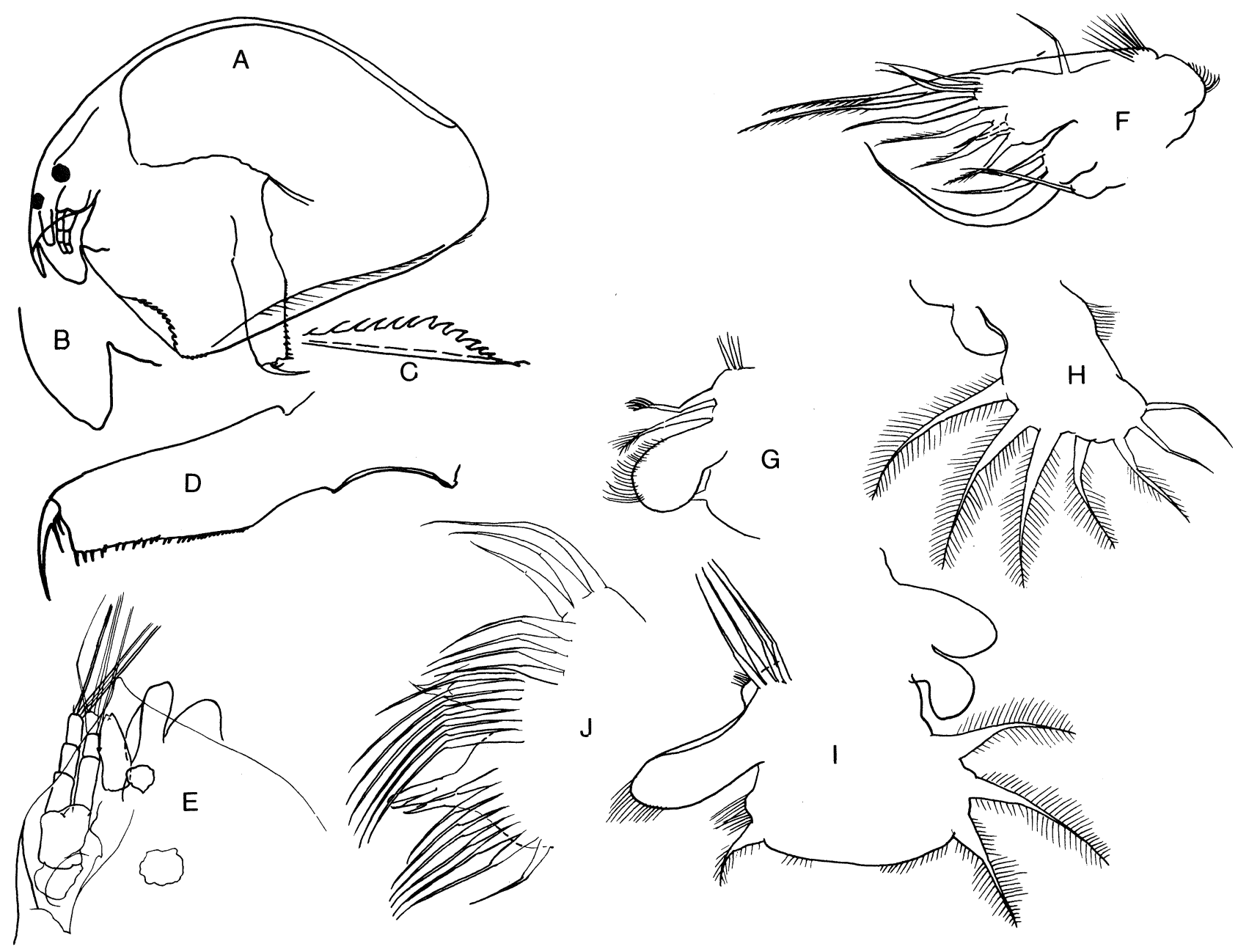

Fig. 38. Australochydorus aporus $\&$, L. Reeves, via Charters Towers, Qld, 19.vi.74. A, lateral view of whole animal, length $0.38 \mathrm{~mm}$; B, labrum; C, ventro-anterior edge of valve; D, postabdomen. (A-D from slide AMP 27696; Nyngan Weir, N.S.W., 13.xii.73.) E, head from above, slide 2710; F, thoracic limb I; G, thoracic limb IV; H \& I, thoracic limb V; J, gnathobases of thoracic limbs II and III. (F-J from slide 2712.)

Loc. Sydney"'. Vic.: 233, 238, 249, 255. Tas.: 301. S.A.: 362, 382.

Slides. AM $९$ P27724, MGU $\subsetneq 1781$.

Length. $0.65 \mathrm{~mm}$.

Ecology. It is known from both weeded littoral areas and muddy sublittoral zones of lentic waters. In Borumba Reservoir, Qld, it is a winter species (Timms and Midgly, 1969), but in L. Purrumbete, Vic., it occurs almost exclusively during summer and autumn (Timms, 1973). It feeds on the bodies of dead cladocerans (Fryer, 1968).

Distribution. Widespread, but not common, throughout eastern and southern Australia; possibly in also in W.A.

Differential diagnosis. It is yellow, commonly with a brown spot on each side. The labrum is without a lamella and the postabdomen is elongated.

\section{Incertae sedis}

Chydorus augustus King, 1853b: 258, pl. VII B.

There is some possibility that this taxon belongs to Pseudochydorus as the postabdomen has parallel edges and a chestnut colour is mentioned. King's figures are inadequate, so no definite conclusion is possible.

\section{Genus Australochydorus n. gen.}

Exopodite of thoracic limb IV with 7 setae. Head shield with no head pores. Rostrum elongated. Labrum with a large lamellar outgrowth. Antennule not reaching tip of rostrum. Antennal setae 0-0-3/0-1-3, spines 0-0-1/0-0-0. Postabdomen elongated. Anterior part of ventral border of valve with a semicircular serrated lobe directed inwards. Along posterior part of valve setae originate from inner surface at some distance from 
ventral margin (a characteristic of Chydorus, Pseudochydorus, Monope group of genera). Mandibular articulation of Chydorinae type.

The type species is Australochydorus aporus n. sp.

\section{Australochydorus aporus n. sp.}

Fig. 38

\author{
Material. Qld: 17, 25. N.S.W.: 176. \\ Holotype. AM ㅇ P27696. \\ Paratypes. MGU $\odot 2740, \mathrm{ZIN}$ \& 2746, BM $\odot 1980.359$, \\ DF \& 2742, MNHB \& 2745. \\ Slides. MGU \& 2710, 2711, 2712.
}

Female. Body in lateral view approximately oval, but with posterior part noticeably narrower. Dorsoposterior and ventro-posterior corners of valve broadly rounded. Ventral border of valve with a peculiar serrated infolded lobe in anterior part, the serrations continuing onto adjacent part of valve; posterior to this setae located on inner surface of valve, but near ventroposterior corner of valve they arise from edge. Rostrum elongated and acute, but its narrow apex truncated. No obvious sculpturing on shell.

Lamella of labrum large, protruding well beyond tip of rostrum. Shallow depressions on both sides of apex of labral lamella. Antennule not reaching tip of rostrum, narrowing distally, and with denticles on its apex. A spinule located lateral to base of antennular seta. Distance from antennule apex to tip of rostrum larger in type population, from L. Reeves, than in population from Nyngan Reservoir (Loc. No. 176). Ends of antennal rami not reaching tip of rostrum. The spine on one of terminal segments of antennal rami small.

Postabdomen elongated, narrowing distally. Its preanal angle protruding a little. Anal teeth small, numerous, and diminishing proximally into small thin denticles. Claw with two long basal spines, proximal one the shorter. Ocellus situated somewhat closer to eye than to tip of rostrum.

Exopodite of limb IV with 7 setae, that of limb $\mathrm{V}$ with 4 setae. Epipodites of these limbs without long outgrowths. External lobe of endite of leg I with 3 setae, each of different length; largest with a long tapering end. Gnathobases of thoracic limbs with fans of long setae, numbering 8 in limb II and 4 in limb V.

Length. $0.38 \mathrm{~mm}$.

Male. Unknown.

Type locality. Lake Reeves (via Charters Towers, Qld) (Loc. No. 17).

Distribution. Inland Qld and N.S.W.

Differential diagnosis. The ventral margin of the valve has a peculiar serrated infolded lobe in the anterior part and setae originating from the inside of the valve in its posterior part. The ventro-posterior corner of the valve is widely rounded, without denticles. The rostrum is acute. The labral lamella is large, reaching well beyond the tip of the rostrum. There are shallow depressions on both sides of the tip of the labral lamella. The postabdomen is elongated, narrowing a little at its end. The claw has two long basal spines.

\section{Genus Rhynchochydorus n. gen.}

General body form elongated; height of valve greatest posteriorly. Rostrum very long and reflexed posteriorly. Setae of ventral margin of valve situated along its edge; a few posterior setae very long. Labrum with a peculiar small rounded outgrowth. Exopodite of thoracic limb IV with 7 setae. Ocellus smaller than eye.

This form is analogous to Holarctic Rhynchotalona but belongs to a different subfamily.

The type species is Rhynchochydorus australiensis n. $\mathrm{sp}$.

\section{Rhynchochydorus australiensis n. sp.}

Fig. 39

\author{
Material. N.S.W. 96, 100. \\ Holotype. AM \& P27761. \\ Paratypes. $\mathrm{MGU}$ ○ 2829, ZIN $\subsetneq 2830, \mathrm{BM}$ ๆ 1980.367 \\ Slide. MGU @ 2833.
}

Female. Valve highest posteriorly and marked with widely spaced longitudinal lines. Rostrum very long and reflexed posteriorly. Dorso-posterior corner of shell just visible and blunt, while ventro-posterior corner broadly rounded and lacking denticles. Postabdomen elongated with parallel dorsal and ventral edges. Side bearing anal aperture much depressed, so that preanal angle is rectangular and prominent. Numerous anal teeth diminishing proximally and finally continuing into groups of small denticles. Claw with one small basal spine. Intestine convoluted.

Length. $0.3 \mathrm{~mm}$ (holotype $q \mathrm{P} 27761$ ).

Ecology. This species is known only from acid dune swamps, where it lives amongst decaying leaves and the stems of Lepironia articulata (Retzius) (Cyperaceae). Observations on living females revealed that the exopodites of thoracic limbs IV and V make continuous undulatory movements. This behaviour and the structure of the limbs suggest it is a secondary filter feeder, i.e. a chydorid collecting its food from substrata and subsequently using filtration.

Type locality. A swamp inland from Sugar Point on The Broadwater, Myall Lakes National Park (Loc. No. 100).

Distribution. North coast of N.S.W.

Differential diagnosis. It is easily recognized by its long rostrum, reflexed posteriorly. The shell is highest posteriorly. The setae of the ventral margin of the valve are situated along its edge; a few most posterior setae are very long. The ventro-posterior corner is broadly rounded, lacking denticles. The postabdomen is elongated, with parallel dorsal and ventral edges. Its anal teeth are well developed, diminishing proximally. The labrum has a peculiar small outgrowth. 


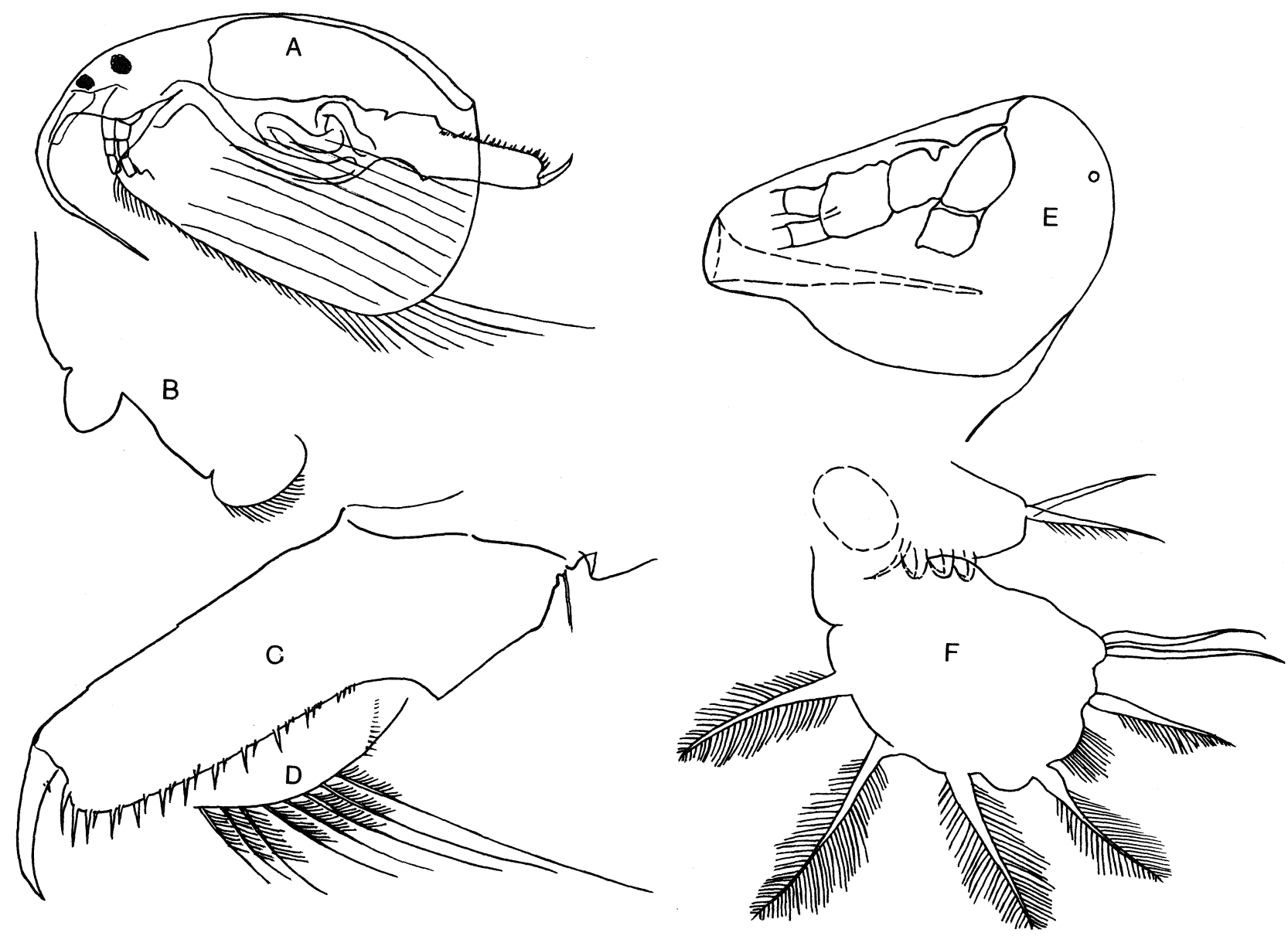

Fig. 39. Rhynchochydorus australiensis $९$, swamp near Sugar Point, the Broadwater, Myall Lakes, N.S.W., 13.v.75. A, lateral view of whole animal, length $0.33 \mathrm{~mm}$ from slide 2829; $\mathbf{B}$, labrum from slide 2830; $\mathbf{C}$, postabdomen from slide 2829; D, ventro-posterior corner of valve from slide 2829; $\mathbf{E}$, head shield from slide 2833; F, thoracic limb IV from slide 2833.

\section{Subfamily ALONINAE Frey, 1967}

Aloninae Frey, 1967: 36.-Smirnov, 1971b: 326-327.

The type genus is Alona Baird, 1843.

\section{Key to All Genera of Aloninae}

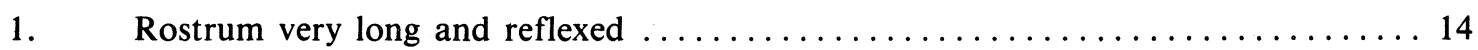

Rostrum comparatively short and not reflexed $\ldots \ldots \ldots \ldots \ldots \ldots \ldots \ldots \ldots \ldots \ldots \ldots$

2(1). Only an ocellus (i.e. no compound eye) ............... Monospilus Sars, 1862

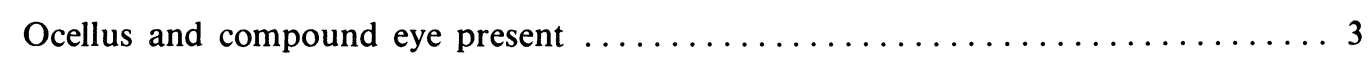

3(2). Head shield with three major head pores $\ldots \ldots \ldots \ldots \ldots \ldots \ldots \ldots \ldots \ldots$

Head shield with two or one major head pore $\ldots \ldots \ldots \ldots \ldots \ldots \ldots \ldots \ldots \ldots$

4(3). Lateral setae of postabdomen extremely large. Anal teeth very small ....................................... Leydigia Kurz, 1875

Lateral setae of postabdomen not very large $\ldots \ldots \ldots \ldots \ldots \ldots \ldots \ldots \ldots$

5(4). Anterior margin of head shield broadly rounded and protruding (in lateral view).

Ventral outline of valve straight. Postabdomen short ...... Graptoleberis Sars, 1862 
Anterior margin of head shield not broadly rounded and not protruding

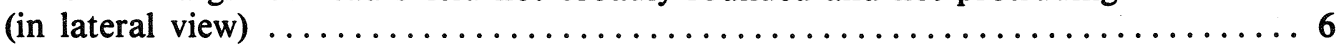

6(5). Postabdomen long and narrow $\ldots \ldots \ldots \ldots \ldots \ldots \ldots \ldots \ldots \ldots \ldots \ldots$

_ Postabdomen of various forms, but not narrow or very long ..... Alona Baird, 1843

7(6). Postabdomen straight with parallel dorsal and ventral

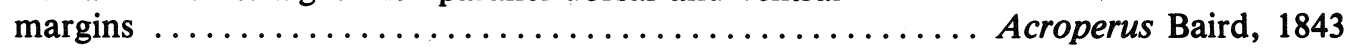

Postabdomen narrows distally $\ldots \ldots \ldots \ldots \ldots \ldots \ldots \ldots \ldots \ldots \ldots \ldots \ldots$

8(7). Rostrum somewhat elongated. Legs III and IV noticeably

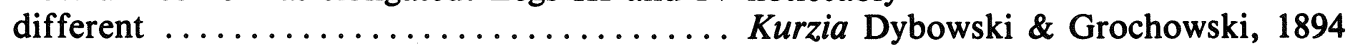

_ Rostrum not elongated. Legs III and IV superficially similar ............ 9

9(8). Postabdomen very long. Most species with a dorsal keel on

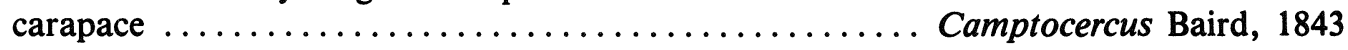

Postabdomen of moderate length (length:width is not more than 4.3).

No cephalic or dorsal keel (Endemic to

L. Baikal) ..................... Kozhowia Vasiljeva \& Smirnov, 1969

10(3). Head shield with two major head pores $\ldots \ldots \ldots \ldots \ldots \ldots \ldots \ldots \ldots \ldots \ldots \ldots$

Head shield with one major head pore $\ldots \ldots \ldots \ldots \ldots \ldots \ldots \ldots \ldots \ldots \ldots$

11(10). Major head pores separate .......... Oxyurella Dybowski \& Grochowski, 1894

Major head pores connected $\ldots \ldots \ldots \ldots \ldots \ldots \ldots \ldots \ldots \ldots \ldots \ldots \ldots \ldots \ldots \ldots$

12(11). Narrow connection between major head pores .......... Biapertura Smirnov, 1971

Wide connection between major head pores (Palaearctic, South Africa) .......... $\ldots \ldots \ldots \ldots \ldots \ldots \ldots \ldots \ldots \ldots \ldots \ldots$ Tretocephala Frey, 1971

13(10). Body length considerably exceeds its height .............. Euryalona Sars, 1901

Body length only just exceeds its height (India, but recently found near Darwin by BVT) .......................... Indialona Petkovski, 1966

14(1). Rostrum very long and strongly reflexed backwards. Few anal teeth, the distal ones especially large (Holarctic) ......... Rhynchotalona Norman, 1903

Rostrum elongated and weakly reflexed backwards. Numerous anal teeth on a wide and oval postabdomen (Neotropical) ....... Leydigiopsis Sars, 1901

\section{Incertae sedis}

Eurycercus spinosus King, 1853b: 257, pl. VIID. -Sars, 1888: 69.

This problematic form is too vaguely figured by King for a generic assignment, but it seems to belong within the Aloninae.

\section{Genus Alona Baird, 1843}

Subgenus Alona.-Baird, 1843: 92. Alona.-Smirnov, 1971b: 337-8.

Of the great variety of species that were once assigned to this genus only the forms having three major head pores are now placed here (Smirnov, 1971a).

The type species is Alona quadrangularis (Müller, 1785).

\section{Key to Australian Species of Alona}

1. Postabdomen somewhat elongated, dorsal and ventral edges parallel .......... 2

Postabdomen not elongated, dorsal and ventral edges not parallel ...........5

2(1). Lateral setae of postabdomen arranged singly $\ldots \ldots \ldots \ldots \ldots \ldots \ldots \ldots \ldots$

Lateral setae of postabdomen grouped $\ldots \ldots \ldots \ldots \ldots \ldots \ldots \ldots \ldots \ldots \ldots$ 
3(2). Claw with a very large basal spine. Ocellus larger than eye ...A. macracantha $\mathrm{n} . \mathrm{sp}$. Claw with a small basal spine. Eye larger than ocellus ....... A. archeri Sars, 1888

4(2). Valve completely smooth $\ldots \ldots \ldots \ldots \ldots \ldots \ldots \ldots \ldots$. laevissima Sars, 1888
Valve granulated
A. pulchella King, 1853

5(1). Distal and dorsal edges of postabdomen widely rounded $\ldots \ldots \ldots \ldots \ldots \ldots \ldots$

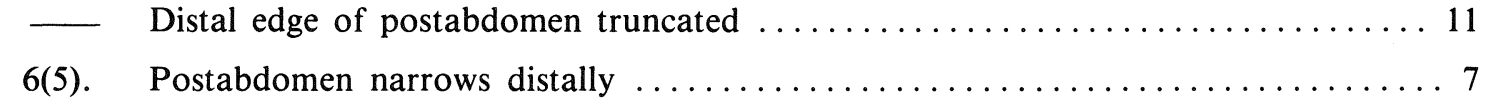

Postabdomen does not narrow distally $\ldots \ldots \ldots \ldots \ldots \ldots \ldots \ldots \ldots \ldots$

7(6). Anal teeth of postabdomen extremely small ............. investis n. sp.

- Anal teeth normal-sized .................... davidi Richard, 1895

8(6). Distal part of postabdomen bearing anal teeth comparatively longer than proximal part without teeth; about 18 anal teeth ... A. quadrangularis (Müller, 1785)

_ Distal part of postabdomen comparatively shorter with $<18$ anal teeth ........9

9(8). Anal teeth rather large, distinctly grouped. Most distal seta in each lateral fascicle reaching beyond dorsal margin of postabdomen

A. poppei Richard, 1897
Anal teeth small. Most distal seta in each lateral fascicle reaching, at most,

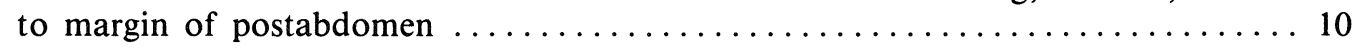

10(9). Major head pores connected. About 9 anal teeth ......... A. rectangula Sars, 1862
Major head pores separate. $>10$ anal teeth
A. setuloides n. sp.

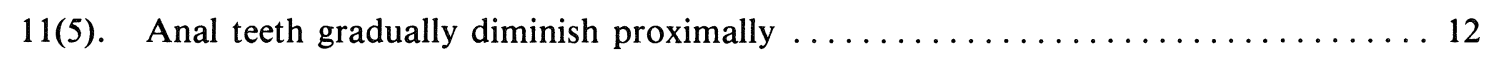

Four distal anal teeth much larger and longer

than proximal ones $\ldots \ldots \ldots \ldots \ldots \ldots \ldots \ldots$. inreticulata Shen et al., 1964

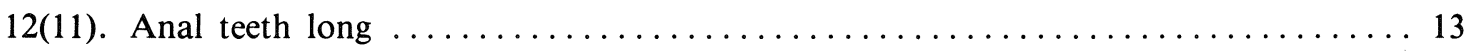

Anal teeth short $\ldots \ldots \ldots \ldots \ldots \ldots \ldots \ldots \ldots \ldots$. clathrata Sars, 1888

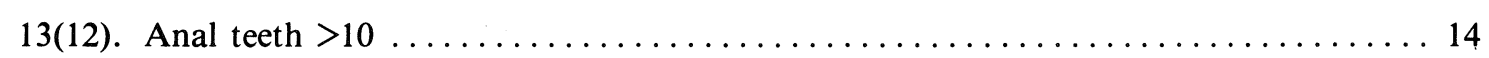

Anal teeth normally $<10$; anal margin of postabdomen deep so that preanal angle protrudes .......................... guttata Sars, 1862

14(13). Valve marked with longitudinal lines. Minor head pores transverse. Anal margin of postabdomen' shallow so that preanal angle wide and protruding little $\ldots \ldots \ldots \ldots \ldots \ldots \ldots \ldots \ldots \ldots \ldots \ldots \ldots \ldots \ldots \ldots \ldots \ldots \ldots \ldots \ldots$ costata Sars, 1862

_ Valves marked with polygons with granules ... A. cambouei Guerne \& Richard, 1893

Alona quadrangularis (Müller, 1785) Fig. 40

Lynceus quadrangularis O.F. Müller, 1785: 72-3, tab. IX, figs 1-3.

Alona quadrangularis. -Smirnov, 1971b: 340-1, figs 382-6.

Material. Vic.: 263. W.A.: 422.

Slides. AM $\odot 31306,31308$, MGU $\odot 3022$, ZIN $\$ 3023$.

Length. $0.52 \mathrm{~mm}$ (slide 3022).

Distribution. Sparse in southern Victoria and in south-western W.A., possibly in other states.

Differential diagnosis. Externally it is very similar to Biapertura affinis. However the head shield has three major head pores, which are connected, and the external branch of the endite of thoracic limb I has three setae, one of them being small and not hook-like. The valves of the females in the studied population have sparsely spaced longitudinal lines.

\section{Alona davidi Richard, 1895}

Alona davidi Richard, 1895: 192-5, figs 5-8.-Smirnov, 1971b: 368-71.

Alona diaphana King, 1853b: 260, pl. VIIIC. 

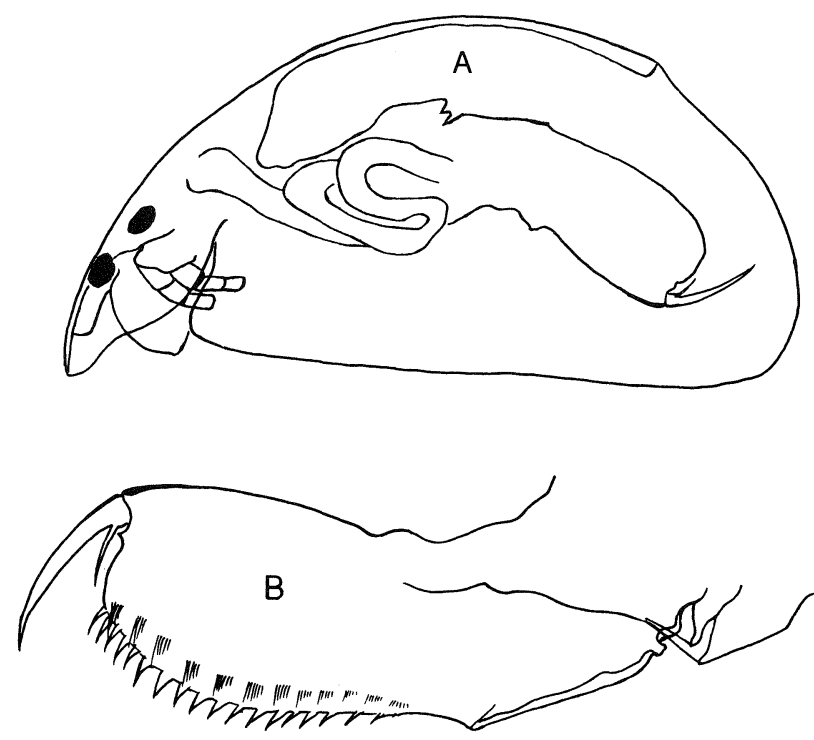

Fig. 40. Alona quadrangularis $\odot$, a swamp near Shannon, W.A., 8.vii.76. A, lateral view of whole animal, length $0.52 \mathrm{~mm} ; \mathbf{B}$, postabdomen. (Both from slide 3022.)

Material. Qld: 9, 11, 15, 21, 23, 31, 32, 35, 59, 61, 65, 66. N.S.W.: 92, 112, 116, 123, 127, 128, 129, 130, 131, 132, $138,139,142,152,156,160,161,166,167,172,181$. Vic.: 224, 225, 229, 238, 257. Tas.: 314, 334. S.A.: 362, 372, 380. W.A.: $401,412,415$.

Distribution. Widespread in Australia.

Differential diagnosis. The body is comparatively high, with both dorsal and ventral sides convex. The rostrum is blunt. The postabdomen narrows distally. key.

The known forms may be identified by the following

\section{Key to Subspecies of Alona davidi}

1. Valve with polygons, but no granules; anal teeth of postabdomen in subgroups of 2-4 arranged in 10-11 groups ....... A. davidi davidi Richard, 1895

- Valve granulated or lineated ......... 2

2(1). Valve granulated (polygons sometimes present) . . . . A. davidi punctata Daday, 1898

- Valve with longitudinal lines ......... 3

3(2). Longitudinal lines on valve sparse ...... A. davidi iheringi Richard, 1897

- Longitudinal lines on valve fine and densely arranged .......A. davidi vermiculata n. ssp.

Alona davidi punctata Daday, 1898

Alona davidi punctata Daday, 1898: 39-41, fig. 18.

Material. Qld: 66. Vic.: 240.

Distribution. Eastern Australia; World: Ethiopic and Neotropical regions.

\section{Alona davidi iheringi Richard, 1897}

Fig. 41

Alona davidi iheringi Richard, 1897: 294-296, figs 42-43. Alonella diaphana Sars, 1888: 47-50, pl. 5, figs 5-7.

Material. Qld: 59, 64. N.S.W.: 166, 172, Vic.: 238. S.A.: $372,374,380$.

Slides. AM q P27686, MGU \& 1581, ZIN \& 1024.

Female. Valve with longitudinal lines, sparsely arranged. Lineation of valves very noticeable in specimens from locality No. 238.

Length. Up to $0.49 \mathrm{~mm}$.

Distribution. Australia: eastern parts; World: Ethiopic and Neotropical regions and south of U.S.S.R.

\section{Alona davidi vermiculata $\mathbf{n}$. ssp.}

Material. N.S.W.: 136, 139, 152.

Slides. AM $\subsetneq$ P27687, MGU $\subsetneq$ 2892, ZIN 2891.

Female. Longitudinal striations of valve very closely spaced leaving no free space. Thus when the valve is viewed in reflected light there is an iridescent reflection.

Distribution. Monaro region of southern N.S.W.

\section{Alona costata Sars, 1862}

Alona costata Sars, 1862b: 286.-Smirnov, 1971b: 371-373.

Material. N.S. W.: 115, 117, Vic.: 201, 253. Tas.: 315. S.A.: 388 .

Length. Up to $0.6 \mathrm{~mm}$.

Distribution. Sparse in south-eastern Australia.

Differential diagnosis. The postabdomen is truncated, its anal teeth gradually diminishing proximally. The margin of the anal aperture is slightly concave. The valve is longitudinally lineated. This species is very similar externally to Biapertura setigera but there are three major head pores.

\section{Alona cambouei Guerne \& Richard, 1893}

Fig. 42

Alona cambouei Guerne \& Richard, 1893: 242-244, figs 10-11.-Henry, 1919: 477; 1922: 42; Smirnov, 1971b: 377, figs $444-446$.

Material. Qld: $8,9,10,13,17,18,19,26,30,31,35,37$, 41, 42, 43, 56. N.S. W.: 87, 93, 110, 137, 139, 156, 160, 169, $171,181,182,184,187$. Vic.: 207, 236, 240, 245. S.A.: 359, $382,384,387$.

Slides. AM $\subsetneq$ P27685, MGU @ 1279, ZIN 1538.

Length. $0.47 \mathrm{~mm}$.

Ecology. Besides inhabiting the weeded littoral regions of a variety of waters, this species may sometimes be limnetic. The same applies for a number of other species of Alona, including A. guttata and $A$. rectangula. 


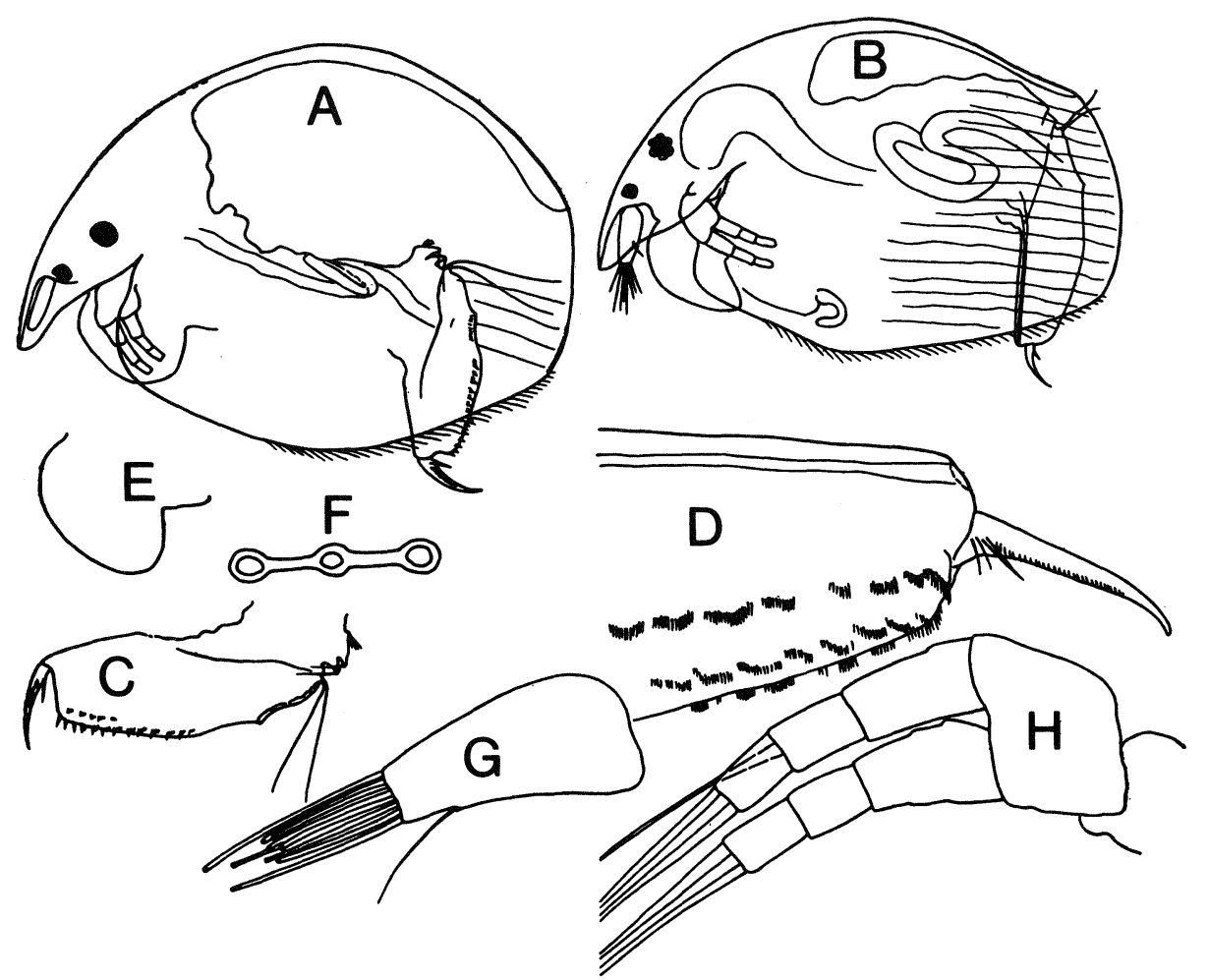

Fig. 41. Alona davidi iheringi $९$, after Smirnov, 1971b. A \& B, whole animals, length $0.42 \mathrm{~mm}$; C \& D, postabdomens; E, labrum; F, head pores; G, antennule; H, antenna.
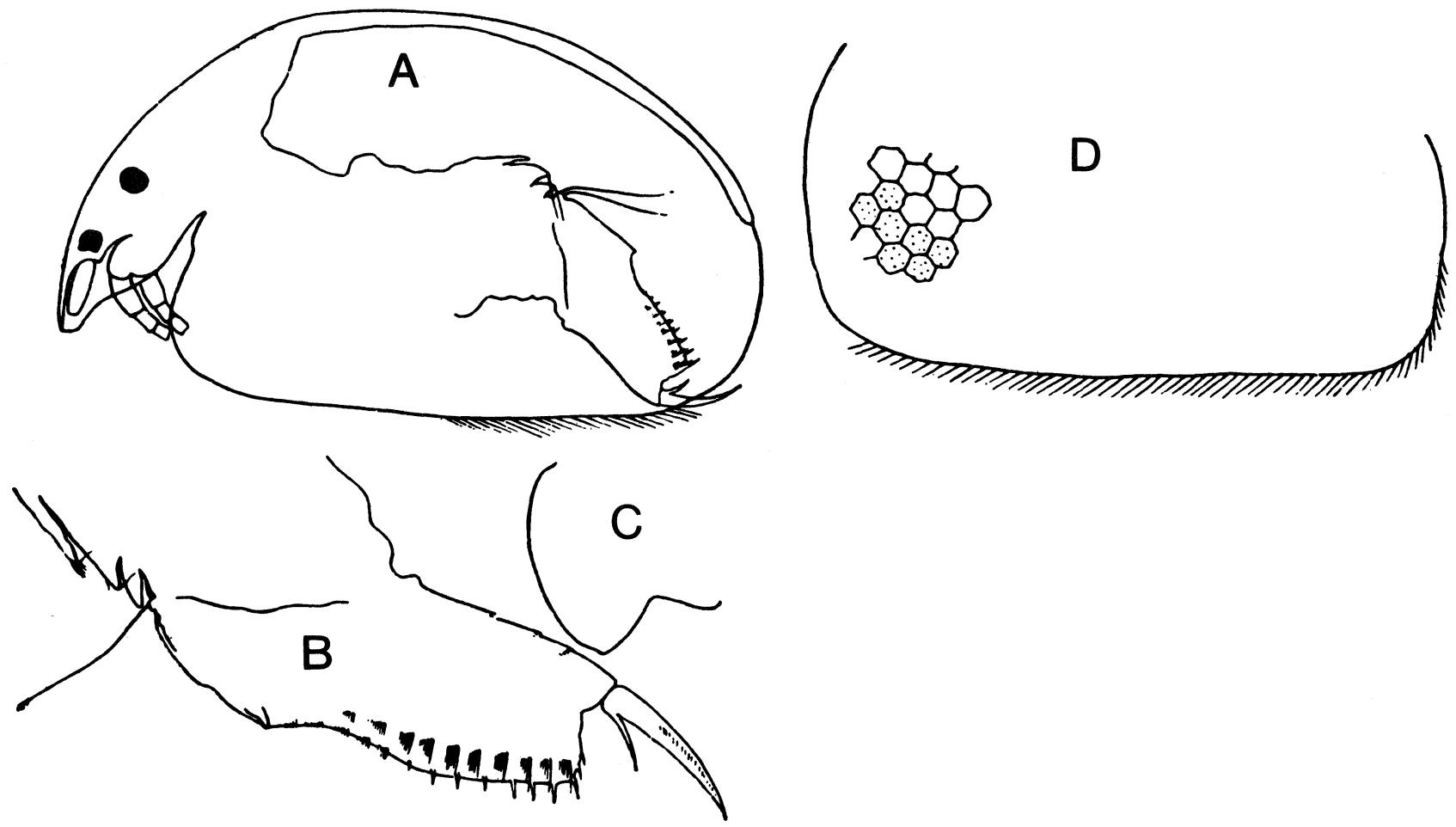

Fig. 42. Alona cambouei $\$$, after Smirnov, 1971b. A, whole animal, length $0.47 \mathrm{~mm}$; B, postabdomen; C, labrum; D, carapace. 
Distribution. Eastern mainland Australia.

Differential diagnosis. The valve is marked in polygons which are distinctly granulated. The labrum has no serrations. The postabdomen of the female narrows slightly distally; its dorsal edge is convex, and distal edge truncated. The anal teeth and fascicles of lateral setae are well developed; the anal teeth gradually diminish proximally.

Alona inreticulata Shen Chia-jui et al., 1964

Fig. 43

Alona inreticulata Shen Chia-jui, Sung Ta-hsiang \& Chen Kuohsiao, 1964: 215, 223-224, figs 9-12.

Material. Vic.: 211. Tas.: 324.

Slides. AM \& 31305, MGU \& 2942, 2950, ZIN \& 2943.

Female. Three major head pores. Antennule not reaching tip of rostrum. Antennal setae 0-0-3/1-1-3, and spines 1-0-1/0-0-1. Thoracic limb I with three setae (one short, two long) on external branch of endite. The long setae feathered differently-one on its distal half, the other at the tip.

Length. $0.62 \mathrm{~mm}$.

Distribution. Sparse in southern Australia.

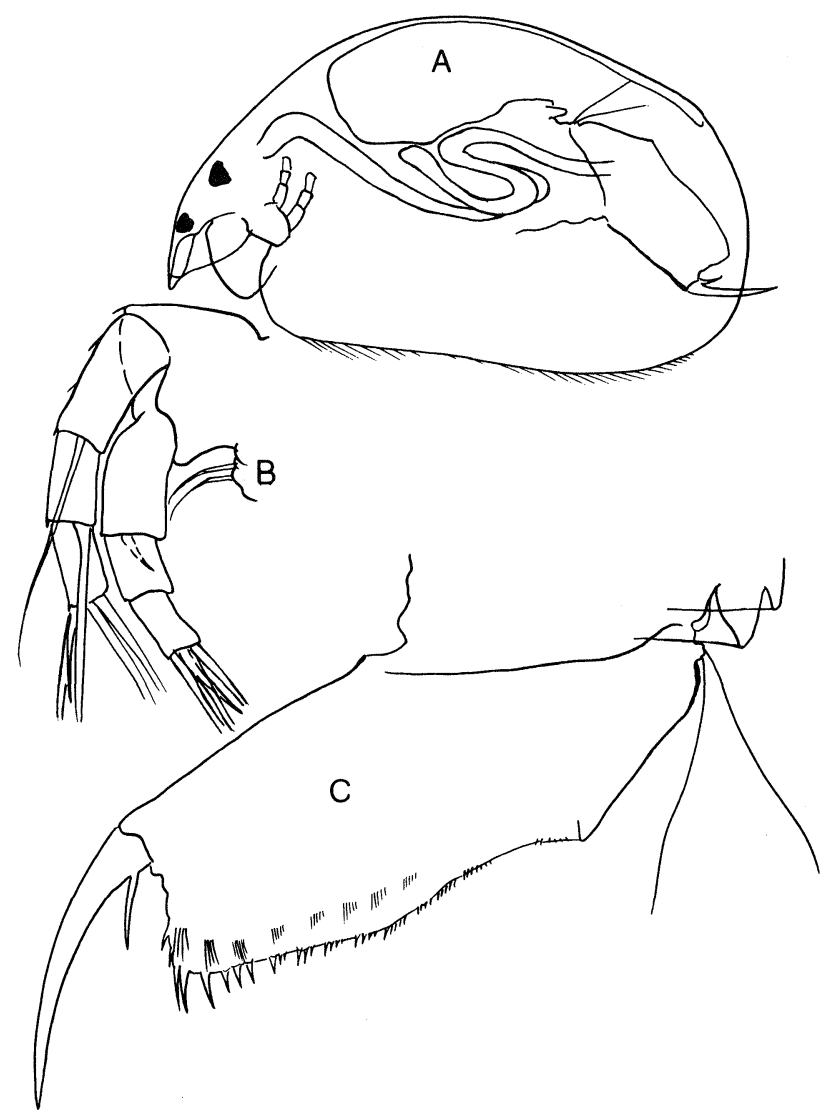

Fig. 43. Alona inreticulata $ᄋ$, farm dam, Cape Liptrap, Vic., 8.ix.74. A, lateral view of whole animal, length $0.62 \mathrm{~mm}$, slide 2942; B, antennae, slide 2950; C, postabdomen, slide 2942.
Differential diagnosis. The postabdomen of the female narrows slightly distally and is truncated. The preanal angle is wide and noticeable. The anal teeth are well developed, the four distal ones being much larger than the proximal teeth.

\section{Alona guttata Sars, 1862}

Alona guttata Sars, 1862b: 287-289.-Smirnov, 1971b: 379-382.

Alona microtata Henry, 1922 n. syn., Henry, 1922: 41-42, pl. VIII, figs 4, 4A. An examination of the type slide in the Australian Museum (P: 5890 Alona microtata Henry (type) Loc. Orange) showed it contained only Alona guttata and Chydorus sp. Judging from Henry's inadequate figures this specimen of Alona must have been considered by her to be Alona microtata. We consider that Alona microtata is identical to Alona guttata, and hence it is a synonym to it.

Material. Qld: 44, 53. N.S.W.: 38, 107, 124, 171. Vic.: 230,232, 249. Tas.: 312.

Length. $0.4 \mathrm{~mm}$.

Ecology. Alona guttata occurs throughout the year in L. Purrumbete, where it is most common in Scirpus weedbeds (Timms, 1973).

Distribution. Sparsely distributed in eastern Australia.

Differential diagnosis. The postabdomen is truncated. Its anal teeth diminish gradually proximally. The margin of the anal aperture is deeply concave, so that the preanal angle protrudes.

A number of subspecies of $A$. guttata are known, but only $A$. guttata guttata has so far been recorded in Australia.

\section{Alona guttata guttata Sars, 1862}

Fig. 44

Material. N.S.W.: 87, 107, 124.

Slides. AM $\odot$ P27688, MGU @ 1155, ZIN $\$ 3012$.

Female. Three major head pores present, as visible in the female from Loc. No. 124 (Slide ZIN $\$$ 3012). In this population the antennule does not reach the apex of the rostrum and the valve is covered with small granules (there are no lines or distinguishable polygons). Sars (1862b: 287) notes of his typical Alona guttata: "Testa striata, striis longitudinalibus parum distinctis et postice infra areolis pluribus parvis lucidis et obscuris alternatim notata." Thus strictly the forms from Loc. No. 124 differ from the typical form, namely in the absence of lines and polygons on the valve and the presence of granulations instead. No other differences were noted so this form is considered to be within the range of variations possible.

\section{Alona rectangula Sars, 1862}

Alona rectangula Sars, 1862a: 160.-Smirnov, 1971b: 376-348.

Material. Qld: $12,19,24,25,44,56,66$. N.S. W.: 87, 93, $100,112,114,116,117,120$. Vic.: $220,225,232,235,237$, 


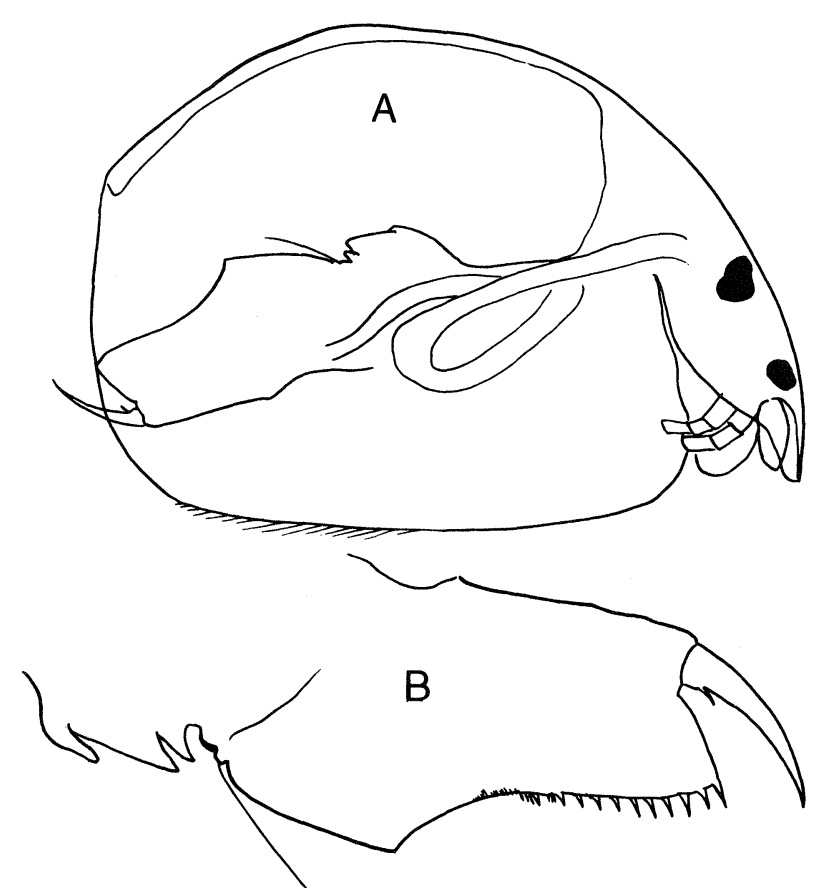

Fig. 44. Alona guttata guttata $९$, Doughboy Ck, N.S.W., 8.viii.65. A, lateral view of whole animal, length $0.4 \mathrm{~mm} ; \mathbf{B}$, postabdomen. (Both from slide 1155.)

254, 258, 259. Tas.: 326, 339. S.A.: 354, 355, 367, 376, 383, 384, 388, 389, 390, 392. W.A.: 405, 414.

Comment. This taxon at present is an assemblage of rather diverse forms needing critical study. A number of subspecies have been described and those found in Australia are discussed below.

Ecology. In a study on the University Pond, Brisbane, Timms (1967) reported this species to occur throughout the year with blooms in spring and autumn.

Distribution. Widespread in Australia.

Differential diagnosis. The postabdomen is short; its distal end is slightly widened and rounded. The postabdominal anal teeth may be grouped or rounded. Length of females does not exceed $0.5 \mathrm{~mm}$.

\section{Key to Subspecies of Alona rectangula}

1. Carapace with hollows .............. ....... A. rectangula pulchra Hellich, 1874

Carapace without dimples $\ldots \ldots \ldots \ldots \ldots 2$

2(1). Lateral setae of postabdomen arranged singly

.. A. rectangula novae-zealandiae Sars, 1904

Lateral setae grouped or absent ....... 3

3(2). Ratio of the distance between the preanal angle and base of claw to the greatest width of postabdomen $<1.7 \ldots \ldots$. .......A. rectangula rectangula Sars, 1862

This ratio $>1.7 \ldots \ldots \ldots \ldots \ldots \ldots$ .....A. rectangula richardi Stingelin, 1895

\section{Alona rectangula rectangula Sars, 1862}

Alona rectangula rectangula Sars, 1862a: 160 .

Material. Qld: 44. Vic.: 225.

Slides. MGU $\subsetneq$ 3016, ZIN $\subsetneq$ 3017, AM $\subsetneq$ P31304.

Female. Sars (1862a: 160) referring to the postabdomen of his new taxon Alona rectangula, notes: "Postabdomen breve, margine posteriore ad angulum inferiorem rotundato aculeis parvis et tenuibis obsita postice et medio processum acuminatum formante." This gives only a very general description of the postabdomen. If the typical female had not been photographed by D.G. Frey (reproduced in Smirnov, 1971 b, fig 391), it would have been impossible to differentiate the typical form from the many variations subsequently described.

Population from Loc. No. 225 has females with their valves characteristically striated (about 17 lines). Three interconnected major head pores. Antenna has setae 0-0-3/0-1-3, spines 1-0-1/0-0-1 (slide 3016). Ratio of distance between preanal angle of postabdomen and base of claw to greatest width of postabdomen about 1.5. About 9 small anal teeth and about 5 groups of lateral setae on postabdomen.

Length. $0.39 \mathrm{~mm}$ (Slide 3016).

\section{Alona rectangula richardi Stingelin, 1895}

Fig. 45

Material. Vic.: 231.

Slide. MGU @ 3011.

Female. Rostrum blunt. Major head pores triple and connected. Valve with longitudinal sparse lines and no teeth. Postabdomen elongated; ratio of length between its preanal angle and base of claw to greatest width of postabdomen 1.94. Anal denticles and lateral setae of postabdomen grouped.

Length. $0.43 \mathrm{~mm}$.

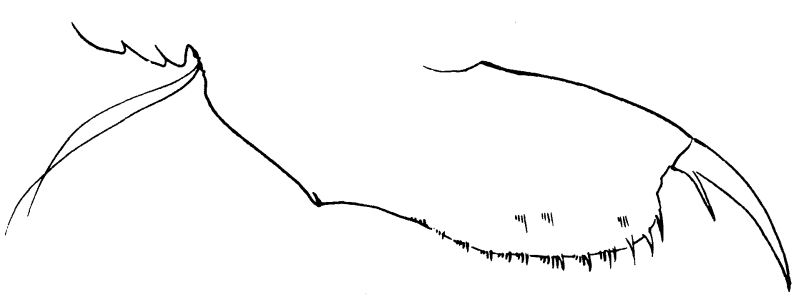

Fig. 45. Alona rectangula richardi $९$, Goulburn Billabong, Alexandra, Vic., 11.viii.76. Postabdomen, slide 3011.

\section{Alona rectangula novae-zealandiae Sars, 1904}

Figs 46, 47

Alona rectangula novae-zealandiae Sars, 1904b: 634-635, tab. XXXV, figs 7, 7a, 6b.-Smirnov, 1971b; 352, figs 401-403.

Material. S.A.: 388, 390, 392.

Slides. AM $९$ P27690, MGU $\subsetneq 1575$, ephippial $\subsetneq 1595$, ephippium 1547, ơ 1550, ZIN @ 53873 (1577). 

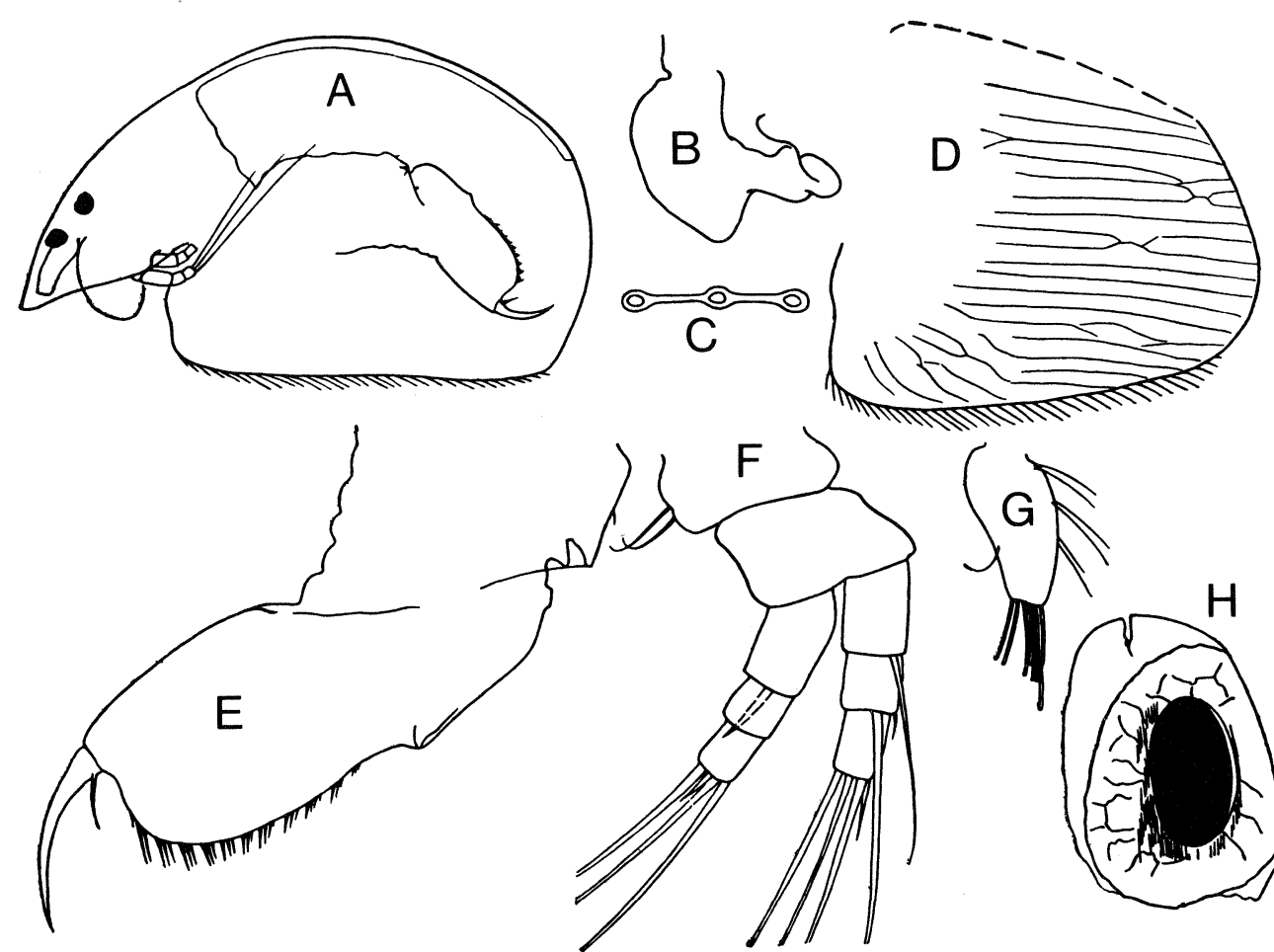

C, head pores; D, carapace; E, postabdomen; F, antenna; G, antennule; H, ephippial egg.
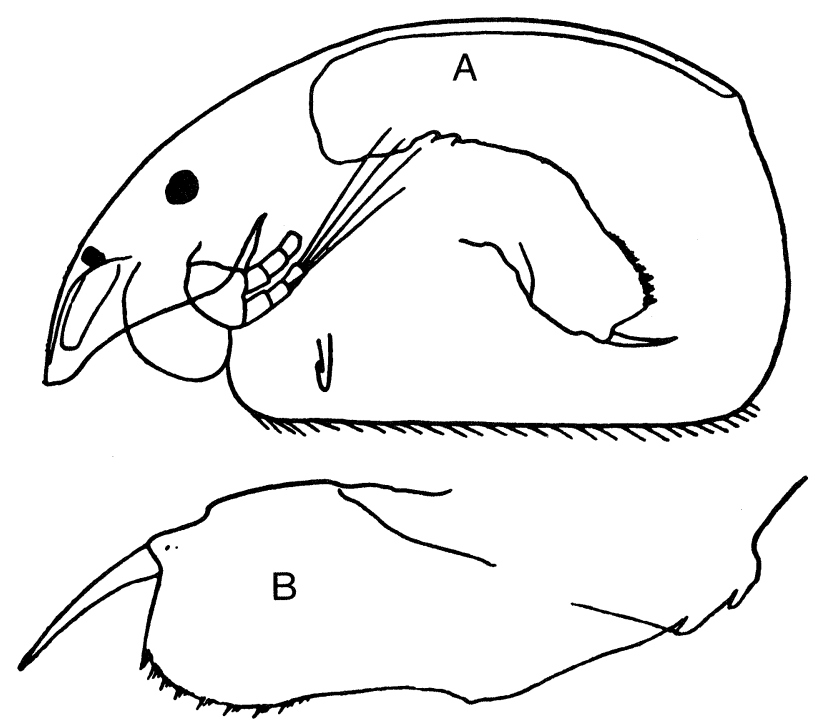

Fig. 47. Alona rectangula novae-zealandiae $\sigma$, after Smirnov, 1971b. A, whole animal, length $0.3 \mathrm{~mm} ; \mathbf{B}$, postabdomen.

Female. Shell surface without depressions. Lateral setae of postabdomen solitary.

Length. Up to $0.39 \mathrm{~mm}$.

\section{Alona rectangula pulchra Hellich, 1874} Fig. 48

Alona rectangula pulchra Hellich, 1874: 219; 1877, fig. 51 (lineata partim).-Smirnov, 1971b: 452-453, fig. 404.
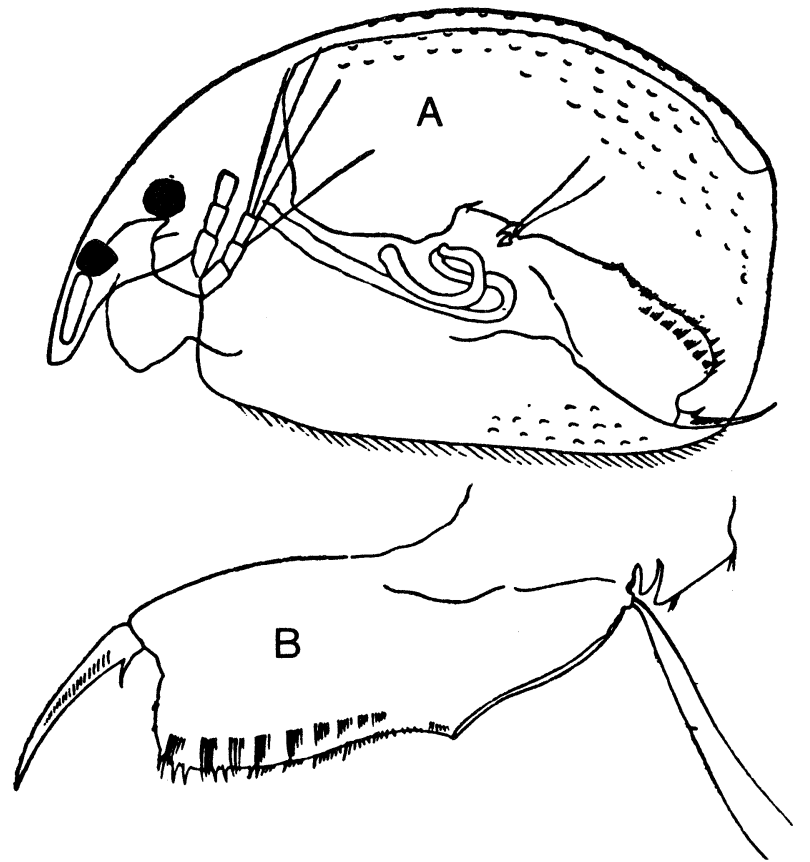

Fig. 48. Alona rectangula pulchra $९$, after Smirnov, 1971b. A, whole animal, length $0.34 \mathrm{~mm} ; \mathbf{B}$, postabdomen.

Material. Qld: 56. N.S.W.: 100.

Slides. $\quad$ AM $९$ P27691, MGU @ 406, 1378, ZIN @ 53877 (415).

Female. Surface of shell with depressions.

Length. $0.43 \mathrm{~mm}$. 


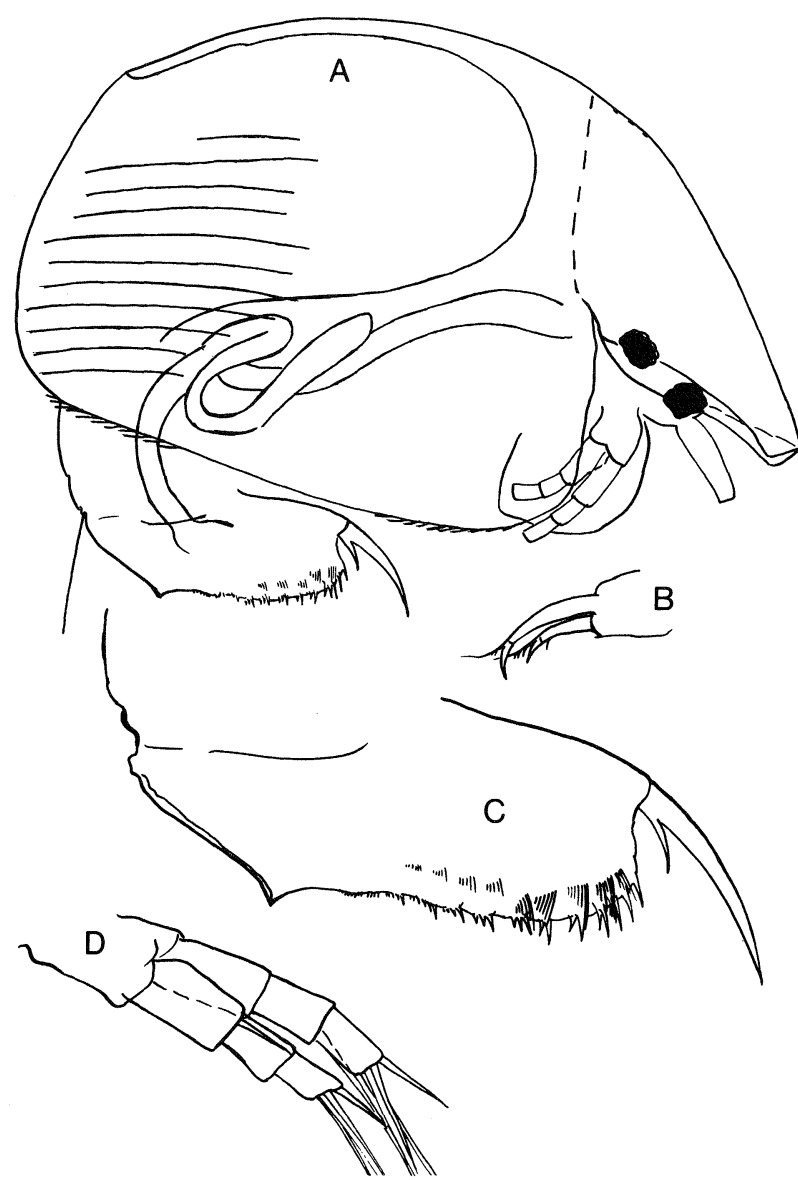

Fig. 49. Alona poppei $९$, L. Cullulleraine, Vic., 8.ix.78 (slide 3076). A, lateral view of whole animal, length $0.44 \mathrm{~mm}$; B, large setae of external branch of endite of thoracic limb I; C, postabdomen; D, left antenna.

Alona poppei Richard, 1897

Fig. 49

Alona poppei Richard, 1897: 290-292, figs 37, 38.

Material. Vic.: 234a.

Slide. AM \& P31307.

Female. The general facies and form of the postabdomen essentially conform to Richard's description. Valve with longitudinal lines (about 16 in studied $q$ ), as noted by Richard (1897: 291) "Les valves présentent des stries assez espacées, peu visibles."

Antennal setae 0-0-3/0-1-3, spines 1-0-1/0-0-1. Two setae of external branch of endite of thoracic limb I transformed into hooks by enlargement of their proximal setules.

Richard (1897: 291) notes concerning the lateral setae of the postabdomen: "Les faces latérales du postabdomen présentent chacune 9 peignes de spinules dont la première seul (la distale de chaque groupe) est bien distinct mais n'atteint pas le bord dorsal du postabdomen . . . .' Contrary to Richard's indication, the large distal setae of the distal groups of the lateral setae project beyond the dorsal margin of the postabdomen in the studied female.
The exact form of the rostrum presents a taxonomic problem. It is blunt, i.e. truncated, in the Australian female studied. Richard did not describe or depict it as his specimen was in bad condition and an exact figure could not be drawn. Delachaux's (1919) description and figures of an American specimen are not helpful as the form of the rostral part of the head is not shown.

Length. $0.44 \mathrm{~mm}$ (slide 3076).

Distribution. Australia: Lower Murray-Darling system. Originally described from Lunache, Chile.

Differential diagnosis. It differs by the characteristic form and armature of the postabdomen. Species with a similarly elongated rounded postanal part of the postabdomen have been described from southern Africa (Alona bukobensis Weltner, 1896 in Sars, 1916, Alona harpularia Sars, 1916, and Alona capensis Rühe, 1921) but these differ in the armature of the postabdomen.

\section{Alona setuloides n. sp.} Figs 50, 51

Material. W.A.: 403.

Holotype. AM \& $\mathrm{P} 27692$.

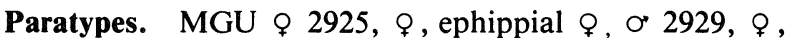
ephippial $\&$, O*, head shield 2930, $\&$, O*, head shield 2931; ZIN $\odot 2926, \mathrm{BM}$ ○ 1980.357.

Female. Body oblong, ventral side being almost straight and bearing setae. Posterior corner of valves rounded, without denticles. Anterior and posterior sides of head shield widely rounded. Three major head pores, separate; minor head pores located well away from them. Antennule not reaching tip of rostrum. Antennal setae 0-0-3/1-1-3, spines 1-0-1/0-0-1.

Thoracic limb I with three setae, one being small, on external branch of endite. Postabdomen rather wide with both its margins slightly convex. Postabdomen with numerous small anal teeth and large fascicles of lateral setae; in most of the latter the posterior setae is largest; reaching margin of postabdomen. Anal margin only slightly depressed so that preanal corner is wide and not protruding. Claw with a long basal spine.

Intestine convoluted. Ocellus larger than eye.

Length. $0.68 \mathrm{~mm}$ (Holotype P27692).

Male. Ventral side of valve slightly depressed anteriorly. Antennule not reaching tip of rostrum. Postabdomen with very small anal teeth and large fascicles of lateral setae. Vasa deferentia open at end of postabdomen, ventrally from base of claw. Claw with a large basal spine.

Length. $0.51 \mathrm{~mm}$.

Type locality. A roadside pond $640 \mathrm{~km}$ north of Perth.

Distribution. North-western W.A.

Etymology. The specific name is derived from Alona setula Megard, 1967, because of similarity in external appearance.

Differential diagnosis. The postabdomen has numerous small anal teeth. The three major head pores 

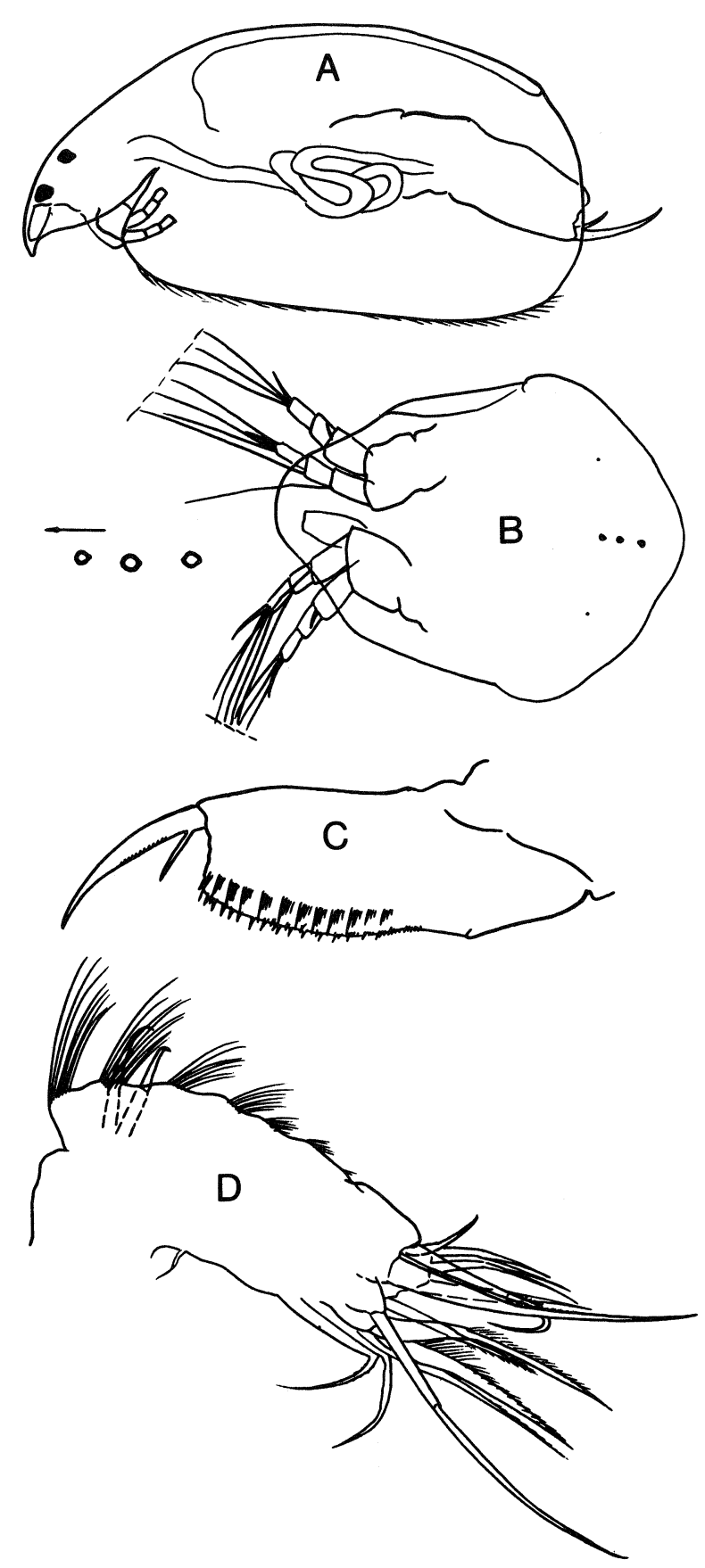

Fig. 50. Alona setuloides $९$, pond $60 \mathrm{~km} \mathrm{~N}$ of Perth, W.A., 22.viii.73. A, lateral view of whole animal, length $0.68 \mathrm{~mm}$; B, head shield and head pores; C, postabdomen; D, thoracic limb I (A and $C$ from slide 2925, B and D from slide 2930).

are separated. The ocellus is larger than the eye. Alona setuloides n. sp. is similar to Alona setula Megard, 1967 in that both have separate major head pores and the dentition of the postabdomen and the form of the male is similar in each. However, $A$. setuloides n. sp. is different because the major head pores are completely separate and the distal part of the postabdomen is comparatively longer and has more anal teeth and groups of lateral setae. It is also larger.

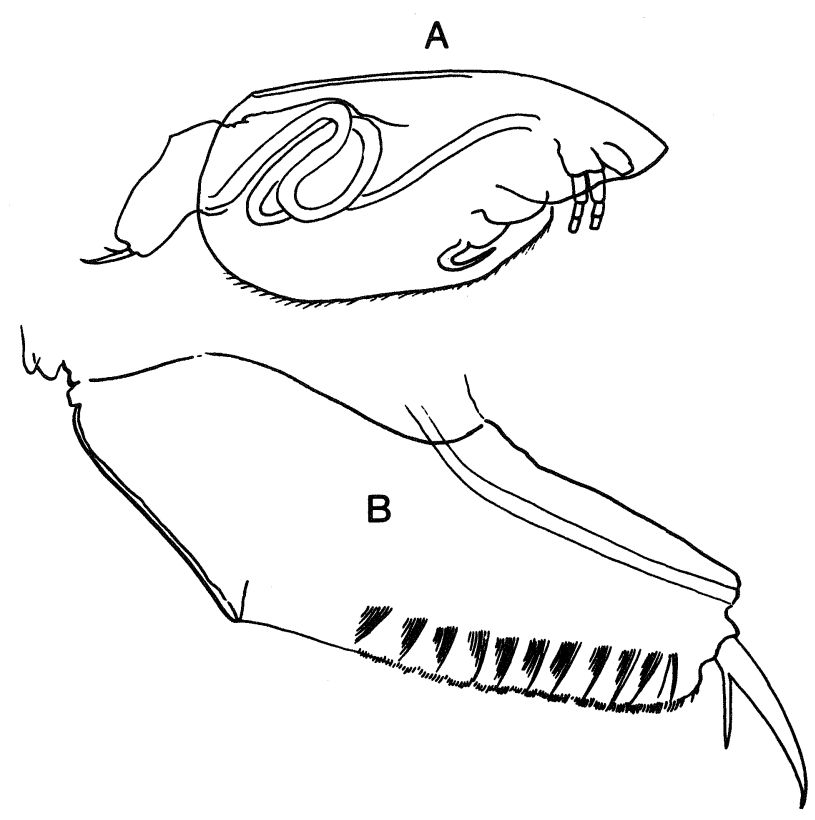

Fig. 51. Alona setuloides $O^{\circ}$, pond $60 \mathrm{~km} \mathrm{~N}$ of Perth, W.A., 22.viii.73. A, lateral view of whole animal, length $0.51 \mathrm{~mm}$; B, postabdomen; both from slide 2931 .

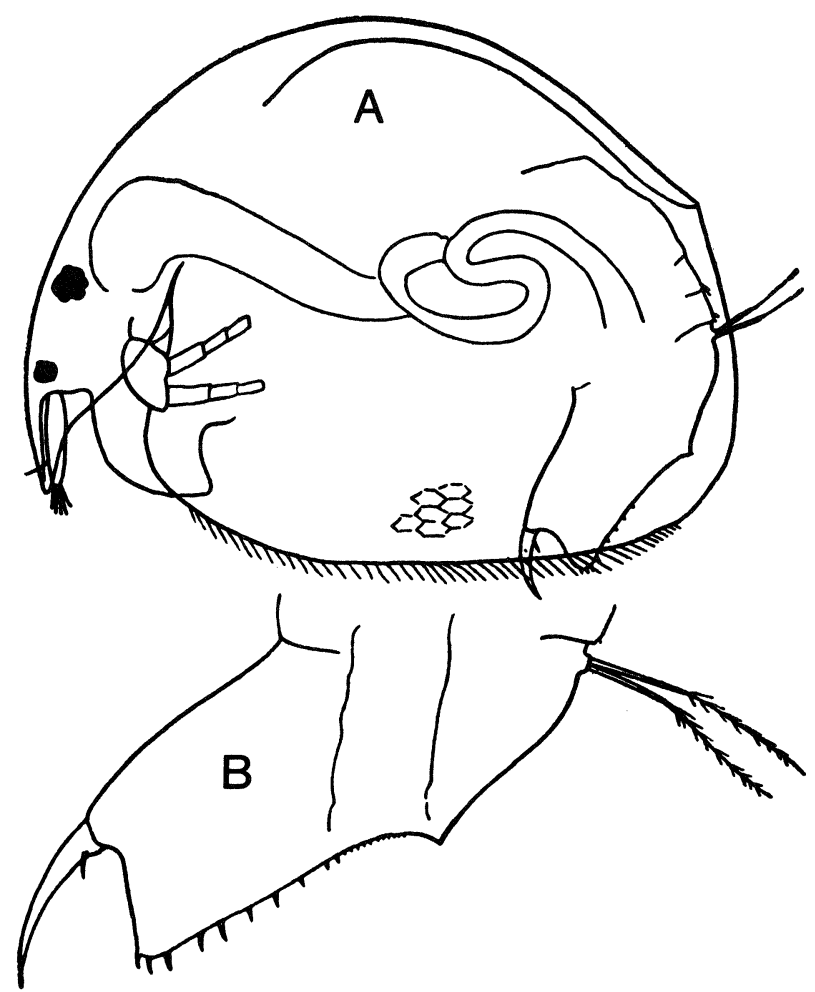

Fig. 52. Alona clathrata $९$, after Smirnov, 1971b. A, whole animal, length $0.28 \mathrm{~mm} ; \mathrm{B}$, postabdomen.

\section{Alona clathrata Sars, 1888}

Fig. 52

Alona clathrata Sars, 1888: 62-65, pl. 6, figs 7-10.-Henry, 1922: 41; Smirnov, 1971b: 382, figs 459,460 . 
Material. N.S.W.: 96 .

Length. $0.38 \mathrm{~mm}$.

Type locality. Crescent Lag., $3 \mathrm{~km}$ from Rockhampton, Qld.

Distribution. Sparsely distributed in coastal Qld and N.S.W.

Differential diagnosis. The valve is reticulated. The postabdomen is truncated and has a noticeable preanal angle. The anal teeth are small; there are no lateral setae on the postabdomen.

\section{Alona archeri Sars, 1888}

Fig. 53

Alona archeri Sars, 1888: 53-59, pl. 6, figs 1-4.-Smirnov, 1971b: 389-390, fig. 466.

Material. Qld: 64. N.S.W.: 107. Tas.: 326.

Length. $0.5 \mathrm{~mm}$.

Type locality. A water body $32 \mathrm{~km}$ from Rockhampton, Qld.

Distribution. Sparsely distributed in coastal eastern Australia.

Differential diagnosis. Alona archeri is easily recognized by the elongated postabdomen with parallel dorsal and ventral margins and solitary large lateral setae. There are 12 anal teeth gradually diminishing
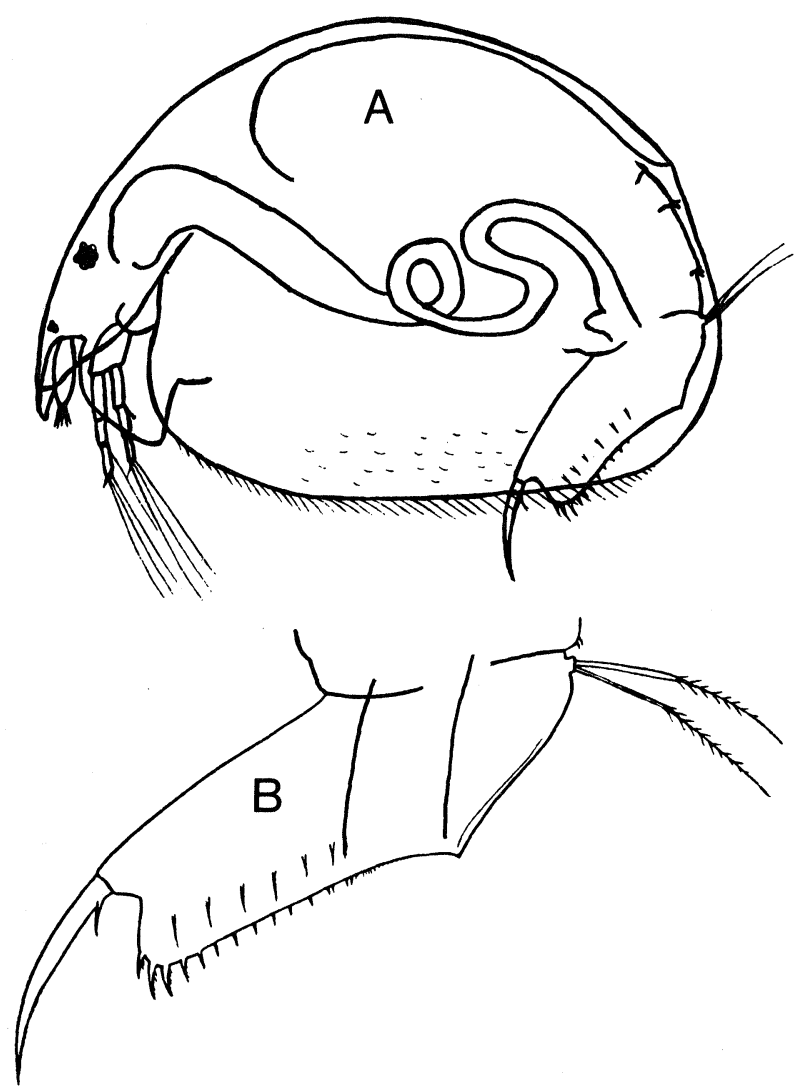

Fig. 53. Alona archeri $९$, from Smirnov, 1971b. A, whole animal, length $0.5 \mathrm{~mm} ; \mathrm{B}$, postabdomen. proximally. The valve lacks denticles on its ventroposterior corner. According to Sars (1888: 53) "Surface of shell (is) sculptured with small depressed pits arranged in longitudinal rows."

\section{Alona macracantha n. sp.}

Fig. 54

Material. N.S.W.: 188.

Holotype. AM \& P31298.

Paratypes. MGU $\subsetneq 3095, \mathrm{ZIN} \subsetneq 3096$.

Slides. MGU $\subsetneq$ exuvium 3101.

Female. Body generally oval in lateral view. Posterior corners of valve rounded; no denticles on ventro-posterior corner. Head shield widely rounded posteriorly, its anterior end elongated into a blunt rostrum. Three major head pores narrowly connected. Minor head pores situated well away from major pores. Antennule reaching tip of rostrum. Antennal setae $0-0-3 / 1-1-3$, spines 1-0-1/0-0-1.

Thoracic limb I with three setae on external branch of its endite, one very short. Postabdomen rather elongated; its preanal angle noticeable, but not prominent, and distal upper angle rounded, narrowing distally. Postanal margin with solitary anal teeth and solitary lateral setae. Claw with a large basal spine.

Intestine convoluted. Ocellus larger than eye, and situated closer to eye than to tip of rostrum.

Length. $0.5 \mathrm{~mm}$ (holotype).

Male. Unknown.

Etymology. The specific name refers to the very large basal spine of the claw.

Type locality. L. Menindee, N.S.W.

Distribution. Lower Murray-Darling System.

Differential diagnosis. This is a large Alona, well differentiated by the form of its postabdomen. The basal spine of its claw is very large. The ocellus is larger than the eye.

\section{Alona investis n. sp.}

Fig. 55

Material. Vic.: 262.

Holotype. AM \& P31297.

Female. Body generally oval in lateral view. Posterior corners of valves rounded; no denticles on ventro-posterior corner. Antennule reaches tip of rostrum. Lamella of labrum with a blunt apex.

Postabdomen short. Its postanal margin with groups of very small spines. Preanal angle prominent. Ocellus smaller than eye and situated closer to eye than to tip of rostrum.

The head pores could not be discerned, so the generic placement is tentative.

Length. $0.39 \mathrm{~mm}$.

Male. Unknown. 


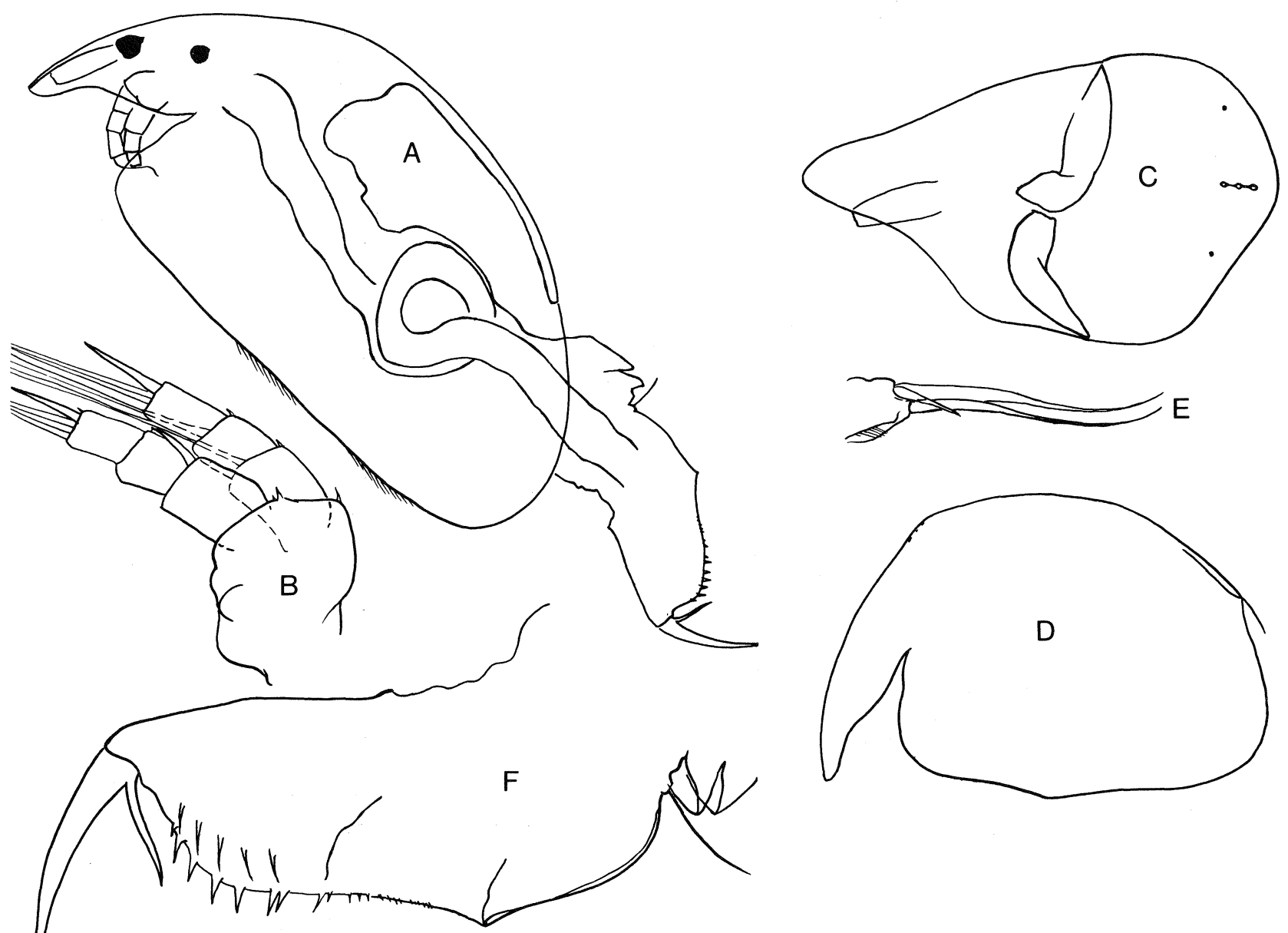

Fig. 54. Alona macracantha $\odot$, Lake Cawandilla, Menindee Lakes, N.S.W., 22.v.78. A, lateral view of whole animal, length $0.5 \mathrm{~mm}$; B, left antenna from above; C, head shield; D, shell of less distorted specimen; E, external branch of endite of thoracic limb I; F, postabdomen. (A from holotype slide P31298; B, F from slide 3094; C, E from slide 3091; D from slide 3095.)

Etymology. The specific name is motivated by the absence of any large spines or setae on the postabdomen.

Differential diagnosis. A postabdomen with very little armature is almost unique among the Chydoridae, the sole exception being Alona inermis Pesta, 1928. This species differs from $A$. investis in the general shape of the postabdomen.

\section{Alona pulchella King, 1853}

Fig. 56

Alona pulchella King, 1853b: 260, pl. VIIIB.-Sars, 1896: 37-40, pl. 6, figs 3,4; Smirnov, 1971b: 373, 376, fig. 442.

Material. Qld: $15,39,52,64$. N.S.W.: 86, 105, 176. S.A.: 352.

Slides. AM $\subsetneq$ P27689, MGU $\subsetneq 1585$, ZIN $\subsetneq 53841$ (1776).

Length. 0. $39 \mathrm{~mm}$.

Ecology. In Borumba Res. (Loc. No. 52) it was present in samples only from July to September (Timms and Midgly, 1969).
Type locality. Varroville (near Denham Court), St. Leonards (in Sydney).

Distribution. Qld, N.S.W., north-eastern S.A.

Differential diagnosis. The valve has granulations, but no polygons. The ventro-posterior corner of the valve lacks denticles. The labrum edge lacks serrations. The postabdomen is elongated, with parallel dorsal and ventral edges. There are about 10 anal teeth. The lateral setae of the postabdomen are arranged in fascicles.

\section{Alona laevissima Sars, 1888}

Fig. 57

Alona laevissima Sars, 1888: 59-62, pl. 6. figs 5, 6.-Henry, 1922: 42-43, pl. VIII, figs 3, 3A.

Material. Literature.

Length. $0.48 \mathrm{~mm}$.

Type locality. Near Gracemere, Qld.

Distribution. Qld, N.S.W.

Differential diagnosis. The carapace is oval in shape and has a smooth surface. There are no denticles on the 

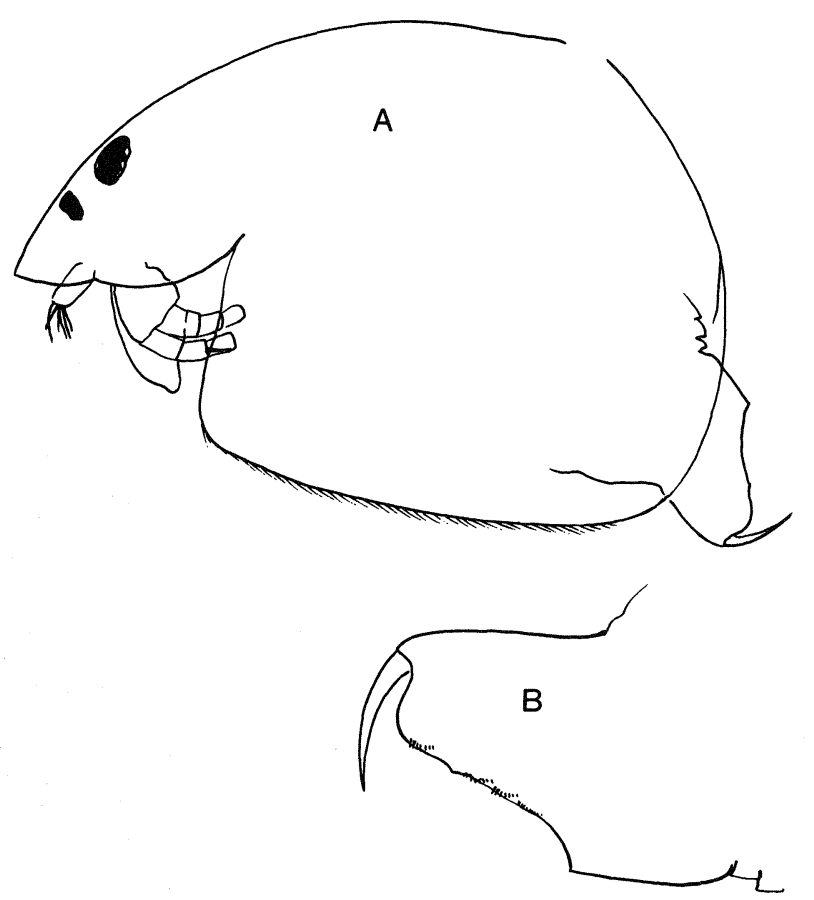

Fig. 55. Alona investis $ᄋ$, L. Mulwala, via Yarrawonga, Vic., 20.v.77. A, lateral view; B, postabdomen from slide AM ९ P31297.
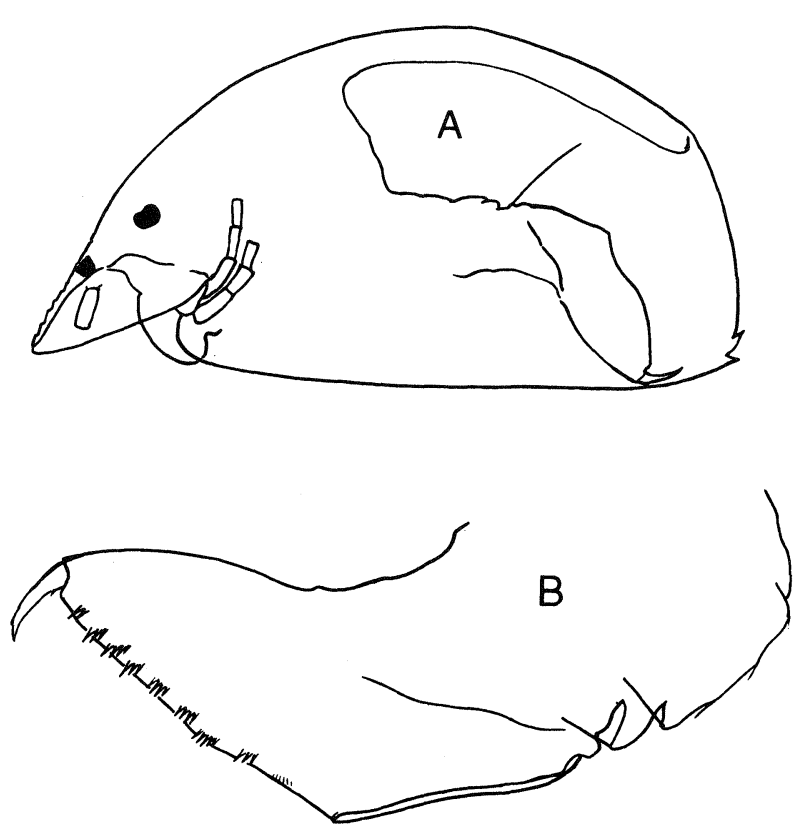

Fig. 58. Graptoleberis testudinaria occidentalis $९$, Ellalong Lag., via Cessnock, N.S.W., 11.ix.66. A, lateral view of whole animal, length $0.5 \mathrm{~mm}$; B, postabdomen. (Both from slide 2148.)

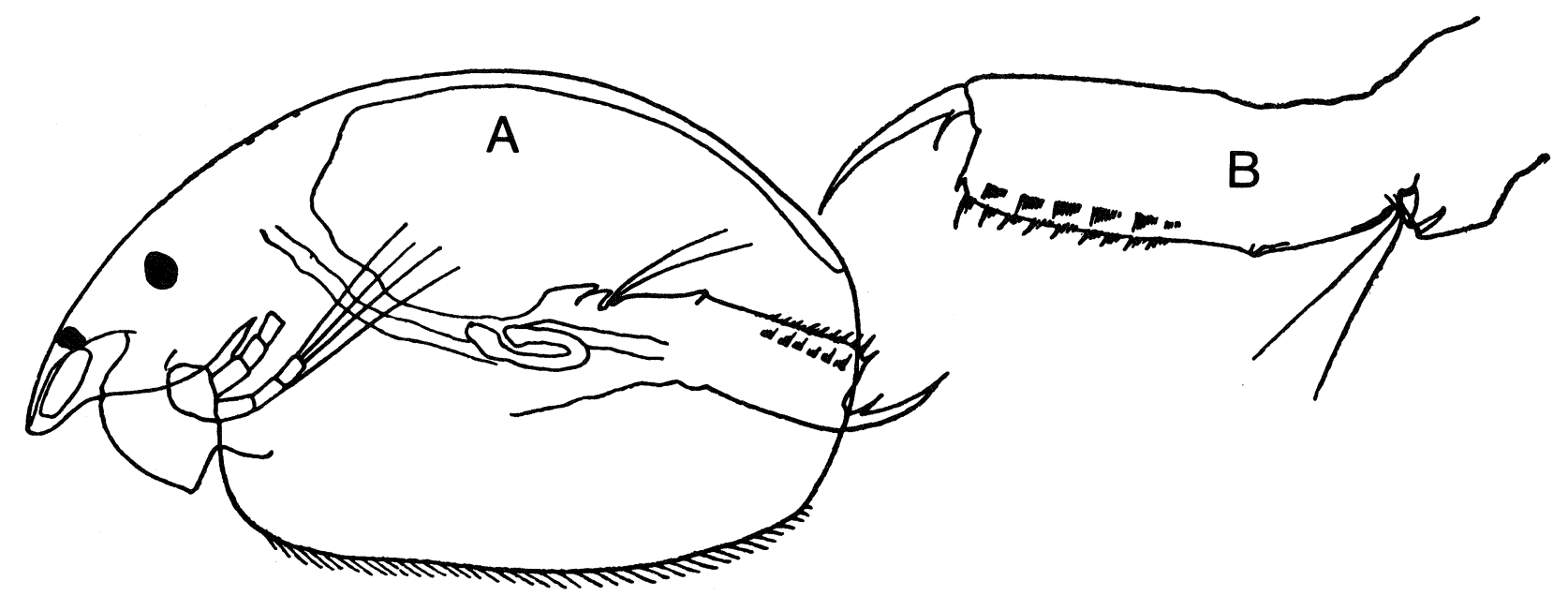

Fig. 56. Alona pulchella $\propto$, after Smirnov, 1971b. A, whole animal, length $0.39 \mathrm{~mm}$; B, postabdomen.

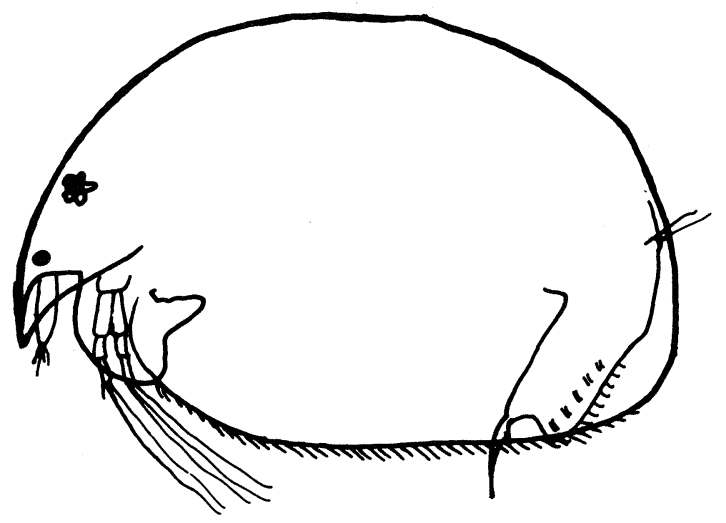

Fig. 57. Alona laevissima $९$, after Sars, 1888. ventro-posterior corner of the valve. The postabdomen is truncated. The preanal angle projects slightly. The anal teeth are small; there are 5 groups of lateral setae.

\section{Incertae sedis}

Alona bairdii King, 1853b: 259, pl. VIIIA.-Sars, 1888, 69.

Alona karua King, 1853b: 260, pl. VIIID.

Alona mascula King, 1853b: 261-262; pl. VIIIE.-Sars, 1888: 70; Smirnov 1966: 121 (erroneously considered to be comparable to Alonopsis). 
Genus Graptoleberis Sars, 1862

Graptoleberis Sars, 1862: 41.-Smirnov, 1971b: 443.

Chydorids with ventral surface of valve straight in lateral view and with denticles at its ventro-posterior corner. Front margin of head shield in dorsal view widely rounded. Shell with expressed polygons. Postabdomen and its claw short.

It is a monotypic genus with type species Graptoleberis testudinaria (Fischer, 1851).

\section{Graptoleberis testudinaria (Fischer, 1851)}

Fig. 58

Lynceus testudinarius Fischer, 1851: 191, Taf. IX, fig 12. Graptoleberis testudinaria.-Stingelin, 1895: 252; Smirnov, 1971b: 443-449.

Material. Qld: 12, 51. N.S.W.: 82, 87, 96, 116, 117, 133, 166, 168, 186. Vic.: 224, 229, 230, 232, 238, 256, 257. Tas.: 312, 314, 317, 320, 332. W.A.: 405, 406.

Distribution. Australia-wide, but particularly the south-east.

Several subspecies have been described, of which two are known for Australia.

Graptoleberis testudinaria testudinaria (Fischer, 1851)

Lynceus testudinarius Fischer, 1851: 191, Taf. IX, fig. 12. Graptoleberis testudinaria testudinaria.-Smirnov, 1971b: 444, figs 545-549.

Material. Qld: 12.

Female. Postabdomen narrows distally. Claw with one small basal spine. Denticles of ventro-posterior corner of valve large $(8-14 \mu \mathrm{m})$.

\section{Graptoleberis testudinaria occidentalis Sars, 1901}

Graptoleberis testudinaria var. occidentalis Sars, 1901: 66, pl. $\mathrm{X}$, figs $8,8 \mathrm{a}, 8 \mathrm{~b}$.

Graptoleberis testudinaria occidentalis. -Smirnov, 1971b: 446, figs $550,553$.

Material. N.S.W.: 96, 116, 133, 166, 186. Vic.: 230, 232 , 238. Tas.: 312, 317.

Slides. AM $\odot$ P27716, MGU $\subsetneq 2137,2138,2148,2153$, ZIN $ᄋ 2142$.

Female. Postabdomen narrows distally. Claw with one basal spine. Denticles of ventro-posterior corner of valve small $(7-10 \mu \mathrm{m})$. Anal teeth in groups of 3 or 4 .

\section{Genus Acroperus Baird, 1843}

Acroperus Baird, 1843: 91 (subgenus Acroperus).-Smirnov, 1971b: 400-402.

Body form oval and compressed. Postabdomen moderately elongated, with parallel dorsal and ventral edges. The Australian species differ only in the proportions of parts of the head and its appendages.
All four species of Acroperus known from Australia are uncommon. As a group they are restricted to coastal areas of southern Qld and northern N.S.W., often in markedly acid waters.

The type species is Acroperus harpae (Baird, 1834).

\section{Key to Australian Species of Acroperus}

1. Antennule protrudes beyond tip of rostrum ........ A. sinuatus Henry, 1919

Antennule does not protrude beyond tip of rostrum .................. 2

2(1). Antennule reaches to tip of rostrum ..... A. neglectus Lilljeborg, 1900

Antennule does not reach to tip of rostrum .................... 3

3(2). Head keel wider than eye ............. .............. harpae (Baird, 1834)

Head keel narrower than eye ............ .......... A. alonoides Hudendorff, 1876

\section{Acroperus harpae (Baird, 1834)}

Lynceus harpae Baird, 1834: 100, pl. II, fig. 17.

Acroperus harpae.-Baird, 1843: 91-92, pl. III, fig. 7; Smirnov, 1971b: 403-406, figs 483-489.

Material. N.S. W.: 81 .

Length. $0.58 \mathrm{~mm}$.

Distribution. Known only from one locality in coastal northern N.S.W.

Differential diagnosis. Body height is $64 \%$ of length. There is a head keel, its width exceeding the diameter of the eye. The antennule does not reach the tip of the rostrum.

\section{Acroperus alonoides Hudendorff, 1876}

Figs 59, 60

Acroperus alonoides Hudendorff, 1876: 51-52, Taf. II, fig. 4.-Smirnov, 1971b: 409, 413, figs 496-499.

Acroperus harpae var. frigida Ekman, 1904: 23-24, figs A, B.

Material. Qld: 50, 51. N.S.W.: 77.

Slides. AM $\subsetneq$ P27683, MGU $\odot$ 1097, ơ 160, ZIN $\subsetneq 157$.

Length. $0.85 \mathrm{~mm}$.

Distribution. Coastal region of southern Qld and northern N.S.W.

Differential diagnosis. The width of the head keel is less than the width of the eye. The antennule does not reach the tip of the rostrum.

Acroperus neglectus Lilljeborg, 1900

Acroperus neglectus Lilljeborg, 1900: 425-428, tab. LXIV, figs 11-21.

Acroperus avirostris Henry, 1919: 469-470, pl. XL, figs 3, 4; 1922: 39, pl. VI, figs 2, 2A., n. syn. 


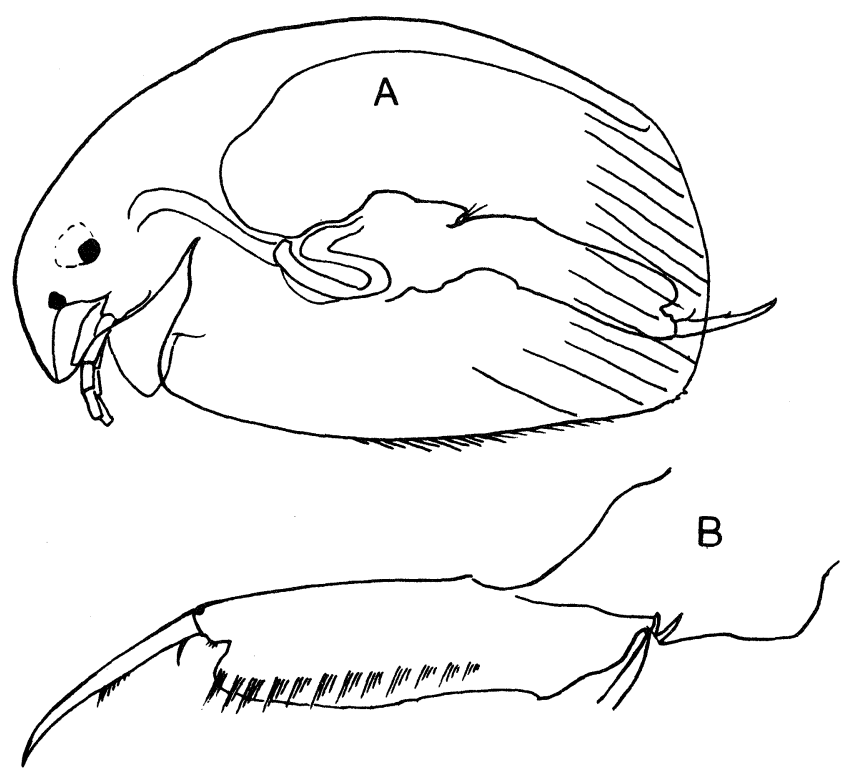

Fig. 59. Acroperus alonoides $ᄋ$, Emigrant Ck near Ballina, N.S.W., 18.vii.65. A, lateral view of whole animal, length $0.85 \mathrm{~mm}$; $\mathbf{B}$, postabdomen. (Both from slide 1097.)

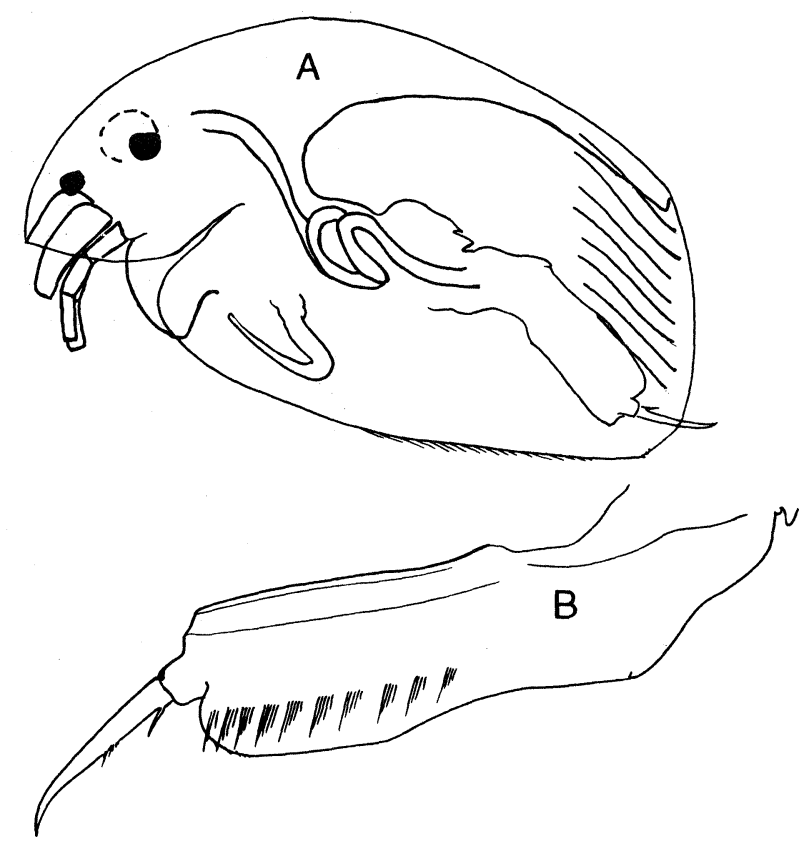

Fig. 60. Acroperus alonoides ơ, Emigrant Ck near Ballina, N.S.W., 18.vii.65. A, lateral view of whole animal; B, postabdomen. (Both from slide 160.)

Material. N.S. W.: 78, 99, Henry's slides in the Australian Museum: "P:4328 Acroperus avirostris, Henry, Holotype, Kendall”; “P:5901 Acroperus avirostris Loc. Kendall.”

Female. In holotype slide P:4328 the antennule reaches the tip of the rostrum. The ratio of body height to length is $65 \%$ (not $60 \%$ as noted by Henry). The female on slide $\mathrm{P}: 5901$ is very similar.

Length. Up to $0.63 \mathrm{~mm}$. Lilljeborg (1900) indicates a length of $0.7-0.78 \mathrm{~mm}$.
Differential diagnosis. The antennule almost reaches the tip of the rostrum which is comparatively blunt. The height is $60-65 \%$ of length.

\section{Acroperus sinuatus Henry, 1919}

Acroperus sinuatus Henry, 1919: 471-472, pl. XL, figs 5, 6; 1922: 39.

Material. Holotype in the Australian Museum "P:4329 Acroperus sinuatus Henry, Holotype, Kendall.”

Length. $0.59 \mathrm{~mm}$.

Type locality. Kendall, N.S.W.

Distribution. Known only from type locality on mid-north coast of N.S.W.

Differential diagnosis. The antennule protrudes beyond the tip of the rostrum.

\section{Genus Kurzia Dybowski \& Grochowski, 1894}

Kurzia Dybowski \& Grochowski, 1894: 380.-Smirnov, 1971b: 395.

Pseudalona Sars, 1901: 85.

Body relatively high and oval in shape. Postabdomen elongated and narrowing distally. Rostrum long.

The species of Kurzia are rarely encountered in Australia.

The type species is Kurzia latissima (Kurz, 1875).

\section{Key to Kurzia Species}

1. Antennule almost reaches to tip of rostrum. Distal angle of postabdomen not protruding .......K. latissima (Kurz, 1875)

Antennule reaches to middle of rostrum. Distal angle of postabdomen protruding ....K. longirostris (Daday, 1898)

\section{Kurzia latissima (Kurz, 1875)} Fig. 61

Alonopsis latissima Kurz, 1875: 46-47, pl. II, figs 13-15. Kurzia latissima.-Behning, 1941: 261-263, fig. 108.Smirnov, 1971b: 397-398, figs 476-478.

Material. Vic.: 225, 231.

Slides: MGU \& 2714, 3020.

Length. $0.6 \mathrm{~mm}$.

Distribution. Australia: central and northern Victoria. World: Holarctic and Neotropical regions.

Differential diagnosis. The antennule of the female reaches the tip of the rostrum. The upper distal angle of the postabdomen does not protrude.

\section{Kurzia longirostris (Daday, 1898)}

Fig. 62

Alona longirostris Daday, 1898: 34, fig. 14.

Kurzia longirostris. - Harding, 1957: 73, fig. 15; Smirnov, 1971b: 398-400, figs $480-482$. 


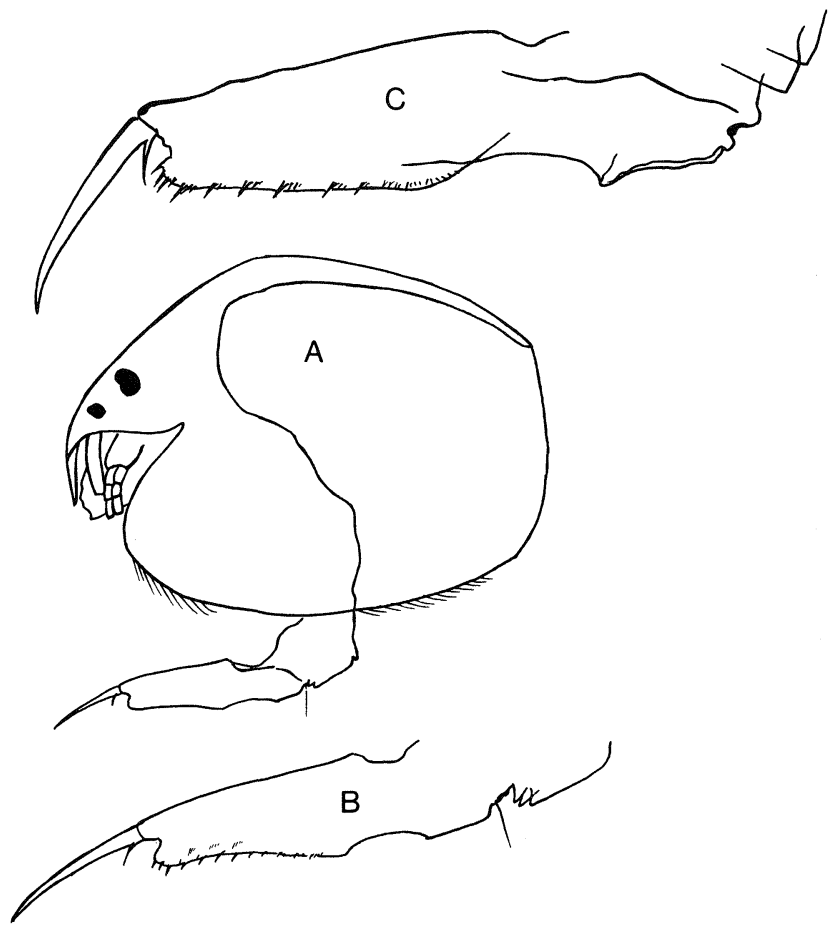

Fig. 61. Kurzia latissima 9 , Snowdons Lag., via Wodonga, Vic., 11.viii.76. A, lateral view of whole animal, length $0.6 \mathrm{~mm}$, slide 2714; B, postabdomen, slide 2714; C, postabdomen from abnormal parthenogenetic $\%$, slide 3020 .
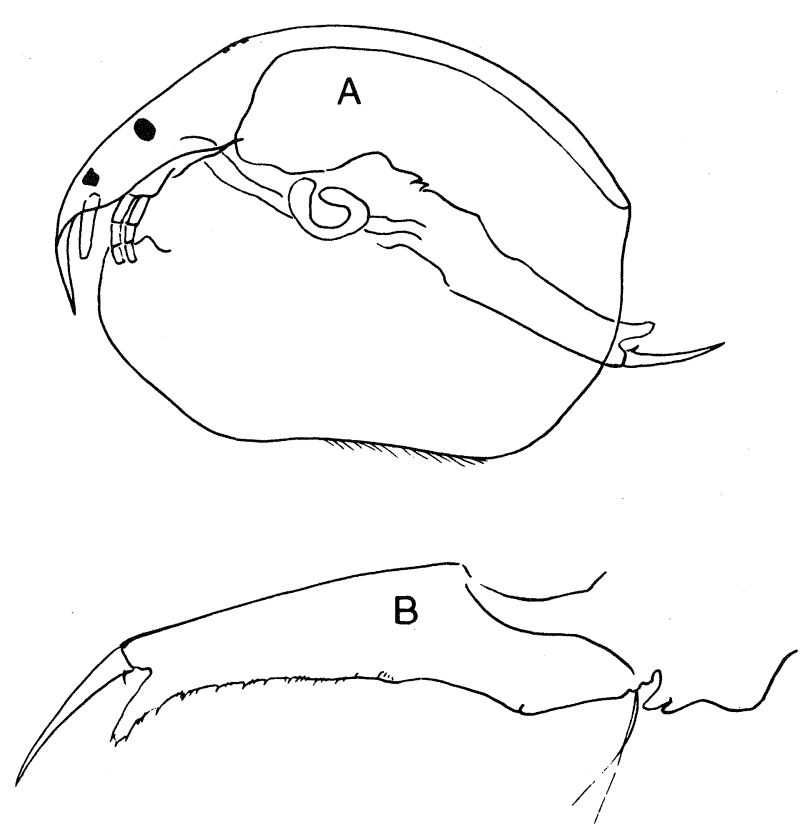

Fig. 62. Kurzia longirostris $\&$, Toomba swamp, via Charters Towers, Qld, 13.vi.74. A, lateral view of whole animal, length 0.57 $\mathrm{mm}$; B, postabdomen. (Both from slide 2784.)

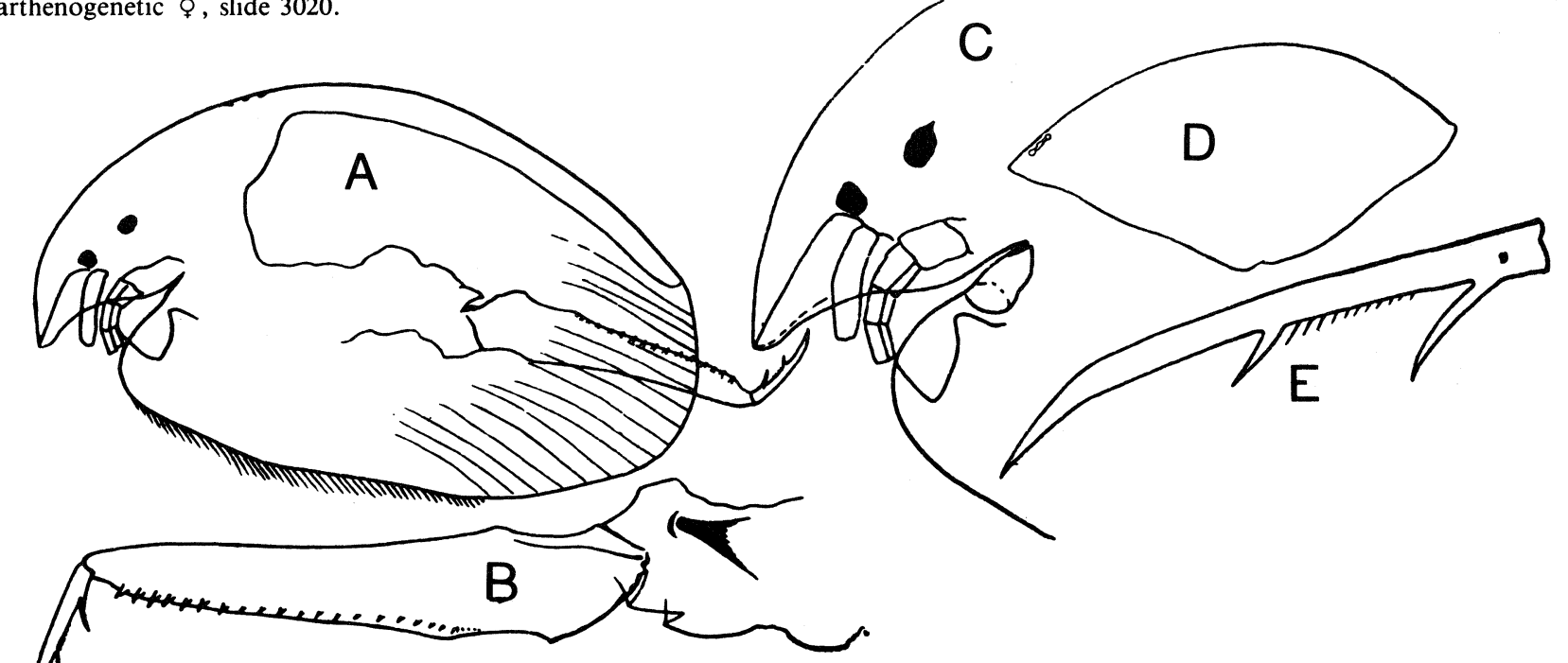

Fig. 63. Camptocercus australis $\&$, after Smirnov, 1971b. A, whole animal, length $0.66 \mathrm{~mm}$; B, postabdomen; C, head; D, head shield; $\mathbf{E}$, claw.

Material. Qld: 16. N.S.W.: 96, 176.

Slides. AM \& P27717, MGU $\subsetneq$ 2784, ZIN 2749.

Length. $0.46 \mathrm{~mm}$.

Distribution. Australia: isolated in Q1d, and northern N.S.W. World: a pantropical species in Ethiopic, Neotropical, Indo-Malayan regions, also New Guinea.

Differential diagnosis. The antennule of the female reaches the middle of the rostrum. The upper distal angle of the postabdomen is variously protruding.

\section{Genus Camptocercus Baird, 1843}

Camptocercus Baird, 91 (subgenus Camptocercus).-Smirnov, 1971 b: 429.

Shell, trunk, and postabdomen elongated. Thoracic limbs III and IV superficially similar.

The type species is Camptocercus rectirostris Schoedler, 1862.

Only one species has been recorded from Australia. 


\section{Camptocercus australis Sars, 1896}

Fig. 63

Camptocercus australis Sars, 1896: 45-47, pl. 6, figs 9, 10. - Henry, 1922: 39, pl. VI, figs 3, 3A; Smirnov, 1971b: 436, fig. 531 ; 1972: 393-409, fig. 3G.

Material. Qld: $12,15,23,51,66$. N.S. W.: 82, 96, 122, 132. Vic.: 226, 232, 233, 242, 257, 259, 260. Tas.: 300, 309, $310,312,313,332,335$.

Slides. AM @ P27707, MGU @ 1788, ZIN 2897.

Length. $0.83 \mathrm{~mm}$.

Type locality. Centennial Park, Sydney.

Distribution. Eastern Australia.

Differential diagnosis. The species is readily recognizable by its elongated body form and very elongated postabdomen. The ventro-posterior corner of valve is rounded and lacks denticles. The external branch of the endite of thoracic limb I has 3 setae possessing setules which gradually increase in length proximally.

\section{Genus Leydigia Kurz, 1875}

Leydigia Kurz, 1875: 57; Smirnov, 1971b: 449-450.

Body high. Postabdomen widely rounded, with very large lateral setae, and very small, almost inconspicuous, anal teeth. Some antennal segments with groups of spines. Ocellus commonly larger than eye.

Five species occur in Australia, but each is uncommon. They live in the surface layer of mud (Sars, 1885; Fryer, 1968), a microhabitat noted for $L$. australis in L. Purrumbete, L. ciliata in Atkinsons Lag., and $L$. leydigi in two shallow lakes on the Monaro Tableland, N.S.W. Our other records of Leydigia spp. are from vegetated littoral regions, but in each case the net probably sampled bottom mud.

The type species is Leydigia leydigi (Schoedler, 1863).

\section{Key to Australian Species of Leydigia}

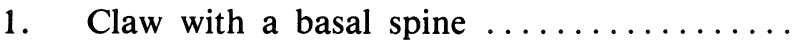
........... L. leydigi (Schoedler, 1863)

Claw without a basal spine ..........2

2(1). Postabdomen widest in its middle part and narrowing a little distally .......... ................ australis Sars, 1885

Postabdomen widest distally ......... 3

3(2). Each group of lateral setae composed of more than two setae ............4

Only two setae in such groups; eye a little smaller than ocellus ............ ....... L. acanthocercoides (Fischer, 1854)

4(3). Longitudinal rows of granules on valve .......... L. ciliata Gauthier, 1939 Valve punctate ...... L. laevis Gurncy, 1927
Leydigia leydigi (Schoedler, 1863)

Alona leydigii Schoedler, 1863: 27.

Leydigia leydigi._Daday, 1902: 265-266, tab. 6, fig. 1.-Smirnov, 1971b: 450-454, figs 554-558.

Material. N.S.W.: 145, 149, 152, 155. S.A.: 362, 363.

Length. $0.7 \mathrm{~mm}$.

Distribution. Limited areas of N.S.W. (Monaro Tableland) and S.A. (near Adelaide).

Differential diagnosis. The claw has a small basal spine. The edge of the labrum is smoothly convex and has short hairs. The ocellus is slightly larger than the eye.

\section{Leydigia ciliata Gauthier, 1939}

Fig. 64

Leydigia propinqua var. ciliata Gauthier, 1939 (January): 169-173, fig. 9 a-g.

Leydigia striata Biraben, 1939 (May): 661-663, figs 14-16. Leydigia ciliata.-Harding, 1955: 242-243, figs 50-60; Smirnov, 1971b: 454, fig. 563.

Material. Qld: 64. N.S.W.: 113, 158.

Slides. AM \& P27718, MGU \& 1769, 2098, ZIN 2102.

Length. Up to $0.97 \mathrm{~mm}$.

Distribution. Isolated areas of eastern Qld and N.S.W.

Differential diagnosis. The claw has no basal spine or a very small one. The postabdomen is widest distally and the distal groups of lateral setae on it contain more than two setae. There are longitudinal rows of granules on the valves.

\section{Leydigia acanthocercoides (Fischer, 1854)}

Lynceus acanthocercoides Fischer, 1854: 431-433, tab. III, figs 21-23.

Leydigia acanthocercoides.-Sars, 1895: 18-22, pl. 4, figs 1-4; Smirnov, 1971b: 458-460, figs 569-570.

Material. Qld: 39. N.S.W.: 113, 158.

Length. Up to $1 \mathrm{~mm}$.

Distribution. Isolated areas of eastern Qld and N.S.W.

Differential diagnosis. The claw has no basal spines. The postabdomen is widest distally and the distal groups of lateral setae on it contain two setae. The valve is longitudinally lineated. The eye is slightly smaller than the ocellus.

Leydigia australis Sars, 1885

Leydigia australis Sars, 1885: 35-43, pls 7, 8.

Material. Vic.: 249.

Distribution. Isolated areas of Qld and Vic.

Of the two subspecies known, only the typical form is found in Australia. 


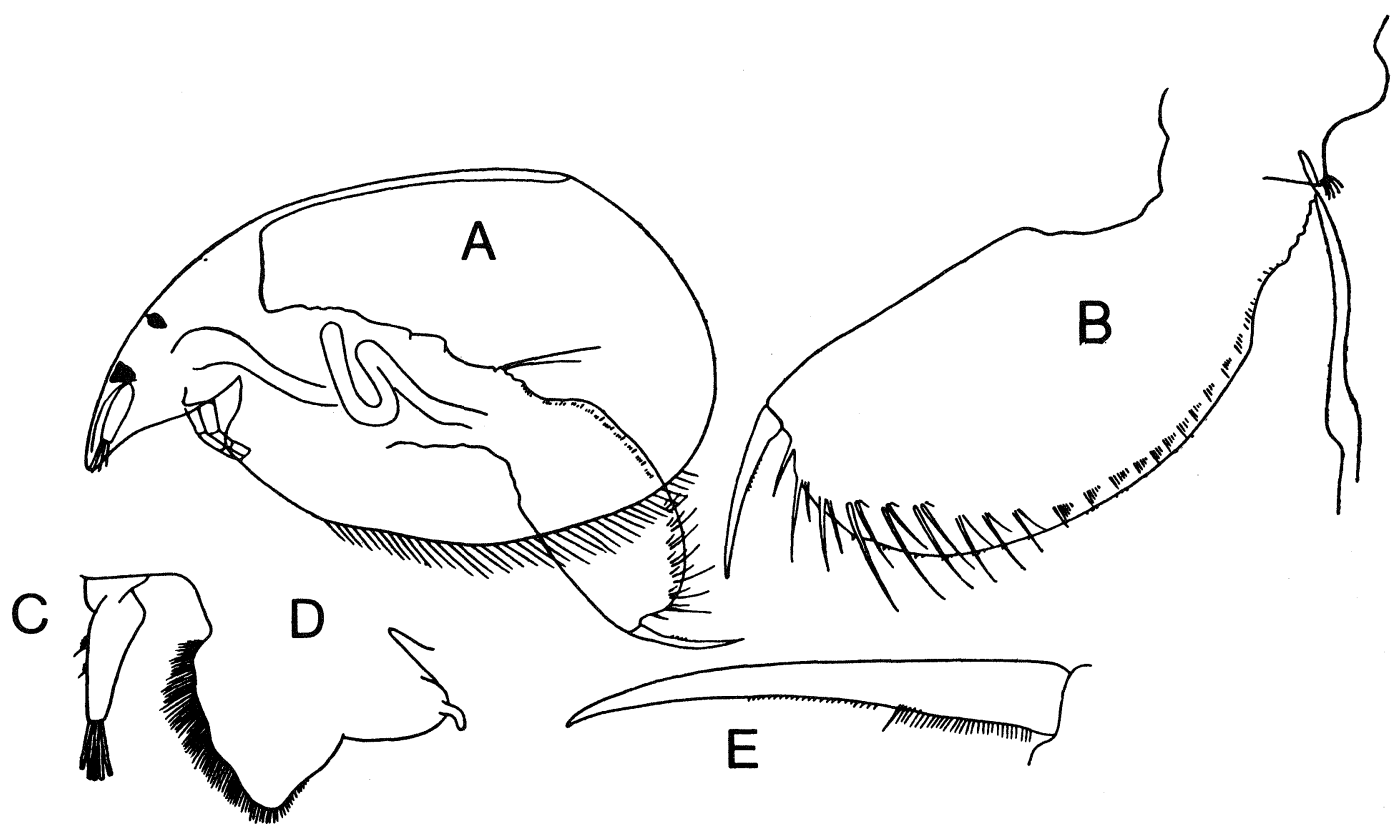

Fig. 64. Leydigia ciliata $\$$, after Smirnov, 1971b. A, whole animal, length $0.62 \mathrm{~mm}$; B, postabdomen; C, antennule; D, labrum; E, claw.

\section{Leydigia australis australis Sars, 1885}

Material. Vic.: 249.

Slides. MGU $\subsetneq 2488, \mathrm{ZIN}$ ○ 2487.

Length. $0.84 \mathrm{~mm}$.

Type locality. Gracemere Lag., $10 \mathrm{~km}$ west of Rockhampton, Qld.

Differential diagnosis. The claw has no basal spine. The postabdomen narrows slightly distally so that it is widest in its middle part. The edge of the labrum is smoothly convex with short hairs. The valve has no longitudinal lines. The ocellus is much larger than the eye.

\section{Leydigia laevis Gurney, 1927}

Fig. 65

Leydigia laevis Gurney, 1927: 73-75, fig. 9.-Smirnov, 1971b: 458, fig. 568 .

Material. Literature.

Length. $0.6 \mathrm{~mm}$.

Type locality. Longreach, Qld.

Distribution. Known only from the type locality in western Qld.

Differential diagnosis. The claw has no spine. the postabdomen is widest distally and the distal groups of lateral setae on it contain more than two setae. The valve is punctate and sometimes has faint polygons. The labrum is smoothly convex and has small hairs along its edge. The eye and ocellus are equal in size.
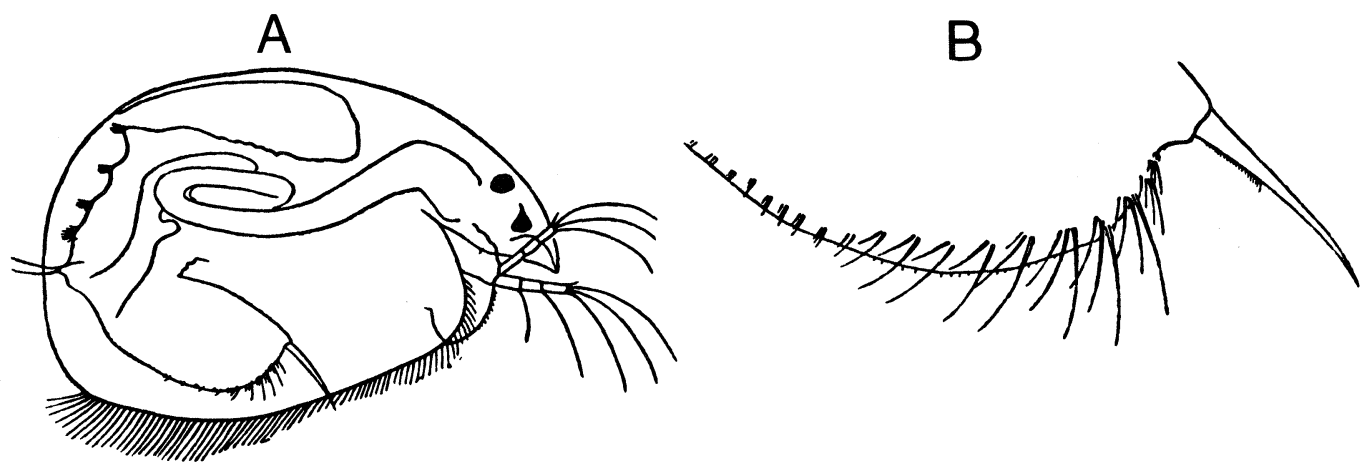

Fig. 65. Leydigia laevis $९$ after Smirnov, 1971b. A, whole animal, length $0.3 \mathrm{~mm}$; B, postabdomen. 
Genus Biapertura Smirnov, 1971

Biapertura Smirnov, 1971b: 466.

The genus was erected for those Aloninae possessing two narrowly connected major head pores, in contrast to forms having three major head pores, or two major head pores with a wide connection, or unconnected major head pores. Harding (1972) and Petkovski (1973a) note that head pores should not be overstressed as a character. Harding further notes that species attributed to Biapertura are not unified by other characters. However, before these species were removed from Alona, the latter was an even more heterogeneous assembly, almost without any common characters.

\section{Key to Australian Species of Biapertura}

1. Labrum with a small notch or angle on its edge $\ldots \ldots \ldots \ldots \ldots \ldots \ldots \ldots \ldots \ldots \ldots \ldots$

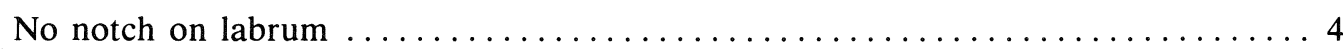

2(1). Some antennal setae in the form of long spines $\ldots \ldots \ldots \ldots \ldots \ldots \ldots \ldots \ldots$

Antennal segments without long spines; antenna comparatively

short ............................ abreviata (Sars, 1896) n. comb.

3(2). Ventro-posterior corner of valve rounded, lacking denticles $\ldots \ldots \ldots \ldots \ldots \ldots \ldots$ ................................ B. macrocopa (Sars, 1895) n. comb.

Ventro-posterior corner of valve with denticles

B. duoodonta (Henry, 1922) n. comb.

4(1). Separate denticles on ventro-posterior corner of valve ....... B. karua (Sars, 1888)

No denticles on ventro-posterior corner of valve $\ldots \ldots \ldots \ldots \ldots \ldots \ldots \ldots \ldots$

5(4). Length of preanal margin of postabdomen equals distance from preanal angle to base of claw ....................... rigidicaudis Smirnov, 1971

Preanal margin of postabdomen short $\ldots \ldots \ldots \ldots \ldots \ldots \ldots \ldots \ldots \ldots$

6(5). Postabdomen dilated distally; lateral setae reaching beyond edge of postabdomen ................................ intermedia (Sars, 1862)

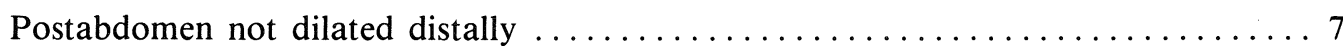

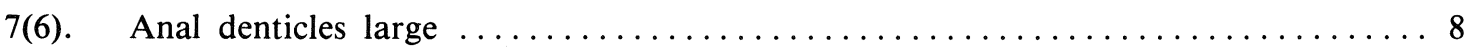

Anal denticles small; dorsal and ventral edges of postabdomen parallel ............................. longinqua Smirnov, 1971

8(7). Dorsal margin of postabdomen convex; its dorso-posterior corner not

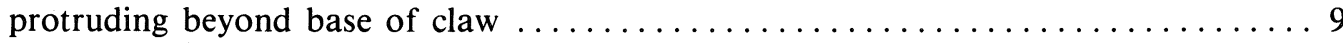

Dorsal margin of postabdomen straight or slightly concave; its dorso-posterior

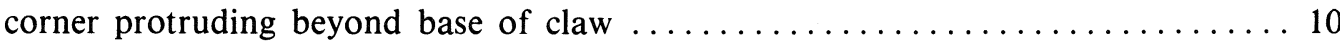

9(8). Anal denticles with setules along their functionally posterior side; no spinule at border between first and second joints of distal swimming setae of antennae ........................ kendallensis (Henry, 1919)

- Anal denticles without setules along their functionally posterior side; spinule present at border between first and second joints of distal swimming setae of antennae ......................... B. affinis (Leydig, 1860)

10(8). Dorsal edge of postabdomen straight; its distal edge truncated $\ldots \ldots \ldots \ldots \ldots \ldots$. ................................. setigera (Brehm, 1931) n. comb.

Dorsal edge of postabdomen slightly concave; its distal edge protruding noticeably beyond base of claw, and its apex rounded ........ B. rusticoides $\mathrm{n}$. sp. 


\section{Biapertura affinis (Leydig, 1860)}

Lynceus affinis Leydig, 1860; 223, Taf. IX, figs 68, 69. Alona oblonga P.E. Muller, 1867: 175-176, tab. III, figs 22-23, tab. IV, figs 1, 2.

Alona whiteleggii Sars, 1896: 35-37, pl. 6, figs 1, 2.-Henry, 1922: 40-41.

Alona affinis. -Sars, 1901: 48-49, pl. IX, figs 1, 1 a-d; Henry, 1922: 40-41.

Alona longirostris Henry, 1919: 474-476, pl. xli, figs 11, 12.Henry, 1922: 40-41, n. syn.

Biapertura affinis. - Smirnov, 1971b: 467-474, figs 582-587.

Material. Qld: 6, 54, 60, 66. N.S.W.: 77, 93, 133, 148, a slide in the Australian Museum "P:5912 Alona affinis Leydig, Byron Bay”. Vic.: 203, 224, 225, 230, 232, 239. Tas.: 303. W.A.: 419.

Comment. The holotype slide of Alona longirostris in the Australian Museum-" $\mathrm{P}: 4332$ Alona longirostris Henry, Holotype, Byron Bay"-contains Biapertura affinis, $B$. setigera, Moinodaphnia macleayi and Simocephalus sp. Obviously Biapertura affinis was noted by Henry as Alona longirostris.

Female. A number of subspecies are known (Smirnov, 1971b). The typical form is found in material from Loc. No. 77. Females from the population of the littoral of Loc. No. 133 have round depressions in the head shields. These forms correspond to "tuberculata" or "caelata" forms known for many species (e.g. Chydorus eurynotus caelatus, Alona rectangula pulchra) and are commonly designated as a separate taxon, in distinction to smooth forms. However the true nature of the tuberculated forms is not known. Harmsworth (1968) notes that tuberculated forms are present in acid peaty (bog) waters. Therefore in the present case this form is noted here but not named.

Length. $0.84 \mathrm{~mm}$.

Ecology. Unlike most other chydorids, B. affinis was often found in Australia living amongst vegetation in flowing water.

Distribution. Probably Australia-wide, but most common in southern Qld, eastern N.S.W. and Vic.

Differential diagnosis. The anal denticles of the postabdomen are large but not wide and have no setulations along its functionally posterior side. The postabdomen is not dilated distally. There is a spinule at the border of the first and second segments of the distal setae of the antennae. The outgrowths of the epipodites of legs IV and V are short.

Biapertura affinis affinis (Leydig, 1860)

Material. N.S.W.: 77.

Slide. MGU \& 598.

Biapertura kendallensis (Henry, 1919)

Fig. 66

Alona kendallensis Henry, 1919: 474-475, pl. xli, figs 9, 10; 1922: 41, pl. VIII, fig. 7 .

Biapertura kendallensis. - Smirnov, 1971b: 474, figs 591-592.
Material. Qld: 66. N.S.W: 92, 133, holotype slide in Australian Museum "P:4331 Alona kendallensis. Holotype. Kendall”. Vic.: 203, 232, 257.

Slides. AM \& P27701, MGU \& 1770, ZIN 2267.

Female. The two major head pores connected in the holotype specimen. Postabdomen with wide anal teeth, the latter with additional indentations. Thoracic limb I with a hook-like seta on external branch of endite. It was impossible to distinguish the antennal setae on the holotype.

Length. Up to $1 \mathrm{~mm}$.

Ecology. Found mainly in acid waters (pH 6.0-7.0).

Type locality. Kendall, N.S.W.

Distribution. Uncommon in southern Qld, coastal N.S.W. and southern Vic.

Differential diagnosis. The anal teeth of the postabdomen are large and have setulations along their functionally posterior side. The postabdomen is not dilated distally. Its dorsal edge is convex and its distal edge rounded. There is no spinule at the border of the first and second joints of the distal swimming setae of the antenna. The outgrowths of the epipodites of legs IV and V are long. Biapertura kendallensis and $B$. affinis are very similar in size and form, but as shown above they can be distinguished by the structure of the anal teeth and antennal setae.
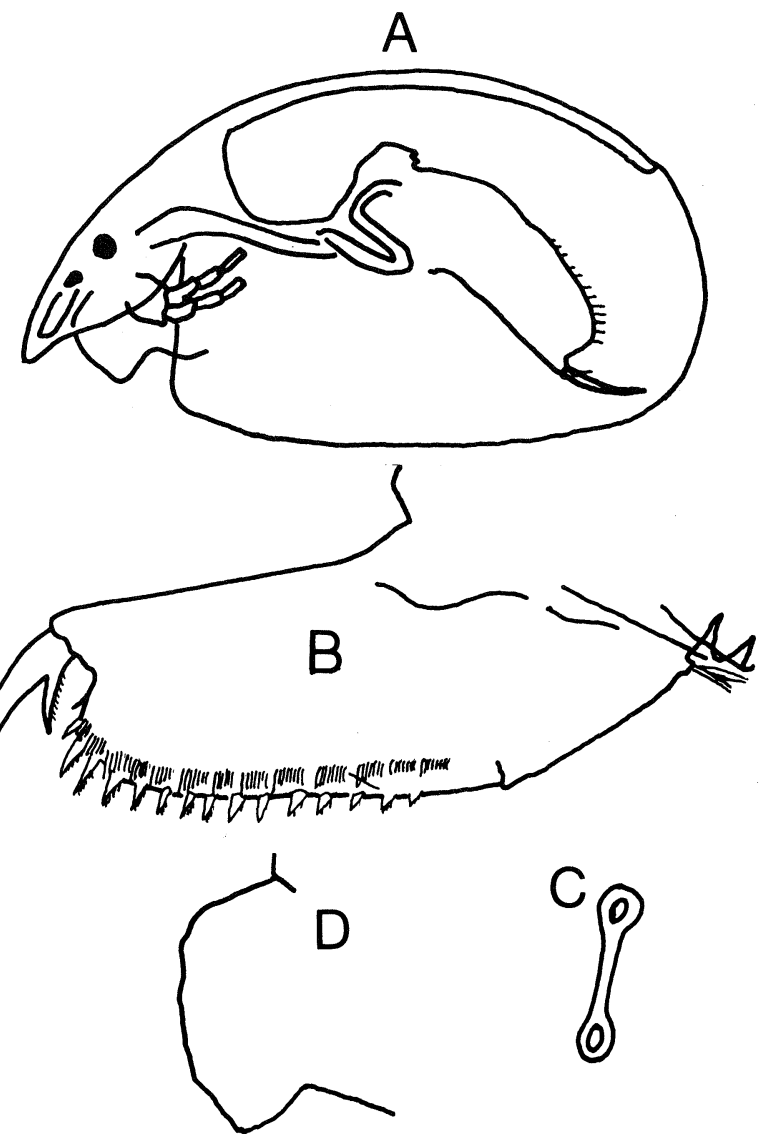

Fig. 66. Biapertura kendallensis 웅, after Smirnov, 1971b. A, whole animal, length $1.06 \mathrm{~mm}$; B, postabdomen; $\mathbf{C}$, head pores; $\mathbf{D}$, labrum. 


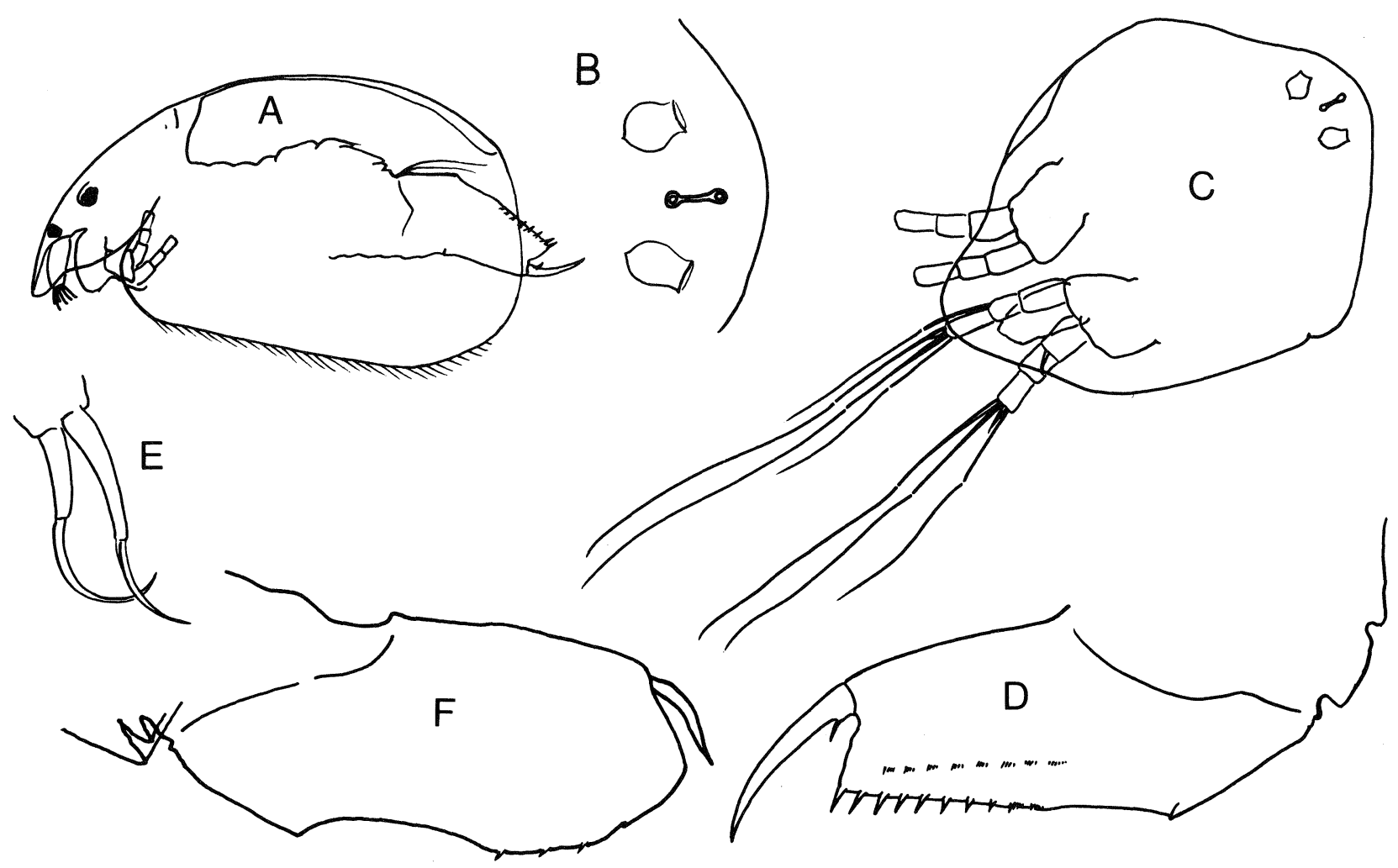

Fig. 67. Biapertura setigera $\$$, Main Bridgewater L., via Portland, Vic., 18.ii.72. A, lateral view of whole animal, length 0.5 mm, slide AMP 27706; B \& C: head shield, slide 1482; D, postabdomen, slide AMP 27706; E, large setae of external branch of endite of limb I, slide AMP 27706; F, abnormal postabdomen of a specimen from L. Freshwater, Cooloola, Qld, 16.vii.76, slide 2866.

A
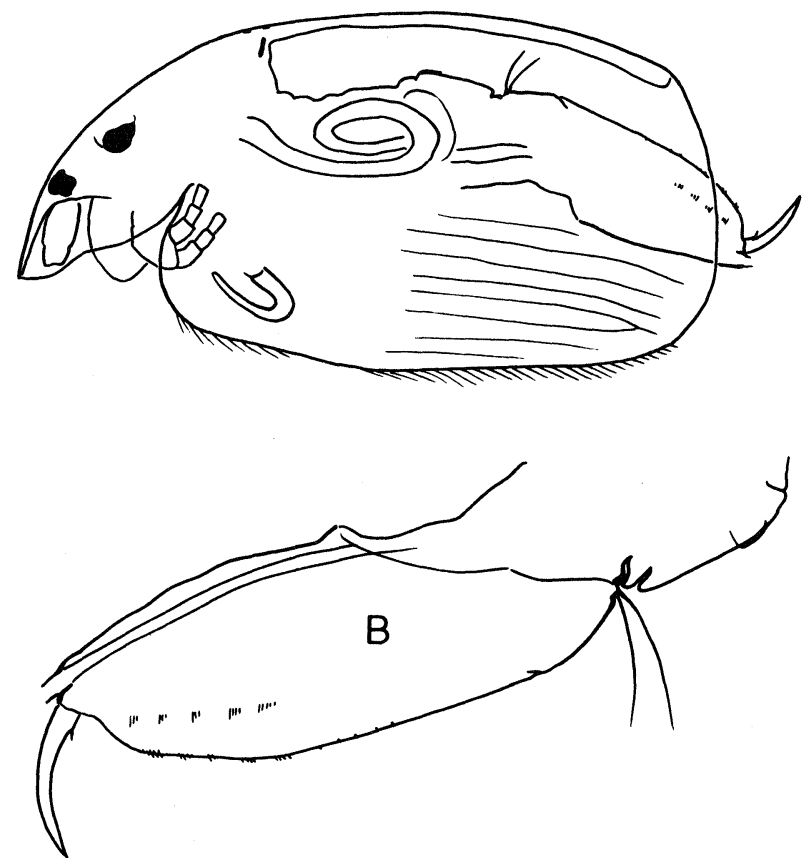

Fig. 68. Biapertura setigera $\sigma^{*}$, Emigrant $\mathrm{Ck}$, near Ballina, N.S.W., 18.viii.65. A, lateral view of whole animal, length $0.3 \mathrm{~mm} ; \mathbf{B}$, postabdomen. (Both from slide 1589.)
Biapertura setigera $($ Brehm, 1931) n. comb.

Figs 67, 68

Alona guttata var. setigera Brehm, 1931: 499-501, figs 7-9. Alona setigera Petkovski, 1973a: 140-143, figs 19-22. Alona archeroides Brehm, 1933: 724-725, figs 28-30.

We agree with Petkovski (1973a) that there is some uncertainty in the identity of Brehm's Alona guttata var. setigera and Alona archeroides. Brehm's $A$. setigera has the antennule reaching the tip of the rostrum. His figure shows that the preanal angle of the postabdomen is wide and just projecting, so that the anal edge is weakly concave.

Material. Qld: 5, 12, 48. N.S.W.: 77, 87, 96, 100, 118, 125, 146, 147, 171. Vic.: 202, 221, 225, 232, 252, 256, 257. Tas.: 305, 316, 326. S.A.: 362, 369, 370, 374, 388 . Also slides in the Australian Museum "P:5910 Alona cambouei Richard, Loc. Pt. Stephens" (two major head pores are present) and "P:5891 Alona laevissima Sars, Loc. Kendall” are Biapertura setigera.

Slides. AM $\odot$ P27706, MGU $\subsetneq 1482,2866$, ơ 1589, ZIN \& 595, BM ९ 1980.361 .

Female. This form is superficially similar to Alona guttata, but is distinguished by the presence of two major head pores, narrowly connected.

Length. Up to $0.5 \mathrm{~mm}$. 


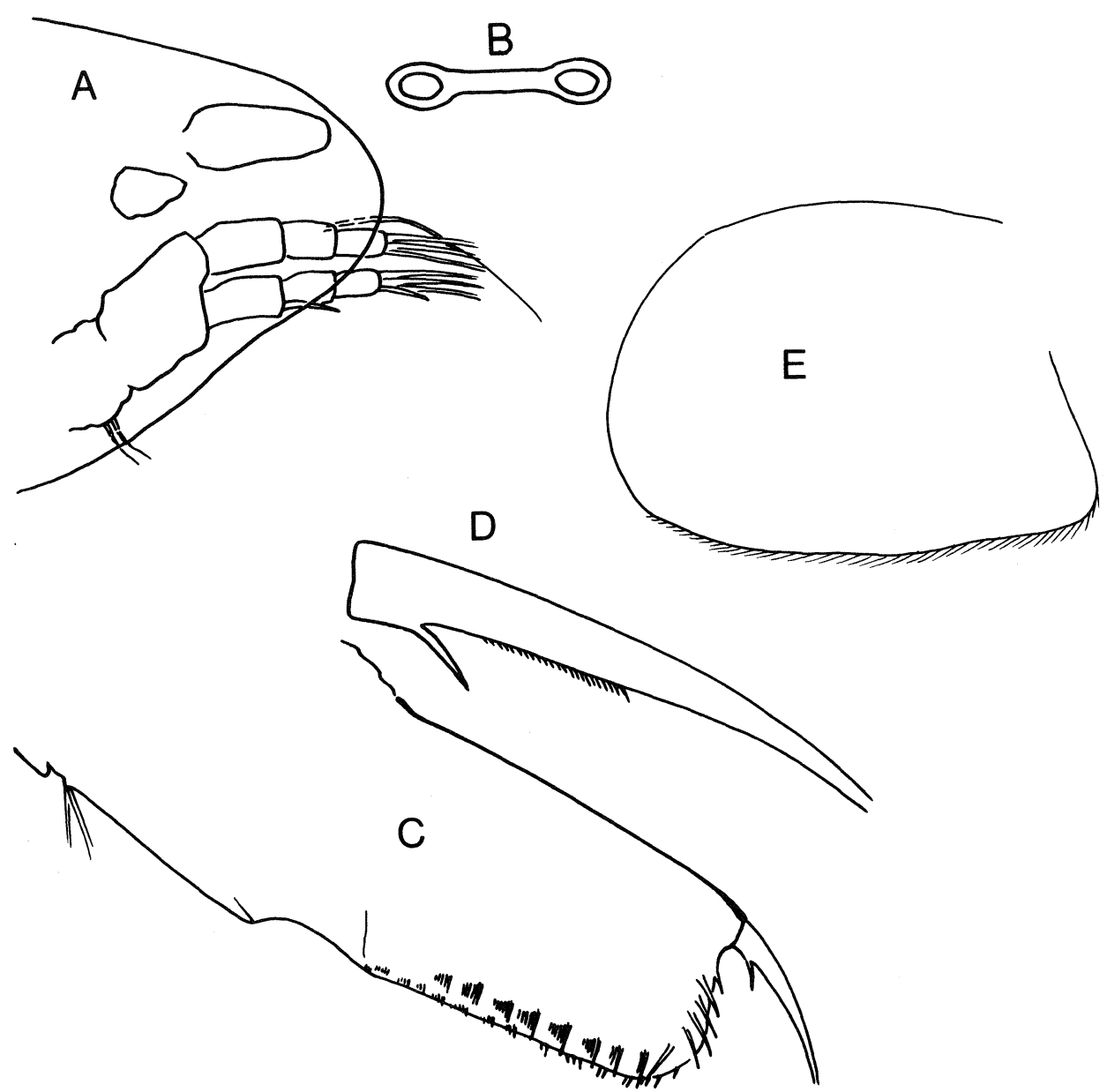

Fig. 69. Biapertura longinqua $\$$, after Smirnov, $1971 \mathrm{~b}$. B, head pores; C, postabdomen; D, claw; E, carapace.

Male. Brehm (1931) notes that the valve is longitudinally lineated and that there is no basal spinule on the claw.

Length. $0.3 \mathrm{~mm}$.

Ecology. Found in a variety of waters including acid coastal lakes.

Distribution. Australia: eastern and southern parts. World: New Zealand and also recently identified by N.N. Smirnov from the Volga Delta.

Differential diagnosis. The postabdomen is not dilated distally, the dorsal edge being straight and the distal edge truncated. The anal denticles on it are large. The minor (lateral) head pores are transverse and obvious.

Biapertura longinqua Smirnov, 1971 Fig. 69

Biapertura longinqua Smirnov, 1971b: 474-475, fig. 593.

Material. N.S. W.: 81, 91, 97, 98, 100. Vic. 204, 215, S.A.: 361. W.A.: 424.

Holotype. MGU $q 676$.

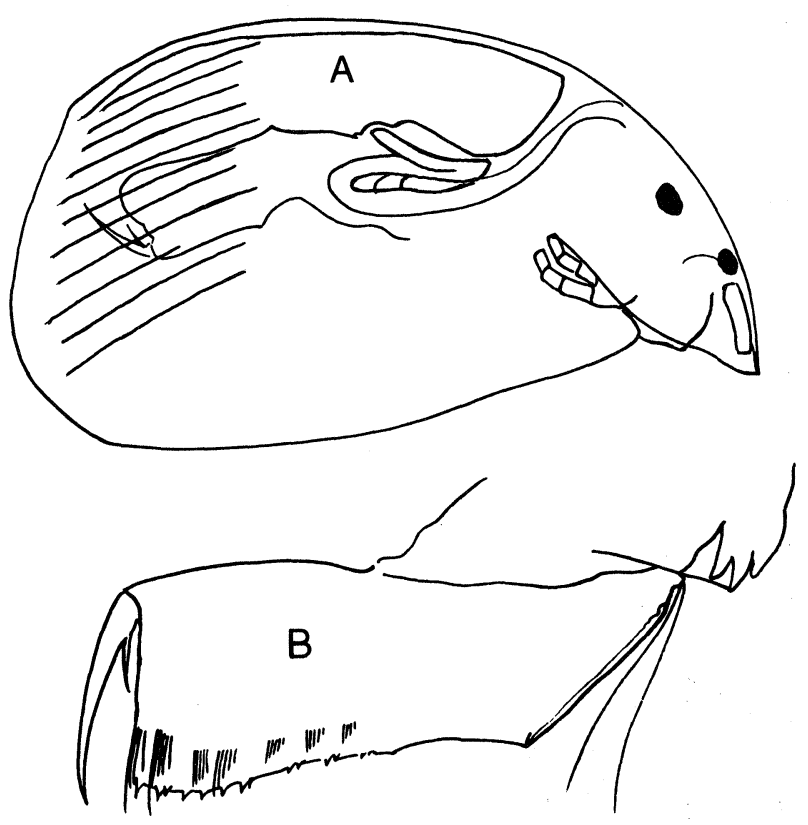

Fig. 70. Biapertura intermedia intermedia ${ }$, swamp in Myall Lakes area, N.S.W., 13.iv.75. A, lateral view of whole animal, length 0.31 $\mathrm{mm}$, slide 2852; B, postabdomen, slide 2855 . 


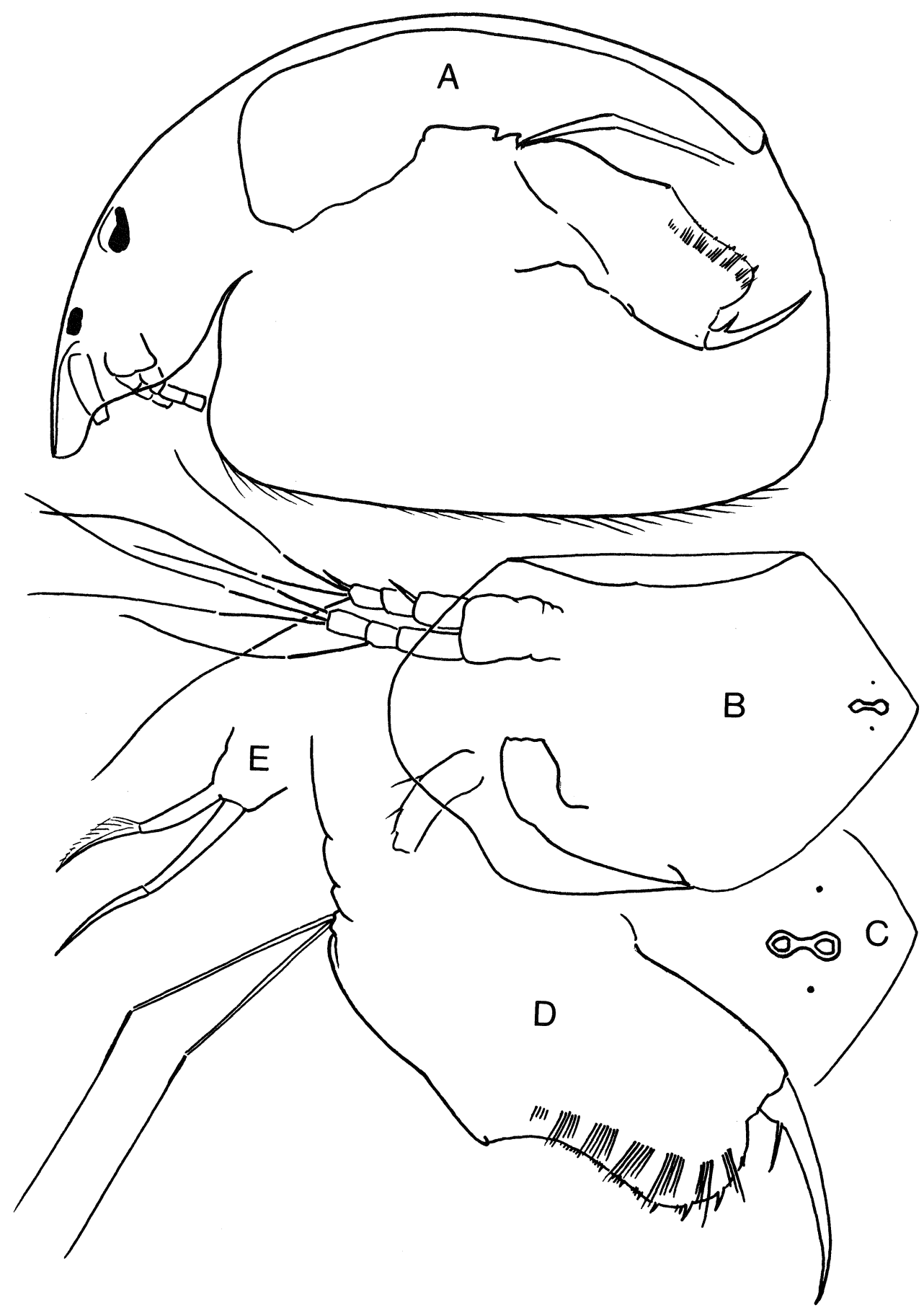

Fig. 71. Biapertura rigidicaudis $९$, Whites Lag., Tunbridge, Tas., 12.x.72. A, lateral view of whole animal, length $0.35 \mathrm{~mm}$; B \& C, head shields, D, postabdomen; E, large setae of external branch of endite of limb I. (All from slide 1873.)

Paratypes. AM $\$$ P27702, ZIN postabdomen of a $\$$ 54155 (954).

Length. $0.4 \mathrm{~mm}$.

Ecology. Most of the known habitats are acid waters on sand. Females from the Myall Lakes area (N.S.W.) were reddish due to pigmented blood.

Type locality. Morisset Hospital Dam, via Newcastle, N.S.W.
Distribution. South-eastern Australia, particularly coastal N.S.W., and one isolated occurrence in W.A.

Differential diagnosis. The ventral and dorsal edges of the postabdomen are parallel. The anal denticles are small. There are lateral fascicles of setae on the postabdomen; its ventro-posterior angle is rounded and anal teeth are extended onto its distal margin. 
Biapertura intermedia (Sars, 1862)

Fig. 70

Alona intermedia Sars, 1862b: 286-287.

Biapertura intermedia.-Smirnov, 1971b: 475, figs 594-596.

Material. Qld: 38. N.S.W.: 79, 96, 98, 125. W.A.: 423. Slides. $\quad$ AM $\subsetneq$ P27699, MGU \& 2851, 2855, ZIN \& 2852.

Female. Of the two subspecies known (Smirnov, 1971b) only the typical form occurs in Australia. A tuberculated form was found in the material from Loc. No. 423 (W.A.).

Length. $0.45 \mathrm{~mm}$.

Ecology. All the N.S.W. records are from acid lakes on sand dunes or sandstone ( $\mathrm{pH}$ c.5.0).

Distribution. East coast and adjacent areas of Australia; also one isolated occurrence in W.A.

Differential diagnosis. The postabdomen is dilated distally; its lateral setae reach beyond its edge.

\section{Biapertura rigidicaudis Smirnov, 1971}

\section{Fig. 71}

Alona intermedia.-Gurney, 1927: 72, fig. 8E (misidentification).

Biapertura rigidicaudis Smirnov, 1971b: 475, 479, figs 598, 599.

Material. Qld: $32,60,62$. N.S. W.: 83, 99, 107, 118, 139, 171, 173. Vic.: 204, 220, 232, 235, 256, 257, 258, 263. Tas.: 314, 319, 326. S.A.: 377, 378, 379, 385, 386, 387, W.A.: 405, 409.

Holotype. MGU @ 1288.

Paratypes. AM ९ P27704, ZIN $\subsetneq 53847$ (1832).
Slides. $\mathrm{AM} \subsetneq \mathrm{P} 31308, \mathrm{MGU} \subsetneq 1873$.

Female. Antennal setae 0-0-3/0-1-3, spine 1-0-1/0-0-1. Postabdomen rather short and wide. Its preanal margin long and same length as distance from preanal angle to base of claw. Lateral setae of postabdomen long and anal teeth very short.

In females from Loc. 107 the ocellus is noticeably smaller than the eye. Specimens from Loc. 263 are a little different from the holotype specimens from Loc. 107-there are very minute denticles on the ventroposterior corner of the valve and the antennal spines are much longer. While individuals typically have smooth shells, those in Loc. 314 (Tas.) have depressions on the shell (see previous comment on Biapertura affinis).

Length. $0.35 \mathrm{~mm}$.

Ecology. Lives in a variety of waters but rarely in acid dune lakes.

Type locality. Doughboy creek, Ebor, N.S.W.

Distribution. Widely distributed in Australia.

Differential diagnosis. The length of the preanal margin of the postabdomen equals the distance from the preanal angle to the base of the claw. There are usually no denticles on the ventro-posterior angle of the valve.

\section{Biapertura karua (King, 1853)}

Fig. 72

Alonella karua Sars, 1888: 50, pl. V, figs 8, 9.

Biapertura karua.-Smirnov, 1971b: 479-480, figs 600-603.

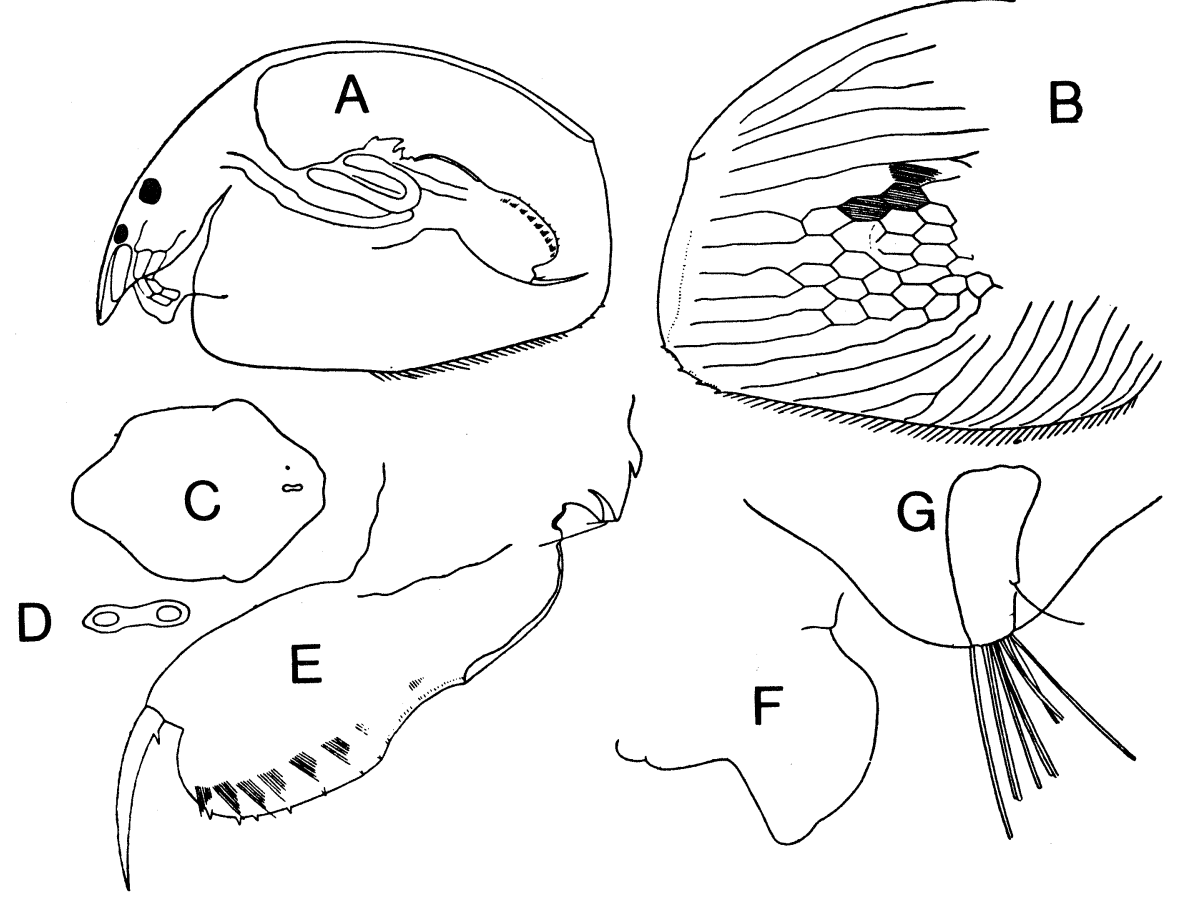

Fig. 72. Biapertura karua $९$, after Smirnov, 1971b. A, whole animal, length $0.29 \mathrm{~mm}$; B, carapace showing surface markings; $\mathbf{C}$, head shield; D, head pores; $\mathbf{E}$, postabdomen; $\mathbf{F}$, labrum; $\mathbf{G}$, antennule. 


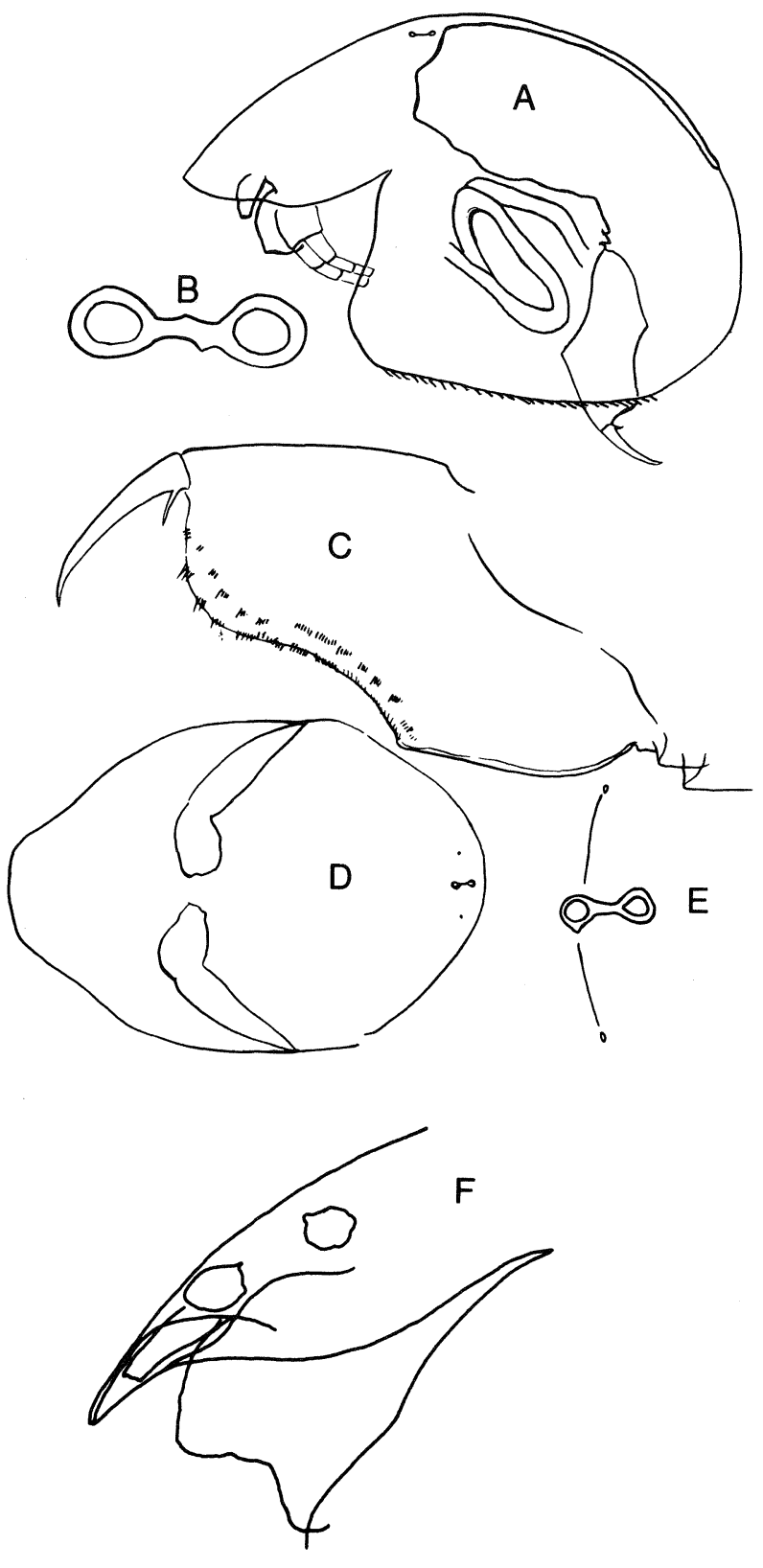

Fig. 73. Biapertura macrocopa $९$, pool, $11 \mathrm{~km} \mathrm{~S}$ of Northcliffe, W.A., 3.vi.77. A, lateral view of whole animal, length $0.61 \mathrm{~mm}$; B, head pores; C, postabdomen. (A-C from slide 374). D, head shield; E, head pores. (D and E from slide 1140). F, head with eye and ocellus, from slide 687

Material. Qld: 4, 11, 12, 15, 18, 27, 37, 39, 40, 41, 42, 43, 64. N.S. W.: 86, 93. Vic.: 232.

Slides. AM $\odot$ P27700, MGU $\subsetneq$ 1496, ephippium 1741, ZIN $\odot 1030$.

Length. $0.29 \mathrm{~mm}$.

Ecology. Unlike other species of Biapertura, it is rarely found in acid waters and is not known from coastal dune lakes.

Type locality. Karua (now Karuah) River, Stroud, N.S.W.

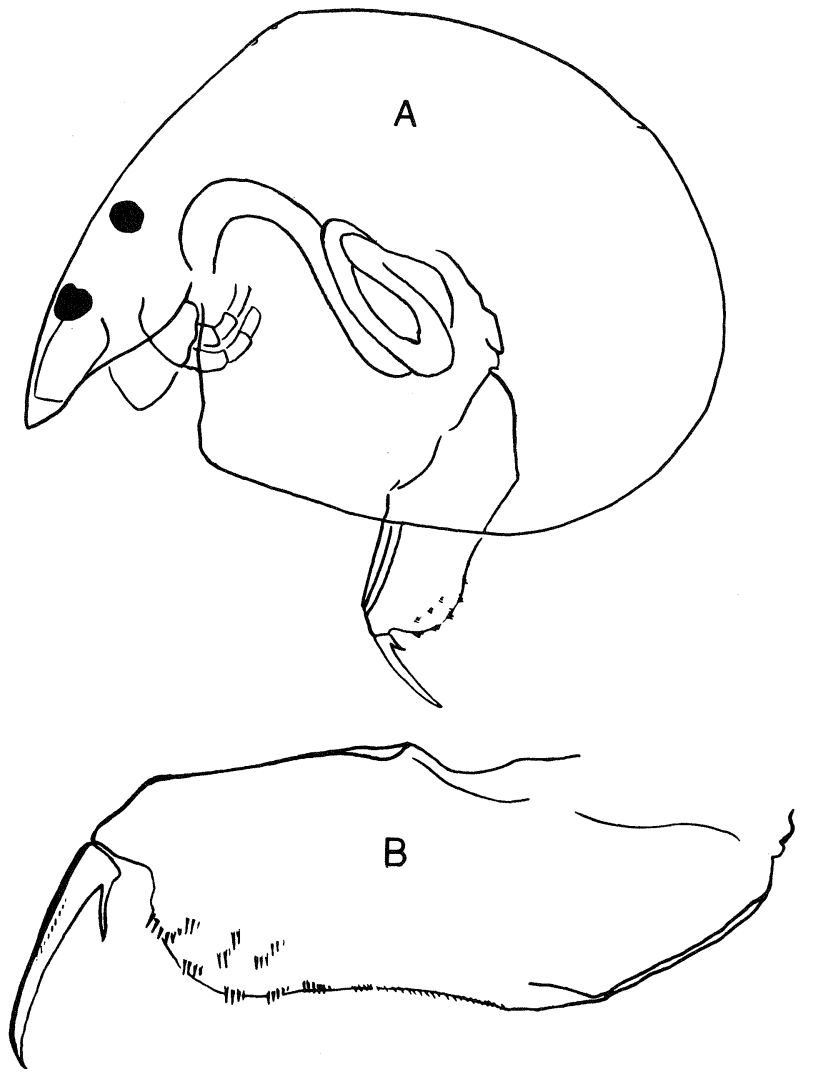

Fig. 74. Biapertura macrocopa or juvenile, pool, $11 \mathrm{~km} \mathrm{~S}$ of Northcliffe W.A., 3.vi.1977. A, lateral view of whole animal, length $0.48 \mathrm{~mm}$; B, postabdomen. (Both from slide 716.)

Distribution. Australia: widely distributed in Qld, localized in N.S.W., Vic., and W.A. (Brehm, 1953b). World: circumtropical.

Differential diagnosis. The postabdomen is rounded and has very small anal teeth. There are separate denticles on the ventro-posterior corner of the valve.

\section{Biapertura macrocopa (Sars, 1895) n. comb.}

Figs 73, 74

Alona macrocopa Sars, 1895: 20-23, pl. III, figs 11-15. Alonella macrocopa.-Gurney, 1927: 75-76, fig. 10.

Material. Qld: 9, 12, 13. N.S.W.: 79, 96, 98. W.A.: 410, 426.

Slides. AM $\subsetneq$ P27703, MGU $\subsetneq 374,1140,1887,2860$, o* 716, ZIN ᄋ 2862.

Female. Two interconnected head pores are present, so this species is transferred to the genus Biapertura. There is variation in some features among populations. In females from Loc. No. 427 (W.A.) labrum widely crenulated (i.e. wavy) in outline; ocellus larger than eye in both females and males; leg IV exopodite with 6 setae, but occasionally 7 present (as on left exopodite of leg IV in slide 1887). In the population from Loc. No. 98 (N.S.W.) labrum of females with a blunt apex and an evenly convex outline; ocellus smaller than the eye. 
Females from Loc. No. 12 (Qld) have round depressions in the carapace (see comments on Biapertura affinis).

Length. Variable. Females $0.61 \mathrm{~mm}$ and males 0.49 $\mathrm{mm}$ in collection from Loc. No. 427 (W.A.) but females $0.26 \mathrm{~mm}$ in sample (slide 2860) from Loc. No. 98 (N.S.W.).

Ecology. It was noted in live specimens that when the thoracic limbs move the exopodites of limbs IV and $\mathrm{V}$ undulate, as they do in most Chydoridae.

Type locality. New Zealand.

Distribution. Localized in north Qld, north-eastern N.S.W., and south-western W.A.

Differential diagnosis. The antenna has spines 1-0-1 $/ 1-1-1$. This species is distinguished by a large spine on the proximal joint of the antennal branches (exopodite); its length exceeds the length of the second joint. The latter also possesses a long spine, much exceeding the length of the terminal joint (this spine is probably a shortened and chitinized seta).

\section{Biapertura rusticoides n. sp.}

Fig. 75

Material. Tas.: 307, 312, 313, 314, 315, 320, 330, 332.

Holotype. AM \& P27705.

Paratypes. MGU $\subsetneq$ 2913, ZIN $\subsetneq 2918$, BM $\odot$ 1980.360.

Female. Body oval in outline with ventral margin of valve only slightly convex and bearing setae. Two major head pores with a narrow interconnection.

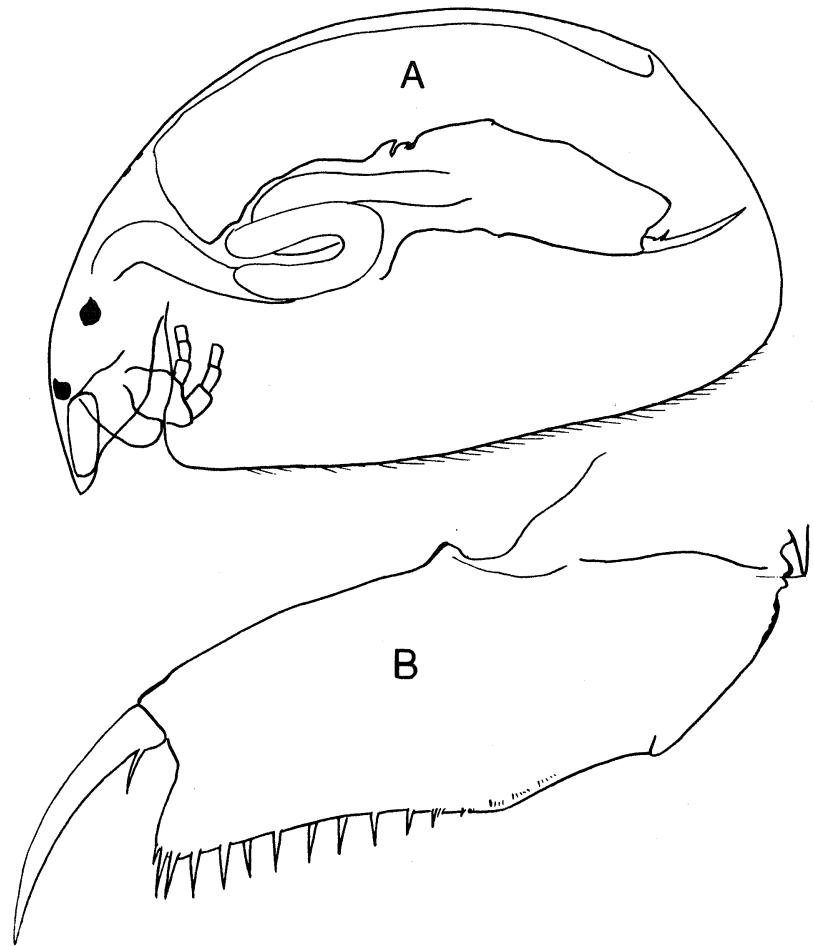

Fig. 75. Biapertura rusticoides $९$, pond near L. Echo, Tas., 20.viii.1974. A, lateral view of whole animal, length $0.49 \mathrm{~mm} ; \mathbf{B}$, postabdomen. (Both from slide 2913.)
Antennule not reaching tip of rostrum. Postabdomen rather wide, its dorso-posterior corner protruding noticeably beyond base of claw. Anal margin only slightly depressed, so preanal corner hardly noticeable. Anal teeth large, gradually diminishing proximally. Claw with a small basal spine. Intestine convoluted.

Length. $0.49 \mathrm{~mm}$ (holotype P27705).

Male. Unknown.

Type locality. A pond near L. Echo, central Tasmania.

Etymology. The specific name alludes to its external similarity to Alona rustica Scott, 1895.

Differential diagnosis. The postabdomen is rather wide, with large anal teeth, gradually diminishing proximally; its dorso-posterior corner protrudes noticeably beyond the base of the claw.

Biapertura rusticoides is similar to $B$. setigera, its closest taxon, but differs in that the postanal margin of the postabdomen is concave, the dorso-posterior corner of the postabdomen is somewhat rounded and protrudes more beyond the base of the claw, and the sculpture of the valve is comparatively more expressed.

Biapertura rusticoides is also similar to Alona rustica but is readily distinguishable by having two major head pores, narrowly connected. Alona rustica has a wide geographical range including Europe and North and South America. In that information on head pores of South American populations is lacking (Frey, 1965) and as an externally similar form with two head pores has now been discovered in Australia, the specific status of the South American taxon might be doubted. However, examination of a female specimen of $A$. rustica from Rio Nhamundá (Brazil) kindly supplied by Prof. H. Sioli and Dr G.O. Brandorff showed it indeed has 3 major head pores, narrowly connected, and noticeable minor pores.

Biapertura abreviata (Sars, 1896) n. comb. Fig. 76

Alona abreviata Sars, 1896: 40-42, pl. 6, figs 5, 6.-Henry, 1922: 42, pl. VIII, Fig. 8. Alonella abbreviata [sic].-Gurney, 1927: 76.

Material. Literature.

Female. Biapertura abreviata is very similar to $B$. macrocopa. However, Sars (1896) expressly notes that it differs in the comparatively small size of the antennule. Gurney (1927:76) writes "If it were not for the fact that Prof Sars definitely states that his $A$. abbreviata [sic] differs from $A$. macrocopa in not having strikingly large antennae it would be necessary to include this species also in the synonymy (of Alonella macrocopa)." We have however noted (in the key) the difference in the setation and size of the antennae. Hence it seems appropriate to retain the two species. Nevertheless there is still a problem as to which genus abreviata belongs. We have not had the opportunity to study its head pores, so that its present inclusion in 


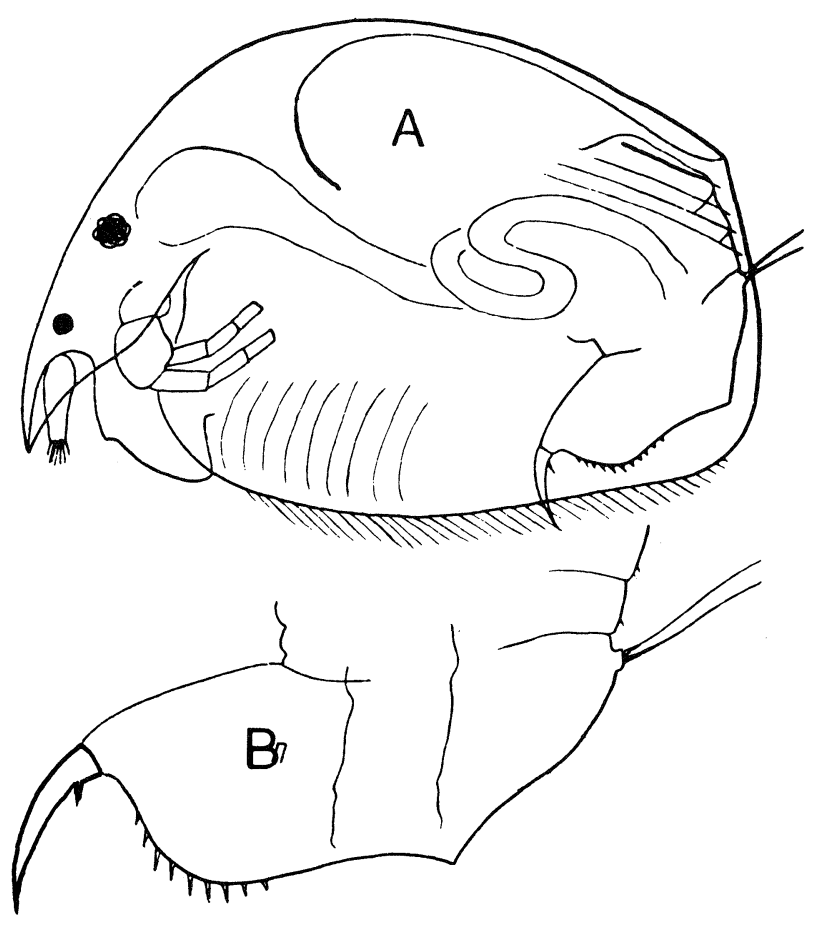

Fig. 76. Biapertura abreviata $९$, after Smirnov, 1971b. A, whole animal, length $0.37 \mathrm{~mm}$; B, postabdomen.

Biapertura is based on its similarity to $B$. macrocopa, which definitely belongs to Biapertura. Further study is needed.

Length. $0.37 \mathrm{~mm}$.

Type locality. Sydney.

Distribution. N.S.W.

Differential diagnosis. The body is relatively high. There is a small notch on the labrum. The postabdomen is short and rounded. The valve is lineated, the lines according to Sars (1896:41) "appear somewhat flexuous thus forming an indistinct reticulation". The antenna is of moderate size and without long spines.

Biapertura duoodonta (Henry, 1922) n. comb.

Alonella duoodonta Henry, 1922: 49, figs 1-4.

Material. N.S.W.: holotype slide in the Australian Museum "P:5888 Alonella duoodonta Henry (Type) Loc. Manly”. Tas.: 299. W.A. 415.

Female. According to Gurney (1927) Alonella duoodonta Henry is synonymous with Biapertura macrocopa (Alona macrocopa Sars). However it is distinct as shown by the following features observed on the holotype slide: the labrum is notched, there are two major head pores which are connected, some antennal setae have the form of long spines and there are two denticles on the ventro-posterior corner of the valve.

The number of denticles on the valves varies, a feature common to many chydorids. In the population from Loc. No. 299 several females had 3 denticles on each valve and some had unequal numbers on the two valves-2-3, 3-2, 4-3 on the left and right valves respectively.

Length. $0.35 \mathrm{~mm}$.

Type locality. Manly, N.S.W.

Distribution. Localized in N.S.W., Tas., and W.A.

Differential diagnosis. Some antennal setae have the form of long spines. The body form is comparatively high. The postabdomen is short. There are denticles on the ventro-posterior corner of the valve. The labrum is notched.

\section{Genus Monospilus Sars, 1862}

Monospilus Sars, 1862a: 165-166.

Monospilus is mainly distinguished by the presence of an ocellus only, the eye being absent. The postabdomen is wide. In the type species ( $M$. dispar) the postabdomen is short and wide and there is one large head pore. The latter does not apparently apply in the Australian species. They also differ from the Holarctic $M$. dispar by not retaining moulted valves.

The type species is Monospilus dispar Sars, 1862.

\section{Key to Australian Species of Monospilus}

1. Body short-ratio length: height about 1.4 Postabdomen wide and with a few small anal teeth ................ diporus n. sp.

Body elongated-ratio length: height about 2. Postabdomen elongated and with long lateral setae reaching well beyond its margin ................ elongatus $\mathrm{n}$. sp.

\section{Monospilus diporus n. sp.}

Fig. 77

Material. N.S.W.: 188. S.A.: 394.

Holotype. $\mathrm{AM} \odot \mathrm{P} 31299$.

Paratypes. MGU \& 346, 3108, 3109, 3110, ZIN \& 3107, 3072.

Female. Body basically oval in lateral view. No denticles on ventro-posterior corner of valve. Ventral border of valve with setae. Shell with slightly expressed hexagons with fine granulations in them. Antennule short, not reaching tip of rostrum. Antennal setae $0-0-3 / 1-1-3$, large spines 1-0-1/0-0-1. Two interconnected head pores.

Postabdomen short and wide. Preanal angle noticeable. A few small anal teeth located on postanal margin of postabdomen; lateral setae in fascicles. Claw with a short basal spine.

Intestine with a double convolution.

Length. $0.49 \mathrm{~mm}$.

Male. Unknown.

Ecology. Known to occur over the temperature range $8.5-21.5^{\circ} \mathrm{C}$, $\mathrm{pH}$ range $7.0-8.3$, conductivity 365-600 $\mu$ S., and turbidities 80-135 NTU's (R. Shiel, personal communication). 


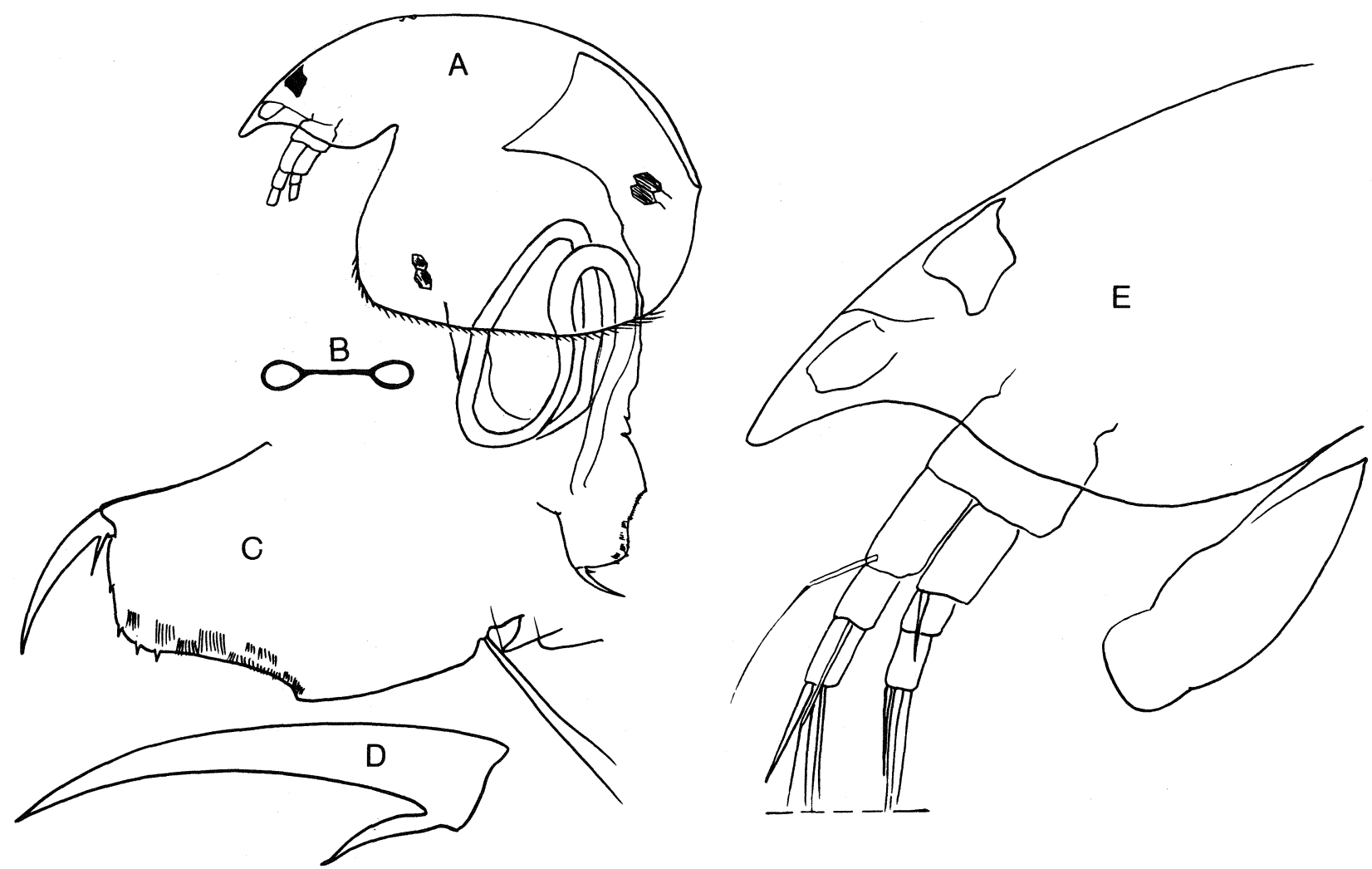

Fig. 77. Monospilus diporus $\&$, Murray R. at Mannum, S.A., 9.viii.76. A, lateral view of whole animal, length $0.49 \mathrm{~mm}$; B, head pores; C, postabdomen; D, claw; E, head. (A from slide 1898, remainder from slide 346. )

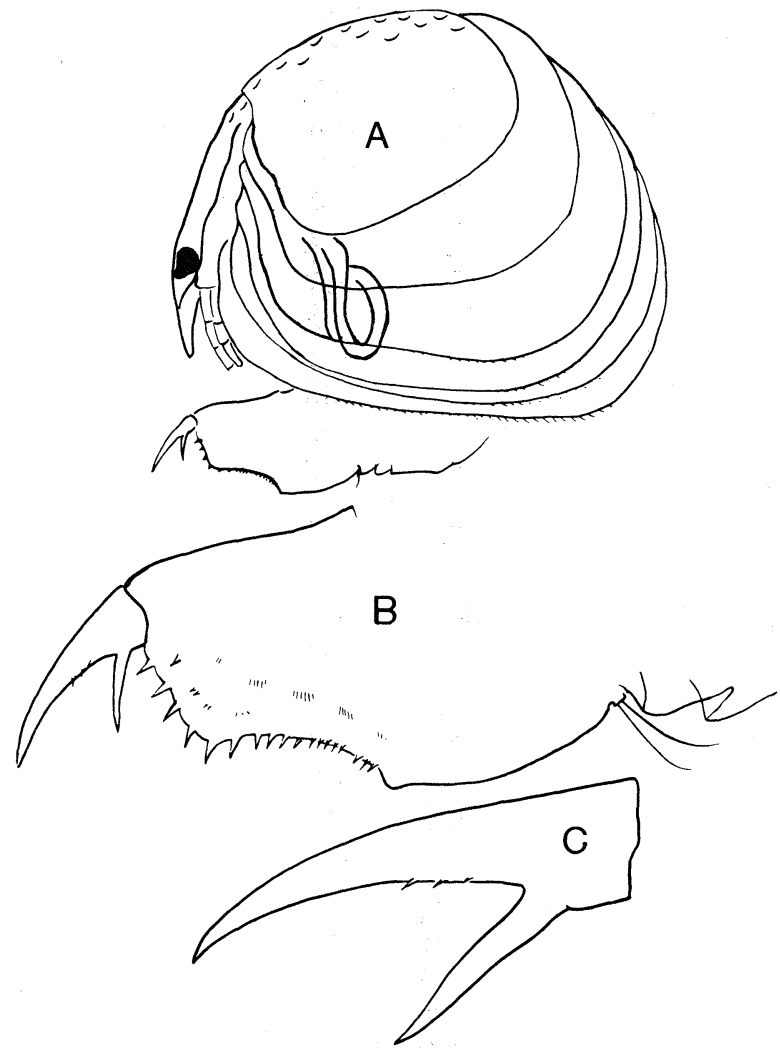

Fig. 78. Monospilus dispar $\$$, Rybinsk Reservoir, Borok, USSR. A, lateral view of whole animal, length $0.4 \mathrm{~mm} ; \mathrm{B}$, postabdomen; C, claw.
Type locality. Murray R. at Mannum, S.A.

Distribution. Lower Murray-Darling system (see R. Shiel, in prep.).

Differential diagnosis. For comparative purposes the type species $M$. dispar, is illustrated in Fig. 78. It possesses one head pore whereas M. diporus has two interconnected major head pores. The ratio length: height in $M$. diporus is 1.4 and in $M$. dispar 1.2 . Monospilus diporus has a seta on the basal segment of one antennal ramus, but it is lacking in $M$. dispar. The general outline of the postabdomen is similar in the two, but in $M$. diporus there are a few anal teeth compared to numerous teeth in $M$. dispar. The basal spine of the claw is comparatively short in $M$. diporus.

\section{Monospilus elongatus n. sp.}

Fig. 79

Material. S.A.: 394.

Holotype. AM $\odot \mathrm{P} 31300$.

Paratypes. MGU $\subsetneq 3111,3113,3114, \mathrm{ZIN} \subsetneq 3112$.

Female. Body oblong oval in lateral view. ratio length: height 1.96 (holotype P31300). No denticles on ventro-posterior corner of valve. Surface of shell without sculpturing. Ventral border of valve with setae, scarce and rather long in its posterior part. Anterior end 

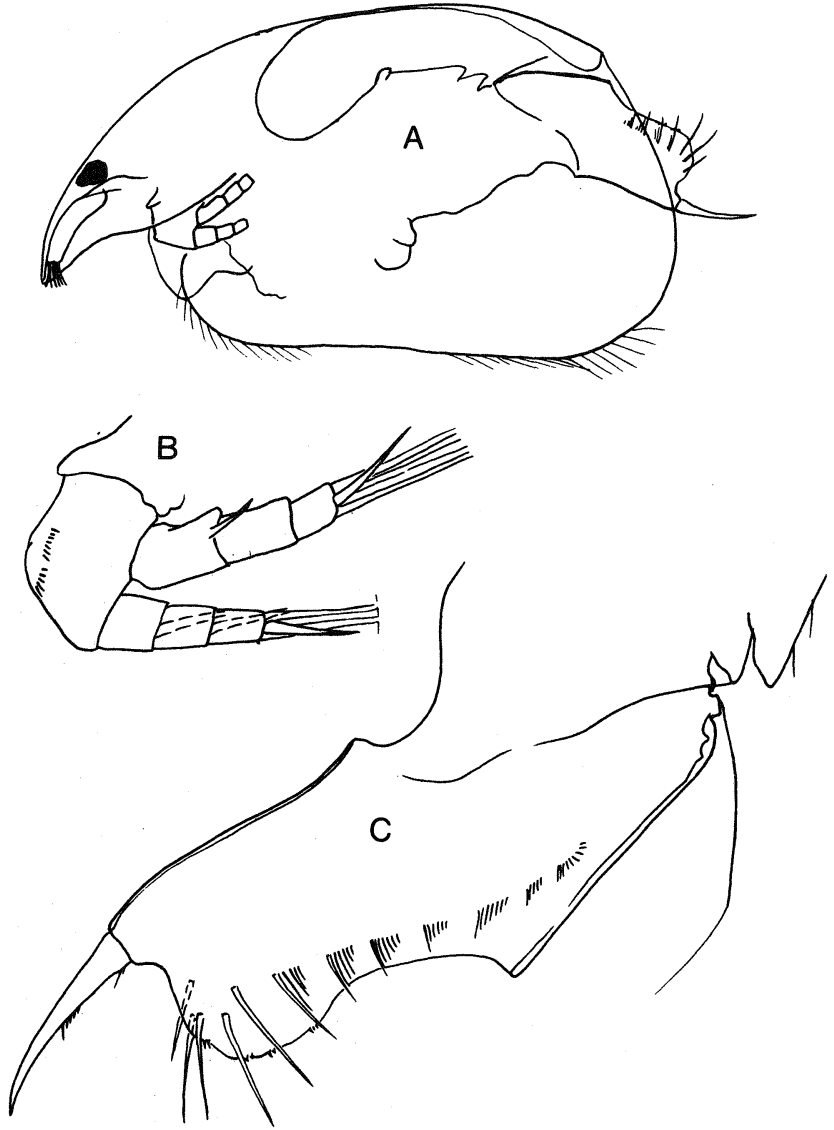

Fig. 79. Monospilus elongatus $\$$, Murray R. at Mannum, S.A., 13.vii.78 A, lateral view of whole animal, length $0.48 \mathrm{~mm}$; , antenna; C, postabdomen. (All from slide AM $९$ P31300.)

of head shield blunt. Antennule not reaching tip of rostrum. Antennal setae $0-0-3 / 1-1-3$, large spines 1-0-1/0-0-1. Head pores could not be definitely discerned in laterial view of the holotype.

Postabdomen elongated. Preanal angle well expressed, so anal margin concave. Upper distal end of postabdomen widely rounded and with a few solitary large lateral setae reaching well beyond its margin. More proximally, these setae shorter and accompanied by other setae. These groups extending onto lateral side of postabdomen far more proximally than preanal angle. A few extremely small anal teeth. Claw with setae on its concave side in middle and basal parts.

Labral plate wide, not ciliated. Intestine convoluted.

Length. $0.48 \mathrm{~mm}$.

Male. Unknown.

Type locality. The Murray River at Mannum, S.A.

Distribution. Lower Murray, though it is associated with intrusion of Darling R. water, so it could be from that system (R. Shiel, personal communication).

Differential diagnosis. Body elongated. Ratio length: height 1.96. Postabdomen elongated and possessing long lateral setae. Basal spine of claw, if any, very small.
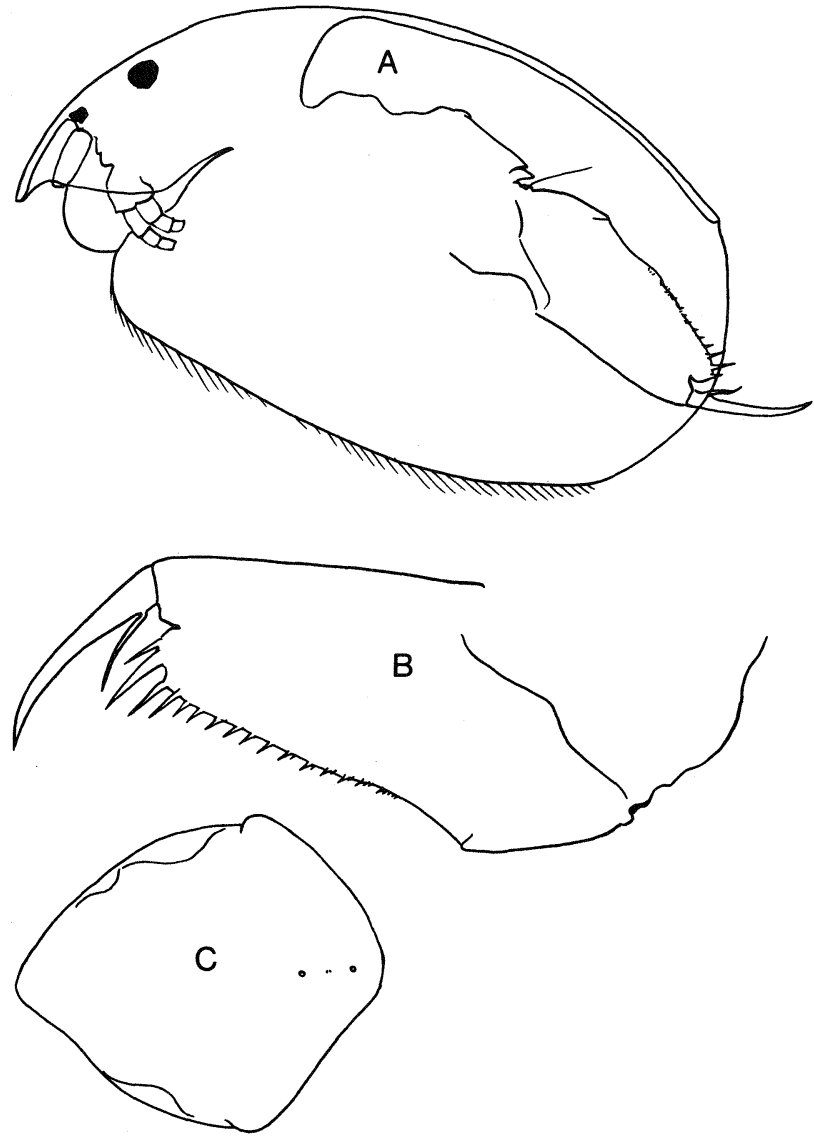

Fig. 80. Oxyurella tenuicaudis $q$, Sheepwash Lag., via Nelson, Vic., 11.viii.72. A, lateral view of whole animal, length $0.37 \mathrm{~mm}$, slide 2195; B, postabdomen, slide 2205; C, head shield, slide 2205 .

\section{Genus Oxyurella Dybowski \& Grochowski, 1894}

Oxyurella Dybowski \& Grochowski, 1894: 381.-Smirnov, 1971b: 491-493.

General body form very similar to that of Alona, however head pores separate in Oxyurella. Postabdomen elongated.

The type species is Oxyurella tenuicaudis (Sars, 1862).

\section{Key to Australian Species of Oxyurella}

1. Claw with one basal spine; a few distal anal teeth much longer than proximal teeth .......... O. tenuicaudis (Sars, 1862)

Claw with one big basal spine and a few small spines proximally; anal teeth gradually increase in size ............... O. singalensis (Daday, 1898)

Oxyurella tenuicaudis (Sars, 1862)

Fig. 80

Alona tenuicaudis Sars, 1862b: 285-286.

Alona wallaciana Henry, 1919: 472-474, pl. XLI, figs 7, 8, n. syn. 
Material. N.S.W.: 81, 118 , a slide in the Australian Museum "P:4330 Alona wallaciana Henry. Holotype. Kendall." Vic.: 203, 259, 260, 261.

Slides. AM \& P27720, MGU 2205, 2195, ZIN 2180.

Female. The valves of the females studied, including that on Henry's slide P:4330, are covered with fine granules; there are no longitudinal lines.

Length. $0.37 \mathrm{~mm}$ (slide 2195).

Ecology. In coastal dune lakes, both acid and alkaline.

Distribution. Coastal areas of N.S.W. and Vic.

Differential diagnosis. There is one basal spine on the claw. A few distal anal teeth are much longer than the proximal teeth.

\section{Oxyurella singalensis (Daday, 1898)}

Alonopsis singalensis Daday, 1898: 43-45, fig. 20.

Material. Qld: 16, also skeletal fragments in mud of L. Euramoo and L. Barrine.

Length. Up to $0.9 \mathrm{~m}$.

Distribution. Australia: northern Qld. World: Ethiopic and Indo-Malayan regions.

Differential diagnosis. The claw has one big basal spine and a few small spines proximally. The size of the anal teeth increases gradually.

\section{Genus Euryalona Sars, 1901}

Euryalona Sars, 1901: 80-81.-Smirnov, 1971b: 497-498.

The type species is Euryalona orientalis (Daday, 1898), which is the only species known in Australia.

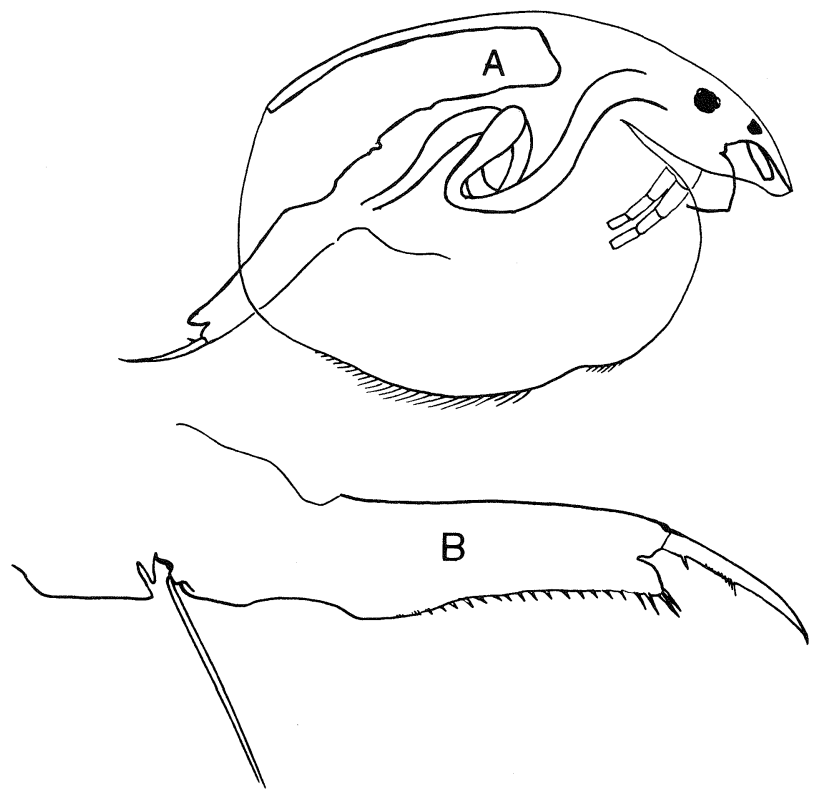

Fig. 81. Euryalona orientalis $Q$, Gladys Lag., via Clare, Qld, 18.vi.74. A, lateral view of whole animal, length $0.62 \mathrm{~mm} ; \mathbf{B}$, postabdomen. (Both on slide 666.)

\section{Euryalona orientalis (Daday, 1898)}

Fig. 81

Alonopsis orientalis Daday, 1898: 45-48, figs 21, 22.

Euryalona occidentalis Sars, 1901: 81-84, pl. XII, Figs 1, 1 a-h.

Material. Qld: 12, 13, 25.

Slide. MGU $\subsetneq 666$.

Length. Up to $1 \mathrm{~mm}$.

Distribution. Australia: northern Qld. World: circumtropical.

\section{Family MACROTHRICIDAE Norman \& Brady, 1867}

Macrothricidae Norman \& Brady, 1867: 9.-Smirnov, 1976: 1-173.

Lyncodaphnidae Sars, 1862: 299.

The type genus is Macrothrix Baird, 1843.

\section{Key to All Genera of Macrothricidae}

(Note: For a shortened key to Australasian genera see p.69)

1. Antennule two-segmented. Postabdomen wide, its dorsal side convex, having the appearance of a wide arc with denticles ..... Ilyocryptus Sars, 1862

_ Antennule one-segmented. Dorsal side of postabdomen straight or convex . . . 2

2(1). Anal opening in middle part of postabdomen $\ldots \ldots \ldots \ldots \ldots \ldots \ldots$

Anal opening in distal part of postabdomen $\ldots \ldots \ldots \ldots \ldots \ldots \ldots \ldots$

3(2). Antennal setae 0-0-0-3/1-1-3, spines 1-1-0-1/0-0-1 (Holarctic) 
4(2). Six pairs of thoracic limbs. Limbs III-V with large exopodites (Holarctic) ...... Acantholeberis Lilljeborg, 1853

Five pairs of thoracic limbs. All limbs with small exopodites $\ldots \ldots \ldots \ldots \ldots 5$

5(4). Valve with numerous papilla-like outgrowths bearing bristles on apices (Neotropical) ............................ Cactus Smirnov, 1976

Valve without numerous papilla-like outgrowths $\ldots \ldots \ldots \ldots \ldots \ldots \ldots$

6(5). Shell with long rough bristles. No claw on postabdomen. Antennae with numerous spines ........................ Neothrix Gurney, 1927

- Shell not covered with long rough bristles. Postabdomen with claws and antenna commonly with only a few spines $\ldots \ldots \ldots \ldots \ldots \ldots \ldots \ldots \ldots$

7(6). Intestine not convoluted $\ldots \ldots \ldots \ldots \ldots \ldots \ldots \ldots \ldots \ldots \ldots \ldots \ldots$

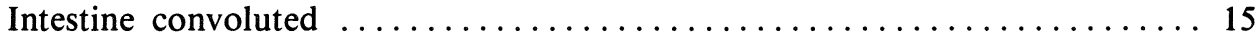

8(7). Setae of ventral margin of valve lanceolate (Holarctic) $\ldots \ldots \ldots \ldots \ldots \ldots$ Lathonura Lilljeborg, 1853

Setae of ventral margin of valve not lanceolate $\ldots \ldots \ldots \ldots \ldots \ldots \ldots$

9(8). Postabdomen with no cuts in dorsal side and usually not widely oval

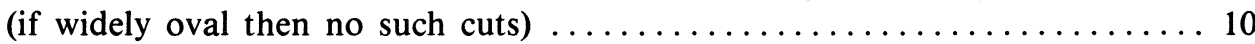

- Postabdomen widely oval, with cuts on its dorsal side $\ldots \ldots \ldots \ldots \ldots \ldots 16$

10(9). Postabdomen tapers towards base of claw. No anal teeth. Claw with a basal spine .......................... Pseudomoina Sars, 1911

Postabdomen does not taper towards base of claw. Claw without a

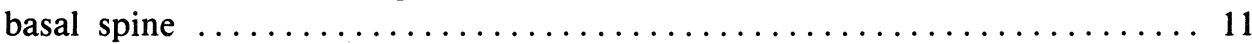

11(10). Head shield with a globular bulge (Neotropical) ....................... ............................ Onchobunops Fryer \& Paggi, 1972

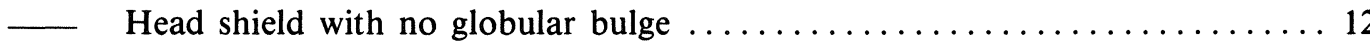

12(11). Valve with a dorsal keel advancing onto posterior side of valve (Holarctic) ............................... Bunops Birge, 1893

_ Valve with no dorsal keel advancing onto posterior side of valve ........ 13

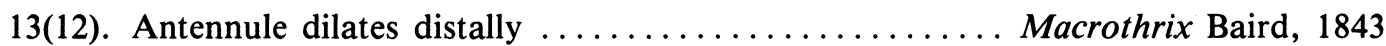
Antennule does not dilate distally .......................... 14

14(13). Exopodite of limb IV with 2-3 setae ............. Echinisca Liévin, 1848 Exopodite of limb IV with 5 setae (Holarctic) ........ Wlassicsia Daday, 1904

15(7). Shell without a dorsal tooth. Four-segmented branch of antenna with 4 setae ............................... Streblocerus Sars, 1862 Shell with a dorsal tooth (in region of dorsal fusion of valves). Foursegmented branch of antenna with 3 setae (Holarctic)

Drepanothrix Sars, 1862

16(9). Groups of anal teeth on postabdomen, one large solitary tooth situated at proximal side of anal opening (pantropical, recently found near Darwin by BVT) ....................... Grimaldina Richard, 1892

No anal teeth. Antennule short and thick (Ethiopian region, Ceylon, Malacca, New Guinea) Guernella Richard, 1892 


\section{Shortened Key to Genera of Macrothricidae Found to Date in Australia}

1. Antennule one-segmented; dorsal side of postabdomen straight or convex ... 2

Antennule two segmented; dorsal side of postabdomen convex, having appearance of a wide arc ................... Ilyocryptus Sars, 1862

2(1). No claw on postabdomen; valve with long bristles .... Neothrix Gurney, 1927 Postabdomen clawed; valve with small setules or glabrous $\ldots \ldots \ldots \ldots \ldots 3$

3(2). Intestine convoluted ...................... Streblocerus Sars, 1862

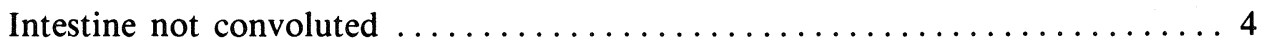

4(3). Postabdomen tapers towards base of claw; claw with a basal spine; no anal teeth ........................ Pseudomoina Sars, 1911

Postabdomen not tapering towards base of claw; claw lacks a basal spine

5(4). Antennule dilated distally Macrothrix Baird, 1843

Antennule not dilated distally

Echinisca Liévin, 1848

\section{Genus Ilyocryptus Sars, 1862}

Acanthocercus, partim, Liévin, 1848: 32.

Ilyocryptus Sars, 1862a: 154; 1862b: 281-282.-Smirnov, 1976: 42.

Head small and triangular. Valve wide and straight on dorsal side; its ventral and posterior margins widely arched. Moulted shells commonly not discarded and many valves seen one over the other. Postabdomen wide, its dorsal side convex and bearing lateral setae while ventral side straight. Claw long.

All species of Ilyocryptus are slowing-moving mud dwellers.

The type species is Ilyocryptus sordidus (Liévin, 1848).

\section{Key to Australian Species of Ilyocryptus}

1. Antennule rather short, its length less than 8 times its width $\ldots \ldots \ldots \ldots \ldots \ldots 2$

Antennule very thin, its length 8-10 times its width ...... I. spinifer Herrick, 1882

2. Lateral setae of postabdomen long ......... ............. I. sordidus (Liévin, 1848)

Lateral setae of postabdomen short ......... ............ I. brevidentatus Ekman, 1905

Ilyocryptus sordidus (Liévin, 1848)

Acanthocercus sordidus Liévin, 1848: 34-37, Tab. VIII, figs 7-12.

Ilyocryptus sordidus. -Sars, 1896: 28-30, pl. 5, figs 1-3; Henry, 1922: 38; Smirnov, 1976: 45-49, figs 12-15.

Material. Qld: 59. N.S.W.: 232. W.A.: 422.

Slides. AM $\odot$ P27745, MGU $९ 3028$.
Comment. Several subspecies of I. sordidus have been described (Smirnov, 1976), mainly by minor differences in postabdominal structure. None has been indicated for Australia.

Distribution. Occurs sparsely in Qld, N.S.W., W.A., and probably other states as well.

Differential diagnosis. The anal aperture opens in the middle part of the dorsal side of the postabdomen. The antennule is short, its length exceeding its width by about 4 times. The shell lacks warts and outgrowths. Lateral setae of postabdomen are long.

\section{Ilyocryptus spinifer Herrick, 1882}

\section{Fig. 82}

Ilyocryptus spinifer Herrick, 1882: 39-41, 246, pl. VIII, fig. 16, pl. IX, figs $1-3$.-Henry, 1922: 37-38, pl. VI, figs 1 , 1A; Smirnov, 1976: 53-56, figs 13, 22, 23.

Ilyocryptus halyi Brady, 1886: 294-295, pl. 37, figs 6-9.

Ilyocryptus longiremis Sars, 1888: 33-41, pl. 4.-Henry, 1919: 468.

Material. Qld: $12,21,25,49,64$. N.S. W.: 80, 87, 88, 93, 100, 120, 128, 132, 185. Vic.: 233.

Slides. $\quad$ AM $\odot$ P27746, MGU $\subsetneq$ 2341, 2573, ZIN $\& 2574$.

Ecology. We recorded $I$. spinifer over a very wide pH range (3.5-8.5) and observed live specimens moving bottom materials, including filamentous algae, with their antennae.

Distribution. Eastern Australia.

Differential diagnosis. The anal aperture opens in the middle part of the postabdomen. Antennule length exceeds its width by more than 8 times. There are no spines on the antennules and the shell lacks warts and outgrowths. Lateral setae of postabdomen are long and not more than 8 in number. 


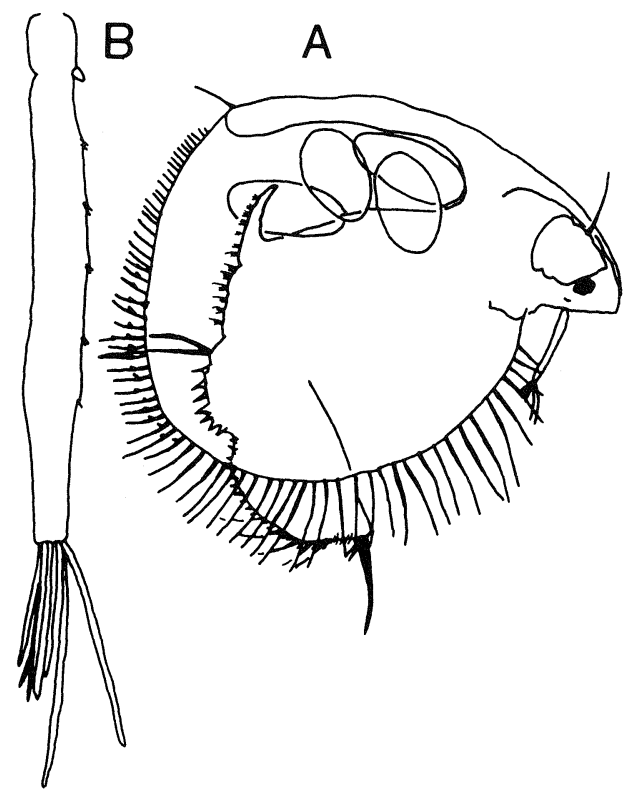

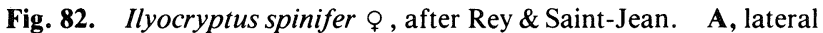
view of whole animal; $\mathbf{B}$, antennule.

\section{Ilyocryptus brevidentatus Ekman, 1905}

Ilyocryptus brevidentatus Ekman, 1905: 5-7, tab. 1, fig. 1.

Material. Vic.: 225.

Slide. MGU $\subsetneq 3074$.

Distribution. Australia: apparently isolated in north-eastern Victoria. World: South America.

Differential diagnosis. The anal aperture opens in the middle part of the dorsal side of the postabdomen. The antennule is comparatively short and bears no spines. The shell lacks warts and outgrowths. The lateral setae of the postabdomen are short.

Ilyocryptus agilis Kurz, 1878 has also been indicated for Australia (Williams, 1978, fig. 4, p 673) but this is a misprint ( $\mathrm{J}$. Williams, personal communication).

\section{Genus Macrothrix Baird, 1843}

Macrothrix Baird, 1843: 87 (subgenus); 1850: 103.-Lilljeborg, 1853: 47; Smirnov, 1976: 69-70.

Until recently the taxonomy of the genus Macrothrix was utterly confused (see comments by Löffler, 1968, p 148), but Smirnov's (1976) review of the morphology and taxonomy of the family and genus is now available. We follow his treatment here and limit the genus Macrothrix to forms having the antennule dilated distally.

The type species is Macrothrix laticornis (Jurine, 1820).

\section{Key to Australian Species of Macrothrix}

1. Dorsal edge of head and valves finely serrated in places ...... M. spinosa King, 1853
- Dorsal edge of head and valves not serrated 2

2(1). Head and valves with short, closely spaced hairs ....... M. hystrix Gurney, 1927

_ Head and valve glabrous $\ldots \ldots \ldots \ldots \ldots$

3(2). Distal joint of setae natatoriae short, its length being several times less than

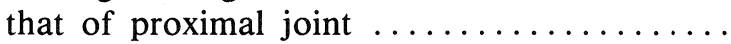
............. M. breviseta Smirnov, 1976

_ Distal joint of setae natatoriae long ..... 4

4(3). Length of distal joint of setae natatoriae a little less than 1.5 times length

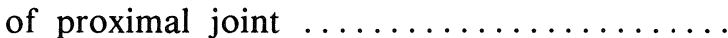
.... M. hirsuticornis Norman \& Brady, 1867

_ Length of distal joint of setae natatoriae much greater than 1.5 times that of proximal joint ... M. longiseta Smirnov, 1976

\section{Macrothrix spinosa King, 1853}

Fig. 83

Macrothrix spinosa King, 1853b: 256, pl. VIF.-Sars, 1888: 25-32, pl. 3; Playfair, 1915: 140-141, pl. VII, figs 1, 2 (M. spinosa and M. spinosa dentata); Henry, 1922: 36; Smirnov, 1976: 73-76, figs 41-44.

Material. Qld: $19,38,60$. N.S.W.: 86, 93, 161, 172. Vic.: 237. N.T.: 453.

Slides. AM \& P27750, P27751, MGU @ 2563, 2566, ZIN ㅇ 2367.

Length. $0.54 \mathrm{~mm}$.

Ecology. Markedly seasonal in occurrence-in the University Pond, Brisbane and in Borumba Dam (Qld) Macrothrix spinosa is common in summer and apparently absent in winter and spring (Timms, 1967; Timms and Midgly, 1969).

Type locality. A roadside pond at South Creek between Sydney and Liverpool-long since destroyed by urbanization.

Distribution. Qld, N.S.W., Vic., S.A. (Petkovski, 1973b), N.T.

Differential diagnosis. The dorsal edge of the head and valves is serrulated, at least in places. As noted by King (1853b) and Sars (1888), there is a denticle on the border between the distal and proximal joints. The distal joint of the setae natatoriae is short.

\section{Macrothrix hirsuticornis Norman \& Brady, 1867}

Macrothrix hirsuticornis Norman \& Brady, 1867: 10-11, pl. XXIII, Figs 6, 7.-Smirnov, 1976: 79-87.

Macrothrix hirsuticornis comprises two subspecies (Smirnov, 1976) though Flössner (1972: p 253) notes that these are not true subspecies. We consider that only the typical subspecies is known in Australia. 


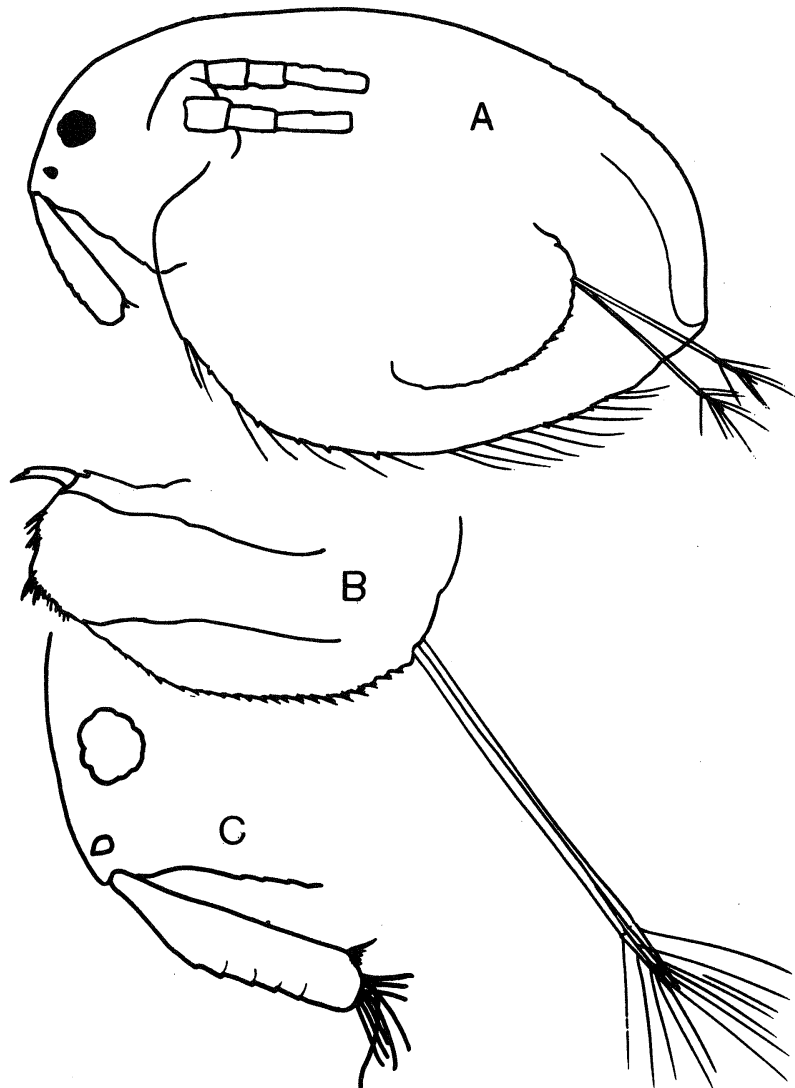

Fig. 83. Macrothrix spinosa ${ }_{\text {, }}$, Gilberts Gulch, via Orbost, Vic., 28.i.71. A, lateral view of whole animal, length $0.54 \mathrm{~mm}$, slide 2563 ; B, postabdomen, slide 2566; C, antennule, slide 2566 .

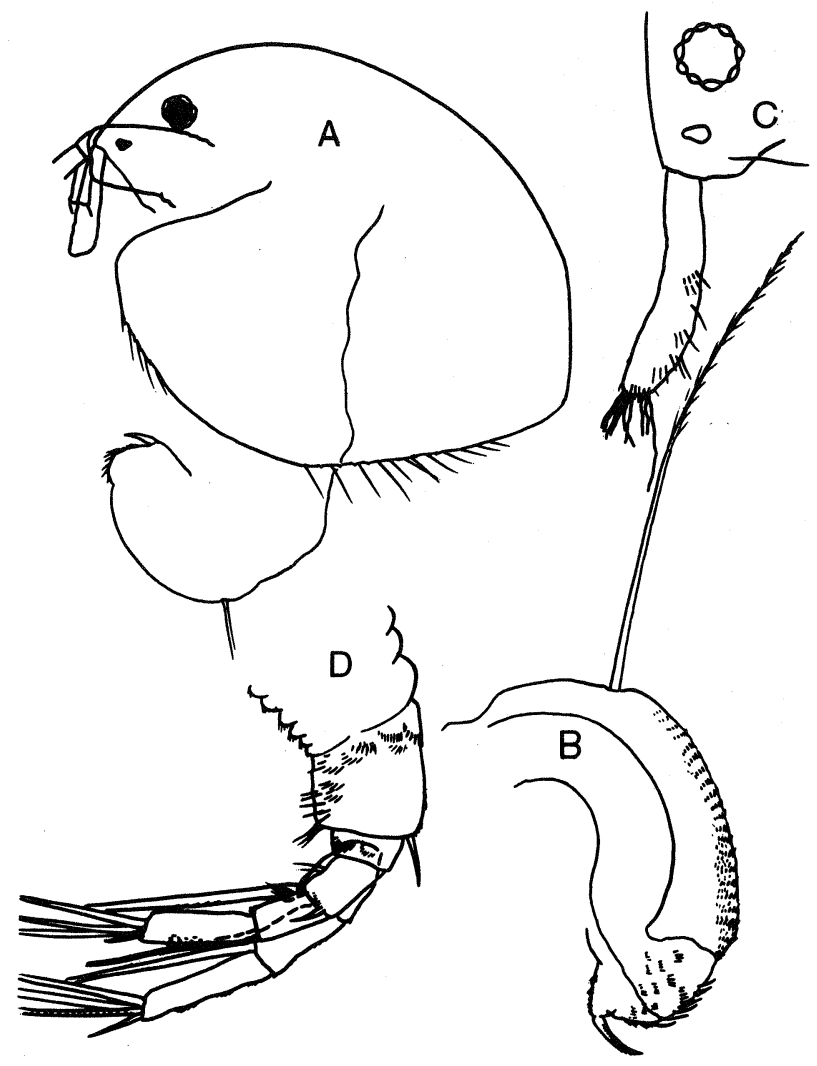

Fig. 84. Macrothrix hirsuticornis hirsuticornis $Q$, pool near L. Omeo, Vic., 10.viii.69. A, lateral view of whole animal, length 1.14 $\mathrm{mm}$; B, postabdomen; C, antennule; D, antenna. (A and B from slide 915, C and D from slide 991 .)
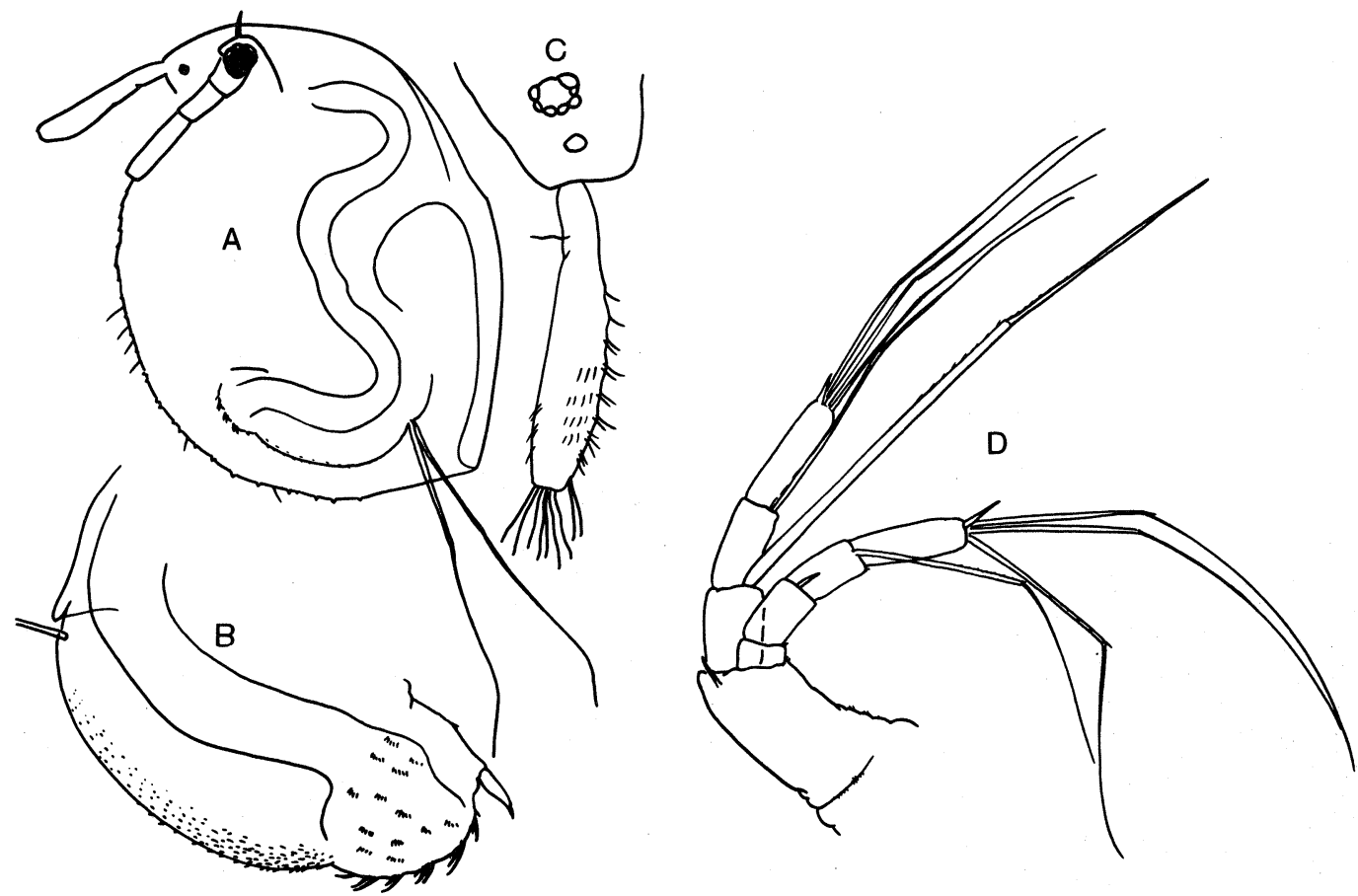

Fig. 85. Macrothrix longiseta $\&$, L. Purrumbete, Vic., 19.viii.70. A, lateral view of whole animal, length 0.73 $\mathrm{mm}$, slide 2644; B, postabdomen; C, antennule; D, antenna. (B, C and D from slide 2648.) 


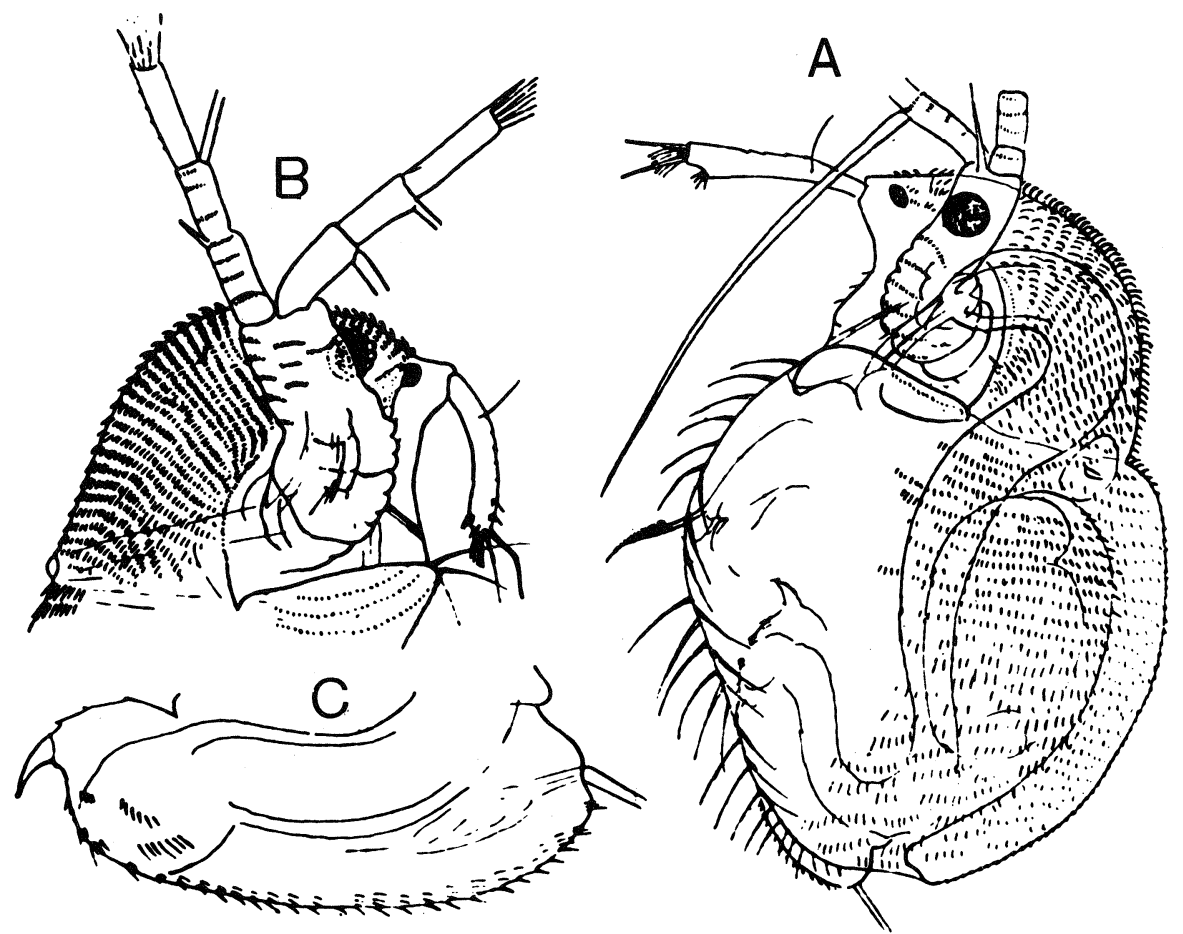

Fig. 86. Macrothrix hystrix $९$, after Gurney, 1927. A, lateral view of whole animal, length $0.72 \mathrm{~mm}$; B, head of female; $\mathbf{C}$, postabdomen.
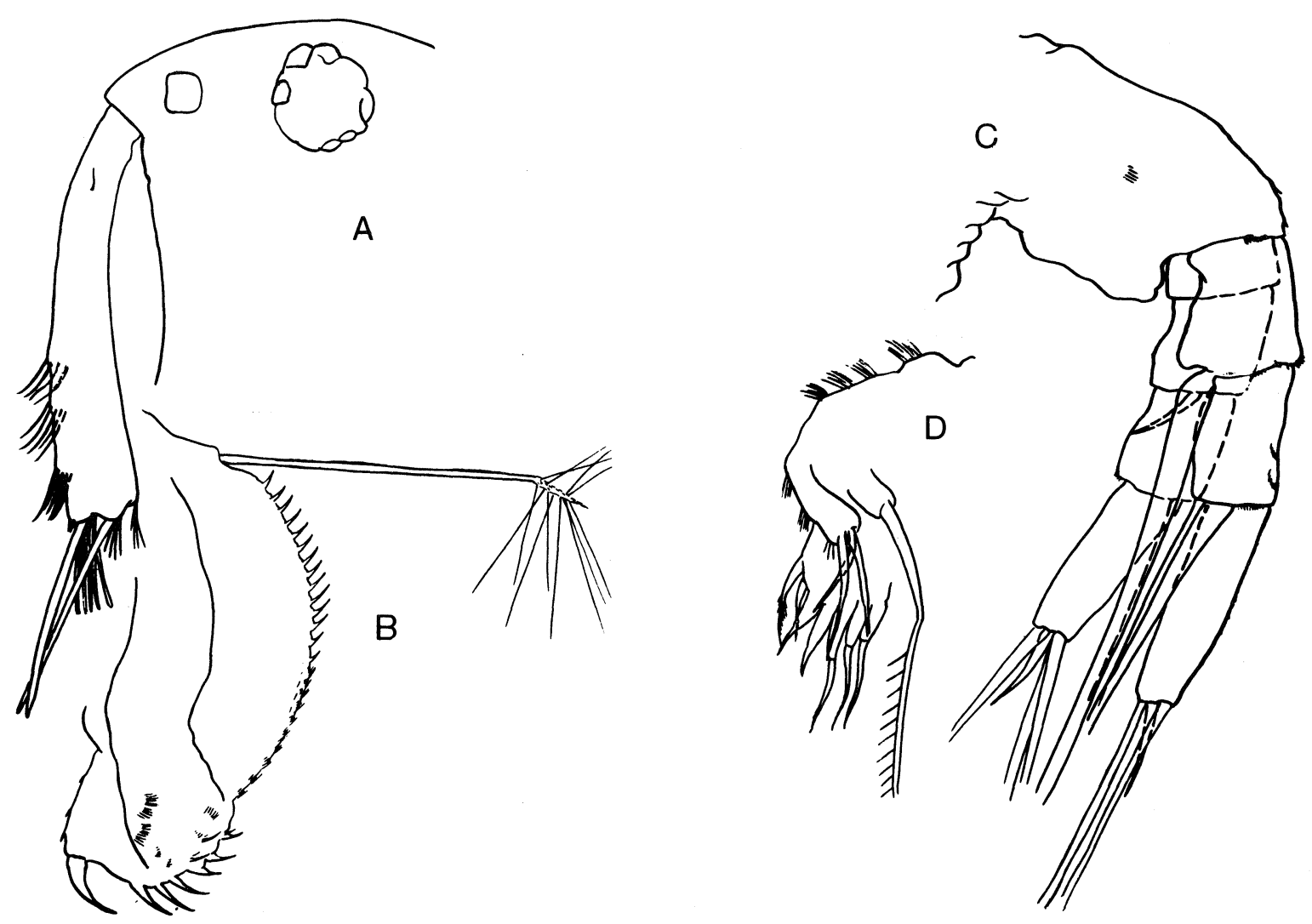

Fig. 87. Macrothrix breviseta $\bigcirc$ L. Buchanan, via Charters Towers, Qld, 16.vii.74. A, head and antennule; B, postabdomen; C, antenna. (A-C from slide 2796.) D, thoracic limb I, slide 2802. 


\section{Macrothrix hirsuticornis hirsuticornis Norman \& Brady, 1867}

Fig. 84

Macrothrix hirsuticornis hirsuticornis. -Smirnov, 1976: 80-85, fig. 52.

Material. Vic.: 207, 219. W.A.: 412.

Slides. AM \& P27748, MGU \& 991, 915. ZIN \& 1027.

Length. $1.14 \mathrm{~mm}$.

Distribution. Vic, W.A., and probably at least other southern states.

Differential diagnosis. The dorsal edge of the shell is not serrated. The head may be separated by a cleft in the dorsal side of the body, but the fold separating the head is simple (not double or triple). The distal joint of the setae natatoriae is long, its length being less than 1.5 times the length of the proximal joint. The head and valves are glabrous.

\section{Macrothrix longiseta Smirnov, 1976}

Fig. 85

Macrothrix longiseta Smirnov, 1976: 91, fig. 61.

Material. Vic.: 298. Tas.: 337.

Holotype. MGU @ 2644.

Paratypes. AM $\subsetneq$ P27749, ZIN $\subsetneq$ 2489, BM 2646.

Slides. AM $\subsetneq$ P31314, ơ P31315, MGU 2648.

Female. Dorsal edge of head smooth, not separated from valves. antenna club-like, clearly widening in its distal part, and with groups of setules. Antennal setae $0-0-1-3 / 1-1-3$, and spines 0-1-0-1/0-0-1. Postabdomen with groups of spines on anal margin and setules in clusters on its lateral surface. Preanal margin with setules diminishing in size and finally disappearing at base of setae natatoriae. Distal joint of setae natatoriae without setules (i.e. not feathered). Ratio of length of distal joint of setae natatoriae to length of proximal joint 5:3. Ocellus situated closer to base of antennule than to complex eye. Intestine not convoluted.

Length. $0.73 \mathrm{~mm}$ (holotype 2644).

Type locality. Lake Purrumbete (Vic.).

Distribution. Vic., Tas., and possibly other southern states.

Differential diagnosis. The dorsal edge of the shell is not serrated. The antennule has groups of setules. The head and valves are glabrous. The length of the distal joint of the setae natatoriae is more than 1.5 times the length of the proximal joint. The anal edge of the postabdomen has groups of spines and the preanal edge has small setules diminishing to the base of the setae natatoriae.

\section{Macrothrix hystrix Gurney, 1927}

Fig. 86

Macrothrix hystrix Gurey, 1927: 68-69, fig. 6.-Smirnov, 1976: 94-95, fig. 65.

Material. Literature.
Length. $0.72 \mathrm{~mm}$.

Type locality. Waters near Longreach (Qld).

Distribution. Known only from type locality in Qld.

Differential diagnosis. The dorsal side of the shell is not serrated, but there are rows of setules on the dorsal side of the head and shell. The head is separated from the valves on the dorsal side. The dorsal side of the postabdomen is convex.

Macrothrix breviseta Smirnov, 1976

Fig. 87

Macrothrix breviseta Smirnov, 1976: 95-97, fig 67.

Material. Qld: 30, 32. Vic.: 213. W.A.: 403. N.T.: 451.

Holotype. MGU $९ 2798$.

Paratypes. AM \& P27747, ZIN 2799.

Slides. MGU @ 2796, 2802.

Female. Dorsal side of head and shell not serrated. Ventral edge of valve with a few serrations on its anterior part and many posteriorly. Dorso-posterior corner of the valve visible. Dorsal (but not cephalic) keel present. Antennule with transverse rows of setules on its anterior distal side; this side wavy in outline. Sensory papillae of different length on distal end of antennule. Antennal setae 0-0-1-3/1-1-3, spines 0-1-0-1/0-0-1.

Postabdomen with a depression on dorsal side, at proximal end of anal opening. Anal edge with spines and groups of small setae on its lateral edge. Preanal edge with small setae, increasing in size to form a row of denticles towards bases of setae natatoriae. Distal joint of setae natatoriae short (approximately 5 times shorter than proximal joint), and bearing long hair-like setules. Ocellus situated closer to base of antennule than to eye. Intestine not convoluted. Leg I with three setae on external branch of its endite, one being short. The long seta of exopodite of leg I with rare setules on one side of its distal part.

Length. $0.56 \mathrm{~mm}$ (holotype 2798).

Male. Unknown.

Ecology. Planktonic. It can live in slightly saline water-L. Buchanan, the type locality was $4 \%$ at the time of collection.

Type locality. L. Buchanan, via Charters Towers, Qld (Loc. No. 30).

Distribution. Mainly a northern Australian species, though there is one record from southern Victoria.

Differential diagnosis. The distal joints of the setae natatoriae are short. The preanal edge of the postabdomen has short setae increasing in size to form a row of denticles towards the base of the setae natatoriae. It differs from Macrothrix hirsuticornis by the anterior distal side of the antennule being wavy and bearing three transverse groups of setae. It is very similar to Echinisca carinata found in the littoral of the type locality, L. Buchanan, but differs by the antennule dilating distally and by having rather long, sparse setules on the long exopodite seta of thoracic limb I. 


\section{Genus Echinisca Liévin, 1848}

Echinisca Liévin, 1848: 31-32.-Sars, 1916: 323, 325; Smirnov, 1976: 103.

The genus Echinisca is understood as comprising Macrothrix- like forms having the antennule not dilated distally. Other characters suggested by Petkovski (1973b) are difficult to apply until they are known for more taxa. Some authors (e.g. Fryer, 1974: 142) still regard Echinisca as inseparable from Macrothrix. Admittedly they comprise an assortment of incompletely studied species, but at present it is convenient to make two main groupings of them as Macrothrix and Echinisca.

The type species is Echinisca rosea Liévin, 1848.

\section{Key to Australian species of Echinisca}

1. Segments (second and third) of four-segmented branch of antenna with groups of large spines ............................. E. pectinata Smirnov, 1976

\section{Segments of four-segmented branch of antenna with no groups of large spines . . . 2}

2(1). Teeth of preanal edge of postabdomen arranged in groups of 2-3; these groups situated in proximal part of preanal edge of postabdomen with their size increasing proximally $\ldots \ldots \ldots \ldots \ldots \ldots \ldots \ldots \ldots \ldots . \ldots \ldots$ timmsi Smirnov, 1976

Teeth on preanal edge of postabdomen, if present, ungrouped $\ldots \ldots \ldots \ldots \ldots 3$

3(2). Head shield stepped in its posterior part (lateral view) so that height suddenly decreases in posterior part of the head shield .......E. hardingi (Petkovski, 1973) Dorsal side of head shield smoothly convex $\ldots \ldots \ldots \ldots \ldots \ldots \ldots \ldots \ldots$

4(3). Blunt unserrated prominence on ventral side of head ...... E. capensis Sars, 1916 No big prominence on ventral side of head ....................... 5

5(4). Carapace markedly keeled ................... E. carinata Smirnov, 1976

Carapace not, or only slightly, keeled $\ldots \ldots \ldots \ldots \ldots \ldots \ldots \ldots \ldots \ldots$

6(5). Distal segment of setae natatoriae very short $\ldots \ldots \ldots \ldots \ldots \ldots \ldots \ldots \ldots \ldots \ldots \ldots \ldots \ldots \ldots \ldots$

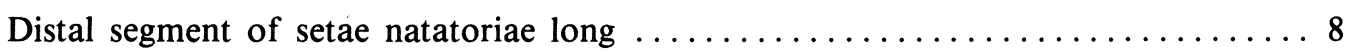

7(6). Long spines on largest seta of antenna ................ williamsi n.sp. Largest setae of antenna with short spines ............ E. triserialis (Brady, 1886)

8(6). Largest setae of antenna with spines ............... E. rosea Liévin, 1848

Largest setae of antenna with setules $\ldots \ldots \ldots \ldots \ldots \ldots \ldots \ldots \ldots \ldots$

9(8). Distal segment of setae natatoriae shorter than proximal one $\ldots \ldots \ldots \ldots \ldots \ldots \ldots$ ................................ E. schauinslandi (Sars, 1904)

Distal segment of setae natatoriae longer than proximal one ....E. Elagellata n.sp.

Echinisca rosea Liévin, 1848

Echinisca rosea Liévin, 1848: 31 tab. 7, figs 3-7.-Smirnov, 1976: 104-109, figs 76-80.

Material. Qld: 12, 15, 16, 17, 21, 27.

Length. $0.7 \mathrm{~mm}$.

Ecology. Littoral.

Distribution. North Qld, but it could live further south as it occurs in northern Europe among other areas in the Holarctic (Smirnov, 1976).
Differential diagnosis. The carapace is not keeled and its dorsal outline is evenly arched. The setae natatoriae have a long distal segment. The ventral edge of the head lacks a prominence. The antennule has rows of setae, but no spines. The antennal segments have no groups of large spines. The postabdomen has small ungrouped teeth along its preanal and anal margins. 

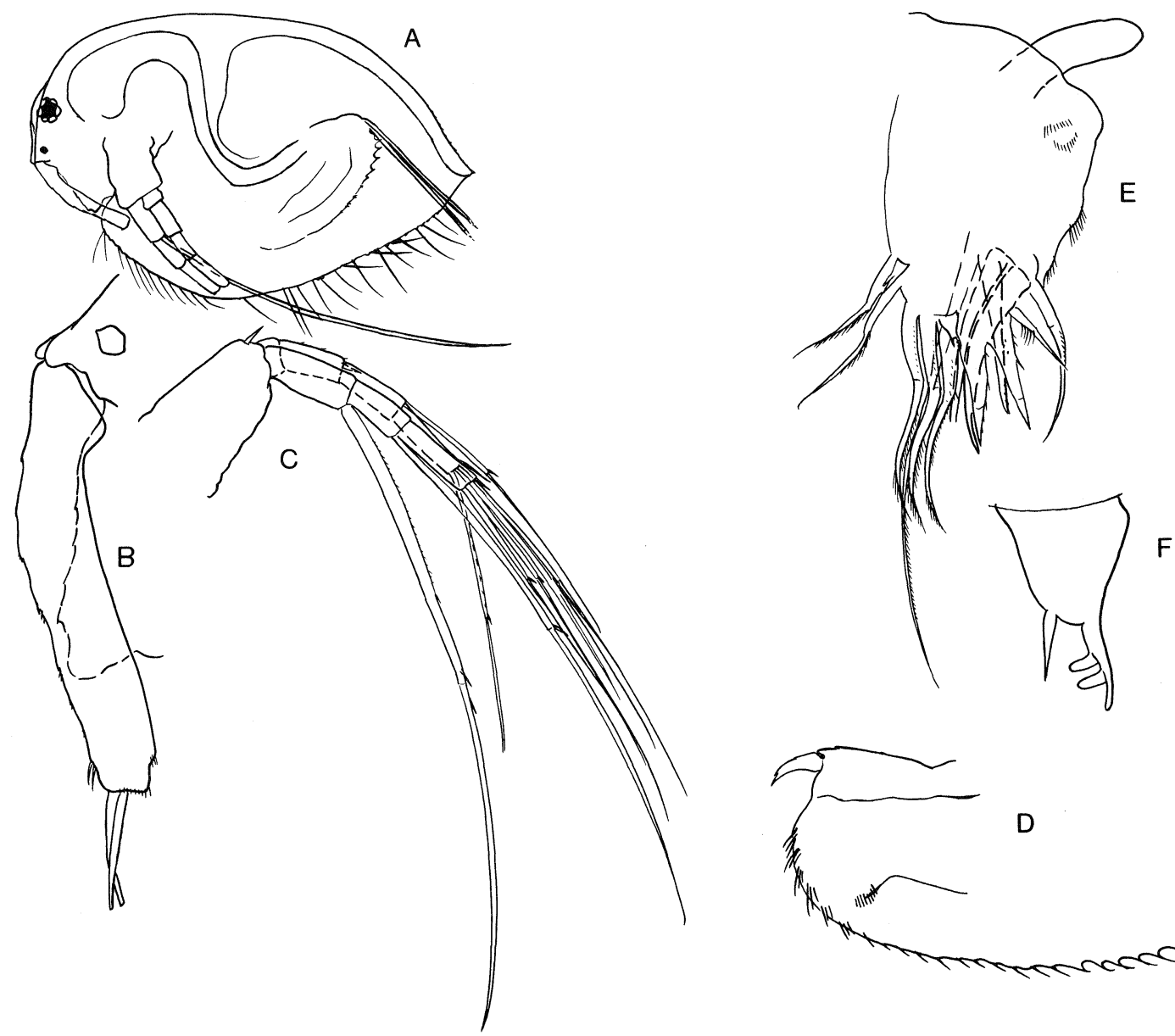

Fig. 88. Echinisca triserialis $\$$, a billabong W of Anakie, Qld, 18.vii.74. A, lateral view of whole animal, length $0.57 \mathrm{~mm}$, slide 2994; B, antennule, slide 2994; C, antenna, slide 3004; D, postabdomen, slide 3005; E, thoracic limb I, slide 3004; F, inner spines of endite of limb I (names according to Fryer, 1974-compare his figs 61, 62), slide 3004.

Echinisca triserialis (Brady, 1886)

Fig. 88

Macrothrix triserialis Brady, 1886: 295.-Henry, 1922: 36-37 (no figures; it is doubtful whether Henry's description pertains to this taxon); Fryer, 1974: 199-203, figs 69-77. Macrothrix chevreuxi Guerne \& Richard, 1892: 530-533.

Echinisca triserialis.-Smirnov, 1976: 109-111, figs 82-84.

Material. Qld: 9, 11, 24, 37, 42. N.S.W.: 80, 85, 143, 145. Vic.: 241. S.A.: 374, 378.

Slides. $\quad$ AM $९$ P27743, MGU $\subsetneq 2994,3004,3005$, ZIN $~$ 2993.

Female. Dorso-posterior corner of carapace pointed; its dorsal margin with fine setulations on its posterior part. Antennule with small indentations along its anterior side, but no transverse groups of long setae. Antennal setae 0-0-1/1-1/3, spines 0-0-0-1/0-1-1. Largest antennal seta (that of basal segment of 3-segmented branch) with two larger spines in the area of the joint between its proximal and distal segments and distally followed by many small spines. Labrum with few serrations.
Thoracic limb I with three setae on external branch of exopodite. The small inner spine of internal branch of endite specialized and similar to that of Macrothrix laticornis as depicted by Fryer (1974: figs 61, 62). Setae natatoriae with a very short distal segment. Postabdomen with teeth, which diminish distally, on its preanal margin, and groups of setae on its anal margin.

Ocellus small and situated much closer to base of antennule than to eye.

Ecology. Littoral.

Distribution. Mainly Qld and N.S.W., also Vic., and S.A, and possibly elsewhere as well.

Differential diagnosis. The carapace is slightly keeled. The setae natatoriae have a very short distal segment (it is long in E. carinata in which the carapace is keeled). The dorsal outline of the head and carapace is evenly arched. The ventral edge of the head has no prominence. The antennule has no spines, and the antennal segments have no groups of large spines. The largest seta of the antenna has short spines. The postabdomen has ungrouped small teeth along its preanal and anal margins. 


\section{Echinisca schauinslandi (Sars, 1904)}

Macrothrix schauinslandi Sars, 1904: 632-633, tab. 34, figs 4, 4a-b.

Macrothrix burstalis Smith, 1909: 83-84, pl. 16, fig. 3, n. syn.

Material. Tas.: 333.

Female. Body oval in outline. Antennule slightly incurved; several setae on distal part of its anterior surface and one seta on proximal part. Antennal setae 0-0-1-3/1-1-3. Preanal edge of postabdomen convex with numerous denticles. Teeth on anal edge of postabdomen. Distal segment of setae natatoriae much shorter than proximal segments. Ocellus small and located much closer to base of antennule than to eye.

Length. $1.1 \mathrm{~mm}$.

Male. Unknown.

Type locality. Lake Wakatipu, South Island of New Zealand.

Distribution. Tasmania, New Zealand.

Differential diagnosis. The distal segment of the setae natatoriae is long, but still much shorter than the basal segment. The largest antennal seta bears short setules distally. The postabdomen has small, numerous preanal teeth, and irregular anal teeth. The ventral margin of the head is even.
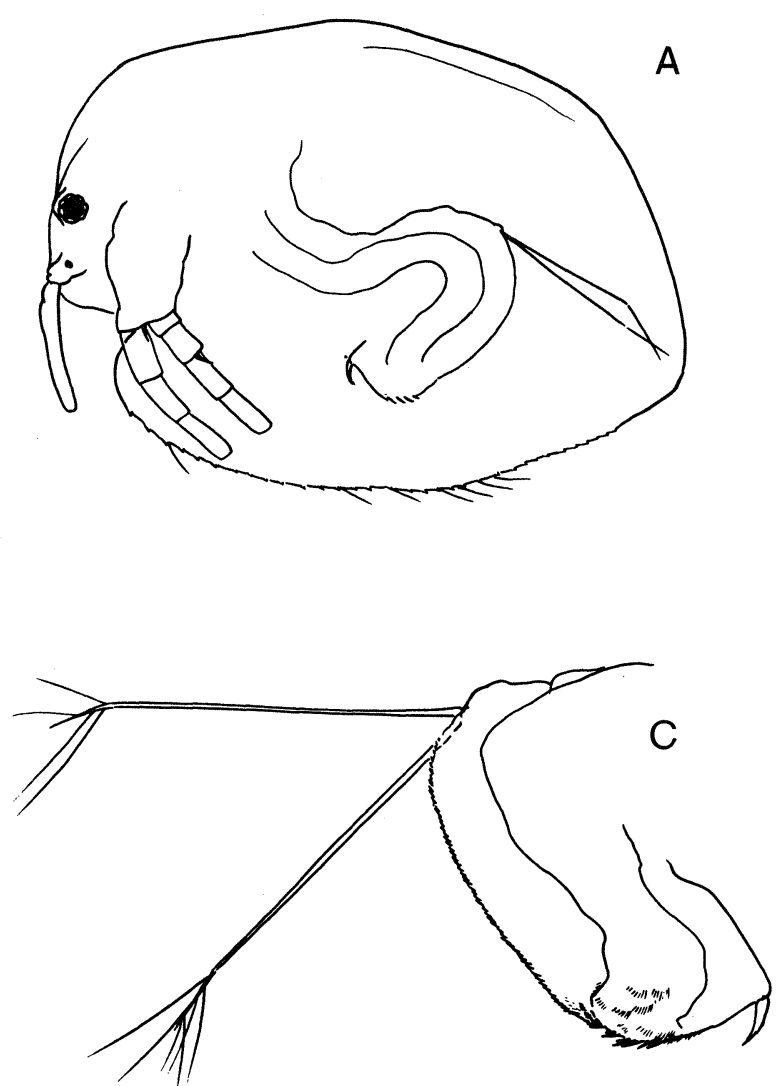

Echinisca capensis Sars, 1916

Echinisca capensis Sars, 1916: 323-324, pl. XXVI, fig 1, 1a-d.-Smirnov, 1976: 122-124.

Of the two subspecies only the typical form is found in Australia.

Echinisca capensis capensis Sars, 1916

Fig. 89

Echinisca capensis capensis.-Smirnov, 1976: 122, figs 100-102.

Material. N.S.W.: 153. Vic.: 224, 254. Tas.: 320, 321, 322. S.A.: 377, 379. W.A.: 404 .

Slides. AM $\odot$ P27738, MGU $\subsetneq 1794,2575,2679,2680$, 2681, 2683, 2683, ZIN $\$ 1622$.

Length. Up to $1.2 \mathrm{~mm}$.

Ecology. Littoral.

Distribution. Southern areas of Australia.

Differential diagnosis. There is a large, blunt, unserrated prominence on the ventral side of the head. There are no groups of large spines on the segments of the four-segmented branch of the antenna, and no grouped teeth on the preanal margin of the postabdomen. The distal end of the postabdomen is obliquely cut. The anal margin has irregular small spines and lateral groups of

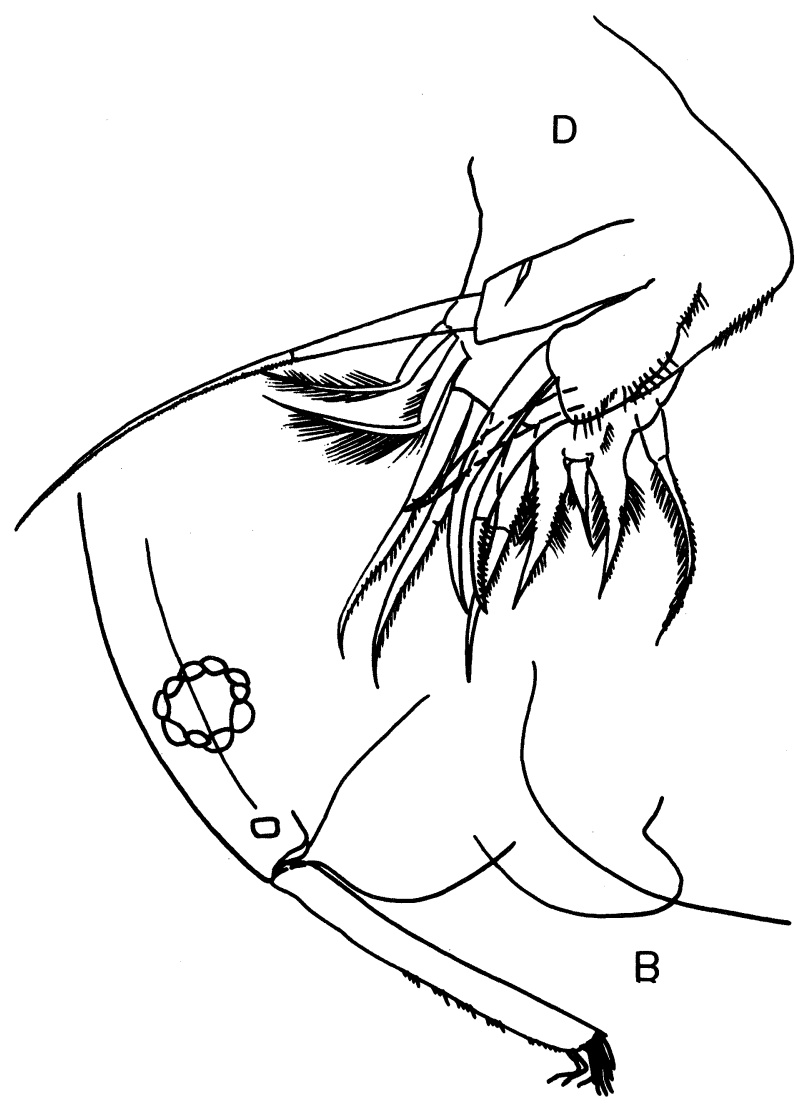

Fig. 89. Echinisca capensis capensis $९$, Tower Hill L., Vic., ii.68. A, lateral view of whole animal, length 1.1 $\mathrm{mm}$, slide 1622; B, antennule, slide 1622; C, postabdomen, slide 1794; D, thoracic limb I, slide 1794. 
setules. The females from Tower Hill Lake (Loc. No. 244) have dense setules on the preanal margin of the postabdomen, while females from a pond near Lake Goldsmith (Loc. No. 254) have denticles.

Echinisca hardingi (Petkovski, 1973)

Macrothrix (Macrothrix) hardingi Petkovski, 1973b: 170-1709, 189, figs 17-34, 60.

Echinisca hardingi.-Smirnov, 1976: 125-130, figs 106-108.

Material. Literature.

Comment. Petkovski (1973b) notes the antennule of his Macrothrix hardingi has a structure characteristic of the genus Echinisca.

Length. Up to $1.57 \mathrm{~mm}$.

Type locality. A large pond at East Yellowdine and Granite Pool at East Merridin (W.A.).

Distribution. South-west Western Australia.
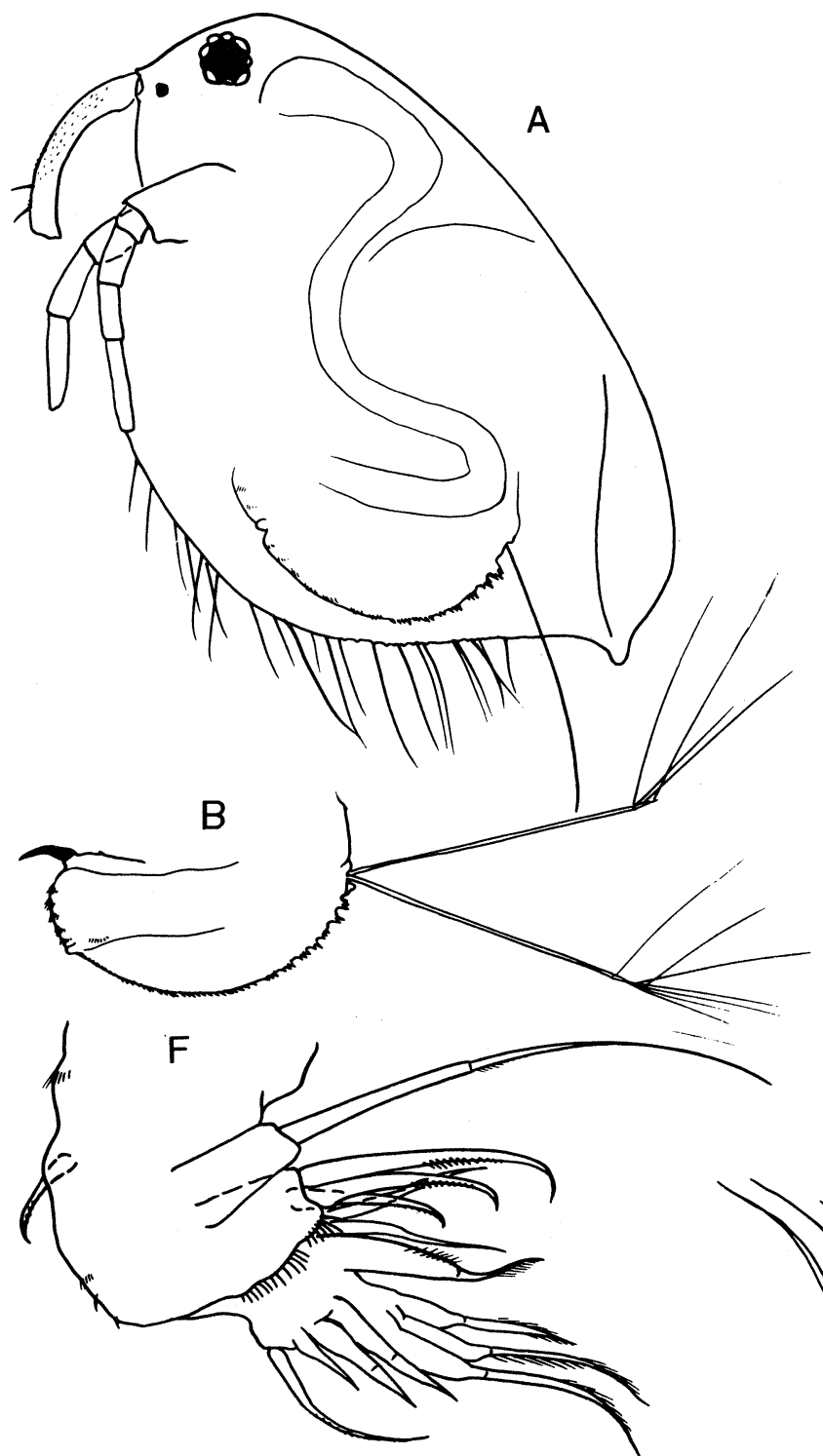

Fig. 90. Echinisca timmsi \&, a swamp near Sugar Point, The Broadwater, Myall Lakes area, N.S.W., 13.iv.75. A, lateral view of whole animal, length $0.68 \mathrm{~mm}$, slide 2567; B and C, postabdomen; D, antennule; E, antenna; F, thoracic limb I; G, limb II; H, limb IV. (B-H slide 2596.)
Differential diagnosis. The head shield is depressed step-wise in its posterior part (in lateral view). There are no groups of large spines on the segments of the foursegmented branch of the antenna and no grouped teeth on the preanal edge of the postabdomen. The setae natatoriae are $1 \frac{1}{2}$ times as long as the postabdomen, the distal $2 / 3$ being feathered.

Echinisca timmsi Smirnov, 1976

Fig. 90

Echinisca timmsi Smirnov, 1976: 135, figs 116-117.

Material. N.S.W.: 83, 96.

Holotype. MGU \& 2567.

Paratypes. AM \& P27742, ZIN $\& 2568$.

Slides. MGU $\subsetneq 2569$.

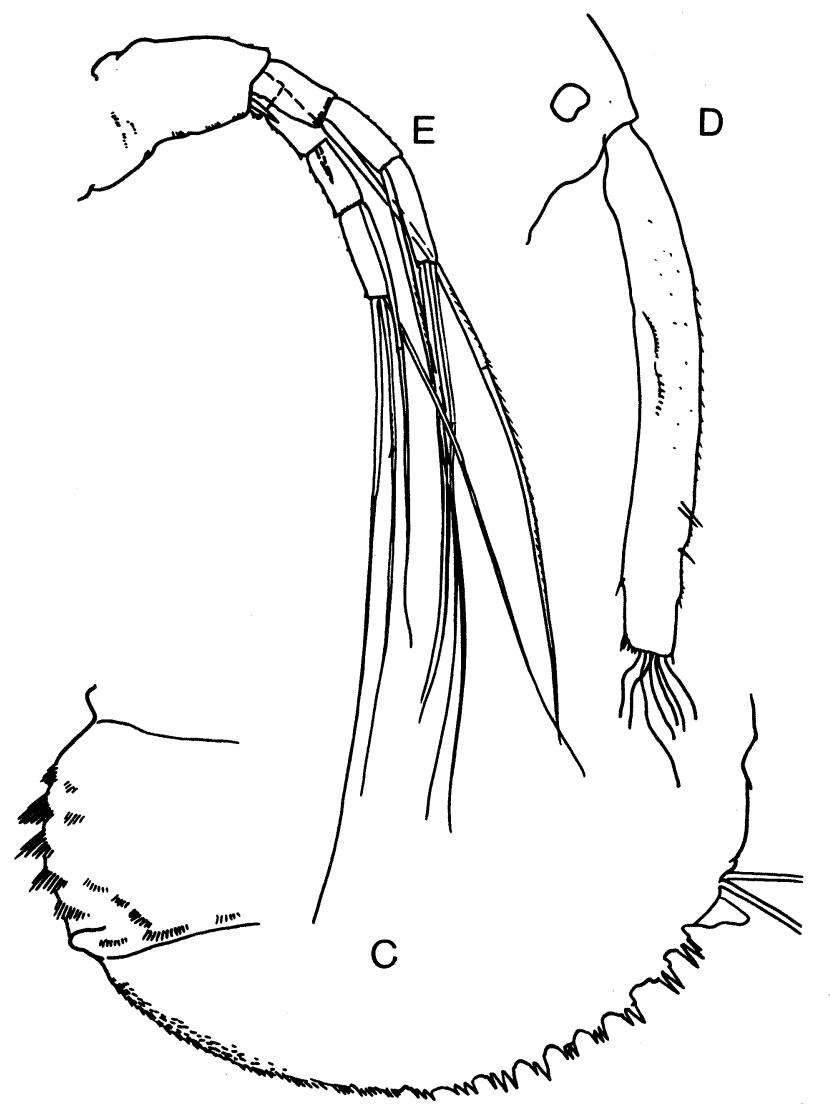


Female. Shell oval in lateral view with no depression between head and valves; dorsal side less convex than ventral side. Latter with long setae and irregular denticles, more expressed posteriorly. Dorsal side of shell smooth, not serrated. Dorso-posterior corner of shell produced into a short blunt outgrowth. Shell with slightly expressed polygons and small dots.

Antennule cylindrical, long and its base narrow. Its distal part with a few short setules and anterior edge with short setules. Sensory papillae, of various lengths, situated on distal end of antennule. Antennal setae $0-0-1-3 / 1-1-3$, and spines $0-1-0-0 / 0-0-0$. Basal joint of antennule with a spine.

Dorsal (preanal) side of postabdomen convex, with groups of denticles gradually transformed, from approximately middle of preanal side, into setules. Anal side with groups of setae. Claw small, chitinized, and without basal spines. Setae natatoriae with a long basal joint and a short distal joint bearing long setules. Short outgrowth on postabdomen, near base of setae natatoriae.

Thoracic limb I with external branch of its endite with 3 chitinized setae of different length. Inner branch of endite subdivided into an anterior lobe with 4 setae and a posterior lobe with large setae. Posterior side of the endite with setae, the anteriormost being the largest.
Intestine without a loop or outgrowths. Ocellus situated closer to base of antennule than to complex eye.

Length. $0.68 \mathrm{~mm}$.

Male. Unknown.

Ecology. Littoral, in acid humic waters.

Type locality. Eurunderee Lagoon, Myall Lakes National Park, N.S.W. (Loc. No. 96).

Distribution. Coastal northern N.S.W.

Differential diagnosis. The posterior end of the carapace has a short blunt outgrowth. The postabdomen has groups of denticles along the anterior part of the dorsal side (morphologically dorsal side). The basal joint of the antennule has a spine. The distal joint of the setae natatoriae is short.

\section{Echinisca pectinata Smirnov, 1976}

Fig. 91

Echinisca pectinata Smirnov, 1976: 135-137, fig. 118.

Material. Qld: 34. N.S.W.: 133, 138, 145. Vic.: 256.

Holotype. MGU $\odot 878$.

Paratypes. AM $\subsetneq$ P27741, MGU $\subsetneq 976, \mathrm{ZIN} \subsetneq 1217$, BM $\subsetneq 2684$.
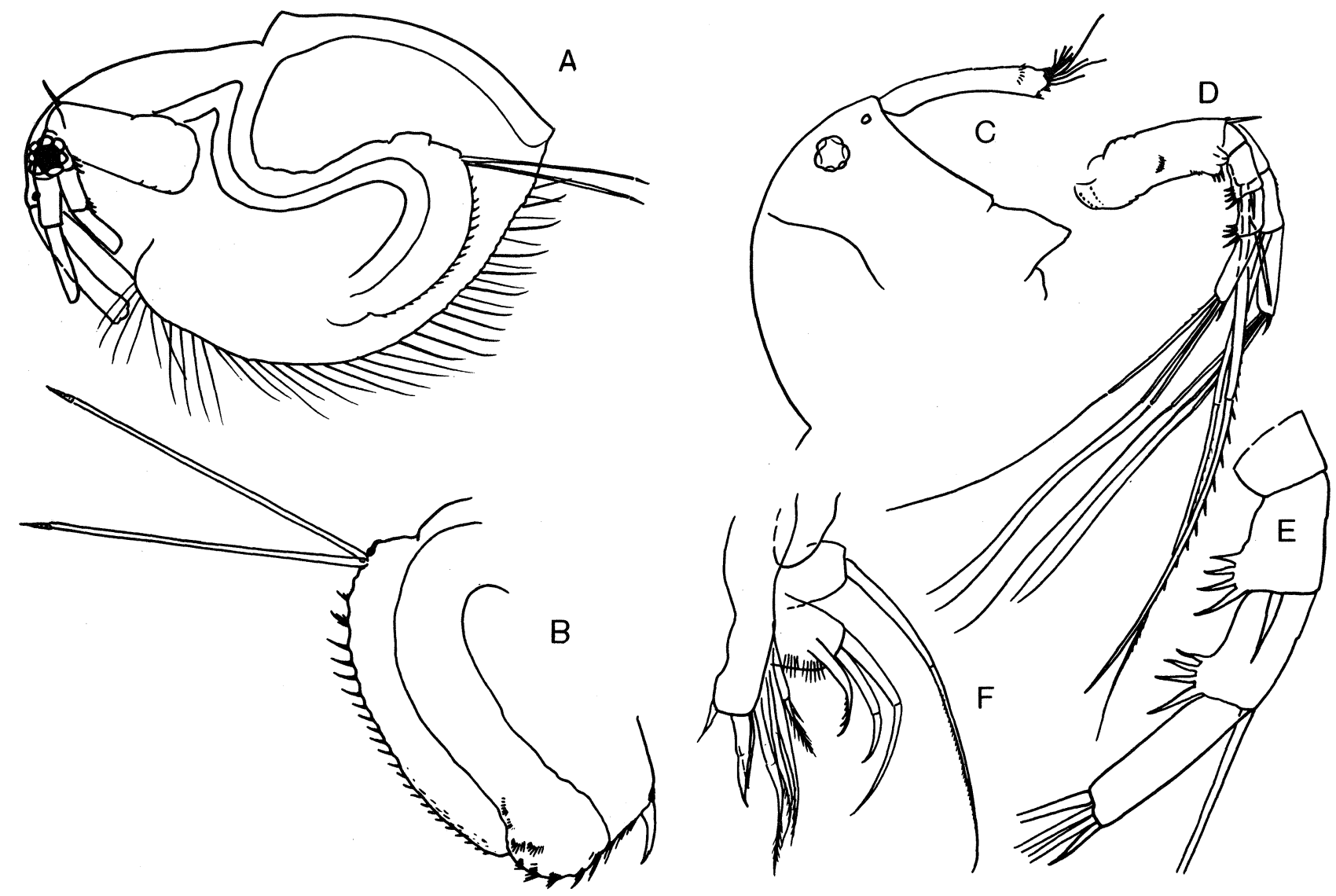

Fig. 91. Echinisca pectinata ९, Main Bridgewater L., via Portland, Vic., 18.viii.72. A, lateral view of whole animal, length $0.67 \mathrm{~mm}$, slide 878; B, postabdomen, slide 1217; C, head, slide 1217; D and E, antenna (right), slide 1217; F, thoracic limb I, slide 1449. 
Female. Shell oval in lateral view. Dorsal side beyond head stepped so that anterior part of brood chamber is higher than posterior part of head. Dorsal side of shell smooth, not serrated, and its dorsoposterior corner acute. Ventral edge of valve with large setae of different thicknesses and broad denticles, occurring mainly posteriorly. Ventral margin of head straight.

Antennule dilated distally. Basal joint of antenna with a group of spines on distal inner angle and a separate spine. Antennal setae $0-0-1-3 / 1-1-3$, and spines
0-5-4-1/0-0-1. Four-segmented branch with four spines forming a pecten on distal inner corner of second and third segments. (Analogous groups of spines on antennal segments are known also for species of Leydigia (Chydoridae). This case may serve as an example of the parallel formative processes within different unrelated genera (Smirnov, 1971b).)

Preanal edge of postabdomen convex and with denticles that increase in size proximally. Anal aperture edged with groups of setae. Claw with no basal spines. Setae natatoriae with a long basal joint and a short distal joint.

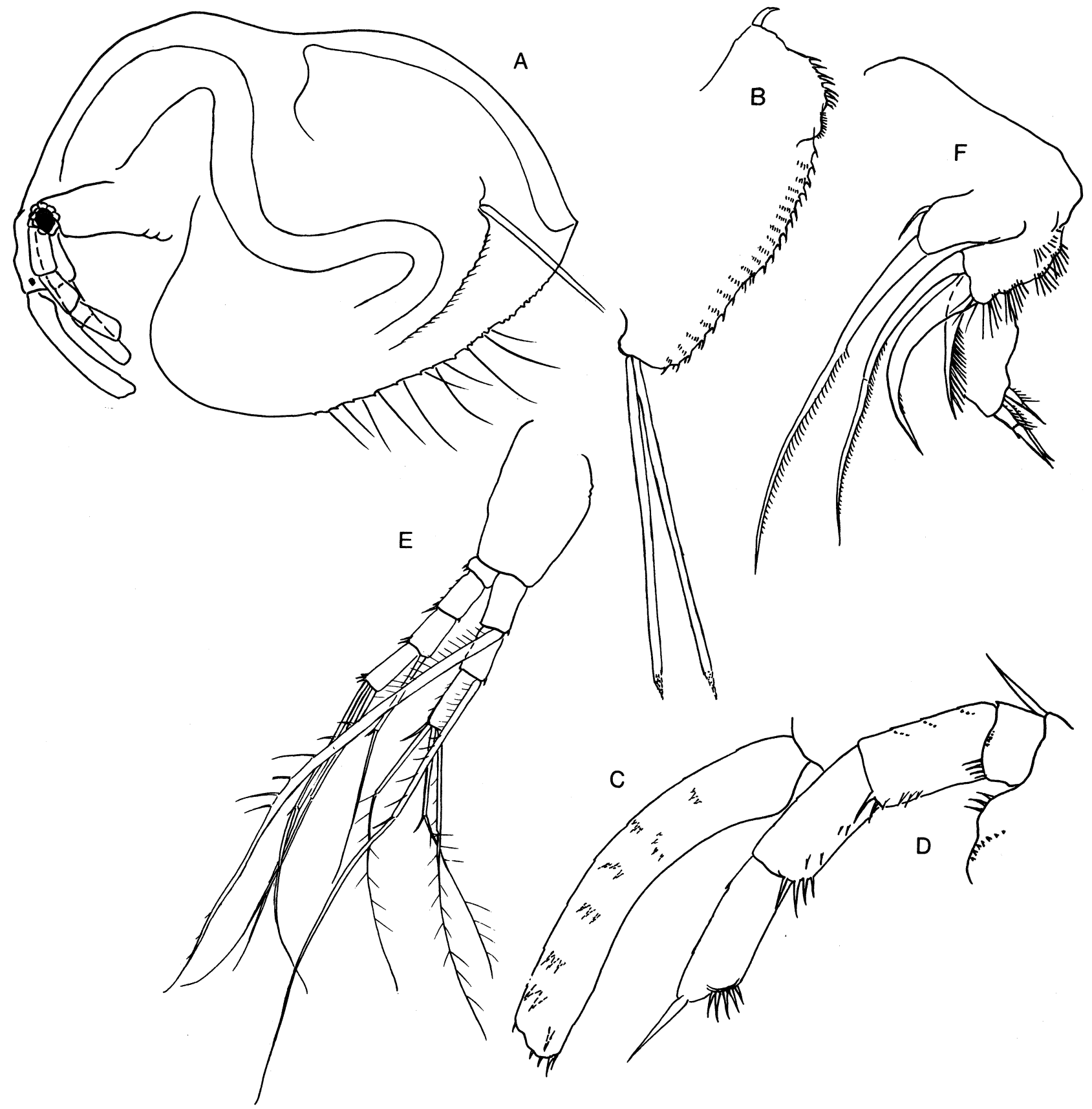

Fig. 92. Echinisca williamsi $९$, L. Powlathanga, via Charters Towers, Qld, 26.vi.74. A, lateral view of whole animal, length $0.58 \mathrm{~mm}$; B, postabdomen; C, antennule; D, four-segmented branch of antenna (left); E, antenna (left); F, thoracic limb I. (A, B from slide 2876, C, D, F from slide 2886; E from slide 2877.) 
External branch of endite of thoracic limb I with 3 setae of different length. Exopodite with one long seta with small setules along one side of its distal joint. Thoracic limb IV with 2 setae on the exopodite and a series of 5 soft setae on its endite.

Ocellus situated closer to base of antennule than to complex eye.

Length. $0.67 \mathrm{~mm}$.

Male. Unknown.

Ecology. Littoral.

Type locality. Main Bridgewater L. (Vic.) (Loc. No. 256).

Distribution. Eastern Australia.

Differential diagnosis. The anterior part of the brood chamber is stepped, so that it is higher than the posterior end of the head. The carapace is not keeled. There are groups of spines forming a pecten on the second and third joints of the four-segmented branch of the antenna. The distal joint of the setae natatoriae is short and bears long setules.

\section{Echinisca williamsi n. sp.}

Fig. 92

Material. Qld: 12.

Holotype. AM $\odot$ P27744.

Paratypes. MGU $\subsetneq$ 2876, 2886, ZIN $~ 2877$.

Female. Dorsal edge of carapace smooth (i.e. not serrated); ventral edge with irregular denticles and long setae. Small dorso-posterior angle to carapace.

Antennule with groups of denticles. Antennal setae $0-0-1-3-1-1-3$. Both its distal joints and the basipodite with long spines; in addition, segments of foursegmented branch with groups of small spines. (Similar spines are present in Echinisca rosea, however, these groups of small spines are not depicted or mentioned by Lilljeborg (1900), Behning (1941) or Flössner (1972).) Largest seta of antenna, i.e. seta of proximal segment of three-segmented branch, with long spines, at least in its middle.

Postabdomen with spines and small setae on anal edge, and spines of comparatively small size along preanal margin, as well as setules on sides of preanal part. Distal joint of setae natatoriae very short. By comparison it is very long in $E$. rosea according to Lilljeborg (1900), Behning (1941), and Srámek-Hušek et al. (1962).

Thoracic limb I with three setae of different length on external branch of its exopodite. Setules of the shortest of these setae long and unilateral.

Ocellus situated close to base of antennule, much closer than to base of eye. Intestine not convoluted.

Length. $0.58 \mathrm{~mm}$ (holotype P27744).

Male. Unknown.

Ecology. Littoral.

Type locality. Lake Powlathanga, via Charters Towers, Qld (Loc. No. 12).
Etymology. The species is named after Professor W.D. Williams, Adelaide University.

Distribution. Known only from type locality in northern Qld.

Differential diagnosis. The carapace is not keeled. The distal joint of the setae natatoriae is very short. The teeth of the postabdomen are of moderate size and rather uniform in length. The antennule bears groups of denticles.

$E$. williamsi is similar to $E$. rosea, but differs in having short distal joints of the setae natatoriae and long spines on the largest seta of the antenna.

\section{Echinisca flagellata n.sp.}

Fig. 93

Material. Tas.: 311.

Holotype. AM $९$ P27740.

Paratypes. MGU @ 2979, ZIN 2980.

Slides. MGU @ 2983.

Female. Body broadly oval in outline; its dorsal margin evenly convex and smooth in lateral view. Antennule thin with many transverse rows of setae. Antennal setae 0-0-1-3/1-1-3, spines 0-1-0-1-/0-0-1; largest seta setulated but lacks spines.

Dorsal side of postabdomen broadly convex. Preanal margin covered with very small setules and anal margin with several teeth. Distal segment of setae natatoriae longer than proximal one.

Exopodite of thoracic limb I with a short and long seta, the latter with unilateral setulation. External branch of its endite with three setae of different length. Internal branch with groups of setae which include the peculiar small inner setae. Limb II with a very big endite with powerful stiff setae, getting smaller towards gnathobase and ending with a feathered seta. Four setae in gnathobasic fan. Limb III and IV with two rows of setae on their endite and comparatively large exopodites.

Intestine not convoluted. Ocellus small and situated closer to base of antennule than to eye.

Length. $1.39 \mathrm{~mm}$ (holotype P27740).

Male. Unknown.

Type locality. A pool $8 \mathrm{~km}$ east of Steppes, central Tasmania (Loc. No. 311).

Distribution. Known only from type locality in Tasmania.

Differential diagnosis. The body in outline is broadly oval with the dorsal margin evenly convex and smooth. The antennule has many transverse rows of setae. The largest seta of the antenna has small setules but no spines. The distal segment of the setae natatoriae is longer than the proximal one.

Echinisca flagellata $\mathrm{n}$. sp. is similar to Macrothrix propinqua Sars, 1909, but it differs in that the antennule does not dilate distally. It is also similar to Echinisca hardingi (Petkovski) in the form of the antennule, antenna, setae natatoriae, and in size. However, $E$. 
flagellata differs in that the dorsal outline is evenly arched and there are teeth on the anal margin.

\section{Echinisca carinata Smirnov, 1976}

Fig. 94

Echinisca carinata Smirnov, 1976: 124, fig. 104.
Material. Qld: 30 . N.S.W.: 136, 137, 139, 158, 163, 165, 167. Tas.: 320, 335. W.A.: 413.

Holotype. MGU ९ 2815.

Paratypes. AM \& P27739, ZIN \& 2816.

Slides. MGU \& 2818, 2819.

Female. Dorsal edge of valve essentially smooth (i.e. not serrated), however in some specimens very small

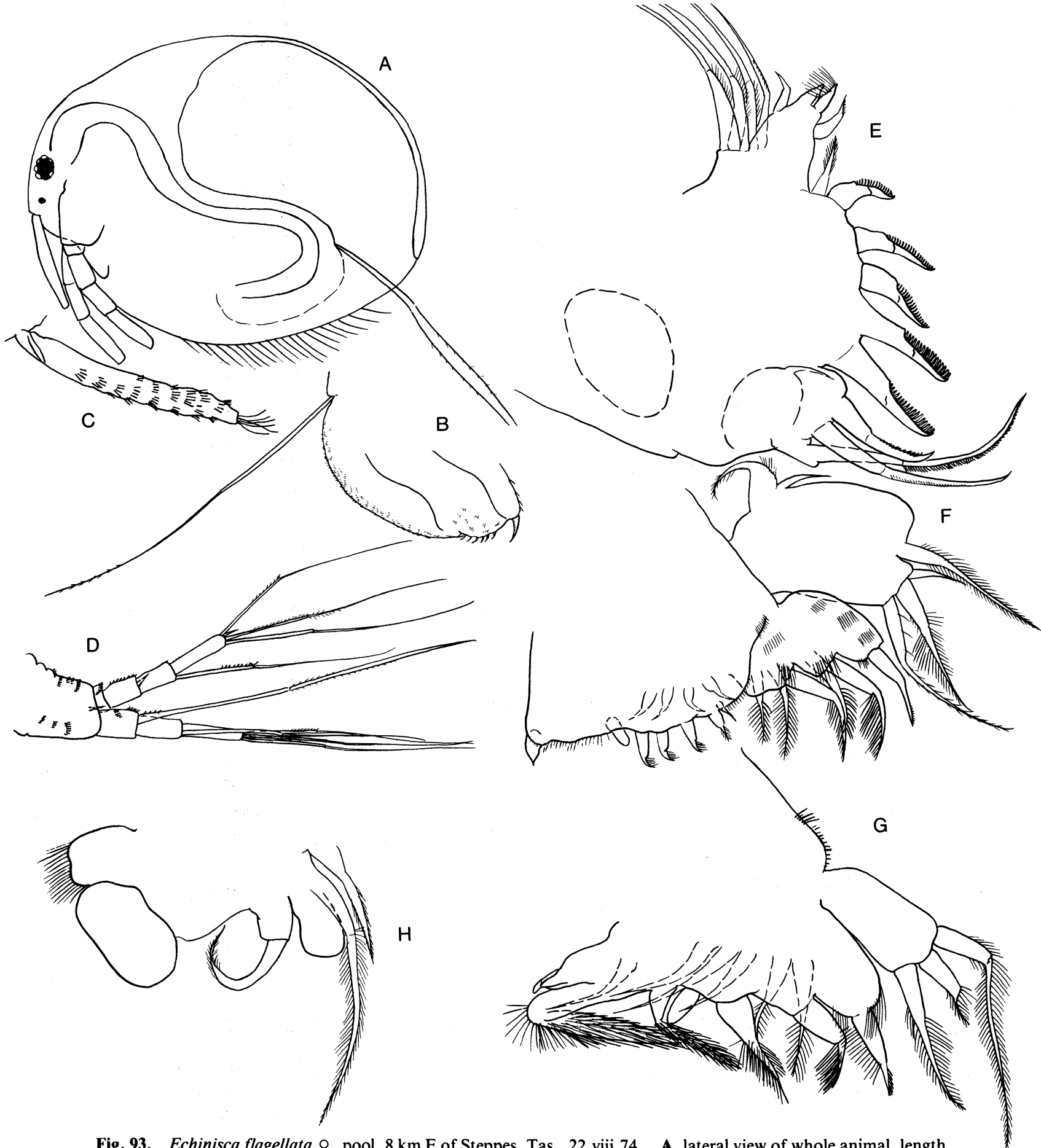

93. Echinisca flagellata $O$, pool, $8 \mathrm{~km}$ E of Steppes, Tas. 22 viii 74. A, lateral view of whole animal, length $1.39 \mathrm{~mm}$; B, postabdomen; C, antennule; D, antenna; E, limb II; F, limb III; G, limb IV; H, limb V. (G-D from slide 2979; E-H from slide 2983.) 


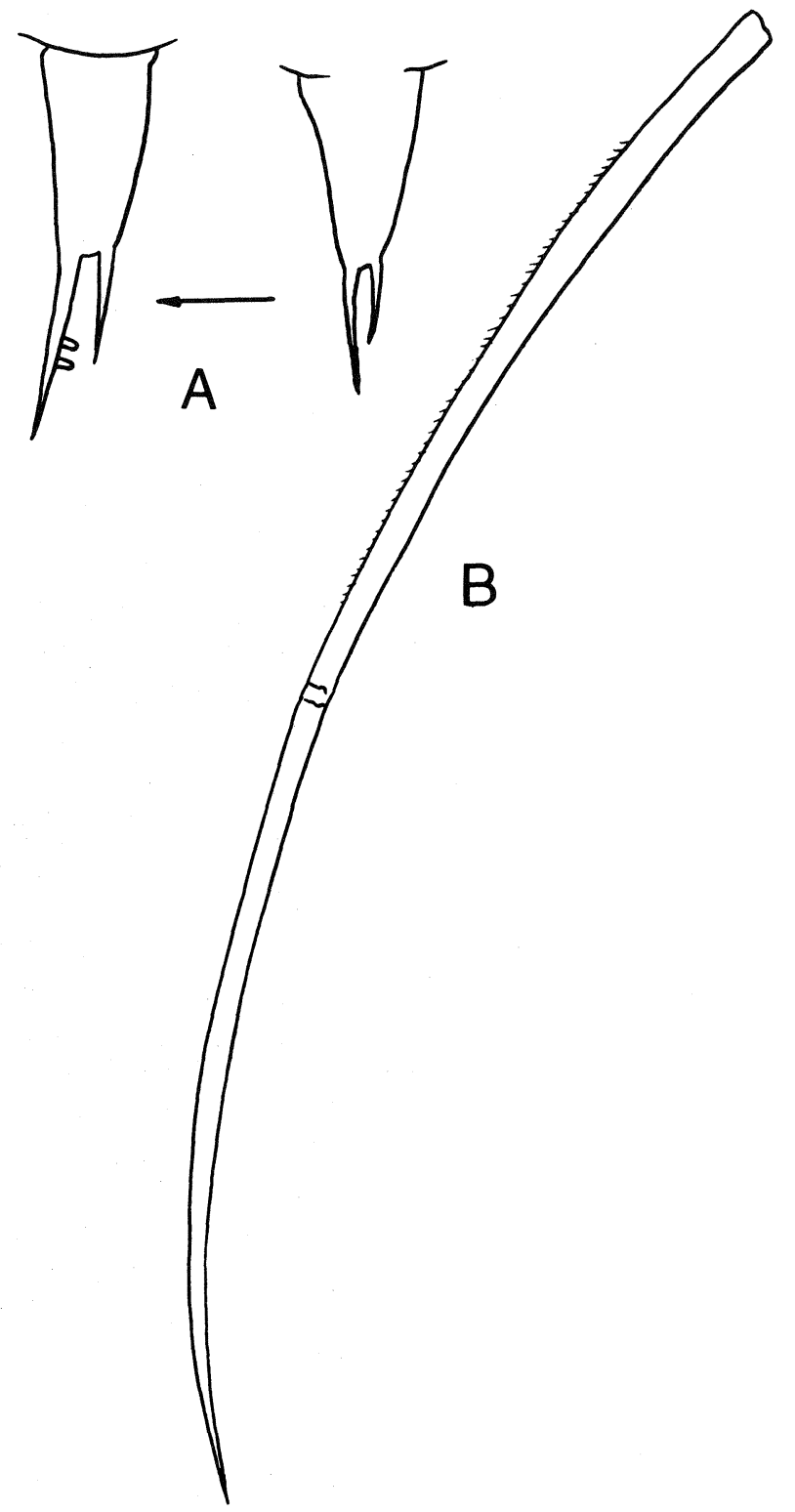

Fig. 94. Echinisca carinata $\&$, L. Buchanan, via Charters Towers, Qld, 16.vii.74. A, inner spines of thoracic limb I (arrow points to the anterior end of the animal); B, largest seta of antenna (belonging to the first segment of the three-segmented ramus). (Both from slide 2819.)

occasional serrations in posterior part of dorsal edge (slide 2816). Marked dorsal (but not cephalic) keel on the carapace. Ventral edge of valves with rough irregular serrations and stout setae with very short setules. Small dorso-posterior angle to carapace.

Antennule not dilated distally, and with groups of setae on anterior surface of its distal half. Sensory papillae of antennule of different lengths. Antennule seta $0-0-1-3 / 1-1-3$, and spines $0-1-0-1 / 0-0-1$; largest seta has setules but no spines.

Postabdomen with spines and groups of seta on anal edge and spines increasing proximally on preanal edge. Distal joint of setae natatoriae very short, but with long setules.
Thoracic limb I with 3 setae on external branch of its endite, one much longer than other two. Small inner spines of internal branch of endite of limb I similar to those of Macrothrix laticornis is depicted by Fryer (1974, fig. 61). The long setae of exopodite of limb I with short densely spaced setules.

Intestine not convoluted.

Length. $0.65 \mathrm{~mm}$ (holotype 2815).

Male. Unknown.

Ecology. Littoral. May live in slightly saline (c. $4 \%$ ) and ephemeral pools.

Type locality. L. Buchanan, via Charters Towers, Qld (Loc. No. 30).

Distribution. Qld, N.S.W., Tas., W.A., and possibly other states as well.

Differential diagnosis. The dorsal edge of the carapace is markedly keeled. The setae natatoriae have very short distal joints. The preanal angle of the postabdomen has spinules increasing towards the base of the setae natatoriae.

Echinisca carinata is similar to Macrothrix breviseta found in the limnetic zone of the type locality (L. Buchanan), but differs in having the antennule not dilating distally, and in the short, densely spaced setules of the long exopodite seta of thoracic limb I.

\section{Incertae sedis}

Macrothrix spinosa Gurney, 1927: 67-68, fig. 5.

\section{Genus Pseudomoina Sars, 1912}

Pseudomoina Sars, 1912: 1-5.-Smirnov, 1976: 151.

Head defined from remainder of carapace by a dorsal depression. Carapace oval, its ventral edges densely setiferous. A tuft of long setae present at ventroposterior corner of valve. Antennal setae 0-1-1-3/1-1-3, and spines $0-1-0-1 / 0-0-0$. Postabdomen tapers distally; no distinct anal teeth present. Five pairs of thoracic limbs. External branch of endite of limb I with 4 setae. Intestine without caeca and convolutions. Both ocellus and eye present.

Pseudomoina is a monotypic genus. The type species is Pseudomoina lemnae (King, 1853).

\section{Pseudomoina lemnae (King, 1853)}

\section{Fig. 95}

Moina lemnae King, 1853a: 250-251, pl. IV.-Sars, 1888: 68. Lathonura lemnae.-Schoedler, 1877: 14.

Pseudomoina lemnae. - Sars, 1912: 5-13, pl. X; Henry, 1922: 37; Brehm, 1932: 81; 1938: 103, 120, Abb. 7; Petkovski, 1973b: 182-188, figs 44-59, 62; Fryer, 1974: 229-230, figs 113-115; Smirnov, 1976: 151-153, figs 134-136.

Material. N.S.W.: 88, 96, 99, 149. Vic.: 210, 214, 216, 232, 233. Tas.: 292, 299.

Slides. AM \& P27754, MGU @ 2584, ZIN 2585.

Length. Female $1.2 \mathrm{~mm}$, male $0.8 \mathrm{~mm}$. 


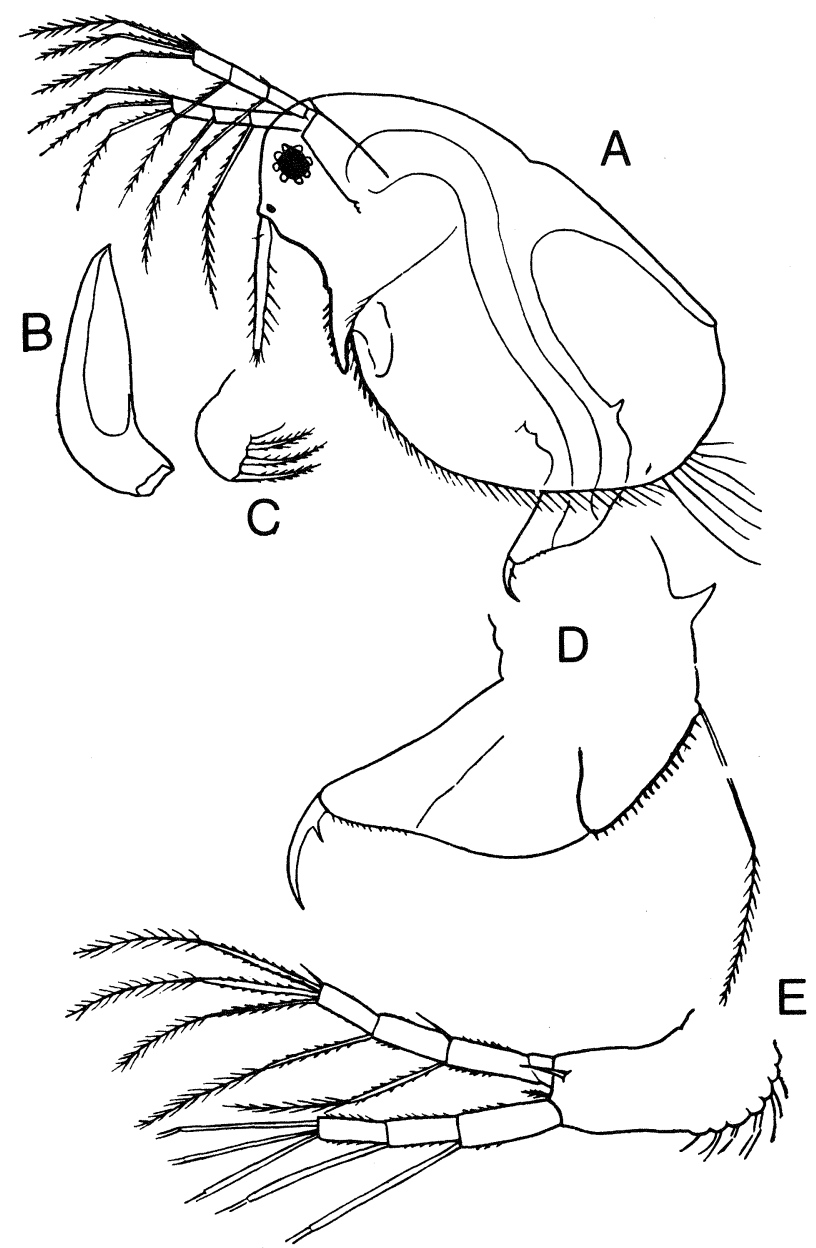

Fig. 95. Pseudomoina lemnae $\&$, after Smirnov, 1971b. A, whole animal, length $1.2 \mathrm{~mm}$; B, mandible; $\mathbf{C}$, maxilla; $\mathbf{D}$, postabdomen; E, antenna.

Ecology. Littoral.

Type locality. A pond near Cook's River close to Sydney.

Distribution. South-eastern Australia.

\section{Genus Streblocerus Sars, 1862}

Streblocerus Sars, 1862b: 284.

Body high, postabdomen short. Preanal edge of postabdomen serrated. Distal joint of setae natatoriae long. Intestine convoluted and an ocellus and an eye present. The genus is easily recognized by the bent antennules with several short and rather thick bristles.

Of the two known species of Streblocerus only the type species Streblocerus serricaudatus (Fischer, 1849) occurs in Australia.

Streblocerus serricaudatus (Fischer, 1849) Fig. 96

Daphnia laticornis Fischer, 1849: 45-50, Taf. IV, figs 11-VIII. Streblocerus serricaudatus Lilljeborg, 1900: 362, tab. 56, figs 15-27, tab. 57, fig. 1.-Smirnov, 1976: 166-171, fig. 155.

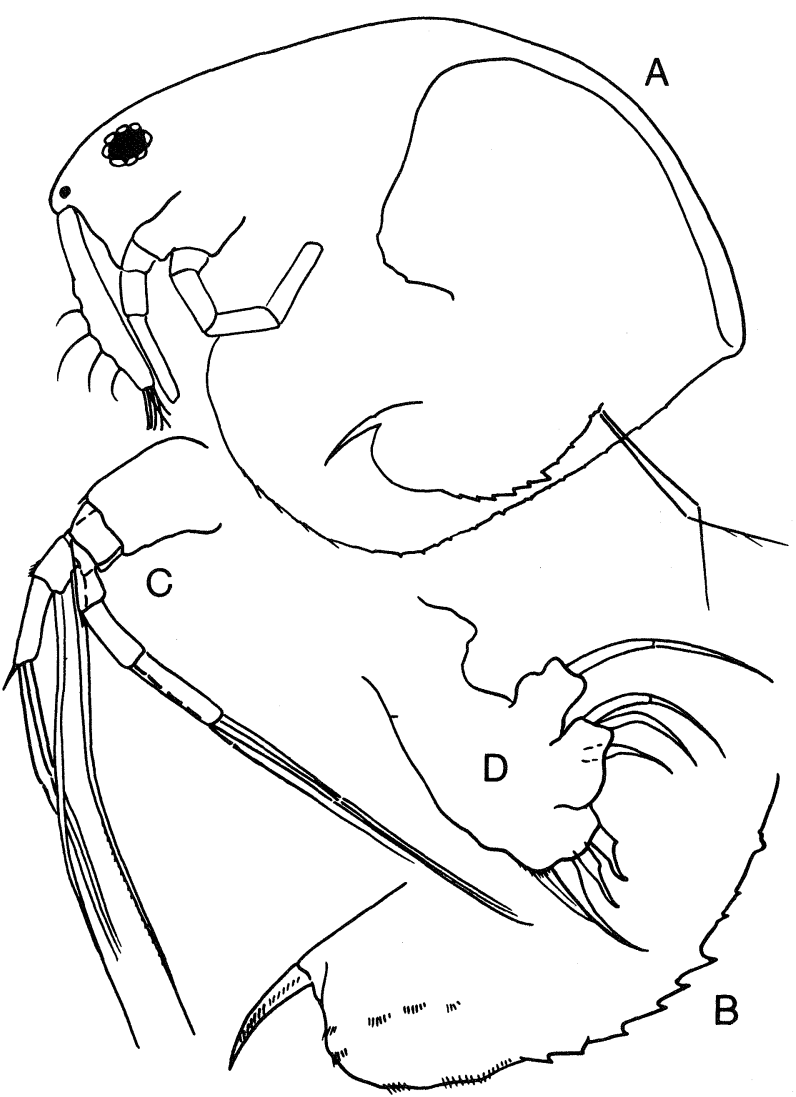

Fig. 96. Streblocerus serricaudatus $९$, "Pine Forest Lag." via Nelson, Vic., 11.viii.72. A, lateral view of whole animal, length $\mathbf{0 . 6}$ mm; B, postabdomen; C, antenna; D, limb I. (A, B, D from slide 1448; C from slide 1649.)

Material. Qld: 49. N.S.W.: 79, 81, 83, 96, 98, 100. Vic.: 226, 258. Tas.: 303.

Slides. AM $\subsetneq$ P27755, MGU $\subsetneq 2379,1448,1649$, ZIN ○ 2545 .

Length. Up to $0.6 \mathrm{~mm}$.

Ecology. Littoral. It 'swims' using strokes of the antennae, in the bottom material which may include filamentous algae. $S$. serricaudatus is usually found in soft acid waters but in Loc. No. 258 the $\mathrm{pH}$ was 7.8 and $\mathrm{Ca}$ content $60 \mathrm{mg} / \mathrm{l}$ at the time of collection. In Europe this species lives in similar habitats-soft acid waters (in sphagnous bogs) but occasionally hard waters (55 mg/l Ca0) (Flössner, 1962).

Distribution. Eastern Australia.

\section{Genus Neothrix Gurney, 1927}

Neothrix Gurney, 1927: 69.-Smirnov, 1976: 171.

General body form ovoid. Carapace and head covered with bristles. Postabdomen with no claw, a unique feature for all known females of Cladocera. External branch of endite of leg I with 4 setae. Intestine not convoluted.

Neothrix is a monotypic genus endemic to Australasia.

The type species is Neothrix armata Gurney, 1927. 


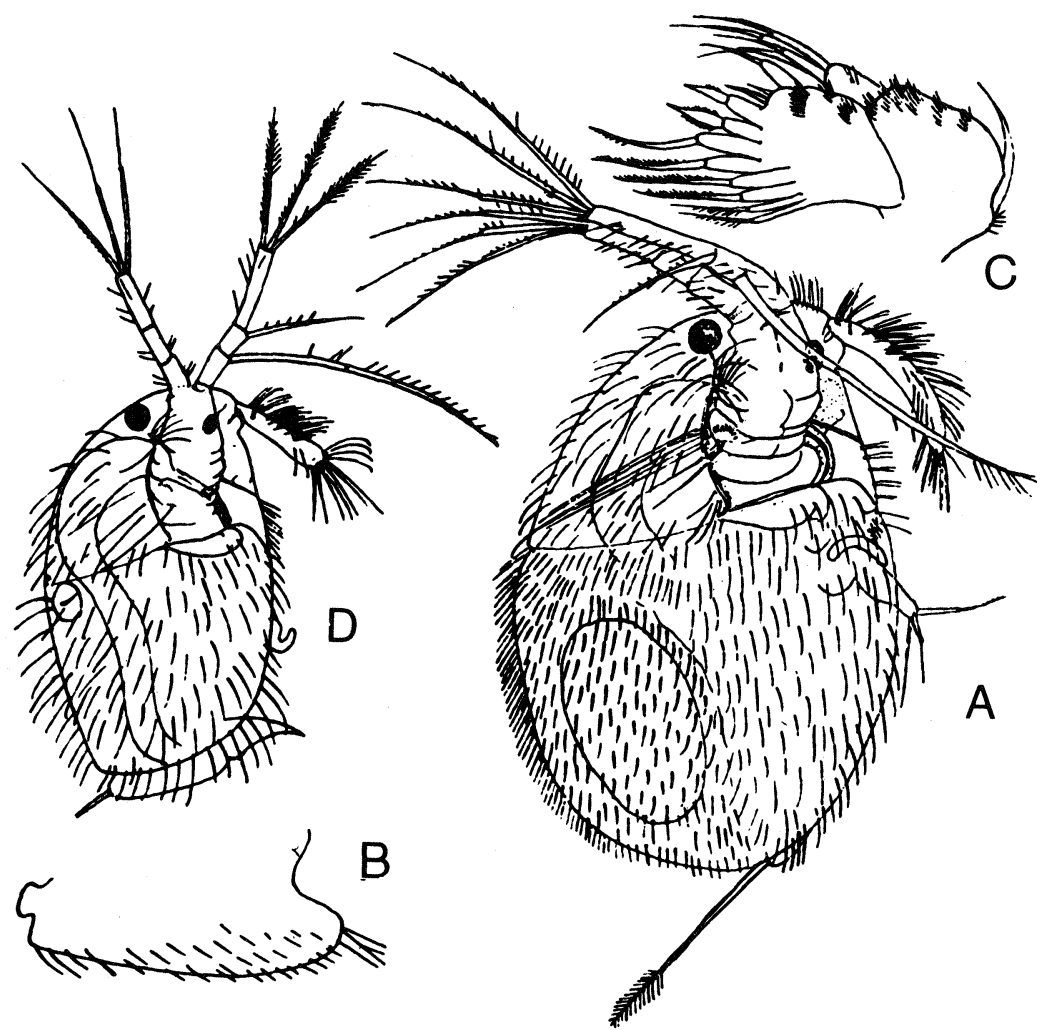

Fig. 97. Neothrix armata $\&$, after Gurney, 1927. A, lateral view of whole animal; B, postabdomen of $\&$; C, thoracic limb I of $९$; D, lateral view of $\sigma^{\circ}$.

Neothrix armata Gurney, 1927

Fig. 97

Neothrix armata Gurney, 1927: 69-71, fig. 7.-Fryer, 1974: 231-236, figs 116-127 (L. Rotoiti, New Zealand); Smirnov, 1976: 171-173, fig. 160 .

Material. Qld: 31. Vic.: 204, 257. W.A.: 403, 406, 422, $425,426$.

Slides. Female: AM P27752, MGU 3030. Ephippium: AM P27753, MGU 3034, ZIN 3031.

Female. The ephippium contains one, rarely two eggs. Its surface bears sparsely spaced bristles and small circles.

Ecology. Neothrix armata has not been studied alive before, so we observed some females collected near the shore of Swan Lake, Vic. (Loc. No. 257). It swims by rapid simultaneous jerks of its antennae, typically ventral side up, above, on the surface of, or among clumps of particulate material. If disturbed it swims in free water. If swimming slowly its head points upwards, but at each stroke of the antennae the head moves forwards and the body is horizontally orientated. Sometimes it rests on the bottom with its head downwards. If arrested by some obstacle (e.g. a filament) it attempts to release itself by numerous jerks of the antennae. If disturbed, Neothrix armata remains still for 1-2 seconds, feigning death.

It feeds by handling clumps of organic matter about $1 / 4$ of its length with thoracic limbs I and II. A food particle is rotated between the legs and the food is scraped-no filtratory currents or permanent undulations of thoracic limbs were observed. These observations concur with those reported by Fryer's (1974) morpho-functional study on preserved material, namely that it is a benthic animal, feeding by mechanical handling of food particles and using no filtration.

It is clean; the bristles on the carapace seem to keep organic particles off its body.

Type locality. Waters near Longreach, Qld.

Distribution. Qld, Vic., and particularly W.A.; possibly other states as well.

\section{Family MOINIDAE Goulden, 1968}

Moinidae Goulden, 1968: 1-101.-Smirnov, 1976: 174-229.

The type genus is Moina Baird, 1850 .

\section{Key to the Genera of Moinidae}

1. Distal segment of four-segmented branch of antennae with four setae; ocellus present ........ Moinodaphnia Herrick, 1887

Distal segment of four-segmented branch of antenna with three setae; ocellus absent (except in Moina reticulata (Daday, 1903), but this species not known for Australia) ......... Moina Baird, 1850. 


\section{Genus Moinodaphnia Herrick, 1887}

Moinodaphnia Herrick, 1887: 35.-Sars, 1901: 15-16; Goulden, 1968: 83-84; Smirnov, 1976: 187.

Paramoina Sars, 1888: 68 .

The shell is wide, the head small. The distal segment of the four-segmented branch of the antenna has four setae.

This is a monotypic genus with the type species Moinodaphnia macleayi (King, 1853) originally described from Australia.

\section{Moinodaphnia macleayi (King, 1853)}

Fig. 98

Moina Macleayi King, 1853a: 251252, pl. 5.

Moinodaphnia macleayi._Sars, 1888: 68; 1896: 28; 1901: 16-19, pl. 3, figs 1-10; Henry, 1922: 34, pl. 4, fig. 6; Brehm, 1933: 669-670, fig. 10; 1953: 324-325, fig. 92; Goulden, 1968: 84-87, figs 45-46; Smirnov, 1976: 187-189, figs $165-166$.

Moina submucronata Brady, 1886: 294, pl. 37, figs 4, 5.

Moina Juanae Brehm, 1948: 99-100, figs 2A-C.

Material. Qld: 24, 48. N.S.W.: 79, 82, 83, 84, 91, 97, 100, 101

Length. Female up to $1.1 \mathrm{~mm}$, male up to $0.6 \mathrm{~mm}$.

Ecology. This species often occurs in the littoral of coastal lagoons and swamps which are markedly acid (pH 3.5-6.0). It is a filter feeder.

Type locality. A pond at Elizabeth Bay (Sydney).

Distribution. Coastal Qld and N.S.W.

\section{Genus Moina Baird, 1850}

Moina Baird, 1850: 100._Goulden 1968: 11; Smirnov, 1976: 189-190.

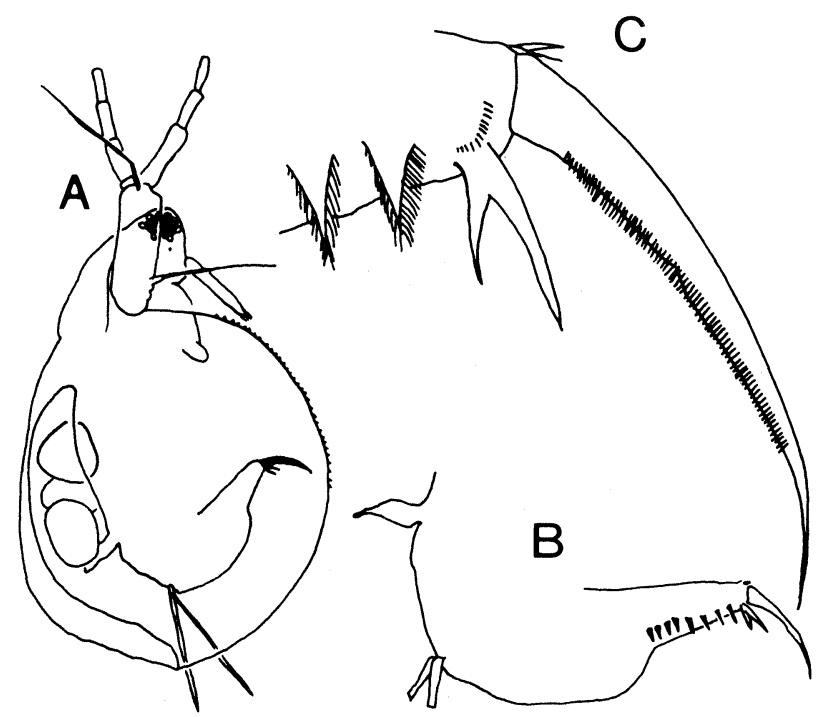

Fig. 98. Moinodaphnia macleayi $\$$, after Rey \& Saint-Jean. A, lateral view of whole animal; $\mathbf{B}$, postabdomen; $\mathbf{C}$, claw of postabdomen.
Body globular with a relatively large head. Distal segment of four-segmented branch of antenna with three setae.

The type species is Moina brachiata (Jurine, 1820).

\section{Key to Australian Species of Moina}

1. Antennule very thin, about 11-12 times as long as wide; ephippium with two eggs ............ tenuicornis Sars, 1896

Antennule not very thin; ephippium with one or two eggs $\ldots \ldots \ldots \ldots \ldots \ldots \ldots \ldots$

2(1). No seta on anterior side of the penultimate segment of thoracic limb I ...... ............... mongolica Daday, 1901

A seta on anterior side of penultimate segment of thoracic limb $I \ldots \ldots \ldots \ldots$

3(2). Ventral edge of valve straight or slightly concave in its posterior half; ephippium with one egg ........ M. flexuosa Sars, 1897

Ventral edge of valve evenly arched; ephippium with one or two eggs .......4

4(3). Ephippium with one egg ............. ............... M. micrura Kurz, 1874

Ephippium with two eggs ............ .............. australiensis Sars, 1896

\section{Moina micrura Kurz, 1874}

Moina micrura Kurz, 1874: 13-15, pl. I, fig. 1.-Goulden, 1968: 28-37, figs 8-12; Smirnov, 1976: 194-200.

Monoculus rectirostris Jurine, 1820: 134-135, pl. 13, figs 3, 4.

Of the three subspecies now recognized only the typical form is known in Australia. However a subspecies key is given to allow the possibility of differentiating the other subspecies.

Differential diagnosis. The antennule is not very long and thin. The ventral edge of the valve is evenly arched. There is a seta on the anterior side of the penultimate segment of thoracic limb I. The ephippium contains one egg.

\section{Key to Subspecies of Moina micrura}

1. Concave side of claw with a uniform row of setules ..................... ........... M. micrura micrura Kurz, 1874

Concave side of claw with proximal setules larger, forming a separate pecten ....... 2

2(1). Dorsal side of postabdomen with comparatively large setae; basal setae of

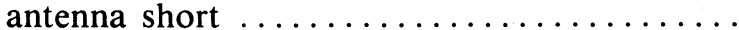
.......... M. micrura ciliata Daday, 1905 
Dorsal side of postabdomen with comparatively short setae; basal setae of

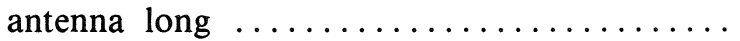
...M. micrura dubia Guerne \& Richard, 1892

\section{Moina micrura micrura Kurz, 1874}

Figs 99, 100

Moina micrura micrura Kurz, 1874: 13-15, pl. I, fig. 1.Smirnov, 1976: 196-200, figs 171-176.

Moina propinqua Sars, 1885: 29-35, tab. 5, figs 5, 6, tab. 6.

Material. Qld: 7. S.A.: 356, 365, 393. N.T.: 451, 453, 454. Slide. MGU $\&$ ephippial $\&, O^{*} 2871$, $~ 2874$.

Length. Female $0.97 \mathrm{~mm}$, male $0.64 \mathrm{~mm}$.

Ecology. This form is limnetic, as is Moina micrura sensu lato (Goulden, 1968; Timms, 1970a).

Distribution. Qld, S.A., N.T., but probably more widespread. M. micrura sensu lato has been reported from N.S.W., and Vic., (Goulden, 1968; Timms, 1970a).

\section{Moina australiensis Sars, 1896}

Fig. 99

Moina australiensis Sars, 1896: 18-24, pl. 3, figs 1-11.Henry, 1922: 34-35; Brehm, 1953a: 6-9, fig. 2; Goulden, 1968: 48-51, fig. 21; Vidal, 1970: 203-208, figs 1, 2 (Moina sp., New Zealand); Smirnov, 1976: 203-204, figs 183-184.

Material. N.S.W.: 154, 162. Vic.: 247. W.A.: 404.

Slides. MGU \& 2624, ZIN \& 2625.

Length. Up to $1.9 \mathrm{~mm}$.

Ecology. This species is euryhaline, for Brehm (1953b) records it from a saline lake and our Victorian record (Loc. No. 247, L. Coragulac) was slightly saline $(5 \%)$ at the time of sampling, but the two N.S.W. records are from freshwater.

Type locality. Sydney.

Distribution. N.S.W., Vic., W.A., but probably more widespread. Goulden's distribution map showing a record for near Rockhampton, Qld, is erroneous; it probably refers to $M$. micrura (syn. M. propinqua Sars, 1885) but it is omitted from the appropriate map.
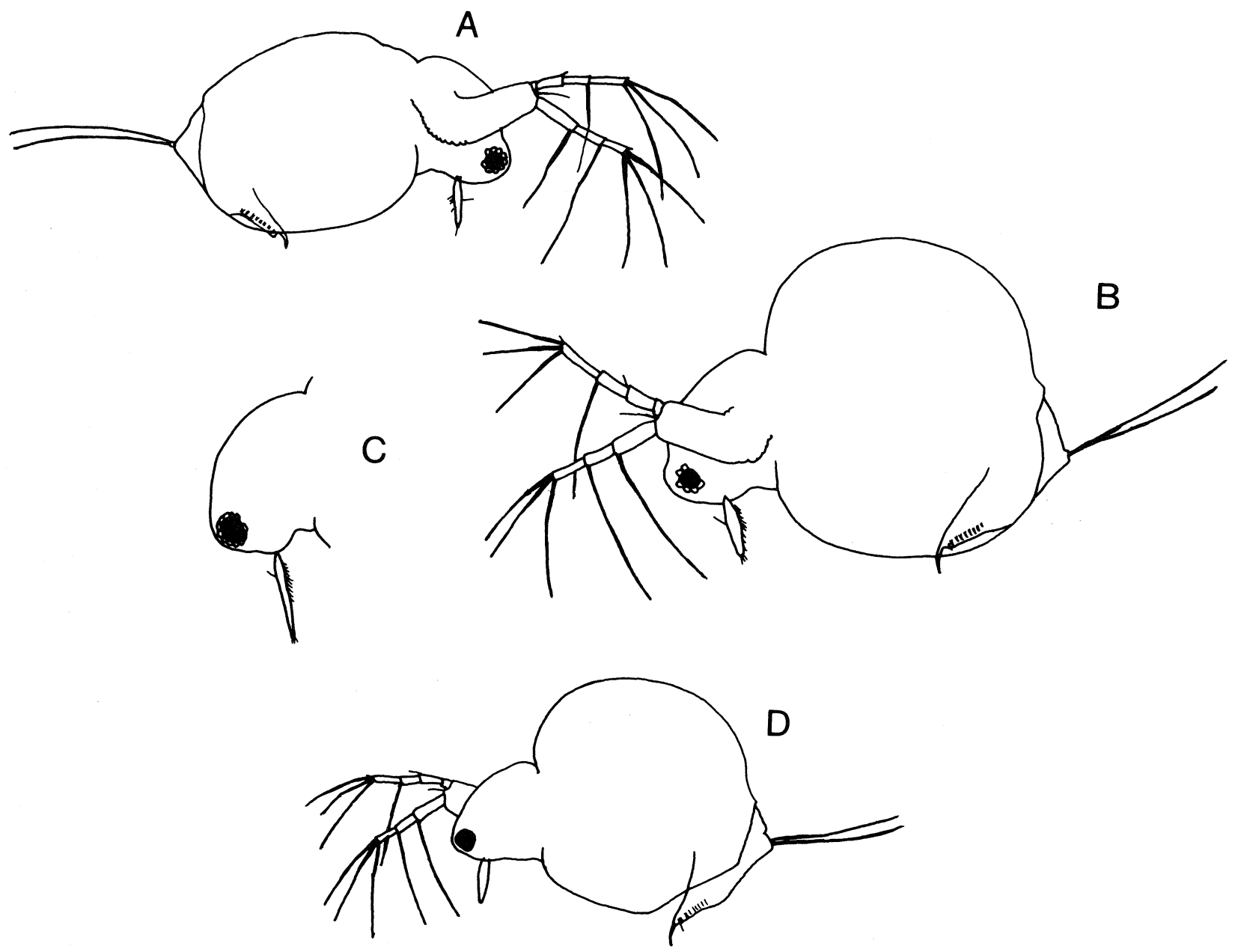

Fig. 99. Various Moinidae. A, Moina micrura $९$; B, Moina australiensis $९$; C, head of Moina tenuicornis $९$; D, Moina flexuosa 9 . 


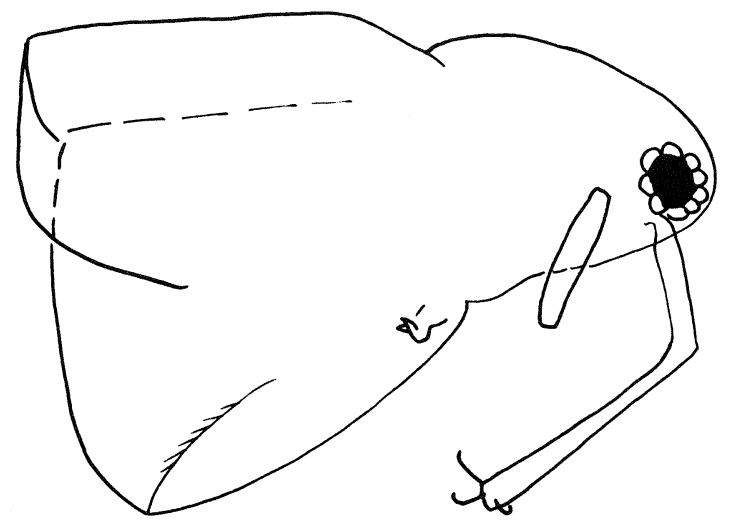

Fig. 100. Moina micrura micrura. Gynandromorphous individual, Anthony Lagoon, N.T., vii.75, slide 2874.

Differential diagnosis. The ventral edge of the valve is uniformly convex. Thoracic limb I has a seta on the anterior side of the penultimate segment. This seta is not pectinate. The seta of the posterior side of the valve are grouped. The ephippium contains two eggs.

\section{Moina tenuicornis Sars, 1896}

Fig. 99

Moina tenuicornis Sars, 1896: 24-27, pl. 4, figs 1-8.-Haase, 1903: 150, fig.5; Henry, 1919: 468; 1922: 35; Smirnov, 1976: 213 , fig. 195.

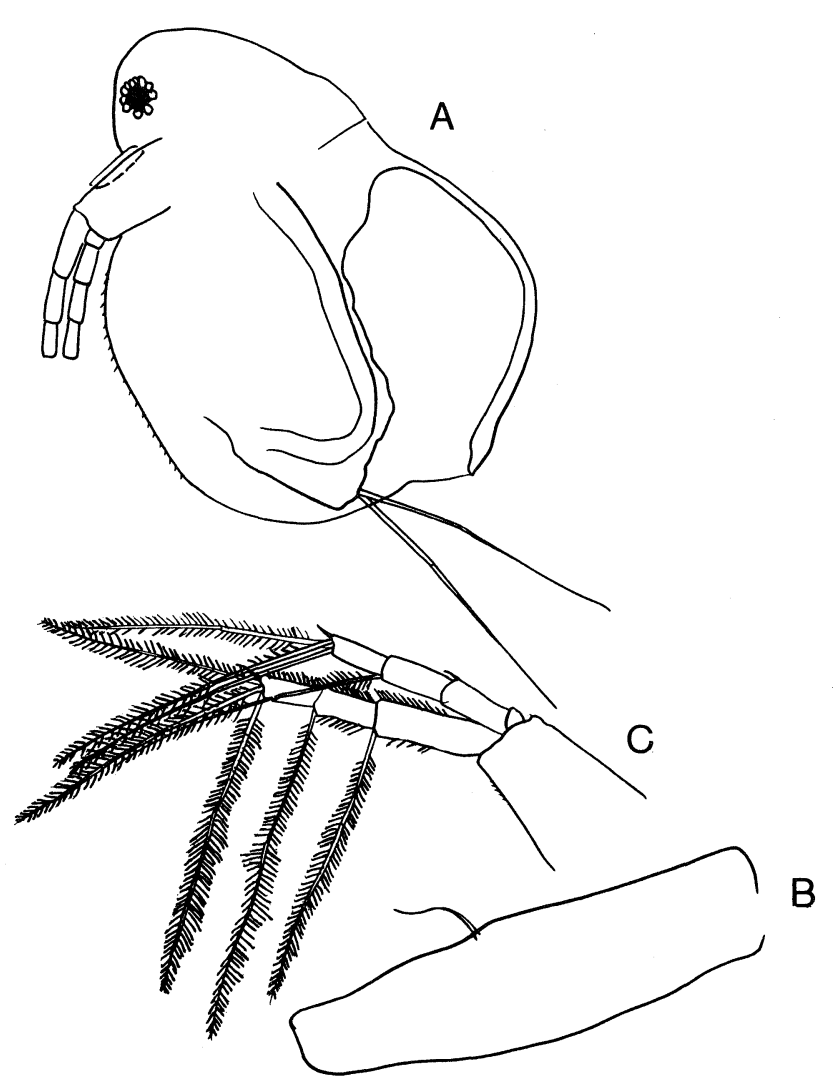

Material. N.S.W.: Parramatta (vial in Australian Museum P:6212), a slide in the Australian Museum "P:5894 Moina tenuicornis Sars, Loc. Corowa'. Vic.: 212, 213, 216, 217, 241. W.A.: 427.

Slides. MGU $\subsetneq 1239$, ZIN 1427.

Length. Up to $1.2 \mathrm{~mm}$.

Type locality. A pond in Sydney.

Distribution. N.S.W., Vic., W.A., but probably more widespread.

Differential diagnosis. The antennule is very thin, its length being 11-12 times its width. The ventral edge of the valve is uniformly convex. Thoracic limb I has a seta on the anterior side of the penultimate segment; this seta is not pectinate. The ephippium contains two eggs.

\section{Moina flexuosa Sars, 1897}

\section{Fig. 99}

Moina flexuosa Sars, 1897: 18-23, pl. 3, figs 1-7.-Goulden, 1968: 55-58, figs 24, 25; Smirnov, 1976: 225, fig. 208.

Material. Literature.

Length. $0.9 \mathrm{~mm}$.

Type locality. A depression $60 \mathrm{~km}$ east of Roebuck Bay, W.A.

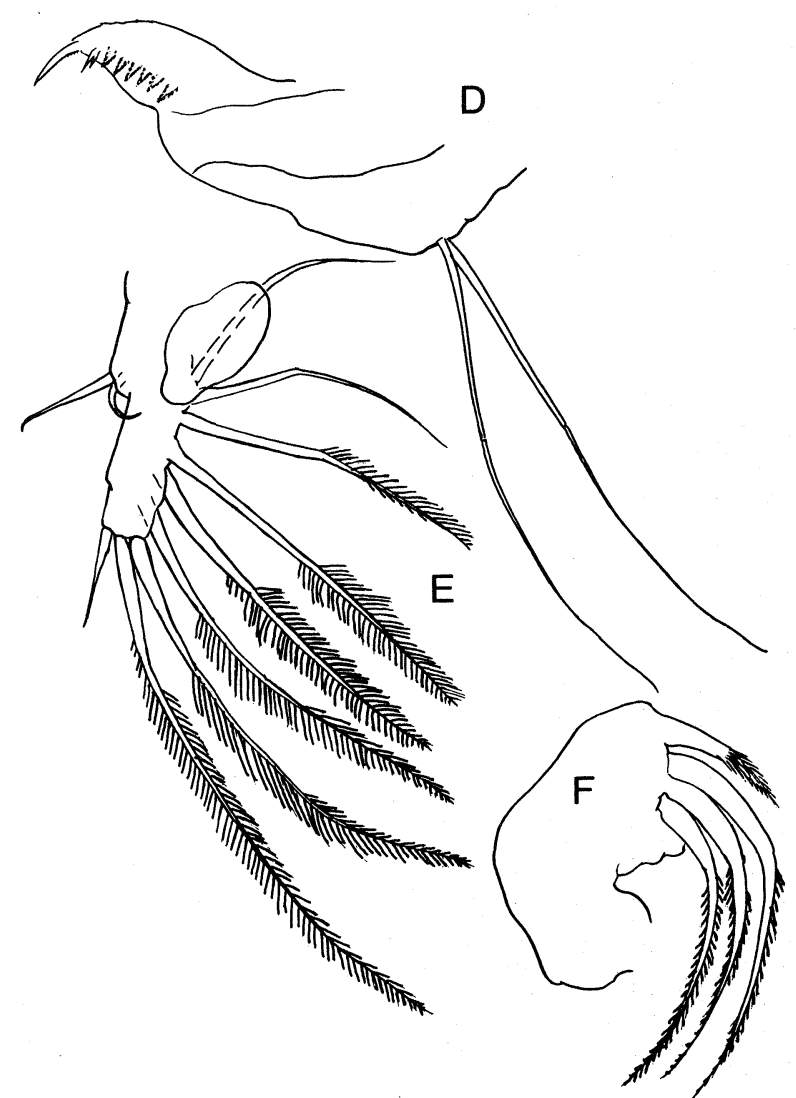

Fig. 101. Moina mongolica $९$, Lake Eyre, S.A., 27.ix.74. A, lateral view of whole animal, length $0.95 \mathrm{~mm}$; B, antennule of an ephippial $\$$; C, antenna (left); D, postabdomen; E, thoracic limb I; F, maxillule. (A-C from slide 2951; D-F from slide 2955.) 
Distribution. Known only from its type locality in north-west W.A.

Differential diagnosis. The ventral edge of the valve is straight posteriorly. Thoracic limb I has a seta on the anterior side of the penultimate segment. The ephippium contains one egg; its surface is knobby.

\section{Moina mongolica Daday, 1901}

Figs 101, 102

Moina mongolica Daday, 1901: 444-445, pl. 21, figs 11-15, pl. 22, figs 1-3.-Goulden, 1968: 64-69, figs 29, 30; Smirnov, 1976: 216-222, figs 204, 205.

Material. S.A.: 353-several ephhippial females and males. A sample in formalin has been placed in the Australian Museum.
Slides. $\quad$ AM $\odot, O{ }^{\circ}$ P27756; MGU $\odot$, ephippial $९ 0^{\circ} 2951$; ○ 2955; O* 2956; ZIN ९O* 2965.

Female. The specimens conform in all main characters to the description of this species as summarized by Goulden (1968). They differ, however, from the European form in the short seta of the distal segment of thoracic limb I being shorter (it is well short of reaching the border between the first and second segment of larger setae of this segment, whereas it almost reaches this place in the specimen figures in fig. 30E by Goulden, 1968).

Male. Thoracic limb I with a strong hook and no exopodite. In some juvenile males in the L. Eyre material the distal end of the antennule lacks hooks and the sensory seta is situated a little proximal to the middle of the antennule.

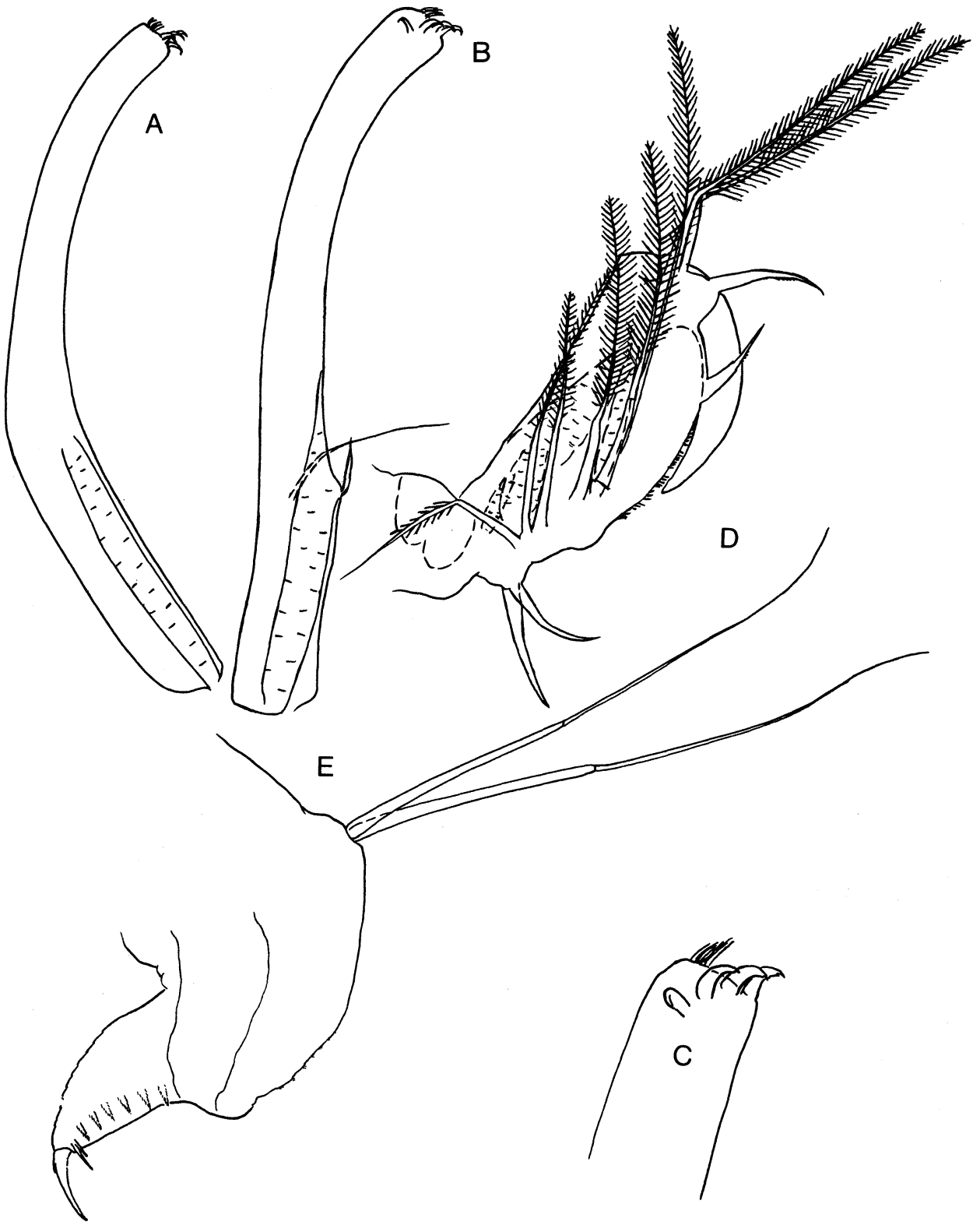

Fig. 102. Moina mongolica ơ, Lake Eyre, S.A., 27.ix.74. A, antenna (above); B, antenna (below); C, tip of antenna; D, thoracic limb I; E, postabdomen. (A slide from 2951, B-D from slide 2956.) 
Ecology. Halophilic-Bayly (1976) records a salinity range of 7-39\% in L. Eyre.

Distribution. S.A.-L. Eyre.

Differential diagnosis. The ventral edge of the valve is evenly arched. The antennule is not very long. There is no seta on the anterior side of the penultimate segment of thoracic limb I. The basal part of the concave side of the claw bears small but noticeable spines.

\section{Family BOSMINIDAE Sars, 1865}

Small cladocerans, about $1 \mathrm{~mm}$ or less. Valves cover trunk and thoracic limbs. Ventro-posterior corner of valve angular or with a spine-like elongation. Antennule of female characteristically fused with rostrum. No ocellus. Intestine not convoluted.

The type genus is Bosmina Baird, 1845.

\section{Key to Genera of Bosminidae}

1. Antennules fused at their bases; postabdomen tapers distally ............. Bosminopsis Richard, 1895

- Antennules not fused at their bases; distal end of postabdomen truncated ........ ................ Bosmina Baird, 1845

\section{Genus Bosminopsis Richard, 1895}

Bosminopsis Richard, 1895: 96-98, figs 1-4. Bosminella Daday, 1903: 594-597.

The type species is Bosminopsis dietersi Richard, 1897.

\section{Bosminopsis deitersi Richard, 1897}

Fig. 103

Bosminopsis deitersi Richard, 1897: 283.

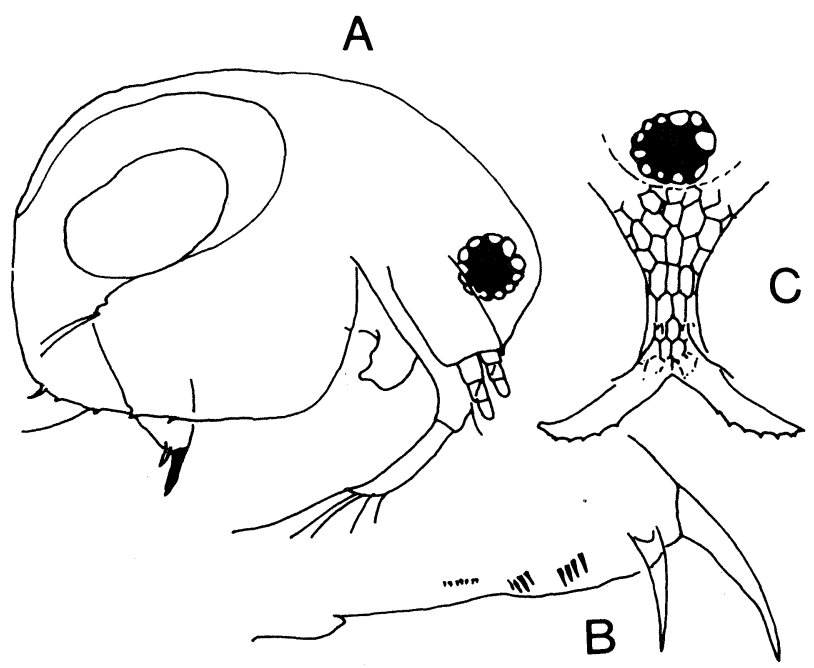

Fig. 103. Bosminopsis deitersi o, after Rey \& Saint-Jean. A, lateral view of whole animal; $\mathbf{H}$, postabdomen; $\mathbf{C}$, frontal view of antennule.
Material. Data from literature.

Distribution. Near Sydney N.S.W.

Genus Bosmina Baird, 1845

(Section written by V. Kořinek)

Bosmina Baird, 1845: 149.

Lynceus (partim) O.F. Müller, 1776: 199.

Eunica Koch, 1841: pl. 23.

Garbinia Grochowski, 1910: 343.

Antennules long, sickle-shaped and fixed to a long rostrum forming a beak. Lateral pore on each side of head shield, near antennal or mandibular articulation. Postabdomen quadrangular, with terminal claws on long processes. Males with movable antennules and a strong, hooklike segment on first leg.

The type species is Bosmina longirostris (O.F. Müller, 1785).

\section{Bosmina meridionalis Sars, 1904 \\ Figs 104-107}

Bosmina meridionalis Sars, 1904: 631-632, figs 3, 3a-c.-Jolly, 1953: 309-312, figs 1-2; Deevey, 1971: 203, fig. 6.

Bosmina rotunda Smith, 1909: 82, pl. 15, fig. 18, n. syn. Bosmina sorelli Smith, 1909: 83, pl. 16, fig. 2, n. syn.

Bosmina brevirostris Smith, 1909: 83, pl. 16, fig. 1, n. syn. Bosmina hagmanni Brehm, 1928: 192-194; 1928: 322-323; 1953: 66-68, fig. 7.

Material. Qld: 15, 31, L. Wendoura, Bee Hive D., via Wallangarra. N.S.W.: 76, 81, 123, 131, 178, 179, 187, Grahamstown Res., L. Burragorang, L. Woronora, Avon Res., Cateract Res., Nepean D., Prospect Res. Vic.: 226, 227, 228, 233, 234, 239, 243, 252, 257. Tas.: 310, 312, 313, 315, 325, 328, Woods L., Arthurs L., L. Petrach, Little Pine Lag. S.A.: 362, 384, 393. W.A.: 405, 406.

Slides. ZMO $\subsetneq$ 169/9748, 172/9799, AM $\odot$ P27682.

Female. Eye small (up to $50 \mu \mathrm{m}$ in diameter). Lateral head pores circular and situated over mandibular articulation. Reticulation of adjoining part of head shield not well pronounced. Antennules of variable length; turned upward or very short in some cyclomorphic populations (in localities 123, 226, Avon Res., Cateract Res., Lake Woronora, Nepean Res.) (as in S. American Bosmina tubicen). Mucrones slender, sometimes with one or several dorsal serrations, and tapering sharply towards end. Postabdomen convex on dorsal side; its terminal claws with a pecten of 4-10 denticles.

Length. Up to $0.8 \mathrm{~mm}$.

Male. Antennules movable, each with two setae near their base. First leg with a large hook, cudgel-like at end, and with two narrow parallel keels; its endopod armed with one tooth or a denticle and also with one seta. Postabdomen strong, female-like with terminal claws shortened with 2-6 denticles in a pecten.

Length. Up to $0.7 \mathrm{~mm}$.

Ecology. Mostly limnetic. 


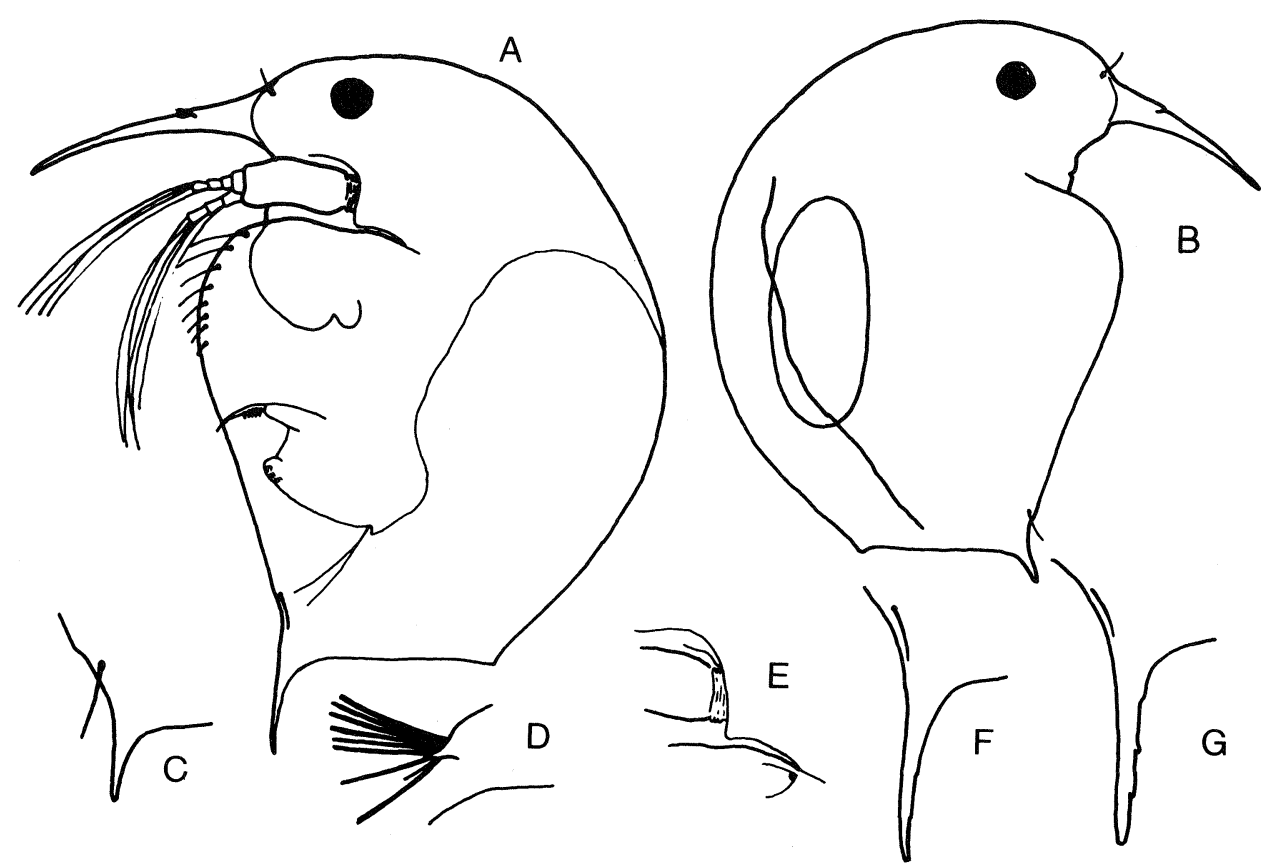

Fig. 104. Bosmina meridionalis $९ . \quad$ A, specimen from L. Wakatipu, N.Z., iv-70; B, ephippial , Mardi Res., N.S.W., 7.x.68; C, seta kurzi and mucro, Burragorang Res., N.S.W., 8.viii.65; D, sensory setae on antennule, idem; E, lateral head pore, idem; F, mucro, first instar, L. Watatipu, N.Z., iv.70; G, mucro, adult instar, idem.

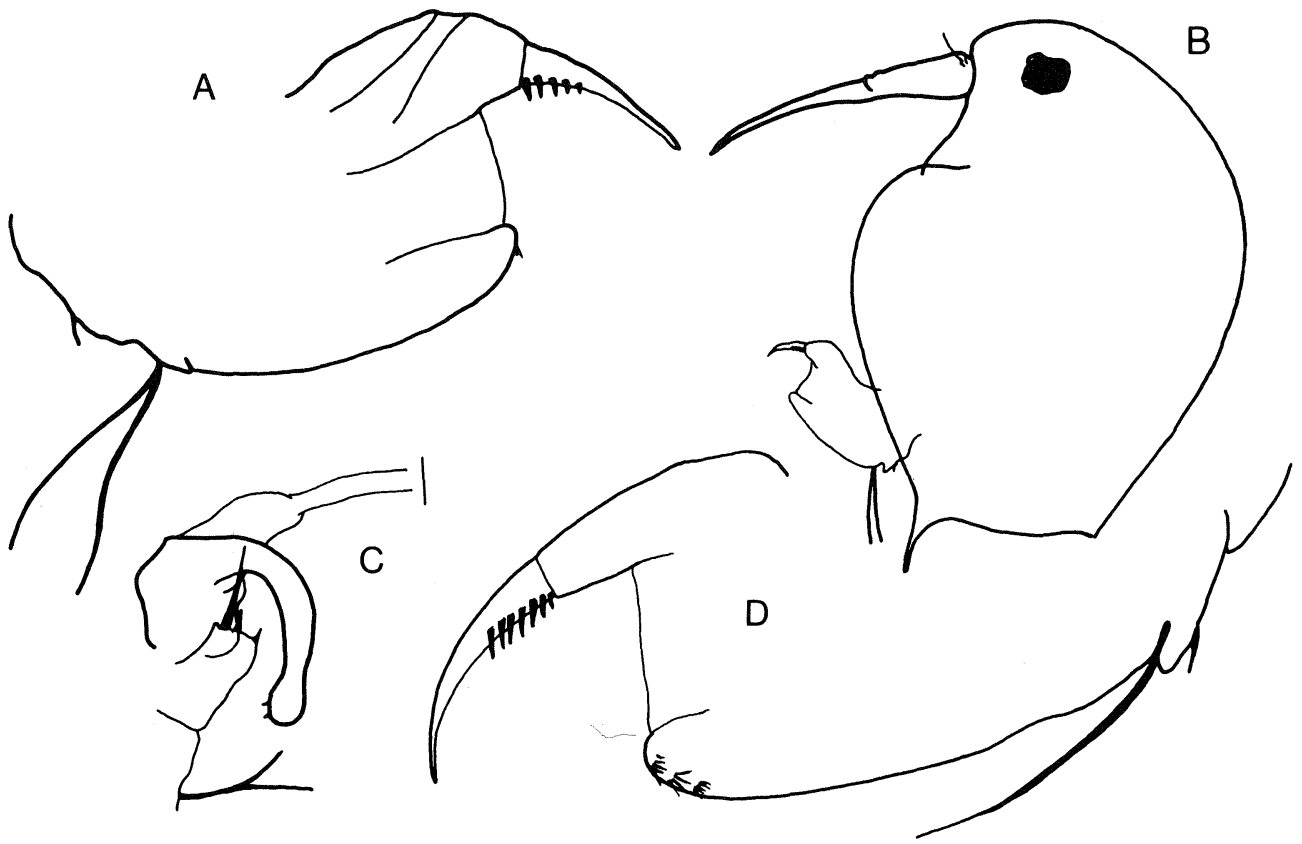

Fig. 105. Bosmina meridionalis. A, ơ, postabdomen, Avon Res., N.S.W., 4.x.62; B, ơ , idem; C, o*, first thoracic limb, clasper, idem; D, ९, postabdomen, Burragorang, N.S.W., 8.viii.62.

Type locality. L. Wakatipu, N.Z.

Distribution. Australia-wide. Also New Zealand, Thailand (uncertain record), Ghana.

Differential diagnosis. Within its distributional range Bosmina meridionalis could only be mistaken for two other species: $\boldsymbol{B}$. longirostris and $\boldsymbol{B}$. fatalis. Females of $B$. meridionalis are easily distinguished by the pattern of lateral head pores which in the other two species are located near the margin of the head shield behind the antennal articulation. Males differ in the shape of the clasper of the first leg: in B. meridionalis it is cudgellike with two narrow keels near its end whereas in $B$. longirostris the claspers are sharp with needle-like ends and in $B$. fatalis there is a distinct knob on the base of the clasper. 


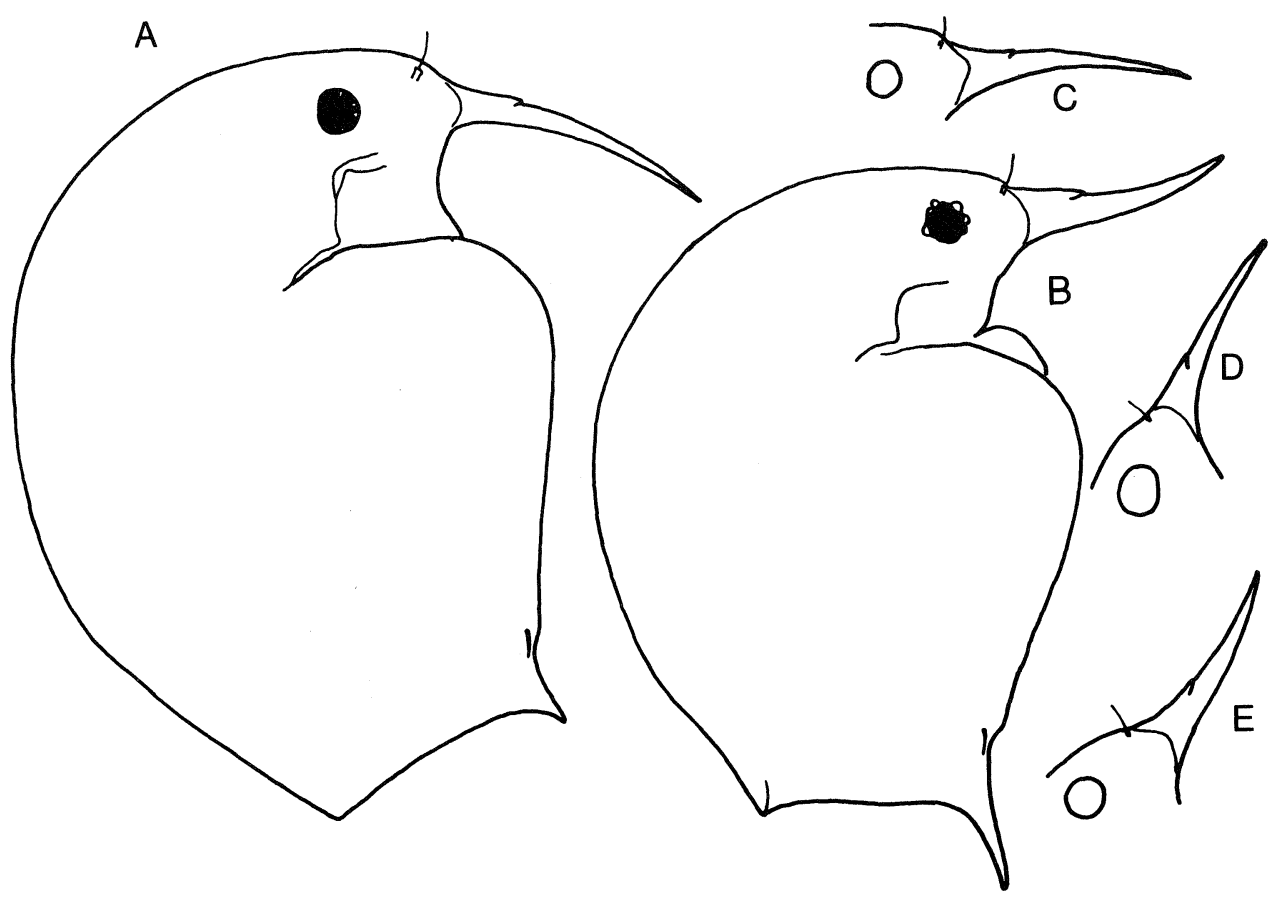

Fig. 106. Bosmina meridionalis $९$.A, whole animal, L. St. Clair, Tas., 15.i.75; B, whole animal, Avon Res., N.S.W., 4.x.62; C, antennule, idem; D, antennule, idem; $\mathbf{E}$, antennule, idem.

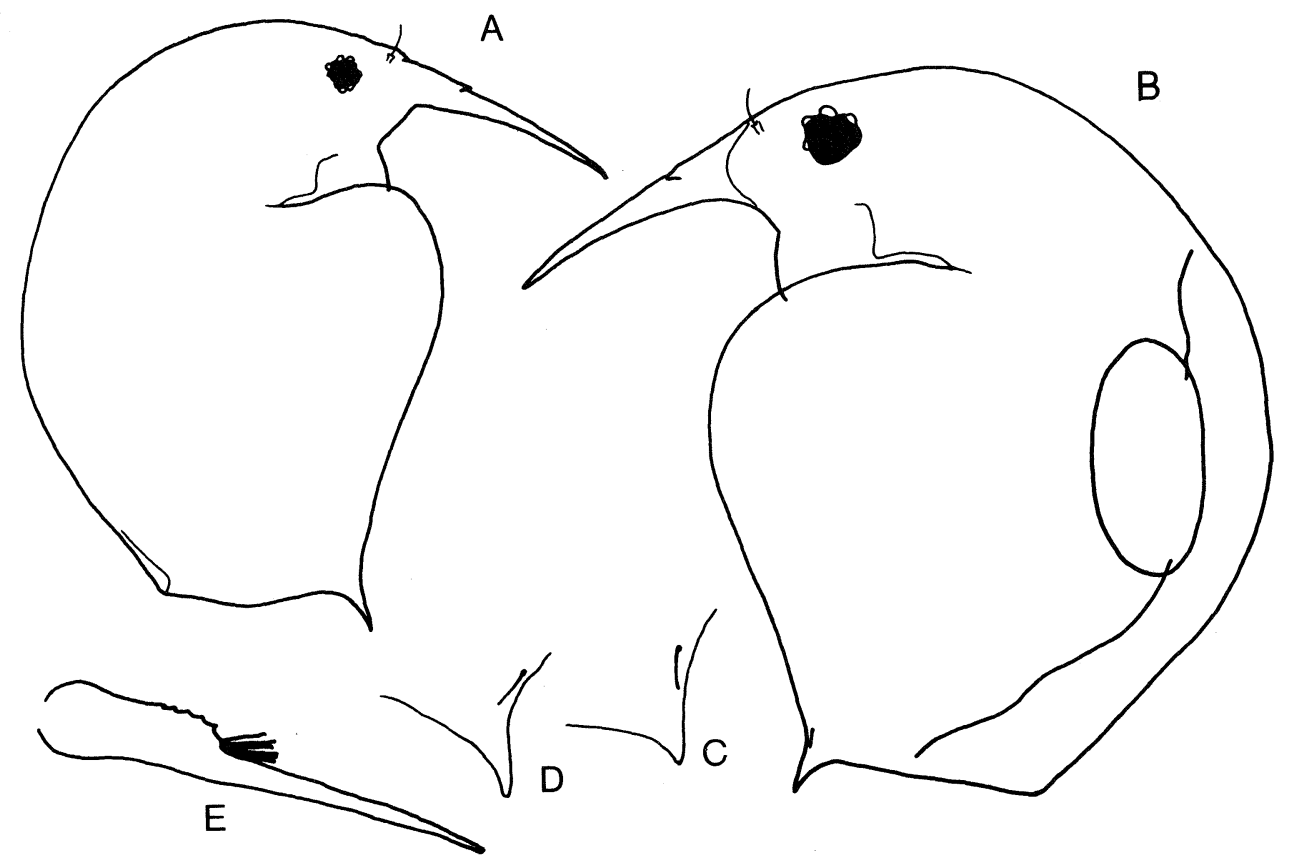

Fig. 107. Bosmina meridionalis. A, \&, L. Sorell, Tas., 15.i.70; B, ephippial \&, Great Lake, Tas., 19.iv.68; C, , seta kurzi and mucro, idem; D, $ᄋ$, seta kurzi and mucro, idem; E, ${ }^{*}$, antennule, Avon Res., N.S.W., 4.x.62.

\section{Family DAPHNIIDAE Straus, 1820}

\section{Daphnides Straus, 1820: 155.}

Daphnidae Lilljeborg, 1900: 64-65.-Šrámek-Hušek et al., 1962: 194-195; Brooks, 1966: 604.

\section{Key to the Genera of Daphniidae}

1. Ventral side of valve convex .......... 2 Ventral side of valve straight ............. ........... Scapholcberis Schoedler, 1858 
2(1). Ventral side of head with a small rostrum . . 3 Ventral side of head without a rostrum ...... .............. Ceriodaphnia Dana, 1852

3(2). Head relatively large; postabdomen relatively elongated, not indented on its anal side .4

Head relatively small; postabdomen short and wide, indented on its distal side ..... Simocephalus Schoedler, 1858

4(3). Dorsal keel on shell present ............ ............ Daphnia O.F. Müller, 1785

Dorsal keel absent; postabdomen tapers towards base of claw .................. ... . . . . . . . . . Daphniopsis Sars, 1903

Genus Daphnia O.F. Müller, 1785

(Section written by P.D.N. Hebert)

Subgenus Daphnia O.F. Müller, 1785.

Subgenus Ctenodaphnia Dybowski \& Grochowski, 1895.

Species in the genus Daphnia can be readily distinguished from species in other genera of the family Daphniidae. In all Daphnia species the head has a pronounced rostrum (absent in Ceriodaphnia, Moina, Moinodaphnia), the ventral carapace margin is curved (straight in Scapholeberis) and the carapace markings are mainly squares or rhomboids (markings are oblique parallel lines in Simocephalus).

The type species is Daphnia longispina (O.F. Müller, 1785).

\section{Key to the Subgenera of Daphnia}

1. Dorsal suture between head shield and valves extending anteriorly; fornix projecting laterally; ephippium roughly rectangular with egg chambers placed obliquely to dorsal margin ..............

Ctenodaphnia Dybowski \& Grochowski, 1895

- Dorsal suture between head shield and valves extending posteriorly; fornix smoothly arched; ephippium roughly triangular, egg chambers at right angles to

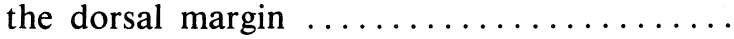
............. Daphnia O.F. Müller, 1785

All Australian species belong to the subgenus Ctenodaphnia with the apparent exception of $D$. jollyi (Petkovski, 1973a). However, the placement of this species in the subgenus Daphnia is questionable as its fornices project laterally and the ephippium was not examined. Moreover the anterior extension of the dorsal suture is very difficult to see in many Ctenodaphnia species and particularly so among species in the $D$. carinata complex.

\section{Key to the Australian Species of Daphnia}

1. Head noticeably enlarged, either anteriorly forming a spine or dorsally forming

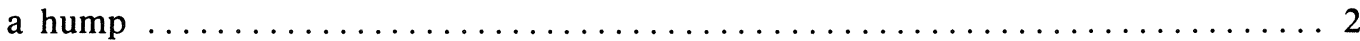

Head not enlarged, anterior surface rounded, dorsal surface nearly straight ..... 9

2(1). Small species, carapace length never more than $1.5 \mathrm{~mm}$, reproductive females

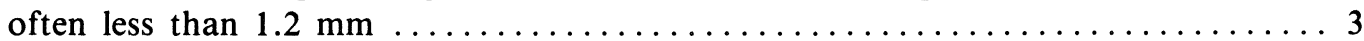

Large species, carapace length often over $2 \mathrm{~mm}$, reproductive females never

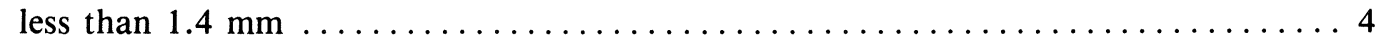

3(2). Anteriorly projecting spike-shaped crest on head; ventral carapace with about 12 strong spines $\ldots \ldots \ldots \ldots \ldots \ldots \ldots \ldots \ldots \ldots \ldots \ldots \ldots \ldots \ldots$ lumholtzi Sars, 1885

Dorso-anterior helmet; no strong carapace spines ........ D. projecta Hebert, 1977

4(2). Distance from antennular mound to rostrum less than or barely equal to

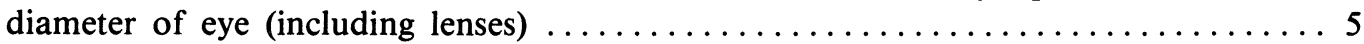

Distance from antennular mound to rostrum much greater than diameter of eye . . 7

*5(4). Rostrum acute and not close to ventral carapace margin ... D. magniceps (Sars, 1896)

Rostrum recurved and in close proximity to ventral carapace margin ........6

*6(5). Helmet unpronounced, centred above the heart and decreasing in size very gradually so that the dorsal margin is smoothly rounded ..... D. carinata King, 1853

Helmet larger, centred above the cephalic area and rather abruptly joining carapace so that the dorsal margin is sinuate ......... D. wankeltae Hebert, 1977 
7(4). Head length at least 1.4 times greater than carapace length D. cephalata King, 1853

Head length less than 1.4 times greater than carapace length $\ldots \ldots \ldots \ldots \ldots \ldots 8$

*8(7). Well developed spines on dorsal carapace margin, those anterior to tail as long as lens of compound eye; ocellus often absent; helmet dorso-anterior; rostrum relatively wide ................... D. longicephala Hebert, 1977

Small spines on dorsal carapace, those anterior to tail much shorter than lens length; ocellus always present; helmet dorsal; rostrum narrow

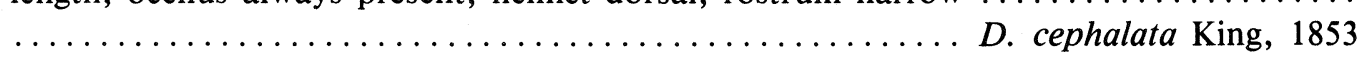

9(1). Small species, carapace length usually less than $1 \mathrm{~mm} \ldots \ldots$ D. lumholtzi Sars, 1885

Large species, carapace length not less than $1.4 \mathrm{~mm} \ldots \ldots \ldots \ldots \ldots \ldots \ldots$

10(9). Distance from antennular mound to rostrum much greater than diameter of the eye $\ldots \ldots \ldots \ldots \ldots \ldots \ldots \ldots \ldots \ldots \ldots \ldots \ldots$. longicephala Hebert, 1977

Distance from antennular mound to rostrum less than or barely equal to the

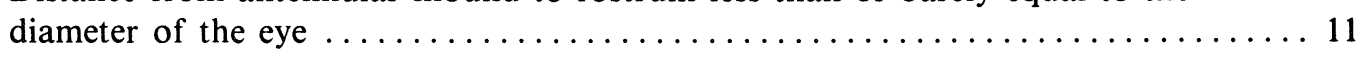

11(10). Postabdominal margin with a distinct bay ........... D. thomsoni Sars, 1894

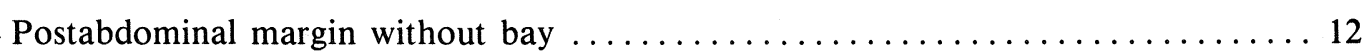

12(11). Head small and incurved strongly below eye; eye nearly touching anterior

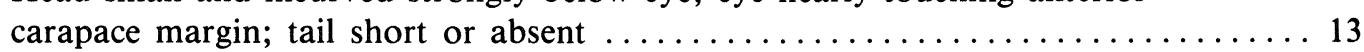

Head larger and not incurved below eye; eye well away from anterior carapace margin; tail usually at least one-half the carapace length $\ldots \ldots \ldots \ldots \ldots 14$

13(12). Eye very large, in diameter nearly one-half the width of the head; ocellus absent ................................. jollyi Petkovski, 1973

Eye smaller, in diameter about one-third the width of the head; ocellus prominent $\ldots \ldots \ldots \ldots \ldots \ldots \ldots \ldots \ldots \ldots \ldots \ldots \ldots \ldots \ldots \ldots \ldots \ldots \ldots \ldots$ nivalis Hebert, 1978

$\dagger 14(12)$. Head shape semicircular with the frontal margin smoothly rounded ......... 15

Head shape angular, frontal margin distinctly flattened, often with a bump on the carapace anterior to the eye .............. D. angulata Hebert, 1977

15(14). Rostrum not touching ventral carapace margin ......... D. magniceps Sars, 1896

Rostrum either touching or in very close proximity to the ventral carapace margin ............... D. carinata King, 1853, D. wankeltae Hebert, 1977

\footnotetext{
* Use individuals $1.5-2.5 \mathrm{~mm}$ in length.

$\dagger$ Use individuals $2.7-3.3 \mathrm{~mm}$ in length. In very dense populations there may be no adults as large as this, but small parthenogenetic females of the four species $(D$. angulata, $D$. magniceps, $D$. wankeltae and $D$. carinata) are very difficult to separate. Males and sexual females are, however, much more useful in recognizing the species (see Hebert, 1977 for details).
}

\section{Daphnia lumholtzi Sars, 1885}

Fig. 108

Daphnia lumholtzi Sars, 1885: 18-25, figs 1-10.

Material. Qld: 3, 12, 17. N.S.W: 117, 187, L. Cargelligo, Centennial Pk, Sydney. Vic.: 228, 232, 234, 249. S.A.: 384. Australian Museum reference series, registration numbers AM P24803 and AM P24804.
Female. Head usually with a narrow, anteriorly projecting crest, but in dense populations this may be absent. Antennular mounds very well developed and situated close to rostrum. Tail varies from one-half to slightly more than carapace length.

Length. Carapace length to $1.3 \mathrm{~mm}$.

Male. Head usually unhelmeted, but a small spikeshaped crest occasionally present. Dorsal postabdominal 


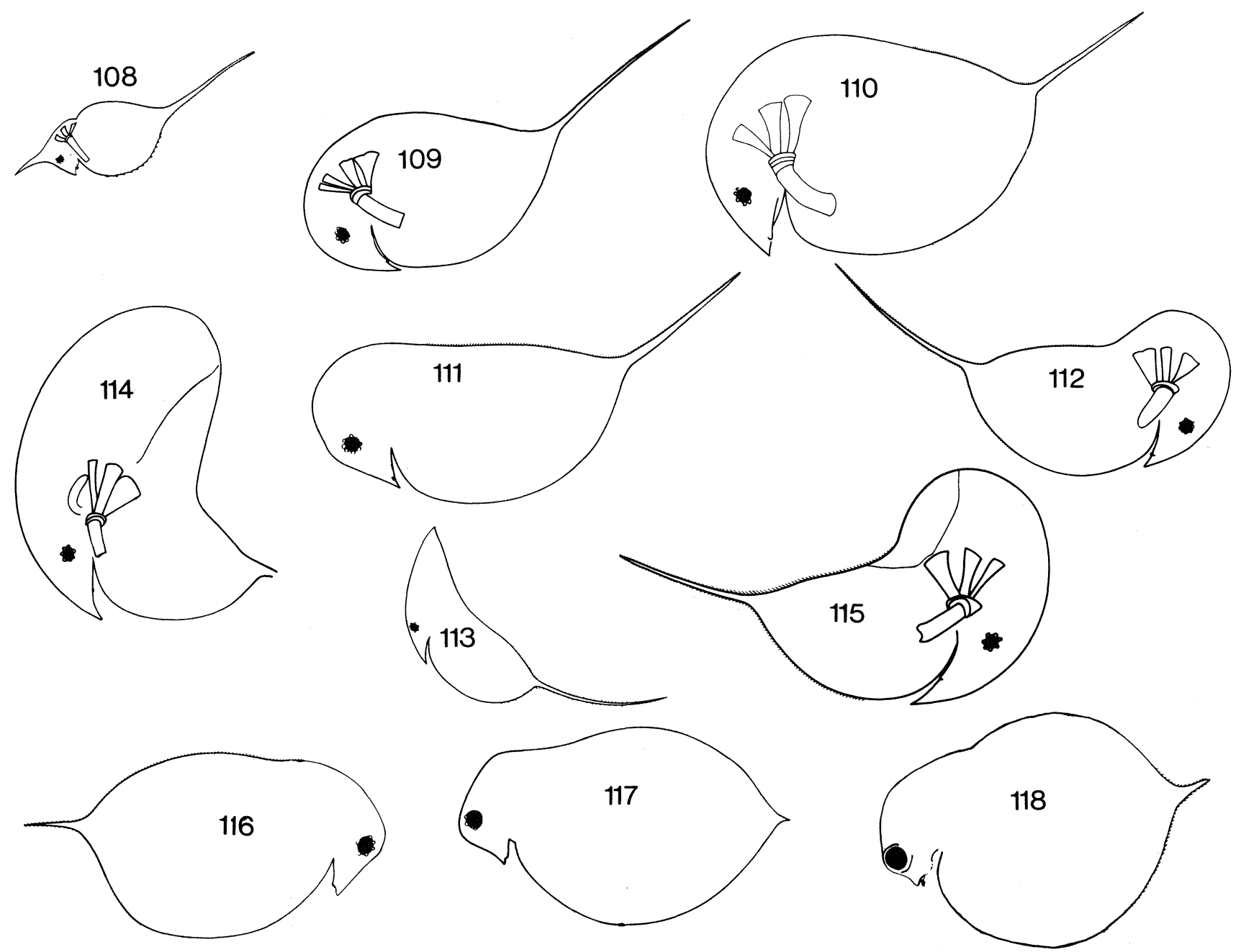

Figs 108-118. Daphnia spp., all $९ \wp$ and lengths given from cephalic crest or spine to base of tail spine. 108, D. lumholtzi, $1.8 \mathrm{~mm} ; 109$, D. carinata, $5 \mathrm{~mm} ; 110$, D. magniceps, $5 \mathrm{~mm} ; 111$, D. angulata, $6 \mathrm{~mm} ; 112$, D. wankeltae, $3 \mathrm{~mm} ; 113, D$. projecta, $4 \mathrm{~mm} ; 114$, $D$. cephalata, $7 \mathrm{~mm} ; 115$, D. longicephala, $4.5 \mathrm{~mm} ; 116, D$. thomsoni, $4.5 \mathrm{~mm}$; 117, D. nivalis, $2.5 \mathrm{~mm} ; 118, D$. jollyi, $3.5 \mathrm{~mm}$.

margin strongly sinuate. Tail about two-thirds of carapace length.

Length of male. Carapace length to $1.0 \mathrm{~mm}$.

Type locality. Gracemere Lag. (11 km west of Rockhampton, Qld).

Distribution. Common in lakes near sea level in both coastal and inland areas of Qld, N.S.W., Vic., and S.A. This species has also been recorded in Africa and Asia.

Differential diagnosis. Adults of this species are much smaller than those of any other Australian species except $D$. projecta. The latter has a different crest shape, and lacks the strong spines along the ventral carapace margin that are present in $D$. lumholtzi.

\section{Daphnia carinata King, 1853}

Fig. 109

Daphnia carinata King, 1853a: 246-247, pl. I, fig. A.-Hebert, 1977: 375-378, figs 15-22 (emended description).
Material. From numerous ponds in the vicinity of Campbelltown, N.S.W. and Whittlesea, Vic. Also from lakes including L. Cargelligo, N.S.W., and Jindabyne Reservoir, N.S.W. Australian Museum reference series, registration numbers AM P24777 and AM P24778.

Female. Helmet, when present, small so that dorsal carapace-head margin smoothly rounded. Antennular mounds very small and set close to tip of rostrum. Tail varies from one-half to more than length of carapace.

Length. Carapace length to $4.5 \mathrm{~mm}$.

Male. Head without a helmet. Dorsal postabdominal margin straight. Tail about one-half length of carapace.

Length of male. Carapace length to $1.2 \mathrm{~mm}$.

Ecology. This species is most frequent in ponds, but also occurs in lakes. It seems to prefer low water temperatures as populations around Sydney, N.S.W., die out during the summer months.

Type locality. Near Sydney, N.S.W. 
Distribution. This species is probably the most widely distributed Daphnia species in Australia, but many literature records undoubtedly pertain to other species of the $D$. carinata complex. However, valid records exist for both inland and coastal areas of N.S.W. and Vic.

Differential diagnosis. Small adult females in very dense populations of this species cannot be distinguished from $D$. angulata or from unhelmeted individuals of $D$. magniceps and $D$. wankeltae. Males of $D$. carinata differ from those of $D$. magniceps and $D$. angulata in having a straight postabdominal margin.

\section{Daphnia magniceps Sars, 1896}

Fig. 110

Daphnia carinata var. magniceps Sars, 1896: 9-10, pl. I, fig. 4. Daphnia carinata.-Hebert, 1977: 378-80, figs 23-32 (emended description).

Material. Ponds in the vicinity of Camden (N.S.W.), Appin (N.S.W.) and Whittlesea (Vic.). Australian Museum reference series, registration numbers AM P24479-AM P24781.

Female. Helmet usually present, and if so, small adults with a sinuate dorsal carapace-head margin. Antennular mounds small and set close to rostrum tip. Tail about half carapace length.

Length. Carapace length to $5.5 \mathrm{~mm}$.

Male. Head without a helmet. Dorsal margin of postabdomen distinctly sinuate. Tail about half carapace length.

Length of male. Carapace length to $1.2 \mathrm{~mm}$.

Ecology. This species is most frequent in pond habitats and seems to prefer low water temperatures as populations around Sydney, N.S.W., normally die out during the summer months.

Type locality. Sydney, N.S.W.

Distribution. Definitely known from the coastal strip of N.S.W. and Vic., but is probably more widely distributed.

Differential diagnosis. Crested individuals of $D$. magniceps are only likely to be confused with crested $D$. wankeltae. However, the tip of the rostrum in $D$. wankeltae is normally in contact with the ventral carapace margin, while in $D$. magniceps the tip is well away from the carapace. Individuals of $D$. magniceps which lack a crest are often impossible to distinguish from uncrested females of $D$. angulata, D. carinata and D. wankeltae.

\section{Daphnia angulata Hebert, 1977}

Fig. 111

Daphnia angulata Hebert, 1977: 380-382, figs 33-40.

Material. Type material in the Australian Museum, registration numbers AM P24795-AM P24798.
Female. Head lacks a helmet, but distinctly angular, large (length $>2.5 \mathrm{~mm}$ ) individuals with a bulge anterior to eye. Antennular mounds small and set close to rostrum tip. Tail from half to slightly more than carapace length.

Length. Carapace length to $4 \mathrm{~mm}$.

Male. Head lacks a helmet, and rectangular in shape. Dorsal postabdominal margin sinuate. Tail from one-third to two-thirds of carapace length.

Length of male. Carapace length to $1.3 \mathrm{~mm}$.

Ecology. This species is known only from L. Omeo, a large but ephemeral lake situated at an altitude of about $700 \mathrm{~m}$.

Type locality. L. Omeo, Vic.

Differential diagnosis. Large females of $D$. angulata can be recognized by their characteristic head shape. Small females cannot be distinguished from unhelmeted individuals of $D$. carinata, D. magniceps and $D$. wankeltae.

\section{Daphnia wankeltae Hebert, 1977}

Fig. 112

Daphnia wankeltae Hebert, 1977: 382-384, figs 41-45.

Material. Females from several farm dams near Whittlesea, Vic. Type material in the Australian Museum, registration numbers AM P24801-AM P24802.

Female. Dorsal helmet often present; restricted to cephalic area in young adults, but extending to middle of brood pouch in very large individuals. Antennular mounds small and set further from rostrum tip than in D. carinata. Tail usually about two-thirds of carapace length.

Length. Carapace length to $4 \mathrm{~mm}$.

Male. Not known.

Ecology. Collected only in farm dams.

Type locality. Whittlesea, Vic.

Distribution. Known only from the general vicinity of the type locality.

Differential diagnosis. Helmeted individuals are only likely to be confused with $D$. magniceps (see differential diagnosis for this species), but uncrested individuals are often impossible to distinguish from unhelmeted $D$. carinata, D. magniceps and D. angulata.

\section{Daphnia projecta Hebert, 1977}

Fig. 113

Daphnia projecta Hebert, 1977: 384-385, figs 46-50.

Material. Type specimens in the Australian Museum, registration numbers AM P24799-AM P24800.

Female. Prominent anteriorly projecting helmet present. Antennular mounds small and situated well away from tip of rostrum. Tail about same length as carapace. 
Length. Carapace length to $1.5 \mathrm{~mm}$.

Male. Not known.

Ecology. This species has been found only in claypan habitats.

Type locality. Tonga Station, western N.S.W.

Distribution. Known only from the general vicinity of the type locality.

Differential diagnosis. This species is morphologically rather similar to juvenile $D$. cephalata. However, in this species reproductive females have a carapace length of at least $1.9 \mathrm{~mm}$, while females of $D$. projecta begin to reproduce when only $0.9 \mathrm{~mm}$ long.

\section{Daphnia cephalata King, 1853}

Fig. 114

Daphnia carinata var. cephalata King, 1853b: 254 , pl. 6, fig. B.-Hebert; 1977: 385-388, figs 51-62 (emended description).

Material. Ponds in the vicinity of Whittlesea (Vic.), Camden (N.S.W.), Coffs Harbour (N.S.W.) and Hay (N.S.W.). Reference series in the Australian Museum registration numbers AM P24782-AM P24784.

Female. Prominent dorsal helmet invariably present; projecting dorso-anteriorly in juvenile individuals, but extending posteriorly in older individuals. Antennular mounds very small and situated well away from tip of rostrum. Tail varies from twothirds to greater than length of carapace.

Length. Carapace length to $6 \mathrm{~mm}$.

Male. Head with prominent dorsal crest. Dorsal margin of postabdomen straight. Tail about half carapace length.

Length of male. Carapace length to $1 \mathrm{~mm}$.

Ecology. This species is restricted to small ponds and dams and is the only Australian species which occurs in weed-filled ponds. It is apparently absent from claypan habitats.

Type locality. Campbelltown, N.S.W.

Distribution. This species is widely distributed in the lowland areas of N.S.W. and Vic. It apparently also occurs in the Oriental region (Heberer, 1923; Daday, 1911).

Differential diagnosis. This species is only likely to be confused with $D$. longicephala. However, in adults of $D$. longicephala the helmet tends to have a distant anterior bulge, while in $D$. cephalata the helmet is dorsal. Spinescence is also well developed along the dorsal carapace margin in $D$. longicephala, but weakly developed in $D$. cephalata.

Daphnia longicephala Hebert, 1977 Fig. 115

Daphnia longicephala Hebert, 1977: 388-391, figs 63-75.

Material. Collections from numerous mud pans in the vicinity of Hay (N.S.W.) and Tilpa (N.S.W.), and from dams and reservoirs on the Dividing Range in N.S.W. including Jindabyne Res. Type material in the Australian Museum, registration numbers AM P24791-24794.

Female. Prominent helmet normally present, but often absent in dense populations. Antennular mounds small and distant from tip of rostrum. Tail varies from one-half to greater than carapace length.

Length. Carapace length to $5 \mathrm{~mm}$.

Male. Head without a helmet. Dorsal margin of postabdomen straight. Tail usually less than a carapace length.

Length of male. Carapace length to $1 \mathrm{~mm}$.

Ecology. This species seems most prevalent in mud pan habitats, but it also occurs in cool water lakes and ponds on the Dividing Range.

Type locality. Fowlers Gap Research Station, western N.S.W.

Distribution. Inland areas from Qld to Vic.; also on the Dividing Range in N.S.W., but apparently not on the coastal strip.

Differential diagnosis. Crested individuals of $D$. longicephala are most similar to $D$. cephalata, but the two species can be distinguished by their differences in head shape and spinescence (see differential diagnosis for $D$. cephalata). Unhelmeted individuals of $D$. longicephala can be easily recognized for the antennular mounds are distant from the tip of the rostrum, but in close proximity to the tip in other unhelmeted species.

\section{Daphnia thomsoni Sars, 1894}

Fig. 116

Daphnia thomsoni Sars, 1894: 5-10, pl. I, figs 18.

Material. Collections from Jindabyne Reservoir (N.S.W.) and numerous ponds on the Monaro Tableland (N.S.W.). Australian Museum reference series, registration numbers AM P24785-AM P24786.

Female. Head without a helmet and weakly indented below eye. Antennular mounds conspicuous and set close to tip of rostrum. Tail often much less than half carapace length.

Length. Carapace length to $3.5 \mathrm{~mm}$.

Male. Head without a helmet. Dorsal postabdominal margin strongly sinuate. Tail short, about onequarter of carapace length.

Length of male. Carapace length up to $1.5 \mathrm{~mm}$.

Ecology. This species apparently prefers cool water conditions as in eastern Australia it is restricted to habitats on the Dividing Range.

Type locality. South Canterbury, New Zealand.

Distribution. In eastern Australia this species is apparently restricted to low montane habitats, but in W.A. populations occur at sea level (Serventy, 1929). This species also occurs in New Zealand (Sars, 1894) and South Africa (Sars, 1895).

Differential diagnosis. The dorsal postabdominal margin of female $D$. thomsoni has a noticeable 
indentation, while the postabdominal margin is straight in all other uncrested Australian species.

\section{Daphnia nivalis Hebert, 1978}

Fig. 117

Daphnia alpina Hebert, 1977: 391-393, figs 76-83.

Daphnia nivalis Hebert, 1978:390.

Material. Collections from several ponds and lakes in the Kosciusko National Park including Lakes Cootapatamba and Albina. Type material in the Australian Museum, registration numbers AM P24795-AM P24798.

Female. Head without a helmet and strongly indented below eye. Antennular mounds large and set close to tip of rostrum. Tail spine very short or absent.

Length. Carapace length to $3 \mathrm{~mm}$.

Male. Head without a helmet. Dorsal margin of postabdomen sinuate. Tail is very short or absent.

Length of male. Carapace length up to $1.5 \mathrm{~mm}$.

Ecology. This species is common in most of the lakes and ponds without fish in alpine habitats on the Kosciusko Uplands.

Type locality. Lake Cootapatamba, N.S.W.

Distribution. Known only from the alpine area of the Kosciusko National Park.

Differential diagnosis. $D$. nivalis is most similar to $D$. jollyi in general body shape, but $D$. nivalis has a large ocellus, whereas $D$. jollyi lacks one.

\section{Daphnia jollyi Petkovski, 1973}

Fig. 118

Daphnia jollyi Petkovski, 1973a: 134-138, figs 1-16.

Material. Literature.

Female. Head without a helmet and strongly indented below eye. Antennular mounds large and set close to tip of rostrum. Tail spine very short, less than one-quarter of carapace length.

Length. Carapace length to $2.6 \mathrm{~mm}$.

Male. Not known.

Type locality. Granite Pool (East Merridin), W.A.

Distribution. Known only from the type locality.

Differential diagnosis. This species is only likely to be confused with $D$. nivalis (see differential diagnosis for $D$. nivalis).

\section{Genus Simocephalus Schoedler, 1858}

(Section written by H. Dumont)

Simocephalus Schoedler, 1858: 17.

The type species is Simocephalus vetulus (O.F. Müller, 1776).

Body slightly compressed. Head plate wide and pointed posteriorly. Three main connected headpores, transversely orientated, and usually two minute lateral headpores. Valves rounded posteriorly and at times with a caudal outgrowth, but no posterior spine. Inner rim of ventral edge of valves with spines and setae over its whole length. Head relatively small and with a well defined but typically small rostrum. Eye large and an ocellus also invariably present. Antennule short, cylindrical in its apical two-thirds and widened at level of implant of lateral aesthete. Antenna daphnoid. Trunk limbs also of a generalized daphnoid type. Postabdomen strongly developed, wide and compressed. End claws long, slightly curved and typically bearing four pectens. Dorsal rim of postabdomen with a row of anal teeth, progressively decreasing in size, each one bearing two rows of denticles. Anal opening situated in a rather deep bay. Ephippium with one egg.

Males of similar habitus to females, but smaller and valves more quadrangular in shape. Antennules as in females but bearing two appendages (an aesthete and a bristle). Claspers on first pair of trunk limbs reduced. Vasa deferentia not opening ventral to anus. Postabdominal end claws and teeth similar to those of female.

Norman (1903) suggested that the name Simocephalus as used in the Cladocera constitutes an invalid homonym and should be used for a genus of snakes. Simosa was proposed in replacement. However, Poche (1903) pointed out that the reverse is true. Details are given in Dumont (1977).

\section{Key to Australian Species of Simocephalus}

1. Postabdominal claw with an outward basal pecten of enlarged spines

(Plate $1,1-2-4) \ldots \ldots \ldots \ldots \ldots \ldots \ldots \ldots 2$

Spines on outward basal pecten of postabdominal claw not enlarged (at moderate magnifcation no pecten visible) ... 3

2(1). Frons pointed $\ldots \ldots \ldots \ldots \ldots \ldots \ldots$

- Frons rounded .................. ..... S. exspinosus australiensis (Dana, 1852)

3(1). Rostrum developed into a prominent 'nose' (Fig. 121); head pores on a tubercle (Plate 2); ocellus rhomboidal ............. ............ S. latirostris Stingelin, 1906

- Rostrum short; head pores not on a tubercle, difficult to see; ocellus elongate ........................... 4

4(3). Posterior rim of valves with a more or less symmetrical rounded protuberance ...... ......... S. vetulus elisabethae (King, 1853)

- Upper posterior part of valves asymmetrically produced (outgrowth of

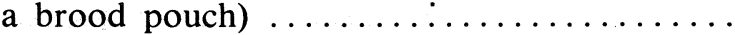
........... vetulus gibbosus (Sars, 1896)

5(2). Posterior rim of valves with a protuberance .. S. acutirostratus (King, 1853)

- Posterior rim of valves evenly rounded ...........S. victoriensis $\mathrm{n}$. $\mathrm{sp}$. 
Simocephalus vetulus (O.F. Müller, 1776)

Figs 119,120

Daphne vetula O.F. Müller, 1776: XXVII, 199, 275.

Comments. Acceptance of Müller's name is largely a matter of convenience, as it was poorly characterized. For instance on page XXVII, he writes: "Bivalvia, Antennae ramosae, ped. 8-12, oculus I" and on page 199 "Daphne vetula. Antennis dichotomis. Cauda inflexa; testa mutica." As there are no figures, even the generic placement is of questionable validity. In fact, the original description introduced little more than a new name, i.e. vetula. His illustrated edition (Müller,. 1785: 91, 92, tab. XII, figs 11, 12 (Daphnia sima)) does not add much-claws are mentioned, but no details given. There is no differentiated basal pecten on the endclaws in fig. 12, which would seem to exclude confusion with the $S$. exspinosus complex, but since the figure is small and lacks details, one cannot be absolutely certain about this point. Baird (1850: 95-96, tab. X, figs 1, 1a [Daphnia]) does not mention a conspicuous pecten either, although the latter is one of the chief diagnostic characters. Lilljeborg (1900: 166-173, tab. XXIV, figs $8-18$, tab. XXV, figs 1-7) was the first to give a good description and definition of what is now generally agreed upon as Simocephalus vetulus.

Two components of the vetulus group are known for Australia.

Simocephalus vetulus elisabethae (King, 1853)

Figs 119, 120

Daphnia elisabethae King, 1853a: 247-249, pl. II.

Simocephalus elisabethae.-Sars, 1888: 22-25, pl. 2, figs 6, 7; Haase, 1903: 149-150, fig. 3; Henry, 1919: 465; 1922: 31 , pl. V, figs $2,2 \mathrm{~A}$.

Simocephalus dulvertonensis Smith, 1909: 81, pl. 15, figs 5-7, n. syn.

Material. Qld: 28, 32, 34. N.S.W.: 170. Tas.: 315, 326.

Comments. King's description and figures are a mixture of vetulus and exspinosus forms, e.g. p. 248: "the extremity (of the abdomen) terminates in two long

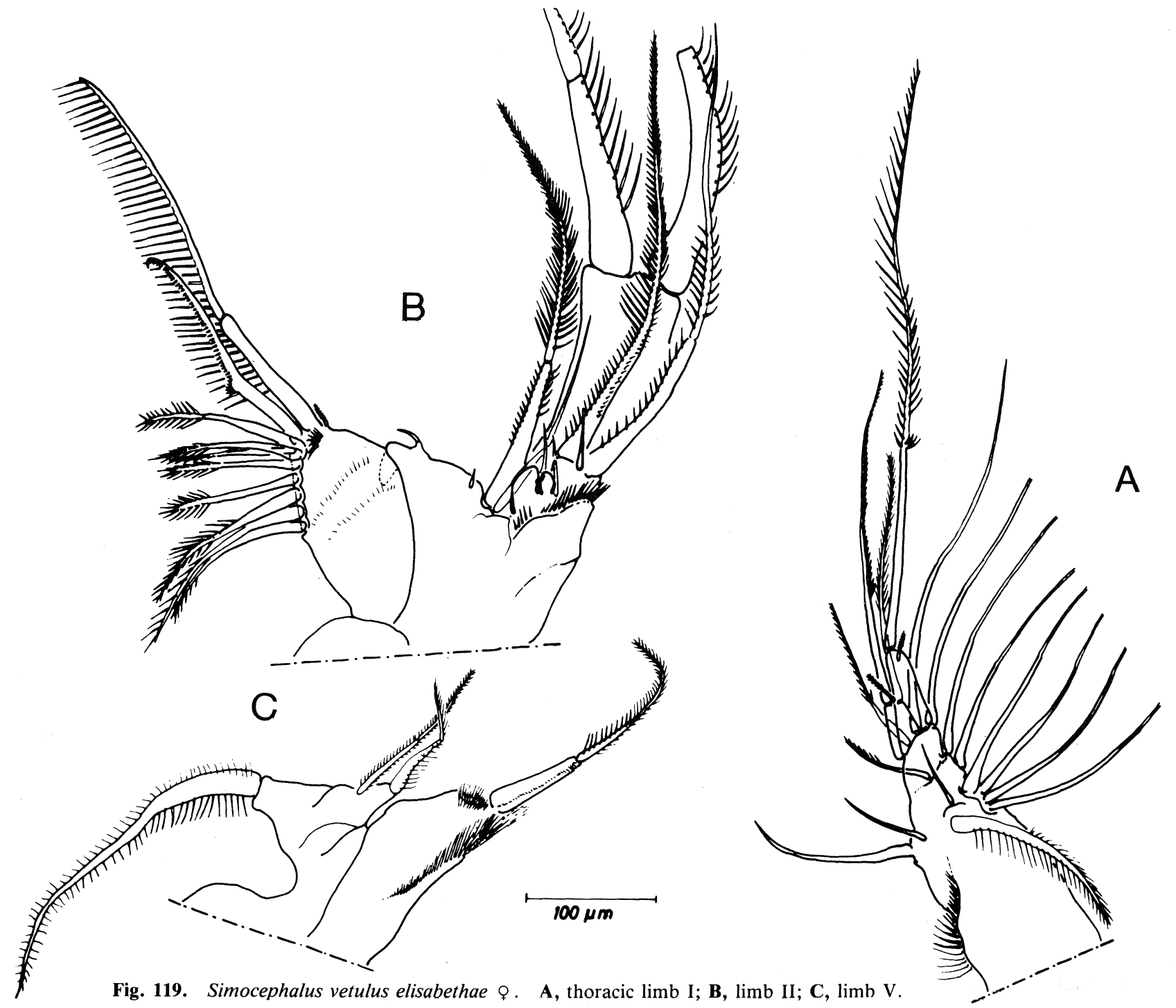




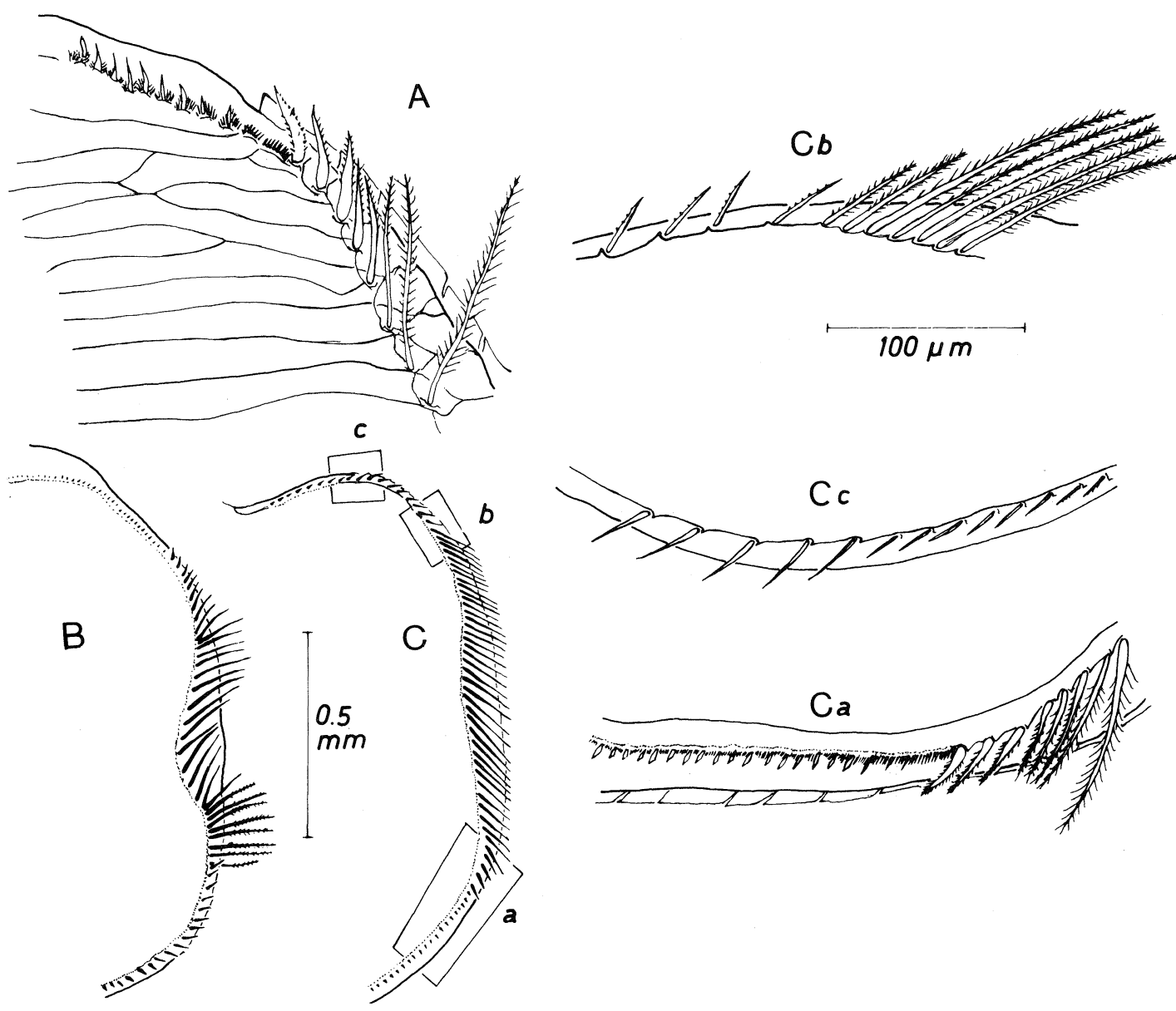

Fig. 120. Ventral edges of valves of various species of Simocephalus. A, Simocephalus vetulus gibbosus $\&$, ventral corner of hind border of valves; B, Simocephalus latirostris $\$$, ventrum of valves; C \&Ca-c, Simocephalus vetulus elisabethae $\$$, ventrum of valves and details of setation.

spines, which are sometimes deeply serrated, sometimes plain", p. 247: "the head is obtuse; beak short, a black spot close to the beak.' Plate II, fig. A shows an animal with a point-shaped ocellus, and a serra (pecten) on the postabdomen. Strictly speaking, one could argue that Daphnia elisabethae King is really is a member of the expinosus group, and has priority over Daphnia australiensis Dana, or alternatively consider it as a species incertae sedis because of the mixed material that served as type material. Since these alternatives cannot be resolved a commonsense solution should be adopted, and the judgment of Sars (1888): " although Mr King would seem to have confounded several distinct species under his name . . .', as well as his clear redescription of the taxon should be accepted.

This taxon was considered as a good species by many authors. Others, e.g. Harding (1960), synonymized it with $S . v$. vetulus, because it is structurally identical to the latter, except for the presence of a hump on the posterior side of the valves, a character which may be indistinct on rare occasions. It was classified as a distinct subspecies by Dumont and Van de Velde (1977), since in Nepal it occurred at lower altitudes, in a tropical and subtropical climatic zone, while in the higher parts of the Himalayas it was replaced by the nominal subspecies.

Simocephalus dulvertonensis Smith is a illcharacterized species, which even the describer himself qualified as "not offering any marked characters". Brehm (1931, 1942, 1953a) repeatedly considered this taxon, strongly suspecting it belonged to the vetulus group, but hesitating on evidence of the geniculate aspect of the spines on the postabdomen as drawn by Smith. However, this character may occur in vetulus populations from any area of the world and in a rather haphazard way, while, on the other hand, it was not present in a large series of specimens examined from Tasmania. These had the elongate ocellus of the vetulus group, the typical shape of trunk limbs I and II as shown in Fig. 119, and a symmetrical posterior hump on the valves. Hence there seems to be no reason to regard dulvertonensis as a taxon distinguishable from elisabethae.

Female. Anterior part (frons) of head rounded. rostrum small, not prominent. Ocellus elongated, somewhat sinuous. Head pores lie in a small depression of head shield (Pl. 2). Shallow embayment on inner rim of ventral sides of valves. Setation as for genus (Fig. 

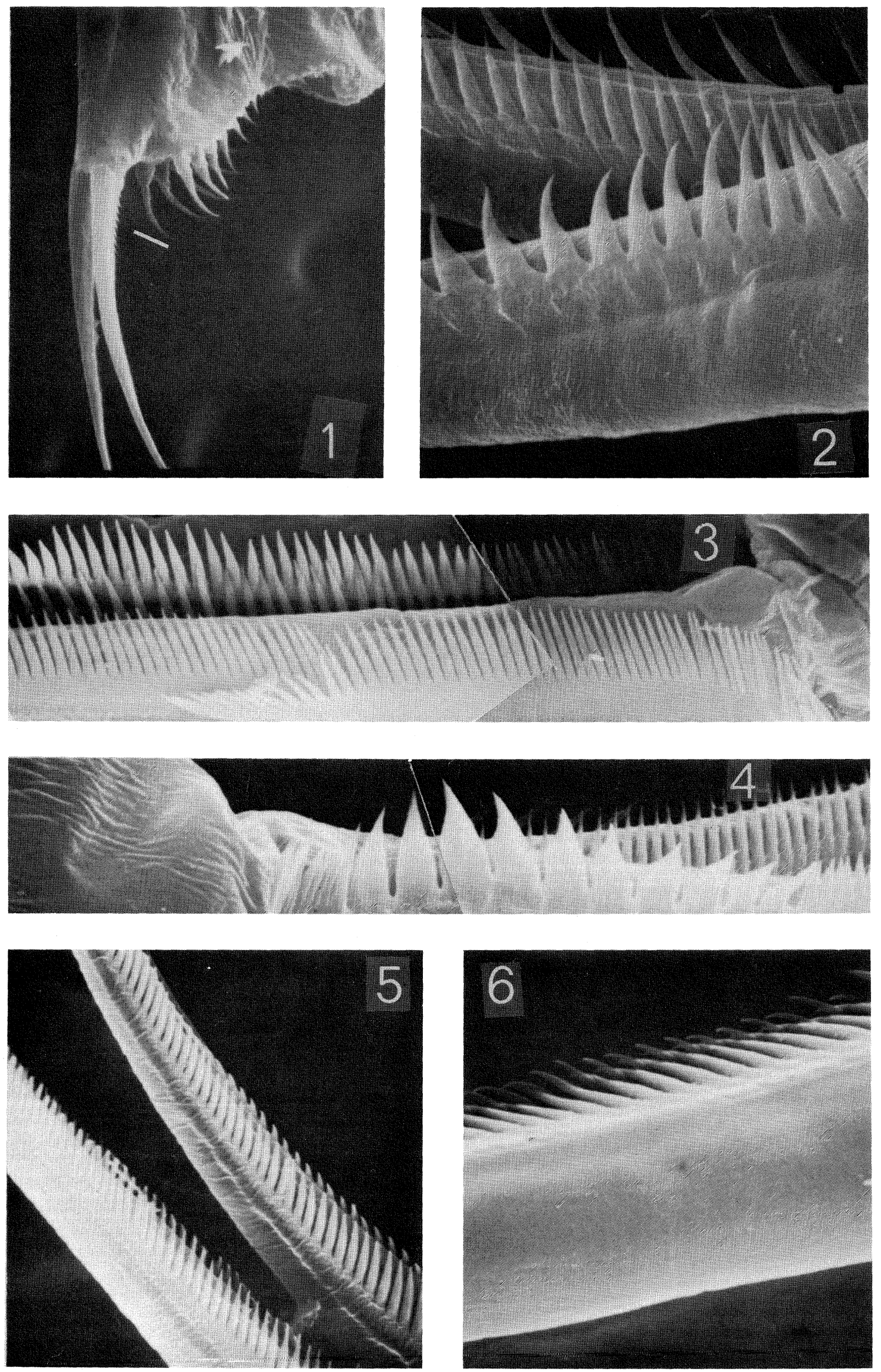

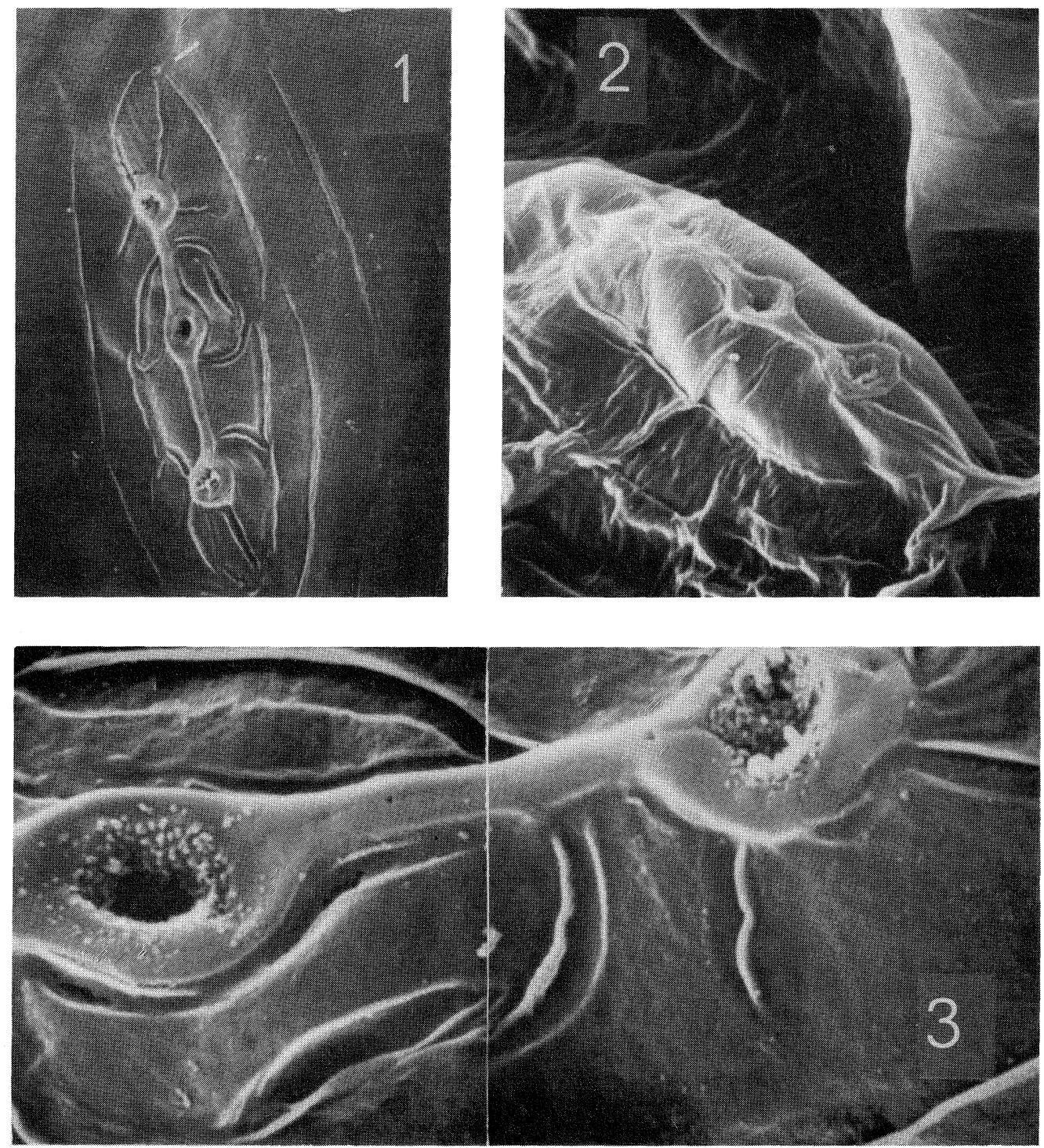

Plate 2. Head pores in Simocephalus.

1. S. acutirostratus $\$$ (Nordellos Lagoon, Qld), head pores (1420X). One of the two minute lateral headpores is indicated by an arrow. 2. S. latirostris $\&$ (L. Toomba, Qld), head pores situated on a tubercle (2500X). 3. The same, the two upper pores enlarged (7000X).

Plate 1 (facing). Postabdominal claws in Simocephalus.

1-2. S. acutirostratus $९$ (Nordellos Lagoon, Qld): 1. postabdomen, basal pecten on end claw indicated by arrow (290X). 2. pecten enlarged (1700X). 3. S. vetulus elisabethae $९$ (Teewarina Waterhole, Qld), base of postabdominal claw, outward view. The homologue of the enlarged basal pecten in S. acutirostratus and S. exspinosus australiensis is not different here from the adjacent pecten (2500X). 4. S. exspinosus australiensis $\odot$ (L. Crescent, Tas.), base of abdominal end claw, showing the basal pecten of big, strong teeth (2200X). 5. S. vetulus gibbosus $\$$ (Aramac Ck., Qld), central sector of postabdominal claws, showing the relative position of the inner and outer pectens (2500X). 6. S. latirostris $\&$ (L. Toomba, Qld), small zone of postabdominal claws, showing the marginal position of the pectens so that their teeth partly interlock (6500X). 


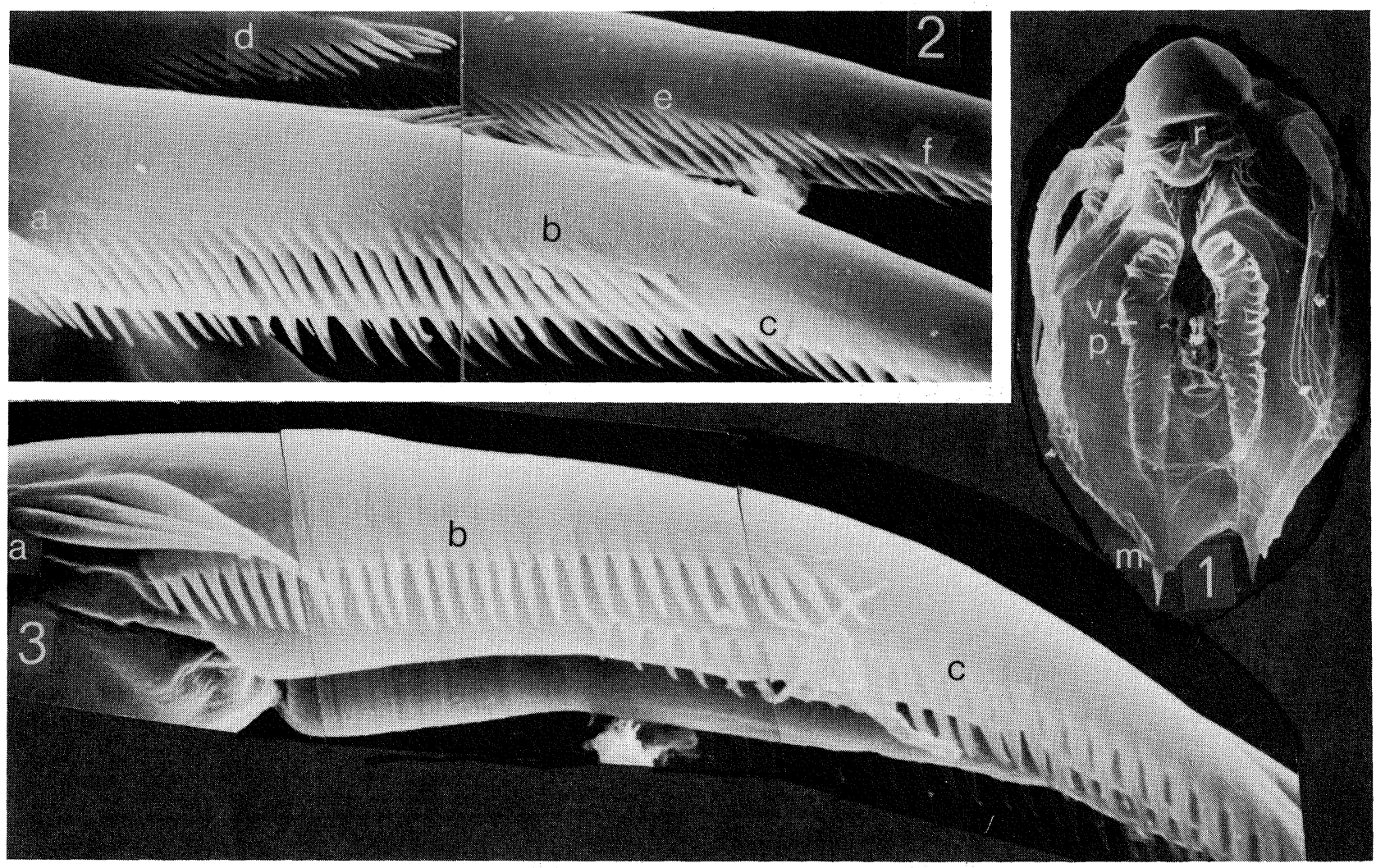

Plate 3. Scapholeberis kingi $\rho$, (Nordellos Lagoon, Qld). 1. Whole animal in ventral view (155X). $r=$ rostrum, $v p=$ ventral plate, $m=$ mucro. $2 \&$ 3. end claws. $a-f$, the 6 pectens (2: 4275X, 3: 4070X).

120). Posterior side of valves produced into a hump more or less symmetrical to body axis. Trunk limbs I, II and $\mathrm{V}$ as shown in Fig. 119. $\mathrm{P}_{2}$ with a strong hook between gnathobase and endite. End claws lack a differentiated basal pecten. Inner and outer pectens located well to side of claw.

Length. Up to $2 \mathrm{~mm}$.

Male. Unknown.

Type locality. Ponds near Sydney, Port Stephens, Karua R.

Distribution. Probably more widespread than in Qld, N.S.W. and Tas., where it certainly occurs. Henry (1922) also mentions S.A. and Vic.

Differential diagnosis. The ocellus is elongate, thus separating it from other known species of Simocephalus in Australia. The posterior rim of the valves has a symmetrical rounded protuberance in S.v. elisabethae whereas it is asymmetrically produced in $S . v$. gibbosus.

Simocephalus vetulus gibbosus (Sars, 1896) n. comb. Fig. 120, Plate 1

Simocephalus gibbosus Sars, 1896: 15, pl. 2, figs 4-6.Shepard et al., 1918: 83; Henry, 1922: 32, pl. V, figs 3, 3A; Serventy, 1929: 68.

Material. Qld: 51. N.S. W.: 78, 84, 85, 129, 130, 132, 133, 156, 164, 165, 166, 167, 168. Vic.: 204, 209, 210, 213, 214 ,
220, 222, 223, 238, 257. Tas.: 291, 292, 294, 295, 300, 307, $312,313,316,319,320,321,322,324,325,327,329,330$, 332, 333, 334, 337, 338. S.A.: 357, 365, 368, 372, 376, 379. W.A.: 410, 414. N.T.: 452.

Comments. Simocephalus gibbosus is undoubtedly a member of the vetulus-group. In fact one might question the value of the sole distinctive character (shape of the valves), and it may well be that gibbosus is the same animal as elisabethae in which the brood pouch is more strongly developed. However regional populations of elisabethae examined were typical in habitus on one hand, while gibbosus-like populations have not been found outside Australia. Therefore, it may well be that the latter corresponds to an endemic taxon with particular ecological requirements. Since gibbosus and elisabethae do not seem to co-occur, and in view of their close relationship, they should be considered subspecies rather than good species.

Female. Simocephalus vetulus gibbosus is very closely allied to the preceding taxon, with which it agrees in all characters except the shape of the valve (see Key).

Length. Up to $2 \mathrm{~mm}$.

Male. Unknown.

Type locality. Centennial Park, Sydney.

Distribution. Australia-wide, but most common in the south-east.

Differential diagnosis. See differential diagnosis for S.v. elisabethae. 

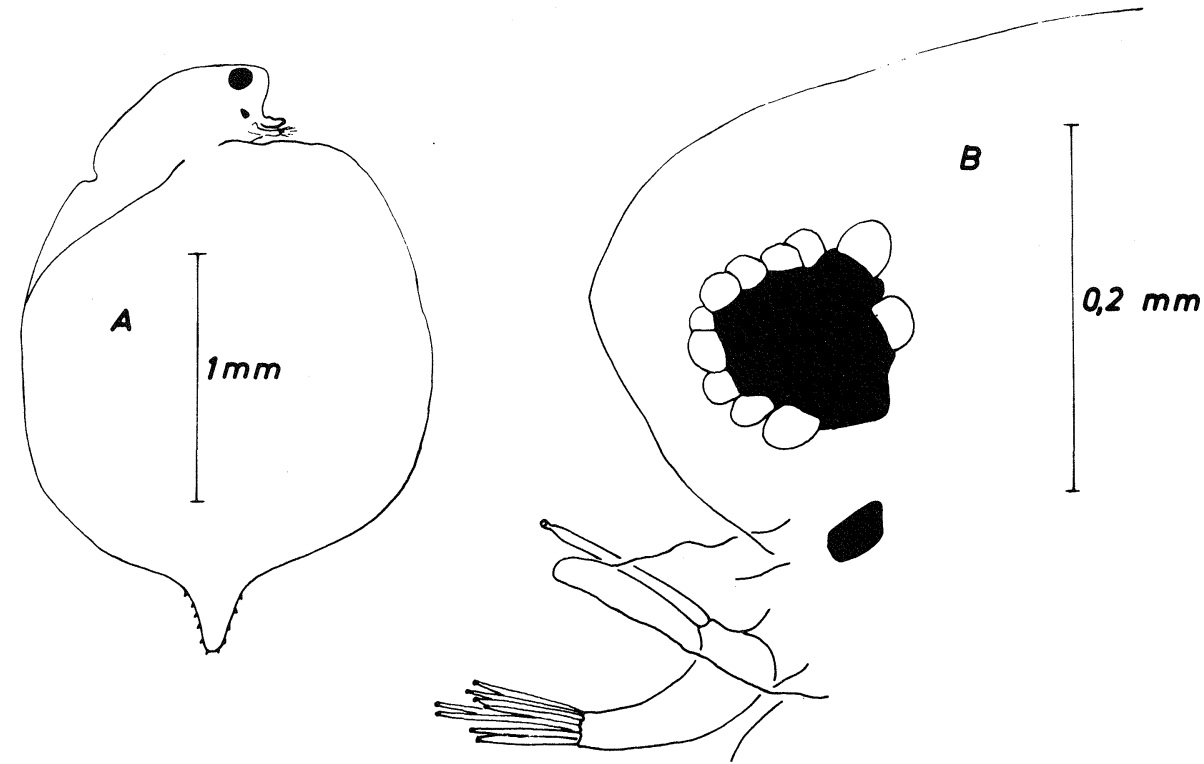

Fig. 121. Simocephalus latirostris $९$, River Niger, Mali. A, whole animal; B, head.

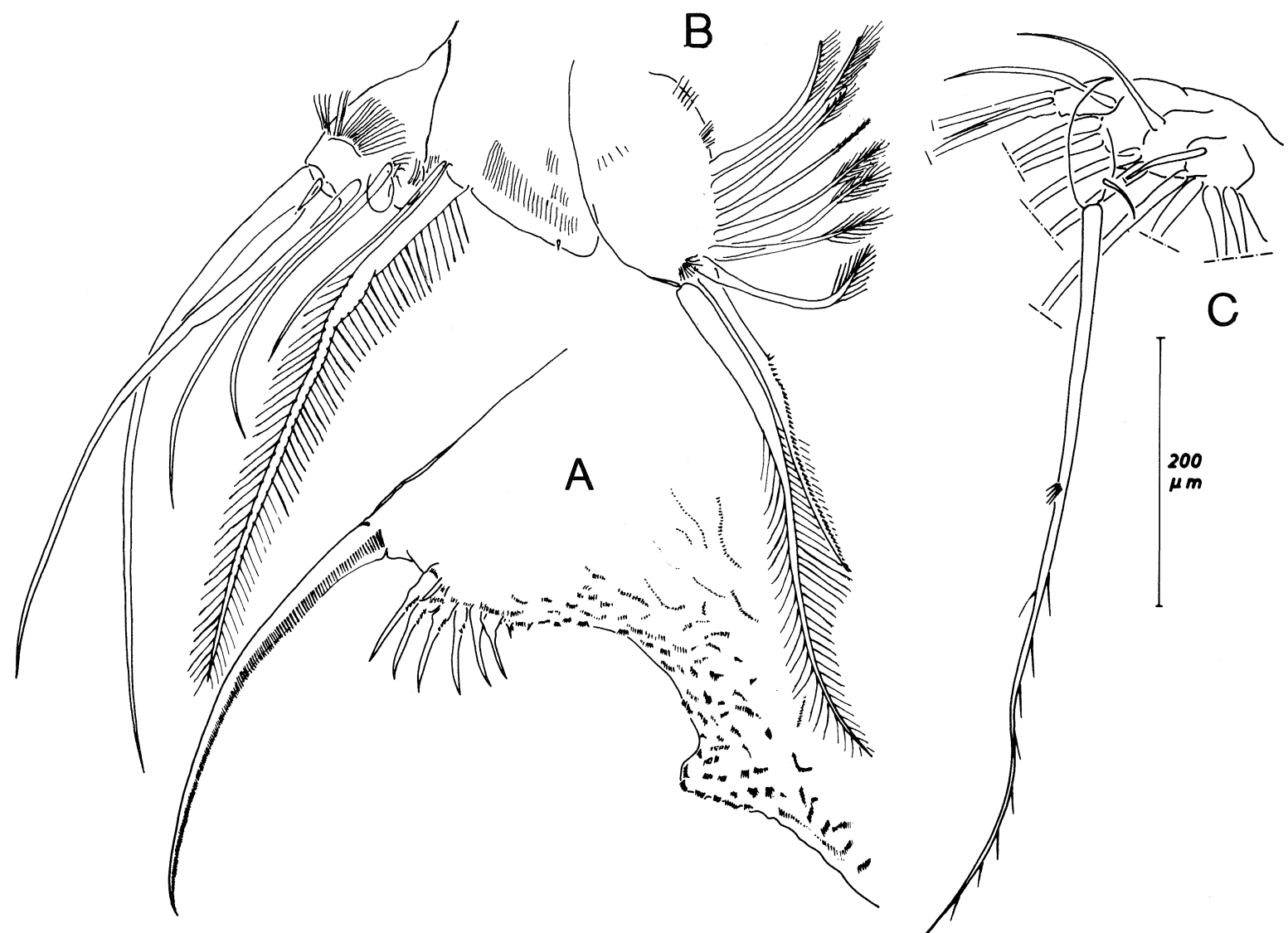

Fig. 122. Simocephalus latirostris $\&$, River Niger, Mali. A, postabdomen; B, thoracic limb II; C, limb I, whole animal.

Simocephalus latirostris Stingelin, 1906 Figs 120-122, Plate 2

? Simocephalus iheringi Richard, 1897: 97.-Henry, 1922: 32. Simocephalus latirostris Stingelin, 1906: 187, figs 5-7.
Material. Qld: 12, 23, 25, 33, 37.

Female. Anterior part of head rounded. Rostrum strongly developed, forming a prominent 'nose', as long as or slightly longer than antennule (Fig. 121). Ocellus 
rhomboidal and rather large. Head pores situated on a tubercle (Plate 2). Valves produced posteriorly into a rather sharp point. Inner side of ventral rim of valves with a deep median embayment (Figs 120, 121); its setation typical. $P_{1}$ and $P_{5}$ typical but $P_{2}$ with a very short spine (Fig. 121) between gnathobase and endite. Postabdominal claws without a differentiated basal pecten (Fig. 122). Spines of apical pectens marginally located (Plate 1), but not so laterally placed as in other species.

Length. $1.5-3.0 \mathrm{~mm}$.

Male. Unknown.

Distribution. North Qld.

Differential diagnosis. Simocephalus latirostris is the only Australian species with a strongly developed rostrum.

Simocephalus exspinosus australiensis (Dana, 1852) n. comb.

Plate 1

Daphnia australiensis Dana, 1852b: 1271-1272; 1855, pl. 89, fig. 4.

Simocephalus australiensis Sars, 1888: 15-25, pl. 2, figs 15.Sars, 1896: II; Smith, 1909: pl. 15, figs 8-9; Henry, 1919: 466; 1922: 31, pl. V, figs I, IA-IC; Serventy, 1929: 68; Brehm, 1953a: 67; 1953b: 9 .

Simocephalus exspinosus Flössner, 1972: 184.

Material. N.S.W.: 80, 128, 130, 166, 167. Vic.: 205, 232. Tas.: 296, 302, 303, 323, 336. W.A.: 405, 427.

Comments. Dana's description is insufficient so Sars's (1888) detailed redescription is widely used. However this proposed specific status is questionable, since $S$. australiensis is closely related to several forms of the exspinosus group. Of the latter, S. exspinosus (Koch) has a short differentiated pecten of 8-12 equally long spines (a comb), and $S$. congener Schoedler has a longer pecten (up to 30 spines) which decreases in size distally. In S. australiensis a characteristic short pecten (8-12 spines) is seen; the spines are thick at their base, triangular, and decreasing in size distally (Plate 1).

Female. Head rounded and rostrum short. Ocellus rhomboidal. Head pores not on a tubercle. Caudal side of valves tending to develop a slight hump, somewhat above longitudinal body axis. Only a slight embayment in inner side of ventral margin of valves; its setation typical. Trunk limbs typical of vetulus group.

Length. Up to $2.8 \mathrm{~mm}$.

Male. Structurally similar to female, but only half its size, and without a posterior hump. Caudal edge of valves almost quadrangular.

Type locality. Freshwater pools near Sydney, N.S.W.

Distribution. Widely distributed in all states (Sars [1888] provides a record for Qld and Henry [1922] one for S.A.-thus complementing our records).

Differential diagnosis. Like $S$. acutirostratus, this species has large spines on the nutward basal pecten of the postabdominal claw. However, it is distinguishable from the former by its round head (pointed in $S$. acutirostratus).

\section{Simocephalus acutirostratus (King, 1853)}

Fig. 124

Daphnia elisabethae var. acuti-rostrata King, 1853b: 254, pl. Vic.

Simocephalus paradoxus Schoedler, 1877: 17-18, fig. 8.

Simocephalus acutirostratus Sars, 1888: 67; 1896: 12-15, pl. 2, figs 1-3.- Hase, 1903: 150, fig. 4; Searle, 1917: fig. 6; Henry, 1919: 466; 1922: 31-32, pl. V. figs 4, 4A; Petkovski, 1973a: 138-140, figs $17,18$.

Material. Qld: 26, 63. N.S.W.: 93, 136, 139, 140, 143, 154, $156,159,160,167,170,177,185$. W.A.: 415.

Female. Anterior tip of head produced into a sharp point. Rostrum short and ocellus rhomboidal. Head pores not on a tubercle (Plate 2). Ventral margin of valves evenly curved; inner rim moderately embayed. Setation of valve rim and trunk limbs of the usual appearance. Postabdomen very broad with two rather deep embayments, and an anal corner forming a right angle. End claws of postabdomen with a basal pecten consisting of 12-18 strong, tooth-shaped spines (Plate 1 ). Valves with a strong posterior prominence situated above longitudinal body axis.

Length. Up to $4.2 \mathrm{~mm}$.

Male. Unknown.

Type locality. Ponds at Denham Court, N.S.W.

Distribution. Probably Australia-wide (but not yet reported from Tas., S.A., or N.T.). It is endemic to Australia, where it seems to take the place of $S$. serrulatus (Koch), which is cosmopolitan except for the Australian continent.

Differential diagnosis. This species can only be confused with $S$. victoriensis $\mathrm{n}$. sp., which is the second

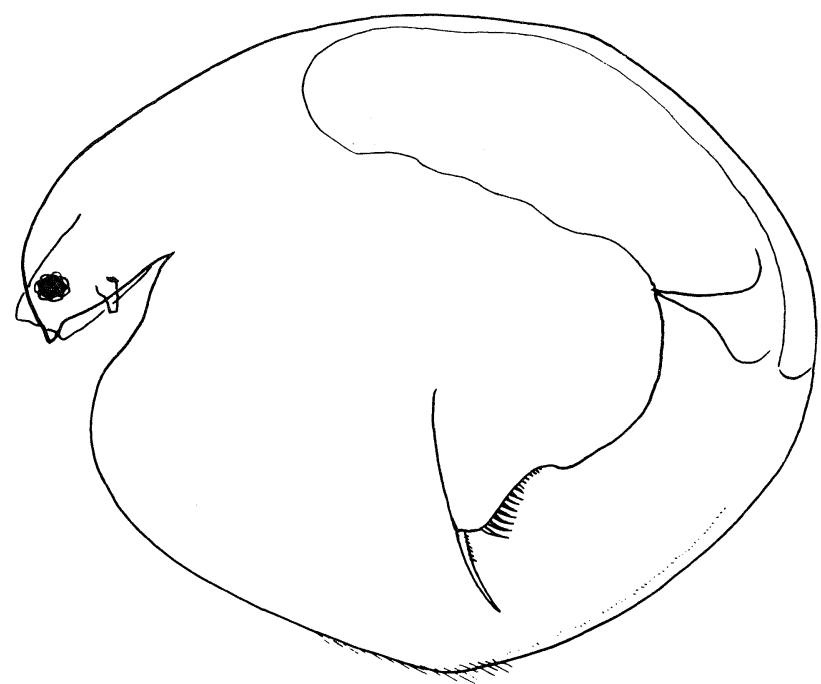

Fig. 123. Simocephalus victoriensis $\overbrace{\mp}$, waterhole near Kaniva, Vic., 23.vi.74. 


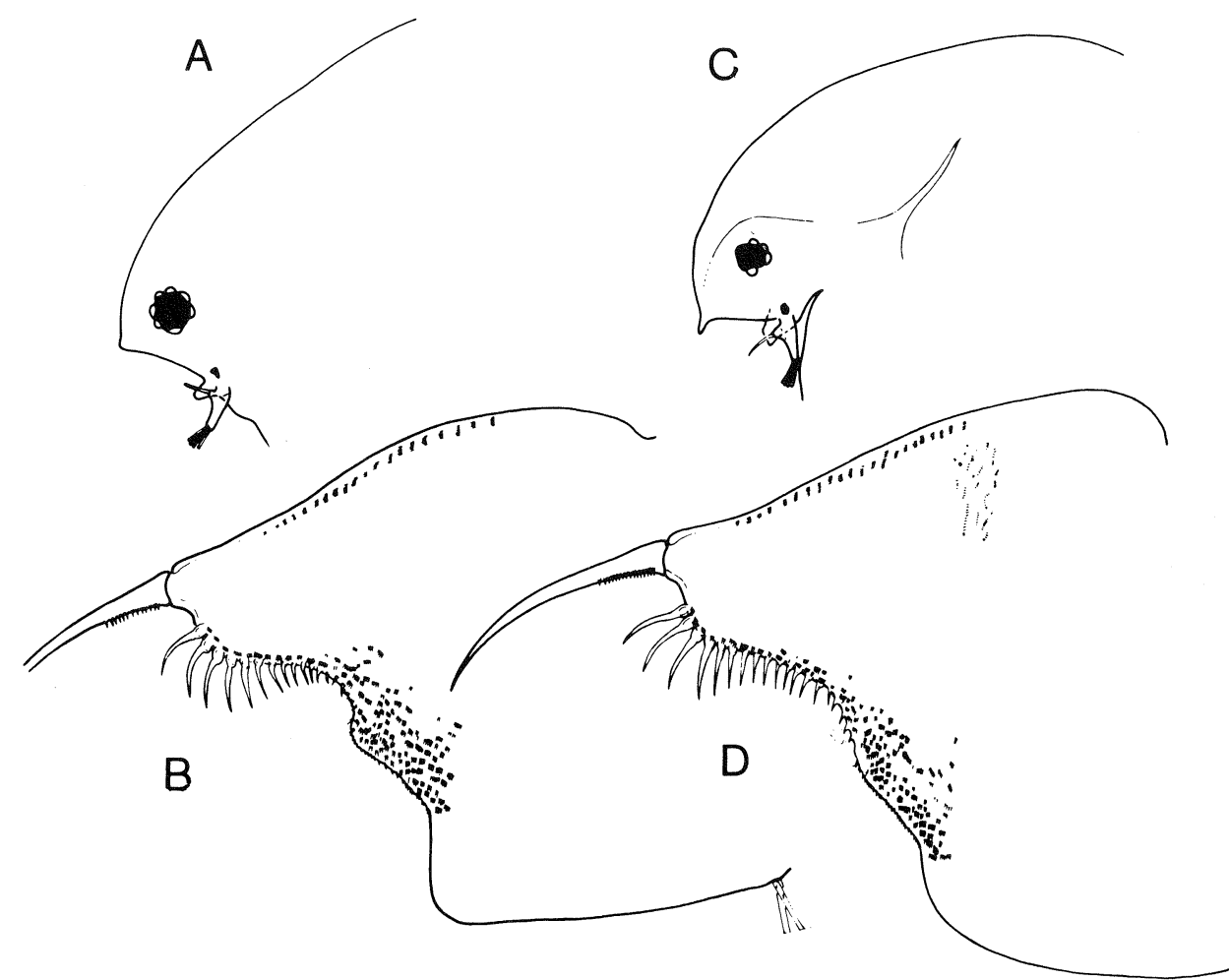

Fig. 124. Simocephalus acutirostratus $\subsetneq$ and $S$. victoriensis $\subsetneq$. A \& B , head and postabdomen respectively of $S$ acutirostratus; C \& D: head and postabdomen respectively of $S$. victoriensis.

Australian species with a pointed frons. It differs in details of the general habitus, head and postabdomen (see hereunder).

\section{Simocephalus victoriensis $\mathbf{n}$. sp.} Figs 123, 124

Material. Vic.: 240, 262.

Holotype. AM $\odot$ P 31316.

Paratypes. Numerous females from Vic. -240 and 262 lodged in the reference zooplankton collection of the State University of Gent, Belgium.

Female. Smaller than S. acutirostratus (maximum recorded size $3.1 \mathrm{~mm}$ ). Ratio length: height 1.2 . Head bent downwards, over rostrum and antennae. Rostrum produced into a finger-shaped expansion, standing nearly at right angles to longitudinal body-axis. Rostrum more strongly developed than in S. acutirostratus. Postabdominal claw with a pecten as in $S$. acutirostratus, and postabdomen broad as in that species, but the two embayments along its margin shallow, and anal corner smoothly rounded.

Male. Not known.

Type locality. A waterhole $25 \mathrm{~km}$ from Kaniva, Vic. also found in Loc. 262 (a temporary pond near Edenhope, Vic.) in which it co-occurred with typical $S$. acutirostratus. Intermediate forms were not observed.

\section{Genus Scapholeberis Schoedler, 1858}

(Section written by H. Dumont)

The type species is Daphnia mucronata O.F. Müller, 1785.

Body slightly compressed but with no keel. Head moderate in size with a large eye and a small ocellus. Rostrum well developed and differentiated. Valves rounded dorsally; hind rim straight and ventral rim differentiated into an adhesive plate. This plate widened into a sinuous triangle in front, gently narrowing posteriorly; numerous fine setae and adhesive leaflets on it. Caudal filaments usually longest and sometimes differentiated into feather-shaped fleeces. Ventroposterior corner of valves with a mucro of variable length. Antennule small and cylindrical; slightly longer in male than in female. Trunk limbs of daphnoid type; first pair in male with a clasper. Postabdomen compressed. End claws relatively short and with a maximum of six pectens, none of which very conspicuous. Two minute head pores may be present and tip of rostrum with elongate pore, except in S. aurita Fischer. Ephippium with one egg. Vasa efferentia open ventral to anus.

Scapholeberis kingi Sars, 1903

Plate 3

Daphnia mucronata O. F. Müller, 1785: 84, pl. 13.-King, 1853b: 255-256 pl. VIE 
Scapholeberis kingii Sars, 1888: 68, nomen nudum. Scapholeberis kingi Sars, 1903: 8, pl. 1, figs 2a-c.

Material. Qld: 2, 12, 14, 39. N.S.W.: 79, 81, 83, 97, 99, 130, 186. Vic.: 212, 232. S.A.: 370. W.A.: 421, 426.

Comments. Dumont (1971) claimed that the circumtropical $S$. kingi, which is the true kingi of King and Sars, and the European form reported under that name by Rammner $(1928,1929)$ might be two distinct species. Scanning Electron Microscope pictures have now shown this to be correct and that the European and Central Asiatic form needs a new name.

Female. Rostrum trilobate (Plate 3); middle lobe evenly rounded, with a narrow hyaline membrane in front, and about half as wide as the head. Head never with a dorsal spine. Antennules project from beyond lateral lobes. At least a rostral head pore present. Postabdomen with 4-6 spines. End claws with six pectens (Plate 3 ) but usually only the three external pectens visible. Head with broad, shallow canal along its side. In some specimens, dorsal ridge of this canal rather sharp, and may appear as a small auricle in front view, but this is not an infallible character.

Length. $0.6-1.0 \mathrm{~mm}$.

Male. Smaller than female,. Dorsoposterior corner of valves more squared than in female.

Type locality. South Ck and Parramatta, N.S.W.

Distribution. Australia-wide but not so common in the south.

\section{Genus Daphniopsis Sars, 1903}

Daphniopsis Sars, 1903: 171.-Serventy, 1929: 65.

Carapace with no dorsal keel or posterior spine. Head separated on dorsal side by a shallow depression; a cephalic fornix on each side and a rostrum. Antennule immovable and not reaching rostrum tip. Antenna with 9 setae and no spines. Postabdomen tapers towards base of claw and with small anal teeth. Ocellus and eye present.

Daphniopsis is closely related to Daphnia; indeed Wagler (1936) included Daphniopsis tibetana Sars, 1903 in Daphnia. Hebert (personal communication) is of the opinion that it should remain separate until more characters are ascertained. We follow this recommendation:

The type species is Daphniopsis tibetana Sars, 1903.

In Australia there is one species, Daphniopsis pusilla Serventy, 1929. D. studeri Rühe is found in East Antarctica (Akatova, 1964).

\section{Daphniopsis pusilla Serventy, 1929}

Fig. 125

Daphniopsis pusilla Serventy, 1929: 65-67, pl. IX.-Bayly and Edward 1969: 21-22.

Material. Vic.: 248. S.A.: 353, 360, 375, 381. W.A.: 402, 408 .
Slides. AM $\odot$ P27731; ephippial $\subsetneq$ or P27732; MGU $\subsetneq$

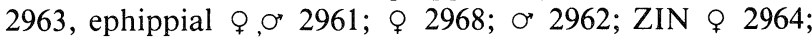
ephippial $\uparrow$, ơ 2958.

Female. Dorsal side of carapace brownish. Antennule not reaching rostrum tip, though its sensory papillae protrude beyond it. This situation is depicted in our figure (Fig. 125) and in Serventy's (1929, pl. IX) and in the latter case is probably the reason for the comment "antennule clearly projecting beyond the rostrum' (Serventy, 1929: p. 65). Antennal setae 0-0-1-3/1-1-3, and no spines. Antenna segments with transverse rows of denticles. Number of anal teeth on postabdomen varies. Hedley (1969) demonstrated a range of 10.6-16.5 (mean 14) for eastern Australian specimens, so that they are similar to western Australian specimens, which also have a mean of 14 anal teeth (Bayly and Edward, 1969).

Length. $1.9 \mathrm{~mm}$.

Male length. $1.23 \mathrm{~m}$.

Ecology. Daphniopsis pusilla inhabits shallow saline waters in the range 5-59\% (Bayly and Williams, 1973). The optimum salinity range is $18-27 \%$. Further details are given by Bayly $(1970,1976)$, Bayly and Edwards (1969) and Hedley (1969).

Type locality. A pond on Rottnest I., W.A.

Distribution. Western Vic. (Bayly and Edwards, 1969; Hedley, 1969 and present record), S.A. mainly in the south (Bayly, 1970, 1976 and present records) and south-western W.A. (Bayly and Edwards, 1969; Serventy, 1929 and present records).

\section{Genus Ceriodaphnia Dana, 1852}

Ceriodaphnia Dana, 1852b: 1273.

Head small and without a rostrum. Shell widely oval. Postabdomen moderately elongated with anal aperture at its distal end. Female size about $1 \mathrm{~mm}$.

The type species is Ceriodaphnia quadrangula (O.F. Müller, 1785).

\section{Key to Australian Species of Ceriodaphnia}

1. Head with an acute beak on ventral side ............ C. cornuta Sars, 1885

Head without a beak ............ 2

2(1). Central region of postabdomen the widest $\ldots \ldots \ldots \ldots \ldots \ldots \ldots \ldots$

Central region of postabdomen not the widest .................. 4

3(2). Frontal and lower margin of head

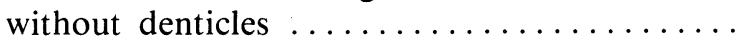
....... C. laticaudata P.E. Mueller, 1867 Frontal and lower margin of head with denticles ........... C. rolunda Sars, 1862 

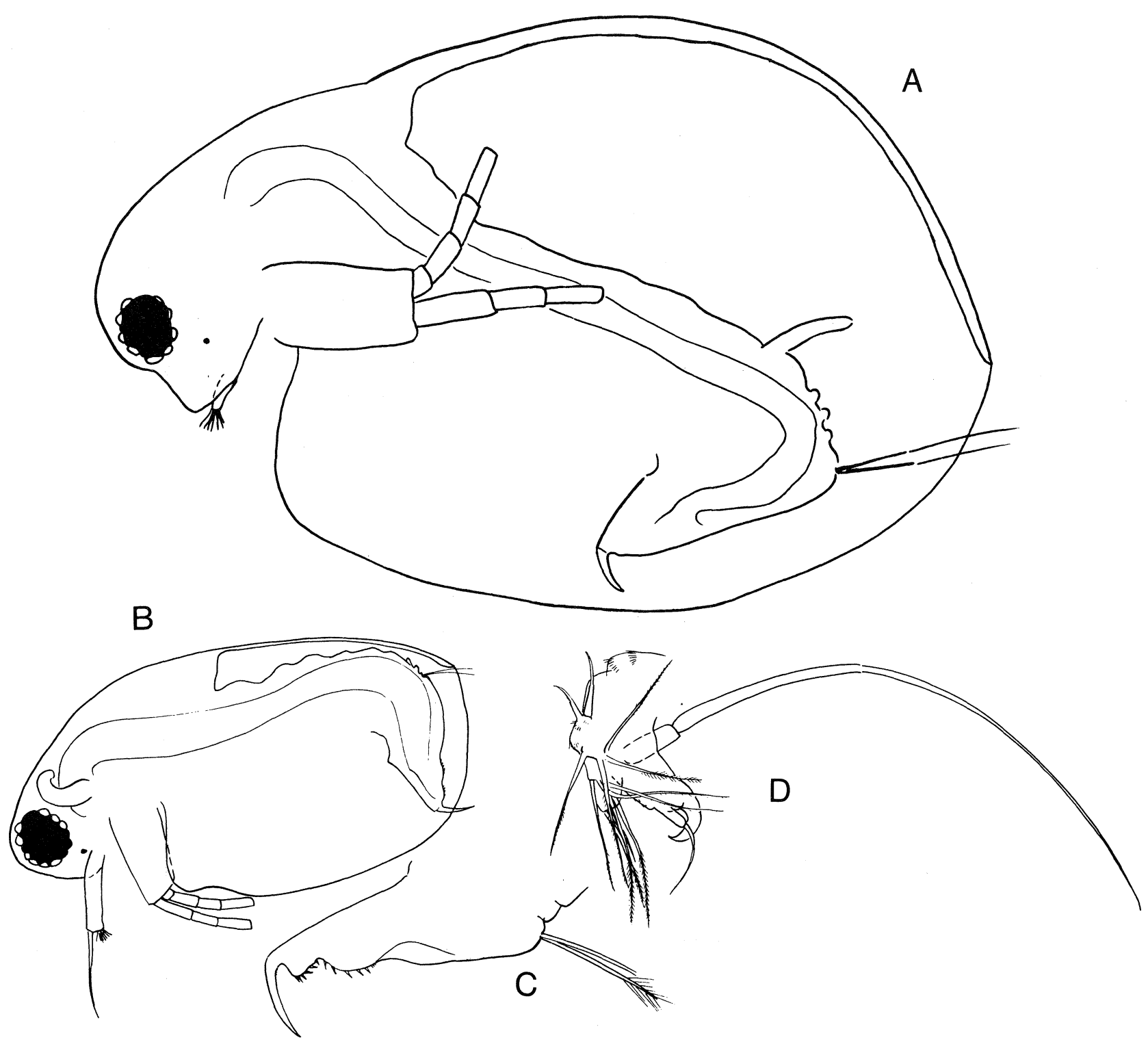

Fig. 125. Daphniopsis pusilla. A, $\odot$, Porters Lagoon, S.A., 16.i.76, length $1.94 \mathrm{~mm}$, from slide 2963; B, ${ }^{*}$, length $1.23 \mathrm{~mm}$, slide 2961; C, o* postabdomen, slide 2958; D, O* thoracic limb I, slide 2962. (B, C and D from a pond near Kingscote, Kangaroo I., S.A., 9.i.76.)

4(2). Fine setules along whole length of concave side of postabdominal claw ........ C. quadrangula (O.F. Müller, 1785) Very small denticles on proximal half of concave side of claw .............. C. dubia Richard, 1894

Ceriodaphnia quadrangula (O.F. Müller, 1785) Fig. 126

Daphnia quadrangula O.F. Müller, 1785: 90, tab. XIII, figs $3,4$.

Ceriodaphnia hakea Smith, 1909: 80, pl. 15, figs 10-16. Ceriodaphnia spinata Henry, 1919: 466-467, pl. XL, figs 1, 2., n. syn.
Ceriodaphnia planifrons Smith, 1909: 81, pl. 15, fig. 17. The type locality is L. Sorell in Tasmania. Williams (1974:41) notes the probability of its synonymicity to $C$. quadrangula. Indeed in recent collections (Burrows, 1968) only $C$. quadrangula was found and an examination of Smith's original collections showed it contained specimens having the characteristics of $C$. quadrangula. N. syn.

Ceriodaphnia quadrangula. - Brehm, 1953a: 65, figs 3-6 (C. quadrangula and $C$. hakea as synonyms).

Material. Qld: 3, 8, 9. N.S.W.: 129, 133, 136, 138, 140, $145,151,153,155,160,162,167,183$. Vic.: $214,228,232$, 241, 249, 251, 257, 258. Tas.: 292, 304, 308, 312, 313, 327, 333, 334. S.A.: 361, 364, 388. W.A.: 415, 416, 418, 425.

Slides. AM $\subsetneq$ P27760, MGU $\subsetneq 2499$, ZIN 2502.

Female. The original description by O. F. Müller is of little value in the differentiation of the species, as 
it does not contain any details on the structure of the claw. Smith (1909) published drawings of the thoracic limbs, including I and II. A comparison of these figures and figures in Lilljeborg $(1900, \mathrm{pl}$. XXVII, figs 18, 19) for limbs I and II of Ceriodaphnia quadrangula typica reveals no noticeable differences.

In holotype slide P:4327 for Ceriodaphnia spinata Henry, 1919 there are only small setules along the concave side of the claw; no small spinules mentioned by Henry are present. Taking into consideration this and the characteristics of the body form and postabdominal structure we define it as being $C$. quadrangula.

Length. Up to $0.8 \mathrm{~mm}$; for " $C$. spinata" Henry, a length of $1.2 \mathrm{~mm}$ is indicated (Henry, 1919).

Ecology. Planktonic. In L. Purrumbete (Vic.) seasonal abundance is variable for while Hussainy (1966) notes that it is common except in autumn, during 1969-70 it was only common in June (Timms, 1973).

Distribution. Australia-wide, though uncommon in Qld and restricted to higher altitudes in north Qld.

Differential diagnosis. There are no basal spines on the convex side of the postabdominal claws of the female. This side is smooth (no small denticles). There are small setules along the concave side of the claw. The head has no beak. The postabdomen is not widest in the middle.
Ceriodaphnia dubia Richard, 1894

Fig. 126

Ceriodaphnia dubia Richard, 1894: 570.-Gurney, 1927: 65-66, fig. 1B; Brehm, 1928: 794.

Material. Vic.: 217, 232, 240.

Slides. AM $\subsetneq$ P27728, MGU ๆ 1947, ZIN 2209.

Ecology. Planktonic.

Distribution. Southern Qld (Timms and Midgly, 1969), Vic.

Differential diagnosis. There are no well-developed basal spines on the concave side of the postabdomen claw of the female (but there are about 20 bristles). The head has no beak and the postabdomen is not widest in the middle.

Ceriodaphnia laticaudata P.E. Müller, 1867 Figs 127,128

Ceriodaphnia laticaudata Müller, 1867: 130.

Material. Vic.: 250. W.A.: 412.

Slides. AM $\subsetneq$ P27729, MGU $\subsetneq 2976$, ZIN 2977.

Female length. $0.93 \mathrm{~mm}$.

Distribution. Localized in Vic. and W.A.
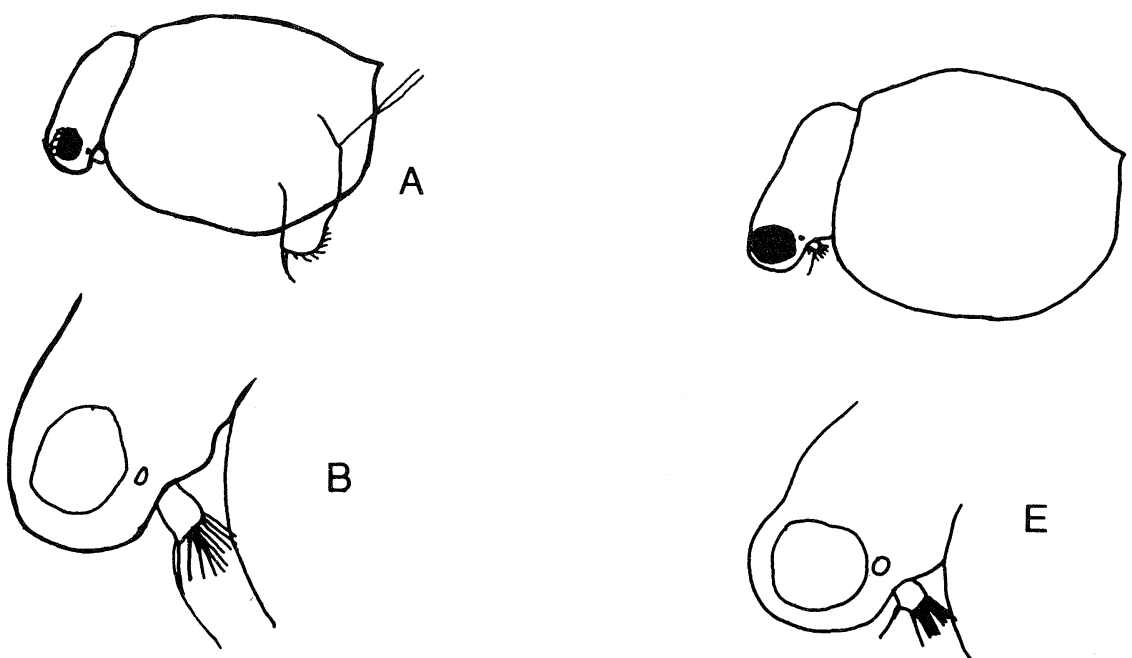

B
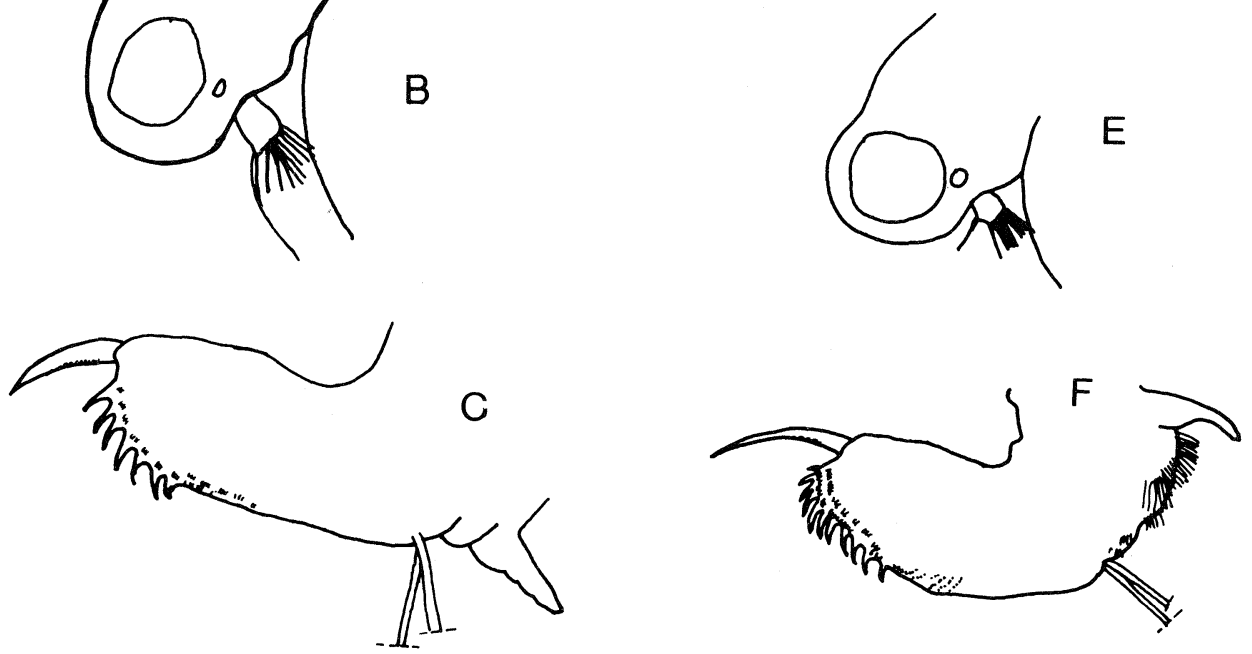

Fig. 126. Ceriodaphnia spp. A, B \& C, Ceriodaphnia quadrangula $९$, after Flössner, 1972. A, lateral view of whole animal, length $0.8 \mathrm{~mm}$; B, details of head and antennule; C, postabdomen; D, E \& F, Ceriodaphnia dubia $\supsetneq$, after Flössncr, D, lateral view of whole auimal, length $0.9 \mathrm{~mm} ; \mathbf{F}$, details of head and antennule; $\mathbf{F}$, postabdomen. 


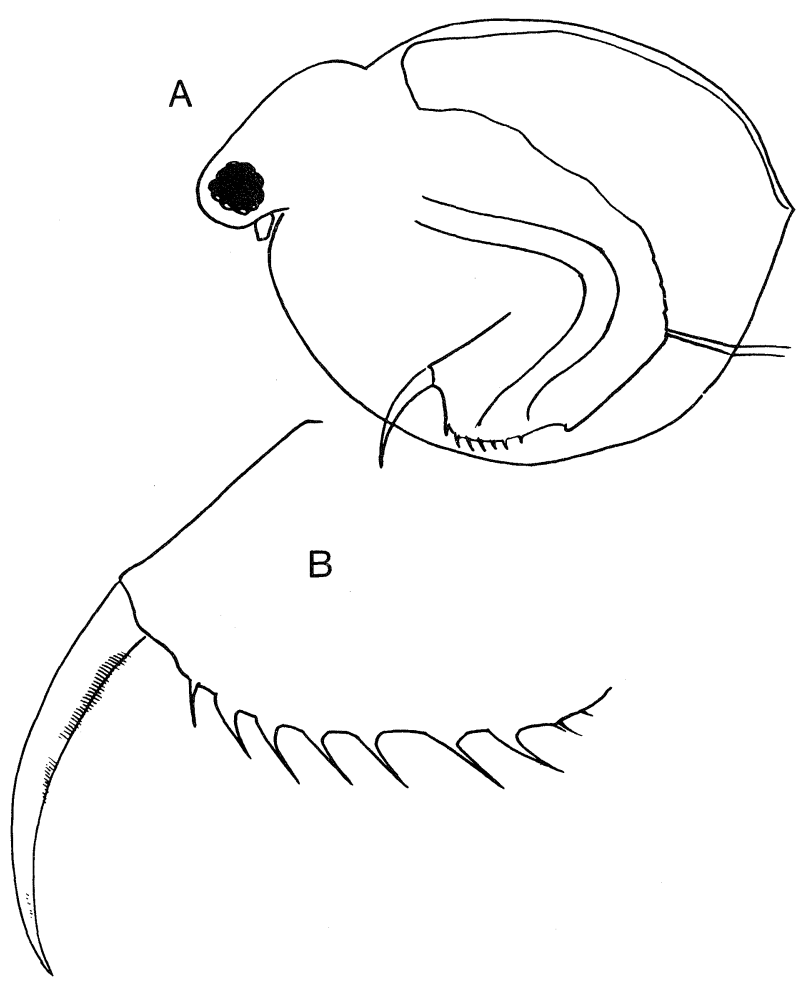

Fig. 127. Ceriodaphnia laticaudata $९$, pond between L. Gnotuk and L. Bullenmerri, Vic., 23.i.76, slide 2977. A, lateral view of whole animal, length $0.93 \mathrm{~mm} ; \mathbf{B}$, postabdomen.
Differential diagnosis. There are no basal spines on the concave side of the postabdominal claw of the female. The postabdomen is widest in its middle. The head has no beak; its frontal margin is rounded and without denticles.

\section{Ceriodaphnia rotunda Sars, 1862}

Fig. 128

Ceriodaphnia rotunda Sars, 1862: 275.-Shepard et al., 1918: 83.

Material. Literature.

Distribution. Vic. (Melbourne-Shepard et al., 1918).

Differential diagnosis. There are no basal spines on the concave side of the postabdominal claw of the female. The postabdomen is widest in its middle. The head has no beak. The margin below the eye bears spinules and the frontal and lower margins of the head bear small denticles.

\section{Ceriodaphnia cornuta Sars, 1885}

Fig. 128

Ceriodaphnia cornuta Sars, 1885: 26-28, pl. 5, figs 1-3.Henry, 1922: 32-33, pl. IV, fig. 4.

Ceriodaphnia rigaudi Richard, 1894: 239.

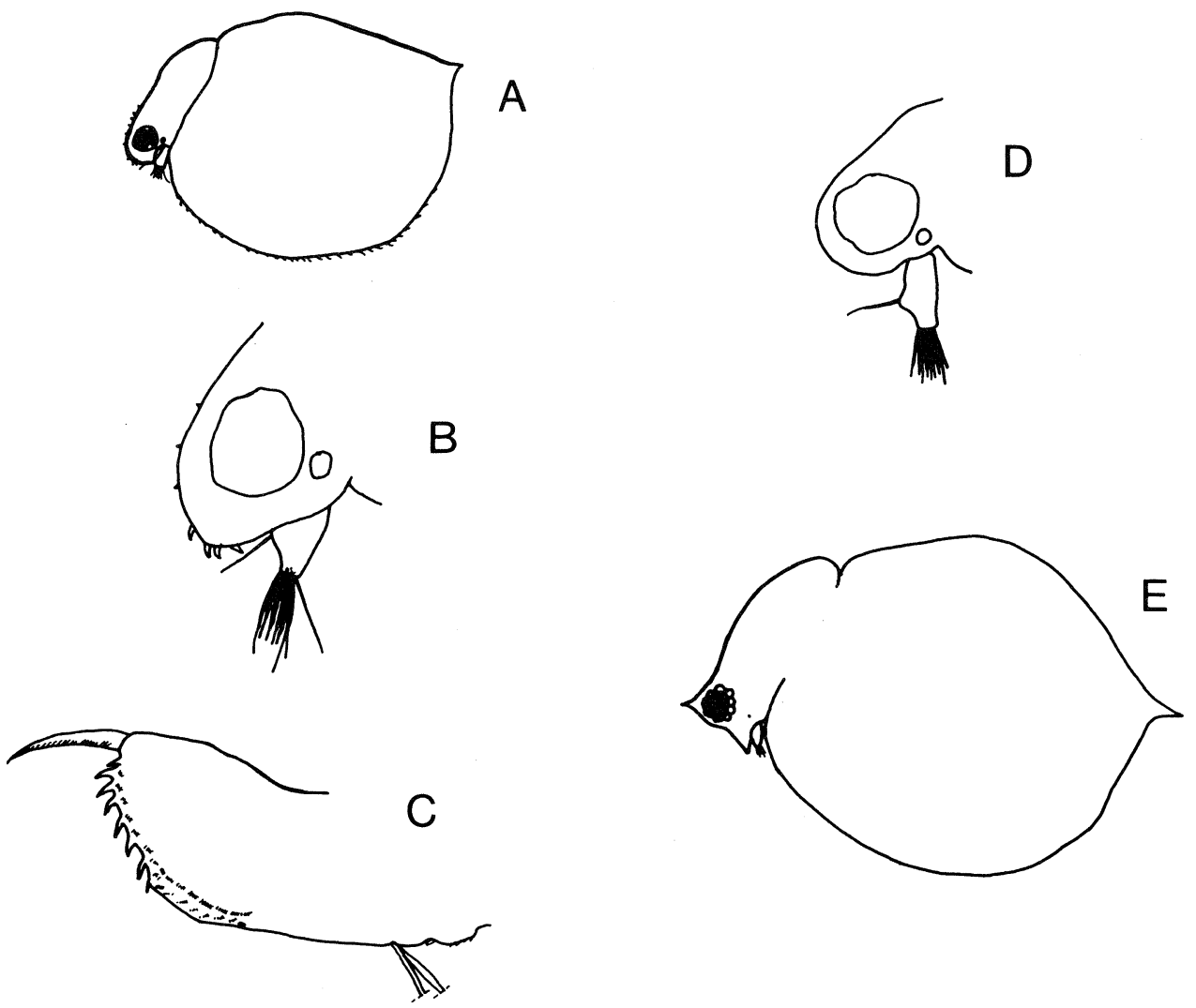

Fig. 128. Ceriodaphnia spp. A, B \& C, Ceriodaphnia rotunda $\subsetneq$ after Flössner. A, lateral view of whole animal, length $0.8 \mathrm{~mm}$; B, details of head and antennule; $\mathbf{C}$, postabdomen; D, Ceriodaphnia laticaudata $\odot$, after Flössner, details of liead and antemule, E, Ceriodaphnia cornuta $\$$, after Sars, outlinc of whole animal. 
Material. Qi̊d: 2, 3, 7, 9, 12, 15, 23, 28, 31, 38, 64. N.S. W.: 80, 85, 95, 131, 156, 169, 173, 180, 187. Vic.: 228 , 234, 238, 239. S.A.: 374, 380, 384.

Slides. AM $\odot$ P27727, MGU $\odot$ 1946, ZIN 1990.

Length. $0.6 \mathrm{~mm}$.

Ecology. Planktonic. In farm dams in the Hunter Valley $C$. cornuta is typically most common in summer (Timms, 1970b). It may occur with its congener $C$. quadrangula. Both species have similar distributions and occur in what seem to be similar habitats. However $C$. cornuta seems to prefer warmer waters than $C$. quadrangula as indicated by (a) its absence in Tasmania, (b) its altitudinal separation from $C$. quadrangula in north-eastern N.S.W. so that it occupies coastal or western waters, not highland lakes (Timms, 1970a), (c) its greater relative abundance in north Qld, (d) differences in seasonal distribution of the two species, and (e) the worldwide distribution of the two species$C$. cornuta is found in warmer latitudes including south Asia, Africa and Central America, while $C$. quadrangula is basically Holarctic.

Type locality. Gracemere Lag., $10 \mathrm{~km}$ west of Rockhampton, Qld.

Distribution. Eastern Australia and S.A. (apparently not in Tas. or W.A.).

Differential diagnosis. This species is distinctive in that the anterior portion of the head is produced into a beak-like acute structure.

\section{Incertae sedis}

Daphnia honorata King, 1853a: 249, pl. III; 1853b: 254-255, pl. VI D.-Sars, 1888: 68.

\section{Biocoenology}

\section{(a) Assemblages}

With few exceptions, the 125 species of inland water Cladocera known for Australia are either euplanktonic or littoral-benthic in habit. Hence typically each is a member of either the open water plankton community or the 'community' (sensu Timms, 1973) inhabiting littoral weedbeds. Since a cursory inspection of the distributional data reveals that certain species occur again and again, particularly in circumscribed areas, it could be that there are communities (sensu lato) with component species ecologically interdependent. On the other hand any species aggregations may simply be due to chance, or at most, to considerable overlap in their responses to environmental variables.

Because of the low diversity of cladocerans in limnetic communities (Timms [1970a] reports a momentary species composition of 1.1 in 103 sites in north-eastern N.S.W.), it is difficult to ascertain whether there are relationships between and within such communities. However, for littoral cladocerans the situation is different: a number of species (up to 20 , mean 4 .14-see later) may co-occur so that analysis of species groupings is possible, despite the fact that the Cladocera comprise only a part of the total 'assemblage' of littoral animals.

Jaccard's (1932) coefficient of community was used in the analyses. By this: $\mathbf{C C}=\frac{\mathbf{a}}{\mathbf{a}+\mathbf{b}-\mathbf{c}}$, where $\mathbf{a}$ is the number of species in the first sample, $\mathbf{b}$ in the second sample, and $\mathbf{c}$ the number of species occurring in both. It perhaps would have been better to use indices based on quantitative data (e.g. see Kontkanen [1950], Whittaker and Fairbanks [1958]), but the available data are qualitative. Rather than treat each site as an individual, it was decided to consider apparently similar lakes as single entities. This approach was adopted because of (1) the increased probability of recording all species living in an area, and (2) the need to simplify operations. The analyses were further restricted to those lakes which formed natural groups (e.g. flood plain lagoons of the Burdekin delta, sand dune swamp localities in the Myall Lakes area).

Hence for Queensland, of 66 localities sampled, only 24 in 7 groups were considered. Figures for the other states are: N.S.W. 113-35-8, Vic. 63-20-5, S.A. 42-15-3, Tas. 49-17-3 and W.A. 23-0-0.

Because a preliminary examination of the species lists for all the groups suggested that those in northern, southern, and coastal dune areas were quite different, separate matrices of CC were constructed for these three areas, but with some overlap. These are now considered in turn.

\section{Qld-Northern N.S.W. (Table 1)}

Here there are two 'assemblages':

(a) That of the flood plain lagoons in Nth. Qld-the Powlathanga-Pentland pair, the lagoons along Lolworth Creek, north-west of Charters Towers, and the lagoons on the delta of the Burdekin River. Some components of this 'assemblage' overlap with elements (1) in the lagoons around Dunn Lake (via Aramac Qld), (2) in the Hunter Valley reservoirs in N.S.W. and (3) in the coastal dune lakes.

(b) That of the coastal dune lakes at Cooloola (Qld) and in north-eastern N.S.W.

\section{Southern Australia. Part A-Southern Qld, N.S.W. and Vic. (Table 2).}

Here there are two 'assemblages' interlinked by the species groupings in the Bombala-Bega lagoons. The first inhabits the lagoons of the Monaro Tableland, N.S.W. Community coefficients for these, particularly those near Cooma, are the highest for the whole analysis. There is some decrease in the values of $\mathrm{CC}$ in a gradient running from Cooma, through the Bombala Lagoons, to those around Bega, so that the coastal lagoons around Bega are different, but related to those on the adjacent highland. The second 'assemblage' lives in the Victorian lakes and lagoons, specifically in the floodplain lagoons of the Goulburn River, around Seymour-Alexandra, in the lakes south of Kerang and in some lakes of the western volcanic plains of Victoria. 
Table 1. Matrix of community coefficients for lake groups in Queensland-Northern N.S.W.

\begin{tabular}{|c|c|c|c|c|c|c|c|c|c|c|}
\hline \multirow[t]{11}{*}{ Hugh } & Powl & CT & LB & Rock & Dunn & $\mathrm{HV}$ & Min & Cool & Myall & \\
\hline & 15 & 19 & 20 & 10 & 10 & 12 & - & - & - & Hughenden \\
\hline & & 42 & 44 & 28 & 24 & $1 \overline{7}$ & 9 & 23 & 22 & Powlathanga \\
\hline & & & 29 & 38 & 18 & 8 & 7 & 18 & 16 & Charters Towers \\
\hline & & & & 30 & 25 & 20 & 7 & 24 & 17 & Lower Burdekin \\
\hline & & & & & 23 & 12 & 17 & 16 & 15 & Rockhampton \\
\hline & & & & & & 19 & 4 & 5 & 3 & Dunn \\
\hline & & & & & & & - & 11 & $\downarrow 7$ & Hunter Valley \\
\hline & & & & & & & & 14 & 31 & Minni-Cook \\
\hline & & & & & & & & & 29 & Coolool \\
\hline & & & & & & & & & & Myall Lakes \\
\hline
\end{tabular}

Table 2. Matrix of community coefficients for lake groups in southern Queensland, N.S.W., and Victoria.

\begin{tabular}{|c|c|c|c|c|c|c|c|c|c|c|c|}
\hline \multirow[t]{12}{*}{ Hda } & Ctr & $\mathrm{AC}$ & Bom & Beg & $\mathrm{EG}$ & Rock & $\mathrm{HV}$ & WD & Ker & Gou & \\
\hline & 60 & 38 & 34 & 15 & 0 & 0 & 13 & 7 & 10 & 12 & Hugundara \\
\hline & & 50 & 45 & 22 & 0 & 12 & 12 & 12 & 15 & 24 & Cootralantra \\
\hline & & & 45 & 37 & 0 & 12 & 12 & 11 & 22 & 24 & Arable-Carrol \\
\hline & & & & 44 & 5 & 5 & 16 & 20 & 28 & $\overline{43}$ & Bombala \\
\hline & & & & & 5 & 15 & 22 & 23 & 37 & 35 & Bega \\
\hline & & & & & & 11 & 7 & 14 & 6 & 7 & East Gippsland \\
\hline & & & & & & & 12 & 7 & 10 & 6 & Rockhampton \\
\hline & & & & & & & & 21 & 22 & 34 & Hunter Valley \\
\hline & & & & & & & & & 38 & 31 & Western District \\
\hline & & & & & & & & & & 35 & Kerang \\
\hline & & & & & & & & & & & Goulburn \\
\hline
\end{tabular}

Table 3. Matrix of community coefficients for lake groups in Victoria, Tasmania and South Australia.

\begin{tabular}{|c|c|c|c|c|c|c|c|c|c|}
\hline Goul & $\frac{\mathrm{Ker}}{35}$ & \begin{tabular}{|r|} 
Purr \\
31 \\
38
\end{tabular} & $\begin{array}{c}\mathrm{MtG} \\
21 \\
27 \\
31\end{array}$ & $\begin{array}{c}\text { Adel } \\
20 \\
40 \\
43\end{array}$ & $\begin{array}{r}\mathrm{KI} \\
32 \\
22 \\
11 \\
31 \\
21\end{array}$ & \begin{tabular}{c} 
Mid \\
21 \\
\hdashline 33 \\
20 \\
27 \\
23 \\
16
\end{tabular} & $\begin{array}{c}\text { High } \\
26 \\
24 \\
20 \\
25 \\
17 \\
27 \\
30\end{array}$ & $\begin{array}{c}\text { Temp } \\
5 \\
14 \\
8 \\
15 \\
13 \\
6 \\
14 \\
23 \\
\end{array}$ & $\begin{array}{l}\text { Goulburn } \\
\text { Kerang } \\
\text { Purrumbete } \\
\text { Mt Gambier } \\
\text { Adelaide } \\
\text { Kangaroo I. } \\
\text { Midland Tas. } \\
\text { Highland Tas. } \\
\text { Temporary Tas. }\end{array}$ \\
\hline
\end{tabular}

The 'assemblage' of the Hunter Valley reservoirs in N.S.W. is sufficiently like those in the Victorian sites to be included with them also. There is some overlap with the species groupings in the Bega-Bombala lagoons and hence with those of the Monaro Tableland.

III. Southern Australia, Part B-Vic., Tas. and S.A. (Table 3).

The 'assemblage' of the Victorian lakes extends into southern South Australia (lakes at Mt. Gambier, dams around Adelaide and lagoons on Kangaroo Island) and also to Tasmania (lagoons in the Midlands). There is some relationship between the communities in the lagoons of the Midlands, Tasmanian eastern Highlands and Kangaroo I. The 'assemblage' in the temporary lagoons in Tasmania is the most divergent, with closest relationship to highland fauna.

Unpublished data on the lower Murray-Darling river system (R. Shiel, personal communication) suggest there is a distinctive grouping of species there also. Among 
Table 4. Matrix of community coefficients for coastal dune lakes

\begin{tabular}{ccccccl}
\hline EG & Beg & Bri & Min & Coo & Myl & \\
& 5 & 14 & 5 & 0 & 0 & East Gippsland \\
& 12 & 15 & 8 & 3 & Bega \\
& & 11 & 27 & 20 & Bridgewater \\
& & & 14 & 31 & Minnie-Cook \\
& & & & 29 & Cooloola \\
& & & & & Myall Lakes
\end{tabular}

others, Pleuroxus inermis, Alona macracantha, Monospilus diporus and $M$. elongatus are characteristic.

\section{Coastal Dune Lakes (Table 4).}

Among these there is a low degree of similarity between lake groups; only the values between the Myall, Minnie, and Coolola groups are high enough to suggest a relationship. On initial appraisal this is surprising in view of the known ecological unity of lakes in coastal dunes in eastern Australia (e.g. Bayly, 1964). However, most members in four of the present groups are not typical dune lakes (sensu Bayly, 1964). Only two of the Bega group are associated with coastal dunes and then only partly. All except one of the East Gippsland group are atypical (Timms, 1973) and none of the Bridgewater group is typical (Timms, 1977). On other criteria the Myall and Cooloola group contain characteristic dune lakes, while only Cook's Lagoon of the Minnie group is typical (Timms, in prep.). Hence a lack of similarity between all lakes is really expected and some relationship between the more typical dune lakes is not surprising. However, the latter is not as high as might be expected from knowledge of other similarities between typical dune lakes. Perhaps this is associated with the difficulty of obtaining adequate samples of uncommon littoral cladocerans amongst dense beds of littoral sedges.
Further information on cladoceran assemblages in lakes may be obtained by examining the chitinized remains in the superficial layer of profundal mud (Frey, 1960). This approach is often more revealing than studying single samples since the remains represent an integrated sample from all habitats and seasons. The only data available for Australian lakes are presented in Table 5. Of the three maars of the Atherton Tableland, Eacham and Barrine are similar but Euramoo is quite different; this supports previous conclusions based on a physiochemical study (McCarraher \& Russel, in prep.) and a survey of their macrobenthos (Timms, 1978). The differences are probably associated with the abundant littoral weedbeds, relative shallowness and dystrophic nature of Euramoo. The western Victorian pair, Purrumbete and Elingamite, are similar to each other and to Eacham and Barrine. They contain a greater variety and proportion of littoral species in keeping with their relatively greater abundance of littoral macrophytes.

\section{(b) Species Groups}

In almost all cases (Tables 1 to 4 ), the values for the coefficient of community are low, indeed, much lower than those accepted by most authors (e.g. Whittaker and Fairbanks, 1958) for the designation of communities and sub-communities. However, the closer relationships of lake groups to some and not to others indicates that the distribution of components of cladoceran communities is not at random. Our data suggest that there are species groups, the members of which tend to recur again and again. They cannot be considered as sub-communities or communities because their cooccurrence is irregular and not interdependent. Further their presence in any lake is not necessarily restricted to areas where a particular species group dominates.

Unfortunately the data are unsuitable for an analysis of recurrent species groups (sensu Fager, 1957). This is because firstly each sample is not considered to represent

Table 5. Per cent ratios of Cladocera remains in mud samples for five lakes.

\begin{tabular}{|c|c|c|c|c|c|}
\hline & $\begin{array}{l}\text { L. Euramoo, } \\
\text { via Atherton, Q., } \\
\text { from } 18 \mathrm{~m}\end{array}$ & $\begin{array}{l}\text { L. Eacham, } \\
\text { via Atherton, Q., } \\
\text { from } 63.5 \mathrm{~m}\end{array}$ & $\begin{array}{l}\text { L. Barrine, } \\
\text { via Atherton, } \mathrm{Q} \text {., } \\
\text { from } 64.5 \mathrm{~m}\end{array}$ & $\begin{array}{l}\text { L. Purrumbete, } \\
\text { Vic., } \\
\text { from } 35 \mathrm{~m}\end{array}$ & $\begin{array}{l}\text { L. Elingamite, } \\
\text { Vic., } \\
\text { from } 6 \mathrm{~m}\end{array}$ \\
\hline Alona sp. & 0 & 2 & 0 & 3 & 0 \\
\hline Alonella excisa & 9 & 0 & 0 & 0 & 1 \\
\hline Biapertura karua & 4 & 0 & 0 & 0 & 0 \\
\hline Biapertura kendallensis & 0 & 0 & 0 & 3 & 0 \\
\hline Biapertura rigidicaudis & 22 & 0 & 0 & 0 & 0 \\
\hline Biapertura sp. & 0 & 0 & 4 & 0 & 18 \\
\hline Bosmina sp. & 0 & 96 & 95 & 85 & 77 \\
\hline Camptocercus australis & 1 & 0 & 0 & 0 & 0 \\
\hline Chydorus sp. & 9 & 0 & 0 & 6 & 4 \\
\hline Daphniidae, filtering limbs & 52 & 0 & 0 & 3 & 0 \\
\hline Leydigia $\mathrm{sp}$. & 0 & 2 & 0 & 0 & 0 \\
\hline Oxyurella singalensis & 3 & 0 & 1 & 0 & 0 \\
\hline
\end{tabular}


Table 6. Species Groups

1. Northern

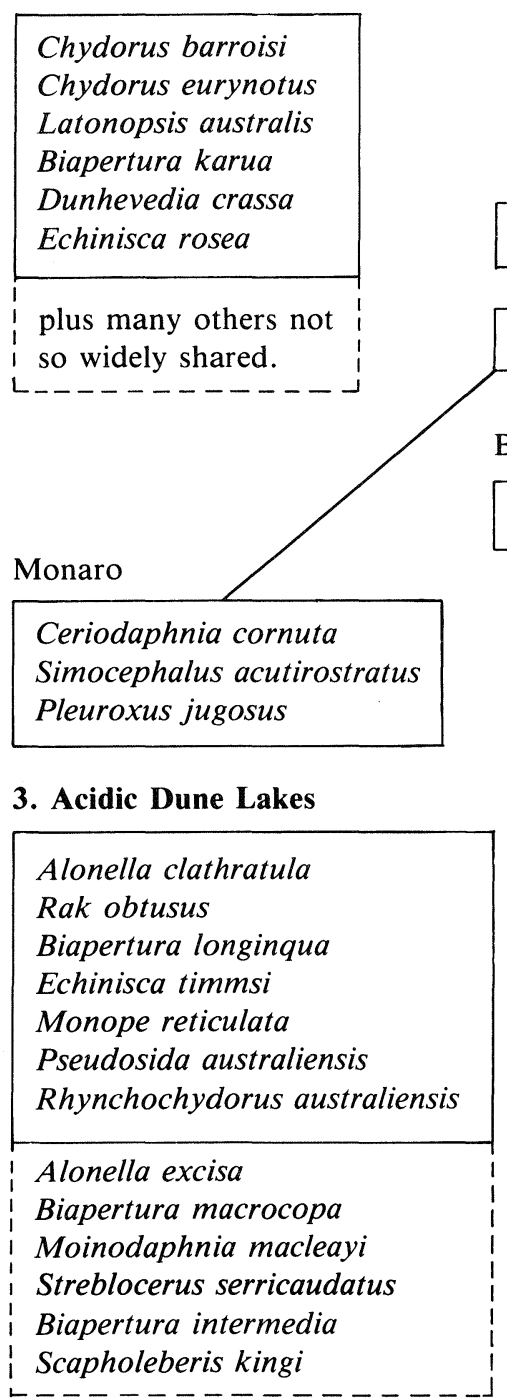

the full assemblage of forms thought to live in any one locality; e.g. our data for the Goulburn lagoons record up to 10 species per lagoon but Shiel (1976) in a detailed study of one of them records 31 species. Secondly, when samples are pooled to overcome this problem (see earlier) there are insufficient numbers for a meaningful analysis of recurrent groups. Hence, all that can be attempted is to list the more common species in each grouping of lakes.

Five species groups can be recognized from our data. the dominant forms in each group are given in Table 6 with the interrelationships within the southern group, which is more diffuse and hence more complex than the others. Although dominant forms may also occur as uncommon species in other areas (e.g. Chydorus barroisi, the leading dominant for north-eastern Australia, is present but uncommon in acid dune lakes), it is significant that there are very few dominants shared between groups so that they are distinctive.

\section{Southern}

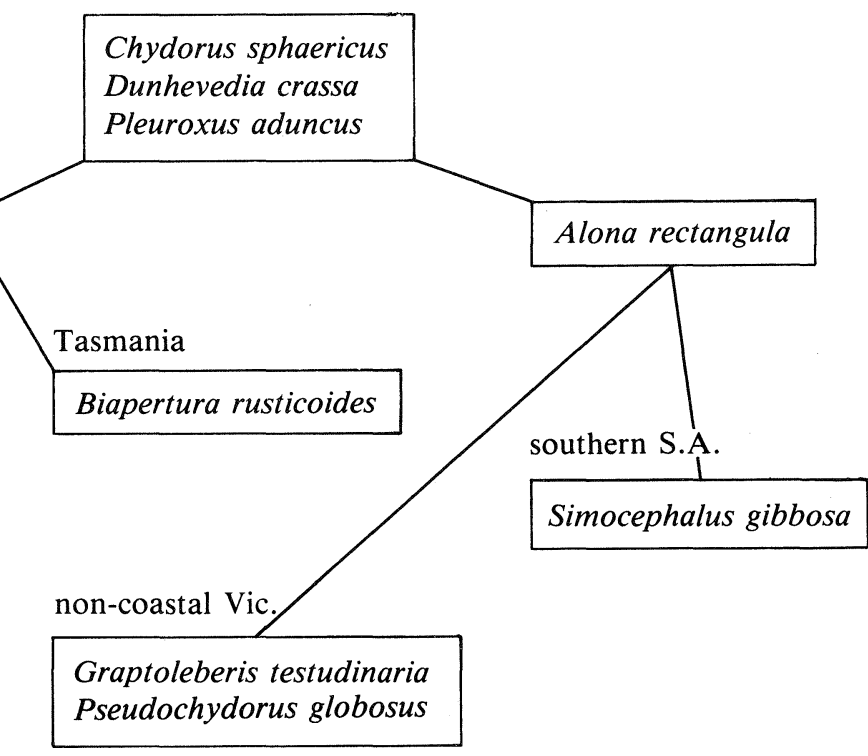

4. Calcareous Dune Lakes

Chydorus sphaericus

Alonella excisa

Biapertura rigidicaudis

Camptocercus australis

Oxyurella tenuicaudis

Pleuroxus aduncus

\section{Temporary Ponds}

Archepleuroxus baylyi
The most distinctive group occurs in acid dune lakes on siliceous sands of the east coast. All seven major species are either unique to dune lakes or rarely found elsewhere. Further, most of the co-dominants in the group, while not so universally present in dune lakes, are uncommon elsewhere.

The calcareous dune group is erected entirely on evidence from the Bridgewater-Nelson series in western Victoria. It shares two dominants and many species with the southern group and in addition a few species also occur uncommonly in acidic dune lakes. It is possible that further data will show that it is a sub-group of the southern group. If so, this will further emphasize the difference of calcareous from acid dune lakes (see Timms, in prep.).

Another distinctive grouping comprises the species inhabiting temporary ponds in southern Victoria and Tasmania. Morton (1973) has studied such habitats in some detail and records many species there, but the most 
Table 7. Numbers of species of Cladocera in various areas of Australia.

\begin{tabular}{llc}
\hline \multicolumn{1}{c}{ Area } & \multicolumn{1}{c}{ Number of species } & $\begin{array}{c}\text { Momentary Species } \\
\text { Composition* }\end{array}$ \\
\hline North Queensland & 30 species in 14 localities & 7.0 \\
Monaro (N.S.W.) & 20 species in 19 localities & 4.2 \\
Victorian lakes & 24 species in 16 localities & 4.9 \\
Tasmanian midlands & 17 species in 13 localities & 4.5 \\
Tasmanian highlands & 16 species in 7 localities & 5.1 \\
Southern S. Aust. & 11 species in 14 localities & 3.5 \\
Kangaroo Island & 18 species in 13 localities & 3.0 \\
Bridgewater (Vic.) & 17 species in 6 localities & 7.0 \\
Myall (N.S.W.) & 31 species in 6 localities & 8.0 \\
Minnie-Cook (N.S.W.) & 30 species in 6 localities \\
\hline
\end{tabular}

* i.e. the average number of species present in all collections from the area.

characteristic one is Archepleuroxus baylyi which rarely occurs in other habitats.

The number of species inhabiting northern localities and acid dune lakes is much higher than that in southern areas and in calcareous dune lakes. This is ascertained in general terms by considering the total number of species recorded in the various areas, or more precisely, from the momentary species composition for the various areas (Table 7). This in part reflects the penetration of many 'Holarctic' and circumtropical species only into northern Australia. Further, if speciation is more active in the north than in the south, as it seems (see later), this would also contribute. An exception to this is the coastal dune lakes of the east coast where diversity is the highest and there is the largest number of endemics.

Overall, in the littoral of all localities sampled there is a momentary species composition of 4.14 , which compares with an average of 4.9 given by Pennak (1966).

\section{(c) Cladocerans in inland saline waters.}

Few species of Cladocera penetrate even moderately saline waters in Australia. Two species live in waters $>20 \%$ compared with five each in Algeria (Beadle, 1943) and Canada (Rawson and Moore, 1944). At lower salinities $(1-10 \%$ o) the comparative status is somewhat reversed: 14 in Australia, 11 in Canada and 9 in Algeria.

The most notable halophilic species in Australia is Daphniopsis pusilla which inhabits shallow, often ephemeral salines. Its field salinity range is $4.4-59 \%$ (Geddes, 1976: Bayly and Edward, 1969) which is not much different from the laboratory range of $1-50 \%$ o reported by Hedley (1969). As the salinity of its habitat increases, Daphniopsis pusilla changes from producing subitaneous to resistant eggs. It is widespread in western Victoria, southern South Australia and south-western Western Australia.

Recently, Moina mongolica, which inhabits very saline ponds in the Old World (Goulden, 1968), was found over a salinity range of c. $7-40 \%$ in Lake Eyre (Bayly, 1976). At this stage it is not known whether this species is more widespread, or what its full salinity range is in Australia.
Six species have been recorded with an upper salinity range 5-10\%o-Echinisca capensis capensis and Biapertura rigidicaudis at $8 \%$, Daphnia carinata sensu lato at $7.3 \%$, Alona cambouei and Alona davidi iheringi at $6.7 \%$, and Moina australiensis at 5\%. All are known from freshwater though only one of five records of Echinisca capensis capensis is from a salinity below 1\%o. It is likely that Moina australiensis occurs at higher salinities than recorded here.

A further six species typically occur in freshwater but occasionally were encountered in slightly saline waters (up to $4 \%$ o). These are Macrothrix breviseta and Echinisca carinata at $4 \%$, Pleuroxus jugosus at $2.5 \%$, and Pleuroxus aduncus, Simocephalus vetulus elisabethae and Ceriodaphnia quadrangula at $2.3 \%$.

Curiously, some widespread species recorded in saline waters overseas have not yet been found at similar salinities in Australia. These are Simocephalus exspinosus and Alona rectangula at c. $12 \%$ in Algeria (Beadle, 1943), Chydorus sphaericus at $20 \%$, Ceriodaphnia quadrangula at $10 \%$, and Pleuroxus denticulatus and Alona costata at 5\%, all in Canada (Rawson and Moore, 1944).

In summary, it seems that in permanent lakes in Australia, a few species are adapted for very low salinities. Three, notably, Echinisca capensis capensis, Daphnia carinata sensu lato and Moina australiensis, can live at somewhat higher salinities (to $10 \%$ ), but only two species are adapted for salinities higher than this. Of these, Daphniopsis pusilla is the most widespread and successful, but where fish predation is likely to be significant it is replaced by Moina mongolica (e.g. Lake Eyre), or no species are present (e.g. Lake Corangamite) (Bayly, 1976).

\section{Faunal Composition and Zoogeography}

The total number of cladoceran species now known to occur in Australia is 125 (excluding marine species); this compares with 114 for Europe and 134 for North America (Table 8), the only other sizeable areas for which comprehensive data are available. 
Table 8. Composition of the cladoceran faunas in inland waters of various areas of the world.

\begin{tabular}{|c|c|c|c|c|c|}
\hline \multirow[t]{2}{*}{ Taxon } & \multicolumn{5}{|c|}{ Number of species in } \\
\hline & Australia & New Guinea & New Zealand & Philippines & Malaysia \\
\hline Sididae & 5 & 2 & 0 & 5 & 6 \\
\hline Holopedidae & 0 & 0 & 0 & 0 & 0 \\
\hline Chydoridae & 68 & 9 & 22 & 31 & 42 \\
\hline Macrothricidae & 21 & 3 & 6 & 7 & 8 \\
\hline Moinidae & 6 & 0 & 2 & 3 & 2 \\
\hline Bosminidae & 2 & 1 & 1 & 3 & 1 \\
\hline Daphniidae & 23 & 2 & 10 & 5 & 5 \\
\hline Daphnia & 11 & 0 & 3 & $0 ?$ & 1 \\
\hline Simocephalus & 5 & 1 & 3 & 2 & 2 \\
\hline Scapholeberis & 1 & 0 & 1 & 2 & 1 \\
\hline Ceriodaphnia & 5 & 1 & 3 & 1 & 1 \\
\hline Daphniopsis & 1 & 0 & 0 & 0 & 0 \\
\hline Polyphemidae & 0 & 0 & 0 & 0 & 0 \\
\hline Cercopagidae & 0 & 0 & 0 & 0 & 0 \\
\hline Leptodoridae & 0 & 0 & 0 & 0 & 0 \\
\hline TOTAL & 125 & 17 & 41 & 54 & 64 \\
\hline Number of endemics & 44 & $?$ & 1 & $2 ?$ & $?$ \\
\hline Source of Data $\dagger$ & (1) & $(2),(3),(4)$ & (5) & (6), (7) & (8) \\
\hline
\end{tabular}

Table 8 contd.

\begin{tabular}{|c|c|c|c|c|c|}
\hline & South America & North America & Europe* & $\begin{array}{l}\text { Africa to south } \\
\text { of Sahara }\end{array}$ & Asia \\
\hline Sididae & 13 & 8 & 6 & 7 & 10 \\
\hline Holopedidae & 1 & 2 & 1 & 0 & 1 \\
\hline Chydoridae & 60 & 63 & 54 & 63 & 80 \\
\hline Macrothricidae & 25 & 18 & 11 & 13 & 27 \\
\hline Moinidae & 6 & 8 & 4 & 5 & 7 \\
\hline Bosminidae & 6 & 4 & 2 & 3 & 6 \\
\hline Daphniidae & 21 & 29 & 33 & 16 & 26 \\
\hline Daphnia & 8 & 15 & 16 & 6 & 10 \\
\hline Simocephalus & 6 & 3 & 5 & 3 & 5 \\
\hline Scapholeberis & 2 & 2 & 4 & 1 & 3 \\
\hline Ceriodaphnia & 5 & 9 & 8 & 6 & 7 \\
\hline Daphniopsis & 0 & 0 & 0 & 0 & 1 \\
\hline Polyphemidae & 0 & 1 & 1 & 0 & 1 \\
\hline Cercopagidae & 0 & 0 & 1 & 0 & 1 \\
\hline Leptodoridae & 0 & 1 & 1 & 0 & 1 \\
\hline TOTAL & 132 & 134 & 114 & 107 & 160 \\
\hline Number of endemics & 41 & 25 & 15 & 26 & 24 \\
\hline Source of data $\dagger$ & $\begin{array}{c}(9),(10),(11),(7) \\
(12),(13),(14)\end{array}$ & $\begin{array}{c}(15),(10),(16) \\
(7),(12)\end{array}$ & $\begin{array}{c}(17),(16) \\
(18),(7),(12)\end{array}$ & $\begin{array}{c}(19),(20) \\
(7),(12),(21)\end{array}$ & $\begin{array}{c}(22),(23) \\
(7),(12)\end{array}$ \\
\hline
\end{tabular}

*If endemic Ponto-Caspian Polyphemoidea are considered (Mordukhai-Boltovskoi, 1968b), then the total is 141 species with 35 endemic.

†(1) Present work, (2) Daday, 1901, (3) Brehm, 1959, (4) Ball \& Gluckman, 1978, (5) Chapman \& Lewis, 1976, (6) Mamaril, 1977, (7) Smirnov, 1971b, (8) C.H. Fernando, pers. comm., (9) Begamin, 1939, (10) Deevey \& Deevey, 1971, (11) Harding, 1955, (12) Smirnov, 1976, (13) Paggi, 1976, (14) Paggi \& Paggi, 1974, (15) Brook, 1966, (16) Goulden, 1968, (17) Flossner, 1972, (18) Sramek-Husek et al., 1962, (19) Dumont, 1979, (20) Sars, 1916, (21) Rey \& Saint-Jean, 1968, (22) Manuilova, 1964, (23) Mordukhai-Boltovskoi, $1968 \mathrm{~b}$. 
The main difference between the three faunas, in addition to the difference in endemics (see later), is the absence in Australia of four families-the Holopedidae, Polyphemidae, Cercopagidae, Leptodoridae-and of many widespread genera e.g. Sida, Acantholeberis, Eurycercus. Compared to North America, an area of similar size to Australia, the Australian fauna is not quite as diverse, for besides the lack of four families, there are also fewer genera in a majority of families. However, in some genera (e.g. Biapertura, Echinisca) and subfamilies (e.g. Chydorinae) there has been considerable speciation, so that species numbers at the family level in the Macrothricidae and Chydoridae are not significantly different.

In analysing the composition and origin of the Australian cladoceran fauna it is necessary to consider the presence or absence of members of the three phylogenetic stems of the Cladocera: the Ctenopoda Sars, 1865 (Sididae, Holopedidae), the Anomopoda Sars, 1875 (Macrothricidae, Chydoridae, Bosminidae, Moinidae, Daphniidae), and the Gymnomera Sars, 1865 (Polyphemidae, Podonidae, Cercopagidae, Leptodoridae).

Among the Anomopoda it is of special interest to consider the presence or absence in Australia of morphologically ancestral forms (sensu Fryer, 1974) in the Macrothricidae and Chydoridae. These two families comprise mainly littoral and benthic forms and are claimed to be the cladocerans most similar to their conchostracan ancestors (Fryer, 1968, 1974). Of the primitive genera, Australasia has the endemic Saycia (1 species) and the widespread (Holarctic, Ethiopian) Ilyocryptus (3 species) but lacks Acantholeberis and Eurycercus (both Holarctic).

In the more general sense all families comprising the phylogenetic series Anomopoda (MacrothricidaeChydoridae-Bosminidae-Moinidae-Daphniidae) are present in Australian inland waters. The Macrothricidae are represented by 6 of the known 17 genera, Chydoridae by 22 of the known 31 genera, and Bosminidae, Moinidae, and Daphniidae by all known genera.

At the generic level Australasia has two endemic genera of Macrothricidae (Neothrix, Pseudomoina) six of Chydoridae (Saycia, Archepleuroxus, Rhynchochydorus, Rak, Australochydorus, Monope), but no endemic genera of Bosminidae, Moinidae or Daphniidae. By contrast, the Holarctic has many endemic genera of Macrothricidae (Acantholeberis, Ophyryoxus, Bunops, Drepanothrix, Wlassicsia), a few genera of Chydoridae (Rhynchotalona, Anchistropus), and no endemic genera of Bosminidae, Moinidae, or Daphniidae.

For the Moinidae Goulden (1968: 93) has noted: "Because Moina tenuicornis and australiensis are the most generalized species of the family it seems probable that they represent the oldest species or at least have retained many primitive characters. These two species now have their centers of distribution in Australiatenuicornis also occurs in South Africa."
In Daphniidae, the presence of Daphniopsis is noteworthy. This genus includes three species-one in Australia, one in Antarctica (Akatova, 1964) and Kerguelen Islands (Rühe, 1914), and another in Central Asia (Sars, 1903). The genus Daphnia is represented by two different forms in Australia-Daphnia lumholtzi having a very elongated and narrow helmet and posterior shell spine, both being produced in the anterior-posterior axis, and Daphnia carinata sensu lato, which has a cephalic helmet developed mostly in a ventro-dorsal direction. Hebert (1977) has described the peculiar forms in the Daphnia carinata complex. It may be mentioned that Wagler (1936) supposed that Daphnia originated in Central Asia.

Turning to the Ctenopoda, which separated from the main phylogenetic stem in remote time, the Holarctic Holopedidae are absent from Australia, while the Sididae are represented by only 3 of the 6 known genera. The Gymnomera are not present in inland waters of Australia, but are widely distributed in the Holarctic.

From the above it is apparent that the Australian fauna of Cladocera is more different from its Northern Hemisphere counterpart than is indicated in Table 8. Indeed, there are basic differences in the distribution of primitive taxa, and in addition a number of endemic highly specialized forms occur in inland waters of Australia. However, there are also many species of extensive world distribution in Australia, so that before the full significance of the pecularities can be realized, it is necessary to examine general zoogeographical relationships.

In their zoogeographical relationships, the Australian Cladocera can be considered to comprise five groups. First, there are cosmopolitan species, e.g. Chydorus sphaericus, Moina micrura, Simocephalus vetulus. This group is not as numerous as indicated by some previous authors, for instance for the Chydoridae it is only $26 \%$ of the total.

The next two groups comprise species distributed throughout appreciable areas of the world as well as in Australia. There are circumtropical forms such as Latonopsis australis, Chydorus hermanni, Biapertura karua. Many species in this group are restricted to, or are most common in, northern Australia. The presence of a number of cosmopolitan and circumtropical species may be considered a secondary event caused by distribution by waterfowl, wind and other means and related to the eurybiontic qualities of these species. Migrations of waterfowl between Eurasia and Australia have been recorded by banding (Lebedeva and Tamkovich, 1977; Mikheev, 1971).

A third group is composed of species common in the Palaearctic or Holarctic, but also occurring in Australia, e.g. Streblocerus serricaudatus, Acroperus alonoides, Biapertura setigera, Moina mongolica, and in limited areas elsewhere (e.g. Pleuroxus similis, Alona archeri). Similar bipolar distributions are known for many other groups besides the Cladocera (Darwin, 1872; Berg, 1947). The disjunct distribution of bipolar cladocerans may be due to dispersal by bipolar migratory birds, but 
Table 9. The distribution of Gondwanaland Cladocera.

\begin{tabular}{|c|c|c|c|c|c|}
\hline Taxon & Australia & India' & $\begin{array}{l}\text { Ethiopian } \\
\text { Region }^{2}\end{array}$ & $\begin{array}{l}\text { South } \\
\text { America }^{3}\end{array}$ & $\begin{array}{l}\text { Other } \\
\text { Lands }{ }^{4}\end{array}$ \\
\hline Diaphanosoma excisum & + & + & + & + & \\
\hline Chydorus eurynotus & + & + & + & + & \\
\hline Chydorus hybridus & + & & & + & N. America \\
\hline Dadaya macrops & + & + & + & + & $\begin{array}{l}\text { East Indies, southern } \\
\text { USA }\end{array}$ \\
\hline Pseudochydorus globosus & + & + & + & & \\
\hline Euryalona orientalis & + & + & + & + & N. America \\
\hline Alonella clathratula & + & & + & + & East Indies \\
\hline Alona cambouei & + & & + & + & $\begin{array}{l}\text { Middle East, southern } \\
\text { asiatic USSR }\end{array}$ \\
\hline Alona poppei & + & & & + & \\
\hline Alona pulchella & + & & + & & Tibet \\
\hline Alona davidi iheringi & + & & + & & Southern asiatic USSR \\
\hline Alona davidi punctata & + & & + & & \\
\hline Alona rectangula novae-zealandiae & + & & + & & \\
\hline Camptocercus australis & + & & + & + & \\
\hline Leydigia ciliata & + & & + & + & $\begin{array}{l}\text { Kazakhstan Rep., } \\
\text { USSR, China }\end{array}$ \\
\hline Leydigia australis & + & & + & & \\
\hline Kurzia longirostris & + & & + & & China \\
\hline Oxyurella singalensis & + & & + & & \\
\hline Graptoleberis testudinaria occidentalis & + & & + & & \\
\hline Ilyocryptus brevidentatus & + & & & + & \\
\hline Moina tenuicornis & + & & + & & \\
\hline Daphnia lumholtzi & + & + & + & & \\
\hline Simocephalus latirostris & + & & + & + & \\
\hline Ceriodaphnia cornuta & + & + & + & & \\
\hline
\end{tabular}

\footnotetext{
1 ex Smirnov, 1971b, 1976.

2 ex Goulden, 1968; Monakov, 1969; Nayor, 1971; Smirnov, 1971b, 1976.

${ }^{3}$ ex Paggi, 1972; Smirnov, 1971b, 1976; Stingelin, 1906; Thomasson, 1963.

${ }^{4}$ ex Brooks, 1966; Smirnov, 1971b, 1976.
}

present restricted distributions could be a relict of a wider distribution in the past, changed by long term fluctuation in climates (Berg, 1947). It has been suggested (e.g. Darwin, 1872; Berg, 1947; Lindberg, 1955 , 1972) that during Pleistocene glaciation, the temperate zones migrated to and from the present equator and that there were considerable changes in sea level. The fauna of the zones went with them, but it is not clear why (Berg, op. cit; Lindberg, op. cit). Further, Berg (1947) is of the opinion that it was mainly northern species that migrated southwards at such times.

A similar explanation may well explain the present distribution of Moina australiensis (restricted to Australasia) and Moina tenuicornis (found in Australia and South Africa) (Goulden, 1968). Goulden's suggestion that they originated in Australia is improbable, since it is unlikely that stem forms of a relatively specialized family would have originated in a land isolated from the main stream of cladoceran evolution. Indeed the presence of $M$. tenuicornis in South Africa, as pointed out by Goulden (1968), suggests that a relict distribution is likely.

The fourth group includes those almost exclusively found in the southern continents (including India and Sri Lanka); they are Gondwanaland forms. However, only 4 of the 24 forms listed in Table 9 are known from all four land masses, but it should be noted that the cladoceran faunas of South Africa and South America are poorly known. Many species are apparently absent from India or South America, or both, while a few (e.g. Indialona globulosa syn. Alona globulosa Daday, 1898, Chydorus ventricosus) are present in South America, South Africa, and India, but not in Australia. There are some species, e.g. Dadaya macrops, which are 
distributed slightly beyond the Gondwanaland continents.

The fifth group comprises the endemics (Table 10). These are comparatively more numerous than in either Europe or North America (Table 8). As indicated above, there are 8 endemic genera in Australia and New Zealand, four of which (all in the subfamily Chydorinae) are known only from Australia. Speciation has been most extensive in Biapertura (7 species), Macrothrix (3 species), Echinisca (7 species), and Daphnia (7 species). In a comparative sense, a large number of endemic Daphniids is not unusual (cf. situation in North America-Brooks, 1957), but it is atypical for Biapertura and Echinisca (and closely related Macrothrix) to have several endemic species.

The majority of Australian endemics occur in the south-east, northern Qld and south-western W.A. (14 in W.A., 3 in S.A., 11 in Tas., 16 in Vic., 26 in N.S.W., 16 in Qld), with the most in coastal N.S.W. (18 species). The genus Biapertura is most diverse in this coastal region while three of the four endemic genera ( $R a k$, Rhynchochydorus, Monope) are found in it exclusively. Within this area speciation is greatest in the acidic waters of the north-east coast (9 out of 17 species including the three endemic genera). North Queensland also contains some of the endemic species of Biapertura, but more notably the majority of endemic species of Macrothrix and Echinisca occur there. It is not apparent why these two areas are especially important, though it might be due to more intensive collecting in them, but it is notable that cladocerans, unlike calanoid copepods (Bayly, 1967), have diversified in the unusual environment provided by coastal dune lakes. This difference is likely to be associated with comparative niche availability; there few niches available to planktonic forms, but many for littoral-benthic animals.

Overall the Australian cladoceran fauna is quite different from that of other major land masses. It is even considerably different from that of its nearest neighbours in south-east Asia. From the somewhat inadequate data available for Malaysia (C.H. Fernando, personal communication) and Philippines (Mamaril, 1977), the fauna of these countries is composed mainly of species from the first three zoogeographic groups (i.e. cosmopolitan, circumtropical, Palaearctic/Holarctic) with a few Gondwanaland and endemic forms. In sum their fauna is much less diverse than Australia's. Interestingly, both lack, in common with Australia, representatives of the Holopedidae, Polyphemidae,

Table 10. List of endemic taxa of Australasia.

\section{Endemic genera}

Saycia-Australia, New Zealand

Rak n. gen.-Australia

Archepleuroxus n. gen.-Australia

Australochydorus n. gen.-Australia

Monope-Australia

Rhynchochydorus n. gen.-Australia

Neothrix-Australia, New Zealand

Pseudomoina-Australia, New Zealand

\section{Endemic species}

Latonopsis brehmi-Australia

Pseudosida australiensis-Australia

Diaphanosoma unguiculatum-Australia

Saycia cooki-Australia, New Zealand

Archepleuroxus baylyi n. sp.-Australia

Pleuroxus hastirostris-New Zealand

Pleuroxus jugosus-Australia

Rak obtusus n. sp.-Australia

Rak labrosus n. sp.-Australia

Chydorus clelandi-Australia

Monope reticulata-Australia

Australochydorus aporus n. sp.-Australia

Rhynchochydorus australiensis n.sp.-Australia

Alona clathrata-Australia

Alona laevissima-Australia

Alona macracantha-Australia

Alona investis-Australia

Alona setuloides n. sp.-Australia

Acroperus sinuatus-Australia

Camptocercus australis-Australia, New Zealand

Leydigia laevis-Australia

Biapertura kendallensis-Australia
Biapertura longinqua-Australia

Biapertura rigidicaudis-Australia

Biapertura macrocopa-Australia

Biapertura abreviata-Australia

Biapertura duoodonta-Australia

Biapertura rusticoides $\mathrm{n}$. $\mathrm{sp}$.-Australia (Tasmania)

Monospilus diporus n. sp.-Australia

Monospilus elongatus n. sp.-Australia

Macrothrix breviseta $\mathrm{n}$. sp.-Australia

Macrothrix longiseta-Australia

Macrothrix hystrix-Australia

Echinisca schauinslandi-Australia (Tasmania), New Zealand

Echinisca hardingi-Australia

Echinisca carinata-Australia

Echinisca flagellata n. sp.-Australia

Echinisca pectinata-Australia

Echinisca timmsi-Australia

Echinisca williamsi n. sp.-Australia

Pseudomoina lemnae-Australia, New Zealand

Neothrix armata-Australia, New Zealand

Moina australiensis-Australia, New Zealand

Moina flexuosa-Australia

Daphnia magniceps-Australia

Daphnia angulata-Australia

Daphnia wankeltae-Australia

Daphnia projecta-Australia

Daphnia longicephala-Australia

Daphnia nivalis-Australia

Daphnia jollyi-Australia

Simocephalus victoriensis-Australia

Daphniopsis pusilla-Australia

\section{Endemic subspecies}

Alona davidi vermiculata n. ssp.-Australia 
Cercopagidae and Leptodoridae, all widespread Holarctic families.

The New Zealand cladoceran fauna has recently been reported on by Chapman and Lewis (1976). They record 37 species to which we add four more: Alonella brachycopa Brehm, Biapertura setigera (syn. Alona guttata var. setigera Brehm) (in Brehm, 1931) and Biapertura longinqua and Ceriodaphnia quadrangula from $\mathrm{Dr}$ I.A.E. Bayly's slide collection. This depauperate fauna is expected in view of New Zealand's isolation. Significantly, almost all of the species occur in Australia as well, mostly only in the south of the continent, suggesting that the majority reached New Zealand from southern Australia.

It is of special interest to note the restriction to Australia and New Zealand of a primitive species Saycia cooki, the only member of the subfamily Sayciinae in the Chydoridae. It has formed two subspecies, one in each country (Frey, 1971).

The large islands (e.g. Tasmania, Kangaroo I.) adjacent to the southern Australian coast have faunas only slightly less diverse than those in adjacent mainland areas. There are even two endemics (Biapertura rusticoides, Echinisca flagellata) in Tasmania. The cladoceran fauna of smaller islands such as King and Flinders is unknown, but only three species (Pleuroxus aduncus, Chydorus sphaericus, and Macrothrix hirsuticornis), which are widely distributed throughout the world, have been recorded on Macquarie Island, $1500 \mathrm{~km}$ south-east of Tasmania. This low diversity must largely be due to its isolation, but lack of habitat diversity may also be important.

The above facts suggest that faunal composition and speciation of the Australian Cladocera are associated with the separation of Australia from other continents in the course of continental drift some 160 million years ago (Wegener, 1925, 1966; Tarling and Tarling, 1971; Zonenshein and Gorodnitskiy, 1976). Many other Gondwanaland distributions are known for invertebrates of inland waters, e.g. Diptera (Brundin, 1966) and Plecoptera (Illies, 1965). Curiously, most Gondwana species are not found in all the component continents, but only in some. For the centropagid copepods the distribution is South America and Australia (Sewell, 1956), and for cladocerans present incomplete data suggest it tends to be South Africa and Australia.

ACKNOWLEDGEMENTS. We are indebted to the USSR Academy of Sciences, which provided facilities for studies of the Australian Cladocera and paid Dr Smirnov's travel expenses to and from Australia, to the University of Adelaide which provided laboratory space in the Department of Zoology and at the Kangaroo Island Field Station and which supported Dr Smirnov while in Australia, and to Avondale College, Cooranbong, NSW, for support of Dr Timms in numerous collecting expeditions and also in Adelaide.

We very much appreciate the encouragement and hospitality of Prof. W.D. Williams who initially suggested that we combine on writing the present manuscript. We are indebted to Dr I.A.E. Bayly of Monash University for a congenial and productive sojourn in Melbourne. In addition our thanks are due to the Director and staff of the Australian Museum for their willing cooperation and assistance, to Monash University for the use of their field station at Colac, to numerous people who were so hospitable to us as we travelled and studied in various places, and to the many landowners who understandingly permitted collecting on their properties.

The willing cooperation of Drs H. Dumont, P. Hebert, V. Kořinek, N.M. Korovchinsky and the late P. MordukhaiBoltovskoi in the giving their expertise in writing chapters on their particular genera is gratefully acknowledged. Dr Dumont wishes to express his thanks to Mrs Isa Van de Velde for preparation of specimens, including the Scan work. We also wish to thank those who made collections and slides available for study-Dr S. Barker, Dr I.A.E. Bayly, Dr G. Brand, Dr M. Geddes, the late Dr V.H. Jolly, Mr H. Midgley, Mr G. Monteith, Mr D. Morton, Dr R. Shiel, Mr K. Tonkin and Dr K. Walker. 


\section{Appendix 1}

\section{List of localities sampled}

Code to collectors:

IAEB Dr I.A.E. Bayly, Monash University.

GB Dr G. Brand, Ministry of Conservation, Victoria.

DE Dr D. Edward, University of Western Australia.

MG Dr M. Geddes, Adelaide University.

VJ Dr V. Jolly, deceased.

HM Mr H. Midgly, Nambour, Qld.

GM Mr G. Monteith, University of Queensland.

DM Mr D. Morton, Monash University.

AR Dr A. Richardson, University of Tasmania.

RS Dr R. Shiels, Adelaide University.

BT author

KT Mr K. Tonkin, student, Avondale College.

PT Dr P. Tyler, University of Tasmania.

KW Dr K. Walker, Adelaide University.

WDW Prof. W.D. Williams, Adelaide University.

\section{QUEENSLAND}

1. L. Bronto, Cape York, 17.iv.73, GM, $10^{\circ} 46^{\prime} \mathrm{S}, 142^{\circ} 34^{\prime} \mathrm{E}$

2. Nordellos Lag., $15 \mathrm{~km} \mathrm{~S}$ Mareeba, 11.vii. $74, \mathrm{BT}, 17^{\circ} 03^{\prime} \mathrm{S}$, $145^{\circ} 09^{\prime} \mathrm{E}$.

3. Tinaroo Res., via Atherton, 8.vii. $74, \mathrm{BT}, 17^{\circ} 10^{\prime} \mathrm{S}, 145^{\circ} 53^{\prime} \mathrm{E}$.

4. L. Euramoo, via Atherton, 3.vii. $74, \mathrm{BT}, 17^{\circ} 10^{\prime} \mathrm{S}, 145^{\circ} 38^{\prime} \mathrm{E}$.

5. L. Eacham, via Atherton, 4.vii. 74 , BT, $17^{\circ} 17^{\prime} \mathrm{S}, 145^{\circ} 38^{\prime} \mathrm{E}$.

6. Leslie Ck, via Yungaburra, 7.vii.74, BT, $17^{\circ} 19^{\prime} \mathrm{S}, 145^{\circ} 35^{\prime} \mathrm{E}$

7. Salt L., $160 \mathrm{~km} \mathrm{~N}$ Hughenden, 23.vi.74, BT, $19^{\circ} 57^{\prime} \mathrm{S}$, $144^{\circ} 06^{\prime} \mathrm{E}$.

8. Agnes L., $160 \mathrm{~km} \mathrm{~N}$ Hughenden, 23.vi.74, BT, $19^{\circ} 57^{\prime} \mathrm{S}$, $144^{\circ} 06^{\prime} \mathrm{E}$.

9. Louisa L., $160 \mathrm{~km} \mathrm{~N}$ Hughenden, 24.vi.74, BT, $19^{\circ} 58^{\prime} \mathrm{S}$, $144^{\circ} 06^{\prime} \mathrm{E}$.

10. Unnamed ck, $22 \mathrm{~km}$ E Richmond, 25.vi.74, BT, 2047' S, $143^{\circ} 29^{\prime} \mathrm{E}$.

11. Sw. at Pentland, 25.vi.74, BT, $20^{\circ} 31^{\prime} \mathrm{S}, 145^{\circ} 28^{\prime} \mathrm{E}$.

12. L. Powlathanga, $35 \mathrm{~km} \mathrm{~W}$ Charters Towers, 26.vi.74, BT, $20^{\circ} 15^{\prime} \mathrm{S}, 145^{\circ} 58^{\prime} \mathrm{E}$.

13. Horseshoe Lag., $95 \mathrm{~km} \mathrm{NW}$ Charters Towers, 20.vi.74, BT, $20^{\circ} 03^{\prime} \mathrm{S}, 145^{\circ} 29^{\prime} \mathrm{E}$.

14. Dry Lag., $90 \mathrm{~km} \mathrm{NW}$ Charters Towers, 20.vi.74, BT, $20^{\circ} 03^{\prime} \mathrm{S}$, $145^{\circ} 30^{\prime} \mathrm{E}$.

15. L. Toomba, $85 \mathrm{~km} \mathrm{NW}$ Charters Towers, 20.vi.74, BT, $20^{\circ} 00^{\prime} \mathrm{S}, 145^{\circ} 35^{\prime} \mathrm{E}$.

16. Toomba Sw., $80 \mathrm{~km} \mathrm{NW}$ Charters Towers, 21.vi.74, BT, $19^{\circ} 58^{\prime} \mathrm{S}, 145^{\circ} 36^{\prime} \mathrm{E}$.

17. L. Reeves, $70 \mathrm{~km} \mathrm{NW}$ Charters Towers, 19.vi.74, BT, $19^{\circ} 53^{\prime} \mathrm{S}$, $145^{\circ} 50^{\prime} \mathrm{E}$.

18. F.D., Mingela, $47 \mathrm{~km}$ E Charters Towers, 15.vii.74, BT, $19^{\circ} 53^{\prime} \mathrm{S}, 146^{\circ} 50^{\prime} \mathrm{E}$.

19. Lagoon Cr., $24 \mathrm{~km} \mathrm{~S}$ Townsville, 15.vii.74, BT, $19^{\circ} 30^{\prime} \mathrm{S}$, $146^{\circ} 50^{\prime} \mathrm{E}$.

20. A lagoon on Townsville Common, 15.vii.74, BT, $19^{\circ} 15^{\prime} \mathrm{S}$, $146^{\circ} 44^{\prime} \mathrm{E}$.

21. Swamp $5 \mathrm{~km} \mathrm{~W}$ Brandon, 12.viii. 73 , BT, $19^{\circ} 34^{\prime} \mathrm{S}, 147^{\circ} 19^{\prime} \mathrm{E}$

22. Mulgvia Lag., $2 \mathrm{~km}$ E Brandon, 12.viii.73, BT, $19^{\circ} 32^{\prime} \mathrm{S}$, $147^{\circ} 24^{\prime} \mathrm{E}$.

23. Hutchings, Lag., $2 \mathrm{~km} \mathrm{~W}$ Ayr. 12.viii.73, BT, 19³6'S, $147^{\circ} 23^{\prime} \mathrm{E}$.

24. Sheepstation Lag., $5 \mathrm{~km}$ W Ayr, 14.vi.74, BT, $19^{\circ} 35^{\prime} \mathrm{S}$, $147^{\circ} 20^{\prime} \mathrm{E}$.

25. Gladys Lag., $40 \mathrm{~km} \mathrm{SW}$ Ayr, 18.vi.74, BT, $19^{\circ} 54^{\prime} \mathrm{S}, 147^{\circ} 12^{\prime} \mathrm{E}$.

26. Roadside pool at Merinda, nr Bowen, 30.vi.74, BT, $20^{\circ} 01^{\prime} \mathrm{S}$, $148^{\circ} 10^{\prime} \mathrm{E}$.

27. Goose Lag., North Mackay, 30.vi.74, BT, $20^{\circ} 07^{\prime} \mathrm{S}, 149^{\circ} 12^{\prime} \mathrm{E}$.

28. Teewarrina Lag., via Charters Towers, 15 .vii. $74, \mathrm{BT}, 21^{\circ} 01^{\prime} \mathrm{S}$, $146^{\circ} 05^{\prime} \mathrm{E}$.
29. Cauckingburra Sw., $3 \mathrm{~km} \mathrm{~N} \mathrm{~L}$. Buchanan, 16.vii.74, BT, $21^{\circ} 29^{\prime} \mathrm{S}, 145^{\circ} 53^{\prime} \mathrm{E}$.

30. L. Buchanan, c. $180 \mathrm{~km} \mathrm{~S}$ Charters Towers, 16.vii.74, BT, $21^{\circ} 35^{\prime} \mathrm{S}, 145^{\circ} 52^{\prime} \mathrm{E}$.

31. L. Galilee, c. $90 \mathrm{~km} \mathrm{NE} \mathrm{Aramac,} \mathrm{17.vii.74,} \mathrm{BT,} 22^{\circ} 22^{\prime} \mathrm{S}$, $145^{\circ} 48^{\prime} \mathrm{E}$.

32. Pond on Lake Dunn Station, via Aramac, 17.vii.74, BT, $22^{\circ} 29^{\prime} \mathrm{S}, 145^{\circ} 38^{\prime} \mathrm{E}$.

33. Swamp on Lake Dunn Station, via Aramac, 17.vii.74, BT, $22^{\circ} 29^{\prime} \mathrm{S}, 145^{\circ} 38^{\prime} \mathrm{E}$.

34. L. Dunn, c. $70 \mathrm{~km}$ NE Aramac, 17.vii.74, BT, $22^{\circ} 36^{\prime} \mathrm{S}$, $145^{\circ} 40^{\prime} \mathrm{E}$.

35. Aramac Ck at Aramac, 17.vii.74, BT, $22^{\circ} 58^{\prime} \mathrm{S}, 145^{\circ} 14^{\prime} \mathrm{E}$

36. F.D., Bogantungan, 18.vii. $74, \mathrm{BT}, 23^{\circ} 39^{\prime} \mathrm{S}, 147^{\circ} 16^{\prime} \mathrm{E}$.

37. A billabong $10 \mathrm{~km} \mathrm{~W}$ Anakie, 18.vii.74, BT, $23^{\circ} 36^{\prime} \mathrm{S}$, $147^{\circ} 38^{\prime} \mathrm{E}$.

38. F.D. at Anakie, 18.vii. $74, \mathrm{BT}, 23^{\circ} 35^{\prime} \mathrm{S}, 147^{\circ} 45^{\prime} \mathrm{E}$.

39. Gracemere Lag., $10 \mathrm{~km}$ W Rockhampton, 11.vi.74, BT, $23^{\circ} 26^{\prime} \mathrm{S}, 150^{\circ} 27^{\prime} \mathrm{E}$.

40. Woolwash Lag., $8 \mathrm{~km} \mathrm{~S}$ Rockhampton, 11.vi.74, BT, $23^{\circ} 26^{\prime} \mathrm{S}$, $250^{\circ} 32^{\prime} \mathrm{E}$.

41. Larcom Vale Ck, nr Mt. Larcom, 11.vi.74, BT, $23^{\circ} 48^{\prime} \mathrm{S}$, $150^{\circ} 59^{\prime} \mathrm{E}$.

42. F.D. $15 \mathrm{~km} \mathrm{~N}$ Gin Gin, 11.vi.74, BT, $24^{\circ} 54^{\prime} \mathrm{S}, 151^{\circ} 50^{\prime} \mathrm{E}$.

43. A billabong $30 \mathrm{~km} \mathrm{~S}$ Rolleston, 20.vii.74, BT, $24^{\circ} 41^{\prime} \mathrm{S}$, $148^{\circ} 28^{\prime} \mathrm{E}$.

44. F.D. near Gayndah, 29.x.64, BT, $25^{\circ} 37^{\prime} \mathrm{S}, 151^{\circ} 43^{\prime} \mathrm{E}$.

45. F.D. near Wonga Lower, 29.x.64, BT, $26^{\circ} 04^{\prime} \mathrm{S}, 152^{\circ} 29^{\prime} \mathrm{E}$.

46. “AB" Lake, Fraser I., ? IAEB, $25^{\circ} 12^{\prime} \mathrm{S}, 153^{\circ} 13^{\prime} \mathrm{E}$.

47. L. Wabby, Fraser I., xii.75, IAEB, $25^{\circ} 28^{\prime} \mathrm{S}, 153^{\circ} 08^{\prime} \mathrm{E}$.

48. L. Freshwater, Cooloola, 16.vii.75, BT, $26^{\circ} 00^{\prime} \mathrm{S}, 153^{\circ} 08^{\prime} \mathrm{E}$.

49. Swamp at Cooloola, 16.vii.75, BT, $26^{\circ} 07^{\prime} \mathrm{S}, 153^{\circ} 03^{\prime} \mathrm{E}$.

50. Upper Tewah Ck, nr Cooloola, 15.vii.75, BT, $26^{\circ} 02^{\prime} \mathrm{S}$, $153^{\circ} 00^{\prime} \mathrm{E}$.

51. Noosa R., nr Cooloola, 15.vii. 75 , BT, $26^{\circ} 02^{\prime} \mathrm{S}, 153^{\circ} 00^{\prime} \mathrm{E}$.

52. Borumba Dam, $40 \mathrm{~km}$ SW Gympie, see Timms and Midgley (1969), $26^{\circ} 31^{\prime} \mathrm{S}, 152^{\circ} 35^{\prime} \mathrm{E}$.

53. F.D. $\mathrm{nr}$ Kenilworth, 15.v.65, BT, $26^{\circ} 36^{\prime} \mathrm{S}, 152^{\circ} 43^{\prime} \mathrm{E}$.

54. Obi Obi Ck, Maleny, 15.v.65, BT, $26^{\circ} 45^{\prime} \mathrm{S}, 152^{\circ} 51^{\prime} \mathrm{E}$.

55. Brown L., Stradbroke I., 13.x.59, IAEB, $27^{\circ} 30^{\prime}$ S, $153^{\circ} 26^{\prime} \mathrm{E}$.

56. University Pond, St. Lucia, Brisbane, see Timms (1967) $27^{\circ} 30^{\prime} \mathrm{S}, 153^{\circ} 00^{\prime} \mathrm{E}$.

57. South Pine R., nr Samford, 18.vii.65, BT, $27^{\circ} 21^{\prime} \mathrm{S}, 152^{\circ} 53^{\prime} \mathrm{E}$.

58. Cedar Ck, nr Samford, 1.viii.65, BT, $27^{\circ} 20^{\prime} \mathrm{S}, 152^{\circ} 52^{\prime} \mathrm{E}$.

59. Pond at Sherwood, Brisbane, 1.v.59, IAEB, $27^{\circ} 31^{\prime} \mathrm{S}$, $152^{\circ} 58^{\prime} \mathrm{E}$.

60. Pool at Enogerra Res., Brisbane, 1.v.59, IAEB, $27^{\circ} 27^{\prime} \mathrm{S}$, $152^{\circ} 55^{\prime} \mathrm{E}$.

61. Gold Ck, Res., Brisbane, 1.v.59, IAEB, $27^{\circ} 28^{\prime} \mathrm{S}, 152^{\circ} 53^{\prime} \mathrm{E}$.

62. Manchester Res., via Ipswich, 15.viii.59, IAEB, $27^{\circ} 29^{\prime} \mathrm{S}$, $152^{\circ} 46^{\prime} \mathrm{E}$.

63. Swamp at Helidon,-, IAEB, $27^{\circ} 33^{\prime} \mathrm{S}, 152^{\circ} 08^{\prime} \mathrm{E}$.

64. Atkinsons Lag., via Ipswich, 10.vi.59, IAEB, $27^{\circ} 26^{\prime} \mathrm{S}$, $152^{\circ} 27^{\prime} \mathrm{E}$.

65. F.D. at Wildash, via Warwick, 16.v.65, BT, $28^{\circ} 22^{\prime} \mathrm{S}$, $152^{\circ} 03^{\prime} \mathrm{E}$.

66. Storm King Dam, via Stanthorpe, 9.xi.64, BT, $28^{\circ} 44^{\prime} \mathrm{S}$, $152^{\circ} 00^{\prime} \mathrm{E}$.

\section{New South Wales}

76. Wilson's Ck Res., via Mullumbimby, 3.i.68, BT, $28^{\circ} 35^{\prime} \mathrm{S}$, $153^{\circ} 27^{\prime} \mathrm{E}$.

77. Emigrant $\mathrm{Ck}, 10 \mathrm{~km} \mathrm{~N}$ Ballina, 18.viii.65, BT, $28^{\circ} 48^{\prime} \mathrm{S}$, $153^{\circ} 31^{\prime} \mathrm{E}$.

78. Dune pond nr Evans Head, 11.ix.77, BT, $29^{\circ} 11^{\prime} \mathrm{S}, 153^{\circ} 22^{\prime} \mathrm{E}$

79. Cooks Lag., via Evans Head, 10.viii.75, BT, $29^{\circ} 12^{\prime} \mathrm{S}$, $153^{\circ} 22^{\prime} \mathrm{E}$.

80. Swamp, via Brooms Head, 18.viii. 77 , BT, $29^{\circ} 38^{\prime} \mathrm{S}, 153^{\circ} 19^{\prime} \mathrm{E}$.

81. L. Minnie Water, via Grafton, 24.viii.67, BT, $29^{\circ} 50^{\prime} \mathrm{S}$, $153^{\circ} 17^{\prime} \mathrm{E}$. 
82. Swamp near Red Rock Nat. Pk, 25.iii.77, BT, $29^{\circ} 54^{\prime} \mathrm{S}$, $153^{\circ} 15^{\prime} \mathrm{E}$.

83. Dune Sw., near Red Rock Nat. Pk, 25.iii.77, BT, $29^{\circ} 54^{\prime} \mathrm{S}$, $153^{\circ} 15^{\prime} \mathrm{E}$

84. Swamp, Red Rock Nat. Pk, 28.iii.77, BT, $29^{\circ} 58^{\prime} \mathrm{S}, 153^{\circ} 15^{\prime} \mathrm{E}$

85. Blue Lagoon, Red Rock Nat. Pk, 27.iii.77, BT, $29^{\circ} 58^{\prime} \mathrm{S}$, $153^{\circ} 15^{\prime} \mathrm{E}$.

86. Pond, $20 \mathrm{~km} \mathrm{~W}$ Grafton, 8.i.67, BT, $29^{\circ} 39^{\prime} \mathrm{S}, 152^{\circ} 46^{\prime} \mathrm{E}$.

87. Kiel's I.D., $10 \mathrm{~km}$ NE Macksville, 24.viii.67, BT, $30^{\circ} 40^{\prime} \mathrm{S}$, $152^{\circ} 58^{\prime} \mathrm{E}$.

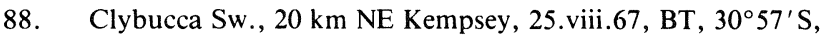
$152^{\circ} 57^{\prime} \mathrm{E}$.

89. Pond, $4 \mathrm{~km}$ W Port Macquarie, 18.viii.65, BT, $31^{\circ} 27^{\prime} \mathrm{S}$, $152^{\circ} 54^{\prime} \mathrm{E}$

90. Allens I.D., $6 \mathrm{~km}$ E Wauchope, 8.vii.67, BT, $31^{\circ} 28^{\prime} \mathrm{S}$, $152^{\circ} 47^{\prime} \mathrm{E}$.

91. Mining Pond $3 \mathrm{~km} \mathrm{~N}$ North Haven, 16.iv.74, BT, $31^{\circ} 27^{\prime} \mathrm{S}$, $152^{\circ} 50^{\prime} \mathrm{E}$.

92. Lansdowne Res., via Taree, 8.viii.67, BT, $31^{\circ} 47^{\prime} \mathrm{S}, 152^{\circ} 32^{\prime} \mathrm{E}$

93. Ellis F.D, $6 \mathrm{~km} \mathrm{~W}$ Stratford, 21.iii.76, BT, $32^{\circ} 07^{\prime} \mathrm{S}, 151^{\circ} 58^{\prime} \mathrm{E}$.

94. Myall L., at Shelly Pt, Bungwahl, 9.ix.73, BT, $32^{\circ} 28^{\prime} \mathrm{S}$, $152^{\circ} 22^{\prime} \mathrm{E}$.

95. Myall R., nr Broadwater, 15.iv.74, BT, $32^{\circ} 32^{\prime} \mathrm{S}, 152^{\circ} 15^{\prime} \mathrm{E}$.

96. Eurunderee Lag., Myall Lakes Nat. Pk, see Timms In Prep., $32^{\circ} 32^{\prime} \mathrm{S}, 152^{\circ} 20^{\prime} \mathrm{E}$.

97. Swamp, nr Eurunderee Lag., Myall Lakes Nat. Pk, see Timms In Prep., $32^{\circ} 32^{\prime} \mathrm{S}, 152^{\circ} 20^{\prime} \mathrm{E}$.

98. Swamp, nr Johnsons Hill, Myall Lakes Nat. Pk, see Timms In Prep., $32^{\circ} 32^{\prime} \mathrm{S}, 152^{\circ} 20^{\prime} \mathrm{E}$.

99. Swamp, nr Bombah Pt, Myall Lakes Nat. Pk, see Timms In Prep., $32^{\circ} 32^{\prime} \mathrm{S}, 152^{\circ} 17^{\prime} \mathrm{E}$

100. Swamp, nr Sugar Pt, Myall Lakes Nat. Pk, see Timms In Prep., $32^{\circ} 32^{\prime} \mathrm{S}, 152^{\circ} 16^{\prime} \mathrm{E}$

101. Mining Pond, Myall Lakes Nat. Pk, 24.iii.74, BT, $32^{\circ} 36^{\prime}$ S, $152^{\circ} 16^{\prime} \mathrm{E}$.

102. Herding Yard Ck, via Amosfield, 14.iv.65, BT, 28 $39^{\prime} \mathrm{S}$, $152^{\circ} 04^{\prime} \mathrm{E}$.

103. Four Mile Ck, via Deepwater, 8.viii.65, BT, $29^{\circ} 23^{\prime} \mathrm{S}$, $151^{\circ} 54^{\prime} \mathrm{E}$

104. Beardy Waters Res., Glen Innes, 18.viii.67, BT, $29^{\circ} 45^{\prime} \mathrm{S}$, $151^{\circ} 47^{\prime} \mathrm{E}$.

105. Llangothlin Lagoon via Guyra, 17.viii.67, BT, $30^{\circ} 04^{\prime} \mathrm{S}$, $151^{\circ} 46^{\prime} \mathrm{E}$.

106. Guyra Water Supply Res., via Guyra 17.viii.67, BT, $30^{\circ} 10^{\prime} \mathrm{S}$, $151^{\circ} 43^{\prime} \mathrm{E}$.

107. Doughboy Ck, via Ebor, 8.viii. 65 , BT, $30^{\circ} 19^{\prime} \mathrm{S}, 152^{\circ} 12^{\prime} \mathrm{E}$.

108. Gara Dam, via Armidale, 16. viii. 67 , BT, $30^{\circ} 32^{\prime} \mathrm{S}, 151^{\circ} 48^{\prime} \mathrm{E}$.

109. MacDonald R., Bendemeer, 9.viii.65, BT, $30^{\circ} 53^{\prime} \mathrm{S}, 151^{\circ} 10^{\prime} \mathrm{E}$.

110. Keepit Res., via Gunnedah, 9.viii.65, BT, $30^{\circ} 54^{\prime} \mathrm{S}, 150^{\circ} 30^{\prime} \mathrm{E}$.

111. Manilla Res., at Manilla, 4.viii.67, BT, $32^{\circ} 38^{\prime} \mathrm{S}, 151^{\circ} 36^{\prime} \mathrm{E}$.

112. Pond at Tocal, via Paterson, 20.vi.67, BT, $32^{\circ} 38^{\prime} \mathrm{S}, 151^{\circ} 36^{\prime} \mathrm{E}$.

113. Maitland Power Station Res., via Maitland, 4.ix.66, BT, $32^{\circ} 45^{\prime} \mathrm{S}, 151^{\circ} 30^{\prime} \mathrm{E}$

114. Kitchener Colliery Res., via Cessnock, 13.viii.67, BT, $32^{\circ} 53^{\prime} \mathrm{S}$, $151^{\circ} 23^{\prime} \mathrm{E}$.

115. Abernethy Res., via Cessnock, 11.viii.66, BT, 32 $53^{\prime} \mathrm{S}$, $151^{\circ} 25^{\prime} \mathrm{E}$.

116. Ellalong Lag., via Cessnock, $11 . i x .66, \mathrm{BT}, 32^{\circ} 56^{\prime} \mathrm{S}, 151^{\circ} 18^{\prime} \mathrm{E}$.

117. Richmond Main Res., via Kurri Kurri, 11.ix.66, BT, $32^{\circ} 52^{\prime}$ 'S, $151^{\circ} 31^{\prime} \mathrm{E}$.

118. Redhead Lag., at Dudley, Newcastle, 16.xi.75, BT, 32 ${ }^{\circ} 59^{\prime} \mathrm{S}$, $151^{\circ} 44^{\prime} \mathrm{E}$

119. F.D. $3 \mathrm{~km} \mathrm{~W}$ Cooranbong, 4.ix.67, BT, $33^{\circ} 03^{\prime} \mathrm{S}, 151^{\circ} 25^{\prime} \mathrm{E}$.

120. Pond, $1 \mathrm{~km} \mathrm{~W}$ Cooranbong, 9.ix.67, BT, $33^{\circ} 04^{\prime} \mathrm{S}, 151^{\circ} 27^{\prime} \mathrm{E}$.

121. F.D. $8 \mathrm{~km} \mathrm{~W}$ Cooranbong, 4.ix.66, BT, $33^{\circ} 02^{\prime} \mathrm{S}, 151^{\circ} 25^{\prime} \mathrm{E}$.

122. Morisset Hospital Res., $2 \mathrm{~km} \mathrm{~S}$ Morisset, 15.viii.67, BT, $33^{\circ} 08^{\prime} \mathrm{S}, 151^{\circ} 29^{\prime} \mathrm{E}$.

123. Mardi Res., via Wyong, 27 viii.67, BT, $33^{\circ} 18^{\prime} \mathrm{S}, 151^{\circ} 22^{\prime} \mathrm{E}$.

124. Mt. Misery Res., via Liverpool, ?, ?, ?, ?, ?.

125. Picton L., via Thirlmere, 10.v.75, BT, $34^{\circ} 14^{\prime} \mathrm{S}, 150^{\circ} 32^{\prime} \mathrm{E}$.

126. Roadside Pond at Dunmore, 15.v.75, BT, $34^{\circ} 37^{\prime} \mathrm{S}, 150^{\circ} 51^{\prime} \mathrm{E}$.

127. Pond at Nowra, 15.v.75, BT, $34^{\circ} 53^{\prime} \mathrm{S}, 150^{\circ} 35^{\prime} \mathrm{E}$.
128. Lake nr Corunna L., via Narooma, 14.v.75, BT, $36^{\circ} 17^{\prime} \mathrm{S}$, $150^{\circ} 08^{\prime} \mathrm{E}$

129. Swamp, at Bega, 14.v.75, BT, $36^{\circ} 41^{\prime} \mathrm{S}, 149^{\circ} 52^{\prime} \mathrm{E}$.

130. Pond nr Bondi L., 14.v. 75 , BT, $36^{\circ} 48^{\prime} \mathrm{S}, 149^{\circ} 58^{\prime} \mathrm{E}$.

131. Bondi L., via Bega, 14.v.75, BT, $36^{\circ} 49^{\prime} \mathrm{S}, 149^{\circ} 58^{\prime} \mathrm{E}$

132. Swamp at Pambula, 14.v.75, BT, $36^{\circ} 57^{\prime} \mathrm{S}, 149^{\circ} 53^{\prime} \mathrm{E}$.

133. Tarago Lag., $30 \mathrm{~km}$ S Goulburn, 10.v.75, BT, $34^{\circ} 54^{\prime} \mathrm{S}$, $149^{\circ} 31^{\prime} \mathrm{E}$.

134. L. George, via Canberra, 10.v. $75, \mathrm{BT}, 35^{\circ} 05^{\prime} \mathrm{S}, 149^{\circ} 25^{\prime} \mathrm{E}$.

135. Muddah L., $16 \mathrm{~km} \mathrm{~N}$ Cooma, $13 . v .75, \mathrm{BT}, 36^{\circ} 07^{\prime} \mathrm{S}, 149^{\circ} 02^{\prime} \mathrm{E}$

136. Unnamed lake No. $1,18 \mathrm{~km}$ W Cooma, $12 . v .75$, BT, $36^{\circ} 15^{\prime} \mathrm{S}$, $148^{\circ} 58^{\prime} \mathrm{E}$.

137. Island L., $25 \mathrm{~km} \mathrm{~W}$ Cooma, 13.v. 75 , BT, $36^{\circ} 14^{\prime} \mathrm{S}, 148^{\circ} 56^{\prime} \mathrm{E}$.

138. Unnamed lake No. $2,28 \mathrm{~km}$ W Cooma, 13.v.75, BT, $36^{\circ} 15^{\prime} \mathrm{S}$, $148^{\circ} 53^{\prime} \mathrm{E}$.

139. Unnamed lake No. 3, $\mathrm{nr}$ L. Cootralantra, via Cooma, 13.v.75, BT, $36^{\circ} 16^{\prime} \mathrm{S}, 148^{\circ} 53^{\prime} \mathrm{E}$

140. Unnamed lake No. 4, nr L. Cootralantra, via Cooma, 13.v.75, BT, $36^{\circ} 16^{\prime} \mathrm{S}, 148^{\circ} 52^{\prime} \mathrm{E}$.

141. Unnamed lake No. 5, nr L. Cootralantra, via Cooma, 13.v.75, BT, $36^{\circ} 17^{\prime} \mathrm{S}, 148^{\circ} 53^{\prime} \mathrm{E}$.

142. Sandy $\mathrm{Ck}, 15 \mathrm{~km} \mathrm{~N}$ Berridale, $13 . v .75$, BT, $36^{\circ} 17^{\prime} \mathrm{S}, 148^{\circ} 48^{\prime} \mathrm{E}$.

143. Hugundara Lag., $16 \mathrm{~km} \mathrm{~N}$ Berridale, 13.v.75, BT, $36^{\circ} 17^{\prime} \mathrm{S}$, $148^{\circ} 47^{\prime} \mathrm{E}$.

144. Kiah L., $10 \mathrm{~km}$ NW Berridale, 13.v.75, BT, $36^{\circ} 20^{\prime} \mathrm{S}$, $148^{\circ} 47^{\prime} \mathrm{E}$

145. L. Bullenbalong, $22 \mathrm{~km}$ NW Berridale, 13.v.75, BT, $36^{\circ} 19^{\prime} \mathrm{S}$, $148^{\circ} 42^{\prime} \mathrm{E}$.

146. Blue L., Mt Kosciusko, 24.ii.69, IAEB, $36^{\circ} 24^{\prime} \mathrm{S}, 148^{\circ} 19^{\prime} \mathrm{E}$.

147. L. Albina, Mt Kosciusko, 8.ii. 77 , BT, $36^{\circ} 26^{\prime} \mathrm{S}, 148^{\circ} 16^{\prime} \mathrm{E}$

148. Pond $\mathrm{nr}$ L. Albina, Mt Kosciusko, 8.ii.77, BT, $36^{\circ} 26^{\prime} \mathrm{S}$, $148^{\circ} 16^{\prime} \mathrm{E}$.

149. Unnamed lagoon $6,12 \mathrm{~km} \mathrm{~S}$ Cooma, 14.v.75, BT, $36^{\circ} 19^{\prime} \mathrm{S}$ $149^{\circ} 06^{\prime} \mathrm{E}$.

150. Unnamed pond $7,17 \mathrm{~km} \mathrm{~S}$ Cooma, 14.v.75, BT, $36^{\circ} 20^{\prime} \mathrm{S}$, $149^{\circ} 04^{\prime} \mathrm{E}$.

151. L. Arable, $20 \mathrm{~km} \mathrm{~S}$ Cooma, 14.v. 75 , BT, $36^{\circ} 20^{\prime} \mathrm{S}, 149^{\circ} 02^{\prime} \mathrm{E}$.

152. Unnamed lake $8,22 \mathrm{~km} \mathrm{SW}$ Cooma, 14.v.75, BT, $36^{\circ} 20^{\prime} \mathrm{S}$, $149^{\circ} 01^{\prime} \mathrm{E}$

153. Unnamed lake 9, $30 \mathrm{~km} \mathrm{SW}$ Cooma, 14.v.75, BT, $36^{\circ} 20^{\prime} \mathrm{S}$ $148^{\circ} 59^{\prime} \mathrm{E}$.

154. Unnamed pond $10,10 \mathrm{~km}$ E Berridale, 14.v.75, BT, $36^{\circ} 22^{\prime} \mathrm{S}$, $148^{\circ} 58^{\prime} \mathrm{E}$.

155. Carrolls Lake, $10 \mathrm{~km}$ E Berridale 14.v.75, BT, $36^{\circ} 22^{\prime} \mathrm{S}$, $148^{\circ} 56^{\prime} \mathrm{E}$.

156. Unnamed pond 11 , nr Wullwye Ck, 14.v.75, BT, $36^{\circ} 23^{\prime} \mathrm{S}$, $148^{\circ} 54^{\prime} \mathrm{E}$

157. Buckley's Lag., $16 \mathrm{~km}$ SE Berridale, 14.v.75, BT, $36^{\circ} 27^{\prime} \mathrm{S}$, $148^{\circ} 58^{\prime} \mathrm{E}$.

158. Maffra L., $18 \mathrm{~km}$ E Dalgety, 14.v.75, BT, $36^{\circ} 32^{\prime} \mathrm{S}, 149^{\circ} 00^{\prime} \mathrm{E}$

159. Unnamed pond $12,19 \mathrm{~km}$ E Dalgety, 14.v.75, BT, $36^{\circ} 32^{\prime} \mathrm{S}$, $149^{\circ} 00^{\prime} \mathrm{E}$

160. Unnamed lake 13, at Bungarby, 14.v.75, BT, $36^{\circ} 40^{\prime} \mathrm{S}$, $149^{\circ} 02^{\prime} \mathrm{E}$

161. Barkers L., near Bungarby, 14.v. 75 , BT, $36^{\circ} 42^{\prime} \mathrm{S}, 149^{\circ} 02^{\prime} \mathrm{E}$.

162. Boundary L., $18 \mathrm{~km} \mathrm{~W}$ Nimmitabel, $15 . v .75$, BT, $36^{\circ} 32^{\prime} \mathrm{S}$, $149^{\circ} 08^{\prime} \mathrm{E}$.

163. Wyuna L., $11 \mathrm{~km}$ W Nimmitabel, 15.v.75, BT, $36^{\circ} 30^{\prime} \mathrm{S}$, $149^{\circ} 11^{\prime} \mathrm{E}$.

164. Unnamed L. 14, $21 \mathrm{~km} \mathrm{~N}$ Bombala, 15.v.75, BT, $36^{\circ} 43^{\prime} \mathrm{S}$ $149^{\circ} 16^{\prime} \mathrm{E}$

165. Black L., $5 \mathrm{~km}$ SE Bibbenluke, 15.v.75, BT, $36^{\circ} 50^{\prime} \mathrm{S}$, $149^{\circ} 18^{\prime} \mathrm{E}$

166. Green L., $6 \mathrm{~km}$ SE Bibbenluke, 15.v.75, BT, $36^{\circ} 50^{\prime} \mathrm{S}$, $149^{\circ} 18^{\prime} \mathrm{E}$.

167. Unnamed swamp $15,4 \mathrm{~km} \mathrm{~S}$ Cathcart, $15 . \mathrm{v} .75$, BT, $36^{\circ} 53^{\prime} \mathrm{S}$ $149^{\circ} 25^{\prime} \mathrm{E}$.

168. Unnamed lake $16,1 \mathrm{~km} \mathrm{~N}$ Cathcart, 15.v.75, BT, $36^{\circ} 52^{\prime} \mathrm{S}$ $149^{\circ} 25^{\prime} \mathrm{E}$

169. F.D. $2 \mathrm{~km} \mathrm{~W}$ Lightning Ridge, 22.vii.74, BT, $29^{\circ} 26^{\prime} \mathrm{S}$, $147^{\circ} 59^{\prime} \mathrm{E}$.

170. Narran L., via Brewarrina, 22.vii. $74, \mathrm{BT}, 29^{\circ} 52^{\prime} \mathrm{S}, 147^{\circ} 19^{\prime} \mathrm{E}$ 
171. Castlereagh R. at Coonabarabran, 10.viii.65, BT, $31^{\circ} 16^{\prime} \mathrm{S}$, $149^{\circ} 17^{\prime} \mathrm{E}$.

172. Ulan Power Station Res., via Ulan, 14.xii.73, BT, $32^{\circ} 17^{\prime} \mathrm{S}$, $149^{\circ} 45^{\prime} \mathrm{E}$

173. F.D. $12 \mathrm{~km} \mathrm{NE}$ Mudgee, $14 . x i i .73, \mathrm{BT}, 32^{\circ} 31^{\prime} \mathrm{S}, 149^{\circ} 41^{\prime} \mathrm{E}$.

174. F.D. $30 \mathrm{~km} \mathrm{NE}$ Gulgong, 13.xii. 73 , BT, $32^{\circ} 23^{\prime} \mathrm{S}, 149^{\circ} 14^{\prime} \mathrm{E}$.

175. Coan Waterhole, Trangie, 13.xii. 73 , BT, $32^{\circ} 02^{\prime} \mathrm{S}, 147^{\circ} 59^{\prime} \mathrm{E}$.

176. Nyngan Res., at Nyngan, 13.xii.73, BT, $31^{\circ} 35^{\prime} \mathrm{S}, 147^{\circ} 11^{\prime} \mathrm{E}$.

177. Unnamed swamp, $35 \mathrm{~km}$ E Cobar, 12.xii.73, BT, $31^{\circ} 31^{\prime} \mathrm{S}$, $146^{\circ} 13^{\prime} \mathrm{E}$.

178. Old Cobar Res., at Cobar, 12.xii. 73 , BT, $31^{\circ} 29^{\prime} \mathrm{S}, 145^{\circ} 52^{\prime} \mathrm{E}$.

179. Bulla Bulla Tank, $100 \mathrm{~km}$ W Cobar, 12.xii.73, BT, $31^{\circ} 34^{\prime} \mathrm{S}$, $144^{\circ} 38^{\prime} \mathrm{E}$

180. Unnamed swamp, $70 \mathrm{~km}$ E Wilcannia, 12.xii. 73 , BT, $31^{\circ} 43^{\prime} \mathrm{S}$, $144^{\circ} 02^{\prime} \mathrm{E}$

181. Darling R. Wilcannia, 12.xii.73, BT, $31^{\circ} 34^{\prime} \mathrm{S}, 143^{\circ} 22^{\prime} \mathrm{E}$.

182. Irrigation Canal at Copi Hollow, Mendindee, 11.xii.73, BT, $32^{\circ} 16^{\prime} \mathrm{S}, 142^{\circ} 23^{\prime} \mathrm{E}$.

183. Umberumberka Res., via Broken Hill, 10.xii. 73 , BT, $31^{\circ} 50^{\prime} \mathrm{S}$, $141^{\circ} 13^{\prime} \mathrm{E}$

184. L. Albert, Wagga Wagga, 29.xi.73, BT, $35^{\circ} 10^{\prime} \mathrm{S}, 147^{\circ} 23^{\prime} \mathrm{E}$.

185. Rice paddy, $8 \mathrm{~km}$ E Yanco, 17 .xii. 75 , BT, $34^{\circ} 40^{\prime} \mathrm{S}, 146^{\circ} 29^{\prime} \mathrm{E}$.

186. Unnamed billabong, $7 \mathrm{~km} \mathrm{~S}$ Yanco, 17.xii. 75 , BT, $34^{\circ} 38^{\prime} \mathrm{S}$, $146^{\circ} 22^{\prime} \mathrm{E}$.

187. L. Yanga, via Balranald, 17.xii. $75, \mathrm{BT}, 34^{\circ} 43^{\prime} \mathrm{S}, 143^{\circ} 36^{\prime} \mathrm{E}$.

188. L. Cowndilla, Menindee Lakes, 22.v.78, RS, $32^{\circ} 28^{\prime} \mathrm{S}$, $142^{\circ} 15^{\prime} \mathrm{E}$

\section{VICTORIA}

201. L. Barracoota, via Mallacoota, see Timms 1973a, BT, $37^{\circ} 32^{\prime}$ S, $149^{\circ} 53^{\prime} \mathrm{E}$

202. L. Elusive, via Cann R. Township, see Timms 1973a, BT, $37^{\circ} 45^{\prime} \mathrm{S}, 149^{\circ} 28^{\prime} \mathrm{E}$

203. L. Beadle, via Orbost, see Timms 1973a, BT, $37^{\circ} 46^{\prime} \mathrm{S}$, $148^{\circ} 26^{\prime} \mathrm{E}$.

204. Roadside pool, $8 \mathrm{~km} \mathrm{~S}$ Buchan, 18.vii.73, DM, $37^{\circ} 37^{\prime} \mathrm{S}$, $148^{\circ} 08^{\prime} \mathrm{E}$.

205. Roadside pool, $9 \mathrm{~km} \mathrm{~N}$ Sale, 19.vii.73, DM, $38^{\circ} 01^{\prime} \mathrm{S}$, $147^{\circ} 03^{\prime} \mathrm{E}$.

206. Pool, Gifford West, via Sale, 22.viii.61, VJ, $38^{\circ} 23^{\prime} \mathrm{S}$, $146^{\circ} 58^{\prime} \mathrm{E}$.

207. L. Omeo, via Omeo 1.xi. 70 , BT, $36^{\circ} 58^{\prime} \mathrm{S}, 147^{\circ} 41^{\prime} \mathrm{E}$.

208. Roadside pool nr Yarram, 9.v.74, DM, $38^{\circ} 36^{\prime} \mathrm{S}, 146^{\circ} 40^{\prime} \mathrm{E}$.

209 Pond, nr Traralgon, 17.vii.73, DM, 38 $11^{\prime} \mathrm{S}, 146^{\circ} 45^{\prime} \mathrm{E}$.

210. Pond, nr Cape Liptrap, 8.ix.74, DM, $38^{\circ} 53^{\prime} \mathrm{S}, 145^{\circ} 58^{\prime} \mathrm{E}$.

211. F.D. nr Cape Liptrap, 8.ix.74, DM, 38 $54^{\prime} \mathrm{S}, 145^{\circ} 58^{\prime} \mathrm{E}$.

212. F.D. nr Tarwin, 9.v.74, DM, $38^{\circ} 37^{\prime} \mathrm{S}, 145^{\circ} 57^{\prime} \mathrm{E}$.

213. Pond, nr Bunyip R, 8.viii. 73 , DM, $38^{\circ} 16^{\prime} \mathrm{S}, 145^{\circ} 29^{\prime} \mathrm{E}$.

214. Roadside pool, Tooradin, 26.vi. $73, \mathrm{DM}, 38^{\circ} 13^{\prime} \mathrm{S}, 145^{\circ} 22^{\prime} \mathrm{E}$.

215. Roadside pool, Cranbourne, 24.v.73, DM, $38^{\circ} 06^{\prime} \mathrm{S}, 145^{\circ} 17^{\prime} \mathrm{E}$.

216. Pond, nr Cardinia, 27.vi.73, DM, $38^{\circ} 07^{\prime}$ S, $145^{\circ} 24^{\prime} \mathrm{E}$.

217. F.D. nr Cardinia, 27.vi.73, DM, $38^{\circ} 08^{\prime} \mathrm{S}, 145^{\circ} 25^{\prime} \mathrm{E}$.

218. Belgrave Reservoir, 11.x.62, WDW, $37^{\circ} 55^{\prime} \mathrm{S}, 145^{\circ} 21^{\prime} \mathrm{E}$.

219. Pool Monash University, Clayton, DM, $37^{\circ} 54^{\prime} \mathrm{S}, 145^{\circ} 08^{\prime} \mathrm{E}$.

220. Swamp, Churchill Nat. Pk, via Dandenong, 24.vi.66, IAEB, $37^{\circ} 57^{\prime} \mathrm{S}, 145^{\circ} \mathrm{E}$

221. Pond, Churchill Nat. Pk, via Dandenong, 24.vi.66, IAEB, $37^{\circ} 57^{\prime} \mathrm{S}, 145^{\circ} 16^{\prime} \mathrm{E}$

222. Above Masons Falls, Kinglake Nat. Pk, 23.vii.73, IAEB, $37^{\circ} 34^{\prime} \mathrm{S}, 145^{\circ} 22^{\prime} \mathrm{E}$.

223. Pond at Glenburn, 31.viii.73, DM, 37 $26^{\prime} \mathrm{S}, 147^{\circ} 27^{\prime} \mathrm{E}$.

224. Johnsons Sw., Wodonga, 11.viii.76, RS, $36^{\circ} 07^{\prime} \mathrm{S}, 147^{\circ} 00^{\prime} \mathrm{E}$.

225. Snowdons Lag. Wodonga, 11.viii.76, RS, $36^{\circ} 07^{\prime} \mathrm{S}, 147^{\circ} 00^{\prime} \mathrm{E}$.

226. L. Kerferd, via Beechworth, 30.xi.73, BT, $36^{\circ} 22^{\prime} \mathrm{S}, 146^{\circ} 44^{\prime} \mathrm{E}$.

227. L. Catani, Mt. Buffalo, 2.xii.73, BT, $36^{\circ} 44^{\prime} \mathrm{S}, 146^{\circ} 49^{\prime} \mathrm{E}$.

228. L. Eildon, via Alexandra, $18 . \mathrm{ii} .76$, RS, $37^{\circ} 14^{\prime} \mathrm{S}, 145^{\circ} 56^{\prime} \mathrm{E}$.

229. Unnamed lag. via Seymour, 2.xii. $73, \mathrm{BT}, 36^{\circ} 59^{\prime} \mathrm{S}, 145^{\circ} 08^{\prime} \mathrm{E}$.

230. Unnamed lag. via Yea, 2.xii. 73 , BT, $37^{\circ} 13^{\prime} \mathrm{S}, 145^{\circ} 25^{\prime} \mathrm{E}$.

231. Goulburn Bb, via Alexandra, see Shiel 1976, RS, $37^{\circ} 13^{\prime} \mathrm{S}$, $145^{\circ}, 42^{\prime} \mathrm{E}$.
232. Goulburn R. near Alexandra, see Shiel 1976, RS, $37^{\circ} 13^{\prime} \mathrm{S}$, $145^{\circ} 42^{\prime} \mathrm{E}$

233. Alexandra, see Shiel $1976, \mathrm{RS}, 37^{\circ} 13^{\prime} \mathrm{S}, 145^{\circ} 42^{\prime} \mathrm{E}$.

234. L. Culluleraine, via Mildura, 18.xii. 75 , BT, $34^{\circ} 16^{\prime} \mathrm{S}, 141^{\circ} 35^{\prime} \mathrm{E}$.

234a. L. Culluleraine, via Mildura, 8.ix. 78 , RS, $34^{\circ} 16^{\prime} \mathrm{S}, 141^{\circ} 45^{\prime} \mathrm{E}$.

235. L. Hawthorn via Mildura, 10 xii. $73, \mathrm{BT}, 34^{\circ} 12^{\prime} \mathrm{S}, 142^{\circ} 06^{\prime} \mathrm{E}$.

236. L. Boga, at L. Boga township, 9.xii.73, BT, $35^{\circ} 28^{\prime} \mathrm{S}$, $143^{\circ} 39^{\prime} \mathrm{E}$.

237. L. Charm via Kerang, 9.xii.73, BT, $35^{\circ} 37^{\prime} \mathrm{S}, 143^{\circ} 51^{\prime} \mathrm{E}$.

238. L. Boort at Boort, 9.xii.73, BT, $36^{\circ} 08^{\prime} \mathrm{S}, 143^{\circ} 44^{\prime} \mathrm{E}$.

239. Teddington Res., via St. Arnaud, 9.xii.73, BT, $36^{\circ} 50^{\prime} \mathrm{S}$, $143^{\circ} 16^{\prime} \mathrm{E}$.

240. Pond near Kaniva, 23.vi.74, DM, $36^{\circ} 37^{\prime} \mathrm{S}, 141^{\circ} 16^{\prime} \mathrm{E}$.

241. Roadside pond near Horsham, 24.v.74, DM, $36^{\circ} 50^{\prime}$ S, $142^{\circ} 24^{\prime} \mathrm{E}$

242. Taylors L., via Horsham, no date given, IAEB, $36^{\circ} 50^{\prime} \mathrm{S}$, $142^{\circ} 23^{\prime} \mathrm{E}$.

243. Beaufort Res., at Beaufort, 9.xii. 73 , BT, $37^{\circ} 27^{\prime} \mathrm{S}, 143^{\circ} 24^{\prime} \mathrm{E}$.

244. Pool nr L. Goldsmith, 9.xii. 73 , BT, $37^{\circ} 32^{\prime} \mathrm{S}, 143^{\circ} 24^{\prime} \mathrm{E}$.

245. F.D., Monmot, 9.xii. $73, \mathrm{BT}, 37^{\circ} 39^{\prime} \mathrm{S}, 143^{\circ} 23^{\prime} \mathrm{E}$.

246. Missens F.D., via Beeac, 25.i.76, BT, $38^{\circ} 10^{\prime}$ S, $143^{\circ} 39^{\prime} \mathrm{E}$

247. L. Coragulac, via Colac, 25.i.76, BT, $38^{\circ} 15^{\prime} \mathrm{S}, 143^{\circ} 31^{\prime} \mathrm{E}$.

248. West Twin L., via Colac, 26.i.76, BT, $38^{\circ} 15^{\prime} \mathrm{S}, 143^{\circ} 30^{\prime} \mathrm{E}$.

249. L. Purrumbete, via Camperdown, see Timms 1973b, BT, $38^{\circ} 17^{\prime} \mathrm{S}, 143^{\circ} 14^{\prime} \mathrm{E}$.

250. Pond $\mathrm{nr}$ L. Gnotuk, via Camperdown, 26.i.76, BT, 38 $13^{\prime} \mathrm{S}$, $143^{\circ} 06^{\prime} \mathrm{E}$

251. L. Elingamite, via Cobden, 26.i.76, BT, $38^{\circ} 21^{\prime} \mathrm{S}, 143^{\circ} 01^{\prime} \mathrm{E}$

252. Cobrico Sw., via Cobden, 26.i.76, BT, $38^{\circ} 20^{\prime} \mathrm{S}, 143^{\circ} 01^{\prime} \mathrm{E}$.

253. L. Mumblin, via Terang, $14 . x i .71, \mathrm{BT}, 38^{\circ} 20^{\prime} \mathrm{S}, 142^{\circ} 55^{\prime} \mathrm{E}$.

254. Tower Hill L., via Warrnambool, ii.68, GB, $38^{\circ} 20^{\prime} \mathrm{S}$, $142^{\circ} 23^{\prime} \mathrm{E}$.

255. L. Surprise, via Macarthur, 28.ii.72, BT, $38^{\circ} 04^{\prime} \mathrm{S}, 141^{\circ} 55^{\prime} \mathrm{E}$

256. Bridgewater L., via Portland, 18.viii.72, BT, $38^{\circ} 19^{\prime} \mathrm{S}$, $141^{\circ} 24^{\prime} \mathrm{E}$.

257. Swan L., via Portland, 17.viii. 72 , BT, $38^{\circ} 13^{\prime} \mathrm{S}, 141^{\circ} 19^{\prime} \mathrm{E}$

258. "Pine Forest Lag." via Nelson, 11.viii.72, BT, $38^{\circ} 08^{\prime} \mathrm{S}$, $141^{\circ} 13$ 'E.

259. Cains Hut S.W., via Nelson, 11.viii.72, BT, $38^{\circ} 08^{\prime} \mathrm{S}$, $141^{\circ} 13^{\prime} \mathrm{E}$

260. Sheepwash Lag., via Nelson, 11.viii.72, BT, $38^{\circ} 08^{\prime} \mathrm{S}$, $141^{\circ} 13^{\prime} \mathrm{E}$

261. Temporary pond, $7 \mathrm{~km} \mathrm{~W}$ Edenhope, 19.x.78, DM, $37^{\circ} 01^{\prime} \mathrm{S}$, $141^{\circ} 13^{\prime} \mathrm{E}$

262. L. Mulwala, via Yarrawonga, 20.v.77, RS, $36^{\circ} 01^{\prime} \mathrm{S}, 146^{\circ} 00^{\prime} \mathrm{E}$.

\section{TASMANIA}

291. Pond $12 \mathrm{~km}$ E Marrawah, 18.viii. $74, \mathrm{DM}, 40^{\circ} 15^{\prime} \mathrm{S}, 144^{\circ} 84^{\prime} \mathrm{E}$ 292. Pond $\mathrm{nr}$ Smithton, 17.viii.74, DM, $40^{\circ} 51^{\prime} \mathrm{S}, 145^{\circ} 08^{\prime} \mathrm{E}$

293. Pond nr Parrawe, 18.viii.74, DM, $41^{\circ} 18^{\prime} \mathrm{S}, 145^{\circ} 34^{\prime} \mathrm{E}$

294. Unnamed Res. at Waratah 19.viii. 74 , DM, $41^{\circ} 27^{\prime} \mathrm{S}, 145^{\circ} 33^{\prime} \mathrm{E}$.

295. F.D. $5 \mathrm{~km}$ W Ulverstone, 17.viii. $74, \mathrm{DM}, 41^{\circ} 08^{\prime} \mathrm{S}, 146^{\circ} 07^{\prime} \mathrm{E}$

296. Pool $\mathrm{nr}$ Devonport Airport, 27.viii.74, DM, 41 ${ }^{\circ} 11^{\prime} \mathrm{S}$, $146^{\circ} 26^{\prime} \mathrm{E}$.

297. Swamp at Hawley Beach, 27.viii.74, DM, $41^{\circ} 09^{\prime} \mathrm{S}, 146^{\circ} 32^{\prime} \mathrm{E}$

298. Pool $2 \mathrm{~km} \mathrm{~N}$ Westbury 27.viii. 74 , DM, $41^{\circ} 31^{\prime} \mathrm{S}, 146^{\circ} 51^{\prime} \mathrm{E}$

299. Roadside pool, $13 \mathrm{~km}$ E Bridport, 26.viii.74, DM, $41^{\circ} 00^{\prime} \mathrm{S}$, $147^{\circ} 23^{\prime} \mathrm{E}$.

300. Swamp nr Big Waterhouse L., 26.viii.74, DM, 40 $53^{\prime} \mathrm{S}$ $147^{\circ} 37^{\prime} \mathrm{E}$.

301. Big Waterhouse L., 26.viii.74, DM, 40 $53^{\prime} \mathrm{S}, 147^{\circ} 37^{\prime} \mathrm{E}$.

302. F.D. $7 \mathrm{~km} \mathrm{~N}$ Scotsdale, 26.viii. 74 , DM, $41^{\circ} 08^{\prime} \mathrm{S}, 146^{\circ} 14^{\prime} \mathrm{E}$.

303. Unnamed L. $1 \mathrm{~km}$ E Derby 26.viii.74, DM, $41^{\circ} 09^{\prime} \mathrm{S}, 147^{\circ} 48^{\prime} \mathrm{E}$.

304. Perched L., Gordon R., 25.i.76, AR, $42^{\circ} 30^{\prime} \mathrm{S}, 145^{\circ} 40^{\prime} \mathrm{E}$.

305. Pond, $10 \mathrm{~km}$ E Derwent Bridge, 20.viii.74, DM, $42^{\circ} 08^{\prime} \mathrm{S}$, $146^{\circ} 14^{\prime} \mathrm{E}$

306. Bronte Lag., 20.viii.74, DM, $42^{\circ} 12^{\prime} \mathrm{S}, 146^{\circ} 29^{\prime} \mathrm{E}$

307. Pond $\mathrm{nr}$ L. Echo, 20.viii. 74 , DM, $42^{\circ} 14^{\prime} \mathrm{S}, 146^{\circ} 37^{\prime} \mathrm{E}$

308. L. Echo, 20.viii.74, DM, $42^{\circ} 10^{\prime} \mathrm{S}, 146^{\circ} 37^{\prime} \mathrm{E}$.

309. Unnamed L. west side of Great L., 24.viii.74, DM, $41^{\circ} 55^{\prime} \mathrm{S}$, $146^{\circ} 40^{\prime} \mathrm{E}$

310. Great L., 24.viii.74, DM, $41^{\circ} 53^{\prime} \mathrm{S}, 146^{\circ} 45^{\prime} \mathrm{E}$

311. Pond nr Steppes, 23.viii. $74, \mathrm{DM}, 42^{\circ} 06^{\prime} \mathrm{S}, 146^{\circ} 53^{\prime} \mathrm{E}$. 
312. Lagoon of Islands, 22.viii.74, DM, $46^{\circ} 06^{\prime} \mathrm{S}, 146^{\circ} 57^{\prime} \mathrm{E}$. 313. L. Sorrell, 9.v.76, BT, $42^{\circ} 07^{\prime} \mathrm{S}, 147^{\circ} 10^{\prime} \mathrm{E}$

314. Hazelwoods Lag., 9.v.76, BT, $42^{\circ} 10^{\prime} \mathrm{S}, 147^{\circ} 08^{\prime} \mathrm{E}$

315. Lake Crescent, 9.v.76, BT, $42^{\circ} 11^{\prime}$ 'S, $147^{\circ} 10^{\prime} \mathrm{E}$.

316. F.D. $9 \mathrm{~km} \mathrm{~N}$ Cleveland, 24.viii. 74 , DM, $41^{\circ} 45^{\prime} \mathrm{S}, 147^{\circ} 20^{\prime} \mathrm{E}$.

317. Cleveland Lag., 25.viii.74, DM, $41^{\circ} 48^{\prime} \mathrm{S}, 147^{\circ} 24^{\prime} \mathrm{E}$.

318. F.D. $3 \mathrm{~km}$ S Conara Junction, 25.viii.74, DM, $41^{\circ} 51^{\prime} \mathrm{S}$, $147^{\circ} 28^{\prime} \mathrm{E}$

319. Unnamed Lag. nr Campbell Town, 9.v.76, BT, $41^{\circ} 55^{\prime} \mathrm{S}$, $147^{\circ} 29^{\prime} \mathrm{E}$

320. Reedy Lag., via Ross 9.v.76, BT, $42^{\circ} 63^{\prime} \mathrm{S}, 147^{\circ} 21^{\prime} \mathrm{E}$.

321. Pump Lag., via Ross, 9.v.76, BT, $42^{\circ} 05^{\prime} \mathrm{S}, 147^{\circ} 21^{\prime} \mathrm{E}$

322. Bells Lag., via Ross, 9.v.76, BT, $42^{\circ} 06^{\prime} \mathrm{S}, 147^{\circ} 21^{\prime} \mathrm{E}$.

323. Pond $5 \mathrm{~km}$ ESE Ross, 25.viii.74, DM, $42^{\circ} 03^{\prime} \mathrm{S}, 147^{\circ} 30^{\prime} \mathrm{E}$.

324. F.D. $22 \mathrm{~km}$ E L. Leake, 25.viii. 74 , DM, $42^{\circ} 08^{\prime} \mathrm{S}, 148^{\circ} 00^{\prime} \mathrm{E}$.

325. L. Leake, via Campbell Town, 25.viii.75, DM, $42^{\circ} 01^{\prime} \mathrm{S}$, $147^{\circ} 49^{\prime} \mathrm{E}$

326. Whites Lag., via Tunbridge, $12 . x .72, \mathrm{BT}, 42^{\circ} 06^{\prime} \mathrm{S}, 147^{\circ} 26^{\prime} \mathrm{E}$.

327. Pool on Kitty R., via Oatlands, 9.v.76, BT, $42^{\circ} 15^{\prime} \mathrm{S}, 147^{\circ} 32^{\prime} \mathrm{E}$.

328. Winspears Lag., via Oatlands, 9.v.76, BT, $42^{\circ} 17^{\prime} \mathrm{S}, 147^{\circ} 39^{\prime} \mathrm{E}$.

329. Johnnys Lag., via Oatlands, 9.v.76, BT, $42^{\circ} 18^{\prime} \mathrm{S}, 147^{\circ} 38^{\prime} \mathrm{E}$.

330. Ashgrove Lag., via Oatlands, 9.v.76, BT, $42^{\circ} 20^{\prime} \mathrm{S}, 147^{\circ} 30^{\prime} \mathrm{E}$.

331. Pond $1 \mathrm{~km} \mathrm{~N}$ Tunbridge, 22.viii.74, DM, $42^{\circ} 08^{\prime} \mathrm{S}, 147^{\circ} 25^{\prime} \mathrm{E}$.

332. Weedling's Lag., via Oatlands, 9.v.76, BT, $42^{\circ} 17^{\prime} \mathrm{S}, 147^{\circ} 22^{\prime} \mathrm{E}$.

333. L. Dulverton, at Oatlands, 9.v.76, BT, $42^{\circ} 17^{\prime} \mathrm{S}, 147^{\circ} 21^{\prime} \mathrm{E}$.

334. L. Tiberas, via Oatlands, 22 .viii. $74, \mathrm{DM}, 42^{\circ} 26^{\prime} \mathrm{S}, 147^{\circ} 22^{\prime} \mathrm{E}$.

335. Pond nr Moulting Lag., via Swansea, 25.viii.74, DM, 41 ${ }^{\circ} 59^{\prime} \mathrm{S}$, $148^{\circ} 14^{\prime} \mathrm{E}$.

336. F.D., $14 \mathrm{~km}$ E Sorell, 22.viii. 74 , DM, $41^{\circ} 49^{\prime} \mathrm{S}, 147^{\circ} 41^{\prime} \mathrm{E}$. 337. F.D. $2 \mathrm{~km} \mathrm{~N}$ Richmond, 23. viii. $74, \mathrm{DM}, 42^{\circ} 44^{\prime} \mathrm{S}, 147^{\circ} 28^{\prime} \mathrm{E}$ 338. Pond, $3 \mathrm{~km}$ NE Longley, 22.viii.74, DM, 42 $57^{\prime} \mathrm{S}, 147^{\circ} 12^{\prime} \mathrm{E}$. 339. Various lakes, Macquarie I. xi.76, PT, $54^{\circ} 45^{\prime} \mathrm{S}, 158^{\circ} 35^{\prime} \mathrm{E}$.

\section{South Australia}

351. Pool, Hamilton Homestead, 3.x.75, KW, $26^{\circ} 43^{\prime} \mathrm{S}, 135^{\circ} 04^{\prime} \mathrm{E}$ 352. Bubbler Mound Spring, 30.ix.75, KW $28^{\circ} 18^{\prime} \mathrm{S}, 135^{\circ} 33^{\prime} \mathrm{E}$. 353. L. Eyre, 27.ix.74, IAEB, $28^{\circ} 30^{\prime} \mathrm{S}, 137^{\circ} 15^{\prime} \mathrm{E}$.

354. Pool in Frome R. at Mulroorina Station, ix.74, IAEB, $29^{\circ} 15^{\prime} \mathrm{S}$, $137^{\circ} 55^{\prime} \mathrm{E}$.

355. Aroona Res. via Copley, ix.74, IAEB, $30^{\circ} 35^{\prime} \mathrm{S}, 138^{\circ} 22^{\prime} \mathrm{E}$

356. Quorn Railway Dam, 18.i.76, BT, $32^{\circ} 31^{\prime} \mathrm{S}, 138^{\circ} 02^{\prime} \mathrm{E}$.

357. Pekina $\mathrm{Ck}$ at Orroroo, 16.i.76, BT, $32^{\circ} 43^{\prime} \mathrm{S}, 138^{\circ} 37^{\prime} \mathrm{E}$

358. Yongala Res., via Jamestown, 16.i.76, BT, $33^{\circ} 08^{\prime} \mathrm{S}, 138^{\circ} 45^{\prime} \mathrm{E}$.

359. Bundaleer Res., via Spalding, 18.i.76, BT, $33^{\circ} 28^{\prime} \mathrm{S}, 138^{\circ} 33^{\prime} \mathrm{E}$.

360. Porter's Lag., via Burra, 16.i.76, BT, $33^{\circ} 50^{\prime} \mathrm{S}, 138^{\circ} 53^{\prime} \mathrm{E}$.

361. Pond nr Black Springs, ix.74, IAEB, $33^{\circ} 54^{\prime} \mathrm{S}$, $138^{\circ} 54^{\prime} \mathrm{E}$

362. Torrens R., Gumeracha, 2.vii.76, RS, $34^{\circ} 50^{\prime} \mathrm{S}, 138^{\circ} 51^{\prime} \mathrm{E}$.

363. Sewage Pond, Gumeracha, 2.vii.76, RS, $34^{\circ} 50^{\prime} \mathrm{S}, 138^{\circ} 51^{\prime} \mathrm{E}$.

364. Torrens Gorge Weir, 21.vii.76, RS, $34^{\circ} 52^{\prime} \mathrm{S}, 138^{\circ} 45^{\prime} \mathrm{E}$

365. Torrens R., Adelaide, 14.i.76, BT, $34^{\circ} 55^{\prime} \mathrm{S}, 138^{\circ} 37^{\prime} \mathrm{E}$

366. Cock's F.D., Ashton, 14.i.76, BT, 34 $56^{\prime}$ 'S, $138^{\circ} 44^{\prime} \mathrm{E}$

367. Pool nr Reynella, 6.i.76, BT, $35^{\circ} 06^{\prime} \mathrm{S}, 138^{\circ} 33^{\prime} \mathrm{E}$.

368. F.D., Lower Inman Valley, 6.i.76, BT, $35^{\circ} 30^{\prime} \mathrm{S}, 138^{\circ} 32^{\prime} \mathrm{E}$

369. Rocky R., Kangaroo I., 9.i.76, BT, $35^{\circ} 56^{\prime} \mathrm{S}, 136^{\circ} 44^{\prime} \mathrm{E}$

370. Stunsail Boom R., Kangaroo I., 9.i.76, BT, $35^{\circ} 59^{\prime} \mathrm{S}$, $137^{\circ} 00^{\prime} \mathrm{E}$.

371. F.D. Harriet R., Kangaroo I., 9.i.76, BT, $36^{\circ} 00^{\prime}$ S, $137^{\circ} 09^{\prime}$ E

372. Edward's Lag., Kangaroo I., 8.i.76, BT, $35^{\circ} 49^{\prime} \mathrm{S}$, $137^{\circ} 01^{\prime} \mathrm{E}$.

373. F.D. $5 \mathrm{~km}$ W Parndana, Kangaroo I., 8.i.76, BT, $35^{\circ} 48^{\prime} \mathrm{S}$, $137^{\circ} 14^{\prime} \mathrm{E}$.

374. F.D. nr Agriculatural Research Station, Kangaroo I., 9.i.76, BT, $35^{\circ} 48^{\prime} \mathrm{S}, 137^{\circ} 31^{\prime} \mathrm{E}$.

375. Unnamed lagoon $\mathrm{N}$ of Eleanor R., Kangaroo I., 11.i.76, BT, $35^{\circ} 57^{\prime} \mathrm{S}, 137^{\circ} 15^{\prime} \mathrm{E}$

376. Eleanor R. Kangaroo I., 11.i.76, BT, $35^{\circ} 57^{\prime} \mathrm{S}, 137^{\circ} 15^{\prime} \mathrm{E}$

377. L. Ada, Kangaroo I., 9.i.76, BT, $35^{\circ} 55^{\prime} \mathrm{S}, 137^{\circ} 22^{\prime} \mathrm{E}$

378. F.D. nr Tea Tree Lag., Kangaroo I., 9.i.76, BT, $35^{\circ} 53^{\prime} \mathrm{S}$, $137^{\circ} 33^{\prime} \mathrm{E}$.

379. Billabong at "Yarrabee", Kangaroo I., 9.i.76, BT, $35^{\circ} 44^{\prime}$ 'S, $137^{\circ} 31^{\prime} \mathrm{E}$.

380. Lagoon on Cygnet R., floodplain, Kangaroo I., 9.i.76, BT, $35^{\circ} 43^{\prime} \mathrm{S}, 137^{\circ} 29^{\prime} \mathrm{E}$

381. Pond, $8 \mathrm{~km}$ W Kingscote, Kangaroo I., 9.i.76, BT, $35^{\circ} 38^{\prime} \mathrm{S}$, $137^{\circ} 30^{\prime} \mathrm{E}$.

382. Currency $\mathrm{Ck}$, via Goolwa, 6.i.76, BT, $35^{\circ} 27^{\prime} \mathrm{S}, 138^{\circ} 45^{\prime} \mathrm{E}$

383. F.D., Wistow, via Mt Barker, 6.i.76, BT, $35^{\circ} 07^{\prime} \mathrm{S}$, $138^{\circ} 53^{\prime} \mathrm{E}$

384. L. Bonney at Barmera, 18.xii.75, BT, $34^{\circ} 15^{\prime} \mathrm{S}, 140^{\circ} 28^{\prime} \mathrm{E}$.

385. Murray R., Teal Flat, 29.vi.76, RS, $34^{\circ} 52^{\prime} \mathrm{S}, 139^{\circ} 32^{\prime} \mathrm{E}$.
386. Murray R., Greenway's Landing, 9.viii.76, RS, $34^{\circ} 40^{\prime} \mathrm{S}$, $139^{\circ} 35^{\prime} \mathrm{E}$.

387. Murray R., Tailem Bend, 29.vi.76, RS, $35^{\circ} 15^{\prime} \mathrm{S}, 139^{\circ} 28^{\prime} \mathrm{E}$.

388. L. Leake, via Mt Gambier, 13.viii. 72 , BT, $37^{\circ} 37^{\prime} \mathrm{S}, 140^{\circ} 35^{\prime} \mathrm{E}$.

389. L. Edward, via Mt Gambier, 14.viii.72, BT, $37^{\circ} 38^{\prime} \mathrm{S}$, $140^{\circ} 36^{\prime} \mathrm{E}$.

390. Browne L., Mt Gambier, 21.i.76, BT, $37^{\circ} 51^{\prime} \mathrm{S}, 140^{\circ} 46^{\prime} \mathrm{E}$.

391. Valley L., Mt Gambier, 15.viii.72, BT, $37^{\circ} 51^{\prime} \mathrm{S}, 140^{\circ} 46^{\prime} \mathrm{E}$.

392. Leg of Mutton L., Mt Gambier 21.i.76, BT, $37^{\circ} 51^{\prime} \mathrm{S}$, $140^{\circ} 46^{\prime} \mathrm{E}$

393. L. Alexandrina, via Goolwa, 7.vi.76, MG, $35^{\circ} 26^{\prime} \mathrm{S}, 139^{\circ} 10^{\prime} \mathrm{E}$.

394. Murray R., Mannum, 28.xii.77, RS, $34^{\circ} 55^{\prime} \mathrm{S}, 139^{\circ} 19^{\prime} \mathrm{E}$.

\section{Western Australia}

401. Hamelin Homestead Pool, via Shark Bay, 20.viii.73, IAEB, $26^{\circ} 26^{\prime} \mathrm{S}, 114^{\circ} 11^{\prime} \mathrm{E}$

402. Salt pool, $43 \mathrm{~km} \mathrm{~W}$ Hamelin Homestead, 21.viii.73, IAEB, $26^{\circ} 37^{\prime} \mathrm{S}, 113^{\circ} 50^{\prime} \mathrm{E}$

403. Ponds N of Geraldton, 22.viii. 73 , IAEB, c. $27^{\circ} 30^{\prime} \mathrm{S}, 114^{\circ} 40^{\prime} \mathrm{E}$.

404. Ponds S of Geraldton, 19.viii.73, IAEB, c. $28^{\circ} 55^{\prime} \mathrm{S}, 114^{\circ} 40^{\prime} \mathrm{E}$.

405. L. Jindalup, via Perth, 11.viii. $76, \mathrm{KT}, 31^{\circ} 45^{\prime} \mathrm{S}, 115^{\circ} 47^{\prime} \mathrm{E}$.

406. L. Gnangara, via Perth, 11.viii.76, KT, $31^{\circ} 47^{\prime} \mathrm{S}, 115^{\circ} 52^{\prime} \mathrm{E}$.

407. L. Coollelal, via Perth, 11.viii.76, KT, $31^{\circ} 49^{\prime} \mathrm{S}, 115^{\circ} 49^{\prime} \mathrm{E}$.

408. Swamp E of Airport, Rottnest I., 11.viii.73, IAEB, $32^{\circ} 01^{\prime}$ 'S, $115^{\circ} 32^{\prime} \mathrm{E}$

409. Temporary pool, Rottnest I., 11.viii.73, IAEB, $32^{\circ} 01^{\prime} \mathrm{S}$, $115^{\circ} 30^{\prime} \mathrm{E}$.

410. Pond at Gosnells, Perth, 5.ix.60, DE, $32^{\circ} 05^{\prime} \mathrm{S}, 116^{\circ} 00^{\prime} \mathrm{E}$.

411. Pond at Kelmscott, Perth, 5.ix.60, DE, $32^{\circ} 07^{\prime}$ S. $116^{\circ} 01^{\prime}$ E.

412. Temporary pool, $\mathrm{nr}$ Forrestdale, 17.viii.73, IAEB, $32^{\circ} 10^{\prime} \mathrm{S}$, $115^{\circ} 57^{\prime} \mathrm{E}$.

413. L. Coolongyp, via Kwinana, 17.viii.73, IAEB, $32^{\circ} 18^{\prime} \mathrm{S}$, $115^{\circ} 47^{\prime} \mathrm{E}$.

414. Temporary swamp $\mathrm{nr}$ L. Walyungup, 17.viii.73, IAEB, $32^{\circ} 19^{\prime} \mathrm{S}, 115^{\circ} 47^{\prime} \mathrm{E}$

415. Temporary pond $\mathrm{nr}$ Dandalup, 17.viii.73, IAEB, $32^{\circ} 34^{\prime} \mathrm{S}$, $115^{\circ} 57^{\prime} \mathrm{E}$.

416. Temporary pond $\mathrm{nr}$ Yunderup, 17.viii.73, IAEB, $32^{\circ} 34^{\prime} \mathrm{S}$, $115^{\circ} 47^{\prime} \mathrm{E}$.

417. Granite rock pool on Sullivan Rock, 8.vi.77, IAEB, $32^{\circ} 25^{\prime} \mathrm{S}$, $116^{\circ} 18^{\prime} \mathrm{E}$

418. Swamp nr C. Leeuwin, 8.vii.76, KT, $34^{\circ} 22^{\prime} \mathrm{S}, 115^{\circ} 09^{\prime} \mathrm{E}$.

419. Lefroy Brook weir, via Pemberton, 19.vi.77, IAEB, $34^{\circ} 27^{\prime} \mathrm{S}$, $116^{\circ} 01^{\prime} \mathrm{E}$.

420. Granite rock pool on Muirillup Rock via Northcliffe, 18.vi.77, IAEB, $34^{\circ} 32^{\prime} \mathrm{S}, 116^{\circ} 03^{\prime} \mathrm{E}$

421. Pond $6 \mathrm{~km}$ S Northcliffe, 17.vi.76, IAEB, $34^{\circ} 41^{\prime} \mathrm{S}, 116^{\circ} 07^{\prime} \mathrm{E}$.

422. Swamp nr Shannon, 8.vii.76, KT, $34^{\circ} 35^{\prime} \mathrm{S}$, $116^{\circ} 25^{\prime} \mathrm{E}$.

423. Granite rock pool, Tutanning Reserve nr Pingelly, 24.vi.77, IAEB, $32^{\circ} 33^{\prime} \mathrm{S}, 117^{\circ} 18^{\prime} \mathrm{E}$.

424. Bolganup Dam, via Mt Barker, 24.v.77, IAEB, $24^{\circ} 40^{\prime} \mathrm{S}$, $117^{\circ} 52^{\prime} \mathrm{E}$.

425. L. Gardiner, via Albany 9.vii.76, KT, $34^{\circ} 58^{\prime} \mathrm{S}, 118^{\circ} 11^{\prime} \mathrm{E}$.

426. Roadside pool, $11 \mathrm{~km}$ S Northcliffe, 2.vii. 77 , IAEB, $34^{\circ} 44^{\prime} \mathrm{S}$, $116^{\circ} 05^{\prime} \mathrm{E}$.

427. Humified roadside pond, Albany, 3.vii. 77 , IAEB, $35^{\circ} 01^{\prime} \mathrm{S}$, $117^{\circ} 53^{\prime} \mathrm{E}$.

\section{NORTHERN TERRITORY}

451. Anthony Lag. vii. $75, \mathrm{HM}, 17^{\circ} 59^{\prime} \mathrm{S}, 135^{\circ} 33^{\prime} \mathrm{E}$.

452. Waterhole at Glen Helen, $160 \mathrm{~km}$ W Alice Springs, 28.ix.62, WDW $23^{\circ} 23^{\prime} \mathrm{S}, 132^{\circ} 13^{\prime} \mathrm{E}$.

453. Wrigleys Waterhole, $11 \mathrm{~km}$ N Alice Springs, 26.ix.62, WDW, $23^{\circ} 37^{\prime} \mathrm{S}, 133^{\circ} 52^{\prime} \mathrm{E}$.

454. Rock pool at Simpsons Gap, $18 \mathrm{~km} \mathrm{~W}$ Alice Springs, 25.ix.62, WDW, $28^{\circ} 43^{\prime} \mathrm{S}, 133^{\circ} 43^{\prime} \mathrm{E}$.

\section{Appendix 2}

List of new taxa (including those recently described elsewhere)

Genera nova

Archepleuroxus, Australochydorus, Monope (Smirnov, 1977), Rak, Rhynchochydorus. 
Species novae

Alona macracantha, Alona setuloides, Archepleuroxus baylyi, Australochydorus aporus, Biapertura rusticoides, Echinisca carinata (Smirnov, 1976), Echinisca flagellata, Echinisca pectinata (Smirnov, 1976), Echinisca timmsi (Smirnov, 1976), Echinisca williamsi, Macrothrix breviseta (Smirnov, 1976), Macrothrix longiseta (Smirnov, 1976), Monope reticulata, Monospilus diporus, Monospilus elongatus, Pseudosida australiensis, Rak labrosus, Rak obtusus, Rhynchochydorus australiensis, Simocephalus victoriensis.

Subspecies nova

Alona davidi vermiculata.

Mas novus

Pleuroxus jugosus.

New combinations

Biapertura abreviata (syn. Alona abreviata Sars, 1896), Biapertura duoodonta (syn. Alonella duoodonta Henry, 1922), Biapertura macrocopa (syn. Alona macrocopa Sars, 1895), Biapertura setigera (syn. Alona guttata var. setigera Brehm, 1931), Monope reticulata (syn. Monoporus henryae Smirnov, 1977), Pleuroxus jugosus (syn. Chydorus jugosus Henry, 1922), Simocephalus vetulus gibbosus (syn. Simocephalus gibbosus Sars, 1896), Simocephalus exspinosus australiensis (syn. Simocephalus australiensis Dana, 1852).

Synonymy

Acroperus avirostrus ( = A. neglectus Lilljeborg, 1900), Alona longirostris ( = Biapertura affinis [Leydig, 1860]), Alona microtata (= A. guttata Sars, 1862), Alona wallaciana (= Oxyurella tenuicaudis [Sars, 1862]), Alonella nasuta (= Pleuroxus aduncus [Jurine, 1820]), Bosmina brevirostris (= $B$. meridionalis Sars, 1904), Bosmina rotunda $(=B$. meridionalis Sars, 1904), Bosmina sorelli $(=B$. meridionalis Sars, 1904), Ceriodaphnia planifrons ( = C. quadrangula $[0$. F. Müller, 1785]), Ceriodaphnia spinata $(=C$. quadrangula [O.F. Müller, 1785]), Chydorus unispinus (= Pleuroxus aduncus [Jurine, 1820]), Macrothrix burstalis $(=E$. schauinslandi [Sars, 1904]), Simocephalus dulvertonensis ( = $S$. vetulus elisabethae [King, 1853]).

\section{Appendix 3}

List of species indicated for Australia for the first time in the course of the present study (some indications have already been published; they are referenced)

\section{SIDIDAE}

Pseudosida australiensis n.sp.

\section{CHYDORIDAE}

Archepleuroxus baylyi n. sp. Pleuroxus denticulatus (Smirnov, 1971), Pleuroxus inermis, Alonella excisa, Alonella exigua, Rak labrosus n. sp., Rak obtusus n. sp., Chydorus barroisi (Smirnov, 1971; Timms, 1967, 1968, 1972), Chydorus hybridus, Dadaya macrops (Smirnov, 1966, 1971), Australochydorus aporus n. sp., Rhynchochydorus australiensis n. sp., Alona inreticulata, Alona macracantha n. sp., Alona poppei, Alona setuloides n. sp., Acroperus harpae, Acroperus alonoides (Smirnov, 1971), Kurzia latissima, Kurzia longirostris (Timms, 1972), Leydigia acanthocercoides (Smirnov, 1971), Leydigia ciliata (Smirnov, 1971), Leydigia leydigi, Biapertura intermedia, Biapertura longinqua (Smirnov, 1971), Biapertura rigidicaudis (Smirnov,
1971), Biapertura rusticoides n. sp., Biapertura setigera, Monospilus diporus n. sp., Monospilus elongatus n. sp., Oxyurella singalensis, Oxyurella tenuicaudis, Euryalona orientalis.

\section{MACROTHRICIDAE}

Ilyocryptus brevidentatus, Macrothrix breviseta (Smirnov, 1976), Macrothrix longiseta (Smirnov, 1976), Echinisca carinata (Smirnov, 1976), Echinisca flagellata n. sp., Echinisca pectinata (Smirnov, 1976), Echinisca rosea, Echinisca timmsi (Smirnov, 1976), Echinisca williamsi n. sp., Streblocerus serricaudatus.

MOINIDAE

Moina mongolica (Bayly, 1976).

DAPHNIIDAE

Simocephalus latirostris, Simocephalus victoriensis n. $\mathrm{sp}$.

\section{Appendix 4}

List of species common in Australian inland waters (i.e. occurred in many samples, and often as many individuals)

SIDIDAE

Latonopsis australis, Diaphanosoma excisum, Diaphanosoma unguiculatum

CHYDORIDAE

Pleuroxus aduncus, Pleuroxus denticulatus, Alonella clathratula, Chydorus barroisi, Chydorus eurynotus, Chydorus sphaericus, Dunhevedia crassa, Pseudochydorus globosus, Alona cambouei, Alona costata, Alona davidi, Alona costata, Alona rectangula s.l., Alona pulchella, Graptoleberis testudinaria, Camptocercus australis, Biapertura affinis, Biapertura karua, Biapertura kendallensis, Biapertura rigidicaudis, Biapertura setigera.

MACROTHRICIDAE

Ilyocryptus spinifer, Macrothrix spinosa.

MOINIDAE

Moina micrura.

BOSMINIDAE

Bosmina meridionalis.

DAPHNIIDAE

Daphnia carinata, Daphnia cephalata, Daphnia lumholtzi, Simocephalus vetulus s.l., Simocephalus exspinosus, Ceriodaphnia quadrangula, Ceriodaphnia cornuta.

\section{Appendix 5}

List of species rare in Australian inland waters (i.e. only found in a few samples or valid species only once reported in the literature)

SIDIDAE

Latonopsis brehmi, Pseudosida australiensis.

CHYDORIDAE

Saycia cooki, Pleuroxus inermis, Alonella exigua, Chydorus herrmanni, Rak labrosus, Rak obtusus, Australochydorus aporus, Monope reticulata, Rhynchochydorus australiensis, Alona archeri, Alona clathratula, Alona inreticulata, Alona 
macracantha, Alona poppei, Alona quadrangularis, Acroperus alonoides, Acroperus negectus, Acroperus harpae, Kurzia longirostris, Leydigia acanthocercoides. Leydigia laevis, Leydigia leydigi, Biapertura abreviata, Biapertura duoodonta, Biapertura intermedia, Biapertura longinqua, Biapertura rusticoides, Monospilus aporus, Monospilus elongatus, Oxyurella singalensis, Oxyurella tenuicaudis, Euryalona orientalis.

\section{MACROTHRICIDAE}

Ilyocryptus brevidentatus, Macrothrix breviseta, Macrothrix hirsuticornis, Macrothrix hystrix, Macrothrix longiseta, Echinisca burstalis, Echinisca flagellata, Echinisca hardingi,
Echinisca pectinata, Echinisca rosea, Echinisca timmsi, Echinisca williamsi, Pseudomoina lemnae, Streblocerus serricaudatus.

MoINIDAE

Moina australiensis, Moina flexuosa, Moina mongolica, Moina tenuicornis.

BOSMINIDAE

Bosminopsis deitersi.

DAPHNIIDAE

Daphnia angulata, Daphnia jollyi, Simocephalus victoriensis, Ceriodaphnia laticaudata, Ceriodaphnia rotunda.

\section{References}

Akatova, N.A., 1964. Occurrence of Daphniopsis studeri Rühe (Cladocera) in a lake of "oasis" Westfal (East Antarctica). In 'Isseledovaniya fauny morey', 1, IX: 185-8 (In Russian).

Arnott, G.H. 1974. Studies on the zooplankton of Port Phillip Bay and adjacent waters with special reference to Copepoda. Ph.D. Thesis, Monash University, Melbourne.

Baird, W., 1843. The natural history of the British Entomostraca VI. Annals and Magazine of Natural History 11: $81-95$.

1845. Arrangement of the British Entomostraca. History of the Berwickshire Naturalists' club, 1845: $145-158$.

1850. The natural history of the British Entomostraca. Royal Society, London. $364 \mathrm{pp}$.

Ball, E., \& J. Gluckman, 1978. Limnological studies of Lake Wisdom, a large New Guinea caldera lake with a simple fauna. Freshwater Biology 8:455-468.

Bayly, I.A.E., 1964. Chemical and biological studies on some acidic lakes of east Australian sandy coastal lowlands. Australian Journal of Marine and Freshwater Research 15:56-72.

1967. The general biological classification of aquatic environments with special reference to those in Australia. In 'Australian Inland Waters and their Fauna: Eleven Studies' (ed. A.H. Weatherley), A.N.U. Press, Canberra.

1970. Further studies on some saline lakes of South-East Australia. Australian Journal of Marine and Freshwater Research 21: 117-124.

1976. The plankton of Lake Eyre. Australian Journal of Marine and Freshwater Research 27: 661-665.

\& D.H. Edward, 1969. Daphniopsis pusilla Serventy: a salt-tolerant cladoceran from Australia. Australian Journal of Science 32: 21-22.

Bayly, I.A.E., \& W.D. Williams, 1973. Inland waters and their ecology. Longman, Melbourne.

Beadle, L.C., 1943. An ecological survey of some inland saline waters of Algeria. Journal of the Linnean Society, Zoology 41: 218-242.

Behning, A.L., 1927. Ueber Penilia schmackeri aus dem Schwarzen Meer. In 'Collected papers dedicated to N.M. Knipovich'. Moscow. pp 345-350.

1941. Cladocera of the Caucasus. Tbilisii. (In Russian.)
Berg, L.S., 1947. Climate and life. Moscow. (In Russian.) Bergamin, F., 1939. Os Cladocera. Revista de Industria Animal, Sao Paulo 2(3): 62-68, 2(4): 87-92.

Birabén, M., 1939. Los Cladoceros de la familia "Chydoridae". Physis, Buenos Aires 17: 651-671.

Birge, E.A., 1879. Notes on Cladocera. Transactions of the Wisconsin Academy of Science, Arts and Letters IV: 77-109.

Brady, G.S., 1886. Notes on Entomostraca collected by $\mathrm{Mr}$ A. Haly in Ceylon. Journal of the Linnean Society, Zoology 19: 293-317.

Brehm, V., 1931. Cladoceran aus Neuseeland. Archiv für Hydrobiologie 23: 491-501.

1933. Die Cladoceren der Deutschen limnologischen Sunda-Expidition. Archiv für Hydrobiologie, Suppl. XI: 631-771.

1942. Ueber Simocephalus dulvertonensis Smith. Zoologischer Anzeiger 140: 59-60.

1948. Datos para la fauna de agua dulce de Cuba. Instituto de Biologia Aplicada, Barcelona 5: 95-112.

1953a. Contributions to the freshwater microfauna of Tasmania. Part 2. Daphnidae, Bosminidae, Chydoridae, Cytheridae. Papers and Proceedings of the Royal Society of Tasmania 87: 63-72.

1953b. Report No.2 from Professor T. Gislen's expedition to Australia in 1951-1952: Bericht über Cladoceren und Copepoden. Acta Universitet, Lund, new series 49(7): 1-11.

1959. Cladoceren und calanoide Copepoden aus Neu Guinea. Nova Guinea, new series 10: 1-10.

Brooks, J.L., 1957. The systematics of North American Daphnia. Memoirs of the Connecticut Academy of Arts and Sciences 13: 1-180.

1966. Cladocera. In 'Freshwater Biology', 2nd Edit. (ed. W.T. Edmondson). John Wiley and Sons, New York. Pp. 587-656.

Brundin, L., 1966. Transantarctic relationships and their significance, as evidenced by chironomid midges. Almquist and Wilsell, Stockholm, $472 \mathrm{pp}$.

Burrows, G.B., 1968. A comparative study of the major zooplankton species in Lake Sorrell and Lake Crescent, Tasmania. B.Sc. Honours Thesis, University of Tasmania.

Calman, W.T., 1908. Notes on a small collection of plankton from New Zealand. Annals and Magazine of Natural History Series 8(1): 232-241. 
1917. Stomatopoda, Cumacea, Phyllocarida, and Cladocera. Natural History Report. British Antarctic Terra Nova Expedition, 1910. Zoology 3, Arthropoda, 137-162.

Caporiacco, L., 1938. Cladocères marins recueillis pendant les croisières du Prince Albert de Monaco. Bulletin Institut Oceanographique, Monaco 740: 1-12.

Chapman, M.A., \& M.H. Lewis, 1976. An introduction to the freshwater Crustacea of New Zealand. Collins, Auckland and London. $261 \mathrm{pp}$.

Claus, C., 1877. Zur Kenntnis des Baues und der Organisation der Polyphemiden. Denkschriften der Akademie der Wissenschaften, Wien 37: 137-160.

Daday, E. von, 1898. Mikroskopische Süsswassertiere aus Ceylon. Természetrajzi Füzetek 21: 1-123.

1901. Mikroskopische Süsswassertiere aus deutsch Neu-Guinea. Természetrajzi Füzetek 24: 1-56.

1902. Mikroskopische Süsswassertiere aus Patagonien. Természetrajzi Füzetek 25: 201-310.

1905. Untersuchungen über die Süsswassermikrofauna Paraguays. Zoologica Sao Paulo 18, 44: 1-374. 1911. Egy ug Cladocero-faj Keletindiabol. Allatani Kozlemenyek 10: 63-68.

Dakin, W.J., \& A.N. Colefax, 1940. Plankton of the Australian coastal waters off New South Wales. Part I. Monograph No. 1, Department of Zoology, University of Sydney.

Dana, J., 1852a. Conspectus Crustaceorum in orbis terrarum circumnavigatione $\mathrm{C}$. Wilkes classe Reipublicae foederata duce collectorum. Proceedings of the American Academy of Arts and Sciences 2: 47.

1852b. United States Exploring Expedition during the years 1838-42 under Charles Wilkes. Vol 13: Crustacea Part II. Sherman, Philadelphia.

Darwin, C., 1872. The origin of species. Oxford University Press, Oxford. 592 pp.

Deevey, E.S. Jr., and G.B. Deevey, 1971. The American species of Eubosmina Seligo (Crustacea, Cladocera). Limnology and Oceanography 16: 201-218.

Delachaux, T., 1919. Cladocères des Andes Péruviennes. Bulletin de la Société Neuchâteloise des Sciences Naturelles 43: 18-38.

Dolgopolskaya, M.A., 1958. The marine Cladocera of the Black Sea. Trudy Sevastopolskaya Biologicheskaya Stantsiya 10: 27-75.

Dumont, H.J., 1971. On "Scapholeberis kingi"' G.O. Sars (Crustacea: Cladocera). Biologisch Jaarboek 39: 207-220.

1977. On the validity of the genus name Simocephalus Schoedler, 1858 (Crustacea: Cladocera). Crustaceana 32: 106-107.

1979. Limnologie van Sahara en Sahel. Rijksiniversiteit, Gent. 557 pp.

\& I. Van De Velde, 1977. Report on a collection of Cladocera and Copepoda from Nepal. Hydrobiologia 53: 55-65.

Dybowski, B., \& M. Grochowski, 1894. O Lynceidach czyli Tonewkach fauny krajowej. Kosmos, Lvov 19: 376-383. \& M. Grochowski, 1895. Spis systematyczny wioslarek (Cladocera) krajowych. Kosmos, Lvov 20: 139-165.

Ekman, S., 1904. Die Phyllopoden, Cladoceren und freilebenden Copepoden der nordschwedischen Hochgebirge. Zoologische Jahrbücher. Abteilung fur Systematik, Ökologie und Geographie der Tiere 21: 1-170.
Fager, E.W., 1957. Determination and analysis of recurrent groups. Ecology, 38: 586-595.

Fischer, S., 1849. Abhandlung über eine neue Daphnienart Daphnia aurita und über Daphnia laticornis Jurine. Byulleten' Imperatorskago Moskovskago Obshchestva Ispytatelei Prirody 22:38.

1850. Ergänzungen, Berichtigungen und Fortsetzung zu der Abhandlung über die in der Umgebung von St. Petersburg vorkommenden Crustaceen. Mémoires Présentés à l'Academie Imperiale des Sciences de St.Petersburg par Divers Savants 7: 1-14.

1851. Bemerkungen über einige weniger genau gekannte Daphnienarten. Byulleten Imperatorskago Moskovskago Obshchestva Ispytatelei Prirody 24: 96-108.

1854. Abhandlung über einige neue oder nicht genau gekannte Arten von Daphniden und Lynceiden als Beitrag zur Fauna Russlands. Byulleten Imperatorskago Moskovskago Obshchestva Ispytatelei Prirody. 27: 433-434.

Flössner, D., 1972. Kiemen- und Blattfüsser, Branchiopoda, Fischlause, Branchiura. Tierwelt Deutschlands und der Angrenzenden Meeresteile 60: 1-501.

Frey, D.G., 1960. The ecological significance of cladoceran remains in lake sediments. Ecology. 41: 785-790.

1965. Differentiation of Alona costata Sars from two related species (Cladocera, Chydoridae). Crustaceana 8: 159-173.

1967. Phylogenetic relationships in the family Chydoridae (Cladocera). Marine Biological Association of India. Symposia series Part I :29-37.

1971. Worldwide distribution and ecology of Eurycercus and Saycia (Cladocera). Limnology and Oceanography 16: 254-308.

1976. Redescription of Chydorus pigroides Lilljeborg, 1900, and allocation to Pleuroxus (Cladocera, Chydoridae). Crustaceana 30(1): 89-97.

1980. On the plurality of Chydorus sphaericus (O.F. Müller) (Cladocera, Chydoridae), and designation of a neotype from Sjaelso, Denmark. Hydrobiologia 69: 83-123.

1982. Relocation of Chydorus barroisi and related species (Cladocera, Chydoridae) to a new genus and description of two new species. Hydrobiologia 86: 231-269.

Fryer, G., 1968. Evolution and adaptive radiation in the Chydoridae (Crustacea: Cladocera): a study in comparative functional morphology and ecology. Philosophical Transactions of the Royal Society, London B 254(No. 795): 221-385.

1974. Evolution and adaptive radiation in the Macrothricidae (Crustacea:Cladocera): a study in comparative functional morphology and ecology. Philosophical Transactions of the Royal Society, London B 269(No. 898): 137-274.

Gauthier, H., 1939. Contribution à l'étude de la faune dulcaquicole de la région du Tchad et particulierment des Branchiopodes et des Ostracodes. Bulletin, Institut Fondamental d'Afrique Noire, Dakar 1: 110-244.

Geddes, M.C., 1976. Seasonal fauna of some ephemeral saline waters in Western Victoria with particular reference to Parartemia zietziana Sayce (Crustacea:Anostraca). Australian Journal of Marine and Freshwater Research 27: $1-22$.

Goulden, C.E., 1968. The systematics and evolution of the Moinidae. Transactions of the American Philosophical 
Society, new series 58: 1-101.

\& D.G. Frey, 1963. The occurrence and significance of lateral head pores in the genus Bosmina (Cladocera). Internationale Revue der Gesamten Hydrobiologie 48: 513-522.

Guerne, J. de., \& J. Richard, 1893. Cantocamptus grandidieri, Alona cambouei, nouveaux entomostracés d'eau douce de Madagastar. Memoires, Société Zoologique de France 6: 234-244.

Gurney, R., 1927. Some Australian freshwater Entomostraca reared from dried mud. Proceedings of the Zoological Society, London, 1927. 59-79.

Haase, J.F., 1903. Records of some Victorian Entomostraca. Victorian Naturalist (Melbourne) 19: 148-150.

Harding, J.P., 1955. Percy Sladen Trust Expedition XIX. Crustacea: Cladocera. Transactions of the Linnean Society, London 1: 329-354.

1957. Crustacea:Cladocera. Explor. Hydrobiol. Lac Tanganyika. Result Scientifique 3, 6: 55-89.

1961. Some South African Cladocera collected by Dr A.D. Harrison. Annals of the South African Museum 46: 35-46.

1972. Review of Smirnov, N.N., "Chydoridae of the world's fauna." Crustaceana 23: 316.

Harmsworth, R.V., 1968. The development history of Blelham Tarn (England) as shown by animal microfossils, with special reference to the Cladocera. Ecological Monographs 38: 223-241.

Heberer, G., 1923. Über eine Population von Daphnia cephalata aus Flores. Verhandlungen der Deutschen Zoologischen Gesellschaft 32: 70-78.

Hebert, P.D.N., 1977. A revision of the taxonomy of the genus Daphnia in southeastern Australia. Australian Journal of Zoology 25: 371-398.

1978. The population biology of Daphnia (Crustacea: Daphniidae). Biological Reviews 53: 387-426.

Hedley, M.E., 1969. Studies on Daphniopsis pusilla Serventy. B.Sc. Honours Thesis, Monash University, Melbourne.

Hellich, B., 1877. Über die Cladocerenfauna Böhmens. Sitzungesberichte der K. Böhmischen Gesellschaft der Wissenschaften 7: 205-220.

Henry, M., 1919. On some Australian Cladocera. Journal and Proceedings of the Royal Society of New South Wales 52: 463-485.

1922. A monograph of the freshwater entomostraca of New South wales. Proceedings of the Linnean Society of new South Wales 47: 26-52.

Herrick, C.L., 1882. Papers on the Crustacea of the fresh waters of Minnesota 2. Geology and Natural History Survey of Minnesota 10th Annual report: 235-52.

1887. Contribution to the fauna of the Gulf of Mexico and the South. List of the freshwater and marine Crustacea of Alabama. Memoirs of the Denison Scientific Assocation 1: 1-56.

Hudendorff, A., 1876. Beitrag zur Kenntniss der Süsswasser Cladoceren Russlands. Byulleten' Imperatorskago Moskovskago Obschestva Ispytatelei Prirody 50: 26-61.

Hussainy, S.U., 1969. Ecological studies on some microbiota of lakes in western Victoria,. Ph.D. Thesis, Monash University, Melbourne.

Illies, J., 1965. Phylogeny and zoogeography of the Plecoptera. Annual Review of Entomology 10: 117-140. Jaccard, P., 1932. Die statistisch-floristische Methode als
Grundlag der Pflanzensoziologische. Handbuch der Biologischen Arbeitsmethoden 11: 165-202.

Jurine, L., 1820. Historie des Monocles, qui se trouvent aux environs de Genève. Paris. $260 \mathrm{pp}$.

King, R.L., 1853a. On some species of Daphnidae found in New South Wales. Papers and Proceedings of the Royal Society of Tasmania 2: 243-253.

-1853b. On Australian Entomostracans-in continuation. Papers and Proceedings of the Royal Society of Tasmania 2: 253-263.

1866. On the anatomy of certain forms of Australian Entomostraca. Transactions of the Entomological Society of New South Wales, 1865: 162-166.

Kontkanen, P., 1950. Sur les diveres méthodes de groupement des récoltes dans la biocénotique animale. Vie et Milieu 1: 121-130.

Korínek, V., 1971. Comparative study of head pores in the genus Bosmina Baird (Crustacea: Cladocera). Vestnik Ceskoslovenske Společnosti Zoologicke 35: 225-296.

Korovchinsky, N.M., 1981. Taxonomic and faunistic revision of Australian Diaphanosoma (Cladocera: Sididae). Australian Journal of Marine and Freshwater Research 32: 813-831.

Kott, P., 1955. The zooplankton of Lake Macquarie 1953-54. Australian Journal of Marine and Freshwater Research 6: 429-442.

1957. Zooplankton of East Australian waters, 1953-54. C.S.I.R.O. Australian Division of Fisheries and Oceanography Report No. 14.

Kramer, A., 1895. On the most frequent pelagic Copepoda and Cladocera of the Mauraki Gulf. Transactions and Proceedings of the New Zealand Institute, new series 10, 27: 214-223.

Kurz, W., 1875. Dodekas neuer Cladoceren nebst einer kurzen Übersicht der Cladocerenfauna Böhmens. Sitzungsberichte der Akademie der Wissenschaften in Wien 70: 7-88.

Leach, W.E., 1816. Annulosa. Supplement to the 4th edition of Encyclopaedia Britannica: 406.

Lebedeva, M., \& P. Tamkovich, 1977. Ringing of birds in Australia. Okhota i okhotnichye Khozyaystvo 7: 40-41. (In Russian).

Leuckart, R., 1859. Über das Vorkommen eines saugnapfartigen Haftapparates bei den Daphniden und verwandten Krebsen. Archiv fur Naturgeschichte 25: 262-265.

Leydig, F., 1860. Naturgeschichte der Daphniden (Crustacea, Cladoceren). Tübingen. $252 \mathrm{pp}$.

Liévin, F., 1848. Die Branchiopoden der Danzier Gegend. Ein Beitrag zur Fauna der Provinz Preussen. Schriften der Naturforschenden Gesellschaft, Danzig 4: 1-52.

Lilljeborg, W., 1853. Om de inom Skane förekommande Crustaceer af Ordningarne. Cladocera, Ostracoda och Copepoda. Lund. $222 \mathrm{pp}$.

1900. Cladocera Sueciae. Nova Acta Regiae Societatis Scientiarum Upsaliensis, Ser. 3, 19: 1-701.

Lindberg, G.U., 1955. Quaternary in light of biogeographic data. Leningrad. Publications of the U.S.S.R. Academy of Sciences. 334 pp. (In Russian.)

1972. Big fluctuations in ocean level during Quarternary. Leningrad. Publications of the USSR Academy of Sciences. 548 pp. (In Russian.)

Lochhead, J.H., 1954. On the distribution of a marine cladoceran, Penilia avirostris Dana (Crustacea, 
Branchiopoda), with a note on its reported bioluminescence. Biological Bulletin 107: 92-105.

Löffler, H., 1968. Die Crustaceenfauna der Binnengewässer ostafrikanischer Hochgebirge. Hochgebirgforschung 2: 107-170.

Lovén, S., 1836. Evadne nordmanni ett hittills okändt Entomostracon. Kungliga Svenska Vetenskapsakademiens Handlingar, 1835.

Mamaril, A., 1977. Freshwater zooplankton of the Philippines. Thesis, University of Waterloo, Canada.

Manuylova, Y.F., 1964. Cladocera of the U.S.S.R. Fauna. Opredeliteli po Faune SSSR izdavaemye Zoologicheskim Muzeem Akademii Nauk 88: 328-655. (In Russian).

Markina, N.P., 1975. Planktonic communities in the Great Australian Bight. Hydrobiological Journal 11: 13-8.

Megard, R.O., 1967. Three new species of Alona (Cladocera, Chydoridae) from the United States. Internationale Revue der Gesamten Hydrobiologie 52: 37-50.

Mikheev, A.V., 1971. Migration of birds. Moscow, Lesnaya Promyshlennost. 208 pp. (In Russian).

Monakov, A.V., 1969. The zooplankton and zoobenthos of the White Nile and adjoining waters in the Republic of the Sudan. Hydrobiologia 33: 161-185.

Mordukhai-Boltovskoi, P.D., 1968a. On the taxonomy of the Polyphemidae. Crustaceana 14: 197-209.

1968b. Cladocera in 'Atlas bespozvonochnykh Kaspiyskogo moria, pp 120-160. Moscow.

1969. Subclass Branchiopoda, Order Cladocera. Opredeliteli Chernogo i Azovskogo Morey 2:12-31.

Morton, D.W., 1973. Studies on some temporary Victorian waters with special reference to the microcrustacea. Honours Thesis, Monash University, Melbourne.

Müller, O.F., 1776. Zoologiae Danicae prodromus. Havniae. Pp. XXXII + 282.

1785. Entomostraca seu insecta testacea quae in aquis Daniae et Norvaegiae reperit, descripsit et iconibus illustravit. Lipsiae et Havniae. $135 \mathrm{pp}$.

Müller, P.E., 1867. Denmarks Cladocera. Naturhistorisk Tidsskrift, Copenhagen 3: 53-240.

Nayar, C.K., 1971. Cladocera of Rajasthan. Hydrobiologia 37: 509-519.

Neale, I.M., \& I.A.E. Bayly, 1974. Studies on the ecology of the zooplankton of four estuaries in Victoria. Australian Journal of Marine and Freshwater Research 25: 337-350.

Norman, C.A.M., 1903. New generic names for some Entomostraca and Cirripedia. Annals and Magazine of Natural History, Series 7, 11: 367-372.

Norman, C.A.M., \& G.S. Brady, 1867. A monograph of the British Entomostraca belonging to the families Bosminidae, Macrothricidae and Lynceidae. Transactions of the Natural History Society of Northumberland 1: 354-408.

Paggi, J.C., 1972. Nota sistematica aperca de algunos Cladoceros del genero Chydorus Leach, 1843 de la Republica Argentina. Physis, Buenos Aires 31: 222-236. 1976. Cladoceros Macrothricidae neuvos para la fauna Argentina. Physis, Buenos Aires 35: 103-112.

\& S.J. Paggi, 1974. Primeros estudios sobre el zooplankton de las aquas loticas del Parana Medio. Physis, Buenos Aires 33: 91-114.

Pennak, R.W., 1966. Structure of zooplankton populations in the littoral macrophyte zone of some Colorado lakes. Transactions of the American Microscopical
Society $85:$ 329-349.

Petkovski, T., 1973a. Zur Cladoceren-Fauna Australiens. I. Daphniidae und Chydoridae. Acta Musei Macedonici Scientiarum Naturalium 13: 133-157.

-1973b. Zur Cladoceren-Fauna Australiens. II. Sididae und Macrothricidae. Acta Musei Macedonici Scientiarum Naturalium 13: 161-192.

Playfair, G.I., 1914. Contributions to a knowledge of the biology of the Richmond River. Proceedings of the Linnean Society of New South Wales 39: 93-151.

Poche, F. 1903. Einige nothwendige Anderungen in der herpetologischen Nomenclatur. Zoologischer Anzeiger 26: 698-703.

Poggenpol, M., 1872. List of Copepoda, Cladocera and Ostracoda of Moscow and surroundings. Izvêstiya Imperatorskago Obshchestva Lyubitelei Estestvoznaniya Antropolgii i Étnografii pri Imperatorskom Moskovskom Universitetê 10: 69-77.

Poppe, S.A., 1889. Ein neuer Podon aus China nebst Bemerkungen zur Synonymie der bisher bekannten Podon-Arten. Abhandlungen herausgegeben vom Naturwissenschaftlichen Verein zu Bremen 10: 295-300.

Rammner, W., 1928. Ein Vorkommen von Scapholeberis kingi G.O. Sars in Deutschland. Zoologischer Anzeiger 77: 325-336.

1929. Zur Systematik der Cladoceren-Gattung Scapholeberis Schoedler. Zoologischer Anzeiger 80: 280-288.

Rawson, D.S., \& J.E. Moore, 1944. The saline lakes of Saskatchewan. Canadian Journal of Research (Series D) 22: 141-201.

Rey, J. \& L., Saint-Jean, 1968. Les Cladocères (Crustacés, Branchipodes) du Tchad. Cahiers ORSTOM, Série Hydrobiologie II: 79-118.

Richard, J., 1894. Cladocères recueillis par le Dr. Theod. Barrois en Pelestine, en Syrie et en Égypte. Revue Biologique du Nord de La France, Lille 6: 360-378.

-1895. Sur quelques Entomostracés d'eau douce d'Haiti. Memoires Société Zoologique de France 8: 188-199.

1895. Revision des Cladocères 1. Annales des Sciences Naturelles, Zoologie, Series 7, 18: 279-389.

1897. Entomostracés de l'Amérique du Sud, recueillis par M.M. U. Deiters, H. von Ihering, G.W. Müller et C.O. Poppe. Mémoires de la Société Zoologique de France 10: 263-301.

Rühe, F.E., 1914. Monographie des genus Bosmina. A. Bosmina coregoni im baltischen Seengebiet. Zoologica 63: $1-141$.

Sars, G.O., 1862a. Meddeelte en af talrige Afbildninger ledsaget ovesight af de ham i Omegmen af Christiania iagtagne Crustacea Cladocera. Forhandlinger i Videnskabs-Selskabet i Christiania, 1861: 144-167. 1862 b. Fortsatte sit Foredrag over de af ham i Omegmen af Christiania iagttanne Crustacea. Forhandlinger i Videnskabs-Selskabet i Christiania, 1861: 250-302. 1885. On some Australian Cladocera raised from dried mud. Forhandlinger i Videnskabs-Selskabet i Christiania, 1885, 1-46.

1888. Additional notes on Australian Cladocera raised from dried mud. Forhandlinger i VidenskabsSelskabet i Christiania, 1888, 1-74.

1894. Contributions to knowledge of the freshwater Entomostraca of New Zealand as shown by artificial hatching from dried mud. Forhandlinger i 
Videnskabs-Selskabet i Christiania, 1894, 1-62.

1895. On some South African Entomostraca raised from dried mud. Videnskabs-Selskabet Skrifter I. Mathematisk-naturviden Klasses 8: 1-56.

1896. On freshwater Entomostraca from the neighbourhood of Sydney. Archiv for Mathematik og Naturvidenskab, Oslo 18: 1-81.

1897. On some West-Australian Entomostraca raised from dried sand. Archiv for Mathematik og Naturvidenskab, Oslo, 19: 1-35.

1901. Contributions to the knowledge of the freshwater Entomostraca of South America, as shown by artificial hatching from the dried material. Archiv for Mathematik og Naturvidenskab, Oslo, 23: 1-102.

1903. On the Crustacean fauna of central Asia. Ezhegodnik Zoolicheskago Muzeya Imperatorskoi Akademii Nauk, St. Petersburg 8: 157-264.

1904a. On a remarkable new Chydorid Saycia orbicularis G.O. Sars, from Victoria, South Australia. Archiv for Mathematik of Nasturvidenskab, Oslo 26: 1-15.

1904b. Pacifische Plankton-Crustaceen. Zoologische Jahrbücher 5: 629-646.

1911. On the problematic form "Moina lemnae King" and its true relations. Archiv for Mathematik og Naturvidenskab, Oslo, 32; 1-13.

1914. Daphnia carinata King and its remarkable varieties. Archiv for Mathematik og Naturvidenskab, Oslo, 34; 1-14.

1916. The freshwater Entomostraca of Cape Province (Union of South Africa). Part I. Cladocera. Annals of the South African Museum 15: 303-351.

Schoedler, J.E., 1862. Die Lynceiden und Polyphemiden der Umgegend von Berlin. Jahresbericht Dorotheen Realschule. $56 \mathrm{pp}$.

1863. Neue Beiträge zur Naturgeschichte der Cladoceren. Berlin. $80 \mathrm{pp}$.

1877. Zur Naturgeschichte der Daphnoiden. Abhandlung Jahresbericht Dorotheen Realschule, 24 pp.

Scott, T., 1895. The inland waters of the Shetland Islands. Notes on the species represented by the drawings on plate V. Annual report of Fishery Board of Scotland, XIII, Part III, Scientific investigations: 174-90.

Searle, J., 1917. The pond and its inhabitants. Victorian Naturalist (Melbourne) 34: 6-10.

Serventy, D.L., 1929. Records of Cladocera (Crustacea) from the South-West province of Australia. Journal of the Royal Society of Western Australia, 15: 63-69.

Sewell, R.B.S., 1956. The continental drift theory and the distribution of the Copepoda. Proceedings of the Linnean Society, London 166: 149-177.

Sheard, K., 1949. Plankton characteristics at the Cronulla onshore station, New South Wales, 1943-46. CSIRO (Australia) Bulletin 246: 1-23.

Shen Chia-jui, Sung Ta-hsiang \& Chen Kuo-hsiao, 1964. Studies on the Cladocera of Peking. Acta Zoologica Sinica 16: 61-69.

Shepard, J., J. Searle, \& J. Strickland, 1918. One year's collection of microfauna, Botanic Garden's Lake, Melbourne. Victorian Naturalist (Melbourne) 35: 79-84.

Shiel, R.J., 1976. Associations of Entomostraca with weedbed habitats in a billabong of the Goulburn River, Victoria. Australian Journal of Marine and Freshwater Research 27: 533-549.
Smirnov, N.N., 1966a. Taxonomic significance of the trunk limbs of the Chydoridae (Cladocera). Hydrobiologia 27: 337-347.

1966b. Pleuroxus (Chydoridae): morphology and taxonomy. Hydrobiologia 28: 161-194.

1966c. Alonopsis (Chydoridae, Cladocera): morphology and taxonomic position. Hydrobiologia 27: 113-136.

1971a. Morpho-functional grounds of mode of life of Cladocera. V. Morphology and adaptive modifications of trunk limbs of Anomopoda. Hydrobiologia 37: 317-345.

1971b. Chydoridae of the world's fauna. Fauna of the USSR, Rakoobraznye, Vol 1(2), new series, No. 101. Leningrad. 531 pp. (In Russian).

1975. Biology of Cladocera. Itogi Nauki i Techniki, Zoologia Bespozvonochnykh, 3, Moscow. 117 pp. (In Russian).

1976. Macrothricidae and Moinidae of the World. Fauna of the USSR. Leningrad. (In Russian). 1977. Quattuor species novae Cladocerorum Australiae. Crustaceana 32: 119-128.

Smith, G.W., 1909. The freshwater Crustacea of Tasmania with remarks on their geographical distribution. Transactions of the Linnean Society of London, Series 2, Zoology, II: 61-92.

Srámek-Hušek, R., M. Straškraba \& J. Brtek, 1962. Branchiopoda. Fauna CSSR, Praha, Vol 16. $470 \mathrm{pp}$.

Stebbing, T., 1902. Lynceus und Lynceidae. Zoologist, Series 4, 4: 101-106.

Steuer, A., 1933. Die "Arten" der Cladocerengattung Penilia Dana. Mitteilungen aus der Zoologischen Sammlung des Museums für Naturkunde in Berlin 19: 80-83.

Stingelin, T., 1895. Die Cladoceren der Umgebung von Basel. Revue Suisse de Zoologie 3: 161-274.

1906. Neue Beiträge zur Kenntnis der Cladocerenfauna der Schweiz. Revue Suisse de Zoologie 14: 317-387.

Strauss, H.E., 1820. Mémoire sur les Daphnia de la classe des Crustacés (seconde partie). Mémoires du Musée Royale d'Histoire Naturelle de Belgique 6: 149-162.

Tarling, D.H. \& M.F. Tarling, 1971. Continental Drift. G. Bell \& Sons, London. 112 pp.

Thomasson, K., 1963. Araukarian lakes. Plankton studies in North Patagonia with notes on terrestrial vegetation. Acta Phytogeographica Suecica 47: 1-139.

Timms, B.V., 1967. Ecological studies on the Entomostraca of a Queensland pond with special reference to Boeckella minuta Sars (Copepoda: Calanoida). Proceedings of the Royal Society of Queensland 79: 41-70.

1968. Comparative species composition of limnetic planktonic crustacean communities in South-East Queensland, Australia. Hydrobiologia 31: 474-480.

1969. A preliminary survey of the Wooli Lakes, New South Wales. Proceedings of the Linnean Society of New South Wales 94: 105-112.

1970a. Aspects of the limnology of five small reservoirs in New South Wales. Proceedings of the Linnean Society of New South Wales 95: 46-59.

1970b. Chemical and zooplankton studies of lentic habitats in North-Eastern New South Wales. Australian Journal of Marine and Freshwater Research 21: 11-33. 1972. The freshwater lagoon, Myall Lakes National 
Park. Hunter Natural History 4: 6-10.

1973. A comparative study of the limnology of three maar lakes in western Victoria. Ph.D. Thesis, Monash University, Melbourne.

1974. Aspects of the limnology of Lake Tarli Karng Victoria. Australian Journal of Marine and Freshwater Research 25: 273-279.

1977. A study of some coastal dune lakes in western Victoria. Proceedings of the Royal Society of Victoria 89: $167-172$.

1978. The benthos of some lakes in north eastern Queensland. Proceedings of the Royal Society of Queensland 90: 57-64.

S.H. Midgly, 1969. The limnology of Borumba Dam, Queensland. Proceedings of the Royal Society of Queensland 81: 27-42.

Vavra, W., 1900. Süsswasser-Cladoceren. Hamburger Magalhaensische Sammelreise herausgegeben von Naturhistorischen Museum zu Hamburg 5: 1-25.

Vidal, I.L., 1970. Moina sp. (Cladocera: Daphnidae) in a sewage plant, Wellington, New Zealand. New Zealand Journal of Marine and Freshwater Research 4: 203-209.

Wagler, E., 1936. Die Systematik und geographische Verbreitung der genus Daphnia O.F. Müller mit besonderer Berücksichtigung der südafrikanischen
Arten. Archiv für Hydrobiologie 30: 505-556.

Wallace, A.R., 1880. Island Life. Macmillan, London.

Wegener, A., 1925. Origin of continents and oceans. Moscow, Leningrad. (Russian translation of 3rd German edition).

1966. The origin of continents and oceans. Dover, New York. (Translated from 4th German edition).

Whittaker, R.H. \& C.W. Fairbanks, 1958. A study of plankton copepod communities in the Columbia Basin, Southeastern Washington. Ecology 39: 46-65.

Williams, J.L., 1978. Ilyocryptus gouldeni, a new species of water flea, and the first American record of $I$. agilis Kurz (Crustacea: Cladocera: Macrothricidae). Proceedings of the Biological Society of Washington 91(3): 666-680.

Williams, W.D., 1974. Freshwater Crustacea. In 'Biogeography and Ecology in Tasmania' (ed. W.D. Williams). Junk, The Hague.

Zernov, S.A., 1908. Penilia schmackeri Richard (Cladocera) in the Black Sea. Yearbook of the Zoological Museum of the Academy of Sciences 13: 500-2. (In Russian.)

Zonenshein, L.P., \& A.M. Gorodnitskiy, 1976. Paleoceans and continental drift. Priroda (Moscow) 2: 74-83. (In Russian.) 


\section{Index to Taxa Covered}

Only the principal text reference to each taxon is listed.

Acroperus ................... 51

A. alonoides ................... 51

A. harpae ................... 51

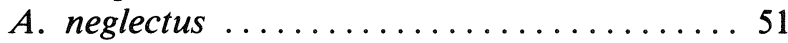

A. sinuatus ................. 52

Alona ....................... 39

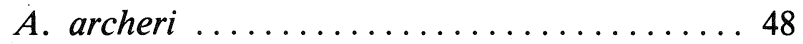

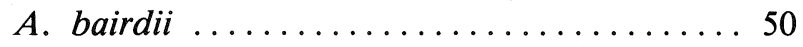

A. cambouei ................... 41

A. clathrata ................. 47

A. costata ................. 41

A. davidi .................... 40

A. davidi iheringi .............4 41

A. davidi punctata .............44

A. davidi vermiculata n.ssp. .........4 41

A. guttata .................. 43

A. guttata guttata $\ldots \ldots \ldots \ldots \ldots \ldots \ldots \ldots 43$

A. inreticulata ................. 43

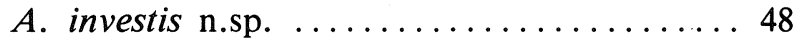

A. karua .................... 50

A. laevissima ................... 49

A. macracantha n.sp. .............. 48

A. mascula ................... 50

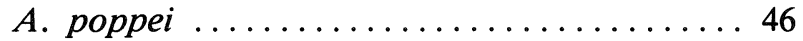

A. pulchella ................... 49

A. quadrangularis .............. 40

A. rectangula ................... 43

A. rectangula novae-zealandiae ........44 44

A. rectangula pulchra ............ 45

A. rectangula rectangula ........... 44

A. rectangula richardi ............ 44

A. setuloides n.sp. .............. 46

Alonella ........................ 26

A. clathratula .................. 26

A. excisa ................... 26

A. exigua ................... 26

A. propinqua ................. 27

ALONINAE ..................... 38

Archepleuroxus .................. 20

A. baylyi ................... 21

Australochydorus n.gen. ............ 36

A. aporus n.sp. ............... 36

Biapertura .................. 56

B. abreviata n.comb. .............63

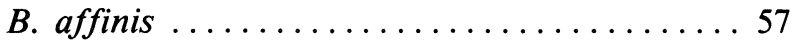

B. affinis affinis ............. 57

B. duoodonta n.comb. ............. 64

B. intermedia ................6 61

B. karua ...................61

B. kendallensis .................. 57

B. longinqua ................ 59

B. macrocopa n.comb. . ............ 62

B. rigidicaudis $\ldots \ldots \ldots \ldots \ldots \ldots \ldots \ldots \ldots \ldots$

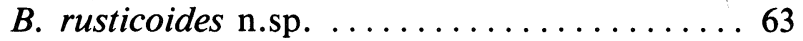

B. setigera n.comb. ............. 58
Bosmina ....................... 89

B. meridionalis ................ 89

BOSMINIDAE ................. 89

Bosminopsis ................... 89

B. deitersi . . . . . . . . . . . . . . . . . . 89

Camptocercus ................... 53

C. australis ....................... 54

Ceriodaphnia .................. 106

C. cornuta ................... 109

C. dubia ..................... 108

C. laticaudata ................. 108

C. quadrangula ................. 107

C. rotunda ...................... 109

CHYDORIDAE $\ldots \ldots \ldots \ldots \ldots \ldots \ldots \ldots \ldots \ldots$

CHYDORINAE ................. 20

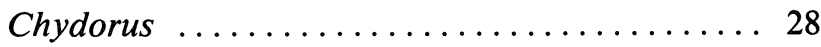

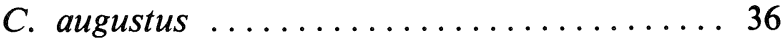

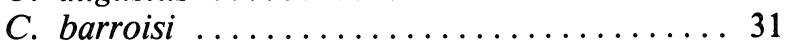
C. barroisi barroisi .............. 31

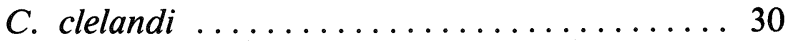

C. eurynotus ................... 29

C. eurynotus caelatus ............. 30

C. eurynotus eurynotus ........... 30

C. herrmanni .................. 29

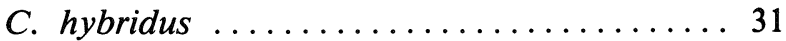

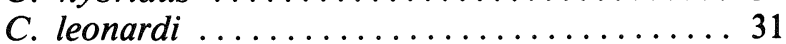

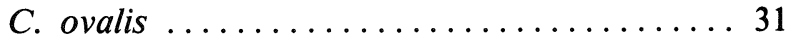

C. sphaericus ................... 29

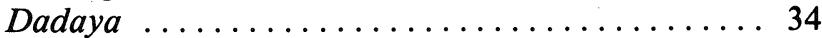

D. macrops .................... 34

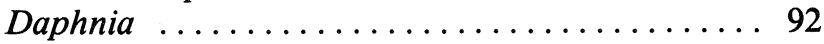

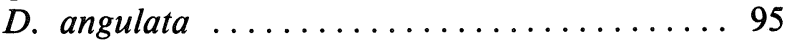

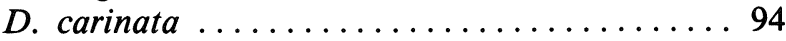

D. cephalata ................... 96

D. honorata .................. 110

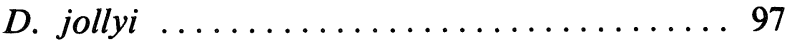

D. longicephala ................ 96

D. lumholtzi ................... 93

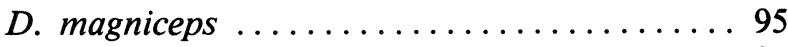

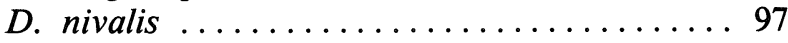

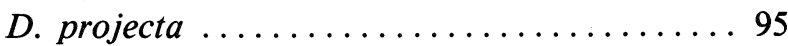

D. thomsoni ................... 96

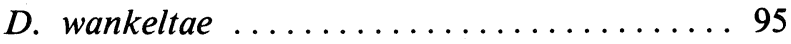

DAPHNIIDAE ................ 91

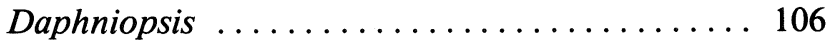

D. pusilla .................... 106

Diaphanosoma .................. 10

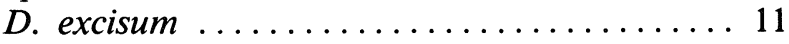

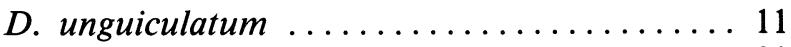

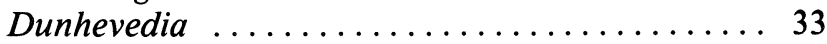

D. crassa .................... 33

D. crassa crassa .............. 33

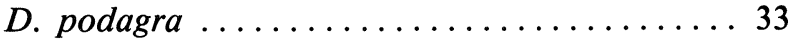

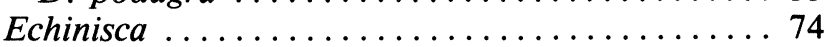

E. capensis ................ 76 
E. capensis capensis ............... 76

E. carinata ........................ 81

E. flagellata n.sp. ................ 80

$E$. hardingi ....................... 77

E. pectinata ....................... 78

E. rosea ......................... 74

E. schauinslandi $\ldots \ldots \ldots \ldots \ldots \ldots \ldots \ldots, 76$

E. timmsi ........................ 77

E. triserialis ..................... 75

E. williamsi n.sp. ................. 80

Euryalona ...................... 67

E. orientalis ....................... 67

Eurycercus cunninghami .................. 25

Eurycercus spinosus .................. 39

Evadne ............................ 16

E. spinifera ...................... 16

E. nordmanni ..................... 17

Graptoleberis $\ldots . \ldots \ldots \ldots \ldots \ldots \ldots \ldots \ldots 51$

G. testudinaria .................. 51

G. testudinaria occidentalis ............ 51

G. testudinaria testudinaria ............ 51

Ilyocryptus ....................... 69

I. brevidentatus .................. 70

I. sordidus $\ldots \ldots \ldots \ldots \ldots \ldots \ldots \ldots \ldots \ldots \ldots, 69 . \ldots \ldots$

I. spinifer .......................... 69

Kurzia ....................... 52

$K$. latissima ................... 52

$K$. longirostris ..................... 52

Latonopsis ........................ 5

L. australis ........................ 5

L. brehmi ...................... 7

Leydigia ............................ 54

L. acanthocercoides .................. 54

L. australis .................... 54

L. australis australis ................ 55

L. ciliata ......................... 54

L. laevis ......................... 55

L. leydigi ........................ 54

MACROTHRICIDAE .....................6 67

Macrothrix .............................. 70

M. breviseta ................... 73

M. hirsuticornis ................ 70

M. hirsuticornis hirsuticornis ........... 73

M. hystrix ....................... 73

M. longiseta $\ldots \ldots \ldots \ldots \ldots \ldots \ldots \ldots \ldots, \ldots \ldots$

M. spinosa $\ldots \ldots \ldots \ldots \ldots \ldots \ldots \ldots \ldots, 70,82$

Moina ........................... 85

M. australiensis ....................... 86

M. flexuosa ................... 87

M. micrura .................... 85

M. micrura micrura ............... 86

M. mongolica ........................ 88

M. tenuicornis . ................ 87

MOINIDAE ....................... 84
Moinodaphnia ...................... 85

M. macleayi ................... 85

Monope (new name) .................. 34

M. reticulata ....................... 34

Monospilus ........................ 64

M. diporus n.sp. .................6 64

$M$. elongatus n.sp. ................. 65

Neothrix ....................... 83

$N$. armata ...................... 83

Oxyurella .........................66 66

O. singalensis $\ldots \ldots \ldots \ldots \ldots \ldots \ldots \ldots \ldots 6, \ldots \ldots \ldots$

O. tenuicaudis ....................66 66

Penilia .............................. 12

P. avirostris .................... 12

Pleopis .......................... 13

P. polyphemoides ................... 14

Pleuroxus .......................... 21

P. aduncus ..................... 24

$P$. denticulatus .................... 25

$P$. inermis ...................... 25

P. jugosus n.comb. ................. 22

P. similis ....................... 25

Podon ............................. 14

$P$. intermedius ..................... 15

PODONIDAE ...................... 13

Pseudevadne ......................... 14

P. tergestina ...................... 14

Pseudochydorus ......................... 35

P. globosus ...................... 35

Pseudomoina ...................... 82

P. lemnae ...................... 82

Pseudosida ........................... 8

$P$. australiensis n.sp. ................ 9

Rak n.gen. ...................... 27

$R$. labrosus n.sp. ................. 28

$R$. obtusus n.sp. .................. 27

Rhynchochydorus n. gen. ............. 37

$R$. australiensis n.sp. ............... 37

Saycia .............................. 19

S. cooki ......................... 19

S. cooki cooki ..................... 19

SAYCIINAE ....................... 19

Scapholeberis ........................ 105

S. kingi .......................... 105

SIDIDAE ......................... 5

Simocephalus ..................... 97

S. acutirostratus .................. 104

S. exspinosus australiensis n.comb. . . . . . . 104

S. latirostris ........................ 103

S. vetulus ..................... 98

S. vetulus elisabethae .............. 98

S. vetulus gibbosus n.comb. ......... 102

S. victoriensis n.sp. ................ 105

Streblocerus ....................... 83

S. serricaudatus .................. 83 